\title{
GREAT ZIMBABWE
}

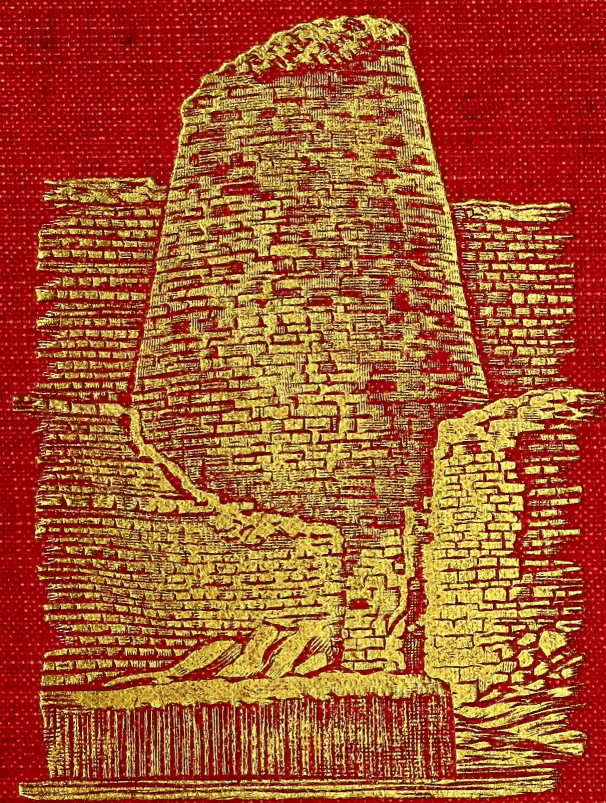

$R \cdot N \cdot$ HALL 




\section{GREAT ZIMBABWE}

MASHONALAND, RHODESIA 
Price ros. 6d. net. With seventy illustrations

\section{THE}

ANCIENT RUINS OF RHODESIA

BY

W. G. NEAL AND R. N. HALL

SECOND AND ENLARGED EDITION 



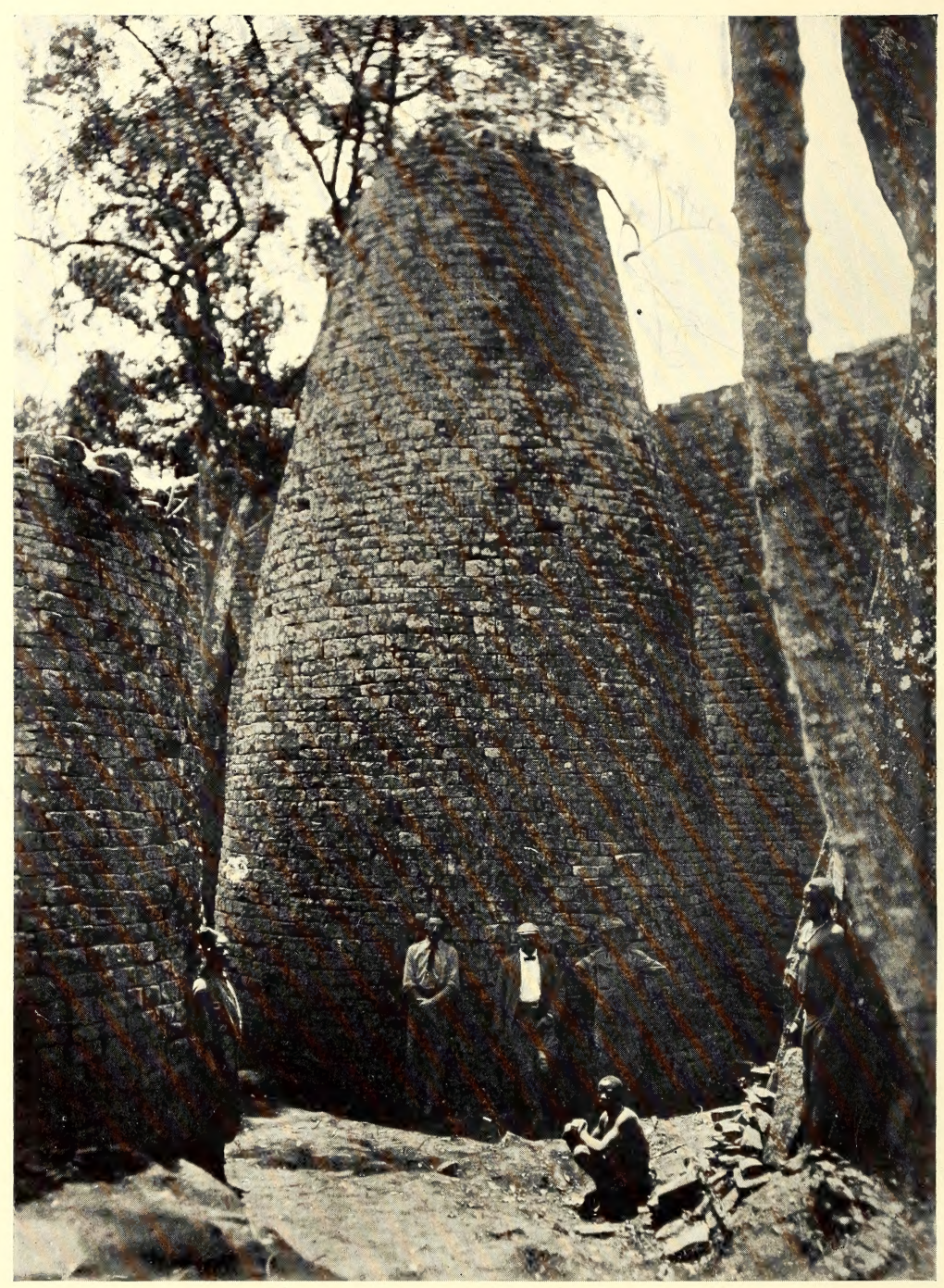

THE CONICAL TOWER, ELLIPTICAL TEMPLE, GREAT ZIMBABWE 


\title{
GREAT ZIMBABWE
}

\section{MASHONALAND, RHODESIA}

\author{
AN ACCOUNT OF TWO YEARS' EXAMINATION \\ WORK IN 1902-4 ON BEHALF OF THE \\ GOVERNMENT OF RHODESIA
}

BY

R. N. HALL, F.R.G.S.

CO-AUTHOR WITH W. G. NEAL OF "THE ANCIENT RUINS OF RHODESIA."

WITH AN INTRODUCTION

BY

PROFESSOR A. H. KEANE, LL.D., F.R.G.S.

WITH TWO HUNDRED ILLUSTRATIONS, MAPS, AND PLANS

NEW AND CHEAPER EDITION

36 ESSEX STREET W.C.

SMITHSONIAN

JUN 271985

METHUEN \& CO. LIBRARIES

LONDON 
First Published. . . . February, 1905

Second and Cheaper Edition . 1907 


\section{CONTENTS}

DEDICATION

Preface
Page xiii

- $\mathrm{xv}$

Introduction, by Professor A. H. Keane, LL.D., F.R.G.S. xxxi

\section{CHAPTER I}

Arrival at Great Zimbabwe-First Impressions-View from Acropolis Hill

\section{CHAPTER II}

Mystic Zimbabwe-Sunday Morning and Midnight in an Ancient

Temple--Sunset on the Acropolis

CHAPTER III

A day at Havilah Camp, Zimbabwe

CHAPTER IV

Zimbabwe District-Chipo-popo Falls-Frond Glen-Lumbo Rocks - "Morgenster" Mission-Wuwulu-Mojejèje, or Mystic Bar -Suku Dingle-Bingura's Kraal-Motumi's Kraal-Chipfuko Hill-Chipadzi's Kraal

\section{CHAPTER V}

Zimbabwe Natives-Natives and the Ruins-Natives (general) . 80

\section{CHAPTER VI}

Relics and Finds, Great Zimbabwe, 1902-4 .

\section{CHAPTER VII}

Notes on Ancient Architecture at Zimbabwe-IntroductionDurability of Walls-Dilapidations-Makalanga Walls-Remains of Native Huts found in Ruins-Passages-Entrances and Buttresses 


\section{CHAPTER VIII}

Notes on Ancient Architecture at Zimbabwe (continued)--DrainsBattering of Walls-Soapstone Monoliths and Beams-Granite and Slate Beams-Cement-Dadoes-Built-up crevices--Holes in Walls other than Drains-Blind Steps-Platforms-Ancient Walls at a Distance from Main Walls-Caves and Rock Holes

CHAPTER IX

The Elliptical Temple-Plan-Construction, Measurements -

Summit and Foundations of Main Wall-Chevron Pattern-

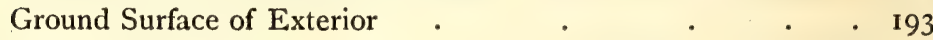

CHAPTER $\mathrm{X}$

The Elliptical Temple (continued)-Main Entrances . . . 216

CHAPTER XI

The Elliptical Temple (continued)-Enclosures Nos. I to 7 . $\quad 225$

\section{CHAPTER XII}

The Elliptical Temple (continued)-Sacred Enclosure-Conical

Tower-Small Tower-Parallel passage .

\section{CHAPTER XIII}

The Elliptical Temple (continued)-The Platform-Enclosures

Nos. 9 to 15-Central Area-Platform Area-Inner Parallel

Passage-South Passage-West Passage-North-East Passage

-Outer Parallel Passage

\section{CHAPTER XIV}

Acropolis Ruins-South-East Ancient Ascent-Lower Parapet-

Rock Passage-Upper Parapet-Western Enclosure . . 27

\section{CHAPTER XV}

Acropolis Ruins (continued)-The Western Temple .

\section{CHAPTER XVI}

Acropolis Ruins (continued)-Platform Enclosure-Cleft Rock

Enclosure-The Platform-Balcony Wall--Little Enclosure-

Winding Stairs-Upper Passage-East Passage-Buttress Passage-South Enclosures A, B, and C-South Cave-South Passage-Central Passage . . . . . . 310 


\section{CHAPTER XVII}

Acropolis Ruins (continued) - Eastern Temple-Ancient BalconyBalcony Enclosure-Balcony Cave - "Gold Furnace" Enclosure - Pattern Passage-Recess Enclosure-North Plateau-North Parapet

\section{CHAPTER XVIII}

Acropolis Ruins (continued)-North-West Ancient Ascent-Watergate Ruins-Terraced Enclosures on North-West Face of Zimbabwe Hill-South Terrace-Ruins on South Face of Zimbabwe Hill-Outspan Ruins

\section{CHAPTER XIX}

"The Valley of Ruins"-Posselt, Philips, Maund, Renders, Mauch Ruins, and South-East Ruins . . . . . . 363

\section{CHAPTER XX}

"The Valley of Ruins" (continued)-No. I Ruins-Ridge RuinsCamp Ruins Nos. I and $2 \quad$. $\quad$. $\quad . \quad 398$

\section{CHAPTER XXI}

Ruins near Zimbabwe-East Ruins-Other Ruins within the Zimbabwe Ruins' Area

Notes AND ADDENDA . 



\section{LIST OF PLATES}

Conical Tower, Elliptical Temple, Great Zimbabwe

PAGE Frontispiece

The late Mr. Theodore Bent, F.R.G.S., explorer of Great Zimbabwe in 1891, author of The Ruined Cities of Mashonaland . . . xiii

Coin of Byblos, Phœnicia, showing Conical Tower . _ . . . xxxyi

Wooden Bowl with Zodiacal Signs, found near Zimbabwe . . . $\quad$ xxxvi

Cylinder with Rosettes found at Phœnician Temple of Paphos in Cyprus xxxviii

Soapstone Cylinder, with Rosettes, found near Zimbabwe . . . xxxviii

"Fuko-ya-Nebandge" . . . . . . . . . . .

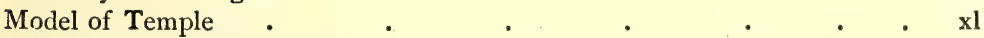

"To Great Zimbabwe" $\quad$. $\quad$. $\quad$. $\quad$. $\quad$. $\quad$. 2

Havilah Camp, Great Zimbabwe $\quad$. $\quad$. $\quad$. 2

View from Acropolis, showing Elliptical Temple in the Valley, Zimbabwe . Io

Conical Tower and Platform (from north), Elliptical Temple, Zimbabwe . 16

The Balcony, Eastern Temple, Acropolis. The parapet wall of Balcony

is built upon the suspended boulder . . . . 16

Carrying débris from the Elliptical Temple . . . . $\quad$. 36

A noontide shelter at the Elliptical Temple . . . . . 36

The Camp Messenger . . . . . . 46

Labourers at the Elliptical Temple . . . . . 46

The Chipo-popo Falls, near Zimbabwe . $\quad$. $\quad . \quad 56$

Rapping the Moje-je-je, or "Mystic Bar," Zimbabwe . . . ${ }_{56}^{6}$

Finger Rock, Morgenster, near Zimbabwe _ . . 62

I-Baku (the cave) at Chicagomboni, where Adam Renders, the rediscoverer

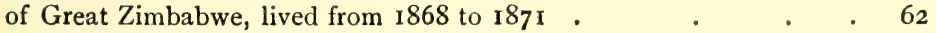

The Bird Rock, near Zimbabwe $\quad$. $\quad$ • $\quad$. $\quad . \quad$. 68

View on Motelekwe River $\quad . \quad$. $\quad$. $\quad$. $\quad . \quad$. 68

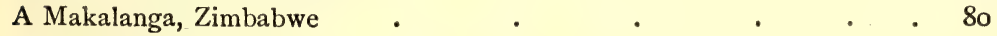

The Camp Watchman $\quad . \quad$. $\quad . \quad . \quad .80$

Makalanga "Boys" fencing, Zimbabwe . $\quad . \quad 4 \quad$. $\quad . \quad .84$

Motumi and Mongwaine, Zimbabwe $\quad . \quad$. $\quad$. $\quad . \quad$. 84

Makalanga mother and child, Zimbabwe . $\quad$. $\quad$ - $\quad$. $\quad$. 88

The Mogabe Handisibishe, chiet of the Zimbabwe Makalanga $\quad$. $\quad$. 88

Makalanga women and girls at the Mogabe's Kraal, Great Zimbabwe 96

Soapstone Beams, with Birds, Zimbabwe. . . . 102

Front, side, and back views of Soapstone Bird, Zimbabwe . . . 106

Soapstone Bird on Beam, discovered at Philips Ruins, Zimbabwe, in 1903

(three views) . . . . . . . 108

An old wall crossing over the foundation of a still older wall, Zimbabwe . 152

Binding of the summits of two separate walls . . . 152

Exterior of Drain, Elliptical Temple . . . . . I70

Monoliths on the Platform, Acropolis . . . . . I70 
PAGE

South-east Wall, with Chevron Pattern, Elliptical Temple, Great Zimbabwe 198

Chevron Pattern, East Wall, Elliptical Temple $\quad$. $\quad$. $\quad 204$

North-east Wall, with Chevron Pattern, Elliptical Temple, Great Zimbabwe 206

North-west Entrance, Elliptical Temple . $\quad$. . . 2 I6

Entrance to Passage, No. 1o Enclosure, Elliptical Temple . . 216

Exterior of North Entrance, Elliptical Temple, Zimbabwe. Discovered 1903 . $\quad . \quad$. $\quad$. . . 220

Summit of South-east Main Wall, Elliptical Temple . $\quad$. $\quad$. 222

West Entrance from interior, Elliptical Temple . . . . 222

Nos. 3 and 4 Enclosures and West Main Wall, Elliptical Temple . $\quad 228$

West Entrance, No. 7 Enclosure, Elliptical Temple $\quad$ • 234

South Wall of No. 7 Enclosure, showing part (to left) reconstructed,

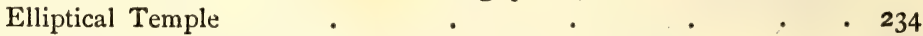

Visitors' Ladder to summit of Main Wall, Elliptical Temple . $\quad$ • $\quad \mathbf{2 3}^{8}$

The small Conical Tower, Elliptical Temple $\quad$. $\quad$. $\quad$. 238

The Parallel Passage (from south), Elliptical Temple . . . 246

The Parallel Passage (from north), Elliptical Temple $\quad$. $\quad$. $\quad 248$

South Entrance to Parallel Passage, looking south, Elliptical Temple 250

Part of Platform Area, looking west, showing drain from No. Io Enclosure, Elliptical Temple

South Wall, with Pattern, No. I I Enclosure, Elliptical Temple • •

Joint between original and reconstructed walls, Nos. I I and I2 Enclosures, Elliptical Temple

South-east interior of Elliptical Temple, looking N.N.E., and showing excavations, I902-4

Circular Cement Platform, with Steps, and carved Soapstone Beams, discovered I903, Elliptical Temple

Entrance to Inner Parallel Passage from South Passage, Elliptical Temple East Wall, with Pattern, No. I I Enclosure, Elliptical Temple . 268

Inner Parallel Passage, looking east, Elliptical Temple $\quad$. . 268

Zimbabwe Hill, or Acropolis. View from Havilah Camp 276

A turn in the Passage of the South-east Ancient Ascent, Acropolis . $\quad 284$

View from South-east Ascent, Acropolis . $\quad$. $\quad$ • $\quad$ - 284

Lower Entrance to Rock Passage, South-east Ascent, Acropolis $\quad$ • 286

View down Rock Passage, South-east Ancient Ascent, Acropolis 286

Entrance to Covered Passage, Western Temple, Acropolis . . 300

Summit of West Wall of Western Temple, Acropolis, showing small tower and monoliths . $\quad . \quad$. . . 300

West Entrance to Parallel Passage, Western Temple, Acropolis . 308

Buttress Passage, Acropolis . $\quad$. $\quad . \quad$. $\quad . \quad 308$

The Cleft Rock, from north side, Acropolis . . . . . 312

Natural Archway, Central Passage, Acropolis _ . • . . 312

View of the Platform from main West Wall of Western Temple, Acropolis $3^{1} 4$

Dentelle Pattern on Platform, Western Temple, Acropolis . • • • $\quad 3^{14}$

Bottom_of Winding Stairs, Western Temple, Acropolis • • • 316

West Entrance to South Cave, Acropolis . . • • 3I6

Exterior of main East Wall, showing Dentelle Pattern, Eastern Temple,

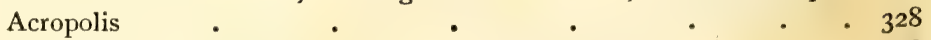

Sunken Passage (looking east), Eastern Temple, Acropolis $\quad$ - $\quad$ - $\quad 328$

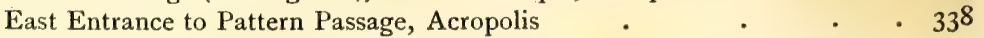




\section{LIST OF ILLUSTRATIONS}

$\cdot \cdot \cdot \cdot 338$

West Wall, Recess Enclosure, Acropolis . . . . . . 340

The Recesses at Recess Enclosure, Acropolis . . . 340

Sunken Passage, section of North-west Ascent, Acropolis • • 346

Herring-bone Pattern, Water Gate, Acropolis . . 346

Rounded end of Wall on west side of Maund Ruins, showing steps to Platform,

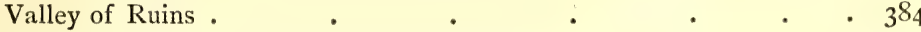

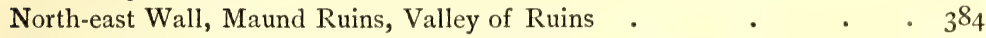

Slate Beam in Recess of Entrance, Philips Ruins, Valley of Ruins . . 430

The Passage, looking south, Mapaku Ruins, near Zimbabwe • • • 430

Map of Rhodesia . $\quad . \quad$. $\quad . \quad$. . $\quad$ xxxii

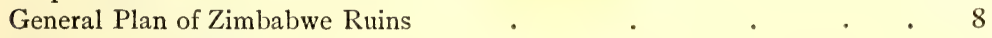

Plate I.-Relics . . . . . . . . 104

Plate II.-Relics . . . . . . . . II6

Plate III.-Relics . $\quad$ • $\quad$ • $\quad$. $\quad$. $\quad$. 122

Plan of Elliptical Temple $\quad . \quad$. $\quad . \quad$. $\quad . \quad$. 194

Plan of Acropolis Ruins . $\quad$. $\quad$. $\quad$. $\quad 278$

\section{LIST OF DIAGRAMS AND PLANS IN THE TEXT}

Great Zimbabwe Reserve

Section of Floors, No. 15 Enclosure . . . . . . 103

Arabian Glass $\quad . \quad$. $\quad . \quad$. $\quad . \quad$. $\quad$ r 28

Arabian Pottery $\quad . \quad$. $\quad . \quad$. $\quad . \quad$.

Section of Floors, No. 6 Enclosure . . . . . . . 134

South and North Entrances to No. 7 Enclosure, Elliptical Temple . I63, I64

North-west Entrance, Elliptical Temple . . . . 217

North or Main Entrance, Elliptical Temple . . . . 219

West Entrance to Parallel Passage, Elliptical Temple _ . . 247

Section of Eastern Temple, Acropolis . $\quad$. $\quad$. $\quad 324$

Plan of Eastern Temple, Acropolis . $\quad$. 326

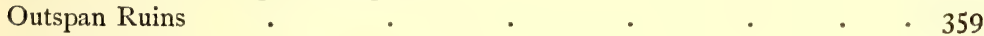

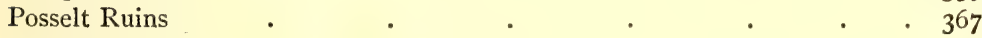

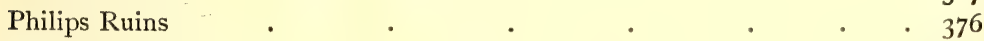

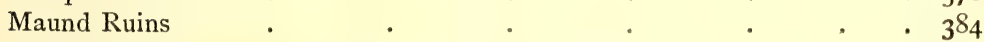

Renders Ruins . . . . . . . . . . . 387

Mauch Ruins . . . . . . . . 393

South-east Ruins . $\quad$. $\quad$. $\quad$. $\quad .397$

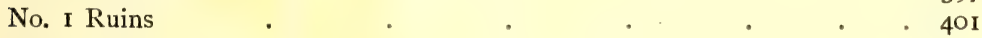

Ridge Ruins . . . . . . . 4 4II

Camp Ruins, No. I . . . . . . . . . 415

" "No. 2 . . . . . . . . 418

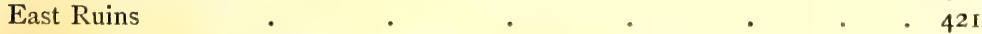

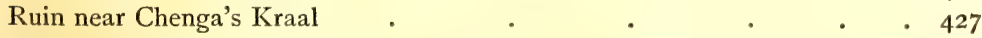

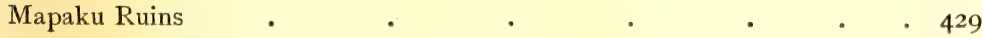






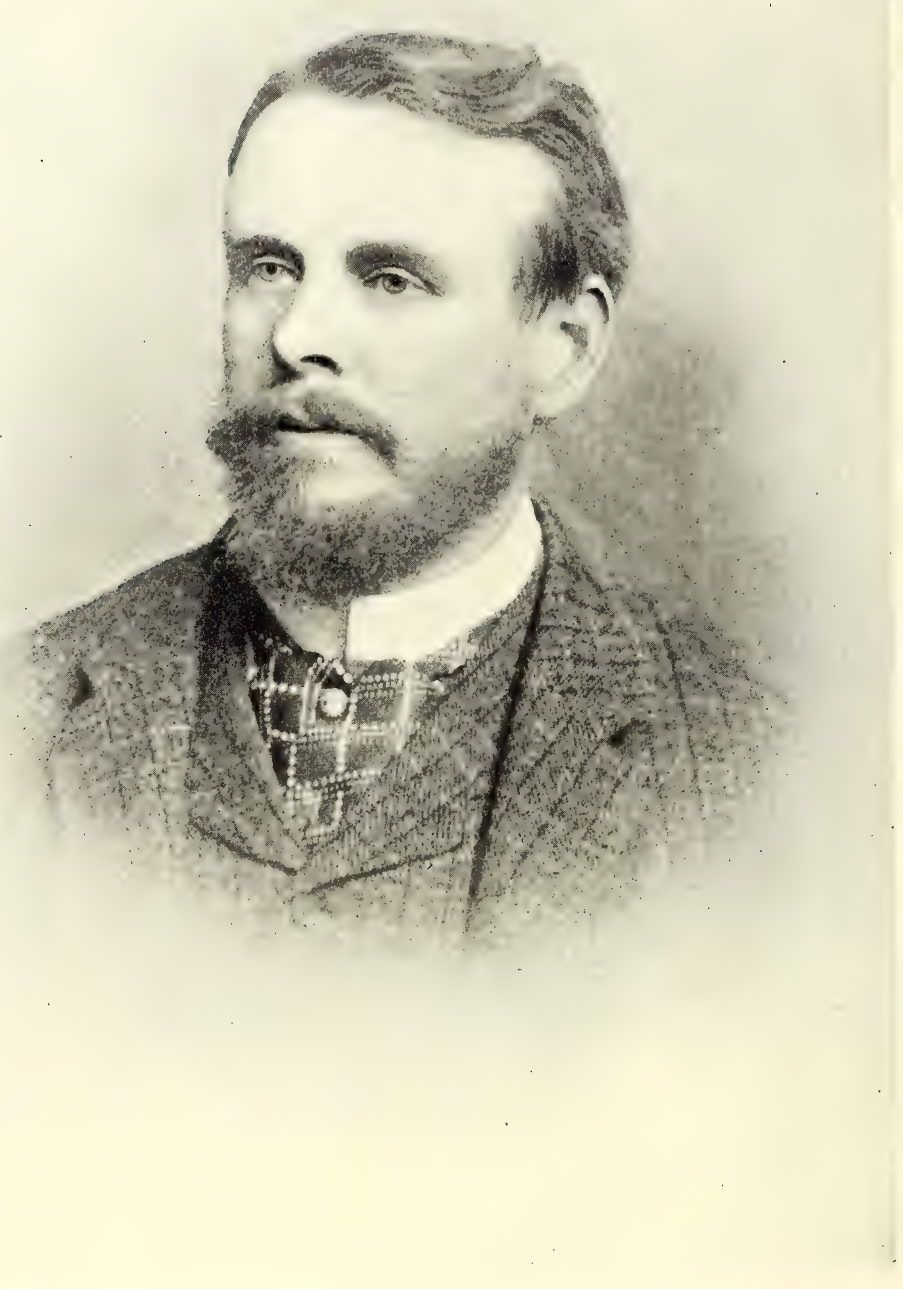

THE LATE MR. THEODORE BENT, F.R.G.S.

EXPLORER OF GREAT ZIMBABWE IN I89I, AUTHOR OF “THE RUINED CITIES OF MASHONALAND" 
THE VOLUME IS DEDiCATED

TO THE MEMORY OF

THE LATE THEODORE BENT, F.R.G.S.

EXPLORER OF GREAT ZIMBABWE, I89I

AND AUTHOR OF

"THE RUINED CITIES OF MASHONALAND" 



\section{PREFACE ${ }^{1}$}

I $\mathrm{N}$ preparing this detailed description of the ruins of Great I Zimbabwe-the first given to the world in modern times - the author has aimed at permitting the actual ruins themselves to relate their own story of their forgotten past unweighted by any consideration of the many traditions, romances, and theories which-especially during the last decade-have been woven concerning these monuments.

The only apology offered for this apparently lengthy Preface is the mention of the fact that the operations at Great Zimbabwe were carried on for six months after the text of this volume had been sent to the publishers in England. The Preface, therefore, thus affords an opportunity of bringing down the results of these operations to a recent date.

\section{RUINS' AREA}

The recent examination of the district surrounding the ruins now shows the Ruins' Area to be far larger than either Mr. Theodore Bent (1891) or Sir John Willoughby (1892) supposed. Instead of the area being confined to $945 \mathrm{yds}$. by 840 yds., it is now known to be at least 2 miles by $1 \frac{1}{4}$ miles, and even this larger limit is by no means final, as traces of walls and of walls buried several feet under the veld have been discovered, not only in Zimbabwe Valley, but in the secluded valleys and gorges and on the hillsides which lie a mile and even two miles beyond the extended

1 The major portion of this Preface was read before the British Association at Cambridge, August I7, 1904. 
area. Huge mounds, many hundred feet in circumference, with no traces of ruins, covered with large full-grown trees and with the remains on the surface of very old native huts, on being examined have been found to contain well-built ruins in which were unearthed small conical towers, gold ornaments, a few phalli, and in one instance a carved soapstone bird on a soapstone beam $4 \mathrm{ft}$. $8 \mathrm{in}$. high, which is more perfect and more ornate than any other soapstone bird on beam yet found at Zimbabwe. The examination of such spots and of all traces of walls which lie at the outer edge of the extended Ruins' Area would, even with a large gang of labourers, occupy almost a lifetime.

Mr. Bent spoke of Zimbabwe as a "city," and recent discoveries show the employment of this title to be fully justified, for not only is the Ruins' Area vastly extended, but the formerly conjectured area can now be shown by recent excavations to have been much more crowded with buildings than could possibly have been seen in I89 I. For instance, 2,300 ft. of passages have recently been discovered within the heart of the old Ruins' Area buried some feet under the silted soil below the veld in spots where the siltation is rapid, the existence of which structures had been altogether unsuspected. In some instances the native paths, used by visitors inspecting the ruins, crossed these passages from $3 \mathrm{ft}$. to $5 \mathrm{ft}$. above the tops of the passage walls. The enormous quantity of débris, evidencing occupations in several periods, scattered over both the old and the extended area, is simply astonishing, and judging by the value of "finds" made during the recent work, it seems quite possible that further exploration would, in the intrinsic value of relics as relics, largely reimburse the expense of its continuance, while securing the opening up of fresh features of architecture and probably some definite clues as to the original builders of the numerous periods of occupation respectively; would bring an immense addition to scientific knowledge, while the more important 
ruins themselves, having been cleared of silted and imported soils and wall débris, are now ripe for the further examination for relics.

\section{BURIAL PLACES OF THE OLD COLONISTS}

The secluded valleys, and also the caves in hills, for a distance of six miles, and in some cases as far as ten miles, from Zimbabwe have been systematically searched in the hope of discovering the burial place of the old gold-seekers. The neighbourhood of Zimbabwe contains several extensive ranges of granite hills each enclosing many secluded and Sinbad-like valleys and gorges, where natives state white men had never previously entered. Such spots on the whole of the Beroma Hills to the east of Zimbabwe, the south end of the Livouri Range to the west, the Bentberg Range to the south, and several hills in the Nini district, as well as several parts in the Motelekwe Valley, have been systematically searched without avail, though there are in certain of these secluded places traces of walls and artificially placed upright stones and other signs of human presence which require some explanation. The siltation of soil from the steep hillsides of many of these most romantically situated valleys has been very extensive. These searches could only be carried on after veld fires had swept the district of the rank grass which here grows to a height of $12 \mathrm{ft}$. Mr. Bent and other writers have shown that the old Arabians religiously preserved their dead, burying them in secluded spots at some considerable distance from any place of occupation. The writer is not without hope that these burial places may yet be found. The population of Zimbabwe at several different periods must have been immense, and, judging by the remains found near some of the oldest types of ruins in other parts of the country where the amount of gold ornaments buried with each corpse ranged from I oz. to $72 \mathrm{oz}$., the discovery of such places in the Zimbabwe district would yield important 
results, especially as, for many reasons, Zimbabwe undoubtedly appears to have been the ancient metropolitan capital and the centre of gold-manufacturing industry of the original and later Arab gold miners, and the place so far has yielded the richest discoveries of gold in every form.

The writer is now perfectly assured that no burial places of the original builders will be found under the interior of the Elliptical Temple or within 30 yds. of the exterior. Holes have been sunk at regular intervals within the temple and immediately outside the walls, and boring-rods have been systematically employed, and the position and lie of the formation rock ascertained throughout, so that sections and levels have been made of the soil and rock under the temple. All the results gained from each hole and boring are recorded. But beyond discovering buried foundations at the higher level, only virgin soil, never before disturbed, was gone through. French and German archæologists who visited Zimbabwe during the operations confirmed what British scientists have affirmed, that no burials of people of Semitic stock would be found within or near to any building so frequently in use as the great temple must have been. The severe restrictions with regard to cleanliness and sanitation, especially as to the dead, are among the most notable features of the old Semitic nations.

\section{ABSENCE OF INSCRIPTIONS}

No ancient writing has been discovered, though close attention has been paid to all stones and pottery likely to bear it, and notwithstanding that the interiors of some of the more ancient portions of the ruins have been cleared down to the old floors where, if any existed, they might reasonably have been expected to be found. Post-Koranic lettering was found on highly glazed pottery, also on glass, but all such specimens are of a fragmentary character; but experts such as Mr. Wallace Budge, the Head Keeper of Egyptian 
and Assyrian Antiquities at the British Museum, state that the glass and other "finds" of pottery are not older than the thirteenth or fourteenth century of this era. Other pottery thickly covered with dull-coloured glazes-mainly purples, greens, and browns-is thought to be somewhat older than that on which the lettering was found. Still, as such a very large portion of what may be considered as the more ancient of the ruins remains to be examined, it may yet be possible to unearth older specimens of Arab writing.

\section{TWO PERIODS OF GOLD MANUFACTURE}

Gold in a manufactured form is found on the lowest and original floors of the most ancient portions of the Zimbabwe ruins. In several ruins this was found as thickly strewn about the cement floors as nails in a carpenter's shop. Gold ornaments discovered at this depth, in some instances from $3 \mathrm{ft}$. to $5 \mathrm{ft}$. below any known native floors, were always found in association with the oldest form of relics yet unearthed at Zimbabwe. Such gold articles are of most delicate make, and are doubtless of an antique character, and expert opinion recently obtained in England confirms this conclusion.

But there are other gold articles which are ruder in design and make, and these by no means are entitled to claim such antiquity. In fact, expert opinion declines to recognise them as being in any sense anclent; for instance, beaten gold of irregular shape showing the rough hammer marks of some very crude instrument, and with holes round the edges of such plates very rudely cut-or rather torn-and placed in imperfect rows altogether in a haphazard style. This form of gold plates is identical in every detail with the copper sheathing with which it is always found associated. The same remarks apply equally to the gold beads also found with this class of plates which betoken crude workmanship, as well as to the iron instruments decorated with small gold knobs. 
With regard to the location of the later-period gold articles there is ample evidence that these are of very old native origin. Such ornaments are commonly met with on the floors of, or in close proximity to, the old native huts of the types of Nos. 2 and 3 (see Architecture, s.s. Native Huts found in Ruins, pp. 154, 155, post), and also in the cement huts with small radiating walls on levels several feet above any ancient floorings. In every instance such gold ornaments are found in association with articles of old native make-such as double iron gongs, copper sheathing, and copper assegai- and arrow-heads.

\section{ELLIPTICAL TEMPLE}

\section{NORTH ENTRANCE}

In 1902 the floor of the North Entrance to the temple was exposed to a depth of $5 \mathrm{ft}$. below the surface, as shown in Mr. Bent's book (p. I06), while a flight of steps in perfect condition leading up to the entrance from the exterior was discovered at a depth of $9 \mathrm{ft}$. below the old surface. This entrance, showing a bold conception and admirable construction, is now considered as one of the principal show features at Zimbabwe. Further, it is the oldest form of entrance and steps as well as the finest of any yet discovered in Rhodesia. A quantity of gold was found on the floor and steps of this entrance, which were once covered with fine granite cement, also a few true phalli.

\section{PARALLEL PASSAGE}

This has been cleared throughout to a depth of at least $3 \mathrm{ft}$., and in one place $7 \mathrm{ft}$. Cement floors were exposed, and these were found to be divided into small catchment areas with a drain from each passing outwards through the main wall. Five additional drains were discovered in this 
passage. Here were found eight ornate phalli, a portion of a gold bangle, some beaten gold and gold tacks of microscopic size, and fragments of carved soapstone beams.

\section{SACRED ENCLOSURE}

This was cleared out to a depth of $4 \mathrm{ft}$. throughout its whole area, and a few phalli of unmistakable form were found, and old granite cement floors and steps were uncovered. Explorers and relic hunters had worked in this enclosure, and had double trenched it from end to end.

A remarkable discovery was made here of distinct traces of granite cement dadoes, $7 \mathrm{ft}$. high, round the interior faces of the walls of this enclosure. In some other enclosures the remains of dadoes can still be seen.

The small conical tower in this enclosure has during the last ten years been seriously damaged by the large trunk of a tree pushing over the summit of the cone. Photographs of this small tower taken in I89I show that it was then almost intact.

\section{PLATFORM AREA}

This open area, lying to the west and north of the Conical Tower and the Platform, corresponds to the open areas immediately in front of the altars in old Grecian temples. This was Mr. Bent's opinion, and possibly it answered at Zimbabwe a similar purpose of accommodating the worshippers. The area, some $120 \mathrm{ft}$. by $60 \mathrm{ft}$., has been cleared out of large trees, and of about $6 \mathrm{ft}$. of soil throughout, and floors-both cement and clay-were disclosed, also a fine circular structure of excellent granite cement, and ascended by two steps. On and close to this structure were found fragments, mainly bases, of carved soapstone beams of slender appearance, also some phalli and gold. This platform lies slightly off the north line between the Conical Tower and the Main North Entrance. 
Some of the walls surrounding this area on the west and north sides, once considered to be ancient, can now be seen to cross over very old native clay huts and native copper and iron-smelting furnaces. The soil contained some phalli, which had been converted by the natives into amulets, also some Arabian glass-thirteenth and fourteenth centuriesVenetian beads, gold wirework, beaten gold, gold scorifiers of native pottery, iron pincers, and fragments of carved soapstone bowls with geometric designs.

\section{ENCLOSURES 6, 7, AND IO}

Gold-smelting operations must have, at some late period, been extensively carried on in these enclosures, for on removing from each enclosure all débris and fallen stones to a depth of from $4 \mathrm{ft}$. to $7 \mathrm{ft}$., there were found burnishing stones of fine grain and still covered with gold, gold scorifiers with gold in the flux, cakes of gold, gold furnace slag, beaten gold, and gold dust.

At a still lower depth in No. 6 Enclosure a quantity of granite clay crucibles, showing gold richly, were met with, and these are undoubtedly of older type than the native pottery scorifiers, also some ingot moulds of soapstone of the double claw-hammer or St. Andrew's cross pattern.

\section{CENTRAL AREA}

This area is only partially excavated, it being covered with old native-built walls which cross over bone and ash débris, old native huts, an iron furnace, and rich black mould in which the vegetable matter was still undecayed. Experimental holes and boring-rods showed that some very old foundations ran below the soil upon which the later and poorer walls are built. However, a key has now been found which will enable further excavations to be made within this area without injury to the upper walls. 
SUMMIT OF MAIN EAST WALL

Along the summit of the east main wall, and only over the chevron pattern which faces east, have recently been discovered the traces of foundations of small circular towers, both on the inner and outer edges of the wall. These correspond in measurement and relative position to the small conical towers on the west wall of the Western Temple at the Acropolis Ruins, which is decorated with monoliths. Some of the best-known surveyors and practical builders in Rhodesia are prepared to certify as to the traces of these foundations. This is entirely a new discovery, as is also the fact that at one time the summit of the wall, only over the chevron pattern, bore beautifully rounded soapstone monoliths, the bases being found displaced under the ruck of loose blocks which runs along the centre of the summit of this part of the main wall. Some carved splinters of these monoliths were found at the bases of the wall. A collection of these "finds" has been sent to the Salisbury Museum.

\section{PROBABLE AGES OF THE WALLS OF THE ELLIPTICAL TEMPLE}

All the walls of the Elliptical Temple are not ancient; that is, not ancient in the sense applying to the suggested Sabæo-Arabian occupation of Rhodesia and also to that of the Solomonic gold period. The evidences pointing to this conclusion, and now for the first time available, are so obvious and general, and the ocular demonstration so positive, that one of the many popular myths concerning Great Zimbabwe must, even at the risk of committing a vandalism on cherished romantic theories and beliefs, go by the board. The writer prefers that the ruins should tell their own story, and this can now be read in the walls, in the débris heaps, and in the relics and their associated "finds" and locations.

The oldest walls of the temple for which great antiquity 
may be claimed are-the main east wall from north to south, the Conical Tower, the Platform, portions of the inner wall of the Parallel Passage (reconstructions are present here), and some adjoining walls, and some buried walls and foundations, and possibly some other walls on the south side, concerning which some doubt exists, as also the west wall of the West Passage, a well-built structure which once was extended at either extremity. As to the question of obviously much later walls, this is involved in the following section of this preface.

\section{WEST WALL CONTROVERSY}

The writer is fully convinced that the original west wall of the temple once extended outwards further west, and that the present west wall extending towards the south is of much more recent construction and is built on a shorter curve, also that most of the structures of the central and western portions of the building are also of much later construction, and this for many substantial reasons, some of which are here briefly stated :-

(a) The west wall is considered by all practical builders and architects to be far slighter, much inferior in construction, fuller of defects, and to contain to a greater extent ill-shaped stones than the main wall on the east side, while the foundations are at many points far more irregular, and the batterback of the interior face of the west wall is less severe than is the case of the east side. Lengths of $25 \mathrm{ft}$. each of both walls have been examined and compared and photographed, and the number of defects of construction recorded. The number of false and "straight joints," false and disappearing courses, and stones supported at their corners by granite chips, which the west wall contains, is roughly about forty odd to every one of such defects in the east wall, which is the architectural marvel for symmetry, grand proportion, true courses of most carefully selected and assorted blocks (some 
of which have been dressed with metal tools) of any other ancient architectural features at Zimbabwe. All this is an ocular demonstration, and is commented upon by the most casual visitor to these ruins. This, too, is very patent when seen from the summit of Zimbabwe Hill, the view looking down upon the temple revealing most obviously the different characters of the walls.

(b) In 1903 the writer cleared the soil away from the gap between the older and later walls, and found that they were widely different in construction; that the later and narrower wall approached the older and well-built and wider wall at an oblique angle; and that the end of the older wall is broken and not finished off as are other ends of ancient walls. In a trench made at a distance of twelve yards west of the gap, and on the curve the older wall, if continued, would have passed, a mass of buried masonry, which might have been a portion of the old wall, was disclosed.

(c) Dr. Hahn, the leading expert in South Africa in chemical metallurgy, analysed the soil underlying the foundation of the west wall, and pronounced it to be composed of disintegrated furnace slag and ashes containing gold and iron. The ground to the west of the west wall has always been the spot at which gold prospectors have washed the soil for gold, and here gold crucibles and scorifiers are to be found. This soil contains 73 per cent. of silica, and would make an excellent foundation for walls, and the west wall is built right along this bed of furnace slag, which is about $2 \mathrm{ft}$. in depth, many yards wide, and extends from north to south.

(d) At a few feet from the exterior of the west wall, and at a depth of four feet below the level of its foundation, and extending as shown in trenches and cross-cuts for at least thirty yards from north to south, is a floor of granite cement laid on the formation rock, hiding its irregularities and making a perfectly level surface. The full extent of this 
flooring has not yet been ascertained. For two feet between the level of this cement flooring and the furnace-slag soil under the foundations of the west wall is fine silted soil. Evidently the later wall was erected at a very considerable period subsequently to the laying of the cement flooring and after the siltation of the soil, and also after the gold-smelting operations had been extensively carried on for a long period.

(e) No single relic of any great antiquity has been found by any explorer or prospector in the western portion of the temple, while the eastern portion has yielded at depth great quantities of phalli and of every relic believed to be associated with the earliest occupiers.

The oldest "find" in the western half of the building is pronounced by Dr. Budge to be of a period dating from between the thirteenth and fifteenth centuries of this era, and other "finds" relate to the same and later periods.

\section{WRITER'S CONCLUSIONS}

The writer is now and for the above and further considerations, and after two years' residence within the ruins, perfectly convinced of the following :-

(I) That on the departure of the ancient builders and occupiers the temple became a ruin, and remained as such for some centuries, the west wall disappearing in the meantime (as explained later); (2) that some organised Arab people, possibly a split of the numerous Arab colonies and kingdoms which existed down the East African coast, possibly of the Magdoshu kingdom, who, according to De Barros, reached Sofala (I IOO A.D.), exploited the gold mines, and formed a mixed population between the Arabs and natives, or possibly the Arabs of Quiloa, who secured as suzerain power Sofala and the kingdom of the Monomotapa (Rhodesia). One of these peoples is believed to be responsible for the ruins of Inyanga, which the writer after examining these remains does not consider to be ancient in 
the fullest sense of the term. One of these peoples are also believed to be responsible for making the "old workings," the distinction between which and the "ancient workings" must always be kept in mind, a distinction which the late Mr. Telford Edwards always pointed out and insisted upon, and concerning which recent investigations prove him to have been correct; (3) that these Arabs made Zimbabwe their headquarters, to which the washed gold dust was brought to be converted into ingots for transport; (4) that these Arabs carried on extensive gold-smelting operations at the west end of the temple in the shelter of the massive walls, which would protect them against the prevailing winds and drifting rains; (5) that after carrying on these goldsmelting operations extensively and for a considerable period, they built a wall across the open space and upon their furnaceslag beds, possibly employing native labour (the Makalanga being notorious for their skill in wall building); and (6) that these Arabs also built several of the enclosures in the central and western parts of the temple to suit their special convenience, and altogether regardless of the buried foundations of the ancient builders.

\section{DESTRUCTION OF THE ORIGINAL WEST WALL}

It may be asked what caused the destruction of the original west wall. Its disappearance may be accounted for as follows. The south and west walls have for centuries borne the full brunt of all the torrential rain and storm water which rushes to these points from the Bentberg Kopjes, which lie close to the temple on the south side. This accounts for the great depth of silted soil which buries the old cement flooring. This must have washed the lower portions of the walls till the cement foundations decomposed and brought down the structure as it has done at other ruins at $\mathrm{Zimbabwe}$. The writer at the commencement of his first rainy season 
at Zimbabwe found a large pool about $30 \mathrm{yds}$. in length, I $5 \mathrm{yds}$. in breadth, and $2 \mathrm{ft}$. in depth up against the present west wall, towards which all surface water from the higher ground rushed unchanged. This had been going on every rainy season for many generations, with the result of forming large cavities under the foundations, and of keeping the wall in a constant drip with damp even at noontide, and of causing the spread of large moss over the walls, while shrubs and small trees grew out of the walls at some height from their base. Trenches and runs-off and banks soon cured this evil, and now the walls have changed from being black with damp to being grey with dryness. The moss has naturally flaked off, and the trees and shrubs in the walls are dead, owing to lack of moisture.

\section{THE ACROPOLIS RUINS}

\section{WESTERN TEMPLE}

Operations in this temple since the description of the earlier work was embodied in the text of this volume have been carried on to June, 1904. Soil to a depth of from $3 \mathrm{ft}$. to $5 \mathrm{ft}$. was removed from the whole of the eastern portion of this area. The excavations showed several layers of native clay floors one above another. The "finds" were those known to be of native origin, though not made by natives of to-day. The later or native period of gold manufacture was greatly in evidence, beaten gold, gold tacks, and gold wire being frequently met with in association with copper sheathing, copper assegai- and arrow-heads, the copper containing no alloy.

A trial hole sunk to a depth of $6 \mathrm{ft}$. below this cleared portion of the temple area, or $9 \mathrm{ft}$. below the surface as it appeared in 1903 , showed in its sides the lines of several clay floors and the side of a Kaffir clay hut, now quite de- 
composed and soft. At the bottom of the pit a rough pavement of closely-fitting stones of irregular shape and size was come upon, and the articles found were identical with those discovered at a higher level.

The clearing of the area also disclosed clay sides of huts with the remains of short walls of stone radiating from the sides of the huts. The wall which Mr. Bent considered might have been the "altar" was found to be the radiating wall of a similar hut built upon a higher level. These small radiating walls are a general feature of exceedingly old native huts found at several places at Zimbabwe.

A large circular platform of granite cement was also disclosed. This spot yielded beaten gold of native make.

\section{A ZIMBABWE REVIVAL}

The writer believes that between the thirteenth and fifteenth centuries, or slightly earlier, a great influx of people took place at Zimbabwe, and that the majority of the minor ruins in the Valley of Ruins were built about this period. This is shown by the number of walls built across exceedingly old débris heaps of native origin, by the "finds" of Arabian articles on their lowest floors, and by the fact that no relic of greater age than that period has been found. Two or three of the better-built minor ruins have the appearance of greater age, and some of the relics found in this class of ruins are of the oldest type. No one who had not spent considerable time at Zimbabwe could have any possible conception of the immense population present here at a period of but a few centuries ago. The remains of their stone walls are scattered thickly over the valleys and hillsides of Zimbabwe. The Makalanga state these are all Makalanga of generations long passed away. Some are constructions by indigenous peoples, and certainly they are not ancient, though largely built of stones quarried from the ancient ruins, and the "finds" are those of old native type, including Arab articles. 


\section{PRESERVATION OF RUINS}

The thanks of all scientific circles, and of South Africans generally, are due to Sir W. H. Milton, Administrator of Rhodesia, whose great interest in the preservation of the ancient monuments in these territories is well known, and to whose direction is due the recent and timely preservation work at Great Zimbabwe. The author desires to express his personal indebtedness to Sir William Milton for the adequate arrangements made by him while engaged in his recent researches at the Great Zimbabwe.

\section{PLAN OF ELLIPTICAL TEMPLE}

The clearing of the Elliptical Temple and its vicinity has enabled Mr. Franklin White, M.E., Bulawayo, to prepare the latest and so far the most perfect plan of that building, and this he has kindly placed at the service of the author.

Indebtedness is also expressed to Professor A. H. Keane, LL.D. (author of The Gold of Ophir), for the contribution of the Introduction to this volume; to Mrs. Theodore Bent for generously permitting the use in this volume of illustrations from The Ruined Cities of Mashonaland; to Mr. Gray, Chief Veterinary Surgeon, Salisbury, Mr. H. S. Meilandt, Government Roads Inspector, Bulawayo, and Trooper Wenham, B.S.A.P., Victoria, for permission to reproduce certain photographs of the ruins, and also to the Directors of the British South Africa Company for permission to include the map of Rhodesia in this work.

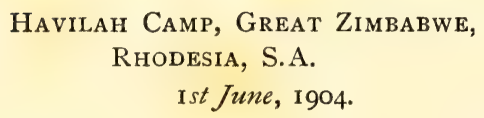




\title{
INTRODUCTION
}

\author{
BY A. H. KEANE, LL.D.
}

$\Lambda^{\mathrm{N}}$ archæological work of absorbing interest, such as the tion. Nor are the following remarks meant to be taken in that sense, but only as a sort of "missing link" in the chain of evidence between past and present, between the Arabian Himyarites and the Rhodesian monuments, the forging of which the author has entrusted to me. In The Ancient Ruins of Rhodesia, of which Great Zimbabwe is the inevitable outcome, Messrs. Hall and Neal did not discuss the problem of origins, speculation was distinctly eschewed, and although their personal views were, and are, in harmony with those of all competent observers, they made no dogmatic statement on the subject, leaving the main conclusion to be inferred from the great body of evidence which they patiently accumulated on the spot and embodied in their monumental work. In Great Zimbabwe, of which Mr. Hall is sole author, and the rich materials for which he has alone brought together, the same attitude of reserve is still maintained, perhaps even more severely, and therefore it is that he has now invited me to develop the argument by which, as he hopes and I believe, the wonderful prehistoric remains strewn over Southern Rhodesia, but centred chiefly in the Great Zimbabwe group, may be finally traced to their true source in South Arabia, Phœnicia, and Palestine.

In The Gold of Ophir, whence Brought and by Whom, ${ }^{1}$

1 Stanford, rgor. 
where several chapters are devoted to this subject, I inferred, on plausible grounds, that the Havilah of Scripture- "the whole land of Havilah where there is gold"-was the mineralised region between the Zambesi and the Limpopo, and that the ancient gold workings of this region were first opened and the associated monuments erected by the South Arabian Himyarites, followed in the time of Solomon by the Jews and Phœenicians. I further endeavoured to show that all these Semitic treasure-seekers reached Havilah (the port of which was Tharshish, probably the present Sofala) through Madagascar, where they had settlements and maintained protracted commercial and social intercourse with the Malagasy natives; and lastly, that the produce of the mines was by them sent down to the coast and shipped at Tharshish for Ophir, the great Himyaritic emporium on the south coast of Arabia, whence it was distributed over the eastern world. It followed that the scriptural "gold of Ophir" did not mean the gold mined at Ophir, which was not, as hitherto supposed, an auriferous land, but a gold mart. ${ }^{1}$ The expression meant the gold imported by the Jews and Phœnicians from Havilah (Rhodesia), viâ Tharshish, Ophir, and Ezion-geber in Idumæa, at the head of the Red Sea.

It is needless here to recapitulate in detail the arguments that I have advanced in support of this general thesis. But I should like to point out that if one or two of them have been invalidated by my critics, several have been greatly strengthened by the fresh evidence that has accumulated since the appearance of The Gold of Ophir.

Of course, incomparably the most important mass of fresh evidence is that which has been brought together by Mr. Hall himself during his two years' researches amid the central

1 On this crucial point I am glad to find myself in accord with Dr. A. H. Sayce, who has independently arrived at the same conclusion. "There is no gold in Southern Arabia," he writes, "and consequently Ophir must have been an emporium to which the gold was brought for transhipment from elsewhere" (The Early History of the Hebrews, I897, p. 463). 




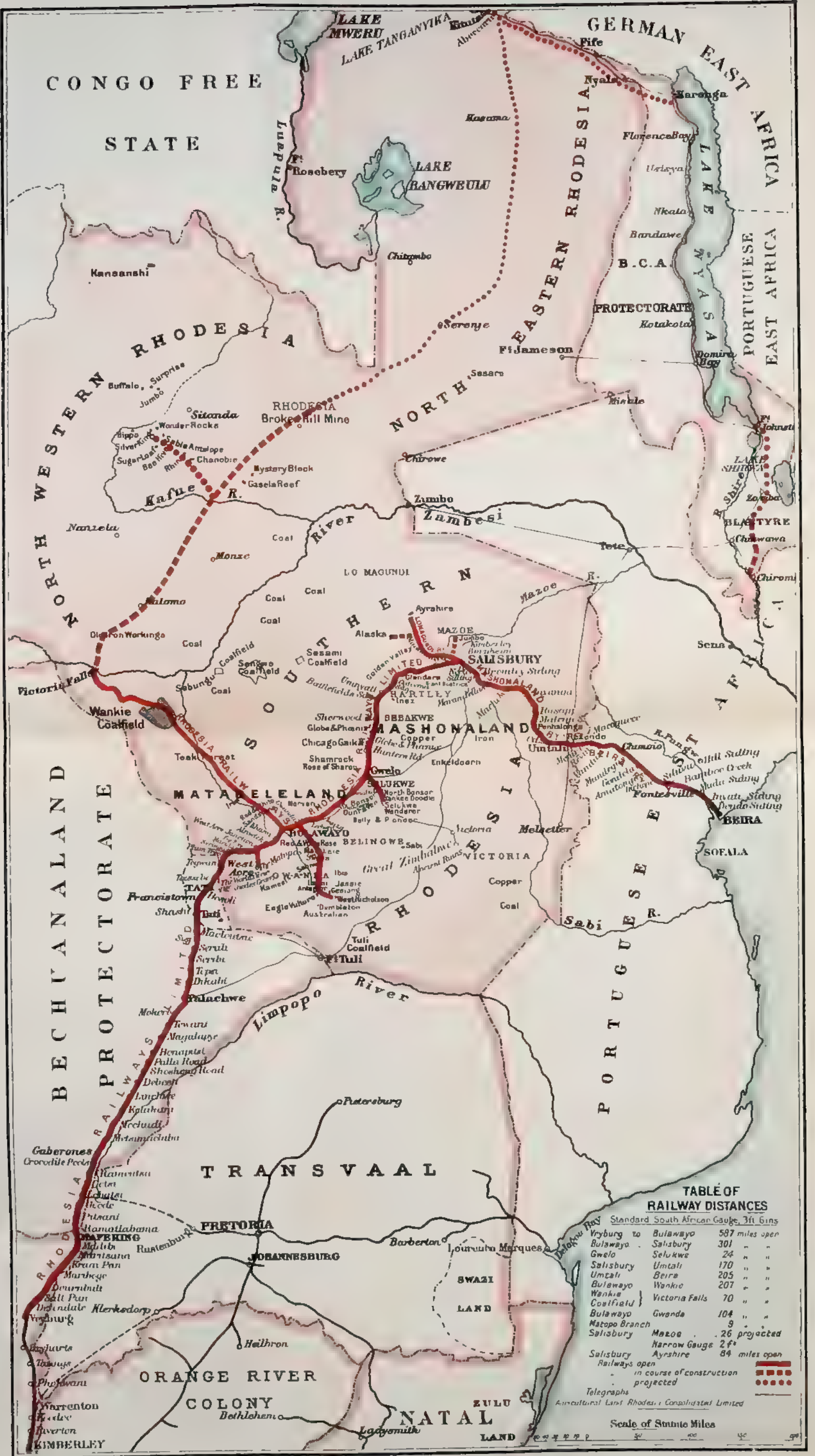



group of ruins, and is now permanently embodied in Great Zimbabrve. Yet the work has in a sense been but begun; it has reached down only to the ancient flooring which has still to be explored; and we are assured by Sir John Willoughby, a most competent authority, that after two months' exploring the wonderful Elliptical Temple with a large gang of labourers, two years will yet be needed to complete the surface work of that structure alone, without touching the old floors. Mr. Hall infers that three further years will be required for the Acropolis itself, besides the "Valley of Ruins," with the groups of buildings extending in all directions for over a mile from the temple. A mere glance at some of the finely reproduced photographs creates a sense of awe and amazement at the huge size and solidity of the containing walls with their patiently interwoven chevron and other patterns, and at the vast extent of the ground covered by these great monuments of a forgotten past. Their erection must have taken many scores of years, one might say centuries, and their builders must consequently have dwelt for many generations in the land which they so diligently exploited for its underground treasures. Here and in all the other strictly mining districts they carried on their operations in the midst of hostile native populations, as is sufficiently evident from the strongholds crowning so many strategical heights, from the formidable ramparts and the immense strength of the outer walls, everywhere rounding off in long narrow passages leading to the inner enclosures.

Under such conditions it will naturally be asked, whence did the foreign intruders obtain their food supplies? The answer to this question is suggested in The Ancient Ruins, where it is pointed out (p. 208) that the auriferous reefs of the central Zimbabwe district, and generally of all the districts in immediate proximity to the fortified stations, show no traces of having ever been worked for the precious metal. "Possibly the reason for the ancients ignoring the gold-reefs 
of this district [Zimbabwe] lies in the fact that the country round about is exceedingly well suited for agricultural purposes, the soil being rich and water plentiful, and all vegetable growths prolific and profuse. The large population of ancients, together with the enormous gangs of slaves, would naturally consume a vast quantity of grain, and this necessity would create a large agricultural class, who, for their own safety and for the protection of their crops and fruits, would naturally carry on their operations within such an area as could be safeguarded by the fortresses of Zimbabwe."

It might at first sight be supposed that the food supplies were drawn chiefly from the extensive agricultural settlements of the Inyanga territory, on the northern slopes of Mashonaland, which drain through the Ruenga and its numerous affluents to the right bank of the Zambesi. This Inyanga district may be roughly described, from the archæological point of view, as an area of old aqueducts, of old terraced slopes, and of old ruins of a less imposing type than the Zimbabwe remains. In a notice of The Ancient Ruins of Rhodesia contributed to the Geographical Journal for April, I902, I first drew attention to the surprising analogy, or rather identity, between these terraces and those of the South Arabian uplands visited by General E. T. Haig in the eighties. So close is the parallelism that Haig's description might almost change places with Mr. Telford Edwards' account of the Inyanga works quoted in The Ancient Ruins, p. 353 sq., as thus :-

\section{TERRACED SLOPES}

\section{(SOUTH ARABIA)}

"In one district the whole mountain side, for the height of $6,000 \mathrm{ft}$., was terraced from top to bottom. Everywhere, above, below, and all around, endless flights of terraced walls meet the

\section{TERRACED SLOPES}

(SOUTH AFRICA)

"The extent of these ancient terraces is astonishing, and there is every evidence of the past existence of hundreds of thousands of inhabitants. It would be quite impossible to convey any idea of 
eye. One can hardly realise the enormous amount of labour, toil, and perseverance which these represent. The terraced walls are usually from 4 to $5 \mathrm{ft}$. in height, but towards the top of the mouutain they are sometimes as much as 15 or $18 \mathrm{ft}$. They are built entirely of rough stone laid without mortar. I reckoned on an average that each wall retains a terrace not more than twice its own height in width, and I do not think I saw a single breach in one of them unrepaired " (Haig, Proceedings Geographical Society, I887, p. 482). the immensity of labour implied in the enormous number of these ancient terraces. I saw at least I50 square miles composed of kopjes from 100 to $400 \mathrm{ft}$. in height literally strewn with the ruins. A contemplation of the enormous tonnage of stones and earth rudely built into these terraces left me amazed. It appears to be abundantly clear that the terraces were for the purpose of cultivating cereals of some sort. The terraces as a rule rise up in vertical lifts of about 2 or $3 \mathrm{ft}$., and extend backwards over a distance of mostly 7 to $12 \mathrm{ft}$. The terraces are all made very flat and of dry masonry, not of hewn stone."

But Mr. Hall, who visited the Inyanga territory in May, I904, now finds that the terraced slopes, ${ }^{1}$ the so-called " slavepits," and the other remains, although "old," are not "ancient." That is to say, they date not from Himyaritic times, but probably from the eleventh or twelfth century of the new era, when parts of Rhodesia were reoccupied by large numbers of Moslem Arabs from Quiloa and their other settlements along the east coast. Hence, although the terraced slopes still form a connecting link between South Africa and South Arabia, the South Arabia here in question is that, not of pre-, but of post-Koranic times.

Of course, the ruined houses and ruined aqueducts are too much obliterated to supply any clear points of comparison. But their mere presence, and especially the vast extent of ground covered by them, will suffice to confirm Mr. Telford

${ }^{1}$ Somewhat similar terraced slopes are to be found in the Lydenburg district of Transvaal Colony. 
Edwards' estimate of the vast numbers of civilised peoples who inhabited the rich Inyanga valleys in prehistoric times, and whom we may now call Sabæans, Minæans, and others Himyarites.

Were the houses still extant, we should expect to find them covered with the same decorative mural motives as are still seen both on the Zimbabwe monuments and on the public buildings of Sana, present capital of Arabia Felix. Manzoni, who visited this city three times between the years 1877 and I880, figures a mansion six stories high, which is richly ornamented with two such motives-the chevron and the vertical block pattern-closely resembling those everywhere occurring on the more ancient Rhodesian walls. The chevron, which is seen both in single and double courses exactly as on the great walls of the Elliptical Temple, is absolutely identical, while the block design differs only in being quite vertical at Sana, whereas it is slightly tilted, or else two rows of blocks converge to produce the herring-bone pattern on the Rhodesian walls, as at Little Umnukwana and many other places. The reader will find Manzoni's mansion reproduced in Mr. D. G. Hogarth's The Penetration of Arabia, 1904, p. 198, and he wil there notice that the various motives fill up all the space between two parallel horizontal lines, as is so often the case in Rhodesia. ${ }^{1}$ Here, therefore, style, motive, general treatment, everything corresponds between the Rhodesian remains and the decorative fancies still flourishing in Sana, heir to the cultural traditions of the neighbouring Mariaba and of the other ancient Himyaritic capitals in South Arabia.

In The Gold of Ophir frequent reference is made to the relations, social and commercial, established between Palestine and Madagascar certainly as early as the time of Solomon, and possibly even during the reign of his father David. On this point I might have spoken even more confidently, for I have since received a communication from M. Alfred

\footnotetext{
${ }^{1}$ See Lundi Ruins, in Ancient Ruins, p. 178.
} 


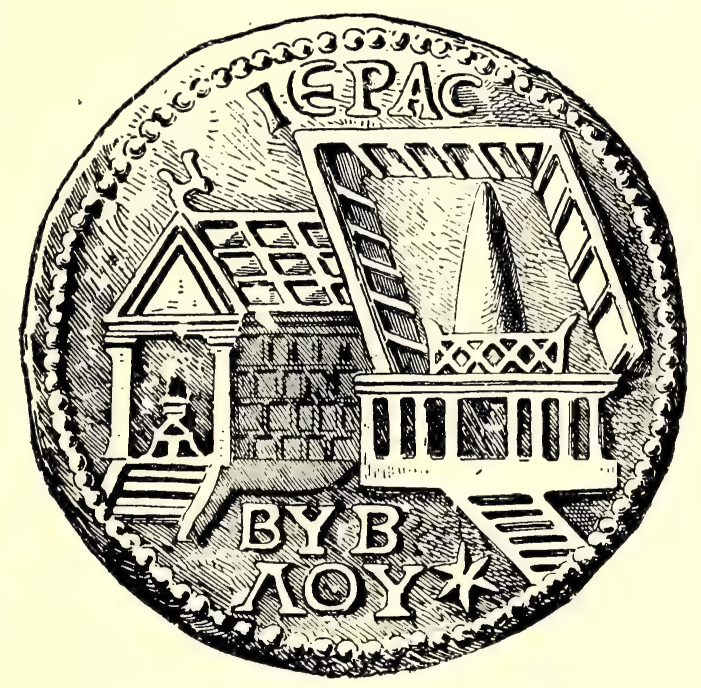

COIN OF BYBLOS, PHENICIA, SHEWING CONICAL TOWER (FIG. I)

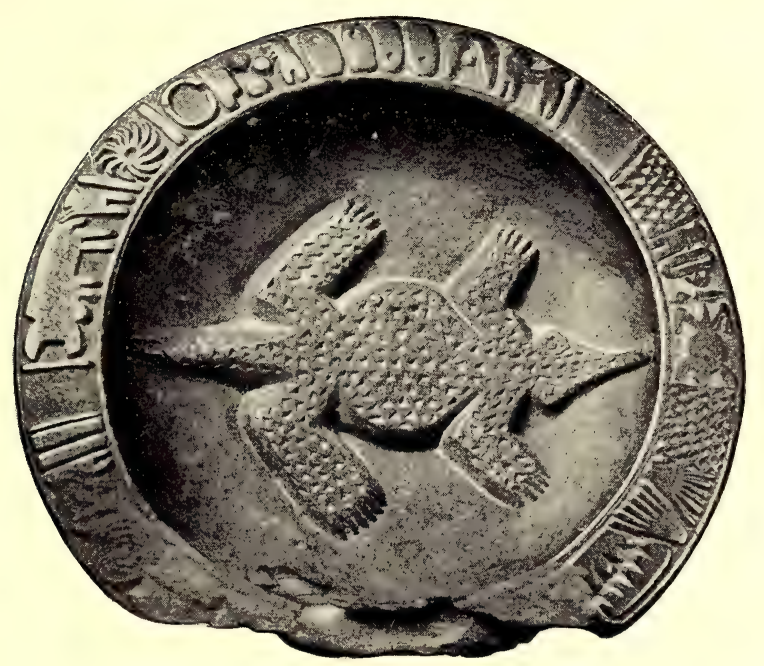

WOODEN BOWL WITH SIGNS OF ZODIAC FOUND NEAR ZIMBABWE (FIG. 2) 

Grandidier, by far the greatest living authority on all things Malagasy, who calls my attention to the evidence supplied in his monumental work, Histoire Physique, Naturelle et Politique de Madagascar (I9OI), of intercourse between the Jews and the natives of Madagascar and neighbouring islands even in pre-Solomonic days. Documents are quoted to show that the Comoros, stepping-stones between Madagascar and Rhodesia, were peopled in the reign of Solomon "by Arabs or rather by Idumæan Jews from the Red Sea," and that the people of the great island preserve many Israelitish rites, usages, and traditions, cherish the memory of Adam, Abraham, Lot, Moses, Gideon, but have no knowledge of any of the prophets after the time of David, "which seems to show that the Jewish immigrants left their home at a very remote date, since if the exodus had been recent they could not have forgotten the great names posterior to the time of David." Hence he concludes that "there is nothing surprising in the presence of an Idumæan colony in Madagascar, for we know that from the very earliest times the Arabs of Yemen had frequented the East African seaboard at least as far as Sofala." These words lend further support to my identification of Tharshish with Sofala, and in a note it is added that "the Jews and Arabian Semites were not the only peoples who had formerly commercial relations with the inhabitants of the African seaboard. From time immemorial these southern waters were navigated by the fleets of the Egyptians, probably even of the Chaldeans, Babylonians, Assyrians, Phœnicians, Tyrians" (op. cit., p. 96). And again at p. IO0: "From the earliest times the Indian Ocean was traversed by Chaldean, Egyptian, Jewish, Arab, Persian, Indian, and other vessels."1

${ }^{1}$ So also M. L. Gallois, in a review of The Gold of Ophir, contributed to the Annales de Géographie for September 15, 1902: "Ces monuments de l'Afrique du Sud ont une parenté certaine, avec les monuments himyarites de l'Arabie méridionale. Les hommes qui ont construit les forteresses de la Rhodesia venaient, portés par la mousson, de la côte méridionale d'Arabie chercher l'or du Manica et du Mashona." 
My statements regarding the long-standing relations of the Northern Semites with the peoples of Madagascar and South Africa as far as Sofala are thus fully supported by the greatest authority on the subject. But there are some minds so constituted that they seem incapable of accepting a new revelation. They can do nothing but stare super vias antiquas, and will strain every nerve to minimise the force of facts and arguments pointing at conclusions which run counter to their deep-rooted prejudices. I here reproduce the famous "Zimbabwe Zodiac" (Fig. I.), which was found near Great Zimbabwe, and shows the twelve signs of the Zodiac carved round the rim, as described by the late Dr. Schlichter in the Geographical Journal for April, I 890. This specialist tells us that "the signs coincide in every respect with other finds which Bent and others have made in Zimbabwe. One of the pictures is an image of the sun analogous to the sun-pictures which Mauch and Bent found on the monoliths of Zimbabwe, and analogous also to finds in Asia Minor which belong to the Assyro-Babylonian period." But a writer in the Guardian attempts to destroy the significance of this document by asserting that the Zodiac or its nomenclature is of Greek origin and consequently of no great age. Now the Hon. Emmeline M. Plunket has recently (1903) published a work on Ancient Calendars and Constellations, in which she maintains that the Babylonian Calendar, with its Zodiacal signs, dates from 6000 B.C., that is, about 8,000 years ago. It is true that this estimate is not clearly made out. But on the other hand, the reader may be assured that Miss Plunket does not hold by the "Greek" theory. Nor does F. Delitzsch, who reminds us that "when we distinguish twelve signs of the Zodiac and call them Ram, Bull, Twins, etc., in all this the Sumero-Babylonian culture is still a living influence down to the present day." 1 Nor does Sayce, who points out that the Babylonian account of the Flood occurs in the eleventh book 


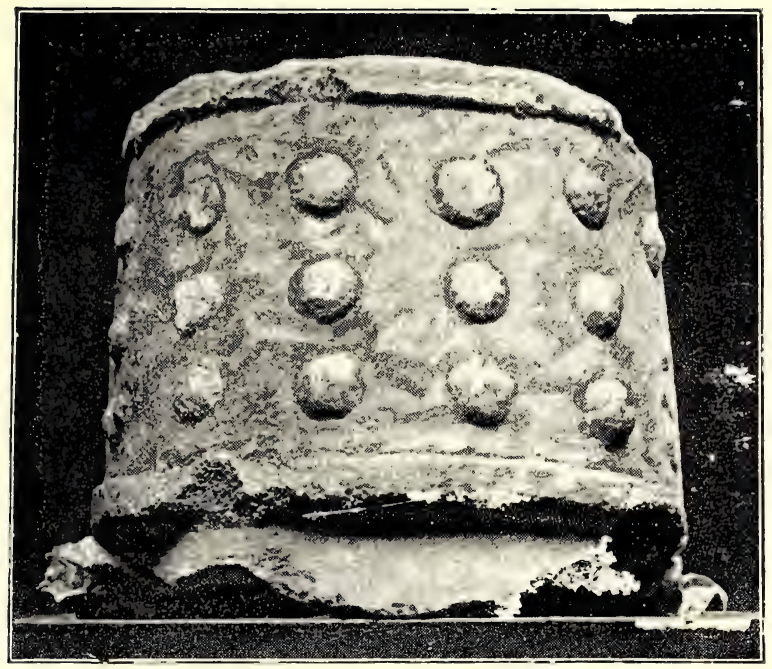

CYLINDER WITH ROALTIES FOLND IN PHENICIAN I E.MPLE OF P'APHOS, IX CIPRL'S

(1.11. 3)

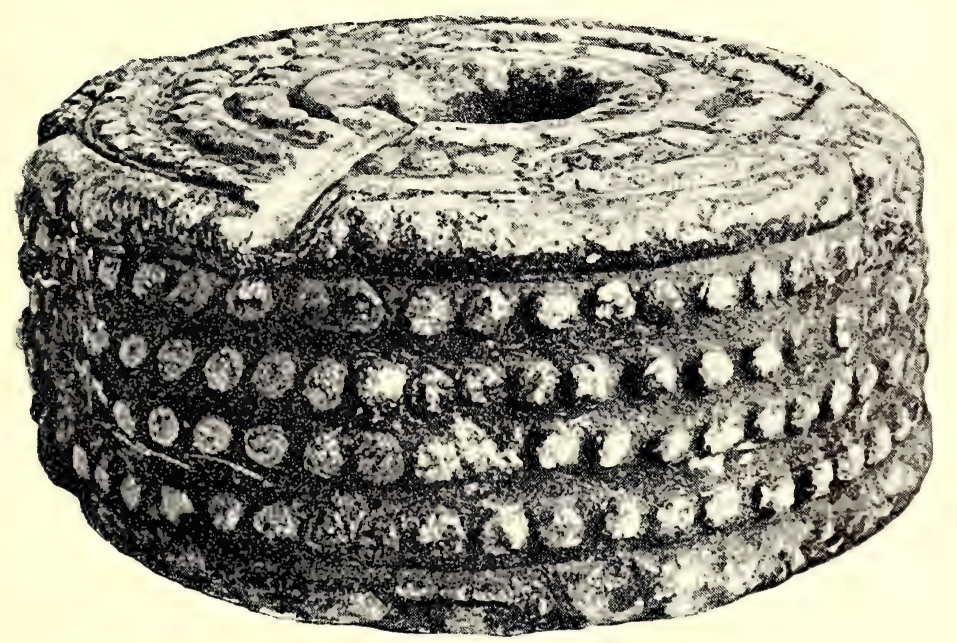

SOAPSTONE CYLINDER, WITH ROSETTES FOUND NEAR ZIMBABWE 

of the epic of Gisdhubar corresponding approximately with the eleventh sign of the Zodiac, at that time Aquarius, just as the fifth book records the death of a monstrous lion by Gisdhubar, answering to the Zodiacal Leo and so on. He further observes that "the Zodiacal signs had been marked out and named at that remote period (certainly before 2000 B.C.), when the sun was still in Taurus at the beginning of spring," " and, let me add, when the Greeks had not yet been heard of, but when the great Gnomon, or Conical Tower, had possibly already been erected by the Semitic builders of Great Zimbabwe.

That this and the numerous other conical towers still standing amid the crumbling ruins of Rhodesia are all cast in a Semitic mould will be at once seen by comparing them with the conical tower of a temple, figured on a medallion found at Byblos in Phøenicia and here reproduced (Fig. I.). The comparison may also be extended to the two embossed cylinders-one from Great Zimbabwe, the other from the Temple of Paphos, in Cyprus, here also reproduced (Figs. 3 and 4) from Bent's Ruined Cities, pp. I7o, I7I. These two objects, so strikingly similar in general design, reminded Bent of Herodian's description of the sacred cone in the great Phœnician Temple of the Sun at Emessa, in Syria, which was adorned with certain "knobs or protuberances," a pattern supposed by him to represent the sun, and common in phallic decorations, such as are constantly turning up with every shovelful of débris removed from the Zimbabwe Temple Enclosures.

But although thousands of stones have been washed and carefully examined for inscriptions, none have so far been discovered. As the inscription which stood originally above the gateway of Great Zimbabwe, as reported by the Arabs to the Portuguese pioneers early in the sixteenth century, ${ }^{2}$ has since disappeared, there are no known written documents

\footnotetext{
1 Assyria, pp. I10, I 16.

2 Gold of Ophir, p. ú.
} 
connecting these monuments with South Arabia or Phœnicia, except a few scratches on the rim of an earthenware vessel figured by Bent and by him supposed possibly to be of Himyaritic type. ${ }^{1}$ As, on the other hand, South Arabia is covered with Himyaritic rock inscriptions, some of considerable length and hitherto reputed to be of great age, their absence from Rhodesia has naturally caused surprise. This negative argument has even by some of my critics been allowed to outweigh the overwhelming positive evidence derived from the monuments themselves, from the hundreds of old gold-workings already described or recorded, from the multitude of objects-phalli, birds, conic towers-which have been found in the ruins, and are, beyond all doubt, intimately associated with Semitic religious observances. But I think it may now be shown that this "negative argument" is no proof at all of non-Semitic origins, but, on the contrary, affords strong indirect evidence of the great antiquity of these Semitic remains in Rhodesia.

It is to be noticed, in the first place, that although the Phœnicians are believed to have migrated from the Persian Gulf to the Mediterranean about three millenniums before the New Era, no Phœnician inscriptions have yet been anywhere discovered in the Mediterranean lands older than about the seventh or the eighth century B.C. Before that time the Phœenicians, like the kindred Canaanites and Israelites, were rude, uncultured peoples, with no knowledge of letters, except, perhaps, of the hieroglyphs, cuneiforms, and other scripts of their Egyptian, Assyro-Babylonian, Hittite, and Cretan neighbours. Even the Moabite Stone, if it be genuine, is post-Solomonic, since its reputed "author" was the Moabite king, Mesha, contemporary of Jehoram of Israel and Jehoshaphat of Judah. How, then, could the unlettered Jews and Phœnicians of the time of David, Solomon, and Hiram leave any written records of themselves in Rhodesia? After that 


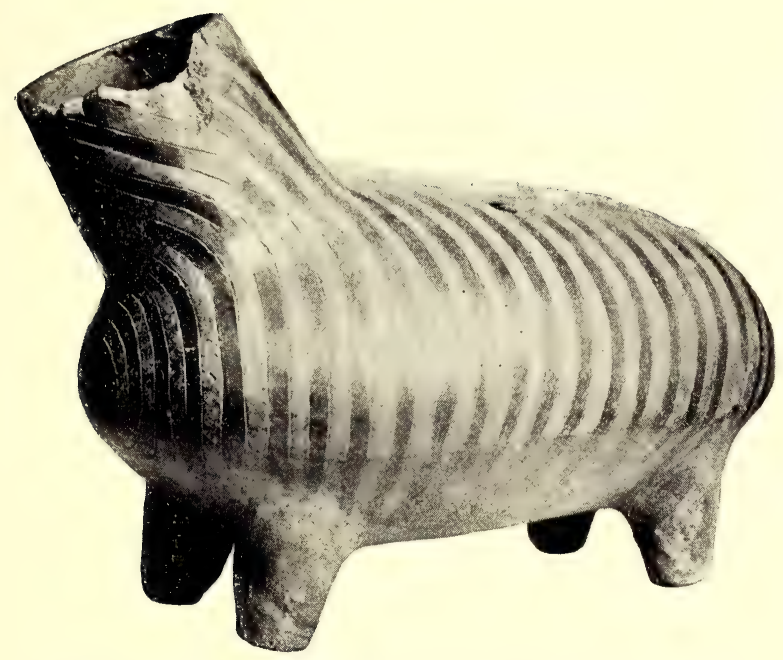

"FUKO-YA-NEBANDGE," THE MASHONALAND RELIC, DISCOVERED NEAR ZIMBABWE (FIG. 5)

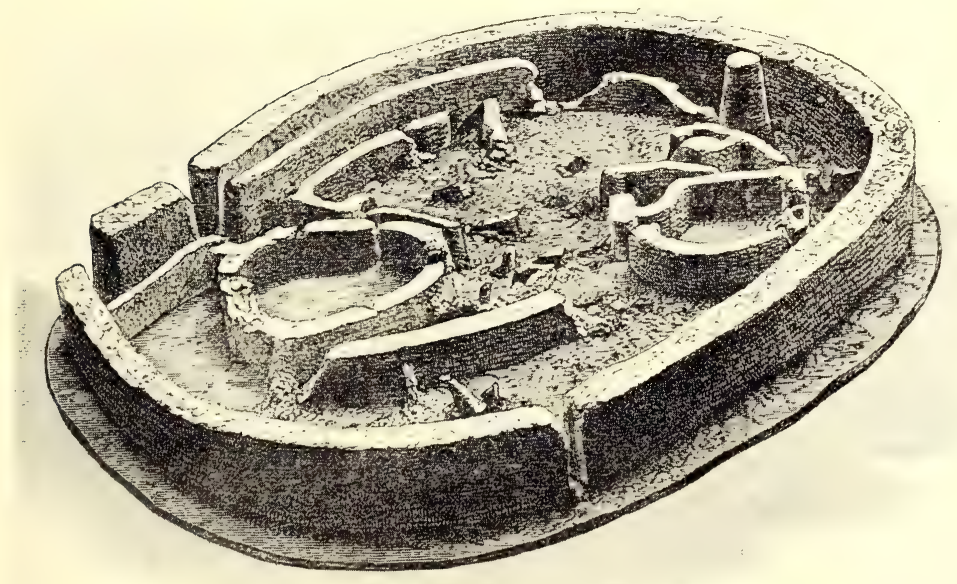

MODEL OF ELLIPTICAL TEMPLE, ZIMBABWE (FIG 6) 

epoch the intercourse with South Africa was interrupted, because "Jehoshaphat made ships of Tharshish to go to Ophir for gold ; but they went not; for the ships were broken at Ezion-geber" (I Kings xxii. 48). And then the star of Jacob waned, and the scattering of the Ten Tribes of Israel was presently followed by the dire calamities that fell upon Judah, and put an end for ever to all further quest of treasure in the Austral seas.

In the second place I find that Semitic students are gradually coming to the conclusion that the age of the South Arabian rock inscriptions has been greatly exaggerated, especially by Glaser, whose authority was at first naturally accepted almost without demur. The language is, no doubt, Himyaritic, that is to say, the oldest known form of Arabic. But that language survived for many centuries after the New Era in the Axumite empire, Abyssina, where it is called Geez, and in Yemen till some time after the Mohammedan irruption, and is still current in the island of Sokotra, and in the Mahra district east of Hadramaut, where it is called Ehkili. Hence the language of the inscriptions is no test of their antiquity, though many afford intrinsic evidence that they date certainly from at least a few hundred years before the New Era. The subject is at present sub judice, and no more can be said until the full results are known of the extensive researches now in progress throughout Yemen. Here a large number of agents of the French Ministère de l'Instruction Publique have been at work since the year I90I, and thousands of impressions or rubbings have already (1903-4) been received in Paris. Some have even begun to appear in the Nouveaux Textes Yéménites, edited by M. Derenbourg, and several of the inscriptions are stated to be in a hitherto unknown alphabet quite different from that of the Himyaritic document which forms the frontispiece of the Gold of Ophir. Great revelations may therefore be pending ; but, meanwhile, so much may, I think, be safely inferred, that the Himyarites 
who first arrived in Rhodesia, worked the mines, and built the monuments, some dating from apparently 2000 B.C., had little or no knowledge of letters, or at least had not yet begun to cover the rocks of their South Arabian homes with wellformed and carefully constructed inscriptions. Thus is also explained the absence of all such documents from their new homes in Rhodesia, where one may now almost venture to predict that none will ever be found. Nothing can be inferred from the vanished inscription over the Great Zimbabwe gateway, since the gold-workings appear to have been resumed for a time by the later (post-Mohammedan) Arabs, who were fond of decorating the façades of their mosques and other public buildings with the ornamental but relatively recent (eighth century) Cufic characters.

Mention should perhaps here be made of Professor Gustav Oppert's Tarshish and Ophir (Berlin, 1903), in which the learned author claims to offer "a final solution" of the problem. But he leaves the question exactly as it stood over three decades ago, is still lost in the tangle of timeworn etymologies, and takes no notice at all of the revelations made by Messrs. Hall and Neal in the Ancient Ruins. The vast body of archæological evidence derived in recent years from the Rhodesian remains is thus completely ignored, and fresh light excluded from the only source whence it might have been drawn. On the other hand, Professor Oppert, rather than admit a Tharshish in the Indian Ocean, suggests that the Tharshish of Kings and Chronicles either means "the sea," possibly the origin of the Greek word $\theta a^{\prime} \lambda \alpha \tau \tau \alpha$ itself, or else was by the authors of those books foisted into the texts instead of Ophir. Hence where Tharshish occurs as the objective of Solomon's gold expeditions we are to read Ophir, although the original Ophir is allowed to have been where I place it on the south coast of Arabia. Now the Greek word $\theta \alpha^{\prime} \lambda \alpha \tau \tau \alpha$ is Homeric, and when the Homeric poems were first sung there were no Greeks in the Indian Ocean. 
Hence, even if the wild etymology could be admitted, it would not serve, and this essay cannot be accepted as "a final solution of the old controversy." 1 It is pleasant to be able to add that my solution has been accepted as final by some of Professor Oppert's fellow-countrymenthe editor of the Coloniale Zeitung amongst others-who declares that "the problem seems now really solved." 2

Let me conclude with a question. Those who still reject my solution, who cast about for the gold of Ophir all over the Indian Ocean-Egypt, Arabia, Persia, India-anywhere except South Africa, what do they propose doing with the hundreds of old Rhodesian workings, which are known to have yielded at least $£ 75,000,000$ in their time, and with the stupendous Semitic monuments connected with these workings, of which Mr. Hall here presents the public with scores of photographic reproductions, drawn exclusively from the central Great Zimbabwe group? Where does India, the spoilt child of the etymologists, stand beside these remains, which betray such undoubted evidence of their South Arabian origin?

1 And, it may be asked, in the above-quoted passage from I Kings, does the expression "ships of Tharshish" mean "ships of the sea"? The Hebrew text

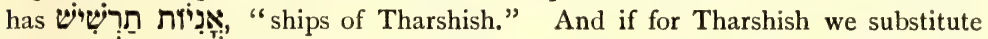
Ophir-Oppert's alternative suggestion-we get nonsense ; "ships of Ophir go to Ophir." Even the "higher critics" will scarcely accept this.

2 Das Problem scheint jetzt in der That gëlost (No. 19, 1902, p. 357). 



\title{
GREAT ZIMBABWE
}

\section{CHAPTER I}

\author{
Arrival at Great Zimbabwe-First Impressions- \\ View from Acropolis Hill
}

$\mathrm{O}^{\mathrm{s}}$

$\mathrm{N}$ the 2 Ist May, I902, I arrived at Victoria in Mashonaland, en route to the ruins of the Great Zimbabwe, which lie about seventeen miles south-east of the township. In I89I, when the late Mr. Theodore Bent visited Zimbabwe, he occupied exactly one week in covering the distance between Victoria and the ruins. Unfortunately for him and his party, he had been advised to follow the Moshagashi Valley, instead of taking the higher ground towards the west, and consequently he experienced great difficulty with his wagons in crossing spruits, rivers, and swamps, which are numerous in that direction.

There is now an excellent road to Zimbabwe, and the distance can be covered by a cyclist well within an hour and a half, while visitors driving can now arrive at Zimbabwe early in the morning and spend the whole day among the ruins and yet be in town in ample time for the evening meal. The

${ }^{1}$ Correctly, Zim-bāb-gi (zimba, pl. buildings; mābgi, pl. stones), words in common use in Chicaranga, the language of the Makalanga. Authorities on Chicaranga agree that $z i m b a$, though applying to dwellings, is also applied to buildings which are not dwellings. 
distance by road is seventeen miles, and by a native path cutting across country it is reduced to fifteen miles.

Victoria is a town with barely one hundred white inhabitants. It is the centre of the largest and finest grain country of Southern Rhodesia, and the opening up of the gold, copper, and coal areas of the Sabi district will tend to increase its importance.

The Acting-Civil Commissioner, Mr. Lawlor, arranged for requisitions to be made for stores, plant, etc., required for the work at the ruins, and the Officer Commanding the British South Africa Police provided wagon and ten mules to transport stores out to Zimbabwe. The Native Commissioner, Mr. Alfred Drew, sent out M'Guti, a native police boy, to the chief Mogabe, who lives near the ruins and rules over a large tract of country and is practically independent, to find fifteen "boys" (afterwards increased to forty) to be at our camp at Zimbabwe at sun-up on Saturday. The work of collecting stores and plant filled up the rest of the day.

Early the following morning we loaded up the wagon and left for Great Zimbabwe, arriving at the main ruins at midday. The wagon was off-loaded, and in the shade of a large candelabra-shaped euphorbia tree we lunched, while the "boys" carried the stores up on to a low granite knoll, where were three spacious native huts, built for the Civil Commissioner, and occupied by Lord Milner in I897. Of course, half the population of Mogabe's kraal came down the kopje sides in black strings to watch all that took place, and a jabbering, laughing, noisy crowd they were. There was not a pair of trousers or a vest among the lot, and all were absolutely bare, save for their aprons. I liked their appearance better than that of the average Matabele, for they had better and more genial faces, and were not at all haughty and reserved.

The camp is within a few feet of the north side of No. 3 Ruins (see map), and faces the south side of Zimbabwe Hill, 


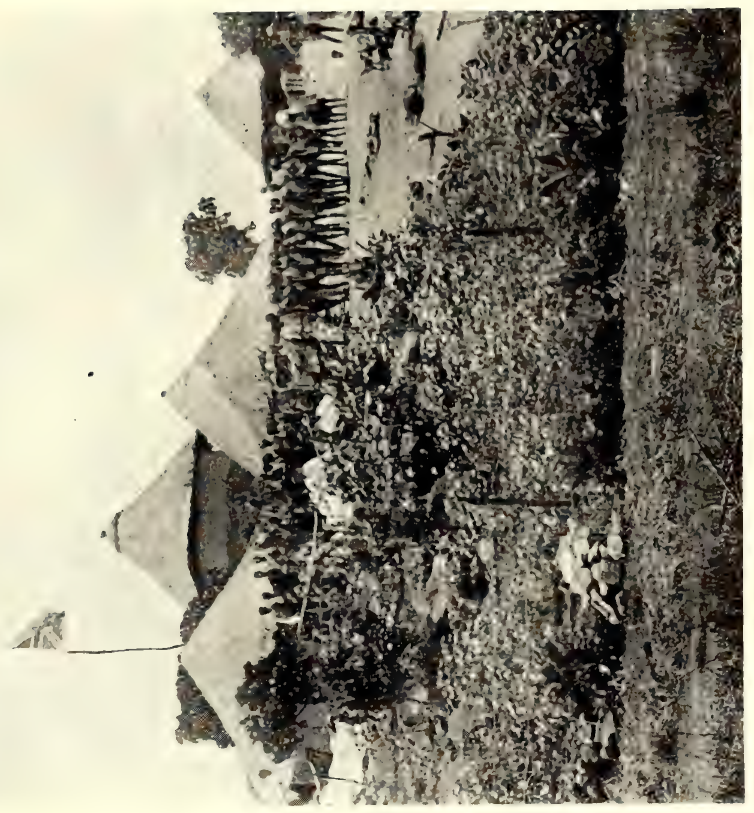

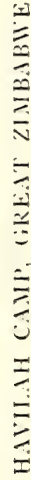

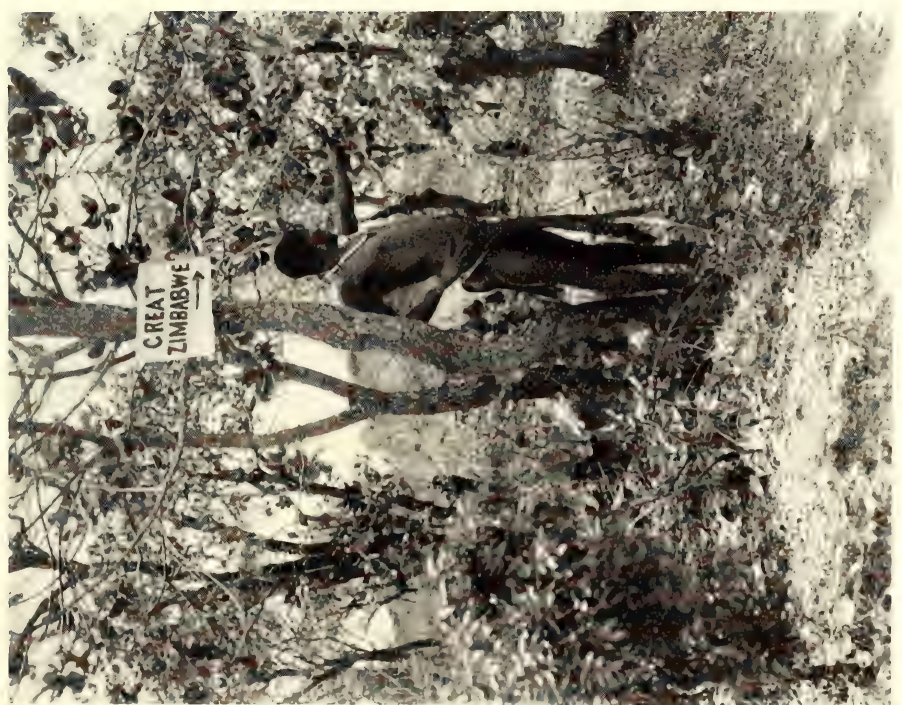



and the Acropolis Ruins are on the summit of a very precipitous cliff, $90 \mathrm{ft}$. high, forming part of the side of the hill, the ruins being $220 \mathrm{ft}$. directly above the camp. The camp of Mr. Theodore Bent, the archæologist, was a third of a mile to the south of our camp. Ours is the more convenient spot, as it is half-way between the two principal ruins, and close to its east side lies "The Valley of Ruins," beside which the situation is far healthier.

Leaving the "boys" to move the stores and plant from our outspan up to the huts, we started for a visit to the Elliptical Temple, which can be seen from the camp. My friends, Mr. Herbert Hayles, of Victoria, and Mr. J. R. A. Gell (cousin of Mr. Lyttelton Gell, one of the directors of the British South Africa Company), had accompanied me out to Zimbabwe to show me the lie of the Zimbabwe Reserve, and to protect me for the first night of my stay in the event of any visits from ancient ghosts.

Approaching the west entrance to the Elliptical Temple one is confronted by the following notice :-

"The public are warned that digging or prospecting for gold, whether alluvial or otherwise, or for curiosities and relics of any sort within the Zimbabwe Reserve, is strictly prohibited without special permission, and that any person or persons found so doing or in any way damaging any of the ruins or cutting or damaging any tree or trees within such Reserve will be prosecuted. And notice is also hereby given that nobody will be allowed to erect any habitation of any kind whatever within the Reserve without special permission. By Order." ${ }^{1}$

But turning from this prosaic notice to the walls themselves, one saw that every stone of this stupendous and imposing structure had gained glories from the hands of Time, and yielded a magnificent subject for the painter's brush. The walls were white with lichen, but on their surfaces were

${ }^{1}$ See Appendix, Note A. Government Notice, No. 103 of 1904, "Great Zimbabwe, Notice to Visitors, with Regulations." 
splashed art colourings of almost every possible shadebright orange and red, lemon-black, sea-green, and pale delicate yellow - while drooping from the summits were heavy festoons of the pink-flowered "Zimbabwe creeper." Over the fallen blocks spread sprays of passion flowers, convolvuli, and other delicate creepers, and clusters of St. John's lilies and large scarlet gladioli rose stately above beds of rich vegetation. Here was one of Nature's most perfect chromographs!

To describe this grand ruin in one chapter would be an utterly impossible task, and any statement of one's first impressions on walking about the temple 'mid its massive Titanic walls must be altogether inadequate. At any rate, one experienced an overwhelming and oppressive sense of awe and reverence. One felt it impossible to speak loudly or to laugh. And yet the ancient builders were what is termed Pagan-Phallic worshippers with Baal and Astoroth among their divinities, but a people so skilled in Zodiacal, astronomical, and other sciences as to amaze and perplex the savants of to-day. Standing close by the Sacred Cone, near which, according to Colonel Conder, the Syro-Arabian archæologist, the altar was placed, one felt disinclined for conversation. Above on a bough was a large owl, with prominent ears and beautiful yellow eyes, who stared at our daring to trespass on the verge of mystery. At our feet lay innumerable cast-off skins of snakes. One thought of the poet Lowell's Lost Angel, where, speaking of a man so deadening his conscience by constant refusals to listen to the appeals of his attendant good angel, he finds that the angel has at last left him alone. Then was the temple of his heart become desecrated, "the owl and snake inhabit there, the image of the God has gone!" The owl and snake inhabit the Temple of Zimbabwe, the altar of which is now broken down and desecrated, but the odious and unmistakable emblems of Nature Worship are still to be found by the 
score. Reverence of the hoary age of these buildings seizes one, for some accredited archæologists give the age of some of these ruins as anterior to the time of Moses. One wonders whether Professor Keane's contention is correct, that Ancient Rhodesia was the Havilah of Genesis, especially when one thinks of the estimated $£ 75,000,000$ of gold believed to have been taken by the Ancients from the surface of the gold reefs of this country before and during the Biblical-Ophir period.

But our stay within these massive walls was brief. The writer would have over two years in which to wander in their labyrinthine passages, and to examine their architectural features, and compare them with those of Rhodesian ruins elsewhere, but his friends must start back to Victoria before sunrise next day. On our way to the other important ruins -the Acropolis or Hill Fortress-we visited the grave of Major Alan Wilson and his party ${ }^{1}$ who were killed on the Shangani during the flight of King Lo 'Bengula in I 893.

We climbed up the 230 feet to the Acropolis ruins, but our visit here also was brief. We clambered round the summits of the walls of the two temples, which have a score of monoliths still standing, more or less erect, and penetrated some of the most intricate passages. The feeling experienced here was one of intense wonder and bewilderment at the stupendous walls erected at such a height, walls which must have taken years to build, and all of granite blocks. The view from the summit is among the finest in Rhodesia. We watched the sunset glow fading on the white walls of the Elliptical Temple below, and then descended to prepare the huts for the night and arrange the stores in their proper quarters. Later, when the round moon one day off the full was shining, we sat outside the huts watching the effects shown on the western temple on the hill where the monoliths high up above us stood out against the greenish moonlit sky. At 4 a.m. the mules were inspanned in the wagon,

\footnotetext{
1 Remains removed to Matoppas, 1904.
} 
and my friends took their departure, leaving me alone among ruins and natives.

As soon as the sun was fairly, up M'Guti, the native police boy, arrived from Mogabe's kraal, followed by a crowd of "boys," all most anxious for work. The majority were young men, and the total clothing of the crowd did not amount to three square yards of calico. They all squatted down in a semicircle in front of the main hut while M'Guti delivered a long oration, but as he was wearing khaki regimentals and had his steel handcuffs (evidently a badge of authority) lying in front of him, the sustaining influence of office possessed him. Finally, all the details were settled, a roll was made up, and the names recorded.

Later, the Mogabe, Handishibishe, and his headmen arrived, and a long indaba took place, M'Guti interpreting. Mogabe recognised the likenesses of Mr. and Mrs. Bent, and that of the previous Mogabe-Chipfuno, his brother. Salt and tobacco sent Mogabe happy away, and next day a large gourd of doro (native beer) and some sweet potatoes arrived at the camp as a present.

The view from the summit of the Acropolis may be described as follows:-

South.-Towards the south and in the nearer distance, and 250 feet below in the valley, the venerable and lichened walls of the Elliptical Temple rise out of luxuriantly green vegetation. So much below the Acropolis cliffs is this temple that one sees over its broken north walls into the interior and on to the floors of some of the enclosures. The summit of the conical tower peeps out from among the giant fig-trees that flourish in the interior of the building. At this distance the white monoliths along the eastern wall, though clearly defined against the dark foliage, seem dwarfed. In almost the same line of view, but slightly eastwards and nearer, and on the north-east side of the temple, is the "Valley of Ruins," full of enclosures, passages, entrances, 
and walls, which up to 1902 had remained practically unexplored by white men. Nearer still is the wagon-track passing Havilah Camp and winding eastwards towards the Mapaku Ruins ("Little Zimbabwe") and the Motelekwe ${ }^{1}$ River seven miles distant. A hundred yards east of the

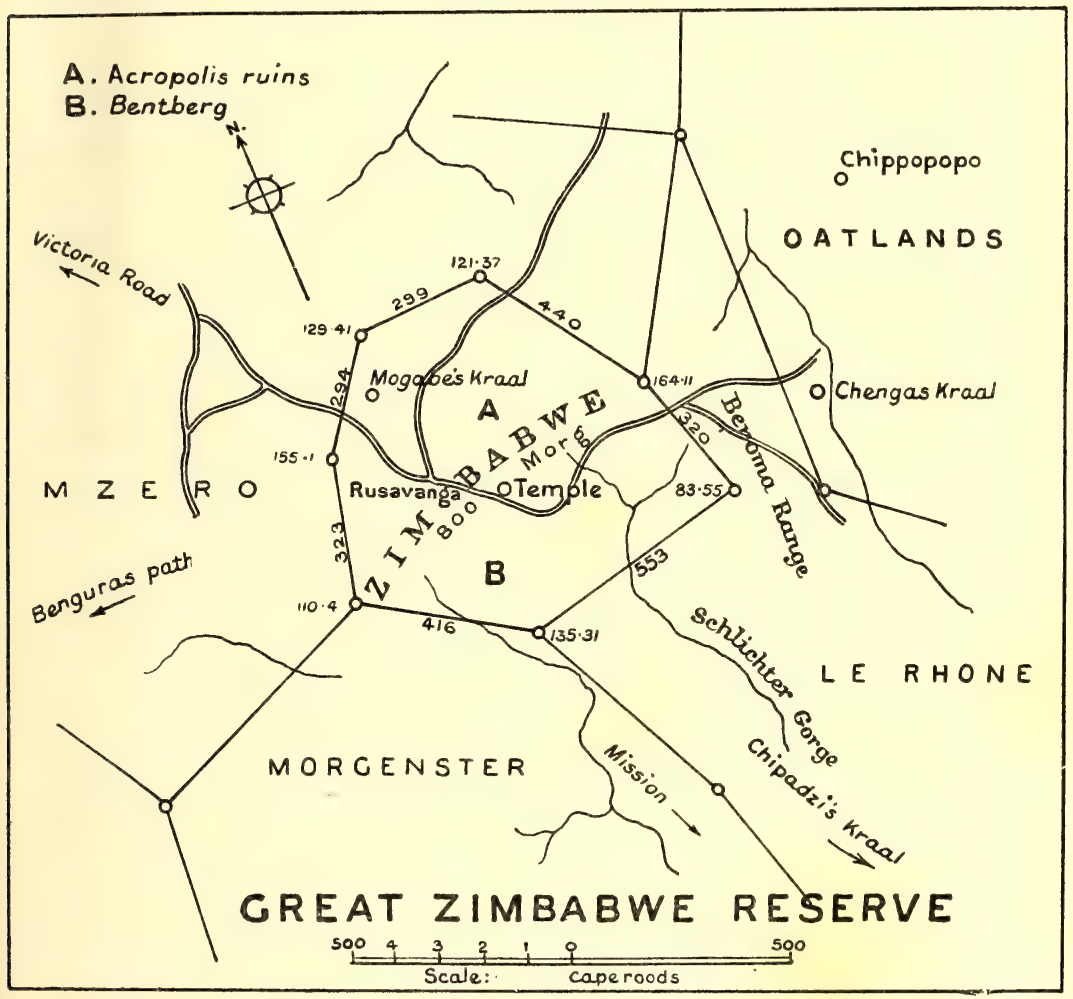

temple on an open granite space overlooking the Valley of Ruins is the site of the camp of Dr. Schlichter, who visited the Zimbabwe ruins in 1897 . Immediately behind this spot and between it and the foot of the Bentberg (Motusa) is the veld land ploughed by Messrs. Posselt in I 888-9.

Still looking south and slightly eastwards of the temple is the Schlichter Gorge, down which the Mapudzi flows towards

${ }^{1}$ Correctly, Motirikoi (Chicaranga, "a river that rises suddenly"). 
the south. At the southern end of the gorge is a succession of ranges of kopjes of fantastic shape descending into, and again rising from, the Mowishawasha Valley, and becoming lost in the blue distance. The Bentberg Kopje, which forms a dark background for the temple, shows its immense flanks of granite glacis and boulders. Here some fifty years ago was the chief local kraal of the Barotse, who had settlements among the Makalanga of this part of the country, and on the north-eastern side of the hill are still to be seen the remains of ancient walls, while a clump of castor-oil trees at the foot of the hill on this side marks the site of Theodore Bent's camp (June and July, I89I).

Slightly to the west of the temple and almost immediately in front of it are No. I Ruins, the walls of which are crowned with aloes and euphorbias. Less than a hundred yards west of these ruins are the Ridge Ruins, on a bare granite ridge, on the east side of which was the camp of Sir John Willoughby, who excavated portions of the ruins (November and December, 1892). Fifty yards behind the Ridge Ruins is the Zimbabwe Spring, marked by a group of trees, where most excellent water can be obtained, even during the driest season. It was close to these trees that Messrs. Posselt had their camp in I888-9. Nearer than Ridge Ruins is the little graveyard where is the granite tomb of Major Alan Wilson and his party. Just a few yards nearer is Havilah Camp, where one can just see the natives moving to and fro across the open spaces between the huts. Behind the Bentberg and further south is broken country, with Lumbo Rocks, one of the landmarks of the district, rising from the summit of a rugged hill like a column piled up against the sky, its lichen mantle showing brilliant red in the sunset. Here is the line of high ground which separates the plateau of Mashonaland from the lower valley of the Limpopo River, the incline in the contour being both steep and abrupt. This also divides 
$\mathrm{M}_{3}^{5 n}$ 


the watershed of the Motelekwe from that of the Tokwe. ${ }^{1}$ In this southern view are scattered many Makalanga kraals, several of which are perched up in almost inaccessible rocky eyries; also some romantic valleys, kloofs, and stretches of park-like land studded with patches of thick woods.

South-rvest.-Looking towards the south-west and in the near distance is the rising ground between the Bentberg and Rusivanga ${ }^{2}$ kopjes, and the native path leading over it to Bingura's kraal. At the foot of Rusivanga and 150 yards from Havilah Camp, and on a knoll on which is a large old tree, was for some time the camp of Adam Renders, known by the natives as Sa-adama, who rediscovered Zimbabwe in 1868 , and who was here visited by Mr. George Philips, the ivory trader of the very early days, and by Dr. Karl Mauch, the latter of whom gave in I87I the first information of the ruins for almost three hundred years. Here Renders traded extensively for ivory. Previously to Dr. Mauch's visit Renders lived at Nini, eleven miles southwest of Zimbabwe.

Beyond the nearer ridge is a deep and wide valley on the near side of which is Bingura's kraal, and from this valley the land rises towards the southern extremity of the Livouri Mountains some ten miles from Zimbabwe, and in the immediate distance, though much nearer the Livouri Range, is Providential Pass, through which the hunter, Mr. F. C. Selous, led the Pioneer Column in I890. In the same line of view, but slightly nearer, is where Renders' first station was located.

West.-Looking due west there are two kopjes-Rusivanga and Makuma-which close in the Zimbabwe Valley on that side at a third of a mile distance. Further west of the two kopjes is a wide undulating valley some six or eight miles

${ }^{1}$ Correctly, Togue (passive); in Chicaranga, "a river where people are swept away." The Togue is a strong and fast-running river.

2 In Chicaranga, "the hill of those who ran away." 
wide which runs along the east side of the Livouri Mountains, and this is studded at intervals with low and bare granite kopjes. The kraal of the dynastic chief Cherimbila is at Rovali, at the southern extremity of the range. The highest point of the Livouri is Niande, a hill in the centre of this range with steep and almost inaccessible sides. Behind the Livouri Range is seen the high conical summit of the Cotopaxi Mountain, which forms one of the principal landmarks of this portion of Southern Mashonaland. Towards the south end of the Livouri Range is a large hill called Mowishawasha. Washa is always associated by the natives with power and authority. The natives never climb to the top of this hill without going through some form of devotion on their way up; also on passing close to the hill they will stop and clap hands. Natives will not state the actual reason. Probably an important Makalanga chief of some past times was buried there. Near to this hill is a smaller one known as Tchib-Fuko, which also has some native superstitions attached to it. It was in this district the wooden platter with the zodiacal signs was discovered by Mr. Edward Muller, also the pot "Fuko-ya-Nebandge."

North-zest.-To the north-west, and on the opposite side of the valley at the foot of Zimbabwe Hill, and beyond the Outer Defence Wall which encloses the Zimbabwe ruins on the west and north sides, is a low granite knoll called Pasosa, with outlying huts belonging to Mogabe's kraal. A few yards behind the huts is a ruin (Pasosa, No. I), with a second ruin (Pasosa, No. 2) 60 yards farther north. The country beyond in this direction is the valley land of the Moshagashi River, which is some six to eight miles broad, the horizon showing low hills, over which are the line of houses and trees of Victoria township, fifteen miles distant as the crow flies, and beyond again are the uplands of the range north of Victoria. The principal kraals in this direction are Baranzimba's (two miles) and M'Tima's (three and a half miles). 


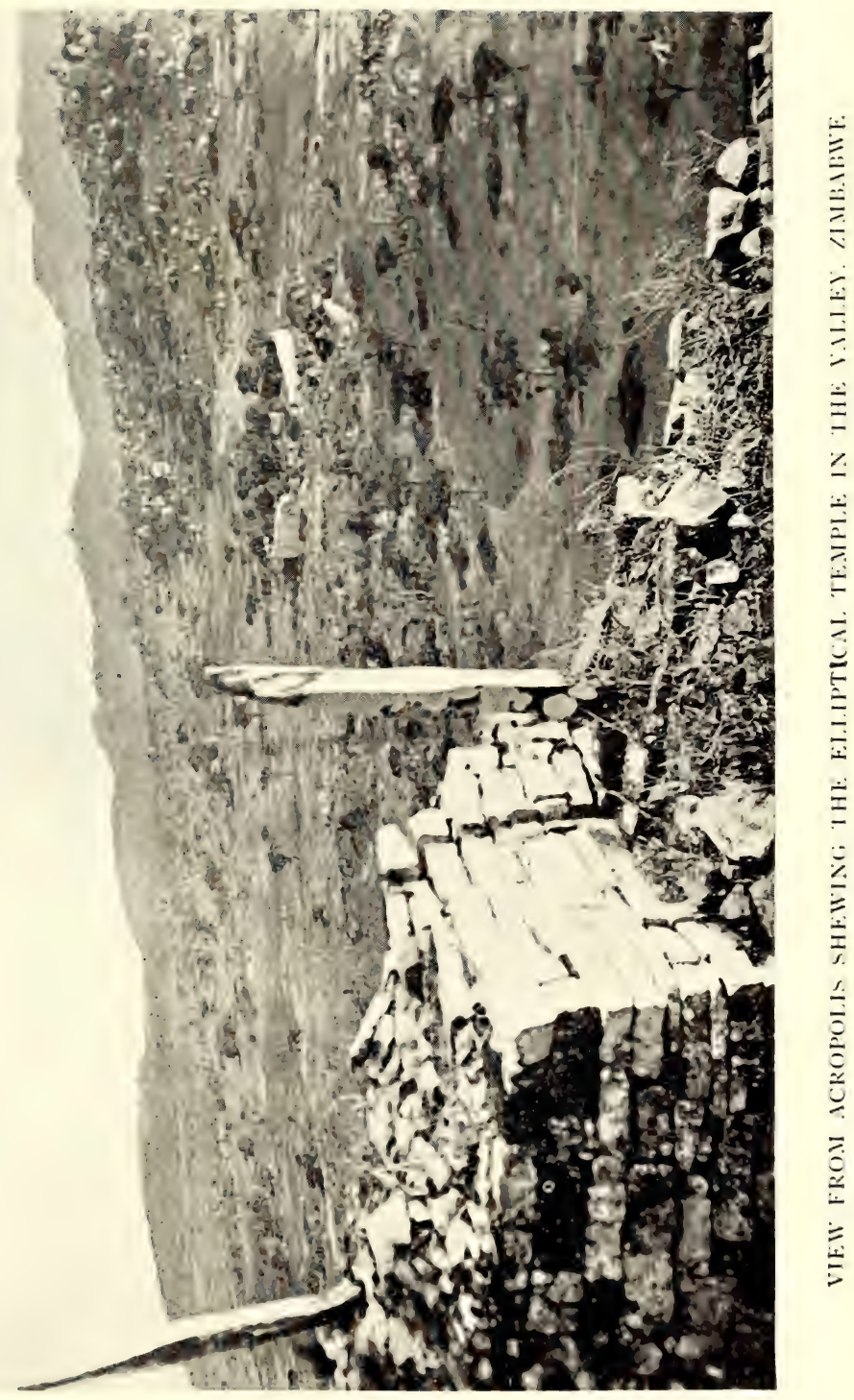



North.-In the north is the lower continuation of the Moshagashi Valley, at this point some eight miles broad. Here the granite formation of Zimbabwe terminates and the slate commences. The principal kraal, and by far the largest in this area, is that of Chinongu, which is four miles from Zimbabwe. Extending from N.N.W. to N.N.E. are the high and romantically shaped Besa Mountains, and at their eastern extremity can be seen in the blue distance the Lovugwe country.

North-east. - To the north-east, at a distance of eight miles and cutting the sky-line, is the range of the Inyuni Hills. Their sides are exceedingly steep and, being slate, their contours contrast pleasantly with those of the kopjes of the granite formation. In the nearer distance is Motuminshaba, a granite kopje four miles away, and farther east Tchivi, another granite kopje three miles distant. The land towards the east-north-east descends to the Motelekwe River, the valley of which can be seen with Arowi, a huge, isolated granite kopje rising twelve miles distant, on the far bank of the Motelekwe. In this area kraals are numerous.

East.-The Beroma Range (written by Bent as "Veroma") fills in the whole of the background towards the east. These hills, which run north and south, appear to be fully four miles long. The most northerly point of this range is formed by a large rounded granite kopje called Sueba, ${ }^{1}$ and between this hill and Chenga's ${ }^{2}$ kraal is the path leading over the nek to the Mapaku Ruins ("Little Zimbabwe") eight miles distant. On the west side of Beroma is a line of lower hills forming its shoulders. The southern end of the Beroma Range is formed by the high rounded Mount Marsgi, with a series of cliffs on its west side, and at its base M'Tijeni's kraal. Marsgi overlooks the Schlichter Gorge. This is the point from which our description started. 


\section{CHAPTER II}

\section{MYSTIC ZIMBABWE}

Sunday Morning and Midnight in an Ancient Temple-

Sunset on the Acropolis.

W

ANDERING about the Elliptical Temple at Zimbabwe on a Sunday morning one is faced at every turn with texts for innumerable "sermons in stones." The hoary age of these massive walls is grandly and silently eloquent of a dead religion-a religion which was but the blind stretching forth of the hand of faith groping in the Dawn of Knowledge for the Diety and seeking the Unknown. Lowell urges that none should call any faith "vain" which in the evolution of religion has led mankind up to a higher level. The builders were "Pagans." Granted, but the world four thousand years ago was in its infancy, and infancy is but a necessary prelude to development in any department of life and thought. The progressive stages of Old Testament faith demonstrate this fact most patently. We of the Christian Era, with our two thousand years of religious enlightenment, have yet to learn of the "many things I have to say unto you, but ye cannot bear them now." The evolution of the Christian Ideal has not yet reached its final stage-it has still to be perfected. But the period of infancy in development should not be too hastily condemned as "vain."

The spires that adorn our churches, the orientation of ecclesiastical buildings, the eastward position of the dead, the candles on the altars, and what is more, the idea conveyed by sacrificial offering, have their origin in the ancient faiths 
and world-wide litholatrous and solar ideas of the Semitic peoples, whether of Yemen or Phœnicia, who built their temples in every part of the then known world which came under their influence. In these, as in many more such instances, parallelisms become identities, but identities adapted by the Christian Church to convey in an oldworld form a figure of a higher faith. The continuity between this old temple at Zimbabwe, Stonehenge, and the modern cathedral, is complete.

When one reviews the forms and practices, so far as they are known, of the Semitic builders of the Great Zimbabwe, what a flood of light shines in upon the history and worship of the Hebrews. The writings of the Prophets live afresh, and the mystic chapters of Job become full of pregnant meaning. A key is provided to the secret of Abraham offering his son, to Jacob's pile of stones, to Jephthah's vow, to the Syro-Phœnician woman's conversation at the well, and to a hundred points of biblical lore which would otherwise barely attract attention, much less provoke interest. These old Semites-of whom the Hebrews were a younger branch-stinted not their worship, and knew the ecstasy of sacrifice. Their best beloved they gave-their dearest, in the belief that the gift which was offered without a pang was not prized by Deity. Bearing this in mind, the Old Testament is found to be replete with unfailing interest, charm, and point; it becomes, in fact, a marvellously new book even to the biblical student.

The builders of the temple at Zimbabwe have now, it is believed, slept through three millenniums, if not four, yet the religious faith of the Semitic family was so strong, so real, and so forceful, that its ramifications can be found in the faith of the Christian Church of to-day. Nor can this be wondered at. One has but to glance round these temple walls to read in granite blocks the fact that to the builders their religious faith was of primal importance. Here is 
clearly envisaged the fact that to them their religion was very real, so much so that were Europe devastated to-morrow, it could scarcely show in proportion to its other buildings such monuments to religious faith as can be seen in Rhodesia to-day. Their finest art, their best constructive skill, and the patient labour of long years, were lavished upon these buildings which thickly stud the country. Thoroughness and devotion are written large on the orientated, massive, and grandly sweeping walls of the Elliptical Temple at Great Zimbabwe. One cannot call their faith "vain" when one realises that it led them out from themselves towards something higher, while for them it must be remembered the True Light had not shined. Struggling though blindly to improve their relationship to Deity provided a no mean factor in the religious progress of the world.

While these ancient Semitic colonisers of Rhodesia have slept their many-centuried sleep, what epochs of the world's history have come and gone, and what empires have risen and decayed! Ah! see that lichen-mantled granite block low down in the cyclopean wall. It has a little chip of stone under one corner as if to steady it. The ancient mason was a careful worker. The chip is still there to-day. One can move it with a finger. Was it there when Moses led the Hebrews towards the Promised Land, or there when young Joseph was sold as a slave into Egypt? Who shall say? Civilisations have come and gone, but the chip is there, and affords not merely an evidence of the careful mason, but a sermon on the brevity of life, the utter smallness of pomp and power, and the absolute absurdity of pride. Still the little granite chip has served its purpose for some four thousand years, and it may yet be there occupying its humble position at the end of the next millennium. The oldest fanes of Europe, whether of Greece or Rome, cannot so deeply move to awe-inspiring feeling as can the massive walls of the temple at Zimbabwe, for these old empires are 
believed to have been almost unborn when Zimbabwe was at its zenith. Thus the walls compel a listening to their sermons.

As one strays through the Sacred Enclosure, thoughts come:-What were the relative positions of magic and religion, especially in the complicated and closely observed Phallic worship of these ancients; whence the zodiacal, astronomical, and geometrical knowledge of the builders; what of the touch of tragedy in their exodus or departure; the exact meaning of the granite, slate, and carved soapstone monoliths on the summits of the walls; the origin of the occupiers; was Rhodesia the Havilah of Genesis; did it provide the Solomonic gold; of the close kinship of these successful ancient gold-seekers from Yemen or Tyre and Sidon to the Hebrews of Palestine; and of their intimate connection in origin, language, and neighbourhood which Holy Writ abundantly declares existed from the ninth chapter of Genesis until Paul preached in Phœnicia?

Gazing at the Sacred Tower, one thinks of the Tower of Siloam, and of the "high places" of Samaria, and of the times when even this form of worship became the state religion of Judah under Ahaziah; and sitting at the conjectured site of the ancient altar, where the writer has found in numbers the stone emblems of their faith, thoughts arise of the Bethel stones of the Hebrews, the Bethûl or "the dwelling-places of God " of the Phœnicians, and the Penuel or "Face of God" of the Midianites.

The Law of Moses adapts the rules and customs and ideas and forms of worship of far greater antiquity than the Mosaic times. So the new faith of every age borrows from the old, and the mighty processions of civilisations and faiths which have encircled this earth from very far back beyond the days of Abraham go on their even course.

But we must leave the temple and return to camp. There is still the great Zimbabwe owl sitting on his favourite bough 
near the "high place." The six-foot python crawls in and out of the stones of the ancient altar. Brightly coloured lizards bask on the once consecrated walls. Blue jays, honey-birds, and doves here find a shelter. The trees, orchidclad and lichen-festooned, throw a weird shadow over all. Possibly ancients are sleeping near.

As one passes out through the entrance into the full glare of an African noontide, one feels as if one had just returned from the far distant mystic past to modern life, for a naked Makalanga waits there with the message that Sunday lunch was cooked and waiting.

Midnight in an ancient temple.-It was the night of the full moon nearest to Midsummer Day in the Southern Hemisphere, and towards midnight the large population of Makalanga round Zimbabwe would be celebrating the feast of the full moon with dancing, singing, and doro drinking. This was evidently a special feast, for its advent had been the theme of conversation among our labourers for the past fortnight, and, unlike the other feasts, it was held simultaneously in each kraal, and not at different kraals in turn on alternate occasions.

At nine o'clock all was still and restful. There were no signs whatever of the forthcoming festivities. Passing through Baranazimba's kraal, on the way to Havilah Camp at Zimbabwe, one found the population had retired to rest. At Mogabe's kraal the only sign of active life was shown by the village dogs. The night was hot and close, and outside the huts natives were sleeping, each in his blanket. Arrived at Havilah Camp, one found a score of labourers, sublimely free from all anxieties, sleeping on the bare granite outside their huts, but so oppressive was the air that in their slumbers they had thrown off their blankets, and were lying in every conceivable posture, and snoring and talking in their sleep as if dancing and beer-drinking were matters that had not the 


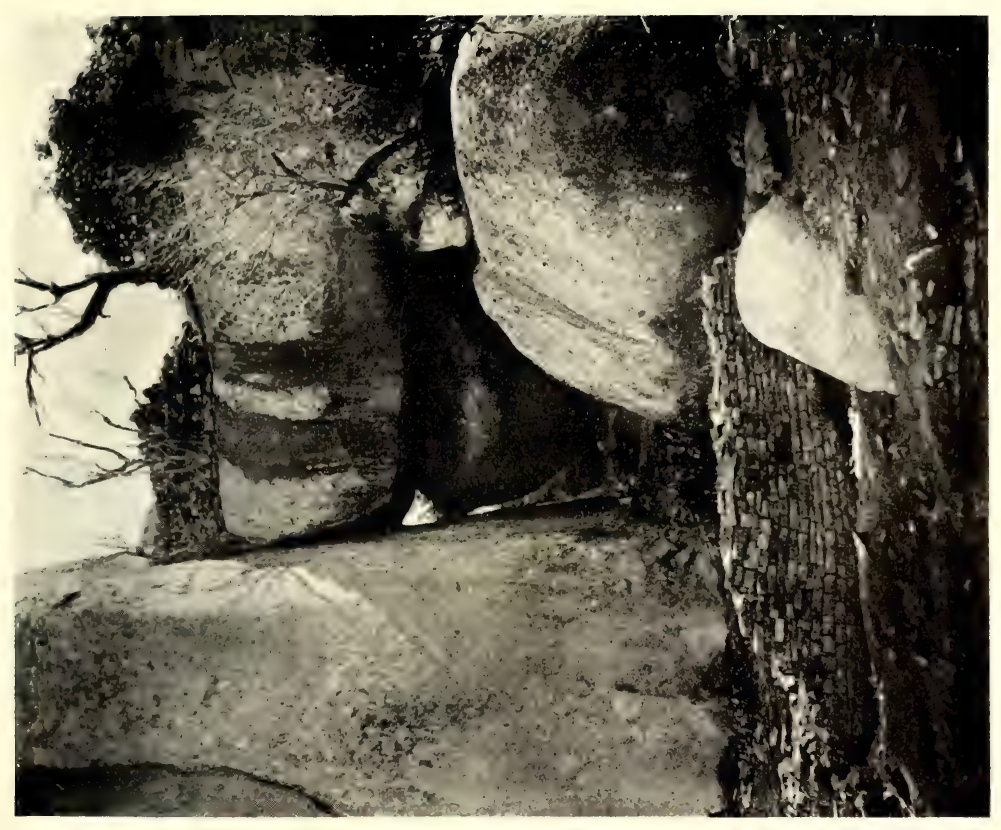

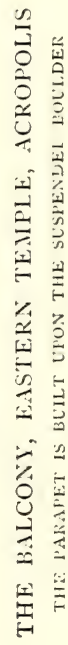
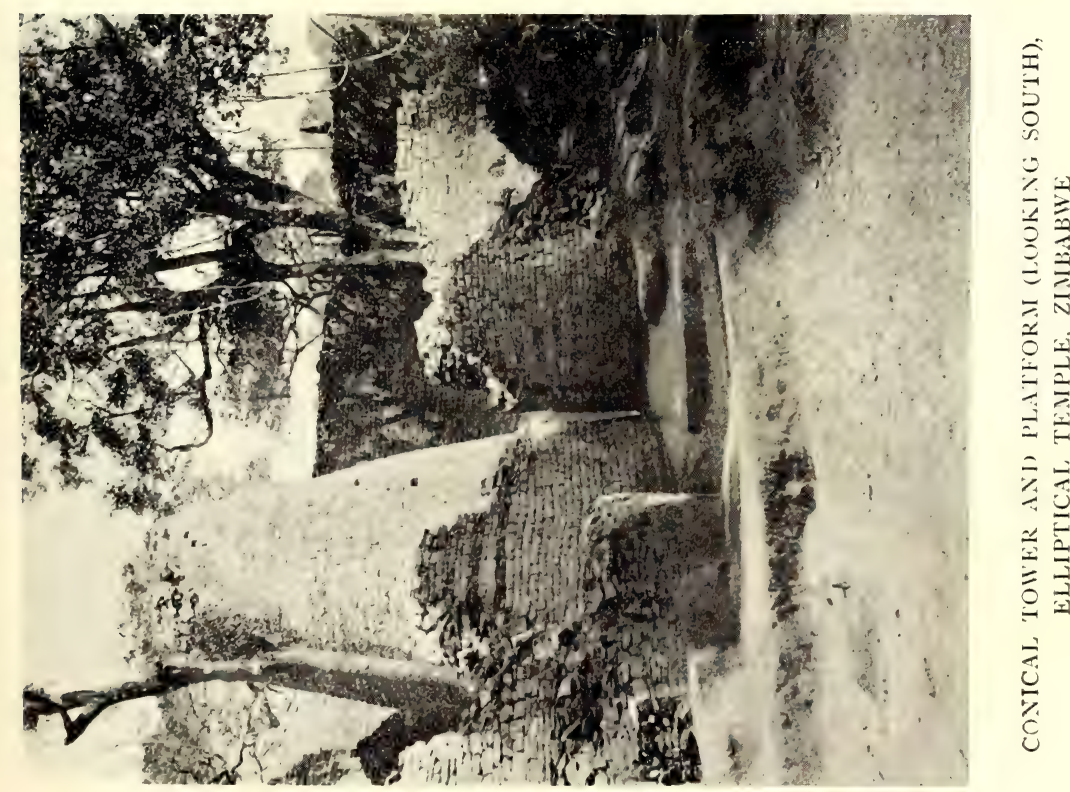

slightest interest for them. The large full moon was yet some distance from its zenith, but the valleys were flooded with a greenish-grey mistiness, which lay over the high grass and ran up into the kloofs and gorges. The light made distant objects distinctly visible, throwing a mantle of romance over every clump, ridge, and kopje, while it was possible to read tolerably small print without the aid of artificial light.

For fully another hour the silence was unbroken. At last the desultory beating of a village drum at Mogabe's kraal was heard. Later a drum was sounded at Chenga's kraal, and another at Bingura's kraal. The villagers were waking up for the feast. One of our labourers sat up, stretched himself and yawned, and commenced shaking his sleeping comrades. Within a few minutes Havilah Camp was all life. One native reached for his leggings of large nuts with dried kernels inside, others a horn, flute, piano, or harp, but all took two knobkerries, some having assegais. Those who possessed strings of wild-cat tails tied them round their waists. The early hours of evening had been devoted to greasing their bodies and limbs, and in the light of the moon their skins shone like burnished metal. Then began a general practising of dance steps, leapings, war-cries, and most hideous howlings. Meanwhile quite a dozen drums were being sounded up on Mogabe's Kopje, and these were answered by similar numbers at Chenga's and the other kraals. Horns were blown, parties of Makalanga, singing and shouting, were passing along the native tracks in front of our camp, each party going to its own kraal. Soon our labourers left in gangs for their respective villages and disappeared in the long mist-covered grass. Being all young men with a superabundant fund of spirits, they made a most fearful din in the course of their progress homewards. By this time the Zimbabwe kopjes resounded with singing, especially of girls' singing, for the women-folk started the festivities with screams and yells, and the loud beatings in 
three-two time of innumerable drums. The great full moon was now fast approaching its zenith. Our camp, save for the watch-men, the kya (hut) boy, and the picaninni, once more became still and lifeless.

Theodore Bent saw in these new and full-moon feasts some connection with the cult of Nature Worship of the ancient Semites, who are believed to have built these ruins and to have mined for gold in Southern Rhodesia, as it is conjectured, some three thousand years ago. The women, who at this moment are dancing in the villages, have on their bare stomachs, worked into the skin, a "breast and furrow pattern," identical to that found on many of the oldest of the prehistoric relics discovered in our ancient ruins, an undoubted emblem, Bent contended, of the ancient conception of Fertility. The men who will be dancing have worked in their skins, mainly in bands round their waists, the three radiating bars, similar in form to the Welsh bardic emblem of the Origin of Life. The articles they will wield in their dancing are carved with chevron pattern, one of the most ancient of all emblems of Fertility. But although the flesh decorations are now merely luck signs, neither man nor woman would on any account be without them. With these signs they say they will not be sick, will have plenty of wives and boys to work for them, and many girls on account of whom to receive lobola (marriage present to the fatherpractically purchase money). Anon, in the pauses of the dance, they will drink beer from pots with herring-bone pattern encircling the lips, a beer made of red millet, prepared, says Bent, in the same way and known by the same name as the beer prepared in Arabia to-day, where its methods of preparation and its name have been handed down from immemorial age.

But to-night will be the finest opportunity for the next twelve months of seeing the Elliptical Temple by moonlight. Sleep this hot, close night is impossible, especially with the 
sounds of noisy revelry proceeding simultaneously from all points of the compass. My native boy is disinclined to follow me to the temple, but after bargaining with him for an Isi-hle (present), he at last grudgingly consents. He mutters something about the place being bewitched, that there are many horrid things there, and alludes to the M'uali, the chief spirit of Makalanga awe and dread; but as within the two years' residence at Zimbabwe I have only discovered two natives, and these elderly men, who would willingly go into any of the ruins, especially the temple, after darkness had settled down, I am not at all surprised at his reluctance to follow me there. However, he is mindful to take his stoutest knobkerries with him.

Looking back at the Acropolis Hill, and at its long line of precipice, one sees the ancient walls on the summit gleaming white in the moonlight, while the tall monoliths stand clear against the sky. In the passages on the hill one might almost expect on such a night to come face to face with Rider Haggard's She at any corner, or to see her draped form issuing from one of the numerous caves which still pierce the cliffs. But we must turn our backs on the Acropolis Hill, and make for the Elliptical Temple, passing the little graveyard where the remains of Major Alan Wilson and his Shangani heroes rest in their granite tomb in the grove of euphorbia trees, whose branches cast black, sharp-cut shadows on the ground. Then across an open granite space, and up the long parallel passage on the east side of Ridge Ruins, out through its intricate southern entrance, and on to the level ground which runs up to the foot of the temple walls. The clumps of tall, old-world-looking aloes and euphorbia trees lining the walls of No. I Ruins on the left of our path appear strange even by daylight, but in the midnight radiance of the full moon they assume intensely weird and fantastic forms thoroughly in harmony with the outlines of the ancient buildings. The lonely grave of Thomas Bailey, an Australian 
gold prospector, lies close to the right-hand side of the path. He died in I893 while searching for relics within the temple.

The temple walls covered with white lichen appear to have been whitewashed for centuries, and these gleam brightly with light in distinct contrast to the dark veld and bush from which they rise; and so white are they that at a fair distance one can see every course, block, and joint in their dry masonry. The broad bases of the walls in comparison with the widths of their summits-though a full-sized wagon and a team of sixteen oxen could stand upon the top of the more substantial portion of the walls-their sloping sides, and the utter absence of any feature of any style of architecture known in Western Europe, lend a strikingly Eastern appearance to the building, which is sufficient in itself to forcibly take one's mind back some two or three thousand years. Meanwhile the noise of village drums, the blowing of horns, and the deep wild choruses of crowds of men, mingled with the voices of women and girls, were waxing louder and more incessant as midnight approached.

Standing in No. 5 Enclosure, just within the west entrance, the interior of the temple is seen to be full of light and shadow. But all is serenely calm and still as if possessed by the silence of the grave. The high, massive walls encircling the temple deaden to faintness the voices of the villagers. The close air, heavy with the scent of verbena wafted in from the veld, is oppressive in the extreme. An inexplicable sensation of trespassing in forbidden precincts possesses one. The native looks scared. Midnight visits to ruins are not his particular fancy.

Certainly the many visitors who travel hundreds, if not thousands, of miles to view these ruins, and who only see them by the glare of day, miss nine-tenths of the charm, fascination, and inspiration which the walls of the temple at Zimbabwe have in store for those who walk its courts in the stillness of the night when the midsummer moon is at the full. 
This is the time to see Zimbabwe aright, for Zimbabwe by day and Zimbabwe by night presents two entirely different aspects.

Trees throw gigantic shadows on the walls and darken the inner courts, and the floors are chequered by moonbeams shining through the foliage overhead. One somehow becomes possessed with the idea that these walls are peopled with the spirits of prehistoric age, who are moving, as of old, about the temple floors and passages, still performing their ancient priestly offices. The movement of every shadow against the walls suggests the passing from point to point of some threemillenniumed spectral form, too engrossed in its sacred avocations to heed the mortal presence of two strangers of the twentieth century after Christ. Would that these hoary-aged walls could speak and tell us of the scenes which took place here when the Great Zimbabwe was in all its glory! Assuredly a midnight hour spent in this ancient temple overwhelms one with most novel sensations, some slightly queer and shivery, others awe-inspiring and soulstirring.

While still standing just inside the west entrance some thoughts suggest themselves. The ancients being Nature worshippers of one of the earliest cults, so says Bent, had sought in the erection of their temple to compel the concentration of thought on the heavens alone, for even the reduced heights of the summits of the walls, averaging from $22 \mathrm{ft}$. to $3 \mathrm{I} \mathrm{ft}$., shut off, except for gaps, all views of the surrounding landscape. Nothing is visible save the moon and a skyful of silent, glittering stars. The Pleiades, by the rising and setting of which the Makalanga mark their sowing and harvesting, are sinking towards the W.N.W. horizon, and Orion, which is prominent in the star-pictures of the natives, is following down in their wake. A large area of the sky is hidden by the bright radiance of the full moon. But such high massive walls enclosing the temple, and limiting the view to the sky alone, 
strike the mind of the stranger unread in the lore of ancient Semitic faiths as the purposed design of the ancient architects, especially so when it is recollected that some of the ancient floors are at a much lower level than the interiors as seen to-day. And just as Britishers in Rhodesia unconsciously turn their gaze at night towards the stars which lie low near the northern horizon, so in the contracted view afforded by the temple walls we can well imagine that during their midnight vigils the eyes of the ancient colonists from the north would, as naturally, frequently and lingeringly glance over the northern wall to gaze on stars known to them in their Homeland. It may be noted, too, that the ancients, as conjectured by Bent and other writers, do not appear to have been greatly interested in the alien stars of the Southern Hemisphere, for in all the ruins in Rhodesia, so far as discoveries have been made, there are no massive stone arcs surmounted with monoliths with mural decorations of old-world emblems of fertility on their outer faces, and with the raised platforms approached by steps, facing towards the south, for all such that are known are directed to some other point of the compass.

Small fragments of granite chips from ancient blocks lie about the floor, and these gleam like stars on the dark ground, and have light-haloes of their own. These suggest the splendid sight these ancient walls must have been when all the newly dressed granite blocks in the faces of the walls sparkled as they must once have done as the fragments gleamed in this glorious moonlight. The walls must have glittered like a fairy palace, as did the castle walls of lordly Camelot. To-day we approach the temple on the same level as the veld, the ground outside having been raised to this level by the silt of ages, but the recently discovered granite cement floors outside the building show that the ancients had to ascend some five feet or more to gain the threshold of the entrance. With such higher elevation for its walls, 
the temple, when freshly built, or perhaps for centuries afterwards, must have been on moonlit nights a most bewitching sight of splendour. But its glories to-night are those which it has gained from the hand of Time.

But on gaining the central area of the building the inexplicable sensations awakened by the weird and strange surroundings and past associations are intensified, and one's nerves are forced to be more alive to anything unusual happening. Large bats and night-moths fly unpleasantly close to one's face. Treading on a rotten stick, and the falling of large dry leaves which rattle on the stones below, make noises sufficient to cause one to turn round expecting the approach of some ancient spectre. A frog in some dark and dank corner startles one with a loud croak of "Work!" The hoot of an owl makes the native start. A low moaning, soughing wind now springing up sweeps round the temple and rustles in the upper branches of the trees.

The temple is now lovely in the extreme. The shadows on the walls are now in quick movement. Fireflies swing their tiny lamps over dark enclosures. The white radiance of the moonlight completely invests the conical tower, its intense whiteness being heightened by the large, thick, and dark-foliaged trees on either side. If but Time's hour-glass were turned back for some long centuries' space, what tales could not this tower unfold, what secrets of ancient faiths disclose!

One passes down the ancient stairs, lately uncovered, which lead into the Sacred Enclosure, and finds the long, deep-sunk Parallel Passage wrapt in sepulchral darkness, and realises the force of the dark lore of ancient priestcraft and of prayers muttered at midnight. It is pleasant to regain the interior of the temple, where broad streams of moonlight flood its surface. Seated on the east wall of No. Io Enclosure, and immediately facing the conical tower, one has a good view all round the temple. Under the dark shades 
of walls and trees a hundred spectres might be lurking unseen. Amidst such surroundings a score of ancient scenes are pictured in one's mind-the approaching priests with processional chant emerging through the north entrance from the Sacred Enclosure, the salutation to the emblems of the gods, the light of altar fire and torch reflected upon the walls and upon the sacred golden fillets bound round the brows of the priest, the incense-laden air, the subdued murmurings of the waiting crowd of worshippers, the invocations of the deity by priests who stand upon the high raised platform in front of the conical tower, the mystic rites, dark enchantments, and the pious orgies. The very air feels as if it were teeming with mystery and midnight loneliness. Here appear to rise "the thin throng of ghosts . . . with beckoning hands and noiseless feet flitting from shade to shade."

The rising wind now wafts into the ancient shrine the confused shouting, singing, tom-tom beating, and general clamour of the natives dancing in the villages on the hills around. The air has become decidedly cooler. One is glad to have visited the temple at this hour. It is one of the experiences of a lifetime.

The Acropolis at sunset.-In the soft sunlight of a glorious late afternoon, when calm broods over all and a profound solitude invests the immense panorama of valley, mountain, and sea of jagged kopje ranges as beheld from the summit of the Acropolis Hill some $300 \mathrm{ft}$. at least above the Zimbabwe Valley, one views a scene of indescribable loveliness. The sharp-cut ranges of hills, deep gorges flanked by cliffs, great crags of rock, and the long and broad Moshagashi Valley with its scattered kraals and patches of native plantations are all as silent as sleep.

The Acropolis itself is still. The long and labyrinthine passages give back no echoes. The temple courts are empty. The tall monoliths, like ghostly sentinels, point 
upwards to the sky, and the sunlight is fast fading on the ancient dentelle pattern at the Western Temple. These massive ruins, once teeming with a dense and busy population of Semitic colonists of prehistoric times, with their innumerable evidences of Phallic worship and extensive gold-smelting operations, are as quiet as the grave. The cry of a baboon, or scream of an eagle returning to its eyrie high up on the cliffs above the Eastern Temple, alone break the impressive silence enfolding one of the greatest archæological wonders of the Southern Hemisphere.

At this height and on a hill so isolated from its neighbours, and just at sunset when shadows are already gathering in the deep defiles in the cliffs upon its summit, an inexpressible sensation of intense loneliness and solitude asserts itself. No other human foot will tread these ancient approaches to the Acropolis till the sun has risen once again. There is no white man round about for miles, and the natives will not venture near the ruins after sunset. Two hours ago the herd was mindful to drive the goats from the high points on the face of the hill down into the valley. The natives will solemnly inform the stranger that as night approaches the spirits of their departed ancestors buried in the caves of the hill awaken, that the ruins are then bewitched. It may be easily understood that in minds made craven with centuries of slavery to a succession of invaders, and haunted, till the last decade, with constant dread of Swazi and Matabele raids, the standard of Makalanga valour is low indeed, and that at nights they shun these scenes of ancient life is not in the least surprising.

Ascending the hill through the sunless Rock Passage, the air is cool and draughty, but on emerging at the upper end one is faced by the rich blinding glow of the setting sun, and here the air is still warm. As we pass through the Western Enclosure and through the gap in the main west wall of the Western Temple, a view down the sheer drop of the hill into 
the valley below presents itself. The Elliptical Temple is just losing its last faint touches of the golden tint of sunset. The "Valley of Ruins" is already in shadow, and its chaos of walls looks now even more chaotic and bewildering than it did in the full light of day. Mogabe's cattle wending their way up Makuma Kopje to the kraal for the night, the bleating of sheep and goats already penned, the far-away talk of women and girls returning from collecting firewood with their bundles on their heads, and the laughter of small parties of natives returning homewards from their plantations, all speak of departing day. The lofty lichened sides of Lumbo Rocks are still bright orange in the sunset, but the nearer side of the Bentberg has become dark and black in shadow, showing up the walls of the Elliptical Temple in the foreground with striking clearness. The long ravine of Schlichter Gorge is now blurred in grey distances, while the Motelekwe and Mowishawasha valleys have already lost the sun for some minutes. The kopjes cast the same backgammon-board-shaped shadows across the valleys just as they did three and four thousand years ago when the tired ancients watched the drawing in of day.

But turning a glance round to the Western Temple, still at this height bathed in golden sheen, one sees only the ancient walls and passages silent and deserted. This area might have been a busy spot for the ancient occupiers at this hour of the day, for monoliths, decorative mural patterns, and conical towers are now all aglow with sunset brightness, and here at this time of day, as the shadow of the slanting granite beam fades on the dentelle pattern on the platform, they might have read as on a dial face, in light and shade, the progress of the season of the year. The call to prayers and the chanting of the evening hymn of the devout at sunset might at this same hour very many centuries ago have rung round the selfsame hallowed walls which look down sphinxlike and blankly upon the modern visitor. 
It is easy to fashion a tale of ancient scenes in such a spot and 'mid such surroundings. Such a scene may have beenthe parties of ancient worshippers approaching the temple up the Higher Parapet or by the sunken passage in the Platform Enclosure, or along the East Passage, filling the amphitheatre and watching the bringing of the sacred vessels possibly from the now dank and evil-smelling Platform Cave to some spot near the centre of the temple, perchance at the centre of the arc of the great curved wall, which is directed towards the setting sun; the disappearance of the priests through the Covered Passage and their reappearance on the Platform, which faces west and overlooks the interior of the temple, or listening to priestly orations, the announcement of the actual sunset to the worshippers. Possibly, too, the chief priest may have announced the commencement of the "Feast of the New Moon."

At this moment the "boys" in Havilah Camp are yelling and dancing most frantically. Something unusual must have happened to cause the sudden outbreak of unearthly din. Right in the dazzling glow of the sun, and low down in the sky, and barely discernible by the eye of white men, is the slender silver scimitar of the young moon. A noisy night of beer-drinking, dancing and singing, and tom-tom beating will follow.

But the dank smell of decay has now usurped the place of the sweet-smelling incense of the ancient ritual. The monoliths still point upwards, but who to-day can explain their plan and purpose, or read the silent intimations their shadows were wont to convey?

The associations of the ruins of the Hill Fortress lie even more with the ancient military occupiers than with those of priests and worship. Traverses, buttresses, screen walls, intricate entrances, narrow and sunken passages, rampart walls, banquettes, parapets, and all other devices of a people conversant with military engineering and defence, are in 
great evidence all over the hill. These in their ingenuity, massive character, and persistent repetition at every point of vantage, baffle and astonish the best experts of modern military engineering science. The ancients were military strategists, and the Acropolis a stronghold, and its most prominent feature was defence.

At this sunset hour no companies of ancient soldiery descend from the fort (East Ruins), at the foot of the Ancient Ascent, to relieve guard and take up their night watches on the wall barriers. In the now dim and scanty twilight one can wander at will through the two hill temples, the residential quarters, and into the caves which once might have held the gold stores of this part of the country. There is no officer on duty to challenge one's approach. The sentry recesses in the narrow passages and at the entrances appear singularly empty. Fate finally came to relieve guard many centuries past, eventually permitting some semi-civilised Abantu people, such as the Makalanga, or "People of the Sun," to desecrate the ancient temple floors with their copper and iron furnaces and bone and ash débris heaps. But the lively bustling crowds of ancients and of mediæval Makalanga, who both in turn, and for very long periods, densely populated Zimbabwe Hill, are no more.

One passes along shoulder-wide and tortuous passages, where at every corner one might expect to come face to face with Rider Haggard's She, and enters some enclosure whose sides are formed by the perpendicular flanks of cliffs and boulders, where the ancients fashioned their gold into beads, wire, plates, and ingots. The intricate entrance still guards the spot where gold crucibles, beaten gold, and gold burnishing tools of the ancient artificers have been found in profusion. There is now no sound of hammering the precious metal on the rounded dolorite anvils, nor reddish glow of light on the cliff sides, as when the furnace was uncovered for the removal of the heated crucibles. The prehistoric work- 
shop is now desolate and damp, and a fitting spot for the loathsome, crawling creatures which inhabit its dark recesses.

But daylight is dying fast. Glancing down through the gaps in the outer walls are seen specks of firelight at near and remote kraals where the evening meal is being prepared, and round which the advent of the new moon will soon be celebrated. An adjoining cave with yawning depth and dense blackness does not now appear particularly inviting to the visitor, and yet here relic-seekers unanimously declare was where the ancients kept large stores of gold dust. The Eastern Temple is in semi-darkness, but as one crosses its floor one sees the hole from which some fifty phalli were taken, and the exact spots from which soapstone birds were removed. Here was the site, as Bent conjectured, of the ancient altar. In this temple, it is believed, the ancients celebrated their daybreak ritual, for the arc of the main wall decorated with dentelle pattern, and on which once stood some of the soapstone birds, faces the rising of the sun. Passing along Central Passage, which is perpetually in shadow owing to huge tall boulders on either side, but is now in deepest blackness, crossing Cleft Rock Enclosure, and descending the sunken passage to the outer face of the great west wall of the Western Temple, one arrives where a slight afterglow of the sunset still lingers over the brow of Rusivanga.

Again one enters into the deep shadow of a sunken and earth-smelling passage with high side-walls, and so rapidly descends the north-west face of the hill, glad to emerge once more into the cool fresh air at a lower level of some Ioo ft. High in the west is Venus, the evening star, shining brightly -Venus, or Almaq, "illuminating," the goddess of the earlier star-worshipping Sabæans of Yemen, whose worship the best-qualified scientists believe was practised by the original builders of Zimbabwe. She complacently shines down upon her ruined shrines, and wonders doubtless why these natives should convert the sacred emblems of her worship into pipe- 
bowls for smoking hemp. The Pleiades have set, for the harvest time is almost over. Orion is sinking towards the western horizon as if with disgust at the land where mere Kafirs ${ }^{1}$ call him "The little pig and two dogs."

${ }^{1}$ Usually but wrongly spelt Kaffir. It is the Arabic Sافِ Káfir=Infidel, Unbeliever, applied indifferently to all non-Mohammedan peoples, hence has no ethnical significance. 


\section{CHAPTER III}

\section{A DAY AT HAVILAH CAMP, ZIMBABWE}

E ARLY to bed, our Makalanga labourers are proportionately early to rise, and as soon as there is sufficient light to enable them to see they are up, stretching their limbs, waking the echoes of the valley with their noisy yawnings, which jar on the lilt of the dawn-anthems of the birds, and sit crouching round fires with their blankets over their shoulders.

The sun will soon be coming up behind the blue Beroma, Range, just over the romantically shaped rocks at Chenga's kraal. The peaks of the range are already edged with the fire of the coming light. At last a notched portion of the sun appears over the distant mountain heights. Now everything is coloured crimson. The granite cliffs and massive boulders, the tall grass, the ruined walls, even the mules outspanned in the valley in front of the camp, are all crimson. The usually dirty-coloured grass roofs of the huts are for some minutes most gorgeously beautified. For the only time in the day the dentelle pattern on the conical tower and on the eastern face of the Eastern Temple, the chevron pattern on the Elliptical Temple, and the huge herring-bone pattern on the ancient water gate, and certain of the slate and granite monoliths, are fully bathed in rich sunshine. Other ancient decorative patterns on the walls will have the full sun shining upon them only at midday, while others will only be fully sun-bathed as the sun is setting.

But at present everything is crimson. The wreaths of 
mist which lie over the tall grass filling the valleys, and which just before were blue, now connect kopje and kopje, making the Acropolis and other summits crimson isles rising from out a crimson sea. The only objects that decline to take on the prevailing tint are some old-world-looking trees with green, metallic leaves. Were the picture of Zimbabwe with this misty colouring resting over it reproduced on canvas the artist would at once be condemned as extravagant. But Nature has more than one colour on her palette. The crimson melts in a rich golden hue which succeeds it. The cliffs, grass hut-roofs, and mist-wreaths become golden. The mules are transformed to gold, and the battered old wagon looks for once quite respectable with its golden bucksail. But the gold in its turn also fades, the mist-veils lift and melt away, and the land once more regains its wonted tawny, sun-bathed appearance so suggestive of lions.

Day has not yet had a fair chance to become commonplace, but in Havilah Camp life is beginning to stir. Three naked boys have gone to the spring for water, others collect wood, clean the pots, and draw rapoka meal and salt from the stores, while a tall pillar of bright blue smoke ascends in the still air from the boys' fire. From our height can be seen a score of native villages, each with its column of blue smoke.

Two or three sit by the Isafuba game-holes, and of course disputations at once ensue. Others settle down to work of their own, such as grass-hat making, carving sticks with chevron patterns, drying tobacco leaves, crushing snuff, dressing skins, or performing the duties of barbers. The boys are most industrious when engaged upon their own work. Others are off to inspect their bird and game traps, of which they seem to have at least a hundred within a short distance from the camp, while the rest sit and watch whatever happens to be going on.

Down the side of Makuma Kopje, where Mogabe's kraal 


\section{A DAY AT HAVILAH CAMP}

is situated, come young men in twos and threes, some of them with musical instruments, such as Makalanga pianos, a flute, and a one-stringed harp with gourd attached to increase the sound, and of course all are singing. These on descending Makuma disappear in the ten-foot grass which fills the valley till they are near the camp. Other young men come from Chenga's kraal in the opposite direction two miles away. These latter are the boys to work. Our best workmen come from Chenga's, for Mogabe's men have not been improved by tips and favours from visitors to the ruins; besides, belonging to the kraal of the paramount and dynastic chief, they deem themselves to be somewhat superior to all direction or reprimand by white men. Though Mogabe's people know "how to be happy though Makalanga," Chenga's people seem to be even more genuinely contented with their environment.

By 7 a.m. the camp is in full life, and all the boys are present with at least a dozen brothers and followers. The trap-owners have returned with rats, small birds, and possibly a rock-rabbit. A boy is given a note to take to Victoria, seventeen miles distant. He places the letter and his pass in a cleft stick, holds it out in front of him, and is off. He will be back in camp an hour after sundown, perhaps bringing a load of $35 \mathrm{lbs}$. on his head. A thirty-four miles' journey is preferred to a day's work in the temple, so that there are always willing runners into Victoria. There are eggs, poultry, milk, honey, melons, pumpkins, rice, and sweet potatoes for sale or barter for salt, and these can always be obtained for half the original price asked for them.

Then there are burns to be dressed, quinine to be administered, or a lung-sick boy to be dosed. The "Parade State of the Malingering Brigade" is carefully kept down to the lowest possible limit. One is amazed at the way the boys bear their injuries. A severe wound which would put an ordinary European on the sick list is to them a mere trifle, 
and without flinching they will take a burning stick from the fire and rub it up and down inside a gaping flesh wound till the bleeding has ceased. Should any one of them meet with serious injury, the rest will laugh immensely as if it were a huge joke. In this respect they are very callous. Toothache, a cold, or a slight touch of fever renders them most pitiable objects. The soles of their feet resemble hides, and one or two large thorns which would completely lame a European is a matter almost too insignificant for them to notice. They think nothing of standing on hot burning embers while lighting their pipes at a fire. On cold nights they sleep near a fire and will roll into it, but they are such remarkably sound sleepers that it is not until the next morning they discover they have been burnt. How they manage to save their skins from thorn scratches is a mystery, for all day they are walking with naked bodies through bushes and thorn creepers. Yet their skins are beautifully smooth and glossy, and are always without the slightest scratch.

But the pots of rapoka meal under the euphorbia trees are now being stirred, and each pot has its circle of men to whom dyspepsia appears to be utterly unknown. Sometimes the boys bring a sack of dried locusts. Locusts are esteemed as a dainty, and make an occasional change in the menu, or possibly small red beans, or monkey-nuts, or toasted mealie cobs are feasted upon. While the meal is being devoured one could hardly imagine there was a native within a mile. The stillness of skoff-times (meal-times) in camp serves the purposes of a well-regulated chronometer. Teeth-cleaning is their first business of the day. On rising from sleep and after each meal this is religiously performed. Each takes a mouthful of water and rubs his teeth vigorously with a forefinger, using what water is still remaining in his mouth to wet the skin of face, neck, breast, and hands, squirting it out in doles as required. To hurry them back to work before their 


\section{A DAY AT HAVILAH CAMP}

teeth had been cleaned would cause them to regard the Baba with looks of genuine horror.

At 7 a.m. the ganger, a man who has worked in the ruins for Bent, Willoughby, and Schlichter, comes to the hut door to report that the men are now ready to start work. Then follows the roll-call, each raising his hand and passing on one side to a separate group as his name is read out. A boy absent for two days on account of alleged sickness is reported to have gone to a distant kraal to attend a "beer dance" where he danced the whole night through. A fine is entered against him. Makalanga split on one another in a fashion which English schoolboys would never permit. Our fines are rarely enforced, but the mere entering them in the book has a most wholesome effect.

One feature in the roll-call generally strikes visitors as interesting, that is, the rhythmic sound of the names of the boys. To an Englishman these names would appear to be more suitable for girls than for men. In fact, all the names of the men are pretty, so pretty that it seems inappropriate to apply them to great fellows like some of our labourers. But like their ideally graceful and poetic gestures, while pronouncing each other's names they unconsciously manage to throw into the pronunciation a delicate softness, rhythm of intonation, and charm of expression that are rather fascinating to the European listener. An Englishman totally unacquainted with the local language, and wrongly pronouncing the names, could not rob them of their poetry.

The roll completed, all set off in Indian file either to the Elliptical Temple or the Acropolis, singing in chorus in a Tyrolese style, one man giving the recitative, which is almost always of a purely extempore and local character. When once within the ruins, blankets are thrown off and the forty boys make, with a background of light-coloured, lichendraped walls, a dark mass of humanity, for, save their insignificant aprons fastened with a bark string to their waists, 
and their necklaces of blue beads and amulets, and brass bangles on arm and leg, they are practically naked, and the sun shines on their glossy chocolate-tinted skins as on burnished metal. The Makalanga have exceedingly strong social instincts, and prefer to work together in one mass even in a small area. To separate them into small gangs would mean little or no work done.

On wet days, or for a few succeeding days, the work is confined to carrying out blocks, which have either fallen from the walls or been piled up by the long succession of archæologists and gold relic collectors who have worked within the ruins. These are carried held up high over their shoulders at arms' length, or else on the tops of their heads, where natives carry anything from the size of a pill-box to a $40 \mathrm{lb}$. load. They never carry anything with arms downwards. In fine weather, leaf mould full of roots and seeds, and past excavators' soil-heaps are removed outside in boxes, the narrow entrances precluding the general use of wheelbarrows. Relics would be lost in the wet and clayey soil were it removed in wet weather. All the boys work en masse, each picks up his box or block, and when all are loaded up they start in one unbroken line for the débris heap outside, singing choruses with recitatives all the way out and on their return. The boxes are carried on one shoulder, a knobkerrie being used as a lever over the other shoulder to hold up the back of the box. The procession of boxes seems interminable-"Milkmaid," "Armour Beef," "Lime Juice Cordial," "Highland Whisky," “Raisins,” “Coleman's," “Mazawattee,” supplemented by buckets, but above all by "Nectar Tea." Each box has a branded notice uncomplimentary to ships' boilers. But "Nectar" is the great triumph of Zimbabwe.

It is a huge box, carried on two short poles, with "Nectar Tea" emblazoned on its sides in blue and white. It courtesies and bobs its way to and fro in a most stately fashion, and after it has left the pile which is being removed, 


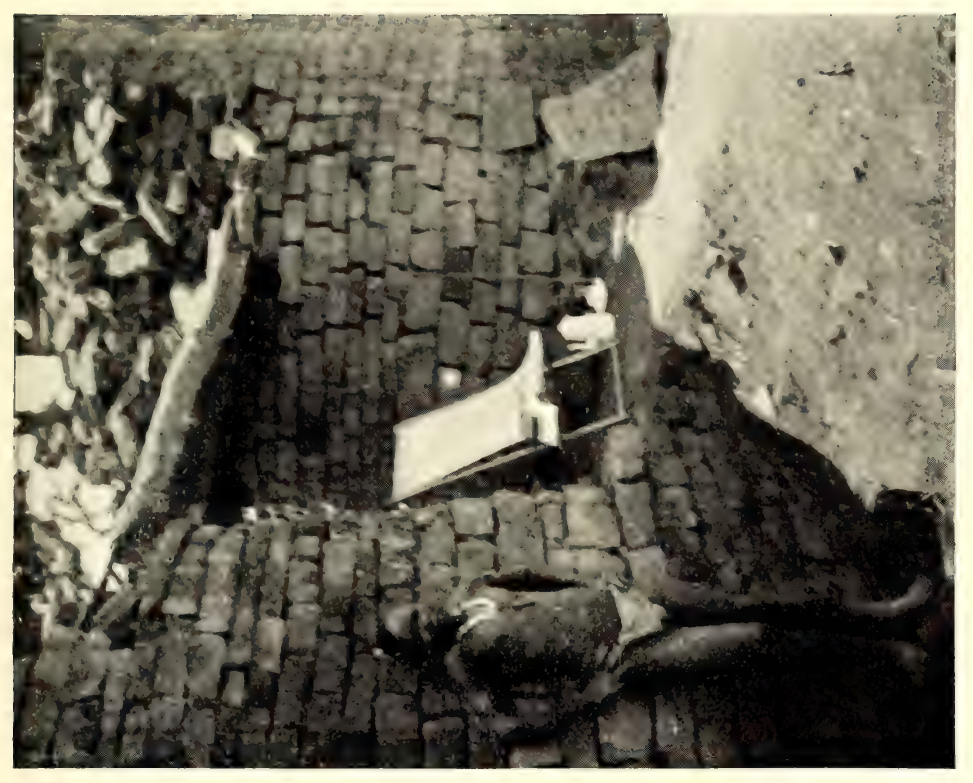

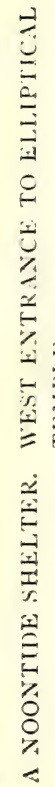

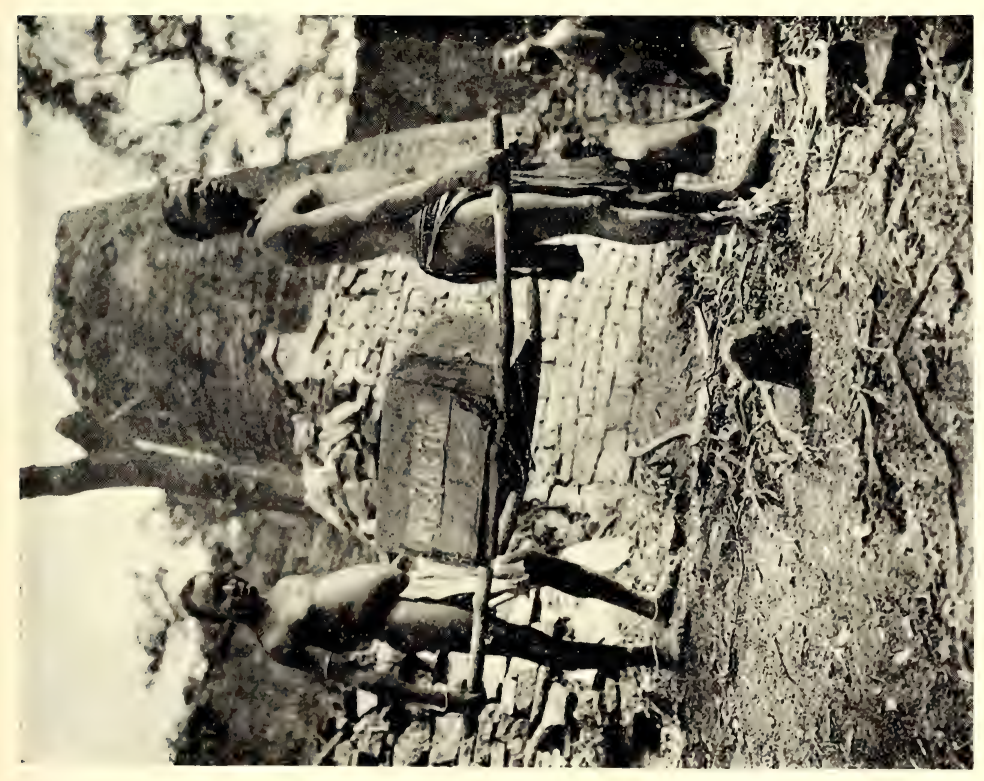

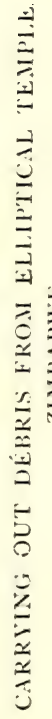



a great reduction in the débris remaining can be noticed. The boys have no particular affection for this omnibus. They are believed to bulala (knock about) this box on purpose to ruin it, for several times a day they will bring it with no sorrow on their faces with the information that the box is meningi gura (plenty sick), each time fatally gura, but a few nails cure it of its injuries. Long may "Nectar Tea," in the interests of archæology, continue to courtesy and bob its way through the western portal of the Elliptical Temple.

The boys when working well will in a day do about as much work as a quarter of the same number of English labourers. They are inclined to be industrious when the Baba is in sight, but they immediately drop down on their haunches with knees up the moment his back is turned. This is a moral certainty. Then singing ceases, for when working they are always singing. Any excuse for a passing diversion is immediately seized upon. On the shout of inyoga (snake) they drop their tools at once, seize their knobkerries and jump into the jungle heedless for the time being of thorns and creepers. In respect of snakes they are not cowards. Inside the bush a perfect pandemonium is going on which never ceases till either the snake, generally a python or a black mamba, has been slain or has escaped into some pile of ancient blocks.

Another day, after a brief absence from the temple, I found about forty women and girls from Mogabe's kraal had arrived in the temple to watch their sons, brothers, and sweethearts at work. This they frequently do. The boys on this occasion, believing $B a b a$ to be further off than he really was, were chasing the dusky Cleopatras up and down the parallel passages, in and out of the enclosures, and dodging them round the base of the Sacred Cone. One burly Junoesque, bead-and-bangle-bedecked mother was having a most delirious and frantic ride round the temple courts in our only wheelbarrow, which is an iron one. As the barrow 
bumped along at full tilt against the stones it would each time shake her up terribly. The shrieking, screaming, and laughter of the girls and the yelling of the boys made the temple ring with a noise sufficient to make the priests of the ancient Phallic cult whirl in their graves with horror. But -Baba! and in thirty seconds the boys were all hard at work with most pious looks on their faces, and singing a well-known mission hymn. These great, fine-grown, franklooking fellows, with their enviable ivories and provokingly pleasant smiles, are far worse than little children to manage. Their characters are perfectly riddled with frivolity, and their minds astonishingly mercurial. Every incident they notice is to them humorous, even the preservation work at the ruins is regarded by them as a sheer waste of time. Not one of them if he tried hard could keep silence for two minutes together. He must either talk, laugh, sing, whistle, or perform some absurd antic. Their utter guilelessness and naive simplicity are in many respects both surprising and entertaining. To blame them before their fellows kills what little spirit they possess for work, while praise, even though barely merited, will cause them to redouble their efforts. To be in the slightest degree friendly or familiar with them is to completely destroy one's influence over them; the granting them any favour is regarded by them as an undoubted sign of the donor's weakness, and of the virtue of gratitude they are absolutely destitute.

One wonders at the dual character which each possesses. In some respects a Makalanga is more moral than many a European, while in others the depth of his immorality cannot be plumbed. In some matters they are as pure-minded as Adam and Eve in the Garden, and know not that they are naked. In their hands their women's virtue is safe. But contact with the "educated native," especially a Cape Kafir, before their minds are prepared to receive even the most elementary education, works on them untold mischief. 
But the boys may be divided into two classes, one industrious and honest, the other lazy and thieving. These diverse characteristics appear to run in separate families. M'Komo stole Mrs. Theodore Bent's honey. Three of his nephews in my employ stole meat, sugar, tobacco, or anything else in the kya (hut) they took a fancy to. Another nephew proved to be a veritable Iago in a moocha (a small leathern apron worn by men), and was always making mischief, not only among the boys, but also between the boys and the Baba. Of course these members of this family, notwithstanding its exalted connections, were warned off the camp, and are not allowed to be seen visiting it. Brothers of unsatisfactory boys are never taken on the works, but should there be any vacancy at the end of a month, and the supply of labour is greater than our demand, the places are offered to the brothers of trustworthy boys, and these always prove a great success.

But to return to the Temple. About eleven o'clock the kya boy arrives with half a dozen wee picaninnies carrying kettle, tea-pot, etc. The kya boy comes in for an amount of chaff from the gang. They call him a "Moccaranga shentilman," because, for two hours in the morning and for the same time in the afternoon, he can lala (rest), seeing that he starts work at 5.30 a.m. and is not free till about 8 p.m. Further, he has perquisites in the shape of meat, tobacco, and tips from visitors, and also in a diluted form acts as a sort of baas (master). But the kya boy takes all the chaff in good part, and gives back quite as much as he receives. The picaninnies, armed with bows and arrows, indulge in target practice, and make it ruinous to stick up lunch biscuits at forty paces.

Probably Mogabe with his headmen will arrive to watch the boys working, and then I know what to expect. It is bound to come. After a long silence he remarks that he is glad to see the Baba. Another long silence, and then-"A 
Baba always gives presents to his children." I assume a complete indifference to his remark. Mogabe is diplomatic, but his diplomacy is very thin. After a long pause he observes- "The Baba will make me a present of money." I inform him I have none to give. Another long pause ensues, then, pointing to a hatchet, he remarks- "The Baba will give me this." I explain that the hatchet is the property of the Chartered Company, and not mine to bestow. He fails to see the point of my statement, and bluntly says so. He pauses to consider what else he can ask for, and after a long cogitation says "Salt, Baba." At last Mogabe is reasonable, and I instruct the kya boy to fetch him half a cup of salt. Mogabe is profuse in his thanks, and his speech is floreated with eulogies of the Baba.

Now my turn begins. Mogabe and the elders of his headmen have a sixty years' knowledge of the ruins, and he is acquainted with everything that took place at Zimbabwe during the time of Chipfuno his brother, who was the previous Zimbabwe chief. Pointing to a gap in an obviously ancient wall which had been rudely filled in with blocks, I ask him who filled up the gap. After a long consultation with his headmen, he says that the Makalanga did it to keep in the cattle, for this part of the temple was used as a cattle kraal, and that was when Chipfuno was a young man. Another gap was filled up when Chipfuno was a young man. I then hand him over some pieces of pottery with geometrical patterns not at all crudely executed, which we have just unearthed, and ask him if the Makalanga made them. For ten minutes he and his headmen are closely examining the pottery, noting the quality of the clay, the correctness of the pattern, and the glaze on both sides. Yes, the Makalanga made it, but not the Makalanga who are now alive, nor their fathers' fathers. The pottery was of Makalanga make, but meningi dara (very old). The assertion he emphasises by gesture, manifestly meaning a great age. 


\section{A DAY AT HAVILAH CAMP}

Mogabe thus confirms the expert opinion of antiquarians that this class of pottery was made by the mediæval Makalanga. Mogabe comes to see us at every place we work at, and his opinion on "finds" belonging to recent generations of Makalanga may be taken, so old hands affirm, as perfectly reliable. The information so obtained is valuable both as to later walls and to articles found.

Sometimes the chiefs Baranazimba or Chenga arrive at the ruins, and an indaba (conference) as to "finds" and built-up entrances always takes place, but the weekly indaba with Mogabe always commences with the same old rigmarole. It is a sheer waste of time to discuss anything ancient with them, for since the new jail at Victoria has been built they all solemnly declare that the marung $u^{1}$ (white men) built the ruins for a "Tronk!" All their old poetic explanations as to the presence of the ruins, such as they were built "when stones were soft" or "when days were dark," have now gone to the winds. The ruins were prisons!

But the kya boy has arrived with the salt, and Mogabe is happy. He wraps the salt up in the corner of his blanket, and is off to his kraal at once. When any marungu arrives in a Cape-cart at the camp Mogabe is down the side of his kopje a few minutes afterwards, and arrives there also. It is the same old story, only then the visitor is given his opportunity of demonstrating his liberality. "I am glad to see the Baba. A Baba alway gives presents to his children." Mogabe, like his fellows all over South Africa, is a born beggar, and yet he possesses seventy head of cattle, is rich in wives, grain, and labour, rules over a large area of country, receives a monthly allowance from the Government as chief, and a further allowance for warning unauthorised prospectors for ancient relics from the ruins.

${ }^{1}$ In Chicaranga the Zulu $l$ becomes $r$. The Sebele $l$ in Abolse (see pp. 3, I7, 133, I34, and 19I The Ancient Ruins, 2nd edition) becomes r-or Barose, Barotsie, etc. 
Mogabe's day has gone. Still, notwithstanding his true Kafir fawning nature, there is something about the aged chief one cannot help respecting. $\mathrm{He}$ is intelligent, and he looks it, and his face, if white, would be taken for that of an educated European, for, like most Makalanga, he has little or nothing negroid in his features. Before the advent of the Chartered Company he was constantly at war with his neighbours, sacking villages, kidnapping women and children, and generally murdering. His last fight was in November, I 892, when he engaged the Amangwa people, the battle taking place just outside the western wall of the Elliptical Temple. His own people seem to somewhat neglect him, except in some tribal arrangements and in affairs in which he represents the Native Department. Formerly it was the rule that he ate first and his people afterwards; now he comes into our camp at skoff-times and asks the boys for some of their rapoko, porridge, and if they should happen to be mindful of his presence they will pass him a handful, but sometimes he sits there unheeded. He has now sold, perhaps for a mere song, the famous necklace of Venetian beads which Bent failed to induce him to part with. But there is a look in his eyes that gives one the impression that the old man does not at all relish the benefits of civilisation, and that he is pining for a return of the good old days of blood-shedding. ${ }^{1}$ Mogabe's biography would be worth writing.

But Mogabe is in my good books, for he gave me permission to move some Makalanga graves made in certain of the passages on the Acropolis. Bent merely told Chipfuno that he was going to move the selfsame graves, and he at once withdrew all the labourers, and this not only caused Bent considerable difficulty, but he was not afterwards allowed to open the passages. Twelve years later Mogabe gives his consent on the understanding that he is given half

1 The Mogabe-Handisibishe is called Benzi, "the quarrelsome man," owing to his frequent quarrellings with the chiefs of other Makalanga tribes. 
a cup of salt, that the remains were to be properly reinterred, and that the boys who did the work should be allowed to go to their kraals to purify themselves. This purification is no mere excuse, but is an actual cleansing of those engaged in this particular undertaking. The boys informed me that until they had washed they could not eat, and that their fellows would keep away from them. The bones were not touched by hand, but were moved with two sticks. Once I picked up a solid copper bangle, which must have come, judging by the presence of scattered human bones, from some grave disturbed years previously by some excavator for relics. The boys were genuinely horrified when I touched it, but more so when I put it on my wrist. They said I must take it off at once and wash myself, and this horror at what I had done possessed them for several days and was a constant theme of conversation.

Tjiya! (cease work!) is sounded, and the boys take up the cry, and spring like chased buck helter-skelter through the western entrance into the hot, sultry atmosphere, singing, laughing, yelling, and caterwauling, just like boys let out of school. The relentlessly broiling heat and glare of noontide make one long for the beautifully cool shade of the huts.

Arrived at the camp, some of the boys lie at full length on the hot boulders and so take sun-baths, others resume their own carving or other work, some make music, or play with dollasses, or fence, while the majority gather round the various sets of game-holes and play isafuba, but there is a camp rule, found by experience to be necessary, that isafuba cannot be played until the cooks state that the pots have commenced to boil. So fascinating is this game that formerly we found the cooking operations often became neglected.

Isafuba is one of a group of games, the origin of which is explained on pages 79,80 of The Ancient Ruins of Rhodesia. In our camp are several sets of game-holes; one set has 
four rows of sixteen holes each, and another two rows of twelve holes. This last is generally patronised by the picaninnies. Some of the isafuba games have different moves, numbers of holes and counters, and the games vary slightly in different districts.

From two to five players sit on each side. Each of the partners on either side appears to have an equal right of moving the counters. The two lines of holes near each set of partners is not intruded upon by the counters of the opponents, but opponents clutch up the counters of the opposite side when such counters have no counter either in the hole behind or in front, and this snatching up of counters is governed by rules which in some moves closely resemble those of chess, while double counters in a hole are as influential as kings in draughts.

Some of the moves strongly remind one of "fox and geese," each side moving in turn, and later in the game, when the holes are full of counters, each side chases the other along parallel lines of holes to the end of the set. This chasing is a cause of great excitement, and is concluded in a perfect babel of shouting, each player as he moves a counter in the chase calling out in-da! and when the final hole is reached, $g a$ !

Always while in camp there is a perpetual shouting of in-da! in-da! in-da! followed by the triumphant shout of $g a !$ The subject of heated discussion during the game is as to the amount of cheating the other side has effected, and the tumult caused by the discussion of this topic, especially with an extraordinarily talkative people like the Makalangas, can only be but partially imagined. The perpetual in-da! in-da! in-da!-ga! trespasses into one's dreamland. After a week of this never-ceasing in-da! the sets of holes were ordered to be removed to a more reasonable distance from the hut door; still, one cannot even now escape this perpetual and monotonous din. Yet in all 
their excited disputations they have never once got beyond mere words. The picaninnies sometimes join in at the larger sets, but a prompter always assists them.

It is the custom for the losers, and not the victors, to record the state of the series of games. This is done by placing large stones, one for each game lost, on the side where the losers sit. The losers invariably have to provide the stones. When all the large stones within arm's reach have been used up as records and the losers have to get up to fetch a stone, there is general laughter in the camp, even from those who are not immediately watching the game. The stakes are for "sisspences," or for doro (native beer), but both winners and losers share alike. Towards the end of a month, when wages are becoming due, the game causes increased excitement, and plenty of doro is brewed by speculative villagers to meet the probable demands of the boys. ${ }^{1}$

The two most pernicious vices of the Makalanga are their inveterate love of I'daha (wild hemp) smoking, and of doro drinking.

The former acts as opium, and incapacitates for work, dulls the intellect, destroys every atom of will-power, and tends, if persisted in, to shorten life. An I'daha smoker is readily known by the glazed look in his eyes, and by his miserable appearance. On our arrival here I'daha pipes were introduced into the camp, but they were very soon destroyed, and the smoking of I'daha is now an offence punishable by dismissal without mali (money). This rule has effected a great improvement in the general tone of the men and in their capacities for work. So injurious to brain and health is this vice that in some parts of South Africa I'daha smoking is prohibited under a penalty. One of the most distressing features of this practice is the painful fit of loud coughing which always follows the use of the pipe.

${ }^{1}$ See also Isafuba, Ancient Ruins, pp. 79, 80, I40, I52, 268. 
Doro, brewed from rapoko (a red millet), is drunk very extensively by the Makalanga in this district, seeing that this part of the country yields grain in such enormous quantities. But the natives do not regard doro as a mere beverage. At new and full moons, or at the rising or setting of the Pleiades, which determine the sowing and harvesting seasons, doro is provided by the native farmers in lieu of wages, and on these occasions it is drunk most extensively by people of all ages. The men delight in gulping it down in quantities with the avowed and deliberate intention of getting drunk as soon as possible. The state of stupefaction induced by doro is one of their most exquisite delights. On Saturday mornings the one topic of conversation of the gang is as to how much beer they will drink on I'zhuba Kuru (Sunday), how soon they will get drunk, and what they will do when they are drunk. On Mondays, in spite of their "large heads" and sodden appearance, discussions take place as to who were the most drunk. The one who lost most control of himself is considered a hero. In their opinion the man who was most intoxicated honours himself, and can afford to boast.

Even those who are in many other respects the most hopeful young men equally delight in getting absolutely intoxicated. The lads from eight years of age imbibe doro most copiously, while boys of twelve get as drunk as their seniors. The brains of the natives are so small that the doro acts upon them speedily, and two hours' drinking will undo all the benefit of two years' contact with civilisation. Then all their innate savage nature reasserts itself in every violent form, and their swaggering insolence, inspired by doro, is intolerable. But the evils of I'daha smoking and doro drinking are not of modern origin, but are ingrained in their blood and bone by many past centuries of devotion to these practices.

The rarefied air of these highlands conducts sound over long distances, and triangular conversations are constantly in progress between the villagers at Mogabe's kraal, our boys 


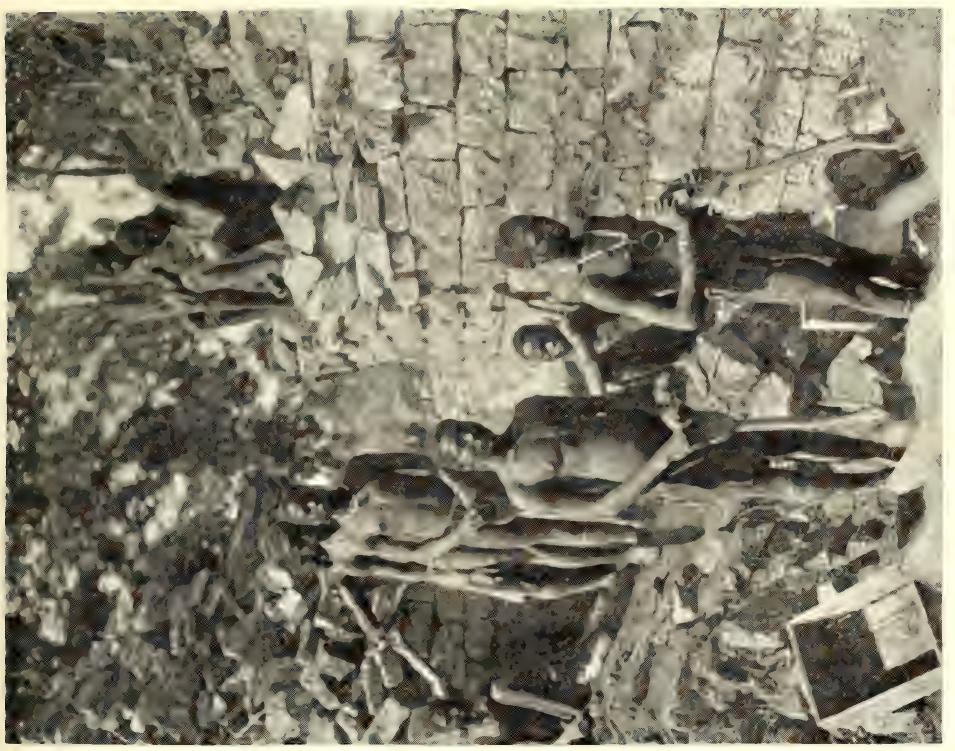

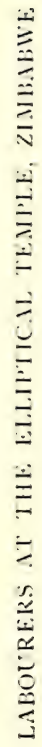

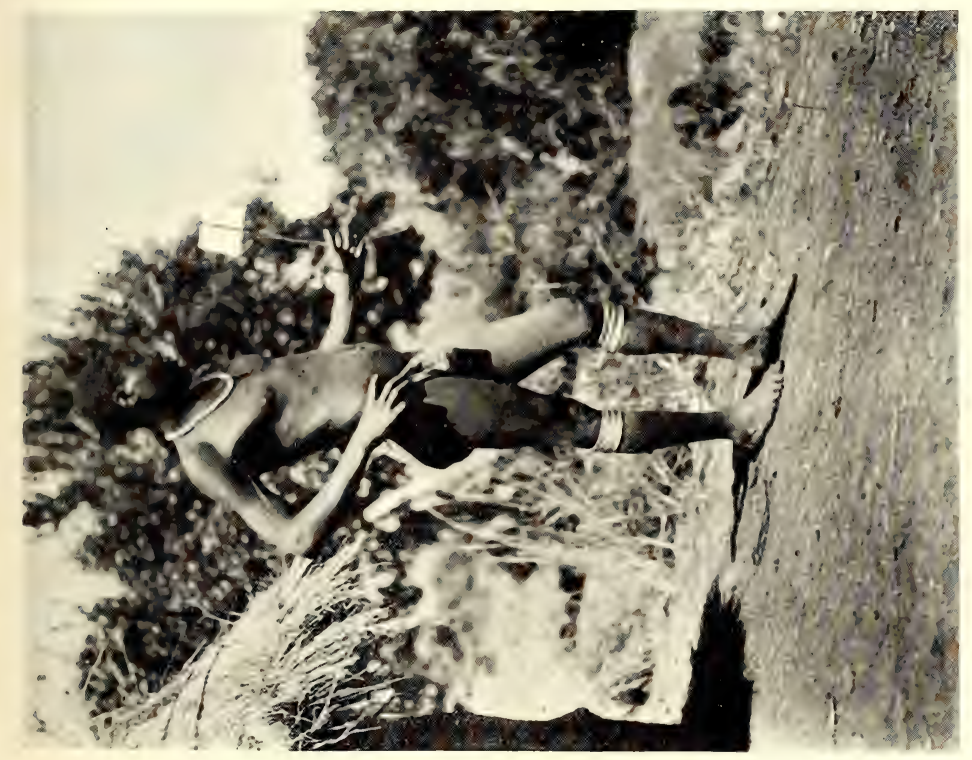

$\vdots$
$\vdots$
$\vdots$
$\vdots$
$\vdots$
$\vdots$
$\vdots$
$\vdots$
$\vdots$
$\vdots$
$\vdots$
$\vdots$
$\vdots$
$\vdots$
$\vdots$
$\vdots$
$\vdots$
$\vdots$ 

at the camp, and those working on the Hill Ruins, though each point is at least a third of a mile distant from the others. These conversations are carried on without the slightest straining of the voice or even shouting, the secret apparently being the slight raising of the voice and speaking very distinctly and very slowly. From their vantage position on the hill the boys are always on the look-out for natives passing and repassing between the villages. While the passing natives are, as one would believe, outside the hearing limit a conversation with the boys has for some time been in progress. Our boys will give the usual salutation, and if this be replied to all well and good. But should it not be replied to, or not promptly, the boys will at once start in chorus to slang the passer-by and all his relatives, commencing with his mother. So long as the passer-by is within earshot, so long do these slanging matches continue. Each boy endeavours to cap each previous remark with something more pungent, and as he succeeds the rest cheer him. Natives state that the sound of their voices travels quickest and furthest in the early mornings.

The visits of marungu to the ruins are highly interesting occasions for the natives. The news of any approaching arrival is shouted down from Mogabe's kraal a third of a mile away, for from Mogabe's Kopje there is a fourmiles' view of the road from Victoria. Long before the Cape-cart or horsemen can enter our valley from over the ridge between Rusivanga and Mogabe's kopjes it is known where we are working, how many visitors are arriving, the description of vehicle, and if there is a lady in the party. Arrivals always attract a score or more naked picaninnies, who accompany the conveyance from the ridge at the foot of the Rusivanga down to the camp. But such visits are infrequent, and three weeks or a month pass without a white man arriving at Zimbabwe, and when, after such intervals, they do arrive, their faces look strange because they are white, 
while the sound of the English language is strikingly odd. On some rare occasions as many as three camps of visitors have been fixed up on the outspan. A patrol of the British South Africa Police calls about once a month, and the troopers generally introduce themselves with some such salutation as "Well, still alive? Not murdered yet?"

Humorous incidents are not absent in the work of excavation in the ruins. For instance, after working for some hours in a trench near the Sacred Enclosure, and passing all soil over boards and through fingers in the search for relics, a common clay pipe of English make was found intact at a depth of over $3 \mathrm{ft}$. At another spot, after hours of careful but unrewarded work in a trench, at a similar depth a very late brand of soda-water bottle was found. Both these finds delighted the boys infinitely more than had they unearthed a cartload of phalli or other prehistoric relics of value. In some respects the boys are extremely practical. The question "aliquid novi ex Zimbabwe?" can in two senses be answered in the affirmative. Such modern articles found "at depth" afford only another proof that the soil in the interior of the temple, as stated elsewhere, has been turned over and over again by archæologists, and also by unauthorised prospectors, for ancient gold and other relics.

After tjiya, when the day's work is done, there is still an hour or so of daylight left, and this is usually occupied in wandering among the kopjes or along sequestered valleys, keeping an eye open for fresh traces of the ancients, or in examining and measuring some one of the minor ruins which stud the valley, or in calling at a village to arrange for labour, or in looking out for buck and guinea-fowl for the pot.

Meanwhile the sun is setting in a gorgeous west, and the golden glow is already fading on the temple walls. Then come the shadows of night, and these settle down rapidly. By the time the hut is reached the kya boy has lit the candles, laid the table, and is ready with the skoff. The boys 


\section{A DAY AT HAVILAH CAMP .}

are sitting round their fire or finishing a game of isafubu in the semi-darkness. Their evening meal is being cooked. One of them has brought a gourd of doro, and another a pot of fat, in which each handful of porridge is dipped before being eaten.

Sitting on the stoep of the hut at this time of the day is a perfect rest. The air is agreeably cooled by a light breeze, which is laden with the scent of verbena. The night is calm and peaceful. Large bats fly swallow-wise, fire-flies dart in all directions, glow-worms shine steadily in the grass, and birds, frogs, and insects join in mild choruses. The call of a boy in our camp to some companion up on Mogabe's Kopje is repeated half a dozen times by the precipices of Zimbabwe Hill, where the echoes die out in a series of sharp raps. The large full moon rises serenely from behind the trees on Beroma Range, and bathes the country in delicate soft light, imparting a greenish-grey tint to the mist-veils which fill the gorges, throwing a deeper suggestion of mystery and awe over the wide expanse of bush where the lion holds his court.

The boys, having finished their meal, now indulge in post-prandial rhetoric, and dialectic ping-pong. The ruddy glow of the fire reddens the huts and shines on the naked bodies and limbs of the crowd, making them resemble polished ebony, while as their tall and well-proportioned figures with kingly walk pass and repass in the flickering lurid light they appear to resemble shades from across the Styx. Such a scene is at least Dantesque, and to many might seem weird. But the boys are as happy as their hearts can wish. Their joviality is irrepressible. Harmony from their instruments, rhythmic chants, peals of laughter, wild recitatives, constant talking, with perhaps a wrestling match and a war-dance executed in simulated form thrown in, fill up two hours, by the end of which they are all under their blankets, sleeping and snoring as only natives can.

"Porridge," the kya boy's under-study, and eight years 
old, has brought in the hut door, which also acts as drawingboard and stoep table, and has gone to the kitchen-hut, where he rolls himself up in his tiny blanket.

An occasional bark of a baboon or wolf, or yelp of jackal, or hoot of owl, is heard in addition to the usual nightjar and frog choruses. The sounds of the village drums, and of singing and dancing at Mogabe's or Chenga's kraal, where the full-moon feast is being celebrated, are wafted down to us. The night is perfectly lovely, but for Havilah Camp the day is past and over.

But the moon-itself a dead world-looks down upon the ruins of a dead city and on the graves of a forgotten race, as it has done ever since the stern policeman Fate ordered these ancients to "Pass on!" 


\section{CHAPTER IV}

\section{ZIMBABWE DISTRICT}

\section{Chipo-popo ${ }^{1}$ Falls}

HESE are about two miles and a half north-east of
Zimbabwe, on the Motelekwe Road. The Chipo-popo, which is a perennial stream with its source on the south side of the Beroma Range, crosses the road and runs towards the Moshagashi River, which it joins four miles lower down. Immediately to the north of the drift (ford) the stream descends abruptly down granite ledges into a deep ravine, on the east side of which is Chipo-popo kraal. The falls are reached by leaving the road at thirty yards on the Zimbabwe side of the drift and going between some large boulders on the north side of the road. This is an interesting spot at any time, but especially so when rains have swollen the torrent. A path from Chipo-popo kraal leads to Oatlands Farm, four miles north-east of Zimbabwe, where Naidoo, an Indian, has an extensive market-garden. The walk to the falls and to Oatlands Farm is a very easy afternoon's exercise.

Frond Glen.-This is a very pretty, secluded, and sheltered spot in a deep ravine about half a mile east of the SouthEast Ruins. A stream from the valley, which extends eastwards from the Elliptical Temple, passes through it in a south-easterly direction. On the banks of this ravine are to be found tree-ferns, palms, royal ferns (osmunda regalis), and maiden-hair ferns. The scenery and atmosphere of this glen

\section{Waterfall (Chicaranga).}


are said to be somewhat similar to those of some tracts on the southern slopes of the Himalayas. To reach the glen one should leave the Motelekwe Road at three-quarters of a mile east of Havilah Camp, cross the small valley on the south to the South-East Ruins, and then go due east from the ruins, the land descending towards the glen.

Lumbo Rocks.-These strikingly picturesque cliffs, which form a prominent landmark for miles around, are a little over two miles south of the Elliptical Temple, and are approached by the native path leading from Zimbabwe to the Morgenster Mission. These granite crags rise perpendicularly for about a hundred feet from out of the summit of a rocky kopje, and form a rude square-sided column of precipice, which is divided into four portions by very narrow fissures, which run through it on all four sides from base to summit. Visitors should climb this hill and inspect the rocks. There are numerous granite boulders split into fantastic shapes all round this kopje. The headman, Lumbo, now has his kraal about a third of a mile to the west of these rocks. Chipadzi's kraal lies one mile to the south-east of Lumbo Rocks, and half a mile nearer Zimbabwe, and on the west side of the path to the mission is the deserted kraal of Baranazimba, situate on a high rugged kopje among gigantic boulders which rendered the kraal most difficult of approach. This chief is a relative of Mogabe. His new kraal is on a kopje close to the Victoria-Zimbabwe Road about four miles from the ruins.

Morgenster ("Morning Star") Mission.-One of the prettiest walks from Zimbabwe is to this mission station, which is barely three and a half miles distant in a south-south-westerly direction. The path passes between the Elliptical Temple and the Bentberg. About two miles along the path and close to the right-hand side is Baranazimba's old kraal perched up high among the boulders of a kopje. The path then crosses 
a nek between Baranazimba's and the Lumbo Rocks, and descends into a narrow valley and up a high ridge, on which, cutting the sky-line, is a tall and prominent Finger Rock, which is only a few hundred yards from the mission, which lies just over the ridge. Morgenster is on a much higher elevation than the Zimbabwe Valley. The walk is highly interesting to anyone fond of romantic scenery. Rugged kopjes, with cliff-boulders on which huge granite masses are most delicately poised, lie along the right-hand side of the path for a great part of the distance to Morgenster.

The mission was founded in I89I by the Rev. A. A. Louw, of the Dutch Reformed Church, Dr. John Helm, the medical missionary, joining the station in I894. Several other European missionaries are attached to the staff, and there are numerous outlying stations.

The mission settlement is ideally situated on the south face of a high ridge overlooking the Mowishawasha Valley on the south and the N'Djena Valley and Motelekwe River on the south-east. Its position is marked by clumps of tall blue gum-trees. The buildings comprise the residence of Mr. Louw, the houses of Dr. Helm and other missionaries, and a school-house. Morgenster is celebrated for its banana plantation, the number of its lemon trees, and its large irrigated gardens. The Mahobohobo trees are very numerous in the vicinity of the station.

The district in which the mission is situated is known to the natives as Amangwa, this being in former times the country of the once powerful tribe of Amangwa, who were driven away from the Zimbabwe district by the present local Makalanga on their arrival almost seventy years ago from the Sabi district. A kopje within a third of a mile on the east side of the mission was, until very recently, occupied by a local tribe of Makalanga, who built up rampart walls of unhewn stones to fortify the kopje against the attacks of the Matabele about 1893 . 
Morgenster is also celebrated for the immense panoramic view of the Motelekwe Valley, extending for at least forty miles, where the tumbling sea of rugged kopje summits fades into the blue distance. The view is so extensive, impressive, and grand that one can never tire beholding it. As far as the eye can reach the land can be seen descending towards the south. The nearest point of the Motelekwe River to the mission is four miles. There are a great many villages in the valley.

A peculiar interest attaches to this view of the Motelekwe Valley, for along it appears to have been the main route of the ancient gold-seekers from the coast to Zimbabwe, and so into the interior of the country. Along the Motelekwe is a chain of ruins (see Ancient Ruins of Rhodesia), of which the Mapaku Ruins, eight miles east-south-east of Zimbabwe, are the nearest. Some of these ruins are of major importance, and two at least are decorated with the chevron pattern, and occupy areas almost as large as the main ruins at $\mathrm{Zim}$ babwe. This line of forts, or "blockhouses," is extended along the Sabi River for a considerable distance into Portuguese territory. In viewing this valley from Morgenster, the thought that within sight lies one of the ancient roads to the coast, and that along it passed the gold-and ivory-laden caravans, makes the contemplation of the Motelekkwe Valley one of absorbing interest.

The sharp-cut kopje with steep glacis sides, about a mile and a half south of the mission, is Rugutsi. This divides the scenery of the Motelekwe from that of the Mowishawasha Valley on the south. This also is a fine view, but not so extensive as that of the Motelekwe Valley. An absolutely bare, granite, balloon-shaped kopje lies to the west.

Two miles due south of the mission, in the Mowishawasha Valley, is a natural stronghold known as Wuwuli.

Wuruli.-This village, which is two miles south of Mor- 
genster, is situated in a deep and narrow ravine immediately west of the Rugutsi Kopje, which forms such a prominent feature in the landscape of the Mowishawasha Valley, as seen from the mission. Formerly this place was of considerable importance to the local Makalanga, for during the times of the Matabele raids the natives between this place and Zimbabwe took refuge in the very extensive caves which run under the north side of the ravine. A strong perennial stream flows through the caves. Here, in time of danger, women, cattle, and grain were hidden. When Mr. and Mrs. Bent visited this village, in I89I, the natives were opposed to their inspecting the caves, and they were only permitted to go a certain distance inside. Now that raidings have ceased the caves are deserted, save for bats, and we were permitted to view the caves without any demur on the part of the villagers.

The present chief is Bungu, a brother of the present dynastic chief Mogabe by another mother. The former Mogabe, Chipfuno, resided at this kraal as well as at Zimbabwe, and it was here he was shot in I 892 .

When visiting this village we saw a man undergoing a cure by blood-letting. Incisions were made in the flesh of the leg, and horns of yearling cattle placed over them. The air was then sucked out of the horns through small holes in the top, and the holes were then stopped with wax. The horns clung to the flesh, owing to the vacuum which drew the blood. Bungu's attention was drawn to an old iron-smelting furnace, on which was the usual female breast and furrow pattern. He said the natives did not smelt iron now because they could buy their garden hoes from the white men, and they were therefore saved the trouble of making them.

Mojejèje, or "Mystic Bar."-There are two of these mystic bars at Zimbabwe, one being on the Motelekwe Road, a quarter of a mile east from Havilah camp and opposite 
Middle Kopje (Chamananga), and the other about a mile from Zimbabwe, on the path to Bingura's. The one on the Motelekwe Road is formed by a bar of aphite crossing a granite glacis, over which the road passes, but the one on Bingura's Path is an arbitrary line drawn across a piece of granite, over which the path crosses. Each bar is at right angles to the path. At either end of each bar is a pile of stones, which show evident signs of having been hammered upon the bar for generations past. A native on a long journey, arriving at one of these bars, will take a stone from the pile on one side and with it tap the whole length of the bar, and lay the stone on the pile on the opposite side. Natives crossing the bar in passing between their kraals and their plantations, or going a short distance only, do not tap the bars. The idea in so tapping the bar is that by so doing the back is strengthened for the journey, and also that the man they are going to see may be at home, that the food will not be cooked till they arrive, and that their journey may be successful. There is no appeal to spirits or ancestors in performing this act.

Suku Dingle.-This is situated but a few yards from the left-hand side of the lower path leading from Zimbabwe to Morgenster, and is about 400 yds. north-east of Lumbo Rocks, about two miles from Zimbabwe. The dingle runs east and west, and is deeply wooded and narrow. This is a good spot for fern collectors. Down the dingle runs a happy little stream in perennial flow. The stream's bed is formed of white clay. The sides of the banks have been trenched extensively for a perfectly white soil. This is used by the natives for whitewashing the outside of huts and for making the check patterns on their interior walls. It is quite possible that the ancients knew of this spot, and used the material in making their more choice pottery. The natives know of no other place in this district where the same 


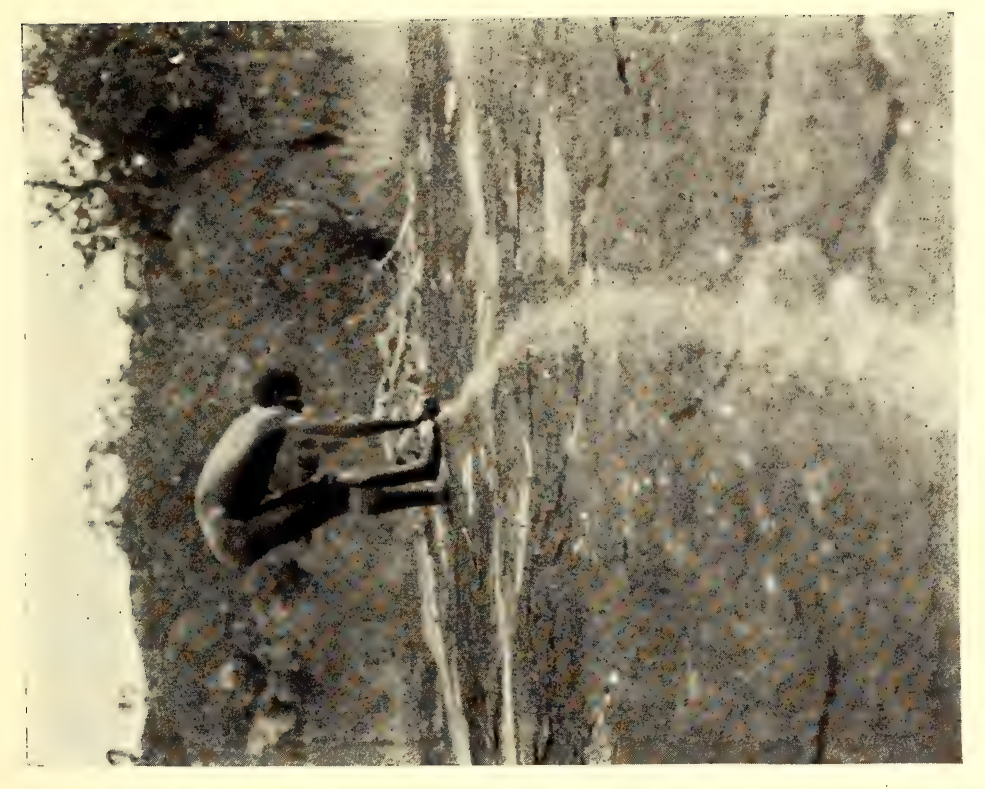

年

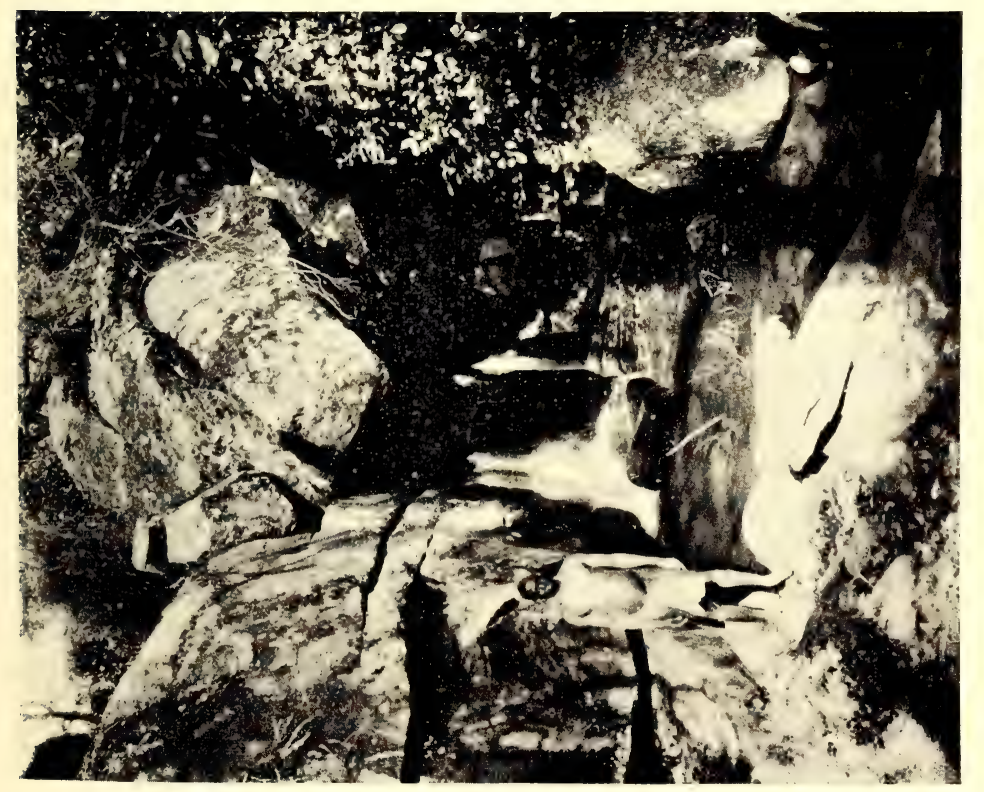

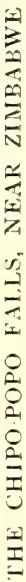



material is obtainable, and they come from many miles' distance to fetch it.

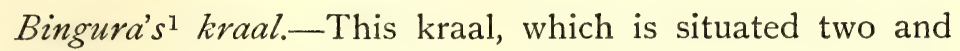
a half miles west-south-west of Zimbabwe, is well worth a visit, the walk itself being interesting and the situation of the kraal romantic. Possessors of cameras will find at this kraal ample opportunities of making "shots" at native life, as well as of taking typical views of the Zimbabwe scenery. The path to Bingura's crosses the valley lying between Havilah Camp and Rusivanga, and then leads up through native plantations to the broad nek on the horizon between Rusivanga and a kopje just west of the western end of the Bentberg. On the nek is another Mojejèje, or "Mystic Bar," crossing the path, where it passes over open granite. The ascent to the nek is for almost a mile, and the path from the nek dips down the western side of the ridge into a wide valley, and passes through the farmstead of a Basuto missionboy named "James."

The kopje on the summit of which Bingura's kraal is located is of horse-shoe shape, and the huts of the kraal are along the line of summit at intervals among huge boulders. The almost inaccessible position this kraal occupies, and its rocky surroundings, is also paralleled by the now deserted kraal of Baranazimba, which is on the summit of a very high hill protected by precipitous cliffs, and lies on the right-hand side of the path leading from Zimbabwe to Morgenster. The men from this kraal, like those of Chenga's, have not been spoilt by contact with white men as are many of the men of Mogabe's kraal. So far Bingura has not yet left his natural stronghold, but the probability is that once the neighbouring fields become poor through over-cultivation he may, like his neighbours, move his kraal into the open country.

Starting to ascend the hill, one hears at a hundred yards'

1 Bingura's people are Amangwa. 
distance the noise of falling water in a ravine at the north foot of the hill. The path ascends steeply up fissures and along narrow ledges, and over slippery slopes of black granite worn white with the passing of many feet. Bingura's hut is about half-way up the hill, and here on a small flat area are about a dozen huts, and on still higher ledges on the north and west faces of the hill are more dwellings almost hidden, even when near to them, among huge boulders, also many circular clay granaries perched on rocks out of the reach of white ants. The large number of these granaries testifies to the industry of Bingura's people. The tree boughs were festooned with mealie cobs drying in the sun. A large, flat rock was covered with locusts, and quantities of melons, pumpkins, and gourds were laid outside the huts. Women were winnowing rapoka corn and cleaning rice. Bingura's youngest wife, a fine and very goodlooking young woman, was sewing pink beads in chevron pattern on to her skin apron, and every man, woman, and child appeared to have some occupation. There were more manifest signs of business here than at any other kraal in the district. Here they have less regard for the need of apparel than any of the inhabitants round about. Bingura is a small man of about fifty years of age, but as agile as a buck, and has a quick shrewd glance. This is in every respect the most interesting village in this district.

Motumi's kraal.-This kraal is about one mile west of Bingura's, and is situate in open country and is worth visiting. Motumi is a very good specimen of a Barotse headman. He is fully seventy years of age, but is still hale, hearty, and straight. The features of the people at this kraal are very fine, and most of the men and boys are well-made. They are a very industrious people and never seem to be idling in their kraal. Motumi is above the average native in intelligence and can give an account of what is now Matabeleland 
long before the Matabele arrived, with long lists of placenames in that country as then known. Matgwain, his eldest son, is exceptionally intelligent. Motumi's people speak Chicaranga, and most of their characteristics and customs are also those of their neighbours, the Amangwa, to whom they are allied by long generations of marriages.

Chibfuko.-This hill adjoins the Mowishawasha Hill, which is about seven miles west-south-west of Zimbabwe. Washa is always associated in the mind of the natives with power and authority. Chib-fuko is never ascended by the natives. Either the hill itself, or something on it, causes them to revere or dread it. They never pass by without kneeling and clapping hands to it. It is said that they hear girls singing on its summit. The hill has a few caves highly suggestive in appearance of ancients and hidden relics. In this district valuable relics taken from the ruins have been discovered. Mr. Drew, Native Commissioner, is of opinion that many generations past some powerful Makalanga chief must have been buried on the hill and that this originated the native awe for the place, but the natives will not divulge the reason. To reach the hill Bingura's path must be taken.

Chipadzi's kraal.-This kraal is three miles south from Zimbabwe, and it may be visited on the same round as Suku Glen, Lumbo Rocks, and Morgenster. The walk is an interesting one, but there is nothing of note in the kraal itself, save the view of the Mapudzi Valley which it overlooks. The Morgenster path must be taken for 1,000 yds. south of the temple, where a well-defined native path branches off to the south-east. Later the path descends into a long, narrow valley till it approaches the kraal. The scenery in this valley is very fine. A small perennial stream, which at one point disappears under the ground for a quarter of a mile, flows down the valley, and on either side of it are palm trees 
and tree-ferns, each with a trunk some 3 to $8 \mathrm{ft}$. in height, also large areas covered with the royal fern (Osmunda regalis). Mahobohobo trees are plentiful, and orchids are abundant on the branches of the larger trees. The kraal comprises about a score of huts. There is a very grand view towards the east of the Mapudzi Valley down which flows the Mapudzi, a stream which has its rise on the east side of the Elliptical Temple. The ravine is at least $200 \mathrm{ft}$. immediately below the kraal which overlooks it. The two large and prominent kopjes on the south are Moroma, the nearer one, and Ragutsi. Morgenster is one mile west on the summit of the high land on that side.

Mapaku, or "Little Zimbabwe."-A walk to these ruins is one of the most interesting in the vicinity of the Zimbabwe. They lie south-east of Zimbabwe at a distance of less than eight miles, and the path runs through the romantic scenery of the Beroma Hills and the Motelekwe Valley. The best way to reach the ruins is through Chenga's kraal, past Mandiara's, which overlooks the lower country on the south side of the Beroma Range, and past the picturesquely situated kraal of Mapaku, which is at the foot of a tall cliff a quarter of a mile north-west of the ruins. The ruins are not extensive (see description of Mapaku Ruins, chapter xxi.), but are well worth inspection. To return to Zimbabwe the path may be taken to some large pools in the Motelekwe River, and from there through Gobele's kraal near to, and on to, Chipadzi's kraal, which is about three miles from Zimbabwe. Making the round journey as suggested enables the visitor to see native life as it is lived beyond the ordinary tracks of the white man. The best time of day to take this walk is to start just before sunrise and arrive at the ruins before the heat can be felt, and so return to Zimbabwe in good time for lunch.

Schlichter Gorge.-This is the ravine a mile to the south- 
west of Zimbabwe, down which flows the Mapudzi stream southwards. The walk in certain parts is somewhat rough, while in the rainy season owing to swollen tributaries and dense jungles of tall reeds it is almost inaccessible. To approach it one takes the path down the valley at the south foot of East Ruins, and directly east of Maund Ruins, and follows a small stream, the banks of which are shaded by trees and covered with royal fern. In the dry season there is very little water flowing, but there are always small pools. The path crosses this stream at its junction with the Mapudzi, the right bank of which must be taken. Where the sides of the valley close in the rocky sides of the hills must be climbed and then descended again. Along the course of the stream, which is densely wooded at the gorge, and flows between large boulders causing numerous pretty waterfalls even in the dry season, are some delightfully shaded pools, round which orchids and palms, and also ferns of rarer species, are to be found in great quantities. Where the gorge opens out at its southern end on to a wide valley a steep path, which leads up to Chipadzi's kraal, must be taken. From the kraal a fine view of the gorge is obtained.

Chicagomboni Hill (Nini district).-This is where the rediscoverer of the Great Zimbabwe ruins, Adam Renders, a German-American, lived from I868 to I87 I. Renders was known to the natives as "Sa-adama," and to this day the Makalanga speak well of him, and are particularly anxious that all Europeans should know that everything which "Sa-adama" bought from them he always paid for. Mogoma, an old man of exceptional intelligence, is the native chief in this locality, and knew Renders intimately, as the latter lived in his village and made it the centre for his elephant-hunting expeditions, on which Mogoma often accompanied him. One of Renders' hunting "boys" still lives in the neighbouring village of M'Tibi. Elephants in those days were very plenti- 
ful, especially in the Beka and Mali districts. Renders, the natives say, was a tall, strong man. He first arrived in $\mathrm{Mr}$. Stokes' wagon. Mr. Stokes was a well-known preoccupation pioneer whose native name was "Setokwe." Mogoma's kraal has been moved from the hill to the valley on the south-west side. The chief states he never knew of the waterfall near Renders' hut as described by Mr. Philips, and certainly owing to the formation of the rock it is difficult to see where there could have been one. In other respects the description of the spot where Renders lived in the Nini country (R. G. S. Journals, Dec., I900, and Feb., I90I) is accurate, save that Chicagomboni is eleven miles south-west of Zimbabwe. Mogoma has distinct recollections of the visits of Dr. Mauch and Mr. Philips to Renders about I87I, and states that Chirimbila, the paramount chief, also visited Renders at this spot. Both Renders and Dr. Mauch took Mr. Philips to see Zimbabwe, but they did not stay long there.

After living in Mogoma's village a little over two years. Renders moved to_Chirimbila's kraal, a few miles north of Mogoma's, and lived there for three years, when he died. He was buried close to the kraal.

The Chicagomboni Hill is at the south-western extremity of the Livouri Range, and on the west side has a precipitous drop of about $700 \mathrm{ft}$. Half-way up the face of the cliffs is a narrow ledge running across them, and at the northern end of the ledge, and on a raised rock platform, was Renders' abode, the remains of which can still be seen. Mogoma's old kraal was on this ledge. At the point where was Renders' hut, the cliff, at a height of $60 \mathrm{ft}$. above the ledge, protrudes outwards some $50 \mathrm{ft}$, thus forming a lofty and gigantic roof over the place were Renders lived. This is known as I-Baku - the cave. There are some narrow fissures in the face of the cliff which open out on to the ledge, but not one of these is worthy of the name of cave. In these Renders stored his trading goods and ivory. 


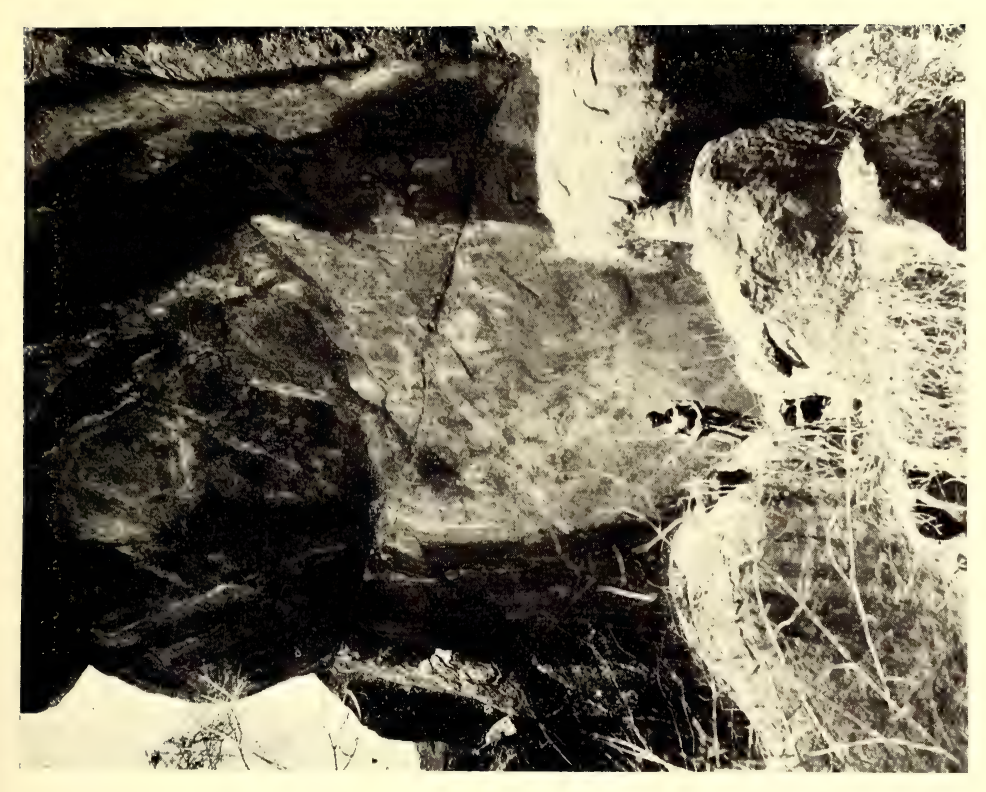

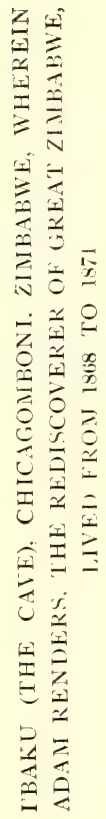

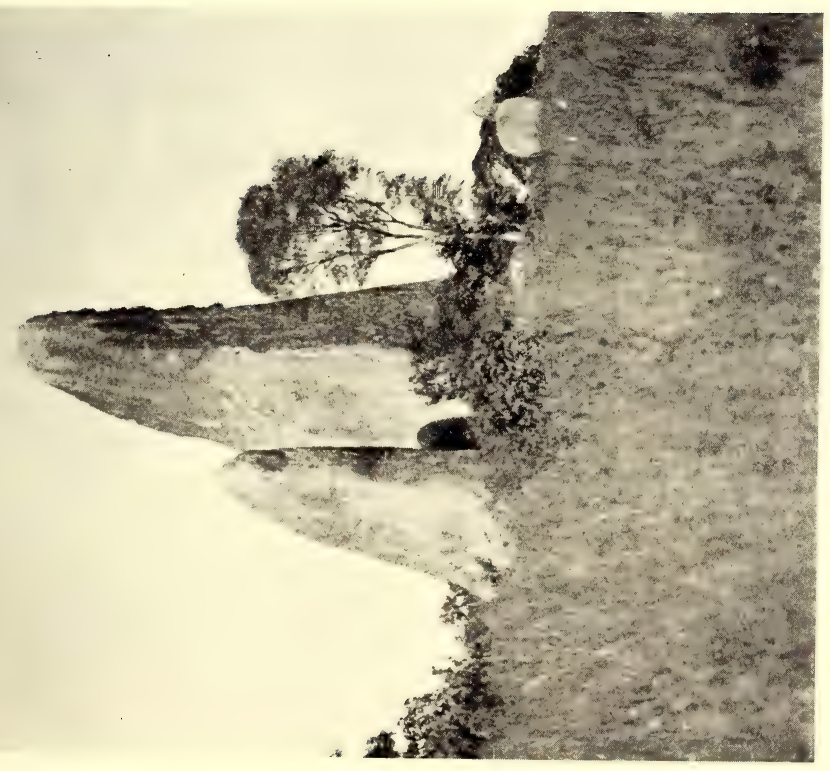

告 



\section{ZIMBABWE DISTRICT}

From this point is gained one of the finest and most extensive views in Rhodesia. It extends over M'Chibi district, the valley of the Tokwe, the Belingwe Hills, the Selukwe Hills, and the high ground further to the west and northwest. Three hundred feet directly below is Mogoma's new kraal and the adjoining village of Passi. Anyone staying a few days at Zimbabwe should not miss visiting this spot. The path from Zimbabwe leads past Motumi's and Masua's kraals, ascending all the way. Any of the "boys" at Mogabe's kraal would act as guide, but on arrival at the hill it would be well to send for Mogoma, or one of his headmen, as this would dispense with the necessity of descending some hundreds of feet to the valley, in addition to which the approach to the ledge being hidden among large rocks, it is difficult to reach it without a local guide.

A jaunt along the Zimbabwe and Motelekwe ancient road.One often wondered along what part of the country on the south or east of Great Zimbabwe lay the ancient road from the coast to this old-world metropolitan centre. Several suggestions more or less possible have been made since the preoccupation days as to the ancient road. That the ruins at Mapaku (the caves), seven miles distant towards the southeast, formed one of the posting stations on such a road may be considered as highly probable. Visitors have generally favoured the conjecture that the road from Zimbabwe to Mapaku must have passed to the north of the Beroma Range, which, seen from Zimbabwe, from which it is two miles distant, forms a continuous granite rampart some $600 \mathrm{ft}$. high, four miles long, and about one and a half miles broad, stretching from north to south. This range appears to present a solid obstacle to any approach from Zimbabwe. A detour round its north end and along its eastern base as far as Mapaku would make the distance at least ten miles. Moreover, on this line the kopjes and valleys have recently been 
thoroughly searched for any traces of ancient occupation, and none have been found. This therefore shows that such suggested route, had it actually been the ancient road, would have been altogether undefended for ten miles in an awkward country where the valleys, gorges, kloofs, and boulders would have provided splendid vantage points for attacks on the gold- and ivory-laden convoys proceeding from Zimbabwe to the coast.

Schlichter Gorge, running south at the east end of Zimbabwe Valley, has also been suggested as the ancient approach to Zimbabwe. Certainly, viewed from the Acropolis, this would appear to be the only natural road, but the position of the gorge, as can be seen when visited, negatives the suggestion. The gorge at its southern end is practically impassable. It is filled up at several points with solid sections of cliff which have fallen into it from the steep sides on either hand, and though the Mapudzi stream finds its way under these obstructions, the traveller must climb the almost perpendicular sides some seventy to a hundred feet to descend again beyond the obstructions, and further on repeat the climbing to pass a further barrier. In this gorge and on the summit of its cliffs there are no traces of walls to defend the defile, while an enemy could easily destroy the convoy, for the pass forms a veritable military trap. The distance from Zimbabwe to Mapaku in this direction would be at least nine miles.

Thus these two conjectured routes may for many reasons be dismissed as impracticable. But there remain two other possible routes to be considered, and both of these pass over the Beroma Range. The first, the one traversed by Mr. Bent and by all visitors to Mapaku, keeps to the Motelekwe track past East Kopje (Mazanda) till opposite Chenga's kraal, through which the path leads, and up the long trough-like valley on the Beroma Range, which depression is formed by the two parallel lines of the summits of the range. On 
the east line of summit are two depressions, and visitors are taken by the northern of these past Mandarali kraal, which is on the edge of the cliff facing east, then down the side of the range and along its base southwards to Molinije's kraal at Mapaku. This line of route makes the distance a little over seven miles. The local natives say that this path from Zimbabwe to Mapaku is a very long one. On it a careful search has failed to discover any traces of ruins.

A well-defined line of route protected at several strategic points by ruins of buildings indicates, beyond doubt, the actual road of the ancients. This makes the distance barely six miles, which is the shortest to Mapaku, and along it runs a much-frequented native track, used by the numerous long string of "boys" coming up, between the harvest and the sowing, from the districts of the Lower Motelekwe and the eastern stretches of the Lundi and Limpopo rivers, to seek work in the gold district west of Victoria. The ruins protecting this route form a chain of forts, which occur at intervals of about one mile and a quarter. On the Zimbabwe-Mapaku section of this route there are the remains of five substantial and well-constructed ancient buildings. It is along this section and a further section of the chain of ruins extending from Zimbabwe to Majerri that the trip here described was taken.

At 3.30 a.m. the six boys to carry blankets, food, cooking utensils, survey and photographic apparatus, botanical case, insect bottles, rifle, and a few tools, were waiting ready to start for the Majerri Ruins in the Motelekwe district, some twenty miles south-east of Great Zimbabwe. The moon was almost at the full, but would set an hour before sunrise. This is the best time of day to start on a walking expedition, as one may then hope to break the back of the distance before the sun's heat could be felt. Five boys took up their loads, each about $35 \mathrm{lbs}$., and our guide marched on ahead with the rifle. Our little party passed down the Motelekwe 
track till the East Ruins were reached. It was perfectly light and a greenish-grey mistiness invested the Valley of Ruins, the Acropolis, and the Elliptical Temple. Walking silently we passed through the ruins of the dead city to the point where the old road to the coast leaves Zimbabwe.

At East Ruins the track to the upper reaches of the Motelekwe, and to Arowi, rounds off at the foot of East Kopje towards the north-east. Our path took us slightly south of east. But the Beroma Range looked like a Titanic wall of granite cliff barring our passage in that direction. "Sheba's Breasts" (Sueba, black; marsgi, a corruption of the word meaning bald-headed), a pair of bare and round-topped hills on the southern end of the summit of the range, stand clearly against the greenish sky, and above them the morning star is just appearing. Sueba is marked on all maps of Rhodesia as "Mount Sheba"; but the names "Sheba's Breasts" and "Mount Sheba" are very modern indeed, dating back only to I89I. This pair of hills can very well be seen from the Tokwe, where the old Pioneer Road from the Lundi crosses that river. Evidently some member of the column familiar with Mr. Rider Haggard's works, knowing that Great Zimbabwe lay just behind those hills, bestowed these names upon them, and so they have been known ever since.

Our path led down a slight valley from East Ruins to the Mapudzi stream, and here the Beroma was found not to be such an obstacle to our progress as was at first imagined, for on its west side is a broad defile leading up to the ledge of land a third way between the base and summit of the range, and at the top of the defile, and a hundred yards to the left, is a well-built ruin which guards the approach up the defile. Chenga's Ruin, as it is called, occupies a position well chosen for defensive purpose, and presents several good architectural and constructive features. Here the coastward-bound convoy would first realise they had quite left Zimbabwe behind them, 
and would start to count the fifteen to twenty days of their tedious and, no doubt, highly dangerous journey to the sea, which should bear them in their gold-laden argosies homewards, either to the port of Eudaemon (the present Aden), or to the Moscha ("harbour") of Ophir, metropolis of the ancient Sabæans, or else, if later, to Ezion-Geber, the Jewish and Phœnician port on the Red Sea during the reign of King Solomon.

Chenga's Ruin is outside the Zimbabwe ruins' area, and is the first posting station on the road to Sofala. In I 540 the Moslem Arab traders in gold and ivory informed the Portuguese that the journey from Sofala to Zimbabwe required from fifteen to twenty days (twelve to fifteen miles a day), so that the later Arabs must have travelled on foot taking native carriers. They too may have used as caravansaries the line of ancient forts that stretches from Zimbabwe towards Sofala along rivers whose valleys form the natural outlet to the coast for the populations of Southern Rhodesia, for they could thus find admirable protection at easy intervals for the night, or halt within the walls built, possibly, by their remote ancestors. So the ancients leaving Chenga's Ruin might know they had at least fifteen days of tramping ahead of them, for no evidence of their employing oxen, horses or camels, or any wheeled vehicles, has come to light. The journey may have even been longer, owing to the delays of the slave gangs and carriers with their burdens of gold and ivory, and to the caution needed in passing through a land clearly shown by the protecting forts to have been hostile territory. The weary stretch of the Sabi Valley lay before them-Sabi, a name which students of Chicaranga and of other native languages state has no known derivation, and of which the natives emphatically affirm "It is but a name. It means nothing to us." It has therefore been repeatedly conjectured that the name Sabi, Sabæ, or Saba has a connection with the river with which they must have 
been very well acquainted. From scriptural accounts we find that such duplication of names of places was a practice of the old Semitic peoples, as in Havilah, the local and pastoral country, and Havilah, the foreign and mineralised country, in a superlative sense the gold land, "and the gold of that land is good" (Genesis ii. 12). Instances, in fact, occur almost everywhere from the remotest time down to the founding of New South Wales, Nova Scotia, New York, and a hundred other well-known places.

Chenga's Ruin was absolutely unknown to white men, as also were the Beroma Ruins, until quite recently. The local natives repeatedly denied the existence of any ruins on the Beroma Hills, and this denial on their part, so authorities on Makalanga customs say, is perfectly natural and to be expected, for all the ruins of this chain, like so many others throughout the country, have been used by the Makalanga up to the present day as burial-places, and being well aware of the clearing of the Zimbabwe ruins, they feared lest these other ruins, too, should be explored. But since they have learnt that in the work at Zimbabwe the graves have been respected, they appear to be less nervous, and as it is known for many miles round that substantial rewards will be paid for information as to other and fresh ruins, they sometimes volunteer their information and offer themselves as guides. Thus some nine additional ruins have now been discovered and inspected. But the three ruins on the Beroma Hills which at strategic points guard our path were found by the author on making a systematic search of all the hills in the district of Zimbabwe.

From the ledge on the west face of the Beroma Range on which Chenga's Ruin is situated the ground rises gently towards a broad depression in the western crest of the range into a long valley, which runs from north to south and from end to end of the top of the hills. The path after passing through the farmstead of David (a native teacher) passes 

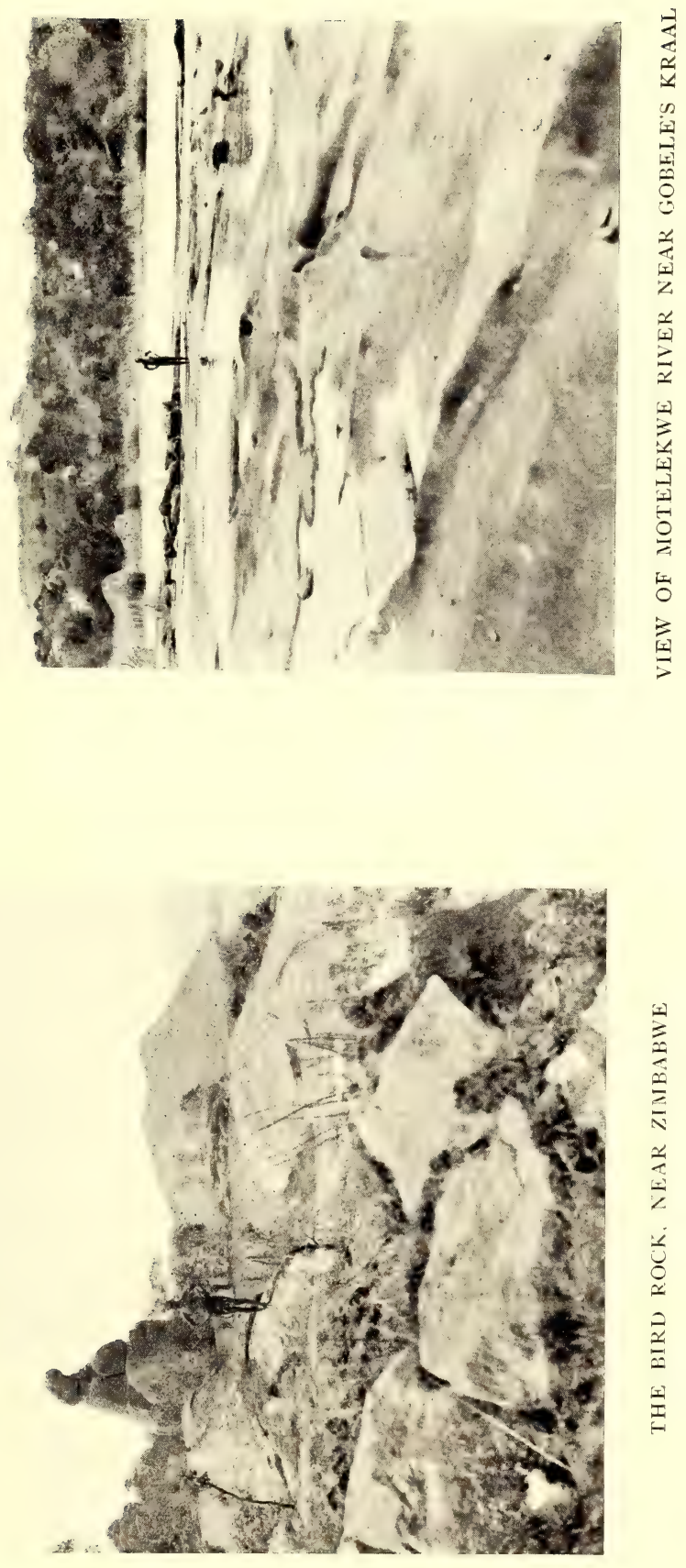

告 

up the valley southwards for half a mile and then turns east at a sharp angle towards the most southerly of the two depressions on the eastern crest. Within a few hundred yards, on the right-hand side of the path where it turns east, and on a low, rocky knoll, is a second ruin-Beroma Ruinwhich is well-built, and has a rather fine, rounded entrance. The southern half of this ruin is now reduced to a few piles of granite blocks. On the south-west side of this ruin is one of "Sheba's Breasts," Marsgi. On the south side of the path is Sueba, the other "Breast." Half-way between Beroma Ruin and Sueba, and on the south side of the path, is a cluster of tall, pillar-like rocks, which look in the serene moonlight, and at a little distance, like a cathedral built of white stone. The natives call these rocks Rusinga. On the left-hand side of the path, on the ridge of the depression on the eastern line of summits, is a tall column of huge boulders, which, when seen from the south side, exactly resemble one of the soapstone birds on beams found by Mr. Bent at Zimbabwe.

On Sueba is another ruin which overlooks the depression, through which the path runs south-east down the east side of the Beroma Range towards the Mapaku Ruins, which form the fourth posting station from Zimbabwe. Climbing Sueba, one can at once see that this line of route, owing to the topographical structure of the range, is not only the most direct from Zimbabwe, but the most natural for anyone crossing the Beroma Range.

Just as the path starts on the descent to the Mapaku Ruins the scenery to the north-east and south, as viewed by moonlight, is truly magnificent. Towards the north-east the skyline is formed by the jagged crest of the romantic Livouri and Inyuni Hills, while the Moshagashi Valley is wrapped in a mantle of greenish mist, above which towers the lofty Arowi Peak in solitary grandeur. Here the ancients on their way to the coast would have their last view of Zimbabwe. 
We arrive at Mapaku kraal (Baku, "cave"; Mapaku, "caves") just as the light is sufficient to make the main features of the scenery perfectly distinct. Here the sub-chief Molinye and his people are already stirring and squatting round fires in the open. The kraal is situated at the east base of a cluster of high cliffs, and these cliffs are full of caves and deep fissures used as passages. The kraal which formerly occupied these rocky vantage grounds is now removed to level ground, and built without a fence of any kind. Molinye is a younger brother of the Mogabe Handisibishe by the same mother, and takes the name of their father, the Mogabe Molinye. $\mathrm{He}$ is an intelligent man and very active. $\mathrm{He}$ considers himself the custodian of the neighbouring ruins of Mapaku, and just as his brother at Zimbabwe says to all visitors, "Here is Zimbabwe. One shilling!" so Molinye's first remark to visitors is, "Here are the caves. Two shillings!" or "Here are the ruins. Two shillings!" Molinye is very proud of the caves, for here his people successfully defied the Matabele and Amaswazi raids. In these caves the women, children, cattle and grain were safely hidden, and the approaches to them could well be defended by two or three men as against a hundred of the enemy.

Molinye's tall figure leads the way to the Mapaku Ruins, which since I89 I have been known as "Little Zimbabwe." Here our breakfast is laid out in the central enclosure, and Molinye sits enviously watching the boys eating "bully beef." Evidently he will not be happy till he receives a tin, and he is given one. Still he is not content, and urges the payment of a further two shillings for taking us to the ruins. He only knows two words of English, and these are "Two shillings," but having already paid him one florin, which is more than his due, he fails to draw a second, and is at last content with a box of matches. Natives always ask for about ten or twenty times more than they expect to receive.

The sun is just showing above a long black hill-In- 
gumaruru-and as we have ten to twelve miles to cover before we reach Majerri's, our journey is taken up afresh. There is another ruin at Mandindindi's, lying on our route, but our time will not permit us to visit it on this trip.

From Mapaku the path leads south to the right bank of the Motelekwe, about a mile and a half away and near Gobele's kraal, which is from this point of view backgrounded at some distance by the steep and rocky Goruma Hill. Here the river is wide, and has, even in the dry season, large pools many acres in area. The granite rocks in the bed of the river are pierced with round holes a few feet deep, all of which have been made by the action of the water. The path then passes through Gobele's kraal and down a small defile towards a drift across the river. This drift is only used by the people of the neighbouring kraals, and the paths on each side of it are very narrow, while the crossing is rather tortuous and slippery. From above the drift we continue on the path south-west to the south end of the Goruma shoulders at a quarter of a mile distant. We were now at least a mile and a half from the river, which has turned south-east through some dark-looking, tall kopjes, and from the higher ground we could see that the rivers which flow to the Motelekwe form swamps just before reaching it, and by keeping on the high ground these are avoided and the rivers are more easily crossed. In fact, by taking this path we cut off an eastward bend in the Motelekwe, striking it again at a wide, easy, and natural drift some eight miles farther on.

About a mile from Gobele's we come to the Meziro, a perennial stream, $300 \mathrm{yds}$. from which on the east side of the path is the Rumeni Ruin, built on the slope of a hill. This ruin occupies an area of II I ft. from east to west and $63 \mathrm{ft}$. from north to south. The highest wall is now only about $6 \mathrm{ft}$. high. The style of building is peculiar-a large, well-built, rounded buttress being at the north entrance, and the walls show both superior and inferior workmanship, while 
the western side is formed of arcs of circles end on end. The Meziro flows south and east of the ruin in the valley below.

Two hundred yards back along the path and about one hundred yards from it on the west side is an old Makalanga wall with portions of the wall of an oval enclosure. The structure is of no great age, and is definitely claimed by the natives as the work of some few generations past. Its total length is $54 \mathrm{ft}$., and the area of the enclosure is I6 ft. at its longest parts. Some old Makalanga clay flooring has been used as building material at different points in the wall.

The journey south, and later south-east, is continued, and the Meziro and Mazili rivers crossed, while the following kraals are passed in order-Chinaka's to the left, Skarduza's on the right, and Manamuli also on the right. In front is a very high kopje with almost perpendicular sides. This is Rushumbi, a noted landmark for many miles round. The path leads past the south of this hill and up another hill, where is Marota kraal. This hill, which has a very considerable elevation, is exceedingly steep on the south side, and there is an extensive view from the summit down the Motelekwe and Tokwe valleys. Marota was the largest kraal seen on this journey. Half an hour's walk from Marota brought us to a natural drift on the Motelekwe, which here bends south-south-east. The river-bed at this point is about $200 \mathrm{yds}$. wide, and in the dry season is very easy to cross, from sandbank island to sandbank island and scrambling over large granite rocks with smooth glassy surfaces. There is no doubt that this is the best drift within a good many miles either up or down the river, and it lies, as seen in the distance from Mount Sueba, the eastern "Sheba's Breast," exactly in the natural and unbroken line of country up which is the easiest and most natural approach to Zimbabwe from the south-east, thus avoiding bewildering mazes of kopjes and rough country which lie on either side. The topography of the country clearly points out the ancient route, and it is 
along this that our present journey is made. At this drift we saw a boy of about nine years of age with a skin no darker than that of an ordinary Spaniard and with almost perfect features. Both parents were ascertained to be Makalanga.

From the east bank of the drift the path ascends for a distance of nearly two miles between the drift and the Majerri Ruins, which at this distance lie half a mile to the south of the path on a line of kopjes to the south-west of another Mapaku ("the caves"). This Mapaku must not be confused with the Mapaku we had visited during the small hours of the day, for wherever there are caves there is a local Mapaku; hence there are several places of this name within a score of miles from Zimbabwe. The name of the headman at this Mapaku is Munda, and on sending to his village, one of his men will act as guide to the ruins, which are rather difficult to find by anyone unacquainted with the district. On our way from the drift we passed several very long gamedrive fences and large game pits, and saw two herds of wild pigs and several large buck.

By three o'clock in the afternoon we had reached the ruins, and a camp for the night was made in one of the enclosures. Soon afterwards the boys were busy with hatchets cutting away brush from the sides of the walls, so that a survey could be made and photographs taken. The ruins are much larger and better built than we had been led to believe. There are sixteen enclosures, also a passage $290 \mathrm{ft}$. long running from end to end of the ruins. Chevron pattern is on the west face of a very substantial wall of what appears to have been an important enclosure. We worked at the measurements till it was dark, when we partook of our evening meal. The full moon rose a little later and flooded the ancient building with light, so that further examinations could be made. The enclosure in which our camp for the night was formed was made most picturesque with the lights of moon and fire, the walls gleaming white with the heavy mantle of lichen which 
covered them. This white appearance of the walls is a prominent feature in all the ruins of the Motelekwe chain, most probably accounted for by the mists that usually hang over the line of the river.

The talking and singing of the boys, the music of their Makalanga pianos, seemed in perfect harmony with the solemn stillness of the ruins and of the night. We turned in early, and at five in the morning we were again busy completing measurements and noting up descriptions of architectural features and styles of construction. At ten o'clock the principal parts of the ruins were photographed, and at eleven we set out on our return to Zimbabwe.

The objective of our next expedition down the Motelekwe Valley will be another set of ruins still further south-east. There are other ruins beyond these again, and we hope to be able by such expeditions to obtain full descriptions, with photographs and plans, of all the ruins of the Motelekwe chain.

Munda, the headman at Mapaku (Majerri), states that only three white men have ever seen these ruins, two came together and one alone, but that these visits were made some years ago. One of the Messrs. Posselts was of this number.

On this journey we found the women were all decorated with the furrow pattern on their bare stomachs. The "female breast and furrow pattern" was on all washing-tubs, drums, granaries, and furnaces, and also on some doors, and further worked out in clay on the sides of the huts. Check pattern adorned some of the huts, but mainly the inside walls. Some very well-built semicircular walls for screening open fires were found at some of the villages.

Some of the denizens of the Zimbabwe district.-These are most numerous in the Elliptical Temple when the size of its area is considered, for this building abounds in bird, animal, reptile, insect, and plant life. Protected by high 
walls all round, it provides an area free from the disturbing effects of grass fires, sheltered from cold winds, and full of rank tropical vegetation and jungle. Here the gorgeous lapis-lazuli and turquoise blue of the jays and the brilliant scarlet and rich metallic green of the honey-sucker flash brightly in keen contrast to the white lichened walls. Yellow and grey hornbills, barn owls and owlets, wagtails, weaver birds, pigeons and doves, and little birds with yellow, white, red or blue or mottled breasts and wings, are constantly to be seen in the temple courts. One large barn owl has its usual perch on a branch near the summit of the Conical Tower, while "Go-away" birds are incessantly urging us to "Go away!"

Numerous squirrels climb the walls and spring along their summits. Chameleons, one minute pale green, the next a mottled yellow, grey, and black, climb with aristocratic movements up the orchid-clad trunks of trees, pausing at intervals to fold their front paws in a comic attitude of prayerfulness. Large and small lizards of brilliant colourings, mainly magenta, Prussian and electric blues, and a startling orange, bask upon the ancient stones. Puff-adders, grass snakes, and mambas haunt the place, the latter climbing the highest trees and ascending steep, smooth sides without any apparent necessity for picking their way up rough surfaces. Pythons have been seen, and a python's nest with about two dozen white leathery eggs, from which the young had been recently hatched, was found in the centre of the temple. On commencing work here in May, I902, scores of cast-off snake skins of all sizes up to $5 \mathrm{ft}$. in length were found all about the temple. Scorpions which hide under the stones suggest to one the necessity of being careful in sitting down. Centipedes and large millipedes, snails with white spiral shells from 6 in. to 9 in. long, frogs, which on wet days persistently urge us to "Work! work!" abound, while after sundown crowds of large night moths and bats flutter in 
the air. Brilliant butterflies, dragon flies, and fire flies, gigantic spiders, spiders which make their trap-doors of clay, hornets, bees, beetles, mosquitoes, and other stinging insects, and those which assume imitative forms. Tortoise-shells and porcupine quills were found, but no tortoise or porcupine. The number of skeletons of wild animals found in the grass was sufficient to suggest thoughts of Noah and his zoological cargo.

The birds of the Zimbabwe district include quantities of blue jays, hornbills, honey-birds, honey-suckers, bee-eaters, several sorts of rollers, crested kingfishers, South African thrushes and babbling thrushes, shrikes, swifts, swallows, and martins, weaver birds, owls, corncrakes, night jars, woodpeckers, larks, wagtails, doves, pigeons, white storks, herons, secretary birds, bush crows, vultures, hawks, guinea-fowl, sand grouse, quails, and partridges, while paaw (bush bustard) is sometimes met with.

Two ostriches with black and white feathers once approached within IoO yds. of Havilah Camp. A covey of African grey parrots fled over the huts going south in the springtime. One bird of the plumage and shape of an ordinary skylark soars high in the air, remaining in one position, but instead of singing it flaps its wings loudly for some minutes together. It is best heard just before sunrise.

During the dry season game animals are not plentiful in this locality, but when the grass has started to grow after a veld fire they arrive in fairly good numbers. Reed buck, sable antelope; and springbok have been within sight of the camp.

Lions for some years past have not been seen at Zimbabwe, though they are in continuous residence on the Livouri Range, some eight miles to the west, and also at one or two other places about the same distance from Zimbabwe. But with the advent of buck they are known to come within two or three miles of our camp. Their spoor has frequently 
been seen on the road between Zimbabwe and Victoria, and they have recently killed donkeys within five miles of Zimbabwe. On one occasion only have we heard lions roaring, and they must have been almost two miles away. Jackals are a nuisance, and come to the camp for poultry. Large leopards have been shot in the neighbourhood during the author's stay at Zimbabwe.

Natives state that within their time herds of tusker elephants have been wont to frequent the Zimbabwe Valley, and they point out certain trees which have been damaged by them. The elephants have now gone south-east. The traces of two ivory trading stations of the late sixties are still to be seen at Zimbabwe.

Eagles soar above Zimbabwe Hill and the topmost line of cliffs. Two eaglets fallen from the nest were found in the Acropolis ruins, one each spring. One died of its injuries, and the other lived for two months at our camp. The boys were fond of feeding "the big chicken," and it eventually died in consequence of its gluttony. Hawks abound on the hill, and there are also kites and owls. Large black crows with a white patch on the back of the neck, and with vulture-shaped beak, also crows with white breast and wing tips, but with a raven-shaped beak, are constantly flying round the hill. Here are also wild tebie cats and tiger cats, ant-bears, conies, squirrels, and at least five species of large baboons. The constant parading of the latter to and fro on the summit has formed a well-beaten track. These creatures bark and crythe crying is exactly like that of a human being. Toward noon they usually descend to the valley and romp about on the open granite spaces. So destructive are these particular baboons that the local Makalanga have been obliged to abandon their gardens on the south side of the hill. Their spoor has been frequently found within our camp. The reptiles here are large pythons, mambas, iguanas, and lizards of all colours. 
The plant life found in the temple was very rich and diversified, and each specimen was of larger growth and bloom than those of the same species growing outside the walls. Here are many sorts of elegant ferns, but mostly small, including maidenhair fern, also the ordinary bracken. Stag'shorn moss and plants of carnose foliage grow in the joints of the walls. Beds of scarlet cannæ, Cape gooseberries, raspberries, crimson and mauve gladioli, convolvuli, large and small, white, purple, yellow, and mauve, verbenas, heliotrope, azaleas, also a flower exactly like the daffodil, and arums or St. John's lilies, flags, mauve-flowered peas, a blue flower like borage, and blue and yellow ground orchids, covered the surface of the interior. Nettles and nettle trees, stinging plants, and thorns of all sorts formed prominent features in the vegetation of the temple. The trees within the walls were numerous, and included varieties of hard and soft woods. Some were of gigantic girth and height, rising to $60 \mathrm{ft}$. Wild fig-trees and evergreen hardwoods predominate. The "Zimbabwe creeper," a climbing plant peculiarly local, is a great feature in all the ruins at Zimbabwe, and so far has not been found elsewhere in Rhodesia. This creeper resembles jessamine in leaf and stalk, only it has light pink, bell-shaped pendent flowers growing in clusters at the end of each spray, these being about the shape and size of a foxglove flower. Orchids with yellow flowers grow on the trees, from which are also suspended lichen festoons some $3 \mathrm{ft}$. long. The monkey-rope trees once interlaced the tops of the trees with their runners and created a semi-darkness in the temple even at brightest noontide.

On the hill tobacco, once cultivated here by the natives, now grows wild. Large beds of scarlet cannæ, Cape gooseberries, hemlocks, and blackjacks are seen in most parts of the hill, while every flower of the veld is represented. Monkey-ropes, wild vines, wild orange, fig, nut, greengage, currant, and raspberry flourish here. The kafir-baum, which 
flowers profusely when leafless early in the spring, and abounds at Zimbabwe, provides a striking contrast of brilliant scarlet to the grey granite cliffs in front of which it flourishes. The flat-topped umbrella trees (mimosa) impart an odd effect to the hill. The Zimbabwe creeper grows very extensively on the north and west sides of the hill. Cacti, euphorbia, and liliums, also bulbous plants, are multifarious, while tall aloes give an old-world appearance to the hill.

Palms with fronds ro $\mathrm{ft}$. long, tree-ferns $8 \mathrm{ft}$. high, and large areas of Osmunda regalis (royal fern) are to be seen in most of the glens and gorges of this locality. The blue lotus lily (Nymphea stellata) grows in most pools of water, while the yellow everlasting flower (Helipterum incanum) is plentiful, and the bright red sealing-wax-coloured flower (Erythrina kaffra) shots the veld grass as daisies do an English meadow. The sugar bush (Protea mellifera) though present is not found in quantity. Bamboos grow in the neighbourhood, also sugar-cane, and wild cotton. The mahobohobo is not indigenous to the country, but is the most usual tree found here. Its area covers many square miles of this district. Like the wild fig, the mahobohobo fruit ripens in the spring only. 


\section{CHAPTER V}

\section{ZIMBABWE NATIVES}

\section{NATIVES AND RUINS}

T may easily be imagined that researches as to the origin 1 of the ruins cannot be furthered by inquiries instituted among the present native peoples as to any history or tradition concerning these structures. The chief value, however, of such inquiries is that they enable us to realise in what conditions both the ruins and the district have existed during the last few centuries. But such inquiries only take us back to a period of two hundred years short of that time when Portuguese writers referred to these buildings.

The migratory character of the South African natives is well known. Not only whole nations move, but the tribes among themselves move also, thus making it exceedingly difficult to trace their migrations except for a few generations back. The Portuguese historians of the sixteenth and seventeenth centuries referred to the Makalanga nation as occupying this country with their centre at "the Great Zimbabwe," where resided the Monomotapa, or supreme chief, and where was "the mightie wall of five and twenty spans thick." Three hundred years after this was written we find a dense population of Makalanga ("the People of the Sun") still occupying Southern Mashonaland and forming the great bulk of its inhabitants. ${ }^{1}$ In this respect, though

1 Mashona, probably a corruption of Mashuli, Mahuli, "slaves," is the name by which the Makalanga are known to the whites; hence "Mashonaland," the now established name of their territory, which should properly be Makalangaland. 

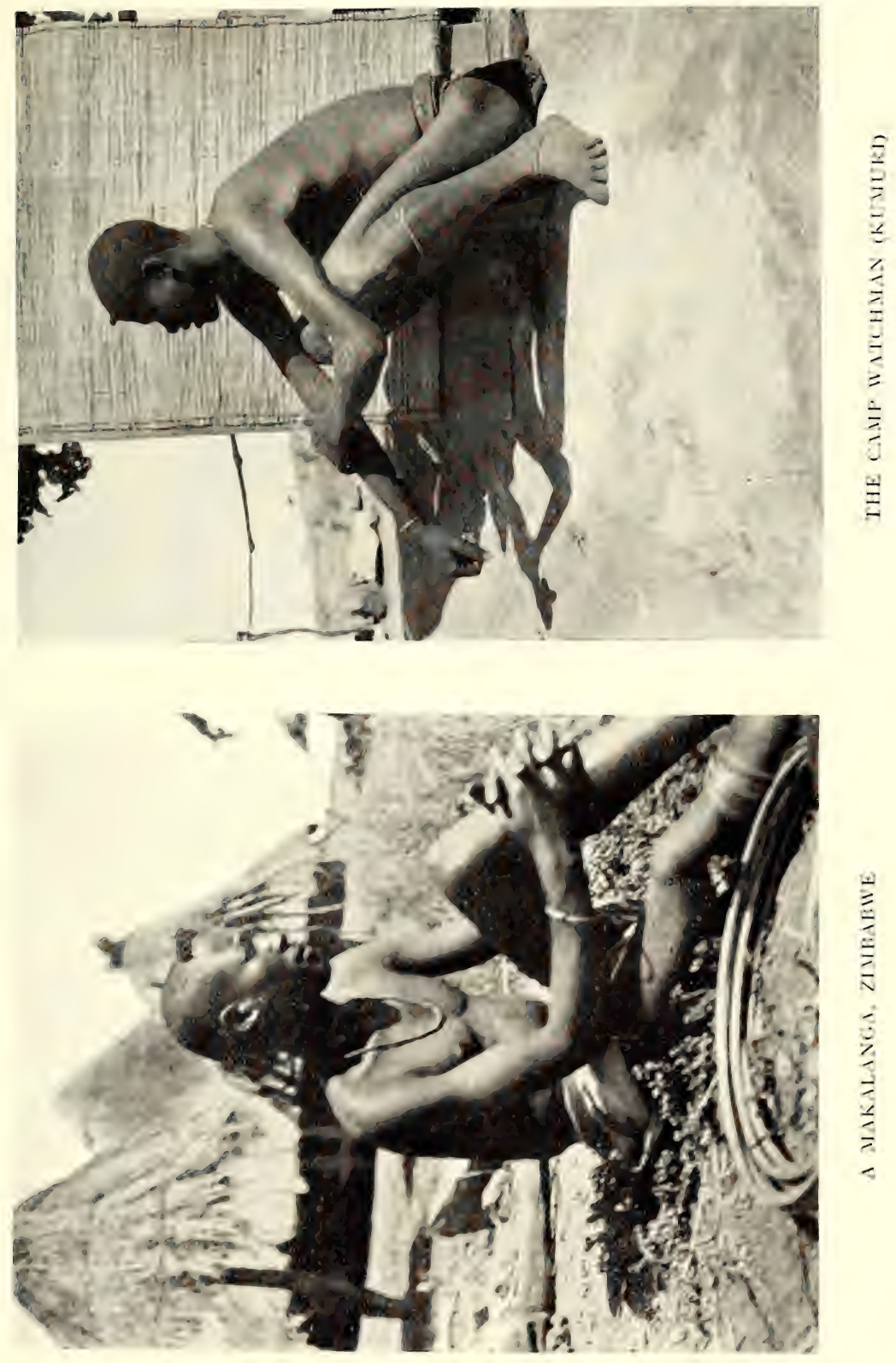

their various tribes have frequently changed localities, the Makalanga as a general rule have not followed the migratory custom of South African peoples. Makalanga are to be found in both Matabeleland and Mashonaland, but mainly in the latter province, where the Chicaranga language, which Dos Santos in 1602 described as "the best and most polished of all Kafir languages which I have seen in this Ethiopia," is still the language of the nation. Makalanga are also to be found in Barotseland, whither the Barotse ${ }^{1}$ and their dependents the Makalanga migrated, in I $836-8$, just previously to, and at the time of, the Matabele invasion of what is now known as Matabeleland.

But for nearly four hundred years the historical relations and the very existence of the Makalanga and their history were forgotten. From being a powerful and semi-civilised people (see The Ancient Ruins of Rhodesia, chapter x.) they have become a people of no account-mere "Makalaka," as the people of the present Bechuanaland scornfully called them in reference to their present slavish position. To their successive conquerors they have always been but "dogs of slaves."

So far as the purely local natives are concerned, the following notes, based upon a series of conferences of the oldest native authorities held at Zimbabwe during 1902 and 1903, at which Mr. Alfred Drew, Native Commissioner, the Rev. A. A. Louw, Dutch Reformed Mission near Zimbabwe, and Dr. Helm, Medical Missionary, and other admitted authorities on native language and customs, have taken part, will explain the local occupations for almost if not more than one hundred and fifty years. The local Makalanga, Barotse, and Amangwa are agreed upon the correctness of the statements here recorded, and the information so obtained has also been verified by the above-named gentlemen in other quarters.

1 Barotse, Barose, Marose, and Varose are all variant forms of Baharutse, who appear to be the original stock of the Bechuana nation, hence are regarded by all the other branches of the family as their "elder brothers." 
(a) In this portion of Southern Mashonaland the Makalanga have formed, since long before I570, the greatest portion of the population, especially in the Zimbabwe district. This is both history and also well-rooted tradition among the natives, going back for very many generations.

(b) The Makalanga have been subject to several successive conquerors, of whom the Barotse in Mashonaland and the Matabele in Matebeleland were the last. They have only very indistinct traditions as to their previous conquerors.

(c) The Barotse occupied both provinces, establishing central strongholds in all districts. They collected tribute from the Makalanga, and this was taken every year from all the centres to the Mambo or Mamba, the dynastic chief, for the time being, of the Barotse. And these Mambos resided at Thabas Imamba. Both Makalanga and Barotse were, and still are, most excellent builders with stones. [Mr. Drew minutely cross-examined the natives with regard to the situation or identity of Thabas Imamba. This is the fixed belief of every Barotse who is questioned on the subject, and the old men say it is also within their own knowledge. Before this fresh evidence was obtained, the authors of The Ancient Ruins of Rhodesia had published a similar statement on the strength of evidences secured in Matabeleland. Mr. Neal also stated that no ruin in Rhodesia showed more evidences of extensive and prolonged occupation than did the ruins on Thabas Imamba.

(d) Jerri's people (Barotse) never lived at or near Zimbabwe, as white men had believed they had, but they left what they called "The Great Buildings of Stone" (Khami) west of where Bulawayo now stands in $1836-7$, and moved to Jerri Mountains, seventy miles south of Zimbabwe. They left Khami immediately before the Matabele arrived. On passing through Zimbabwe they encamped for one night only on a hill one mile west of the ruins. There are many 
old men who remember these circumstances, while the general local belief is that Jerri's people lived at Khami Ruins, which are well known to the natives here. [It has always been contended that this tribe of Barotse resided at Khami for very many generations, but there are very many evidences in support of this established belief, which are now in hand, and are now forthcoming.]

(e) The head kraal of the Zimbabwe Barotse was at the foot of the south-east side of the Rusivanga Kopje, and not on the summit, where the walls and the remains of very substantial huts are old Makalanga. The Barotse also had a large kraal on the north-east side of the Bentberg overlooking the Elliptical Temple. [The present Barotse headmen claim the pottery in the débris at these places as having been made by their people some four or five generations back, if not earlier.]

$(f)$ The Zimbabwe Makalanga did not reside in the ruins, as this in later generations was opposed to their traditions, but they used the ruins up to ten years ago as cattle kraals and places for carrying on their copper and iron-smelting operations, for offering sacrifices, and for burial-places. Once they occupied them as residences, but possibly the fear of the ruins at night caused them to desert them as residences, probably owing to the increased number of graves which they contained. The Barotse did not appear to have been inspired by this fear, for they have occupied ruins all over the country.

All the remains of native huts and many of the native articles found in the ruins must be at least six generations old, if not much older. When the present Mogabe-Handisibishe took up his residence on the north side of Zimbabwe Hill, in the ruins of the Acropolis, there had been no Makalanga occupations for many generations previously. All the remains of Makalanga huts found on the Acropolis, and round the faces of the hill, and outside the area occupied by Mogabe's kraal, 
belong to Makalanga, who had ceased to occupy them for very many years previously. When Mogabe arrived these remains were considered by his people to be exceedingly old.

$(g)$ The present Zimbabwe Makalanga originally came from Masungye, in the direction of the Lower Sabi. Mogabe is the dynastic title of each succeeding chief of this tribe. The Mogabe-Molinye moved to Jena and finally to the Beroma country, in the neighbourhood of Zimbabwe. The succeeding Mogabe, a son of Molinye, moved up from Beroma to Mangwa (Morgenster), four miles south of Zimbabwe, from which place he drove out the Amangwa people, who occupied the Zimbabwe district and the country for a considerable distance round about. The next Mogabe, Chipfuno, a son of the previous Mogabe, settled at Wuwuli, five miles south of Zimbabwe, and later his younger brother, Handisibishe, the present Mogabe, succeeded Chipfuno in the dynastic rule. Handisibishe is seventy years of age, but Chipfuno was much older.

The connection between the present Zimbabwe Makalanga and the Zimbabwe ruins only dates back authoritatively for some sixty or seventy years, but their opinion as to the age of the native remains at the ruins, as found by them when they arrived, added to a similar account based on the longer residence of the Barotse and Amangwa, and on their history and traditions, enables investigations to be carried back at least eight generations.

(h) The oldest known natives who have resided at Zimbabwe are the Amangwa, who were driven out by Mogabe Handisibishe. These were originally a tribe of pure Makalanga, but by marriage with their erstwhile over-lords, the local Barotse, many of their people have acquired some of the distinctive features of the Barotse, while a large proportion are still in every respect true Makalanga. These people now reside in Nini district, eight miles south-west of Zimbabwe, their nearest kraal being Bingura's, which is two miles distant. 


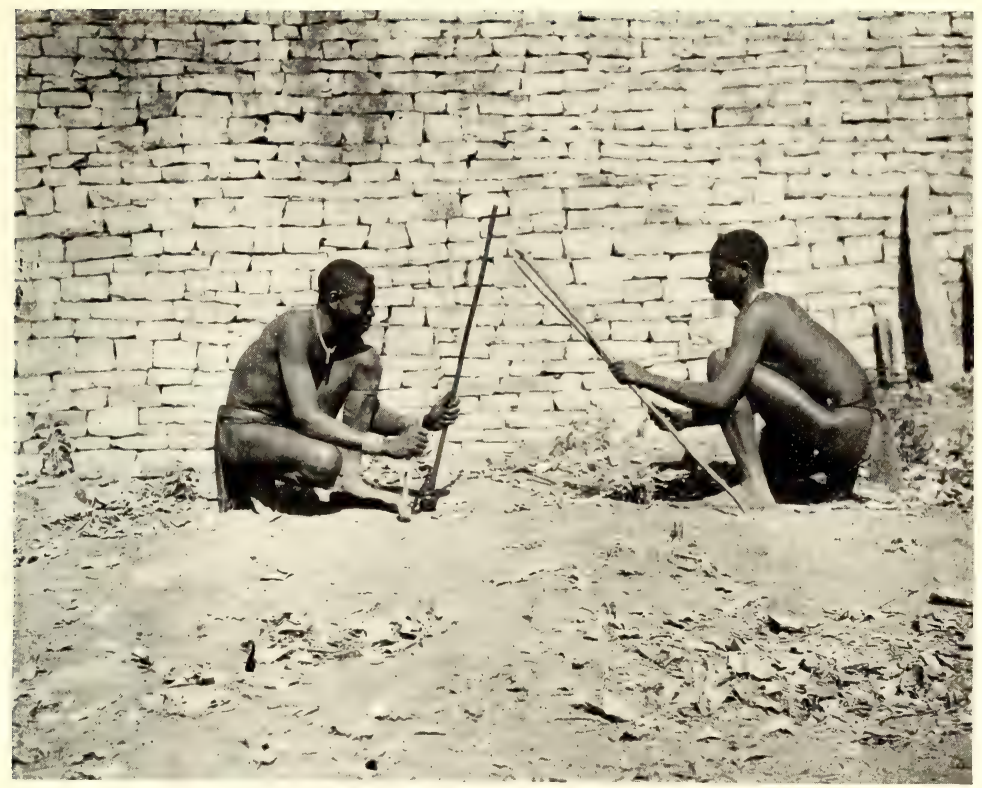

MAKALANGA "BOYS" FENCING, ZIMISABWE

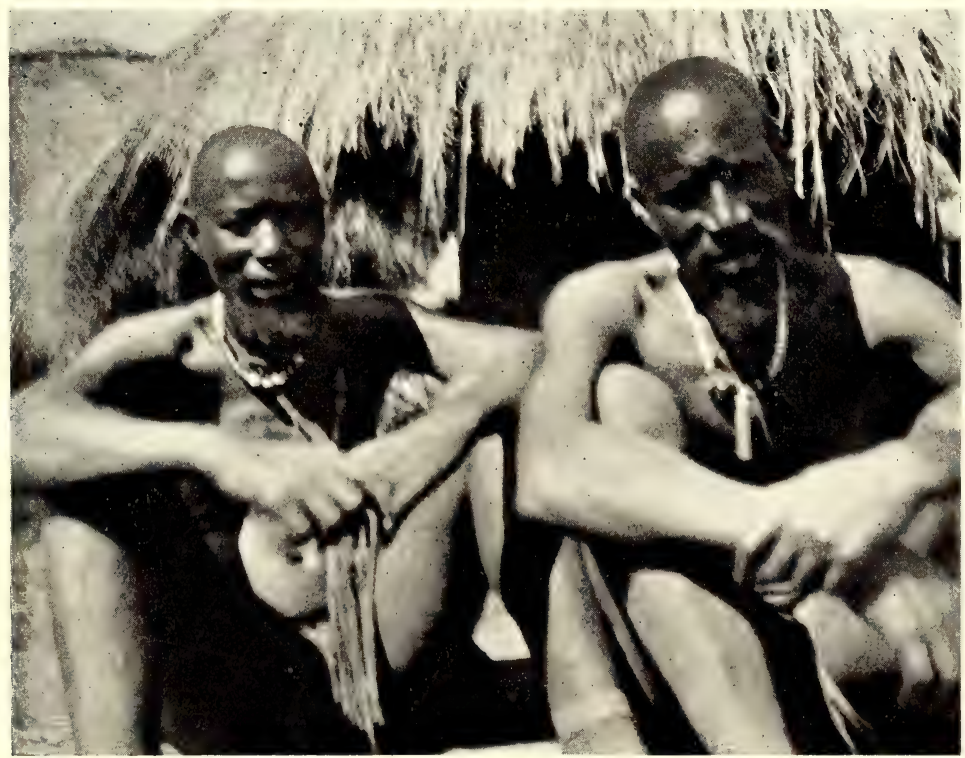

MO'TUMI

MONGWAINE 

They can speak with regard to the state of the ruins as they were conditioned some generations ago. They state they never occupied the Acropolis ruins except when Amaswazi raiding parties were in the district, and then only as a temporary refuge, and that many large walls have completely fallen down. The Amangwa were once a numerous and powerful people. Their kraals were built in the valleys, close to the ruins and on the nearest kopjes.

Mogabe Handisibishe took advantage of a famine in the Zimbabwe district when he attacked them, and perpetrated great cruelties on their women in order to make them divulge where the relics from the ruins were hidden, but the Amangwa did not yield on this point. It is curious that so many relics of prehistoric value have been found in the Nini district where the Amangwa now reside. The wooden bowl, carved with the zodiacal signs, the soapstone cylinder, etc., were discovered in Nini, and the best native authorities affirm that the Amangwa still have relics in their possession.

(i) The correct name for Zimbabwe is Zim-bab-g $\bar{z} w i$, meaning "buildings or houses of stones." The natives never apply the name Zim-bab-gwi to the Elliptical Temple, but always speak of it as Rusingu, "the wall." Zim-bab-gwi is only applied to the ruins on the hill.

$(j)$ The natives have no recollection or tradition with regard to the Monomotapas, the dynastic chiefs of the mediæval Makalanga who resided at Zimbabwe.

(k) Barotse, Amangwa, and Makalanga have built walls in and near the ruins. They state that their ancestors used to construct excellent walls. [Mr. Drew, N.C., is of opinion that the Barotse now build better walls than do the present Makalanga. The Makalanga were always famous as good builders with stone.]

(l) The natives show little or no interest as to the original builders of the ruins. Some will say they were built by white men for prisons, others will affirm the ancestors of 
their tribe built them. Some tribes make definite claims to have built them, but Mr. Drew considers these claims to be only poetic expressions conveying the idea that such tribes had lived for so very many generations in the ruins that they knew of no occupiers before them, and so imagine that their ancestors must have built them. Of course, their claims to have built minor walls within the ruins are, in many instances, obviously well founded.

( $m$ ) The natives assert, when pressed as to who removed the relics from the ruins, that large birds came out of the sky, took them, and carried them into the heavens.

(n) "Fuko-ya-Nebandge" - the Mashonaland relic-possesses an unique history and a weird romance, and is also of great intrinsic value for such in Rhodesia as revel in researches into the history of past occupiers of this country. The image is made of pottery, and is hollow, the head (which has not been discovered) forming the stopper. It was discovered by Mr. Harry Posselt in a cave near Zimbabwe. It stands I I in. high, and is about 16 in. long, and is marked with geometric exactness with zebra stripes all over its body. The pot is black, but the stripes are of a dull red colour. The name of it is "Fuko-ya-Nebandge" ("the king's favourite adviser"), and for at least some generations of Makalanga it has exercised a potent magic spell over the minds of the natives. It has now been secured for the museum at Bulawayo.

The following is Mr. Posselt's account of its discovery:In I89I he was encamped at Fern Spruit, south of Victoria, near which point are some hills. His Mashona boy informed him that among these hills could be heard by anyone going near them the sound of cattle bellowing, girls talking and singing, and that up on the hills was a pot full of beads, but the local natives were too much afraid of venturing up there in search of the pot, as it would mean certain death. He did not ascend the hills, but his drivers and leaders went up, but 
heard and saw nothing unusual. Until I 899 he had quite forgotten the incident, but in August of I 900 he happened to be near these particular hills collecting labour for the Chamber of Mines, and conversed with a chief living there. $\mathrm{He}$ asked the chief the native name of the hills, and the chief told him about the pot containing the beads. He further told him that long ago a native went out hunting on the hills, and found the pot with the beads in. The chief's story was to the effect that the native seeing the pot wanted to take the beads out, and putting his hand into the pot, the pot got hold of his hands and he could not shake it off, and he was obliged to carry the pot poised on his head with his hand still fixed inside it. When he arrived at the kraal his people prevented him entering it, as he might bring evil upon the tribe. He was consequently compelled to encamp on a stream near the kraal until his hand dropped off. He was fed secretly by some of his people. After his death, instead of being buried in the usual way, they pushed him with long sticks into a cave.

The pot was left there for some considerable time afterwards, and it was eventually discovered in another cave in the same hills, and was regarded, and still is to this day, by the natives as a mystery, and held in awe by them, and their belief was that if anyone approached the cave he would die. If the pot changed its colours to dark red it meant certain death.

After he had secured the pot the natives came from near and far to see it. One old native then told him of another pot, made like a mare zebra, and that the "female pot" contained beads that glittered, and that the pot in his (Mr. Posselt's) possession was the "male pot." The native was ignorant of what gold was. The two pots, so he stated, used to travel by themselves from their cave to Fulachama, a distance of eight miles, to obtain water from the stream where they drank, coming and going so often as to make 
a path. This Kafir asked where the "female pot" was, well knowing Mr. Posselt had not found it.

After his discovery he went to a chief who lives close by to where the pot was found. This chief used to live in Zimbabwe. He said that the chief who now lives in Zimbabwe was an enemy of his, and had supplanted him, and that he had all the relics. To compel him to disclose the place where the relics were hidden he resorted to torture, cutting off women's breasts and putting nose reims through men's noses. Before the ex-Zimbabwe chief was expelled from Zimbabwe he was in the habit of offering up sacrifices of black oxen, and on each occasion used to collect and display relics taken from the ruins. These consisted of "yellow metal with sharp points" brought down from the top ruin, also a yellow stick about $3 \mathrm{ft}$. 6 in. long with a knob on it, also a bowl or dish, by information most probably of silver. The stick is now stated to be in the possession of the chief.

\section{LOCAL NATIVES (GENERAL)}

The Zimbabwe district is very thickly populated by Makalanga. These formerly lived in natural strongholds on the summits of rocky kopjes difficult of approach, but now in almost every instance they have removed their kraals from their almost inaccessible eyries, and have built their villages on open country, without erecting any fences whatsoever for their protection. Thus, locally, Mogabe has left his hillfortress and caves, Baranazimba his strongly defended rocks, Lumbo his rock-pillar, and now these three kraals, as in many scores of other instances, are built in open country in absolutely indefensible positions, with no post, rail, or thornbush to bar approach. At night one can pass through almost any village unchallenged save by a Kafir dog. Large stores of corn are in their granaries. Their belongings are strewn about outside their huts, and everything is open to 


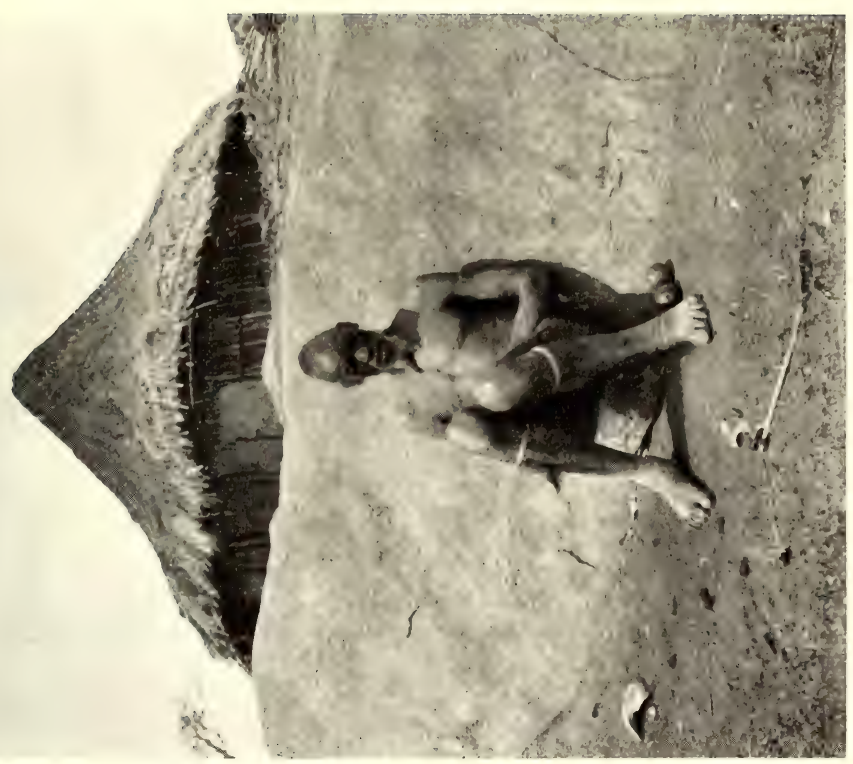



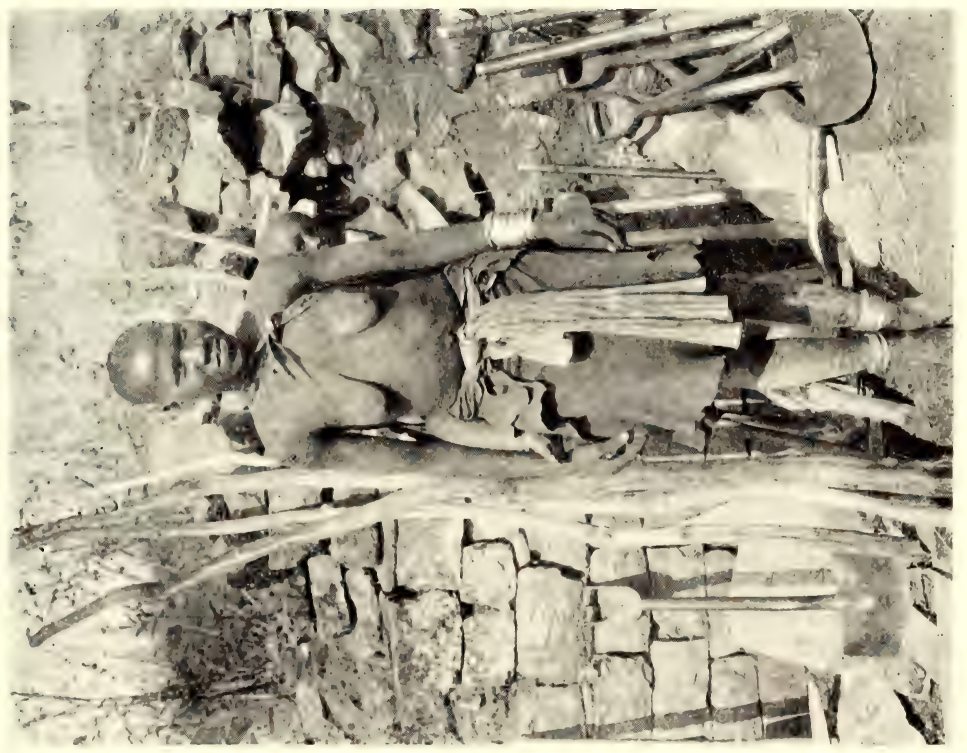

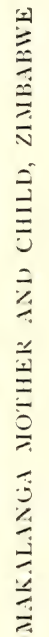



the spoiler. But the inhabitants sleep soundly, assured and content, because they recognise they are safe under the rule of a civilised Government.

Slightly more than a decade since all was most terribly different. Tribe fought with tribe and village with village. Repeated Amaswazi and Matabele raids "wiped out" without warning and without mercy whole populations, capturing slaves, seizing the women, and killing, as was their practice, the old people and children. None dared to stir from his rocky fastness to cultivate his little patch of ground. Little wonder is it that the spirit of these people was broken.

To-day these Makalanga, who are essentially an agricultural race, have covered the erstwhile devastated country with their plantations, and converted these parts into the "Granary of Rhodesia," and the leading grain-producing district of this part of Mashonaland. Standing on Zimbabwe Hill either at sunrise or sunset, one sees scattered over the open country scores of columns of smoke rising from the villages, each with its large area where the Makalanga work in absolute security, and one is forced to realise that untold benefit has undoubtedly been conferred upon the natives by the British occupation.

The Makalanga of Zimbabwe district are considered to be, in intellectual and physical qualifications, above many of their tribes elsewhere. In some respects they are marvellously intelligent and quick to perceive, shrewd, calculating, and clever, while in others they are astonishingly dull, so that it is almost impossible to get them to understand the simplest matter. They certainly evince far more feeling and sensitiveness, are more amenable to direction, and readier and more anxious to work, and are more honest and reliable than the average Matabele. Physically, they are as a whole somewhat shorter in height, are less robust, and have not the weight and strength of the Matabele, but their vigour and agility give them the greater advantage. Yet there are very 
many Makalanga in this district equal to any Matabele in height, strength, form, and endurance.

More than the French nation among Europeans, the Makalanga are distinguished for their taste, tact, and courtesy among the Kafir races of South-East Africa, only in their case the graceful movement, kingly walk, politeness, neatness, rhythm of speech, and poetic expression, are not the outcome of study, but are perfectly natural qualities bred in the race.

The contact of these people for many generations with the Portuguese is shown in their speech. This is a feature noticeable in all native tribes in Mashonaland, which were at any time located in or near Portuguese territory. As stated below, Mogabe's people originally came from the direction of the border. The terminations of some of their words are as distinctly Portuguese as one may hear at Lisbon or Oporto. Their connection with the Portuguese caused them to follow the rule common to that and some other Latin nations, viz. the interchange of $R$ and $L$. Selukwe thus becomes Serukwe, Belingwe Beringwe, Bulawayo Burawayo, while in almost every word used by their people further west containing $L$ the latter is substituted for $R$. Locally they call themselves Mokaranga ( $m o$ is a Chicaranga plural prefix), "the people of the sun." The Portuguese writers, De Barros (1552), Dos Santos (1570), and Livio Sanuto (I 588), give their name as Mocaranga. Makalaka, the name of derision bestowed upon them by the tribes in Bechuanaland, is known to them, but is never used by them, nor is M'Holi (slaves), a title which some of the more degenerate Makalangas in Matabeleland have adopted as their personal and tribal name.

The totem or distinguishing sign of the local tribe of Makalanga is moyo, the heart. Each tribe has its own totem, which may be the leg of a certain buck or some particular bird. Should a bird or an animal be the totem the tribe bearing that sign do not eat of the flesh of such bird or animal, nor will they kill them. A man of one totem must 
not marry a wife of a tribe bearing the same totem, but must seek one of a tribe of Makalanga having another totem. Thus, as they affirm, "Heart must not marry Heart, nor Lion marry Lion." This rule enforced through past ages has no doubt tended to maintain and improve their physical condition, and accounts for their fine figures, splendid health and general freedom from illnesses, and the almost utter absence of deformity and lunacy. A tribe of the Baduma people also bears the totem of the heart. The sub-tribal totem of the local Barotse ${ }^{1}$ is the lion. The lion, which is also the totem of the local Amangwa, only includes rapacious animals, such as wild cats, wild dogs, etc. Certain families in the same tribe or kraal have distinguishing signs, or what may be termed sub-totems. The totem system also prevailed amongst the early Semitic peoples prior to biblical times, and was later a feature of Hebrew history; for instance, "The Lion of the tribe of Judah." The totem of the Ephraimites was a bull.

In addition to the animal or bird that may constitute the totem there are other animals and birds which they venerate, and will not kill, eat, or touch. The slaying of such creatures is regarded as a crime against the whole of the tribe. The spirits of dead ancestors, relatives, and chiefs are supposed to reside in such birds and animals. The principal bird of local reverence is the Harahurusei (Bird of God), which is the chapungo, a large and beautiful bird, quite black except its tail, which is red. The peculiarity of this bird is that it soars overhead exactly as does a bird of prey. The natives assert that the nest, eggs, or feathers of this bird have never been found by anyone, nor do they know on what food it lives. A native will not proceed on a journey if the chapungo appears in the air or settles on the ground in front of him, but will at once return home. Natives hail the bird and ask it for favours.

The local natives will not eat the following: Common grey

1 The proper totem of the Barotse people is the Chuene (Cape baboon), but sub-tribes of Barotsie each have also a totem of their own. The Mamba (puffadder) was the totem of the Barotsie of Thabas I'Mamba districts. 
hawk, black crow, owl, wolf, crocodile, snake, or wild dog. Some will not eat hippo or eland flesh. They will not kill the chapungo, owl, wild dog, heron, and certain small birds. But while these are the general practices of local Makalanga tribes, certain families in different tribes frequently have additional and special objects of veneration, and any one native may have some particular object for his own personal veneration. The tribal custom with regard to not partaking of the flesh of certain birds and animals is very strictly adhered to, even though natives starve. To touch such, living or dead, is a defilement, and the remains can only be moved by using sticks.

Of insects, they eat locusts, two kinds of cricket (mashu and zukumge), a caterpillar (masonya), a worm called mambene, and different kinds of ants, including shua and madjuro, but especially flying-ants. All these insects they consider dainties, and cook them in the soup-pot into which they dip each handful of rapoka porridge. The soup is made of fat, ground monkey-nuts, and many other ingredients.

The natives are known to draw certain star-pictures in the sky; for instance, Orion is made out to be "two pigs and a dog." The three stars in the Belt form one of the principal subjects of children's songs. They, of course, know the Morning and Evening Star, while the Pleiades in their rising and setting mark the sowing and reaping seasons. They evidently only see six stars in the latter, as they call them Tshimtanatu, which means anything containing six.

They believe the sun returns across the sky at night when everyone is sleeping, and that it travels from west to east ready to start over again at daybreak, but high up in the expanse of the heavens and hidden from sight by unseen clouds. They ridicule the idea of the earth being round.

Eclipses of the sun or moon foretell war or some other great calamity. They most usually say of them that the sun or moon is "rotten," frequently that they are "sick." 
They generally believe that each moon dies, and that every new moon is new in the strict sense of the word. Some, however, think that it does not die altogether, but leaves a seed or germ, which in turn grows big and then small until only the seed is left. The rising and setting of the Pleiades, the new and full moon, are occasions of great rejoicings, dancing, and beer-drinking.

Sacrifices are still made by local natives. Formerly a large number of black oxen were killed at one sacrifice, but since the scourge of rinderpest visited Rhodesia goats have been substituted. The last sacrifice at Zimbabwe took place in February, 1904. The local natives sacrificed in the Elliptical Temple, but they have no settled point within the temple where they hold these ceremonies. The sacrifice was conducted during the prolonged drought then prevailing. The natives kept the ceremony private until after it was over, and the rain had arrived.

Makalanga of several tribes from near and far used to come to the Elliptical Temple for sacrifices, and these were offered up within the walls, but at different spots inside; while on several occasions the ceremony took place just outside the walls. Once every village had its own ceremony, and these took place in January, black bulls being offered for males and black cows for females.

The sacrifices now made are to the spirits of departed chiefs, and are offered on the suggestion of witch-doctors, who receive fees for their advice, and who, to make money, declare that the spirit of some dead chief or relative is angry and must be appeased. Some portion of the meat was taken to the spot supposed to be haunted by the spirit, and the rest is eaten by those present, the bones being sometimes burnt or thrown into a river; but recently they have been left about the spot. Sacrifices were usually offered to secure success in any venture to be undertaken, or to obtain good harvests. Till recently they practised a similar rite to that 
known in Mosaic times, and in this instance also the animal was not killed, but was led out on to the veld and purposely lost. If found it was not killed. The natives are aware that this rite was once observed by their people, but state it is not practised now.

The Makalanga undoubtedly believe in the immortality of the soul, but they have very vague ideas as to a future life beyond a thorough faith in the transmigration of souls. They do not conceive the existence of a Creator or Supreme Being, their highest conception being M'uali, a spirit, who can make their crops a failure and their herds sick, and to this spirit they offer sacrifices. The M'uali, judging by native account, is not in any way an ennobling spirit, and they are constantly in dread of him. The witch-doctors in order to acquire wealth for themselves interpret the wishes of the M'uali in the light of their own purposes and interests.

With regard to burials the customs, even among the Makalanga, vary considerably. In some instances the bodies are laid lengthwise and on the left side facing the north. This seems to have been the original custom of these people, but it is not now a general one. Burial in a sitting position is very commonly met with. On the Acropolis, during the preservation work (1902-3), about fifty Makalanga graves were found, and the remains in a score of instances were removed. Practically all were in a sitting position, only three having been buried lengthways. These were discovered in entrances and passages, the bodies having been laid on the surface, soil and stones, taken from the nearest wall, placed round and over them. None of these were very old, and most were Mogabe's people. Their bark hunting-nets, assegais, pots, and other personal belongings, were placed on the top of the grave, and not inside with the corpse.

The Baduma, who live in Gutu's country, and also the Barotse, still embalm or, rather, dry the bodies of their 
chiefs, and also the dead of certain families, though generally the bodies are buried lengthways on their right side, facing the sun. The body is placed in the hut on a bier made of poles near a large fire, and continually turned, any blisters which may appear being carefully broken, until the body is dry. Then it is wrapped up in a blanket and hung from the roof. Annual sacrifices are made to the spirits, and the bodies are regularly visited and kept in order by a person appointed for that work. The rain-makers, who live on the Sabi, also dry their dead.

The manufactures of the Makalanga are fast declining. In very rare instances may be found villages where bark and cotton are still woven. Limbo from the stores is so cheap and attractive looking that it has practically driven out the local article, and the clay whorls used in spinning cotton are now discarded. Their once famous iron and copper smelting industries almost disappeared on the advent of cheap and substantial tools. At one time every village had its blacksmith and its furnaces and forges, but during the last few years iron-working has become far less general. Derembghe, near Mr. Nolan's farm, in the Victoria district, is the only representative of the old industry. Pottery is still made, but at Chikwanda, near Arowi and east of Zimbabwe, the people make pottery of a superior quality. This is also the case at Mazuwa's, in Nini district.

The people are essentially a race of agriculturists and cattle breeders, and dislike working in mines. Though they are most industrious in their own plantations, yet they will not work for a white man for more than a month or two in a year, preferring to spend the rest of the year in absolute idleness. Many are adepts in brass or copper wire-work, with which they adorn their sticks and weapons. They are also very skilful in wood-carving, basket-making, and in tanning and preparing skins.

The Makalanga of this district are certainly above the 
average type of natives in the possession of both intellectual and physical qualifications. Light skins, Semitic noses, fine features, with an absence of high cheek-bones, small, wellshaped hands-are frequent features met with among them. The men, who wear but insignificant aprons, are well proportioned, are as straight as an arrow, and have athletic figures. Large turquoise-blue beads of glass form the neck ornament of men, women, and children in this district, and these contrast effectively with the colour and polish of their skins. Both men and women frequently wear a narrow band of pink and white beads round their heads. Brass bangles are worn on wrists, arms, legs, and ankles, the women and girls wearing these in great profusion.

Women are bare to the low hips, and wear a short skin skirt reaching almost to the knees. This is most generally adorned with chevron pattern of pink and white beads. Their stomachs are covered with two sets of lines worked into the flesh, one set under each breast. This pattern is very general here, and is identical with the "breast and furrow" pattern found not only on the fronts of the clay furnaces, pillows, drums, and granaries, but on the ancient relics and sacred emblems (phalli) discovered in the ruins. Bent and other writers believe that these flesh-markings are a survival of the occult idea of Fertility. There are generally about thirty rows of these lines or cicatrices, and their regularity is most surprising.

The men are practically bare-skinned, and have their waists, shoulders, and sometimes each side of their foreheads, marked with a row of bars in threes, thus: / and these closely resemble the sign of Light as seen in the Welsh bardic symbol. These, many natives state, are luck signs, and they would not be without them, for with them on their skin they believe they shall always be healthy and strong and have many wives and children. Other natives state that the flesh-markings on the men's bodies are but 


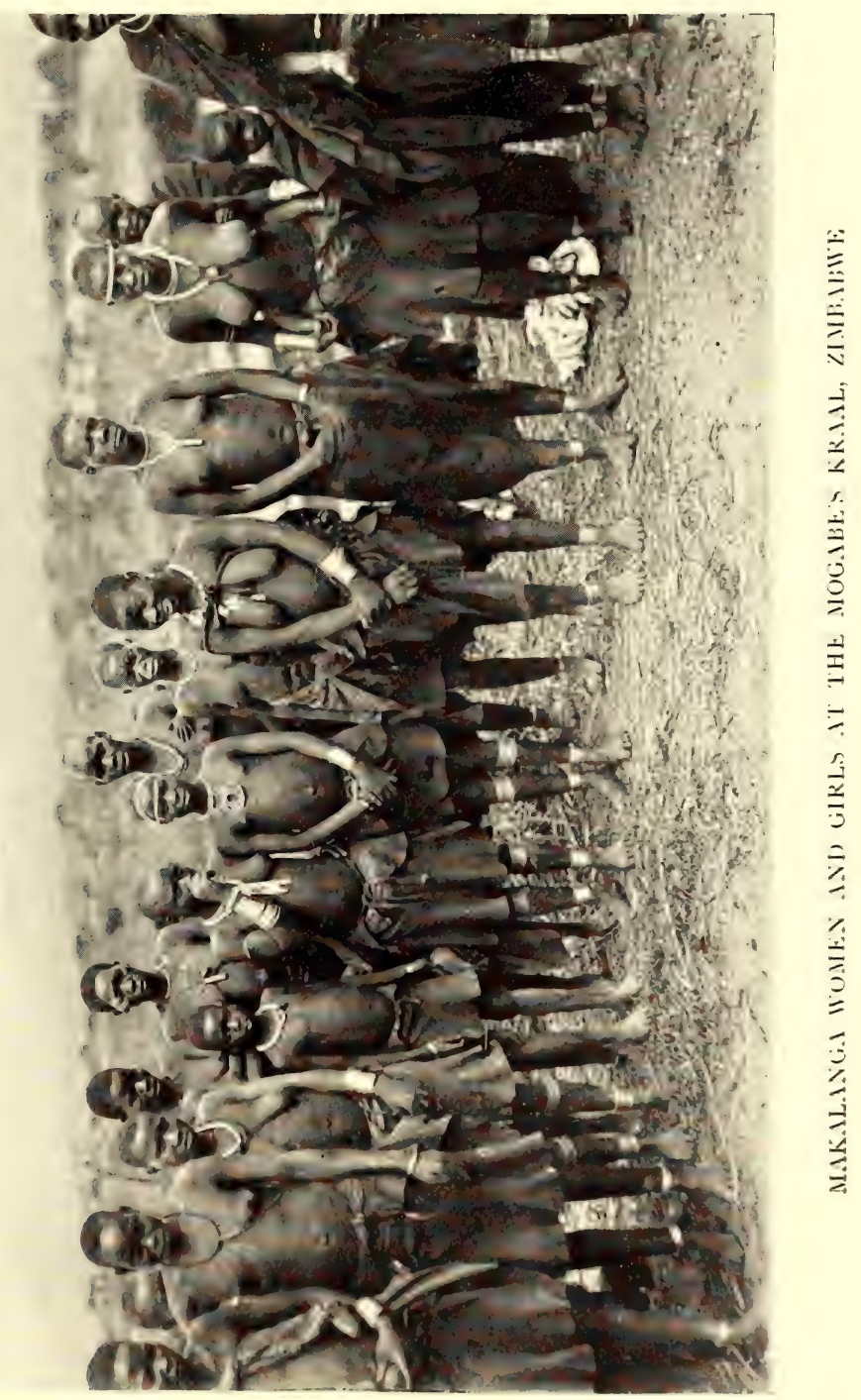



ornaments to attract the attentions of women, while others assert they only bear the marks because it is a custom. Each male has a forelock, some of these being erect and others pendent, the latter being usually threaded with pink and white beads. These often reach below the eyes. They are very proud of their forelocks, and will spend most of their spare time in trying to pull them out longer.

Witchcraft still possesses a tremendous influence over the native mind, although the practice of it is punished by imprisonment, but it is most difficult to obtain evidences in most cases of offence. Before the country was occupied by the British the witch-doctors practically ruled the people, and their influence in many known instances was greater than that of dynastic chiefs. The inclination of the people is to revert to the old practices, and fear of punishment alone prevents them doing so. There is no doubt that some of the infanticides and murders happening to-day are the results of witch-doctors' machinations.

Though every native appears to have a good idea of medicine and of the uses of certain herbs and roots, and to be able to cure simple complaints, yet the remedies for more serious matters are in the hands of the medicine-men, who keep all such knowledge to their own profession.

A rain-maker for a large present would, until recently, kill a child of one of his many wives, and as long as the mother mourned for her child the rain was supposed to continue.

The Makalanga undoubtedly possess a keener appreciation of music and singing than many of the other native races in this part of the continent. When at work, digging, hoeing, or threshing, they sing continually, and in one morning they will spontaneously render fully a dozen different songs and a large number of extempore recitatives and choruses interspersed, also a few part-songs and catches. They sing going to and returning from labour, and always sing at their work, and when they cease singing one may be certain they are 
idling. There is far greater harmony and variety of music produced from their pianos, and their songs are brighter and more spirited, than any music or song a Matabele can evolve, and the dreary monotonous chant of the latter is almost entirely absent. The subjects of their songs are numerous, and comprise many items which only a people who live face to face with Nature could sing without offending the decencies as regarded by civilised people, and in these songs the smallest child most lustily joins. They will sing impromptu songs having reference to the tools they happen to be using, or to anything they may chance to see. The Native Commissioner is a great subject of their songs. They have war-songs, lullabies, songs to the bride, to the child just able to walk, to the new moon, to the butter they are making, besides a number of children's songs.

They also have a large number of proverbs which somewhat resemble those employed at Home, thus :-

\section{Translation.}

"The grass which is in the belly of the wild ox is his own; that which is in his mouth he might die with."

"Difficulty makes a plan."

"Water spilt cannot begathered again."

"He is strong at the dish"; said of one who does not work, but knows well how to eat.

"Comes out with holes in his skins (garments)."

"A tame dog is the one that eats at the skins."

"Who has thrown out my basket of seed?"

"The short hare cannot eat the tall grass."

\section{English Equivalent.}

"A bird in the hand is worth two in the bush."

"Necessity is the mother of invention."

"No use crying over spilt milk."

"He is a good trencherman."

"Escaped by the skin of his teeth."

"Do not trust one who looks very innocent."

"Who has meddled with my affairs?"

"Don't attempt things too high for you." 
The natives can make fire (sika) very easily. The woods usually selected for this purpose are Zumbani and $B g_{g}^{\circ} e g_{g}^{\circ} a$. One piece is rounded, and the lower point is inserted in a small hole in the other wood, and then twirled with the palms of the hands round rapidly till sparks are emitted, and then very dry grass is placed at the bottom of the rounded stick, when it will light. Should the wood be slightly damp, a very small pinch of sand is placed in the hole to increase the friction. The sika sticks can obtain fire almost as quickly as can a magnifying glass.

On felling a tree in clearing a plantation it is a general custom in this district for the native to make a small ring of grass and lay it on the tree stump, and then to spit on the ring and to cover it with a large stone. Natives state, in explanation of this practice, that their people have always done it, but they cannot say for what purpose.

The pottery whorls found in very old native huts are known to many natives, but not to all, for the author has heard natives explaining their purpose to other natives. These whorls had sticks inserted top-fashion through the centre hole, and were spun rapidly between the hands. These were used for drawing the threads from the mass of cotton, also, some say, in producing fire. The children find them and use them for tops. The whorls which are found in ruins, and which are doubtless antique, are made of soapstone and are excellently finished.

The natives decorate the wooden doors of their huts, also the interior walls-check pattern being general for this purpose. The best decoration of doors is to be found in Gutu's and Chibi's districts.

The native name for Victoria is Duruben, or Durubeni, sometimes Vitori. Duruben is derived from the Dutch word dorp, and Vitori is an attempt to pronounce Victoria. Campeni is the name of the old township of Victoria, which used to be known as The Camp. Several isolated settle- 
ments of white people towards the south are called by the natives of those districts Durubeni, the termination being that of the locative case. The hillock in Victoria, near the gaol, used to be called "Gòna Zhon" ("They failed to capture the elephant"). The open veld about Victoria was called "Bani ro moteio" ("The plain without trees").

The salutation Moro! or Morra! employed by the natives is simply a corruption of the Dutch word Morgen! i.e. Good Morning! In Cape Dutch Morrè! is used, and from this the word Morro! was evidently derived. The natives agree in stating that it is a Dutch word brought into the country by Dutch hunters and Cape Boys long before the British arrived. They ridicule all idea of its being of native origin, and state that in some districts it is not used. The practice of handshaking on meeting is one which the natives state has been copied from the white men.

The salute on meeting is by clapping hands. On greeting a man they will clap the palms with the hands slightly crossed, the forefinger of the right hand crossing the base of the forefinger of the other; but on saluting a woman the forefinger is placed to forefinger with wrists together. The length of time of clapping depends on the position of the person saluted. On joining a group to talk, eat, or drink the new-comer claps hands before sitting down and again when the food or drink is offered him.

Among the Jewish customs of the Makalanga the following may be noticed. (I) Monotheism and no worship of idols ; (2) worship of, and sacrifices to, ancestors-a practice condemned by the Prophets; (3) rite of circumcision; (4) despising the uncircumcised : the taunt of non-circumcision is commonly employed between disputants; (5) purification and shaving of the head; (6) transferring impurity or infection from individuals to some animal, which in some instances is slain and in others purposely lost on the veld; (7) reception by women of parties returning from hunting or war, as in 
the case of Jephthah; (8) feasts of new moons and invocations to new moons; (9) feasts of full moons; (IO) offerings of first fruits; (II) defilement by touching the dead; (I2) defilement of eating flesh containing blood; (I3) abhorrence of swine as unclean; (I4) sprinkling the worshippers with blood; ( I 5) places of refuge for criminals or people believed but not found guilty of offending tribal custom ${ }^{1}$ (I6) observance of Sabbath, either every five or seven days; (I7) marriage only among themselves, but cannot marry into the same tribe; (18) casting of lots; (19) sacrifices of oxen in times of trouble, such as drought; (20) practice of espousal before marriage; (2I) brother succeeds to brother in office and property; (22) brother takes to wife the wives of his deceased elder brother, and raising offspring, they rank in office as if they were the children of the deceased; (23) a daughter does not inherit property or position except on the death of all her brothers; (24) rigid morality with regard to all fleshly sins, adultery and fornication being punished with death and outlawry.

Additional parallelisms with Jewish customs could be stated, and all these peculiar practices, together with the lighter skin and the Jewish appearance of the Makalanga, distinctly point to the ancient impress of the Idumean Jews, which can also be traced on the present peoples of Madagascar and of the coasts of Mozambique and Sofala. ${ }^{2}$

Many of these customs are now falling into desuetude on the advance of white civilisation. The Molembo tribe of Makalanga is noted for the preservation and observance of the majority of these Jewish practices, which are in character distinctly pre-Koranic in origin.

${ }^{1}$ Coillard, pp. 220, 224, and 333.

2 See Dr. Keane's Introduction to this volume; also The Gold of Ophir; also M. Grandidier's work on the Sabæan, Phønician, and Idumean Jew influences on South-East Africa and Madagascar; and The Ancient Ruins of Rhodesia (2nd edition). 


\section{CHAPTER VI}

RELICS AND “FINDS” AT GREAT ZIMBABWE, 1902-4 WITH DESCRIPTIONS, LOCATIONS, AND ASSOCIATIONS ${ }^{1}$

\section{SOAPSTONE ARTICLES}

GIR JOHN LUBBOCK once observed that one anti$\checkmark$ quarian relic found by itself was no testimony as to any particular ancient occupation of the spot at which it was discovered, but that the discovery of many identical relics in one place, and under identical conditions, might be considered as evidence of such occupation. Single specimens are known to have been transported from one hemisphere to another during the course of three or four thousand years.

At Great Zimbabwe it is not, except in a few instances, with single relics that we have to deal, but with those found in tens and scores, practically in identical and corresponding locations, and under exactly similar conditions. So regularly are these relics situated on certain floors that, with a few exceptions explained later, one is always certain as to the class of relics which will be met with on any particular floor which is being cleared. Of course, these relics and "finds" are not distributed generally on their respective floors, and frequently the realisation of one's hopes of meeting with them were greatly deferred, while on other occasions half an hour's work yielded them in quantities. Still, when

I See The Ancient Ruins of Rhodesia, 2nd edition, pp. 14I-3, for descriptions of relics found at Zimbabwe in 1891 and 1892 . See Appendix hereto, Note F, for inventory of relics found by the author at Zimbabwe, 1902-4. 


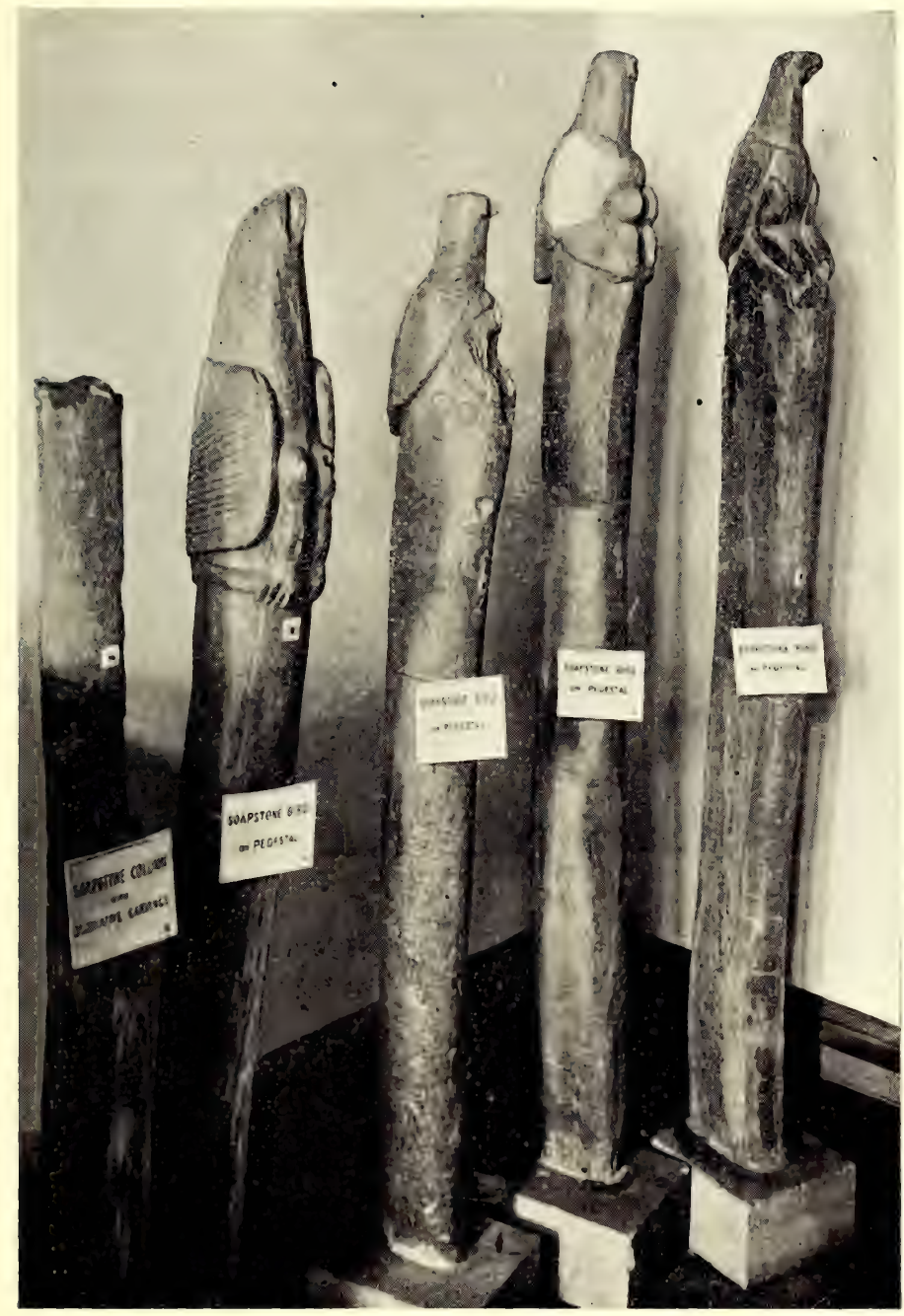

SOAPSTONE BEAMS WITH BIRDS, ZIMBABWE

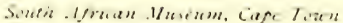



once found, they were generally abundant-at least, on those floors that were expected to yield them.

A small quantity of articles having claim to some antiquity were found out of relative position to the bulk of similar relics. For instance, phalli, which were found in quantities on certain floors in the eastern half only of the Elliptical Temple, also at the Eastern and Western Temples on the

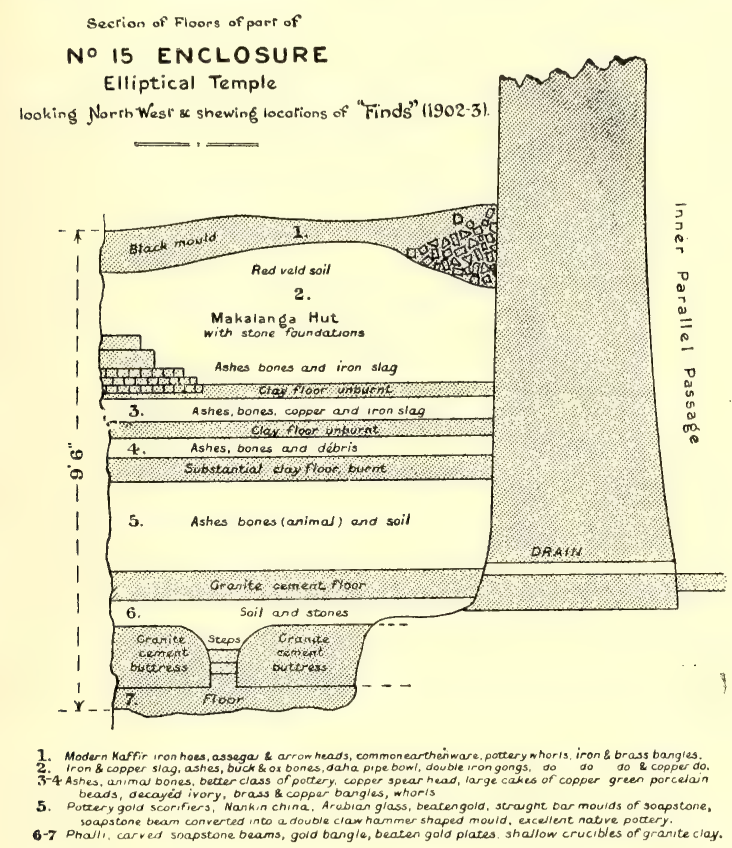

hill, and at Philips Ruins in the Valley of Ruins, have, in some few instances, been found singly, but most frequently fractured or damaged, in positions which could not have been those occupied by any of the ancient inhabitants. Single specimens are sometimes found in the débris piles immediately outside the entrances to the three temples and Philips Ruins. Those found lower in such piles were no doubt thrown out by old native peoples who would not be aware of their purpose. Some of these have been converted 
into amulets or charms, while others are known to have been used for making daha (hemp) pipe bowls. Those phalli found in the higher portions of such débris piles are shown by the stratification of the débris to have been brought out by the numerous relic hunters by whom the excavated soil from the interiors was deposited on these débris heaps outside. This experience extends also to almost all the more antique relics found at Zimbabwe.

The phalli found at Zimbabwe must now amount to at least one hundred, of which more than half have been found recently. It is very probable that on further examination of the lower floors of these four ruins other specimens will be met with. The phalli found vary in size and design. The largest (Pl. I., fig. 6) stood $7 \frac{1}{2}$ in. high, was perfectly plain, but highly polished. The smallest were seveneighths of an inch long, but each had its base bevelled and a ring carved round the summit. Except where the base is fractured, all stand erect on any tolerably flat surface. The bases show signs of extensive scratchings, as if they had been constantly moved. The average heights of the phalli are from two to four inches. Round the bases of many of the recently discovered phalli are small bevels, sometimes in two circles. The majority were unadorned, but their identity was unmistakable. The more ornate specimens bore the "female breast and furrow" pattern, one had chevron pattern round its bevelled base, several showed the circumcisional markings, and on the top of one (Pl. I., figs. I 2 and I3) were carved in relief rosettes formed of a circle completely surrounded by eight small circles, the latter a pattern which is frequently found on soapstone beams and bowls, and is also used to form the eyes of one of the soapstone birds found at Zimbabwe.

Worked and decorated soapstone beams have been found only in four localities within the ruins' area, viz. (I) the Elliptical Temple, on the summit and at the bases of the 


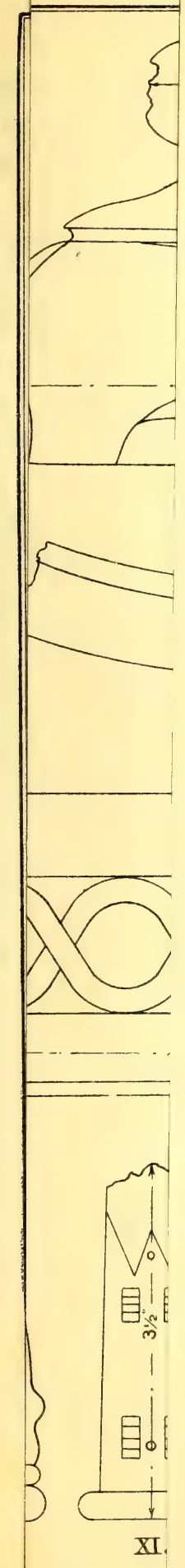





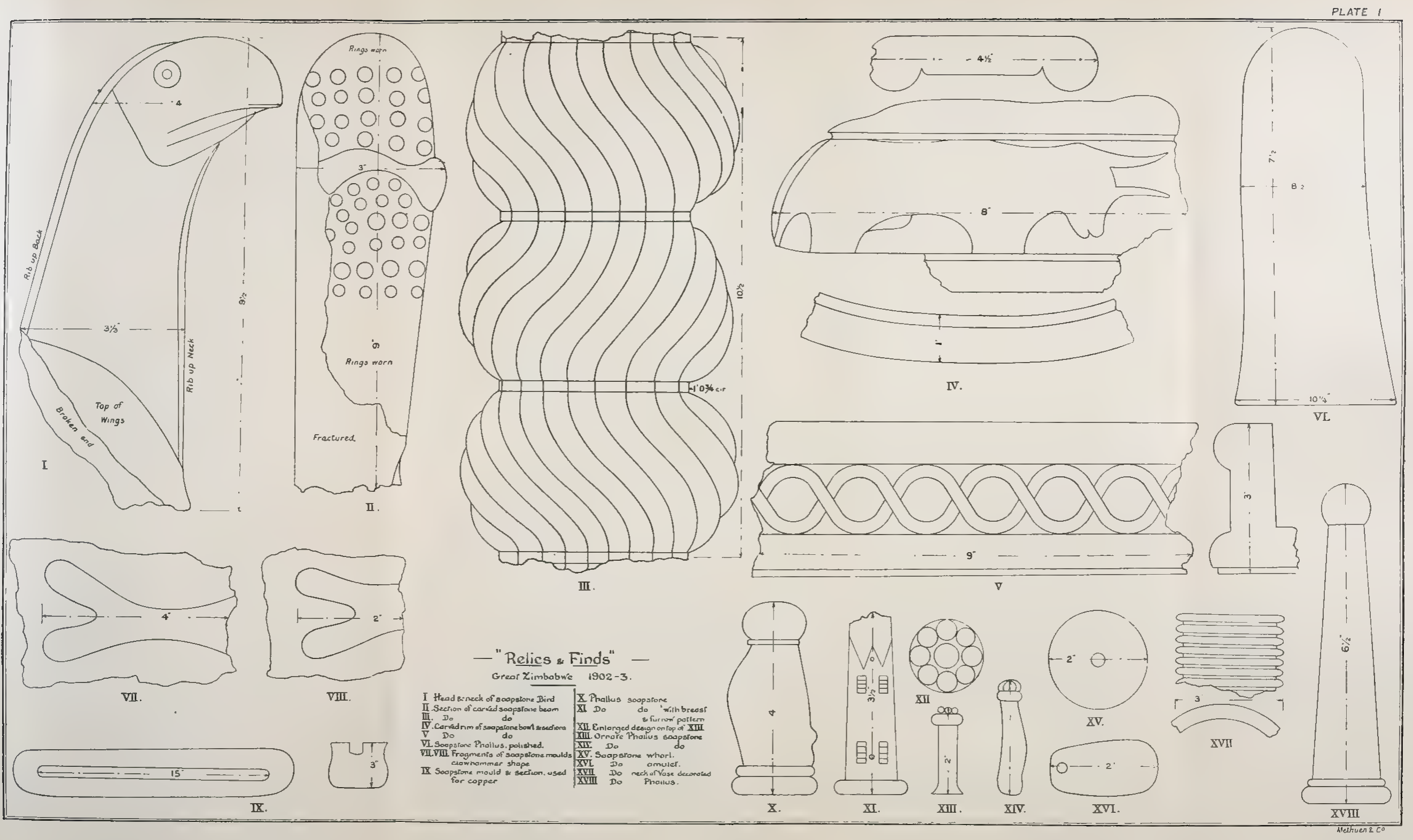



main east and south-east wall within the limits of the chevron pattern; (2) also in quantities on the summit and at the base of the circular granite cement platform which lies to the north of the Conical Tower; (3) on the summit and at the bases of the north wall of the Western Temple on the hill; (4) on the summit and at the bases of the arc wall of the Eastern Temple, decorated with dentelle pattern and facing east; (5) on or near the two granite cement platforms in the interior, and on the site of Mr. Bent's "altar," also in the same temple; and (6) on the summit and at the bases of the arc wall facing east at Philips Ruins, the fragments of beams found at this latter place being exceedingly numerous. Splinters of soapstone beams are found in the soil in the larger ruins, showing that some of the beams fell from their position and became fractured after the filling in with soil which took place at least one hundred and fifty years ago. Few, if any, worked soapstone beams were found in any of the Valley Ruins, save at Philips. All beams have been worked, and the marks of the tools and their sizes can still be seen on many; some are also carved, the chevron pattern predominating.

A portion of a soapstone beam, $2 \mathrm{ft}$. 6 in. long and I ft. 5 in. in circumference, formed part of what is known to have been a very tall and slender pillar, which was once surmounted by a bird. This stood on the north wall of the Western Temple on the Acropolis, and was found in 1902. The beam is completely covered with most delicately carved chevron pattern.

A carved soapstone beam, I I ft. high, which showed signs of once being taller, stood on the platform of the Western Temple on the Acropolis. It fell about I890, and broke into two parts, and these Mr. Bent removed.

A section of a soapstone beam (P1. I., fig. 3), carved into rounds resembling a chain of connected balls and decorated with spiral lines, was found in No. I 5 Enclosure 
of the Elliptical Temple, on the lowest floor and $2 \mathrm{ft}$. below the foundation of the north-east wall of that enclosure.

A curiously carved piece of soapstone (P1. I., fig. 2), evidently a portion of a beam, was found close to the circular platform in the Platform Area at the Elliptical Temple, among the numerous soapstone beams found at some depth at that spot. The fragment has so broken that it resembles a slipper with a band across the instep. The whole face of it is covered with small raised circular knobs.

Eight carved soapstone birds and birds on beams ${ }^{1}$ are known to have been removed from the ruins prior to I902, and they were mostly found on the Acropolis. Two, it is known, were taken to Johannesburg in 1890 , and about the same time the lower portion of a bird (of which the upper portion was found by the author in 1902) was removed and sold to Mr. Rhodes. In I89I Mr. Bent removed four birds on beams and also the lower portion of another bird, but he did not discover any of them, as the position of all these was well known to settlers both before the occupation and previously to this visit, many attempts having been made to buy these relics from the Mogabe Chipfuno, who persistently refused to part with them. These four birds on beams and another beam on which had once been a bird were standing more or less erect and fixed in granite cement on the Eastern Temple on the Acropolis, which for years previously had been used as a cattle kraal, and the holes and places in which they once stood, and from which Mr. Bent removed them, can be seen to-day. But on the authority of very early visitors, and of the Mogabe Handisibishe, there are still two birds unaccounted for. Possibly the mention of this fact may lead to their recovery. There is a general belief that one of these birds is in a certain museum in Austria, and this is quite possible, seeing that at least two Austrian scientists have visited this

All the birds found at Zimbabwe either by Mr. Bent and the author were discovered occupying an eastern position, cut off from south-west, west, and north by cliffs or large and high walls. 


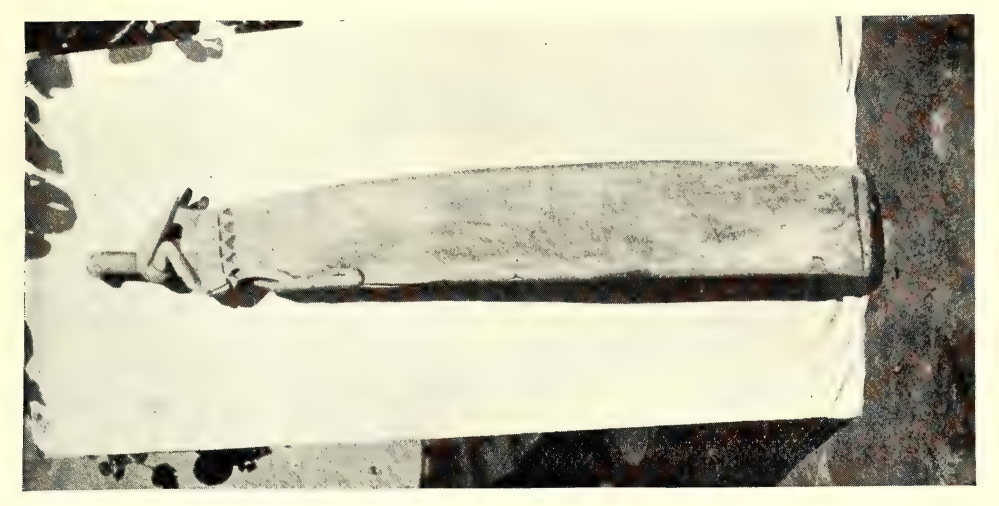

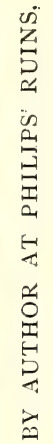

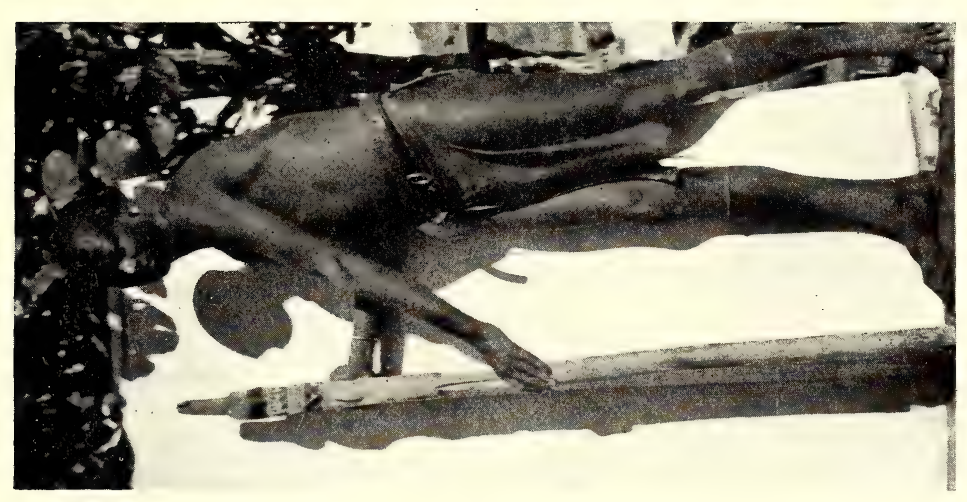

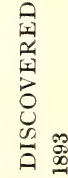

资

되 되

棸

0

츳

1
7
2
0
5
2
3
0
0
0

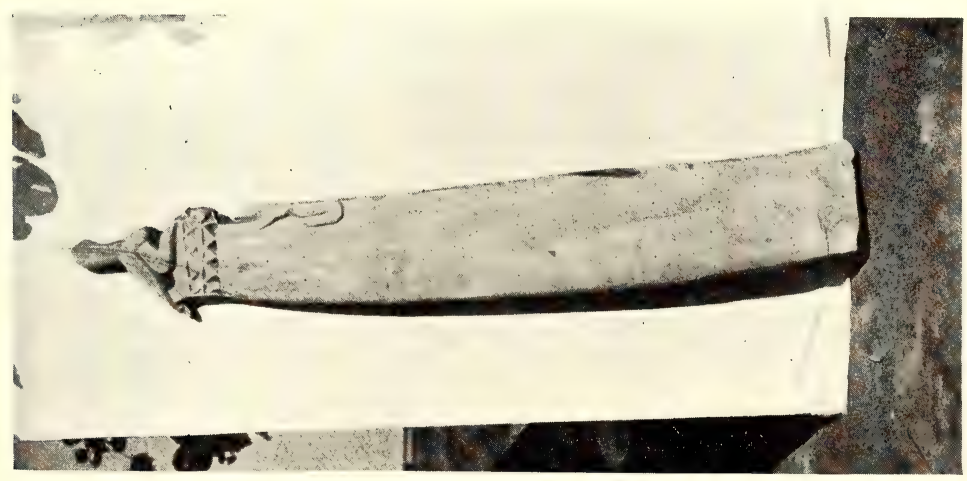

동

空

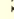

क

学

帘 

country. The total number of birds known to have been found at Zimbabwe prior to 1902 was eight.

In 1902-3 the author unearthed the upper portion of the fractured bird (Pl. I., fig. I), the lower portion of which was found on the Acropolis in I890, together with a section of the beam upon which it once stood. The head, neck, and shoulders of this bird are $9 \frac{1}{2}$ in. long. Up the neck, front, and back is a carved protruding rib. This portion of the bird is in an extremely good state of preservation, and the carving shows more artistic skill than do any of the birds on beams in the Cape Town Museum.

In 1903 the author discovered the tenth carved soapstone bird on beam. This was found in Philips Ruins, the most interesting buildings outside the Acropolis and Elliptical Temple. The bird and beam, which are still intact, were found on the east side of a high and massive wall and at the south side of a small conical tower in the North-East Enclosure of these ruins, being buried in soil and block débris to a depth of $3 \mathrm{ft}$. It was upside down, with the base resting against the side of the cone, from the summit of which it most probably had fallen, as the cone, which is approached by two steps and a platform on its east side, was covered with granite cement, while the base of the beam bears marks of its having once stood embedded in granite cement. All the birds at Zimbabwe found standing, with one exception, had the bases of the beams fixed in excellent granite cement. This bird and beam are undoubtedly not only in the best state of preservation of any yet found at Zimbabwe, but show evidence of more artistic workmanship having been bestowed upon them than any of those previously discovered. Up the face of the beam is carved a crocodile 16 in. long, and round the cestus beneath the bird's feet, which is 3 in. deep, is carved work - on one side a large double row of chevron pattern, similar to the pattern on the east wall of the Elliptical Temple, and on the opposite side a single row of chevron, surmounted by two large em- 
bossed circular discs ; the back edge of the beam is plain, and the front edge above the crocodile has two small embossed circular discs. The bird stands I I in. high, the total height of the beam and bird being $5 \mathrm{ft}$. 5 in., its width $8 \mathrm{in}$. on the flat sides, and $2 \frac{1}{2} \mathrm{in}$. on its end edges.

Miniature soapstone birds on pedestals have been found by other explorers of Zimbabwe, but the writer discovered only a portion of one of such birds.

In Mr. Bent's work are given the opinions of several of the best-known scientists of Europe, who, by means of the birds and associated relics found at Zimbabwe, connect the worship carried on there with that of the ancient Sabæan people of South Arabia, who worshipped the goddess Almaquah (Venus), the Morning Star. See Preface, also pages 181-87 of The Ruined Cities of Mashonaland.

The best-made soapstone bowls are found on the lower granite cement floors of the ruins and far below any native clay floors, the southern side of the Acropolis, the eastern half of the Elliptical Temple, and Philips Ruins yielding these in quantities. The fragments of bowls with carved processions of horned animals, of which a dozen pieces have recently been discovered, and which fragments represent different sized bowls, were found only on the lowest floors, and these only on the Acropolis. This was also the experience of $\mathrm{Mr}$. Bent. But there is an exception to this rule, viz. that the ancients, or some people of a period prior to the Makalanga, had, on the bowls becoming broken, thrown the fragments over the west and south edges of the Acropolis Hill, where fragments may still be found among and under the wall débris which has fallen down the precipitous sides of the hill. Probably before these fragments became, at a later date, completely covered by further falls of wall débris, native people of a remote age converted some of these into slabs for the isafuba game, and cut the sets of game-holes on their flat bases and on the inside of the higher rims, while they 


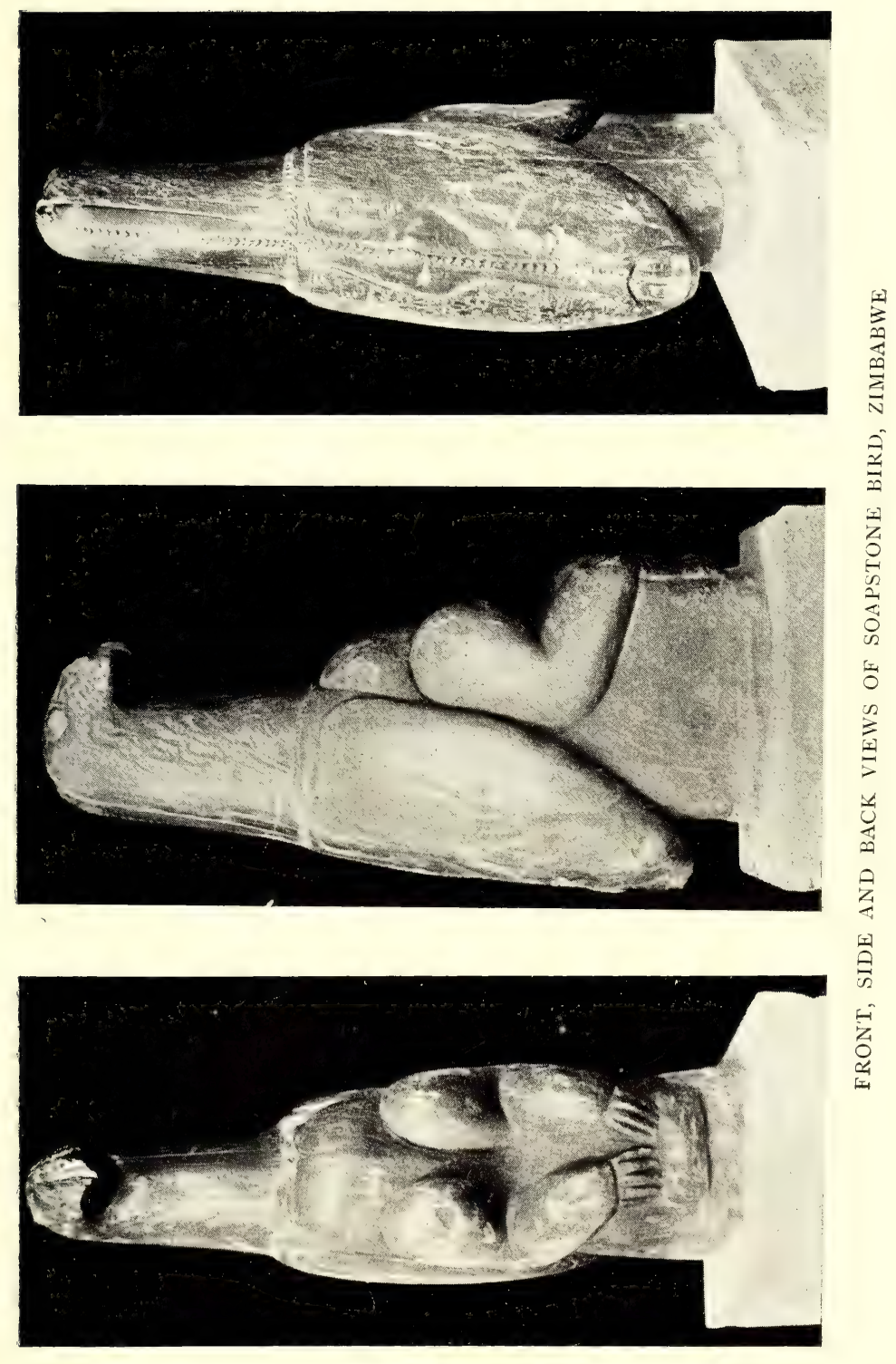



have also rudely scratched the usual native designs on the opposite side to the carving-crude designs which are obviously in striking contrast to the artistic work of the original makers of the bowl. Such portions, and but a few only, have been found on very old native clay floors on the Acropolis.

The fragments of the soapstone bowls recently found vary in style, size, and carving, and these fragments represent at least thirty different bowls. Mr. Bent also found fragments representing some ten different bowls, and as there still remain large areas of lower floors to be opened out, there may be still further evidences of even more extensive use of these articles by the ancients of all periods at Zimbabwe. The diameters, judged by the radii of the segments, vary from I ft. $\mathrm{I} \frac{1}{2}$ in., which is the smallest size yet found, to I ft. $3 \frac{3}{4}$ in., the largest so far discovered. The heights of the outside of the rims range from 2 in. to $3 \frac{1}{2}$ in., the majority being about $2 \frac{3}{4}$ in. The rims, which are all without flange, except in one instance, are from $I \frac{1}{8}$ in. to $I \frac{5}{8}$ in. in thickness. The bases of the bowls have about the same average thickness, but in a few cases they are somewhat thinner. The insides of the bowls from rim to rim are always beautifully flat and smooth. The bottoms are thickly covered with fine scratches, as if the bowls had been constantly pushed along the top of stone or fine cement work. The insides of some of the bowls show signs of having been subjected to very great heat previously to the breaking of the article. It may well be imagined that bowls of these dimensions, cut out of solid soapstone, itself an exceedingly heavy stone, must have been of great weight, and that without considering any contents they might have held.

A few bowls only were plain-that is, with no decorative pattern on the outside-though all are finely worked, and the plainest has rounded sides which slightly project at the top of the rim. The designs on the relics vary, and include procession of horned animals (Pl. I., fig. 4), zebras, dogs, a bird, 
and a man. The decorations on the majority of the bowls comprise (I) herring-bone, plain ; (2) herring-bone on cords, i.e. two parallel cords with their respective lines of strands inclining opposite ways, and thus together forming a herringbone pattern; (3) cord pattern, the strands of the parallel cords both inclining in the same direction. These cords in (2) and (3) are found both vertically and horizontally. In the case of cord pattern of any sort the cords are carved in lengths, the lengths being divided by plain protruding squares at intervals; (4) circular discs sunk into the surface, the discs being either plain or covered with rings within rings till the centre is reached; (5) a chain of diamondshaped panels with centres completely filled up with lines parallel to the outer lines.

A pattern (6) (P1. I., fig. 5), new in Zimbabwe relics, was recently found on the rim of a soapstone bowl discovered in Maund Ruins in the Valley of Ruins. This consists of two wave bands crossing and recrossing each other throughout their length, and thus making a continuous line of perfect circles. This is very correctly carved, and the artistic merit of its workmanship is equal, if not superior, to that of any soapstone relic yet found at Zimbabwe. ${ }^{1}$

Among other soapstone "finds" made recently at these ruins are two fragments of two double claw-hammer-shaped ingot moulds (P1. I., figs. 7 and 8), each fragment being the major portion of such mould. These were cut into the broken section of an ornamented beam. Moulds of this shape are not, therefore, necessarily ancient, though the form may have been handed down from ancient times. Mr. Selous, some years ago, discovered considerable quantities of copper ingot moulds in actual use by the natives of Katanga, and these were almost the identical shape of the ingot mould discovered by Mr. Bent at Zimbabwe. The Administrator of North-Eastern Rhodesia reported in March, 1900, that

1 Professor Dr. Flinders Petrie informs the author that this pattern is decidedly of Eastern origin, possibly Assyrian. 
ingots of copper in the form of a St. Andrew's Cross were common articles of trade in the Katanga district. It must also be recollected that three such ingots have been found in Southern Rhodesia. Though old, their appearance does not in any instance suggest antiquity. The author, taking these points into consideration, does not believe that the ingot mould discovered by Mr. Bent can be any evidence of the occupation of this country by the Phonicians, and this opinion is further confirmed by the locations of the moulds found. (See The Ancient Ruins of Rhodesia, pages 128 and I4I ; also Appendix thereto, Note C.)

A straight bar mould (PI. I., fig. 9) which shows signs of considerable use has also been found, but on an upper clay floor. It is believed that this was used for moulding copper bars. The natives of Kafue, the Melembo people of modern times, and the local Barotse, all these being races of skilful copper workers, are known to have made identically shaped copper bars.

Other soapstone articles include a ball, a few whorls, amulets, and daha pipe-bowls, the latter being of Makalanga make, while it would be extremely difficult to say to which period the other articles belonged.

\section{GOLD ARTICLES ${ }^{1}$}

Gold in almost every form has been found in quantities on several of the lower floors of the ruins, and from its locations must have been produced and worked, not only by ancients, but by very old Kafir people, possibly under Moslem Arab supervision, for concave fragments of Kafir pottery of a very far back period (and so pronounced by Dr. Hahn and other experts) have been used as crude scorifiers, and the gold can still be seen on them in the flux, while other undoubted Kafir remains, some of which are claimed to be Makalanga of an exceedingly old make, are found associated with the scorifiers. The mediæval Makalanga, as early Portuguese records show,

1 See also Preface, "Two Periods of Gold Manufacture at Zimbabwe." 
not only produced gold but manufactured it, especially into gold wire. It may be conjectured that this style of metal work was due to Arab influence, for the earliest Portuguese records frequently testify that the Arabs possessed important colonies in the country of the Monomotapa, colonies sufficiently influential to mould the policy of successive Monomotapas, especially as against the incursion of Portuguese, and that the main purpose of the Arab intruders in the country was to obtain gold and ivory. Until the last decade, when the cheap and ready-made European goods became obtainable by the natives, the Makalanga can be conclusively shown to have been a nation of metal smiths capable of producing most excellent work, and of drawing very fine wire, while to-day their art of making wire bangles and covering articles with work in correct patterns is such that the difference between the quality of the native work and that produced by machinery in Europe can hardly be detected. It must be remembered, too, that previously to, and for some time after, the occupation, it was possible to buy gold beads from the natives in Mashonaland. These might to a large extent have been found in ancient ruins, but the majority of such articles so bartered for from the natives consisted of Kafir-made copper and iron bangles with gold beads at intervals round the circle.

Gold and gold articles of the more delicate and artistic manufacture belong mainly to the period of the ancients, but gold, as shown by tradition, history, and "finds," was also a product of mediæval Makalanga, as can be further demonstrated by any excavator of very old Makalanga floors, and of this the proofs exist abundantly.

The small gold crucibles of granite clay similar to those described on page 22I of Mr. Bent's work, and found on the lowest floors and in rock holes and fissures used for depositing débris, where they must have been thrown away as rubbish after the small cakes of gold had been removed, 
although they still contained in the flux large beady pieces of gold. A large number of these have been found in positions where the Kafir clay scorifiers are not met with. It would be well in considering the "finds" of crucibles not to treat them with the pottery gold scorifiers, for, so far as discoveries lead, they undoubtedly appear to belong to entirely different ages.

Several sizes of gold beads have been found. There is no doubt that some places in certain enclosures of the older ruins will yield a fair quantity when the soil on the lower floors is systematically treated. Several beads are perfectly round, others are round but with flat ends, others again show two facets encircling them and meeting at the widest point.

Beaien gold to the amount of about 6 ozs. was found on the lower floors. This was discovered in the form of plates usually about $\mathrm{I} \frac{1}{2}$ in. to 2 in. by $\mathrm{I}$ in., each plate having small holes round the edges, in many of which holes the gold tacks still remained. One piece was wider at one end than at the other, and this is believed to have been a sheathing encircling a section of a piece of ebony found with it, the ebony stick being thick at the top and tapered towards the end. There were remains of embossed designs on two pieces of beaten gold, one of diamond pattern and the other a plain circle with curved radiating marks.

Gold tacks were most usually found with the beaten gold. These are of microscopic size. The majority have wedgedshaped heads, and the others flattened heads. It is believed that these tacks served to fasten the gold sheathing on to wooden articles used by the ancients.

Bar-gold and gold-cake were found on the lowest floors in the Elliptical Temple and North-East Passage respectively. Gold-dust is found in certain enclosures only, but on the lowest floors. Over two hundred pannings of the soil in various enclosures have been made. The soil of some enclosures is absolutely destitute of any trace of gold, so also 
is the veld-soil brought into the ruins by native people over one hundred and fifty years ago. In some places outside the ruins pannings show gold, and pieces of beaten gold and gold wire have been found in such places.

One complete gold bangle of twisted wire, most artistically wrought and weighing $2 \frac{1}{2}$ ozs., was found on the bed rock in an enclosure on the Acropolis Hill. Another complete gold bangle was found on the lowest floor of No. I 5 Enclosure of the Elliptical Temple. Short pieces of twisted gold wire of various gauges have been found at several ruins. Most of such pieces are parts of broken bangles.

Gold scorifiers of native pottery were found in quantities on an intermediate floor in No. 6 Enclosure of the Elliptical Temple, together with a pair of iron pincers and Arabian glass. The report made by Dr. P. Daniel Hahn, PH. D., M.A., Professor of Chemistry, South African Chemical and Metallurgical Laboratory, Cape Town, on these scorifiers, is as follows :-

"The several fragments of scorifiers sent for analysis did not all contain sufficient flux to be removed without being mixed up with the substance of the scorifier. A fair quantity of flux could, however, be separated in sufficient purity for analysis.

"The flux was composed of :-

Silica

Ferrous Oxide

Aluminic Oxide

Lime

Magnesia

Gold

Sodic Oxide .

Potassic Oxide

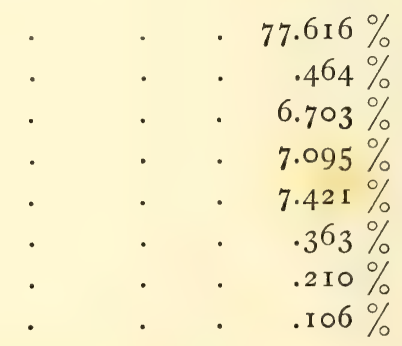

"No Borate or Flouride was found in the flux.

"The composition of this flux is remarkable, inasmuch as the alkalies are present in very small proportion only, while the alkaline earths prevail. Also the amount of silica is very high. 
"The flux melted readily when it was heated on a platinum lid in a muffle furnace at the temperature required for expelling auriferous lead."

Dr. Hahn has further informed the author that pieces of scorifiers are fragments of native pottery similar to that found in different parts of South Africa, and he adds, "They are certainly not European but native pottery."

\section{COPPER ARTICLES}

Discoveries of copper in several forms are made on intermediate and higher levels. So far no copper article has been found by any explorer at Zimbabwe which could be claimed as being ancient, though doubtless the ancients worked also in copper, and it is quite probable that copper articles made in pre-Kafir times may yet be found. Such copper articles as have been found show a decided Kafir form, the copper battleaxes and barbed spear-heads, bangles, beads, and wire-work closely resembling the iron articles still made by the natives, though of a somewhat superior design and make, and some of these in all probability, judging by their location and the associated finds, covered a period extending from mediæval times until comparatively a few years ago. The floors and immediate vicinity of native huts of the oldest construction yield copper articles abundantly, while later native floors have a larger percentage of iron articles.

Three pounds' weight of thin and narrow strips of copper sheathing with tack holes round the edges and copper tacks were found on one of the higher levels, and at a depth of several feet below were granite cement steps and buttresses of excellent construction. This sheathing had evidently covered some wooden article.

The copper used in most instances is pronounced to be pure metal and free from the usual alloys. The metal in these is of so pliable a nature that spearheads can be easily 
twisted by hand into almost any shape. One spearhead was copper and tin, but the latter was present in very small proportion. Several articles once thought to be bronze are now pronounced to be of copper only. A small piece of a bar of tin was found on an intermediate floor. Copper wire, mostly in the form of bangles, is very plentiful on intermediate floors, also large cakes of copper and copper slag, but so far the actual remains of copper-smelting furnaces in situ have not been met with at Zimbabwe, though judging by the amount of copper slag and copper ore found at the extreme east of the Acropolis ruins, copper-smelting was carried on in that locality during the period when the gold scorifiers made of native pottery were being used. Here were found portions of clay cupolas which had been used for copper smelting, circular and deep, about the size of a small teacup. The fine and delicate copper chain found in Renders Ruins is believed to be of Arab origin, and used to suspend the lamp-holder found with it. Pieces of a small copper box, and several solidly made copper bangles, and copper fingerrings in snake form with the extremities coiled, were also found in Renders Ruins on the same level where the copper chain and several articles of Arab origin were discovered.

\section{IRON ARTICLES}

Objects made of iron are found in all floors, but mainly on intermediate and upper floors. Makalanga iron tools, ornaments, weapons, and iron slag are found in great profusion on the upper floors, especially in the black surface mould and among grass and shrub roots. Modern nativemade iron hoes are as a rule without any sign of bevel to strengthen the blade, but iron hoes with a peculiar bevel down the centre of the blade on both sides are found among native articles of a rather superior character and at slightly lower depths. These latter have a depression stamped down the centre of the blade which raises a bevel on the opposite 


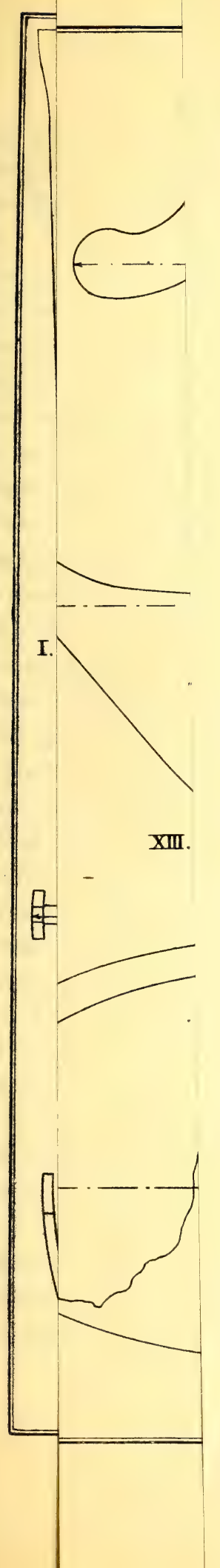





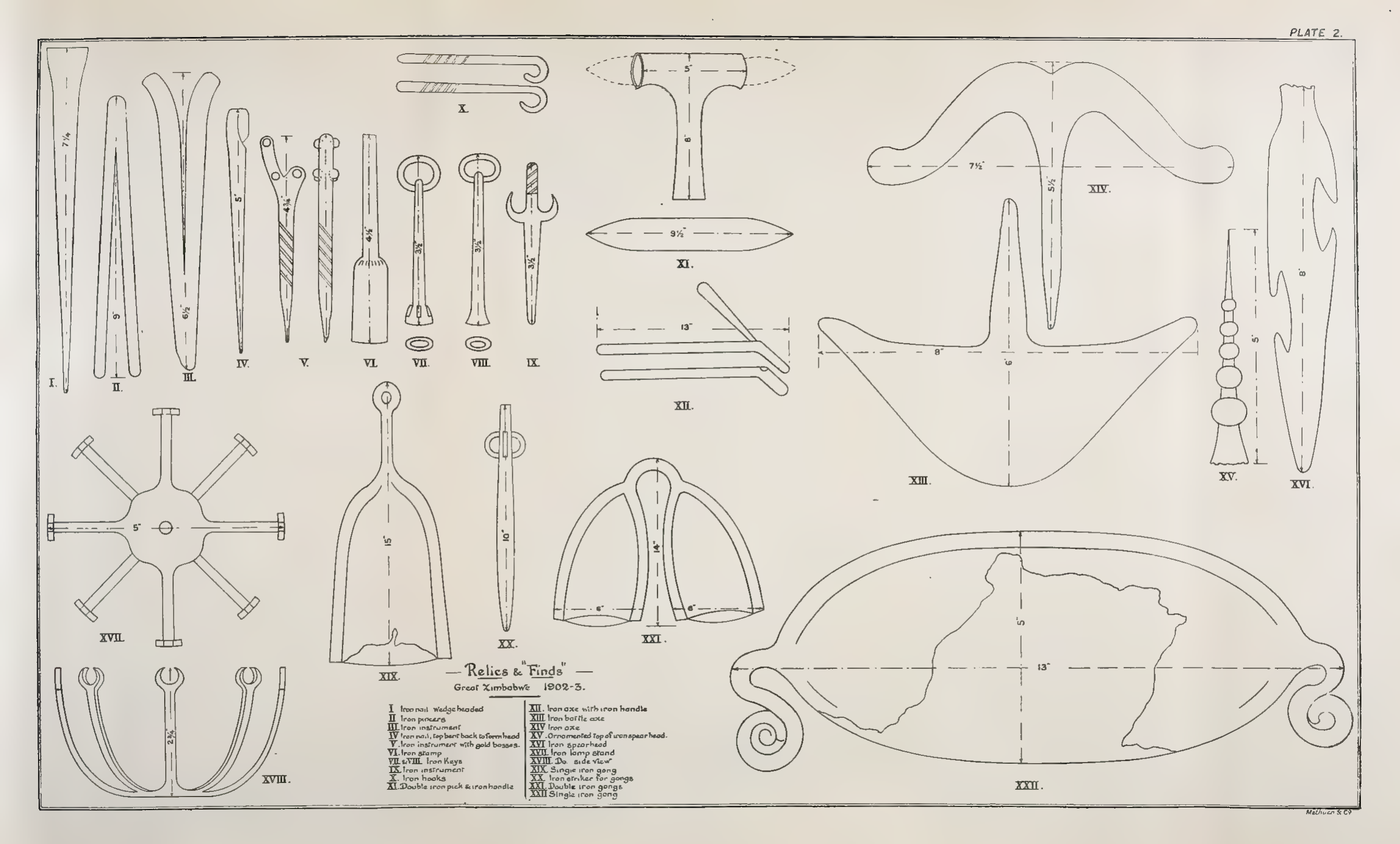



face, while on the opposite side another depression has been stamped parallel with the raised bevel on that side, thus providing a rib on each face, which greatly strengthens the hoe. This class of bevel has been pronounced by experts to be an old form employed also in other parts of the world, and local authorities on Makalanga iron-work assign this make of hoe to several generations ago, while the Makalanga themselves state that such hoes are found in very old deserted villages of their people, but have not been made during their time, but used to be so made by their fathers' fathers.

Iron chisels (Pl. III., figs. I and 2) are found on almost all floors, and were it not for noting the actual spots where they are found and the associated articles, it would be difficult to state, so closely do they resemble each other, which of them were antique and which old or modern native. This difficulty is increased when old Kafir iron-chisels and picks are found to be greatly corroded, while some of the iron tools found in positions suggesting a great antiquity are sometimes found in an almost perfect condition. The sizes of the various chisels used by the ancients on blocks in the oldest portions of the ruins, and also on the soapstone beams, are still clearly distinguishable.

Iron picks are found on older native floors, and these vary in make and design, and may be classified as follows :-

(a) Double-pointed picks made of a short, thick piece of iron tapered at each end, the middle part of which is held by a short iron handle (Pl. II., fig. I I). These have also been found in old workings in both Matabeleland and Mashonaland, and especially in the Mazoe and neighbouring districts. Several of the early writers on this country state that these picks had been supplied to their native labourers by the mediæval Portuguese, but it is impossible at present to state whether this belief be correct or otherwise. Certainly these picks have been mostly found in districts once occupied by 
the Portuguese. There is a character in the design, class of iron used, and the make that does not suggest a native origin.

(b) An iron pick (Pl. III., fig. 3), similar to the one shown on page 217 of Mr. Bent's book, but in a better state of preservation, was recently found at Zimbabwe. It is almost certain that this class of pick once had wooden handles up the middle of which was a hole, and through it passed the iron bar which bound the pick and the handle firmly together.

(c) The pick (Pl. II., fig. II) is formed by a bar of iron which is bent back a few inches from the top, and in the front of the bend is a hole running up the centre inside the bent-back portion, and into this hole the haft of the pick is fixed. These have been found complete.

All three classes of picks are found on intermediate and upper clay floors, yet the local natives affirm that they have never known them to be made, though they are aware of their purpose.

Included in the finds of iron articles was a well-made iron spoon with a long handle squared at the end. This was found among the Arab belongings in Renders Ruins, also an iron spearhead (P1. II., fig. I6) with peculiarly designed spaces in its edges as if for inflicting a more than usually serious wound. An ornamented spearhead (Pl. II., fig. I5) with its point decorated with bead-like bevels diminishing in size from base to point. An iron lamp-stand (P1. II., figs. I7 and I8) with eight bent-up arms (with which was found $12 \mathrm{ft}$. of fine copper chain in lengths of about I 8 in. with pottery affixed at intervals) was also found with the Arab articles.

Iron bangles, both solid and of wire-work, are found on upper floors in the black surface mould and among grass roots. Some of these must be exceedingly old, and in the wire bangles the fibre or zebra hair (this, in some instances, being found intact), round which the wire was twisted, has completely disappeared. In many instances some traces more or 
less distinct of the fibre or hair still remained. Twisted iron wire-work, evidently imported wholesale, has been found at one spot only, and in great quantities in the form of coils, and not cut up into lengths for use as bangles. The coils, which are now fused, must have contained very many feet of this twisted wire. The same applies to coils of twisted brass wire in large coils found also at the same spot, which, as is shown later, was evidently an old Arab trading station.

Iron nails (Pl. II., figs. 2 and 4) are not limited to any particular floor, and are found almost everywhere in the ruins. But these vary considerably in make. The oldest form of nail and the best designed is that found at greatest depth. This is wedge-shape headed. Another form of exceedingly old class of nails is that where the head is formed by doubling the nail back for about half an inch. But the head is not welded, the bottom part of the bent-back portion being slightly tapered where it meets the side of the nail. These nails in several instances were made difficult of extraction from the wood by being barbed and notched, and in some cases, especially of a rivet class of smaller nails, the nails, when the iron was hot, were twisted in the centre only, and a rude sort of screw was thus made with protruding edges. It can be seen that several twisting operations were required to form these spiral bandings, and that these separate twistings do not connect together as in a perfect screw. The larger nails are from 4 in. to 6 in. long, the rivet class varying from $\mathrm{I} \frac{1}{2}$ in. to 4 in.

Iron shoes and collars once having served as bands round wooden posts, possibly to keep them from splitting, especially in a climate where there are daily such rapid changes from heat to cold, and which plays such havoc with the modern imported timber. These bands, which average almost an inch in width, generally passed twice round the post, and the shapes of the circumference of the post are square, oblong (these are the most frequent), or circular, but always per- 
fectly exact, showing that the ancients and older inhabitants of the ruins used wood that had been specially shaped with tools, and not the rough, unworked poles used by old and present natives, many of which can be still seen never to have been touched with any tool save in cutting it from the tree and in lopping off small branches. These shoes and collars are found on very old floors, their greatest length or diameter being $4 \frac{3}{4}$ in.

One important fact is clearly demonstrated by the presence in quantities on the older floors of nails and shoes, and it is that the original builders and their more immediate successors extensively employed woodwork in the fittings of all the enclosures, some of it being of large dimensions, and in all probability worked with tools, and not used in the rough state. The general distribution of these nails and shoes throughout the enclosures, and at some depth, convinces one that substantial wooden fittings once existed in these enclosures, for the large sizes of the older forms of nails and the make of the shoes and collars preclude any suggestion of many of them having been used in woodwork which could have been easily removed.

A forked iron instrument (P1. II., fig. 5), with six gold bosses riveted with gold on to the iron, is certainly of a very antique character, though possibly not an article belonging to the original builders, for the condition of the iron and its location, while pointing to some antiquity, rather precludes any idea of its being of the earliest date. This was found in the Western Temple at the Acropolis ruins, at a point near, but not so deep as, the spot which Mr. Swan styles "the centre of the arc of the curved and decorated main wall of the Western Temple on the hill."

The iron pincers (Pl. II., fig. 2), found with the gold scorifiers on an intermediate floor in the Elliptical Temple, are of simple construction, and are made of a bar of iron tapered at each end and doubled together, the doubled end being 
hammered close, but not welded. Traces of flux are on the tapered points. A second pair of iron pincers, but not in such good condition, were found on an intermediate floor in the Acropolis ruins.

Some six pairs of double iron gongs were also recently found, but not in any position or associated with articles suggesting antiquity. These were found on old Makalanga floors, also among grass roots and in black surface mould Yet the type and pattern of gong is undoubtedly ancient, being found in Egypt and seen in the ancient paintings in that country, but like the rod of iron, the pillow, the ingot mould, and a score of other articles used not only by Makalanga but by other peoples of this continent, the form and make of these gongs have been handed down from time immemorial. The local natives know the use of these gongs, and say that they were beaten with an iron striker (P1. II., fig. 20), but they have not seen any at Zimbabwe since they arrived seventy years ago, nor can they say that their own people ever made them, but they suppose that the old Makalanga, who, up to at least one hundred years ago, are known to have lived in the Zimbabwe ruins, made and used them. These gongs are known to local natives who have travelled, and these say they have seen them in use in the Zambesia districts, where they are used to greet the arrival of chiefs and the appearance of the new moon, also as a signal of warning. The two gongs are bound together by an iron band, which forms the handle. One pair was found on the floor of a hut built on block foundations with the usual clay-rounded, bevelled, and circular base, exactly similar to those on the filled-in plateau of No. I Ruins at Khami (see Chapter VII., section "Native Huts found in Ancient Ruins," post, p. I 52). The gongs found at Zimbabwe average ${ }_{1} 6 \frac{1}{2}$ in. high, and their sides are hammered together out of two thick sheets of soft iron. They have no clappers, and are intended to be struck from without. They have frequently been found in Kazembe 
country between the Zambesi and Lake Tanganyika, where the natives state that the gongs are not made now, and that they are very old (Anthrop. Journal, 1901, Article 39). Dr. Holub (vol. ii., p. 147) gives an illustration of a double iron gong of crude make and design, still in use among the Barotse as a musical instrument. Sir H. M. Stanley states that these double iron gongs were in use by the natives of Urangi (Upper Congo), and also at Mangala on that river. His illustrations of these gongs show great similarity to those found in various parts of Southern Rhodesia. Several writers on South-East Africa describe an identical iron gong still in use among the natives. Each gong gives a different sound to its companion gong.

A single iron gong (Pl. II., fig. 22) was also found among old native articles. The gong is oblong, and has an ornament at each end made of tapered strips of iron coiled into circles, and these ornaments strongly suggest that the gong was only used when suspended. It is $13 \frac{1}{2}$ in. long and $5 \frac{1}{2}$ in. deep. No explorer in this country appears to have seen a gong of this description. Its style and make are altogether unique.

One iron rod or sceptre, $3 \mathrm{ft}$. 5 in. long, was also found in a position not suggestive of antiquity. This was recognised by the natives as the rod of a chief, being a native symbol of power. Some of the dynastic chiefs of the Makalanga still possess these iron rods. The end of the rod is bent back to form the handle. Mr. Bent says the iron sceptres borne by Makalanga chiefs have their parallels in the north of the African continent! Ruling "with a rod of iron" is a scriptural description of despotic government.

Pieces of worked iron, with rings let through the top ends and broadening at the base, where there is a different shaped hole of a distinct form on each base, appear to have been keys (Pl. II., figs. 7 and 8). These were found with the Arab belongings in Renders Ruins. 
PLATE 3.

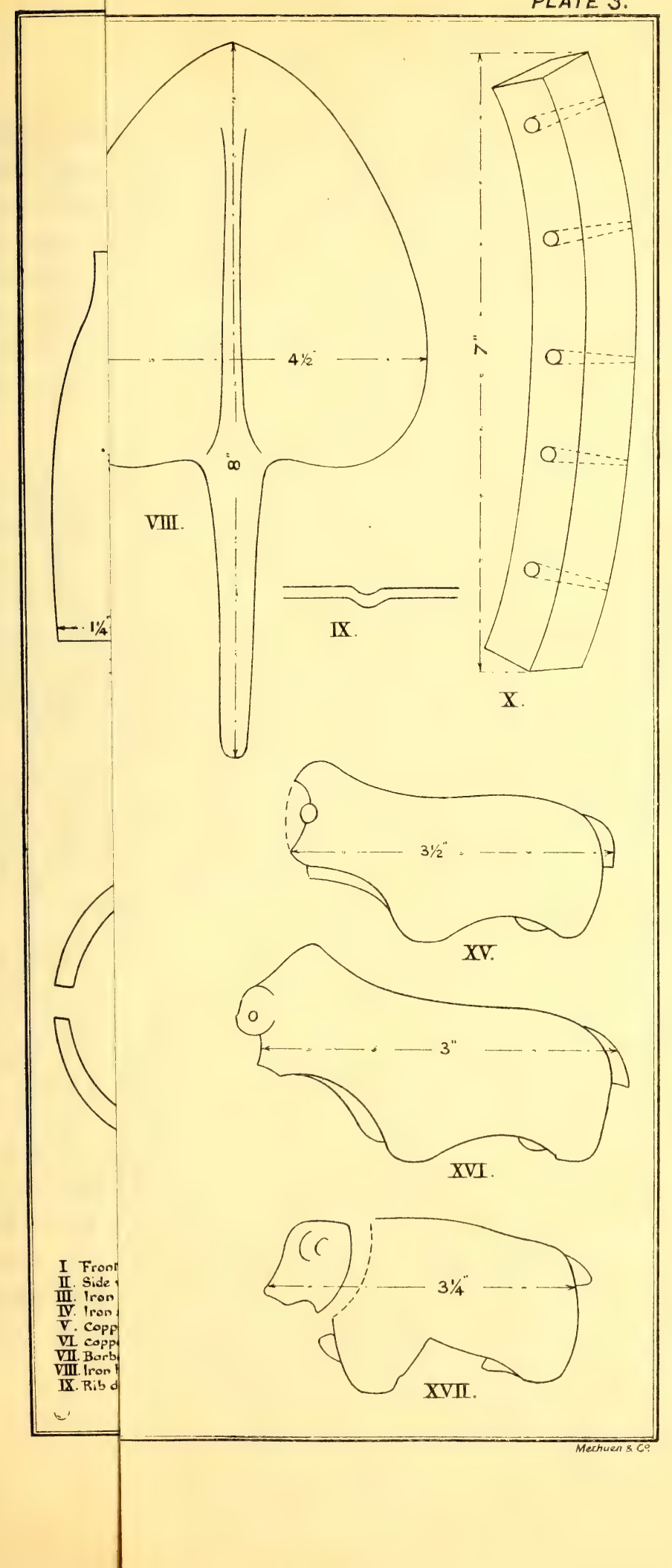





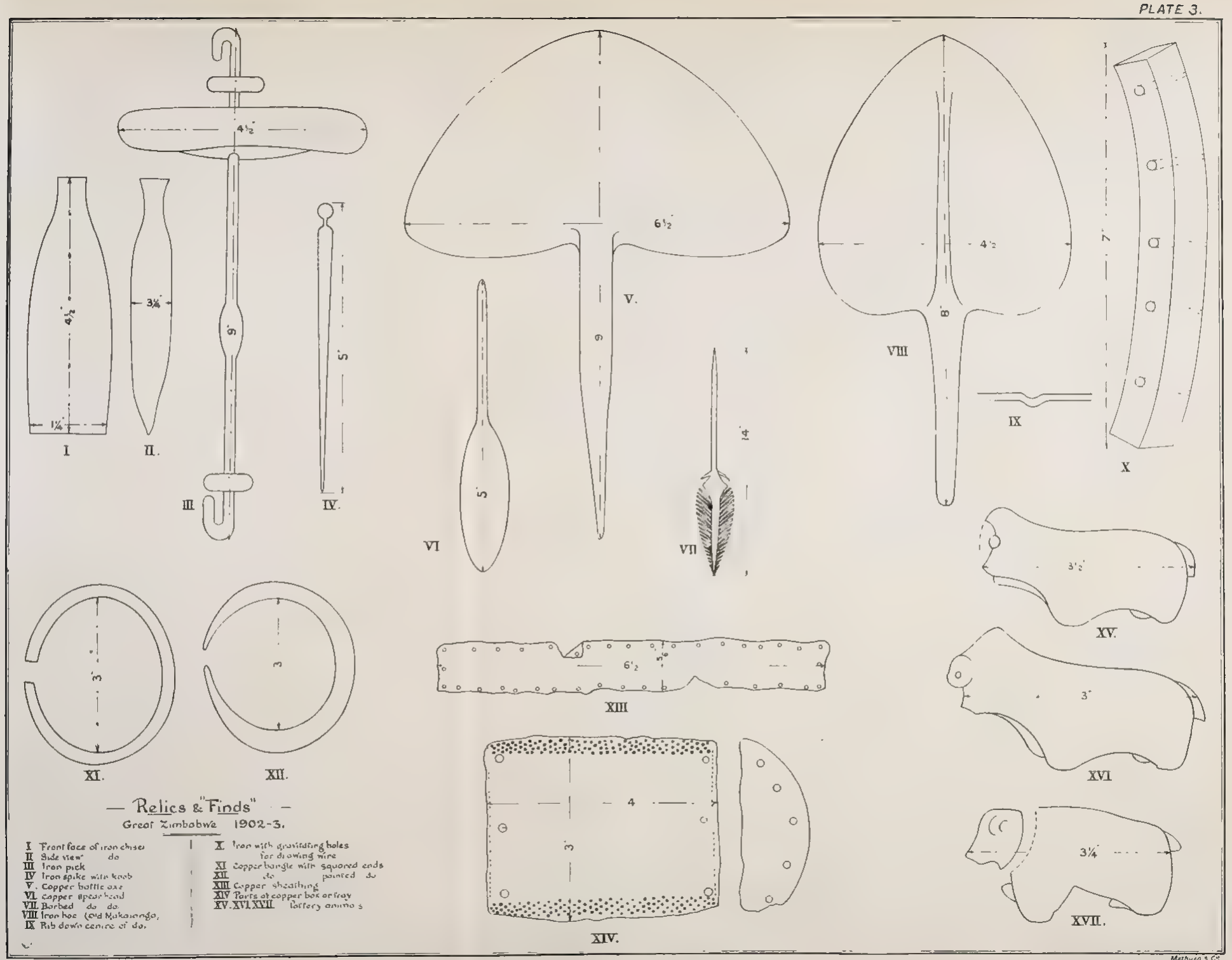





\section{RELICS AND "FINDS"}

There are still to be seen the remains of native ironsmelting furnaces, one being in almost perfect condition, but all are exceedingly old, and were found standing seventy years ago, when the present Makalanga came to live at Zimbabwe. The "female breast and furrow" pattern is on every native furnace. Portions of blow-pipes and great quantities of iron slag are found on the higher floors of clay in several of the ruins.

\section{BRASS ARTICLES}

So far as investigations lead, no relics of brass have been found on the lower floors of any of the ruins at Zimbabwe. But on the upper clay floors brass in several forms is found in abundance. It will be remembered that in 1514 Duarte Barbosa wrote, "The people of Monomotapa come to Sofala charged with gold, and give such quantities that the merchants gain one hundred for one." This was written soon after the first arrival of the Portuguese at Sofala, and given in a description of Arab trade on the coast, which they found to be flourishing. But before that period the Arab barter article for the gold was mainly brass, though "coloured stuffs and beads of Cambay" were also used for the purpose of barter, for the Arab trade with this country dated back long before the arrival of the Portuguese. The Arab writer, Omar ibn l'Wardi, stated (circa I200 A.D.), in alluding to South-East Africa, "The most remarkable produce of this country is its quantity of native gold ... in spite of which the natives adorn their persons with ornaments of brass." So to-day a native will gladly pay an enormous amount over the cost price for any attractive-looking but shoddy brass article. The brass ornaments of women weigh from $\mathrm{I} \frac{1}{2} \mathrm{lbs}$. to $3 \mathrm{lbs}$., while the men spend hours in polishing and rearranging their brass bangles. Therefore it is not surprising that brass wire, brass wire bangles, and solid brass bangles, should be found on the clay floors of the ruins. 
The quantity imported as barter goods for gold must have been simply enormous, especially in view of the prevailing custom of these people from time immemorial to bury with their dead all their personal ornaments.

There is one class of brass bangle that deserves some attention, and this is found in positions suggesting a greater age than any other finds of brass articles. This is a twisted wire bangle, but the wire is flat and exceedingly narrow. In many of these the hair or fibre round which it was coiled has disappeared with time. Coils of this make of wire-work ready to be cut into lengths for bangles were found in Renders Ruins. This and some coils of very fine rounded wire-work were discovered in a fused condition. Brass beads both imported and of native make are plentiful.

\section{FOREIGN STONES}

Every enclosure in the ruins at Zimbabwe which has been recently examined yields stone altogether foreign to the granite formation of the district. Many tons of slate have been brought here from a distance of at least eight miles, and also large quantities of soapstone from a similar distance, while dolorite, once used as anvils, was discovered, also diorite used as hammers, quartz, jasper stone showing gold, serpentine stone, calcedony pebbles, crystal pebbles, metamorphic slate, mica schist, ironstone and copper ore, and one or two small fragments of flint, and some natural wind-worn stones of peculiar form. A lithologist could very easily add considerably to this list. Two pieces of water-worn diorite of the shape of rolling-pins were found in the débris below the Platform at the Western Temple on the Acropolis. The finding of one such stone might not in itself be considered of any moment, but the discovery of two such pieces similar in shape may possibly have some significance for the student of the litholatrous practices of the ancients. The same might be said of several stones discovered here, many 
of which in quantities naturally assume suggestive shapes, while some are of purely imitative forms and not artificially treated. Several of the quartz pebbles showed gold very richly. All these, with the exception of the quartz, ironstone and copper ore, were found on the lowest floors.

There were also found water-worn stones, mostly slates, with artificial depressions which had undoubtedly been used as tools, in some instances as burnishing stones, these latter being found associated with the older form of gold crucibles, and some of these had been most probably selected on account of their shape admirably suiting the fingers of the right hand. Some small slabs of slate found at considerable depths show evidences of having been extensively used as whetstones for sharpening edge tools.

About one ton and a half of metamorphic slate, called by Mr. Bent "black slate," and similar to that used in the mural decorations on the north face of the wall of No. I I Enclosure and on the north-east wall of the Platform, was found among the débris in the Sacred Enclosure and in Nos. 9, I I, and I2 enclosures of the Elliptical Temple, especially at the base of the wall containing the pattern formed by means of these stones. All loose blocks are now stacked together in the Sacred Enclosure (west) at the angle formed by the Platform and the wall dividing off No. 9 Enclosure. At least some four tons of these blocks had been brought to Zimbabwe, the nearest point being on the Motelekwe River, at eight miles east-north-east of Zimbabwe. It is somewhat remarkable that no such blocks were found in the western half of the Elliptical Temple, nor on the Acropolis, nor at any other ruin in the locality.

Beds of small splinters of imported quartz have been found at several points within the ruin's area, the largest being on the west side of No. I Ruins and on the north side of the summit of Rusivanga Kopje. Splinters of quartz are 
found on all cement floors and on such floors as are made of burnt clay. Some of the quartz showed traces of gold, but most of the pannings were blank. It has never been supposed that the original builders carried on extensive quartz-crushing operations at Zimbabwe, but that the gold was brought to Zimbabwe in the form of dust to be smelted into ingots, both for export and local manufacture. Possibly the quartz was brought here for testing purposes, for these people who were so well acquainted with the nature of quartzmining must have had some centres throughout the country where quartz could be tested, and it is quite natural that the "assay office" of the ancients for the surrounding districts might have been at Zimbabwe.

\section{BEADS}

In addition to beads of gold, copper, and brass, several other descriptions of these articles have recently been found at Zimbabwe.

The most important are two large beads similar to one found by Mr. Bent, and to which he attributed a great antiquity, also some broken pieces of similar beads. These are black, and are covered with flowers resembling primroses, and the flower is outlined by parallel white lines. The spaces between these lines are filled in with dark brown and violet glaze. These were all found at great depth. The local natives had not seen beads of this make before.

Beads of ivory and bone, also opaque glass beads-green and yellow, porcelain beads of sea-green colour and ribbed, have been found, the glass and porcelain beads being quite unknown to the present natives. A diamond-shaped calcedony bead, ${ }^{1}$ some clay beads bearing chevron and herring-bone patterns, were found on the lower clay floors.

${ }^{1}$ Dr. Flinders Petrie has informed the author that calcedony beads, identical in shape and size to those found in ruins in Rhodesia, are of mediæval Arab origin. 


\section{WHORLS}

Pottery whorls of about $1 \frac{1}{2}$ in. to 3 in. in diameter have been found in hundreds. These were used by old natives for drawing the threads out of a mass of cotton. A stick was passed through the centre, and the bottom end was inserted in the cotton, while the upper part was twisted round quickly between the palms of the hand. Most whorls are cut out of fragments of native bowls and pots. Many old natives will explain how they were used. These clay whorls are found in old deserted villages and in Makalanga débris heaps. The native children search for them, and use them as tops. It is said they were once also employed in creating sparks for a fire, but to-day the natives twirl the sticks between their palms without using a whorl. A few soapstone whorls have been found, but not in any position suggesting antiquity. The Makalanga of but a generation past were adepts in carving soapstone.

\section{GLASS POTTERY AND CHINA}

These finds are so numerous and diversified that they require a special work for their proper treatment. Some two hundred specimens selected from the bulk have been collected, and these with particulars as to their locations and associated articles, with specimens found elsewhere in Rhodesia, will be laid before an expert for technical classification, when another avenue of research with regard to the ancient and mediæval occupiers of this country, both native and foreign, will certainly be opened up. Meantime a brief reference to the finds, or some of them, will here suffice.

Two portions of glass prisms, fragments of Venetian glass of dark green colour, being as thin and sometimes thinner than an ordinary watch-glass, have quite recently been found. 
Sections of two bowls of Arabian glass ${ }^{1}$ covered with very fine and delicately engraved tracery of scroll-work of flowers and tendrils. The engraving is so minute that it can only be seen in a strong light.

Over and across the engraved designs are hand-painted flowers of primrose shape, each flower outlined in white, light blue, and pink, the buds being pink and white, and the stems a dark red. The shape of the bowls was that of the modern finger-glass. All these were discovered at considerable depths.

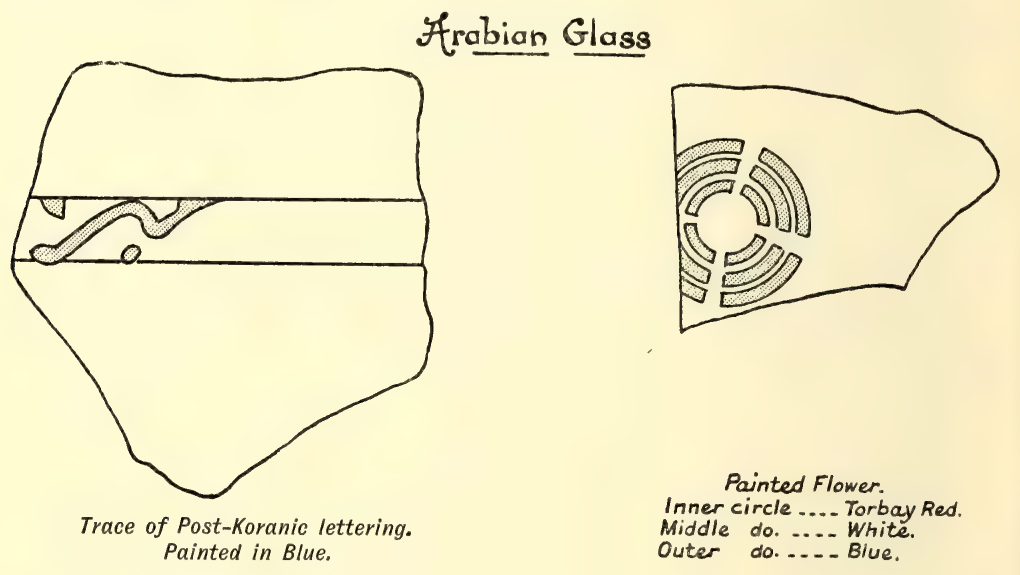

Most of the pottery was found in hundred-weights in débris heaps and scattered throughout all the clay floors in all the ruins with the exception of some enclosures in the Valley of Ruins. But such pottery can be shown to be of native make. To anyone casually inspecting the pottery it may appear as of one and the same make, save perhaps in the colour of the clay of which it is made. But there are wide differences in the pottery, both in the clays, the make, designs, ornamentation, colourings, and also in their loca-

1 Dr. Budge, Head Keeper of Egyptian and Assyrian Antiquities at the British Museum, considers this glass to belong to the thirteenth or fourteenth century of this era. 


\section{RELICS AND "FINDS"}

tions and in their manufacturers, just as among the present natives.

The Barotse pottery, for instance, is of a more substantial make than is that of any known period or tribe of Makalanga. The patterns are large, bold, and entirely geometrical, and are coloured yellow, red, or black, with the designs painted in strong contrast to the general colour of the pot. Thus black patterns are laid on yellow and red grounds, red patterns on yellow and black, and yellow patterns on black and red. A collection of Barotse pottery made by Major Corydon from north of the Zambesi is a facsimile in make and design of the Barotse pottery found at Thabas Imamba, Khami, Zimbabwe, and other ruins known to have been occupied by Barotse up to seventy years ago. A collection of pottery from Khami which was brought for comparative examination to Zimbabwe was at once claimed by the local Barotse as being of Barotse make, while the local Makalanga not only emphatically denied that it was of their class of make and design, but added that it was the work of the Barotse people. The encircling bands of ornamentation on Barotse pottery vary from $I \frac{1}{2}$ in. to 3 in. or more in depth. ${ }^{1}$

Thus Makalanga pottery has its own peculiar characteristics which are easily discernible on examination. It is generally found to be black with a highly polished surface. The bowls and pots have a lighter and more delicate appearance, and the excellent quality of clay used, and its thorough manipulation, enables it to be much thinner in make yet equally as strong as those of coarser make; the coloured decoration also is altogether absent, while the pattern is more neatly executed, and is enclosed in encircling bands of from only half an inch to one inch in depth. Further, the Makalanga have always decorated their pottery with protruding bosses of shapes and designs peculiar to themselves, the

1 The author is preparing a monograph on the pottery of the Barotse and Makalanga. 
female-breast pattern predominating. There are at least fifty different sorts of such protruding designs already found on undoubted Makalanga floors, and these have been selected for examination. The pot shown in the illustration facing page 90 of The Ancient Ruins of Rhodesia is of very old Makalanga work, of which many scores are found represented at Zimbabwe.

Finds of native pottery bear no traces of the potter's wheel. All native pottery is made by hand.

Very common sun-burnt earthenware, more earth than clay, and very light, is found in great quantities everywhere in the ruins, most of this having no decoration.

Old Makalanga smeared the body of a pot with several thin coats of different-coloured clays, and sections of such pottery show the lines of smearings very distinctly.

The best quality of pottery was found on one of the lowest floors in the Elliptical Temple. The fragments are very heavy for their size, and the surface is coated with soapstone clay, giving them a light greenish-grey colour. These must be exceedingly old if not ancient.

The china discovered includes Nankin china identical in every particular with the Nankin china discovered at these ruins by Mr. Bent and others, and with that found in Mazoe and so many other districts where there still exist distinct evidences of occupation by the early Portuguese. The china, or porcelain, is covered completely with a highly rich glaze of bright blue and sea-green shades, and the articles when pieced together resemble in shape an ordinary soup-plate. The edges are bevelled in sections of circles, the bevels extending in fluted form to the base, where can be seen evidences of the use of the potter's wheel. The fragments found represent three different plates. These were discovered at some depth, but not on any ancient floor.

One find made among the Arab belongings in Renders Ruins consists of excellent china of a light brown colour, 
about a quarter of an inch thick, and covered with a high glaze of blue, white, and gold enamel, the white forming the background. There are at least four bands of pattern encircling what was a large open bowl with upright edges. The conjectured Arab lettering is laid on with blue enamel and is outlined with fine scroll-work tracery in gold. The inside
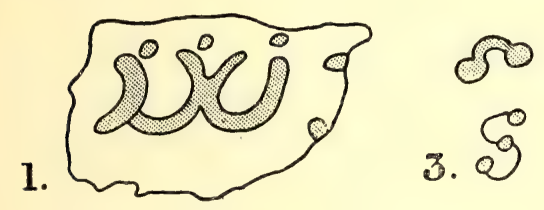

2.
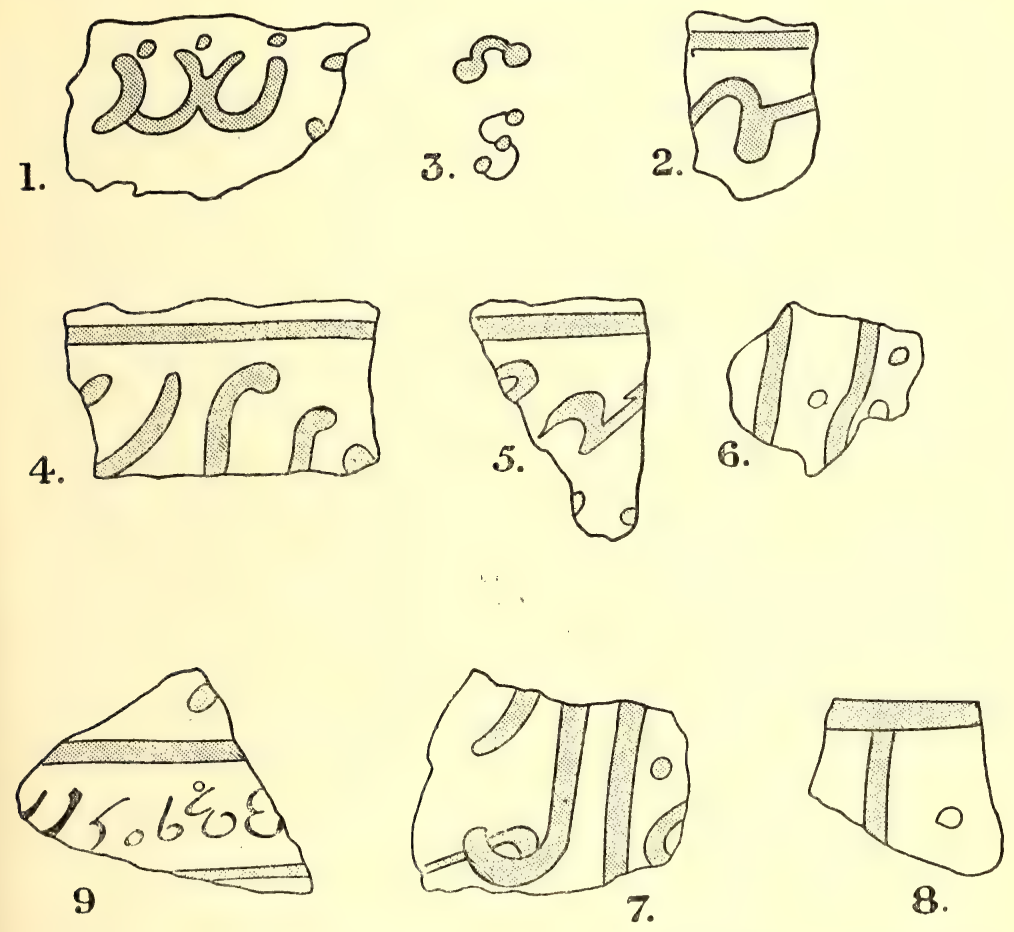

is glazed white, and has lines of faint blue enamel artistically drawn without being of any set pattern. The pattern on the lowest band is of palm fronds in brown paint and in outline only. ${ }^{1}$

Some very thin pottery covered with white enamel some inches only down from the rim towards the outer and inner

1 See Note C, Appendix to this volume, which gives a fuller description of this "find." 
base, with thick perpendicular bars of dull blue glaze. Excellent pottery of brown clay, very thickly covered with glaze of sea-green and deep lake colours, was found near the same spot.

\section{IO. A MEDIÆVAL ARAB TRADING STATION}

One of the most interesting discoveries recently made was at Renders Ruins in the Valley of Ruins. In a corner of one of the enclosures of these ruins, and at some depth, and all within a few feet, were found the glazed pottery with Arab lettering, an iron lamp-stand and copper chain, an iron spoon of great age, copper snake-rings (pronounced not to be of native make), and several other articles suggesting some far-back period of an Arab occupation, most probably of mediæval times. Over this collection of finds was a deep bed of soil silted by rains from higher ground, and on this surface were fragments of a Makalanga clay floor broken up by the roots. The Arab traders gave the first description of these ruins to the Portuguese, and Barbosa (I 5 I4), De Barros (1552), and Livio Sanuto (I588), mention the existence of Great Zimbabwe on the strength of information concerning it received from the Arab gold and ivory traders.

In all probability this was an Arab trading centre of mediæval times, and by "taking stock" of the barter goods, some corroboration of this suggestion may be obtained. The "stock in trade" consisted of :-

2 pints of small yellow and green glass beads which are unknown to present natives.

I pint of similar beads of larger size, also unknown to present natives.

IOO (at least) porcelain beads, ribbed, and of sea-green colour, also unknown to natives.

I 5 lbs. of twisted iron wire-work in large coils for making bangles, and cut up into lengths for bangles.

$5 \mathrm{lbs}$. of twisted brass flat wire in large coils also, not cut into lengths for bangles. 


\section{RELICS AND "FINDS"}

5 lbs. of twisted brass rounded wire, ditto.

4 doz. brass flat wire bangles and a great quantity of fragments of other bangles.

Cowrie shells.

The mediæval traders might have received the following from the natives:-

2 elephant tusks (decayed).

2 swart-hog tusks.

20 (about) pieces of beaten gold.

Several pieces of broken gold-wire bangles.

As the Arabs traded for gold produced by the natives, and also for ivory, no doubt they or the natives would fossick in the ruins, then much clearer of débris, for gold which they or the Arabs might have known was to be found in the enclosures. The beaten gold was all found within a few inches, and though its edges were pierced with tack-holes, pannings of the soil showed no gold tacks. As the Makalanga of those times were at their zenith of power, it is quite possible they did the actual searching themselves, and then parted with their finds to the Arabs, who, as history shows, only occupied the land on sufferance, the Arabs making their usual gain, which, according to Barbosa, was "one hundred for one."

It might well be asked why these old Arabs left their goods behind them. The fickle policy of successive Monomotapas might be a sufficient explanation of their apparently hasty exodus. According to Portuguese records Kapranzine, the Monomotapa in 1620 , sided with the Portuguese as against the local Arabs, and the succeeding Monomotapa "Pedro" in 1643 maintained this policy. But the disappearance of the Arab traders from Renders Ruins will in all probability always remain an unsolved enigma. But one question may be asked with regard to the beads found hereWere they "beads of Cambay"? 
A large piece of coral still in perfect condition was found with the Arab articles. It has been stated, with what truth the author cannot say, that finely ground coral powder makes an excellent metal polish, and that the Arabs and Indian metal-workers on the coast use it for this purpose. Certainly the Arab traders up country would constantly require to refurbish their brass goods, and so keep them attractive for sale to the natives. Fragments of coral have been found in other ruins at Zimbabwe, also at ruins in different parts of Southern Rhodesia very much further inland from the coast than is Zimbabwe.

Section of Floors of part of

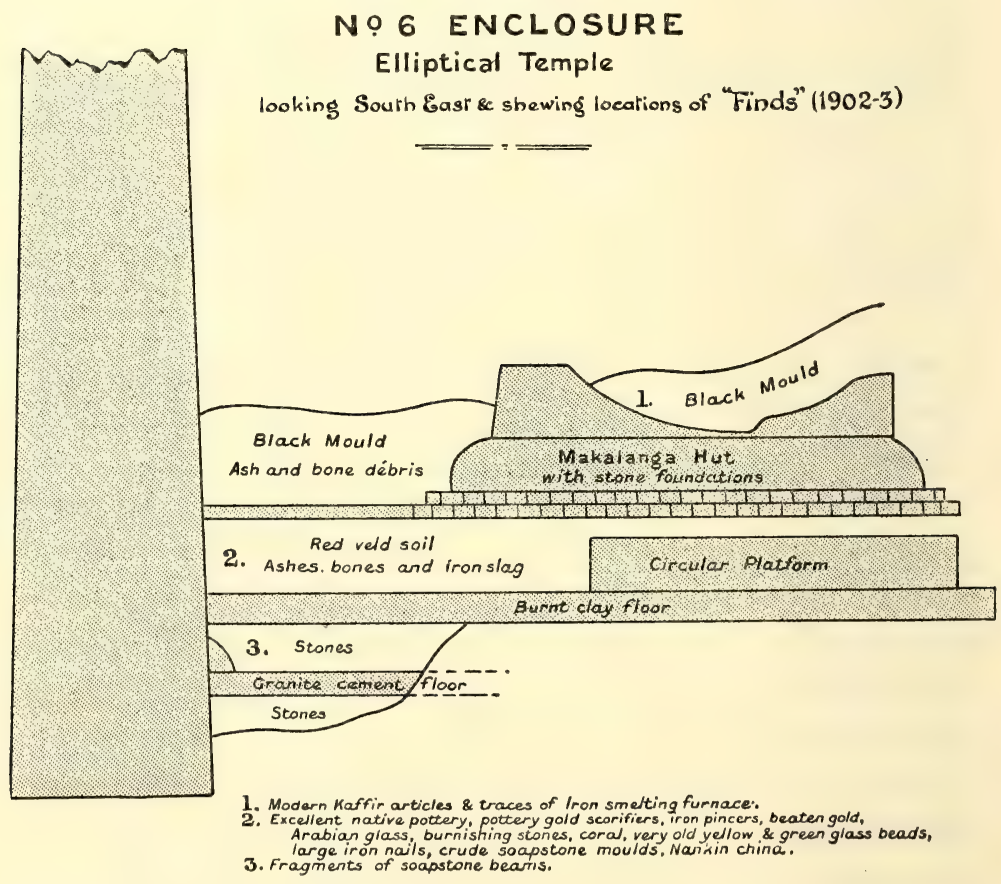




\section{CHAPTER VII}

\section{NOTES ON ANCIENT ARCHITECTURE AT GREAT ZIMBABWE ${ }^{1}$}

Introduction-Durability of Walls-Dilapidations-Makalanga Walls within the ruins-Remains of Native Huts found in Ruins--Passages -Entrances and Buttresses.

GINCE I892, when the late Theodore Bent published his $\checkmark$ work on The Ruined Cities of Mashonaland, and 1893 , when Sir John Willoughby issued his monograph on Further Explorations at Zimbabwe, though much has been discovered concerning the varying architectural types of ancient ruins throughout Southern Rhodesia, little has been added to our previous meagre store of information concerning the important group of ruins at Great Zimbabwe.

But in the work now in progress of preserving these ruins from preventable decay and dilapidation, and of clearing away the block débris from the faces of the walls and the huge piles of soil débris deposited within the ruins by a long succession of explorers, both authorised and unauthorised, there have been within the last two years rescued from oblivion many important architectural features, the existence of which was altogether unsuspected by previous writers. Many of the interiors of the ruins are now exposed to view, thus enabling examinations, comparison, and measurements to be taken which before had been altogether impossible.

${ }^{1}$ For descriptions of ancient architecture in the ruins of Rhodesia generally, see The Ancient Ruins of Rhodesia (2nd edition), Chapter XII. 
Within the last eighteen months Zimbabwe has revealed many of the long-buried secrets of the ancient architects which were hidden from the eyes of Bent, Schlichter, and other scientific explorers of the ruins.

Zimbabwe is stored with surprises for archæologists and antiquarians. Absorbing romance is buried deep below its floors. Its soil is richly charged with long-ungazed-at gold and prehistoric relics of high intrinsic value. The mysteries of the absence in Zimbabwe of any definite records in the form of inscriptions, ${ }^{1}$ and also of the non-discovery within the Zimbabwe area of the burial-places of the ancients, have yet to be solved.

It has quite recently been held by scientists at home that the late discoveries of ancient ruins in Rhodesia, with their classifications into types and probable time-sequences and periods of distinct forms of architecture, have so advanced investigations in this country that, until similar work has been carried on among such of the ruins of Southern Arabia as are believed to synchronise with, or be the architectural prototypes of, the earliest of the Rhodesian monuments, it would be idle to speak dogmatically as to the lands of origin of the succession of ancient builders and gold miners who toiled so industriously in this portion of South-East Africa.

Still, but so far only as authentic discoveries have been made, the suggested occupation by the Sabæo-Arabians as outlined in chapter iii. of The Ancient Ruins of Rhodesia affords for the present a good working hypothesis for the student in Rhodesia whose aim should be to closely watch the operations of archæologists and antiquarians in the land of ancient Yemen, while at the same time recording with the utmost exactness and fullest detail all and every possible architectural feature of such of the ruins in Rhodesia as may fall within the description of the First Period of Zimbabwe

${ }^{1}$ For a probable explanation of the absence of inscriptions, see Dr. Keane's Introduction to this volume. 
Architecture, of which the Great Zimbabwe is undoubtedly a most perfect example. This work will awaken the most piquant interest and fascination, for in this direction may be found the definite solution of our local problem as to which particular wave of the Semitic migrations is responsible for the erection of certain of our ruins.

That the Great Zimbabwe will be found to be pregnant with clues to solve the mystery is undoubted. Notwithstanding two years' work in clearing the ruins of fallen walls and silted-in soil, nine-tenths of the ruins still remain practically buried. Sir John Willoughby, after spending two months in exploring the Elliptical Temple with a large staff of labourers, writes that it would take at least two years to complete the exploration of that building, and this without touching anything ancient or piercing ancient floors, but simply leaving the building clear of all débris and just in the same condition, save for dilapidations, as the last race of ancient occupiers knew it. If, therefore, the Elliptical Temple would require this amount of time to be spent upon it-and this is a fair estimate of work yet to be done-then the Acropolis ruins must require at least a further three years to be spent upon them, and this calculation does not include the large number of ruins in the Valley of Ruins, which, if situated elsewhere in the country, would be considered of major importance. But the area of the Zimbabwe ruins, as known to Sir John Willoughby, was only 945 yds. by 940 yds. To-day, after carefully searching the surrounding kopjes, kloofs, and valleys, other ruins and walls, and traces of ancient walls, can be found at a distance of a mile from the Elliptical Temple. The Bentberg has its northern face covered with walls. Rusivanga Kopje shows foundations of walls and débris. Near Bingura's kraal, a mile to the south-west, is a ruin, while extensive beds of imported gold quartz-the nearest reef being some miles distant-with piles of ancient blocks are to be discovered after a grass fire in almost all directions 
within the distance of a mile, and fresh traces of old peoples, other than those early Makalanga, are to be met with in the course of almost every walk. Thus the probabilities of new and important discoveries are incalculably great.

Degree of durability of walls.-(a) As may be seen by anyone inspecting the walls, as well as on perusing the published description of many ruins of the earliest types, the elliptical and curved form of building has proved the most durable. In many instances the elliptical structures are more or less intact, while the angular and less skilfully built additions, extensions, and alterations of a later period have largely become ruinous and chaotic.

(b) This is accounted for by the more excellent workmanship in the construction of the ruins of the elliptical type, which have far broader foundations, are more massive, have a decided batter-back both inside and outside, bonded courses, the blocks of each course being more carefully selected, and the summits tied with "throughs," while the angular type of ruins, with their plumb walls built on straight lines, with independent faces either side and carelessly filled-in interiors, and a less superior workmanship, have caused these walls to suffer more than the older type of ruins.

(c) Walls built on curved lines are in a far better state of preservation than those built on straight lines, the curves having served to strengthen the walls.

(d) Rounded ends of walls and rounded buttresses have proved to be far more durable than angular ends or squared buttresses, though most of these latter erections are obviously of a later date.

(e) The portions of divisional walls near main walls are in a better state of preservation than the other portions which are in the open parts of the ruins. This is owing to the protection and support of the larger walls. Many of the divisional walls are practically independent, and therefore 
more liable to collapse, but if not independent the number of entrances passing through them practically makes them such.

Dilapidations.-At Zimbabwe both the ravages of time, as well as preventable damage during the last decade, have brought about the wholesale destruction of walls as seen to-day in their dilapidated condition. This is the plaint of all who have known the ruins since the time of the occupation. These all bemoan the fact that on each renewed visit to the ruins some wall is found to have disappeared, or some new bulging out of the massive structures threatens serious and immediate destruction, which no amount of lateral support or pinning up can now possibly prevent. Many such visitors complain that the decorative patterns are becoming less perfect. Photographs show this to be the case. In fact, so much dilapidation has taken place within the last few years that it is a common remark of pioneers that "the ruins are becoming less and less every year," while intense disappointment and vexation are expressed by "old hands" when they revisit the temple after an interval of a few years at the serious reduction in the height of the Conical Tower. Photographs of the tower taken as recently as 1896 represent the summit as being higher than is seen to-day, while almost every photograph taken within the last two or three years of any single part of these ruins shows portions, if not the whole, of walls, with their distinctive features that have completely disappeared. To those who venerate these ancient edifices nothing can be sadder than a comparison of the ruins as seen to-day with the ruins as they were some years ago.

But before dealing with the dilapidations of later years it might be well to examine the history of such of the dilapidations as can be read in the wall débris heaps which line the bases of every wall, for these débris heaps can be read with the same facility as one can read a book. These dilapidations 
are what might be termed legitimate, being the natural results of the ravages of time, which no means taken could possibly have avoided, and which have extended for very many centuries on end since the latest of the ancient occupiers disappeared.

In Tintern, Melrose, and many another old building at Home we have ruins even now incomplete, owing to the dilapidations of but a few hundred years. But the most ancient ruins of Great Britain, excepting, of course, Stonehenge, the round towers of Ireland, the Druidical circles of Wales, the stone circles and cloven stones of the Isle of Man, and the reputed pagan temples found elsewhere, and certain of the Roman remains of which at present little is known, possess histories, and Domesday Book, and even much later records, state the names of the actual builders of these castles and abbeys. These buildings have a stamp upon them of modernity which is altogether absent at Zimbabwe, in comparison with the age of which the term "ancient," as applied to those at Home, elastic as it is, sounds strangely inappropriate. And yet after a comparatively short period of non-occupation of these castles and buildings only sections of them can now be seen. Guides will state that the walls have been quarried for material for farm buildings, most probably for the erection of the adjoining mansion, and that portions were destroyed by lightning.

But Zimbabwe, with its minimum age of some three millenniums, stands far more firm, more intact, and complete than any one of the comparatively few-centuried old ruins to be found anywhere at Home. Planted in South-East Africa at over two hundred miles inland from the coast, in the midst of populations that know nothing whatever of its origin, Zimbabwe's massive and imposing walls reveal even to the most casual and indifferent of visitors the plan, purpose, and design of the original builders. Yet has it been subjected for three millenniums to the destructive agency of lightning storms, the 
frequency and severity of which in South-East Africa are well known. Severe earthquakes must have shaken its foundations, but the massive walls remain practically intact. Arab tradition speaks of violent earthquakes in South-East Africa during the fifth century, while the condition of some of the ruins in Rhodesia, where the walls have fallen en bloc sideways on to the ground, testifies to frequent, general, and violent earth-movements and earth-strains having taken place. The South-East African cyclones passing over it during thirty centuries probably have caused further dilapidations. Still, though so many walls at Zimbabwe remain more or less intact, it would be impossible to estimate the extent to which many walls may have suffered, or what have possibly disappeared altogether from the effects of earthquakes, for it would be difficult to suppose that these extensive ruinssome walls being built on the actual brink of precipices-have escaped all the destructive effects of earth-movements and storms which have occurred during the last three thousand years.

The action of sub-tropical rains for centuries has destroyed whole lengths of walls. For instance, a trench which occupied half a dozen labourers two days to excavate was, after a heavy shower lasting but an hour, completely filled up by mud streams from a higher level. There is hardly a wall on the Acropolis Hill that has not had to bear some added weight of silted soil from higher levels, and these in places have been so extensive that when accumulated on the upper sides of walls the effect has been to push the wall bodily over. In this way the terraces of enclosures round the north, west, and south faces of the Acropolis have in most instances been entirely filled up and buried, while in others the outer and downside wall has been burst through and destroyed. Streams of water during storms of real African violence have worn deep channels along the bases of some of the walls, exposing the foundations which bridge across the holes, the 
water causing the decomposition of the cement bed of the foundations and making the wall throughout its complete height to sway downwards and to bulge threateningly outwards. Some of these water-made holes up against the bases of the walls contained damp and moisture all through the dry season, especially those on the south side of walls where the holes were protected from the sun. In as many cases as possible for the time engaged on the preservation work (1902-4) these spots were levelled, and catchment areas were made, so that for the future no rain-water can lodge there, but the waving lines of the courses in the walls still show where these holes existed.

In a similar way block débris falling from higher levels has lodged behind lower walls and eventually pressed them over. In some instances on the Acropolis a mass of walling has fallen from a great height and completely demolished walls below. These were no gradual dilapidations, but instances where sections of the higher wall had gone completely over en masse. Such falls almost entirely explain the damage done to the outer walls of the South-East Ancient Ascent, lengths of which have evidently been made good by Kafirs of a very old period, as the well-built ancient foundations can be seen below the later walls.

But some walls have also been seriously damaged by falls of huge slabs and boulders from the faces of the granite cliffs, buttresses have been broken, entrances and passages completely blocked up if not utterly demolished. These falls, though later than the times of the ancients, occurred very long ago, for the depressions in the cliffs from which these slabs and boulders fell are now become weather-stained, but the shapes of the depressions and of the slabs and boulders still agree. It is conjectured that the gap in the central portion of the main wall of the Eastern Temple was caused by the fall of an immense boulder from the summit of the sixty-foot cliff on the north side of the temple. By 
the moving forward of a boulder for six feet from the position it occupied at the time of the ancients-and they had utilised this boulder in forming the west entrance of the same temple-the entrance was completely blocked up.

But there is a process of dilapidation going on continually, a process which, judging by the débris piles, has been operating for many centuries. When walking near a wall one has to be very careful not to walk under any of the overhanging blocks on the summit of the wall. Some of these blocks are very delicately poised on the edges of the walls, so much so that it seems as if a shout would cause them to fall. Wherever possible these blocks have been drawn back flush again with the face of the wall, but in very many cases the walls are so ruined that it would be dangerous work to do this. It is one of the unfortunate effects of this ancient dry masonry that when one block topples over a small cascade of blocks usually follows it. Such falls, followed by cascades of blocks, are continually taking place. One hears them night and day, especially after rains, and frequently these cascades, especially those from walls above the precipice on the Acropolis, will continue uninterruptedly for some minutes together. There are many points in walls so threatening to collapse that no builder's art of shoring-up could possibly prevent their fall, for sooner or later they must come down with a crash. Natives give the information that from the time of their childhood they always remembered these falls taking place when no one was near the walls. Probably the noise of falling blocks, especially at night, has served to inspire the local natives with some of the dread in which after sundown they regard the ruins. After a heavy shower one can always find some damage done to the walls. This is mainly due to the quantity of silted soil behind walls, which, becoming overgutted with water, forces the walls over. The only remedy, and that a partial one, would appear to be to remove the silted soil from behind the walls, but to 
complete such operations a large gang of labourers would have to be engaged for many months. Still the complaint of the early pioneer that the walls at Zimbabwe are gradually becoming not only less but fewer remains perfectly incontrovertible.

But there is an infinitude of other causes working for the dilapidation of the ancient walls at Zimbabwe, and some of these are undoubtedly preventable. It was for the purpose of removing such causes of damage that the recent work of preservation was undertaken on behalf of the Rhodesian Government, and these operations it is the purpose of this volume to describe.

The Great Zimbabwe, as also the many associated ruins scattered throughout Southern Rhodesia, has been subject to wholesale destruction of its walls by the growth of trees, the presence of damp, the falling of immense trees across walls, the quarrying of its walls by past and present natives for building material, for cattle kraals, and other purposes. All the ruins at Zimbabwe afford ample evidences of the ravages caused by vegetable growth, and no ruin appears to have escaped some measure of destruction from this cause.

In 1902 the Elliptical Temple was found to be full of large trees of immense girth, some being at least sixty feet in height. The shelter from the chilly winds prevailing at night and in the dry winter season, and the protection from damage to bark by grass fires provided by the high and massive walls, together with the perpetual state of damp from wet season to wet season prevailing within the walls, the close, hothouse temperature most favourable to the promotion of growth, provided an area in which trees and plants could flourish most luxuriantly.

The trees within the temple are almost all hard woods of slow growth. One tree, not by any means a large one, showed by its rings an age of over a hundred years. The 
numerous fig trees must be of great age. The three immense hard-wood trees in the centre of the building may possibly be a hundred years old. The rest of the temple was as full of soft-wooded trees as space permitted, while the branches of trees near the main walls crowded over the tops of the walls towards the outside. Undergrowth of monkey-ropes, wild vines, thorn creepers, and large bushes formed a dense jungle through which it was almost impossible to pass, while the damp maintained the soil in a wet, soggy state, the trees being covered with orchids and long, trailing festoons of lichen, the shaded walls being one mass of creepers, green moss, lichens, and ferns, and dripping with damp. Certainly such growth made the temple beautifully picturesque, and added greatly to its weird, desolate, and solemn appearance.

But a succession of "dust-devils" or "wind twisters" that very frequently pass over the country in the breathless sultry hours of noon passed over Zimbabwe on the second day after our arrival, and at once demonstrated what damage the trees were inflicting on the ruins. Branches were set crunching and thumping on the summits of all the walls, soft-wood trees bent and swept the walls of loose blocks, two huge hard-wood branches remorselessly scraped noisily up and down the sides and on the top of the Conical Tower, while small trees growing on the actual summits of the walls shook and bent and still further loosened the blocks among which their roots extended. During the few minutes these "twisters" lasted the labourers studiously avoided the walls from which the ancient blocks were falling. Under every branch that crossed over a wall was a deep depression in the summit caused by the branch thudding upon it. Many of the trees growing close to the walls had, with long years of banging against the side of the wall, lost all their bark on their inner sides, and these had become perfectly flat. All this havoc, caused by rocking trees and sweeping branches, and by huge broken limbs falling upon interior walls, must 
have been going on for many years. The effect has been to cause the removal of the "throughs," ties, and large bonding stones with which the ancients secured the summits of the walls, and these once gone the wall was subject to rapid dilapidation. Later, during high winds which prevailed for some days, it was most distressing to hear the noise of the trees grating and heavily beating against the walls, and the constant falling down of ancient blocks. The effects of such destruction can be seen to-day in the broken edges of the summits and in the deep depressions which occur at intervals along the lines of both main and divisional walls. Even the chevron pattern has been irretrievably damaged by branches of trees growing outside the temple, while the little tower in the Sacred Enclosure has, within the last few years, been thrown over by a huge branch.

But in 1902-4 all trees growing near walls were felled, all projecting branches and rotten limbs were removed, as well as all trees which caused damp to collect on walls, while a general thinning out was made of all branches which interfered with a general view all round the building. Such trees as had done all the possible harm they could do and all trees standing at a distance from walls were left standing. The result has been to make the temple less "picturesque" than in its neglected state, but it still remains picturesque. The temple now appears to be larger, and its massive proportions now made visible stand out far more prominently than before.

The present trees appear to have been the first that ever grew within the temple area. In the soil removed from ancient floors there were no signs of any older generations of trees having existed. The first appear to have arrived with the soil brought in by the past Makalanga in the course of their usual practice of converting ancient enclosures into platforms on which to erect their huts. The trees evidently flourished in the soil made rich by huge piles of bones of 
oxen and buck, the remains of feasts and sacrifices. Except in a few instances where rain-water was unable to escape, and has caused the ancient cement flooring to become decomposed, the roots of the trees rarely pierce below the ancient floors, the surfaces of which are covered with matted roots closely interwoven in masses like the roots of a large plant growing in a small pot.

The jungle growth of small trees, bushes, and creepers would seem to be the result of excavators, who have broken up the hard clay floors of the old Makalanga and thus ventilated the soil below, as those places where most excavation work has been done have produced the greatest quantities of trees and the densest jungles. Until the whole of this foreign soil is removed down to the level of an ancient floor this jungle growth will always spring up afresh.

But the growth of creepers such as monkey-rope, wild vines, and a climbing plant known as "Zimbabwe creeper," has wrought untold havoc, but mainly on the faces of the walls. These creepers pierce into the joints of the dry masonry and emerge at a point some feet higher up. Later the branch inside the wall swells and forces out of the face of the wall all the blocks between the points where it enters into and emerges from the wall. This destruction of the walls by creepers is seen in many places at every one of the numerous ruins at Zimbabwe. Monkey-rope at the Elliptical Temple and wild vine on the Acropolis have been the most destructive agents of any of the creeper plants. The "Zimbabwe creeper" was found to be growing on the temple walls with its roots on the summits. This plant covered the main walls as with a thick green mantle, at some points completely hiding the entire surface of the walls. It also had its roots in the interstices of the Chevron Pattern, from the blocks of which it hung in festoons of over one hundred-weight each. This constant strain on the pattern has effected some destruction in addition to the injuries caused by the over- 
hanging boughs of trees. The dilapidation of the walls of the Elliptical Temple is fairly typical of the dilapidations at all the ruins at Zimbabwe.

But there are also minor causes for the dilapidation seen in the walls outside the larger ruins. The restless herd of some seventy cattle belonging to the Mogabe climb the lower walls with ease, and will walk along their whole length clanking the ancient blocks, and awkwardly clamber down broken ends of walls and gaps, bringing down a cataract of blocks as they descend. Some two hundred goats appear to live on the walls. Large baboons can be seen taking their morning exercise on the walls of the Acropolis, and as these scamper about and chase one another the blocks fall off the walls. Natives pull out the faces of the walls to secure honey, or in ferreting out small animals for food.

It must also be remembered that the ancient walls have been quarried by Makalanga of past times and even by the present local Makalanga, all of whom have extensively used the ancient blocks for their inferior walls. But perhaps the greatest amount of dilapidation was effected when the large enclosed areas of the ruins were filled up and converted into raised platforms. In these instances, which are very numerous, the divisional walls suffered most, the blocks from their summits being thrown into the area till the interior was raised from $4 \mathrm{ft}$. to $7 \mathrm{ft}$. above the ancient floors, when clay floors were laid upon the filling in.

On entering the Elliptical Temple of the Acropolis one of the first questions asked by visitors is-Are all these walls ancient? It is to the interest of our local archæological researches that such a question should be fairly dealt with, and the frank admission made that certain of the walls are not ancient. In examining the evidences against the antiquity of such walls a further proof is secured, were it needed, that such of the walls as are ancient possess undoubtedly the true seal of antiquity. 
Makalanga walls within ancient mins at Zimbabwe.It would be preposterous to expect anyone who visited the ruins to believe that every single wall one saw at Zimbabwe, whether at the Elliptical Temple or on the Acropolis, was necessarily ancient.

Some of the slighter-built walls within the ruins, which are of poor construction, and were once thought to be ancient, can now be shown to have been built by the Makalanga, the evidences of whose long and successive periods of occupation of these ruins are not only most obvious to all explorers and are confirmed by finds and conditions generally, but are a matter both of actual history as well as of tradition among the local natives themselves. Some of the ruins have been used by them for kraals, others-the smaller ones-were converted into cattle kraals with the huts outside the walls, while some have served both purposes. It is highly probable, judging by the state of the wall-débris, that the natives, in converting an ancient enclosure into a cattle kraal, have found portions of the divisional walls to be so dilapidated that they have rebuilt those portions after their own peculiar and recognisable fashion in order to keep in the cattle, at the same time building up gaps and entrances.

While, according to statements of natives and judging also from the state of the ruins, there has been no occupation of the Elliptical Temple as a place of residence for the last three generations, still there are Makalanga walls to be seen, both here and in the Acropolis, at which latter ruins was the kraal, till four years ago, of the present Mogabe; and on the Acropolis are walls of Makalanga construction, both old and comparatively recent. The western enclosures of the Elliptical Temple have been used as cattle kraals up to the early seventies.

The following are some of the evidences of Makalanga construction of walls within the ruins :-

(a) The definite and circumstantial claim of the Makalanga 
to have built certain walls, and their ability to assign particular generations for the erection of other walls.

(b) The construction of such walls is identified with obvious Makalanga buildings in their kraals, where there are no ancient ruins. The purpose of the later walls is in many instances patent, especially when the smell of the modern byres still lingers in the soil of the areas used by natives as cattle kraals enclosed by such walls.

(c) Stones once part of the faces of ancient walls are used in the construction of those walls, the weather-stained, lichen-covered, and decomposed faces of the blocks being turned inside the walls either sideways or backwards, while the walls show no sign of age, and have a comparatively fresh appearance. Slate and granite monoliths, as well as ordinary slate beams which had once been lintels, have been used as building material.

(d) Débris heaps of ancient blocks have been used as foundations, and sometimes these heaps acted as sections in the length of wall.

(e) Frequently such walls are built in a very irregular line along the almost buried summits of ancient walls, and across filled-in entrances and even passages, the foundations of such walls projecting from underneath the Makalanga walls on either side.

$(f)$ Some of the Makalanga walls are built over damp, black leaf-mould containing undecayed vegetable matter and also ordinary Kafir articles, the mould being over a stratum of red clay foundations of Makalanga huts, and with two or three feet of soil and stones between the clay and any floor below for which antiquity could be claimed. Makalanga pottery has been used to support and wedge up uneven ends of blocks.

$(g)$ The made foundations of Makalanga walls are of common clay, those of ancient walls being of a splendid quality of granite cement. 
(h) Nothing ancient or even approaching to antiquity is ever discovered on the levels of the bases of Makalanga walls, but round about their bases quantities of Makalanga articles may be found, some perhaps of better make and quality than now produced by them.

(i) Local natives can to-day build very fair stone walls, but these have straight joints and are without tie or bonding, the courses are most erratic, and the line of wall wavering. The common feature of Makalanga wall construction is to build the stones up exactly over one another, giving the appearance to the wall of being built on columns. Their stone walls of cattle kraals can be seen in many deserted villages, as well as other of their walls where there are no ancient ruins. The Makalanga graves in the passages, both in the Elliptical Temple and in the Acropolis, were very well built in with cross-walls.

(j) The Makalanga since mediæval times have always been known as builders in stone. Their circular hut and granary foundations of stone can still be seen in many parts of the country, especially on the clay floors of filled-in enclosures of ancient ruins of the terraced order. This art is mentioned by Mr. Selous and by almost all writers on this country before the Occupation, and pioneers and early settlers have affirmed this to be the case. Bent gives the names of Makalanga villages which he visited where these contained stone buildings of native construction. The names of other villages where such buildings are to be found are given by other writers. Bent actually saw their stonebuilding operations being carried on at Chipanza's kraal. Professor Bryce describes a Makalanga village with stone buildings, but just as the arts of mining, smelting, wiretwisting, and cloth weaving are now fast disappearing on the advent of the cheap imported article, and on the natives finding other objects upon which to spend their time and labour, the art of stone building is becoming neglected. Old 
pioneers visiting the ruins are unanimous in affirming that such walls so built and so conditioned are of undoubted Makalanga construction. There are stone buildings at Cherimabila's kraal, nine miles west from Zimbabwe. Mr. Drew considers the Barotse to be now the best stone builders in this district.

Other walls not ancient. ${ }^{1}$-But there are other walls in these ruins which are not believed to be ancient, and these have not been erected by recent generations of Makalanga, but possibly by mediæval Makalanga, or by Arabs, who had large influential colonies in this country, especially at the various Zimbabwes of the successive Monomotapas. The arguments against these walls being ancient are just as numerous and equally as cogent as those just enumerated, but the consideration of such walls is dealt with in detail in the description of the walls themselves.

Remains of native huts found in the ruins.-In many of the enclosures of the ruins at Zimbabwe are to be found on the present surfaces, and frequently, if the floor of the interior is not formed by the rock formation, on two floors beneath it, the remains of at least three entirely different descriptions of native huts. This is a feature constantly met with in ancient ruins throughout Southern Rhodesia, and in the early days of investigation these remains occasioned considerable perplexity to the explorer. In some ruins only one type of such structures is found, in others two classes of such dwellings, and in others three if not four different types of structure, all the three main types presenting different features in plan, construction, and material.

That these erections are not ancient is a matter of ocular demonstration.

(a) This is shown by their position on the clay floors laid over the débris which has been filled into the enclosure to the 

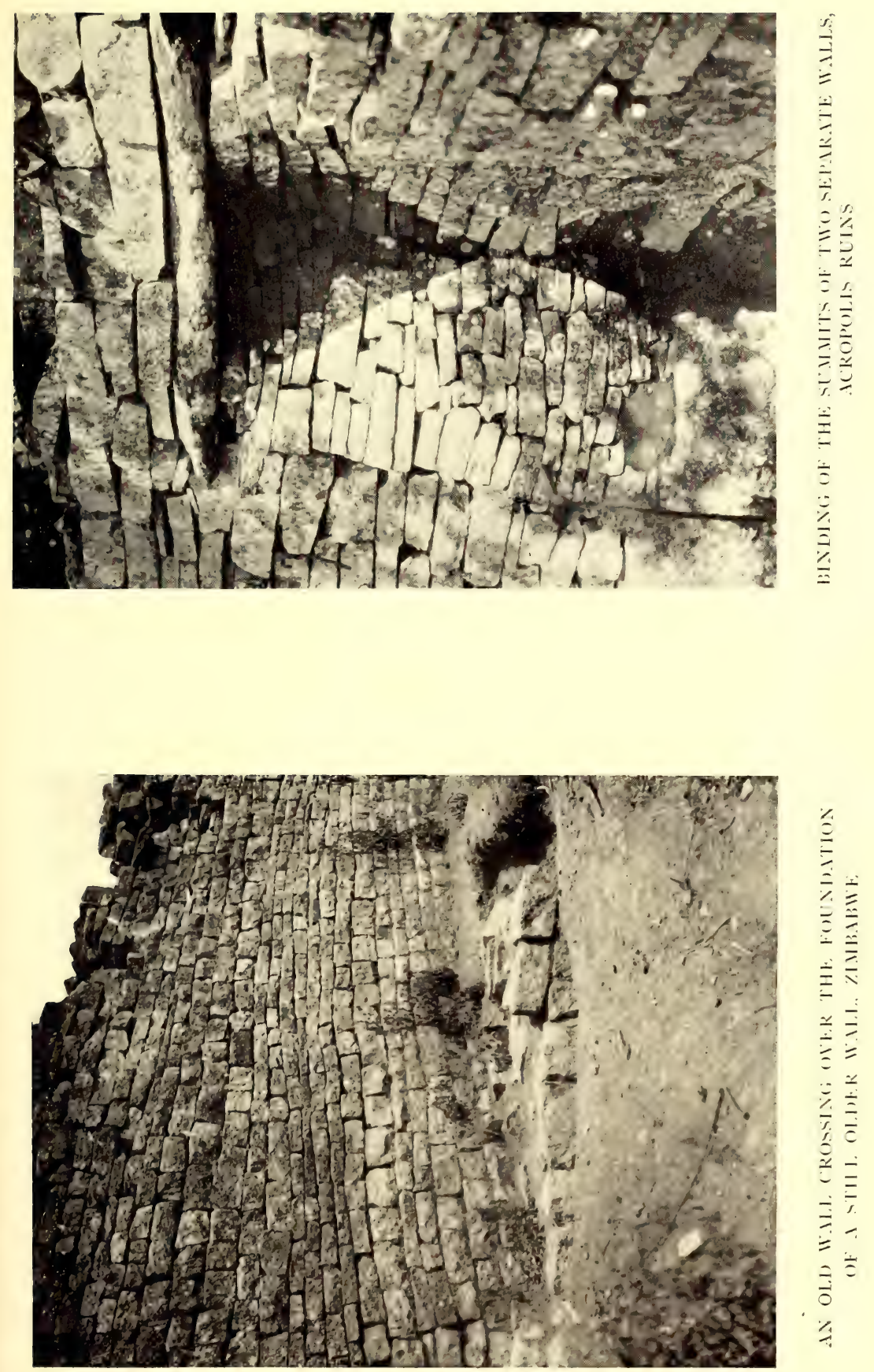

depth of from $3 \mathrm{ft}$. to $7 \mathrm{ft}$. above any ancient floor, hiding rounded entrances, passages, and smaller sub-divisional walls, and burying, as at some ruins, the ancient decorative patterns on the walls. The examination of the material employed, and the class of its make so similar to the remains of native huts in old deserted villages, all negative any suggestion of antiquity.

(b) The stonework of the foundations is, as is shown later, of a totally different character from that in undoubted ancient walls, and is practically identical with the stone foundations of granaries still to be seen in any of the villages, some of which are not twelve months old.

(c) The "finds" in these structures do not suggest ancient occupation, but they include articles of superior native make and design, some of which are either not now used by Makalanga or Barotse, or are only met with in rare instances, but are claimed by local natives as having been made and used by previous generations of their people. For instance, double iron gongs, such as are plentifully found north of the Zambesi and in the higher Congo districts, where they may still be seen in actual use, pictures of which occur in works of travel in Central Africa ; or copper bangles of exceedingly fine wire, which ornaments have fallen into desuetude and can be but seldom met with now ; or carved soapstone daha pipebowls, for the making of which the Zimbabwe Makalanga, even at the time of the Occupation, were famous.

(d) Several of these structures at Zimbabwe are claimed by the local Makalanga and Barotse to have been built by their respective people of previous generations. The Barotse lived on the Bentberg at Zimbabwe up to fifty or sixty years ago. The remains of their old kraal can be seen to-day. The circular shallow stone foundations of their huts, the courses rising in "catsteps," the immense rounded clay rims which supported the poles of the sides of their dwellings, are still in evidence. These were erected on platforms made by 
filling in the spaces between the inner sides of ancient enclosure walls and the slope of the hill, a practice to be noticed on all the faces of Zimbabwe Hill, except the eastern.

The different types of such structures so found in the ruins may be described as follows :-

(I) The ordinary clay ruins of a present-day Makalanga hut, with clay floors, butt-ends of side poles still in position, clay ruins on floor marking off the fire-place, the stand for pots, the higher floor for sleeping-place of occupants and the lower floor for goats. These are found on the present surface or immediately under black leaf-mould soil, and resemble huts built in local kraals, only they are neater, of better make, and of slightly superior quality of clay. The articles found here are similar to those belonging to present Makalanga.

(2) The foundations of huts with large rims of clay with rounded edges on both sides, the diameter being some $9 \mathrm{ft}$. to $12 \mathrm{ft}$, and the rims 16 in. in length and about the same width, the poles being fixed along the centres of the rims. The material in the floor and in the rim is of a superior quality of clay, which builders state it would be misleading to describe as cement. Under the clay floors, which are about 3 in. thick, are platforms of stones laid flatwise in three or four courses, the outer faces of the courses receding from I in. to 3 in. behind the faces of the courses below. Sometimes the stonework is laid upon a bed of clay. This class of hut is found upon a lower level than the undoubted Makalanga dwelling. In the Eastern Temple this type of remains was uncovered at a depth of $3 \mathrm{ft}$. below the surface, and there were no less than two clay floors, each with a layer of ashes, and two granite cement floors below it. These can be seen in the trench made alongside the stone foundation. Glass beads of old make, copper spearheads, and thick copper bangles, beaten copper and copper tacks were among the principal finds discovered in this type of building. In and 
near such remains were found the four double iron gongs (May, 1902-March, 1903), piles of animal bones split open in ordinary Kafir style for marrow, broken pottery, and quantities of ashes.

(3) On still lower levels were found the floors and lower portions of the sides of huts made of a red-coloured cement without poles fixed in the cement sides. This is not ordinary daga. The inside faces of the walls, as well as the floors which are beautifully smooth, have been baked with fire, and fragments will ring almost like metal, portions having become white with the heat. This cement has in most instances been faced with a thin yellow glaze. On the floors are quantities of small rims very neatly bevelled, with three or four parallel faces on the top, the ends of the rims being rounded off. The bevelled rims are from $1 \frac{1}{2}$ in. to 4 in. wide. The roofs of these buildings were supported by poles inserted in the cement floors outside the huts at the distance in many instances of $\mathrm{I} \mathrm{ft}$. The posts round the outside of the huts were from I ft. 6 in. to $2 \mathrm{ft} .4$ in. apart, and, judging by their butt-ends, which have been preserved by the cement, were made of hard woods, including mahobohobo, which is plentiful at Zimbabwe. The best examples of these huts, of which some score can be seen, are in No. I Enclosure in the Elliptical Temple, in the North-West Enclosure, Acropolis, and on the cleared section of floor in the Western Temple. These huts stand on cement platforms without stone foundations, and the platforms are about I ft. high, and the top edges are neatly bevelled. In two of these remains at Zimbabwe have been found gold dust, iron spring pincers with flux on the top, pottery, gold scorifiers, and the crudely-shaped soapstone moulds.

Old pioneers assert that these buildings are of Makalanga construction. The Makalangas themselves claim these as having been built by their people in a very remote past. Similar buildings, but without traces of gold smelting, are 
known to have been built by the Makalanga in different parts of Southern Mashonaland.

Mr. Alfred Drew, Native Commissioner for Victoria district, who arrived in this country in 1890 , and is a recognised authority on old Makalanga buildings, expresses his entire agreement with the above descriptions of old native clay huts, also with the conclusions arrived at concerning them.

(4) There is another class of native hut which is not very frequently found in Southern Rhodesia, but is commonly met with in Basutoland and Swaziland, and in other territories further south. At Zimbabwe there are four such huts on the higher floors of filled-in ruins. This class of hut is constructed of cement of a good quality and of great thickness, with no poles to support the roof. It is circular in form, and from its exterior sides are four, sometimes five, short radiating walls of stones extending outward some $5 \mathrm{ft}$. or $6 \mathrm{ft}$. The walls are about $4 \mathrm{ft}$. wide, and in height reach almost to the top of the cement sides of the hut. The entrance usually has an immense cement buttress on either side, while between each radiating wall, and at the base of the side of the hut, runs a cement bevel rounded on its outer edge as if to form a seat. This bevel is about 14 in. high and 16 in. wide. In all weathers and at any time of day the occupiers could have sat in some one of these partially open spaces between the radiating walls sheltered from sun, rain, or wind. The remains of two such huts were found in the Western Temple on the Acropolis, and one of the radiating walls of one of them, which was more exposed and less ruined than the other short walls, was fixed upon by Swan as an "altar." This wall is B wall, mentioned in the description of the Western Temple, which follows in Chapter XV.

Passages.-Every writer on Zimbabwe appears to have been greatly struck with the number of passages both at the 
Elliptical Temple and on the Acropolis, and particularly with their labyrinthine character. During I902-4 further passages were discovered and opened out, and these had a total length of $2,130 \mathrm{ft}$. The total length of passages opened out, or which can be clearly traced, now amounts to $5,202 \mathrm{ft}$. As is shown later in this section, this by no means exhausts the tale of passages to be found at Zimbabwe.

Elliptical Temple:-

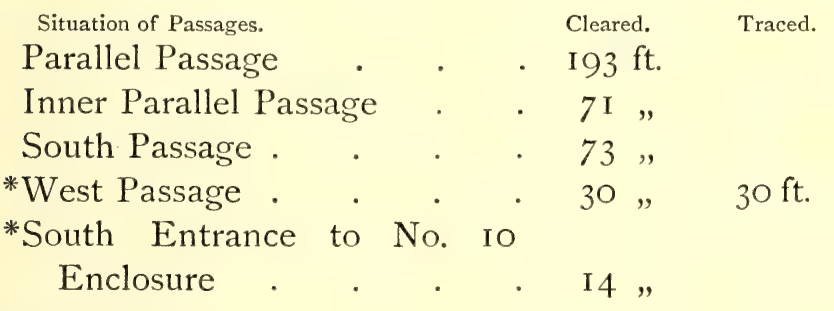

Outside Elliptical Temple:-

Outer Parallel Passage . . I $25 \mathrm{ft}$.

* North-East Passage (remainder

of length included in the

"Valley of Ruins" passages) 50 ,

Acropolis or Hill Ruins :-

South-East Ancient Ascent . $349 \mathrm{ft} . \quad$ I $260 \mathrm{ft}$.

Higher Parapet . . . 78 ,

Central Passage . . . IO3"

* Sunken Passage, Eastern Temple (traced further) . . 28 ,

North Passage, Eastern Temple 23 ”,

* South Cave Passage . . . 46 "

Covered Passage(cleared in I9O2) $\mathrm{IO}_{\frac{1}{2}}$,

Parallel Passage . . . 7I, $20 \mathrm{ft}$.

* Cleft Rock Enclosure to foot of

Platform stairs . . . IO ,

Winding Stairs . . . I4" 
Acropolis or Hill Ruins :-

Situation of Passages.

Upper Passage .

Cleared.

Traced.

East Passage .

Buttress Passage . . 39 "

*South Passage . . . 38 "

Pattern Passage (upper portion cleared in I902) . . . 5I ,

North-West Ascent:-

* Sunken Passage in Platform Enclosure . . . . $72 \mathrm{ft}$.

Ditto through main wall . . I6 ,"

Ditto on Northern Parapet . 28 ,

*Ditto from Northern Parapet to

Visitors' Part . . . 223 ”

*Ditto from Visitors' Part to

Water Gate . . . I5O , 5 IO ft.

Minor Ruins :-

*Outspan Ruins . . . . $56 \mathrm{ft}$.

Ridge Ruins, Parallel Passage . 246 ,

*Ridge Ruins, other passages . 25 ”

No. I Ruins . . . . I42,

Valley of Ruins :-

*North-East Passage . . . . . $\quad 600 \mathrm{ft}$.

Passage referred to by Mr. Bent ... 300 ”

*Posselt Ruins, Parallel Passage $65 \mathrm{ft}$.

*Philips Ruins . . . . 5 I ",

*Maund Ruins . . . . 24 ”

*Mauch Ruins . . . . 99 "

*Renders Ruins . . . . 3 I "

Totals $.2,752 \mathrm{ft} . \quad 3,620 \mathrm{ft}$.

* These passages were discovered in 1902-4. 
In addition to these totals of lengths of passages cleared out or traced, there are many other passages still buried in débris, the outcrop of their side walls being seen here and there on the surface near several ruins. Many, of course, must be completely buried under the veld, for some were lately discovered at least $3 \mathrm{ft}$. below the surface, with native paths crossing them in all directions, while it is quite reasonable to suppose that with the great area of ruins yet unexplored very many more passages will yet be found, especially when it is recollected that the discovery of one buried passage has most frequently led to the discovery of several side passages.

Traces were found of two other passages leading from the base to the summit of the Acropolis Hill, and these remain unexplored, and each would be fully $900 \mathrm{ft}$. in length, while traces of several lines of passages are to be seen encircling at various heights the south, west, and north faces of the Acropolis Hill. These also at present remain unexplored.

There are many points of interest concerning these passages :-

(a) Passages were evidently constructed as part of the plan of the fortifications, but in some instances only as means of communication between certain buildings within the fortified area and for securing privacy. In the one class of passage buttresses and traverses are repeated with a marvellous redundancy; in the other class of passage not a single buttress or traverse is to be found.

(b) In passages leading from main ruins to exterior buildings the walls of the passage nearer the main ruins are better built, and the steps and floors are better constructed in the portions nearer the main ruins than are those of the more distant portions of the passage. So imperceptibly do the better-built portions merge into the less superior class of wall that it is extremely difficult to ascertain the exact point where the change in the quality of the construction takes 
place, though the difference in the class of building at one end of the passage and that of the other is most obvious. But though this difference in the construction of the passage walls is so apparent, there is no suggestion that portions were of a later period, for they are built upon one plan, have one line of direction, serve as a complete communication with one obvious and particular point, and one length of the passage without the other would be purposeless, so far as the intention of the builders may be gathered. With regard to the passages ascending the Acropolis Hill, the completeness of the plan of these passages is best seen from the summit of the hill or from the summit of Makuma Kopje on the opposite side of the valley, from which heights respectively a complete view of those passages in their entire length is to be obtained.

(c) Excepting some of the passages in the Elliptical Temple and a few others on the Acropolis, all the passages at Zimbabwe are exceedingly narrow and tortuous, many being only shoulder wide, while, owing to their winding lengths, it is not possible to see many feet on ahead. Such of these passages as have their floors below the levels of adjoining enclosures have in many places their side walls bulged by the weight of earth and débris behind into the passage-ways, and in some such instances the side walls have collapsed and blocked up the passages.

(d) Almost every passage appears to have originally been paved with blocks which were covered over with granite cement, but the cement, except in a few instances, has decomposed and been washed away by centuries of rains, though abundant traces of it remain.

(e) Sunken passages built very much below the levels of the ancient floors on either side of them are numerous. The best instances of sunken passages are the North-East Passage between the Elliptical Temple and the Valley of Ruins, also the North-West Ascent to the Acropolis (upper portion), 
and the sunken passage in the Eastern Temple on the Acropolis.

(f) The walls of the ascents to the Acropolis as originally built would have precluded any outsider from seeing, even if standing on an adjoining kopje, the movements of people passing up and down the ascents; and to-day as a native ascends these passages it is almost impossible to see him till he reaches the summit, except as he is passing gaps or walls which have become considerably dilapidated. Some of the outer walls of these ascents are still Io ft. in height.

$(g)$ The Elliptical Temple and the Western Temple on the Acropolis have each long and narrow and deep parallel passages on the inside of their main walls, and it is possible that the Pattern Passage served for a similar purpose at the Eastern Temple. The Parallel Passage in the Elliptical Temple communicated only between the North Entrance and the Sacred Enclosure where are the conical towers, and this passage has no communication with any other portion of the interior of the temple. Several of the known writers on these ruins, including Bent, have conjectured that these parallel passages in the temples were reserved for the use of the priests.

(h) Cliffs and large boulders have been frequently utilised to form lengths of passages. Instances of this practice are to be seen on the Acropolis in the Rock Passage of the SouthEast Ancient Ascent, Buttress Passage, North Passage, and elsewhere. In some instances the walls are made to go out of their line so as to include neighbouring boulders, the sole object, so it would appear, being to deprive any invading force of the vantage offered by the height of the boulders for an attack to be made on the passage.

(i) There are no evidences that any of the passages, except as stated later, were ever roofed. Possibly the winding stairs and the sunken passage in the Eastern Temple were originally covered over, as a great quantity of long, flat slate beams 
were found on their floors. It is believed that a single wall once crossed over the sunken passage in Platform Enclosure at about I $5 \mathrm{ft}$. from its upper end, for when this passage was opened in 1902 slate beams were found at this spot, but at no other point in the passage. The passage through the main west wall of the Western Temple, which was blocked up by a Makalanga-built wall, of course, was covered over by the main wall, while the Covered Passage in the same temple remains intact as originally built. Moreover, the widths of many of the passages though narrow on their floors are wide at the summits of their side walls, and their irregular form precludes suggestion of any roofing having been placed over them, some being doubly as wide as the longest of the slate and granite beams found, beside which the general absence of long slate and granite beams on the floors of the passages would seem to further negative any such conjecture. The West Passage leading to the South Cave was not artificially roofed over, but the outer wall was raised up to the height of the boulder which overhangs the passage.

Entrances and buttresses.--When in I891 Bent approached Zimbabwe through North Bechuanaland, Gwanda, Tuli, and Belingwe, he passed through the centre of that area in which the earliest of the many ancient ruins of Rhodesia are located. All the ruins he described or mentioned had rounded ends of walls and rounded buttresses, all angular features being conspicuous by their absence. This fact appeared to him so striking that he was constrained, after comparing these ruins with Zimbabwe, to believe that such rounded features belonged to the earliest period of Zimbabwe architecture. Fully a score of competent writers on our ruins, whose valuable and trustworthy contributions, based on personal examination of the same area, have been welcomed by the leading scientific associations of Great Britain and Germany, are also emphatic as to the rounded entrances and buttresses 
being one of the chief distinctive features of the earliest Zimbabwes. This is further demonstrated in the detailed descriptions of almost one hundred ruins within the same area which are given in The Ancient Ruins of Rhodesia, in the great majority of which ruins angular features, except in reconstructions of a later period, are altogether absent.

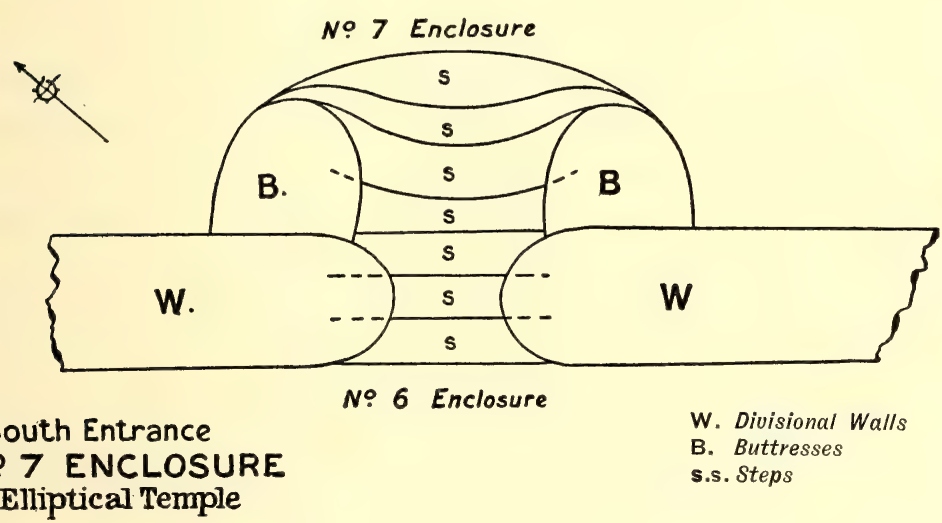

But the Great Zimbabwe being the finest type of that early class of ancient building, it may be interesting to know that Bent's conclusion is thoroughly confirmed by these ruins.

\section{ENTRANCES}

Ruins. Rounded. Angular.

Elliptical Temple . $23 \quad \ldots \quad I$

(One other entrance is partly rounded and partly angular.)

Acropolis

(One of the angular entrances is of obviously later construction.)

No. I Ruins . $\begin{array}{lll}3 & \ldots & 4\end{array}$

(One entrance is partly rounded and partly angular.)

Valley Ruins. 


\section{BUTTRESSES}

Ruins.

Elliptical Temple .

Rounded. Angular.

(Two buttresses are partly an-

gular and partly rounded.)

Acropolis

No. I Ruins .

Valley Ruins .

* All rounded except three as so far discovered.

All ends of walls which are still intact are rounded, there being only a few examples so far discovered of angularended walls.

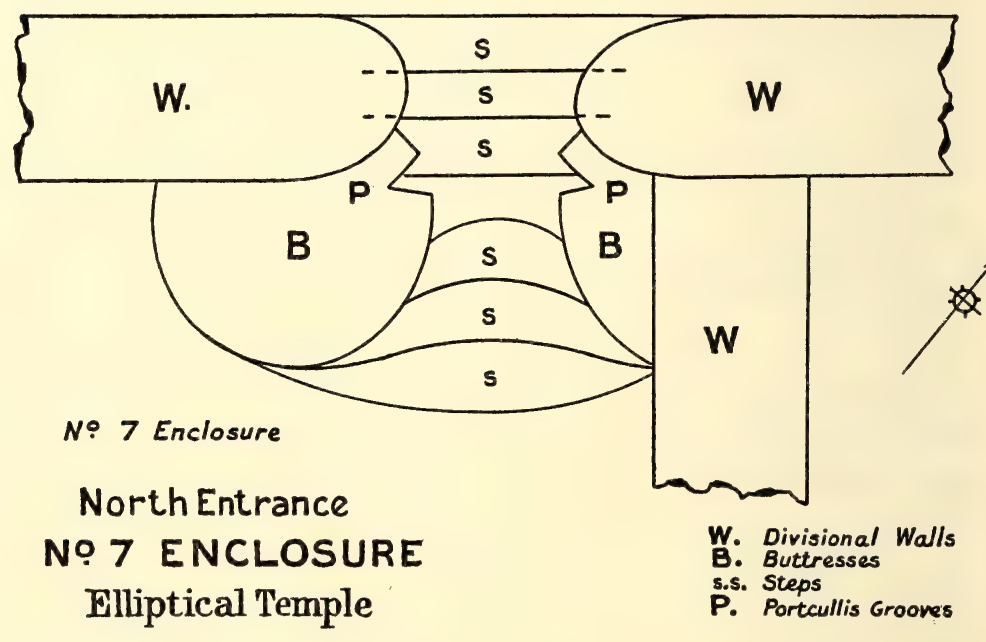

The above figures show conclusively that these rounded features, excluding the ends of walls which are almost always rounded, are in a far greater proportion than 146 to 13 which are angular, and at least three of the latter, if not others, for reasons explained elsewhere, can be shown to have been erected at a much later period, one being built upon a floor of common Makalanga daga, and another débris containing ordinary Kafir articles of no very great age.

All the entrances in the main outer walls, save one, are 


\section{ANCIENT ARCHITECTURE}

rounded, the few angular entrances being found, with two exceptions, in slighter walls, mainly divisional, some of which were erected later possibly to suit the immediate convenience of later occupiers, for divisional walls had been removed, reconstructed, or entirely fresh ones erected in new directions in almost every ruin, and in some instances the foundations of the later walls cross at right or oblique angles over the reduced summits of older divisional walls.

Walls of the earliest period widen out as they near entrances. This feature is not present in plumb and angular walls of later construction.

There is no evidence whatever in the rounded entrances that they were ever covered over, but in two angular entrances on the Acropolis the butts of the broken slate lintels still remain in the side walls.

Although there are not sufficient proofs to enable one to definitely determine whether the rounded entrances as a rule were once covered over, some of the evidences to negative the covering in of rounded entrances may be noted :-

(a) Had such entrances been roofed in, the collapse of the lintels must have brought down far more of the walls than have fallen.

(b) The courses of the blocks at the necessary height above the floor of the entrances on either side do not always correspond.

(c) The top courses near the summit of the walls on either side of the entrances show distinct signs of curving inwards towards the entrances. This is particularly noticed on the east side of the north-west entrance to the Elliptical Temple.

(d) No splinters of slate or granite beams which could have been used as roofing were found in any of the very many rounded entrances.

(e) Two intact rounded entrances, one open up to the summit on either side to a height of $19 \mathrm{ft}$., one entrance being at the east end of Pattern Passage on the Acropolis. 
No main entrance has buttresses on either hand on the outer side, possibly because these would have provided any attacking party with excellent shelter. All buttresses of such entrances are on the inside. Divisional entrances which have buttresses have them on the inside only.

The entrances through a wall of the earlier period are carried over the common foundation in the opening forming the steps, which were evidently constructed before the side walls were erected. These steps are large, broad, and high, and where intact look most imposing. Such entrances resemble stiles, as they are much higher than the levels of the floors on either side.

The entrances through an angular wall of a later period have steps which are not part of either side walls, but were built in after the entrance passage had been constructed, and these show poor workmanship and are very shallow, and recede only two to four inches. As the levels of the enclosures on either side have filled in over the original floors, such "cat-steps" have in some instances been built over the original large steps for the purpose of raising the floor of the entrances, seeing that the enclosures on either side had been filled in some feet above their original levels.

Directly opposite the main entrance of the "Outspan Ruins" is a large circular buttress, as if it were intended to divide any attacking party into small numbers.

Cause of dilapidation to entrance buttresses. -The entrance buttresses with portcullis grooves are in most instances comparatively small, some projecting only two to three feet towards the interior of the building, and these are built up against main and divisional walls, and are in point of construction altogether independent erections, there being no dovetailing or binding between the buttresses and the walls.

In some of the entrances the side lintels of slate, granite, and unworked soapstone beams have been found built into 
the portcullis grooves. In The Ancient Ruins of Rhodesia it was noticed that at several of the ruins therein mentioned stone side lintels were found in situ. The stone lintel posts in situ at Zimbabwe had not then been discovered. The tallest of such stone lintels at Zimbabwe is $8 \mathrm{ft}$. above the ground. The buttresses appear to have been built after the stone posts had been erected, for the walls at the sides of the lintel follow the irregularities of the side faces of the beams.

The great destruction which has occurred to these structures might possibly be accounted for by (I) the weight of the stone lintel on getting off the perpendicular, which would lever down the buttress into which it was built; (2) the foundations of buttresses are not so deep as those of the main wall up against which they were built ; (3) when some later people, possibly natives, deliberately built up and blocked the entrances they might have used the blocks of these buttresses for their building material ; (4) the passageway between each pair of buttresses being so very narrow, damage could easily have been wrought by ordinary traffic; and (5) the main walls are much higher than the summits of the buttresses, and the walls on either side of the entrances being always more dilapidated on the summits, the falling of huge masses of masonry on to the buttresses immediately below might have effected their destruction. 


\section{CHAPTER VIII}

\section{NOTES ON ANCIENT ARCHITECTURE AT GREAT ZIMBABWE \\ (Continued)}

Drains - Battering of Walls - Monoliths - Soapstone Monoliths and Beams - Granite and Slate Beams - Cement dadoes - Built-up Crevices-Holes in Walls other than Drains-Blind Steps and Platforms-Ancient Walls at a Distance from Main Walls-CementCaves and Rock Holes.

\section{DRAINS IN ELLIPTICAL TEMPLE}

$D^{2}$ RAINS through main walls:-

I. At $\left(35^{2} \mathrm{ft}.\right){ }^{1}$ from Parallel Passage to exterior of temple; has a decided fall outwards; curves round at half through towards south; covered with large slabs; inner hole I in. below granite cement floor of passage, which slopes downwards from either side towards hole; interior opening I 4 in. high, 9 in. wide ; exterior opening, I 2 in. high, 6 in. wide.

Between Nos. I and 2 drains the cement floor rises a few inches to a raised step-barrier $4 \mathrm{in}$. high, $3 \mathrm{ft}$. Io in. broad, from which the flooring slopes down to No. 2 drain, thus forming catchment areas for each drain to clear off rainwater, so that each drain only had such an area to clear which its capacity would allow.

2. At (39I ft.); from Parallel Passage to exterior of temple; decided fall outwards; curves towards north-east;

${ }^{1}$ Figures in round brackets are points of the circumference of the interior face of the main wall measured from the south side of the west entrance and going south. 
covered with large slabs; cement floor of passage level with floor of drain; interior opening I I in. high, I I in. wide; exterior opening I 7 in. high, I I in. wide.

[Facing this drain and on the west side of the passage is the drain (No. 7) from No. I4 Enclosure, described later.]

3. At (442 ft.); from Parallel Passage to Outer Parallel Passage; fairly straight; steep fall outwards; covered with large slabs; interior opening 12 in. high, 8 in. wide; exterior opening 15 in. high, 6 in. wide. [It was from this drain that fragments of cement lining were taken.]

4. At (476 ft.); from Parallel Passage to Outer Parallel Passage; partially obstructed at half-way through by stones and dirt ; very decided fall outwards ; curves slightly towards east; covered with large slabs; interior opening I I in. high, 7 in. wide; exterior opening Io in. high, 10 in. wide.

5. At (5I5 ft.); from Parallel Passage to Outer Parallel Passage; interior opening buried in débris supporting wall threatening to collapse; exterior opening Io in. high, 6 in. wide; covered with large slabs; exterior portion shows decided fall outwards ; clear for $8 \mathrm{ft}$., probably further.

6. At ( $549 \mathrm{ft}$.); from No. 2 Enclosure to exterior of temple; clear for $\mathrm{I} 3 \mathrm{ft}$. from interior; exterior opening buried under very old Makalanga clay floor; covered with large slabs; interior opening I I in. high, 8 in. wide; shows a fall outwards.

[Drains Nos. I- 6 pass through main wall at points where it is from $\mathrm{I} 3 \mathrm{ft}$. 6 in. to $16 \mathrm{ft}$. wide.]

Drains through divisional walls:-

7. From No. I4 Enclosure to Parallel Passage facing drain 2 at (39I ft.); exterior opening 12 in. high, 7 in. wide; shows outward fall; covered with large slabs; passes through wall $6 \mathrm{ft}$. wide at drain level; interior end blocked up.

8. From No. I I Enclosure to Sacred Enclosure (east); on north side of small conical tower; penetrated for $6 \mathrm{ft}$., at which point it is blocked up; rises sharply inside; exterior 
opening 9 in. high, 6 in. wide; interior opening blocked up and covered over.

9. At north end of South Passage; from South Passage to Parallel Passage; decided fall outwards; covered with large slabs ; clear for $5 \mathrm{ft}$; interior opening Io in. high, 8 in. wide; blocked up at outer opening by débris supporting dilapidated wall.

[Pieces of granite cement lining also found here in 1892 and I902.]

IO. From No. I to No. 3 Enclosures; at south corner of No. 3 ; exterior opening $\mathrm{I}$ in. high and 7 in. wide; shows fall outwards; covered with slabs; curves towards south; clear for $6 \mathrm{ft}$. 6 in.; interior opening covered by clay floor of Makalanga hut.

I I. From No. 15 Enclosure to Inner Parallel Passage; fall outwards; exterior opening $\mathrm{I} 2 \mathrm{in}$. high, 8 in. wide; interior opening blocked up and covered over by soil and wall débris ; clear for $5 \mathrm{ft}$.

Drains at entrances:-

I2. Through south entrance to South Passage; discovered by Sir John Willoughby; under centre of steps; outlet on lower face of steps.

I 3. Under step and parallel with wall at entrance to Sacred Enclosure (west) from No. 9 Enclosure; two similar drains on Acropolis.

Drains through an outer wall:-

I4. On north-west side of southern end of North-East Passage; through base of wall $4 \mathrm{ft}$. 6 in. wide; eastern exterior opening 8 in. high, 9 in. wide; covered with lintels; clear for $3 \mathrm{ft}$; extended eastwards as an open drain $8 \mathrm{in}$. wide towards foot of steps of north entrance to the temple.

I 5. Through wall dividing No. Io Enclosure from Platform Area. This has a fall eastwards, and is in a good state of preservation. 


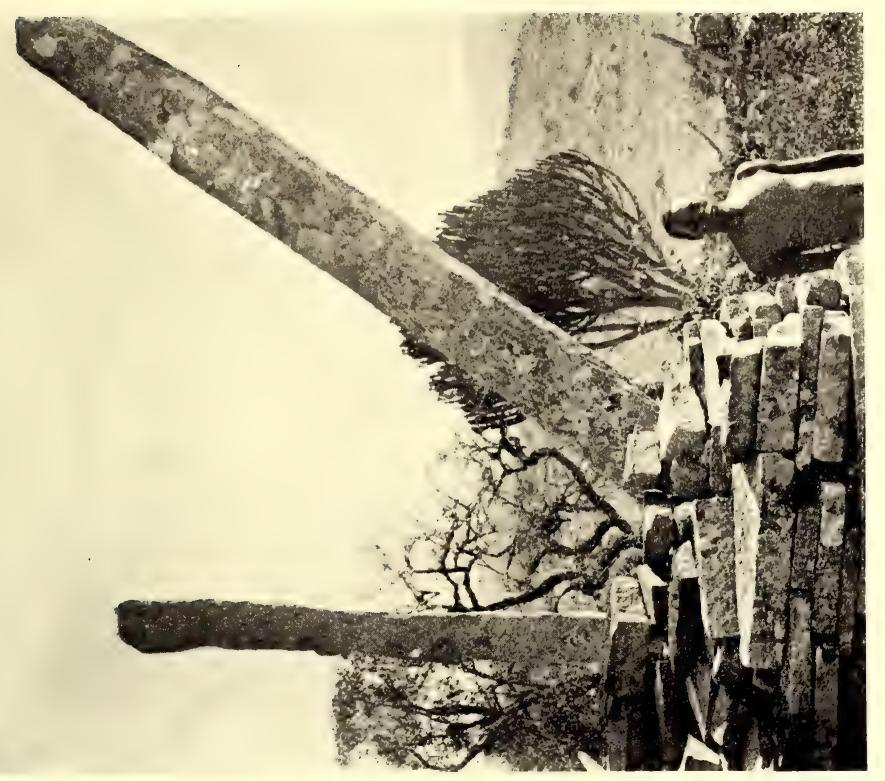

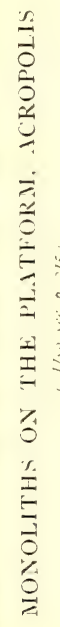

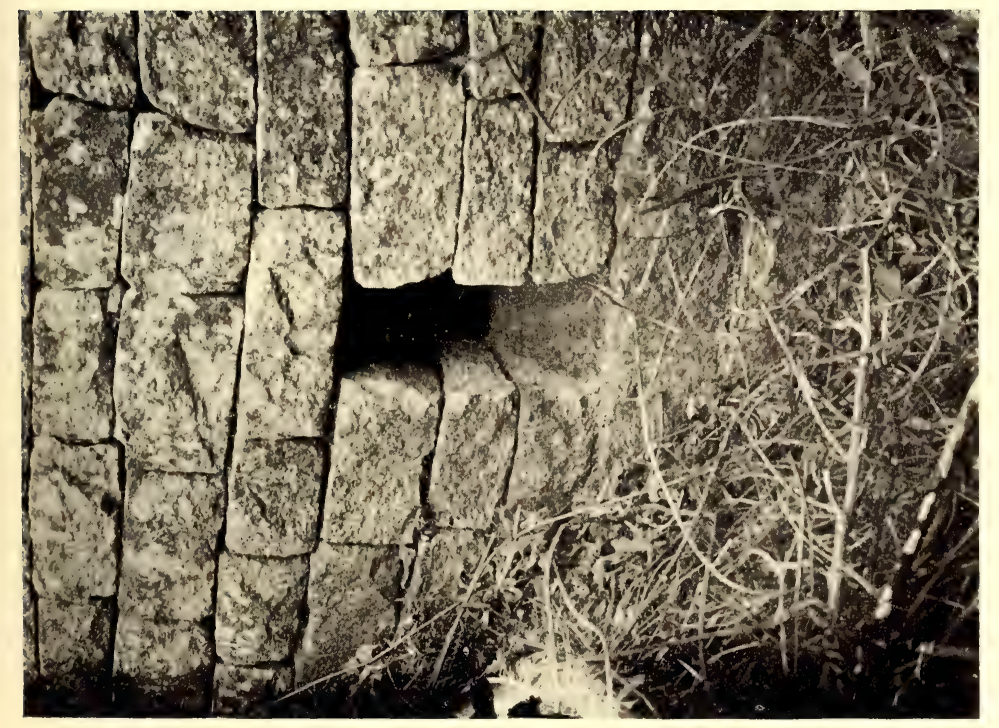

王 

DRAINS AT ACROPOLIS RUINS

I6. In Western Temple, in divisional wall "A" (see plan and description); drain-hole passes $5 \mathrm{ft}$. from north to south; northern opening 9 in. high, II in. wide; impossible to state the fall owing to stones and dirt inside; fragments of cement lining were found here in I891, I892, and 1902. [The interior of this temple was on the north side of wall "A," as well as on the south side of wall " $D$," much higher than between these two walls, which form a small amphitheatre (Bent) within and at the west end of the larger amphitheatre formed by the main walls of the temple. This is obvious to anyone examining the interior. Practical builders have recently stated their belief that when the lower and western side of this smaller amphitheatre is cleared of débris drains will be found at the base of the main west wall, which, so far as discoveries have been made, is the widest ancient wall in Rhodesia. The whole interior of the temple, and the formation rock over which, but not upon which, it is built, slant at all points downwards to the foot of the inner face of the main wall.]

I7. On west side of Upper Passage and leading from Little Enclosure; exterior opening 9 in. high, 6 in. wide; clear for $3 \mathrm{ft}$. inwards; interior opening covered with débris.

I8. East corner of South Enclosure A; through south wall ; $4 \mathrm{ft}$. long; fall outwards; covered with large slabs; exterior opening 12 in. high, 8 in. wide; interior opening dilapidated.

I9. East entrance of Eastern Temple leading from temple to Gold Furnace Enclosure; under pavement of entrance; still 5 in. deep.

\section{DRAINS IN VALLEY OF RUINS}

20. In $\mathrm{B}$ section of Posselt Ruins in a divisional wall at extreme north-west end of ruins. 
2I. In B section of Posselt Ruins in a divisional wall on north side $4 \mathrm{ft}$. wide.

22. In B section of Posselt Ruins in main south wall.

23. In Philips Ruins through a substantial wall east of large curved wall.

24. In Philips Ruins through wall on east side of previous drain.

25. In Mauch Ruins in divisional wall.

26. In Mauch Ruins in east main wall.

27. In Mauch Ruins in east wall of the outer enclosure.

The battering of walls.-The backward incline of both faces of walls from their bases to summits is a general characteristic in ancient architecture at Zimbabwe, and in all other ruins which belong to the earliest known type of ancient buildings in this country. This feature, so far as examinations have been made, is conspicuous by its absence from all buildings of the second or later period. So noticeable is this feature in the main walls of the Elliptical Temple that visitors viewing the walls from the interior constantly affirm their belief that the walls have commenced to lean over towards the exterior, and when viewing the exterior faces of the identical walls declare that the walls are leaning inwards and must ultimately fall inside the building. This is a mere optical delusion.

The main walls, portions of which are believed to have stood some 3,500 years, are, if given the same conditions to which they have been subjected in past times, quite likely to be standing at the end of another millennium, if not longer, for the battering-back is a most important element of their massive strength, and has proved to be the main factor in securing their durability. Of course, some main walls in certain places show signs of bulging out and of damage caused by earth movements, possibly earthquakes, also by lightning, the sinking of foundations by water or damp, or 
growth of trees within their open dry masonry during the long period since their erection. Some faces of the walls show a complete swagging from end to end of their lengths, and yet the batter-back has preserved the walls practically intact throughout with each block occupying its original relative position. The appearance of such walls strongly suggests the effects of earthquake, and while these earthmovements would destroy a plumb wall, a wall with a severe batter-back, such as is seen in all the older walls at Zimbabwe, would on this account be comparatively safe from such effects.

In some instances the battering is very severe and exceeds that of $\mathrm{I} \mathrm{ft}$. in $6 \mathrm{ft}$., and the native labourers can scale such with ease. Looking at the rounded extremities of any of the most ancient walls, one notices that their sides resemble the lines of a lighthouse as popularly conceived, in many instances the batter-back being more severe near the base and near the summit, and many of such rounded ends of walls where still perfect show very graceful lines of battering. So carefully is the batter-back worked out in the courses that looking up or down the face of the wall one can scarcely see a quarter of an inch of face of protruding block out of the line of the battering.

To secure the batter of the walls the blocks are not slanted downwards at their inner side, but are laid on a true dead level reaching from face to face of the wall on either side, and in their outer courses their outside edges are placed back from the outer course below. So slightly do these courses recede one above another that in the height of only a few courses it would be almost impossible to detect the presence of any battering, while it is very decidedly noticeable in a height of some few feet.

Bent's estimate of the extent of the battering of walls at Zimbabwe, namely, I $\mathrm{ft}$. in $6 \mathrm{ft}$., is fairly exact with regard to many of the walls, but excessive with regard to others, 
such as the main walls of the Elliptical Temple, while for many walls it is perfectly correct. The battering in most instances being more perceptible near base and summit than on the intermediate face of the wall, and the summits in many cases having disappeared, the batter-back, as ascertained by plumb lines, has consequently been considerably reduced. Where the original summits are still practically intact, and where there have been no bulging out of the faces of the walls, and the top courses on the edges do not lean outwards as they frequently do, on account of creeper and tree growths, the I ft. in $6 \mathrm{ft}$. is frequently approached, for instance, south wall Western Temple, $4 \mathrm{ft}$. 8 in. in $3 \mathrm{I} \mathrm{ft.;}$ Pattern Passage, $2 \mathrm{ft}$. in $13 \mathrm{ft}$. In low walls $\mathrm{I} f$. in $6 \mathrm{ft}$. is very frequently reached.

The main walls of the Elliptical Temple, as shown in the Table of Battering (see Elliptical Temple, Main Wall, Chapter IX.), are much less than I ft. in $6 \mathrm{ft}$., a fair average for inside faces being I $\mathrm{ft}$. in I I $\mathrm{ft}$., but at some points it is only I ft. in $I 5 \mathrm{ft}$., and for outside faces $\mathrm{I} f \mathrm{ft}$. in $\mathrm{Io} \mathrm{ft}$. and I $\mathrm{ft}$. in $8 \mathrm{ft}$.

(For the battering of the Conical Towers, see descriptions of those structures.)

Monoliths.-In most of the ruins of both major and minor importance at Zimbabwe, numerous beams of slate and granite, varying from $4 \mathrm{ft}$. to $14 \mathrm{ft}$. in length, have been found, some of the slate beams showing signs of having been treated with tools. It has been the custom of many writers to call these beams "monoliths." In the greater number of instances these beams can be shown never to have been employed as monoliths. So far, at Zimbabwe, authenticated monoliths have been discovered only at the Elliptical Temple, and the Eastern and Western Temples of the Acropolis and Philips Ruins. Many of the beams found in these buildings are not and never were employed as 
monoliths, and the greatest possible care has to be taken in discriminating between monoliths and ordinary beams.

Monoliths have their bases marked and worn by the stones in the sides of the holes on the summits of the walls in which they now stand or once stood, as if they had later become loose and had moved or even oscillated constantly while still in a fairly upright position. The marking of such as have fallen shows that they were made by rubbing against the edges of the enclosing blocks when the monoliths were in a perpendicular position, while some of the jagged notches on the bases must have been made when the monoliths were in a slanting position. The stumps of beams left in the side walls of entrances and passages which were once covered by slate and granite lintels, and across which the upper portions of the walls were carried, do not show the same markings; in fact, such ends of slate and granite lintels are not found to be worn by the friction caused by contact with the edges of blocks, and besides, these lack all evidence of having occupied a perpendicular position, or of having been exposed to the weather. Monoliths are decomposed and weather-worn on all faces, but there is generally more lichen on their south faces.

Further, the bases of monoliths, plain or carved, especially those of soapstone and slate, are found to have their lowest extremities water-worn into smooth faces or grooves at such points round their faces where the bases did not come in contact with the enclosing blocks, and this smoothing has obviously been caused by rain-water running down the faces of the monoliths to the lowest part of their bases, till at last, especially those of slate, the bases which were once of greater circumference have become worn and tapered. The thickness of the wall and the depth to which the bases of the monoliths were built into them would prevent the sun's heat drying the damp bases, and would so keep them moist for a long time after every shower. This constant moisture has 
caused the bases to splinter while the exposed portions of the monoliths remained practically intact. This waterwearing and the splintering on account of damp are absent in beams employed for any purpose in a horizontal position, and these usually show unmistakable signs of having been very well preserved from the effects of the weather, and the extremities of such beams do not taper, neither have they become splintered, and are usually as wide as the main portion of the beam.

Undoubted monoliths of granite and slate have been found used by Makalanga as building material for their walls, and also as posts for cattle kraals. Also, in many cases, as posts for graves, and for decoration of Makalanga walls.

Soapstone monoliths and beams.-Monoliths of soapstone have only been found in the three temples, but in greater profusion in the Eastern Temple on the Acropolis, and at Philips Ruins. Here they were found by their sections to have been of various diameters, but every one had been shaped with tools, some being artistically, others only crudely, decorated, but the majority were plain. Chevron pattern was evidently the favourite design employed. The Makalanga are believed to have used some of the broken sections of soapstone monoliths and beams for carving their I-daha pipebowls, in making which they are known to have excelled. This would save them the necessity of transporting the material to Zimbabwe from the soapstone formation, the nearest point of which is twelve miles in a north-western direction. Natives to-day have been seen taking away very small splinters of soapstone found in the débris heaps. These they cut with a knife into any crude shape that may be suggested to their passing fancy. The number of bases of soapstone monoliths is far greater than the number of splintered or broken sections found in the wall-débris heaps along the foot of the walls. 
Several sections of rounded soapstone beams were also found among the blocks on the summit of the main wall of the Elliptical Temple, and other sections were also discovered here in the débris at the foot of either side of the main wall. These sections, though plain, are beautifully finished, but being the lower portions above the bases, are without pattern. Probably the higher portions were decorated, as the decoration in several instances of soapstone beams discovered does not extend low down on the monoliths. The radii of the sections found in the Elliptical Temple varied considerably, while some had flat-worked faces with narrow ends artificially rounded.

The discovery in all three temples of so many bases and sections of different sized soapstone monoliths suggests the question: Have the present standing slate and granite monoliths been, at any rate in some instances, erected at a later period to replace fallen or fractured soapstone monoliths?

(a) Splinters of undoubted soapstone monoliths, some carved with geometrical patterns, have been found in large quantities in the lowest strata of wall-débris at each of the three temples only; sometimes they were found on the formation rock and below the wall débris, but at the foot of all the faces of the walls on the summits of which are at present only slate and unhewn granite are monoliths still more or less complete and erect.

(b) On the summits of walls on which are slate and granite monoliths numerous small fragments of rounded lengths of soapstone, identical with soapstone beams and some similarly carved, have been found. These instances were frequently noticed in all the temples, May-November, I902, but especially in the Elliptical Temple, where are now only granite and slate monoliths.

Bent deduced from the various succeeding styles of $\mathrm{Zim}$ babwe architecture that the ancient style of workmanship 
changed its form some time between the period of the earliest builders and the later ones, and this would explain why the original monoliths were of more artistic form, with carvings and decorations. How far this has any connection with the theory of the probable substitution, patent, at any rate, in some instances, of plain and unhewn granite and slate monoliths for the fallen and ornate soapstone monoliths, it might be premature to enlarge upon at present, for, judging by the condition of the oldest walls on which certain granite monoliths are fixed, some of these monoliths sunk deep into the summits of the walls were obviously erected when the walls were originally constructed. For instance, one carved soapstone monolith was found built into a wall on the north side of the Western Temple to a depth of $5 \mathrm{ft}$., while the original height of the wall could not have been more than $8 \mathrm{ft}$.

However, both ancient architecture and relics unquestionably prove that between the earliest and the latest periods of ancient occupation there was a marked falling off and decadence in the conception and erection of both buildings and in the character of the articles found.

Number of monoliths still more or less erect.-The number of monoliths still erect, or which have fallen, is as follows, but the number may be further increased as the débris at the bases of the temple walls is examined :-

At Elliptical Temple.-Nine granite monoliths still erect, nine fallen; no slate monoliths erect, five fallen; two granite monoliths, one of which is fractured, stand in No. 5 Enclosure.

At Eastern Temple, Acropolis.-There are no soapstone monoliths now standing, but a considerable number of sections of slate and soapstone monoliths, including bases, were found in the débris. Mr. Posselt, who resided at Zimbabwe before the Chartered Company took possession of the country, states that in I 888 three soapstone beams, 
with birds on their summits, were standing in the interior of the left-hand side of the West Entrance, and one at the northern end of the summit of the main east wall, on which is the dentelle pattern. The three beams stood on a small raised platform, and as this temple was then used as a cattle kraal, the cattle rubbed against them and eventually pushed over the beams.

At Western Temple, Acropolis.-There are twelve slate and four granite monoliths still standing on the walls, and four slate monoliths, three still intact, have been found in walldébris. Originally those on the south and west walls were exactly equi-distant. Bent found and removed several sections of different soapstone monoliths, both decorated and plain, but he found no soapstone bird in this temple. In I89I the lower portion of a soapstone bird was discovered and taken to Johannesburg, and its whereabouts are at present unknown. In August, 1902, the head and neck of this same bird were found, as also a length of the beam upon which it stood, and this is beautifully carved with chevron pattern. This beam originally stood on the summit of the north wall.

All slate monoliths are plain, but many of those of slate have been rounded with tools of which they bear the markings.

Several monoliths have fallen since i 888 . One immense granite beam which occupied an upright position immediately north of The Platform in the Elliptical Temple has disappeared since I89I. A monolith in the interior facing the Western Entrance has fallen within the last few years, while a tall granite beam at the same spot has broken off just above the ground within the same period. Another tall granite beam occupied the Central Area in the temple, and this has also disappeared within the last seven years. ${ }^{1}$ Relic prospec-

1 This has now been discovered. It had been removed by relic hunters in 1892 . 
tors of the nineties appear to have excavated round the spots occupied by monoliths and caused their fall.

The finest specimen of a bird on a soapstone beam yet discovered at Zimbabwe was found by the author in Philips Ruins in February, 1903.

Slate and granite beams.-These are plentifully found in all the enclosures. Sections and splinters of slate beams are found in entrances which have portcullis grooves, one still standing in position $8 \mathrm{ft}$. above the floor. Slate beams used as entrance posts in portcullis grooves were erected before the building of the entrance, as the enclosing blocks follow the irregularities of the beams. Wood posts found in some portcullis grooves in poorer built walls are not considered ancient, and their comparative modernity is testified to by experienced builders who have very recently examined a collection of such posts. Mopani hard wood and mahobohobo have not been used in all such instances, some of the posts being of soft wood. Wooden posts have not so far been found in well-built entrances. The posts outside the clay huts of old Makalanga are older in appearance and condition than the majority of the posts found in the poorer entrances, though they very closely resemble one another in measurements and in the wood used. In one instance the groove was too large for the wooden post which had been wedged in with granite splinters, the granite being only slightly weathered.

Slate and granite beams were also employed for the bonds and ties of walls, also for ties in sharply curved walls, also for supporting the roofs over covered passages.

The nearest point to the slate formation is seven miles in a north-easterly direction. It is believed that the long granite beams were brought from the Lumbo Rocks, one and threequarter miles to the south, where a great quantity of exactly similar shaped beams are to be seen lying scattered round 
the high perpendicular column of granite, the sides of which split off into the shape of the long monoliths found on the Acropolis.

Cement dadoes. - One of the discoveries made recently in clearing the lower portions of interior faces of walls from débris, which appears to have covered them for centuries, is that some portions of such walls have been found to be covered with the remains of excellent granite cement dadoes. This is particularly to be noticed on three walls of the Sacred Enclosure, on the south wall of No. II Enclosure, and at the Little Enclosure and the Upper Passage on the Acropolis, and in other ruins where portions of this dado still remain.

These dadoes extended to a height of $7 \mathrm{ft}$., the cement being found in patches still intact and in the joints of the blocks to this height, the courses above this height being entirely free from traces of cement.

In passages and narrow places great quantities of this cement lay on the original floors along the bottoms of the walls on either side, some fragments showing on their backs the ribbed markings of the courses up against which the cement had been pressed, also bevelled edges, as if from the top and ends of such dadoes. This was particularly the experience on clearing out the Parallel Passage in the Elliptical Temple. It is possible that these dadoes had once facings of white soapstone clay, beautifully smoothed, for this was found on some fragments of such cement dadoes, and the facing, when cut with a knife, powdered exactly as soapstone does.

It can be noticed by anyone that the lower portions of the walls which once had dadoes have their block faces somewhat roughly built as compared with the upper portions of the walls. This appears to suggest that the original builders, in erecting the wall, had calculated upon certain portions of the faces being covered with dadoes. These rougher 
surfaces would provide a better hold for the cement than would the smoother faces of the walls above.

The cavities in the dry masonry of the main walls of the Elliptical Temple contain cooled air even at noontide, and this rushes out from between the courses with such a force as to make it impossible to light a match close to them, while it is a very easy matter to carry on a conversation through a wall $15 \mathrm{ft}$. thick and $32 \mathrm{ft}$. high.

To the original builders who, as is shown elsewhere, thoroughly understood and appreciated the art of sanitation, it is quite probable that these dadoes were considered necessary, especially as these dry masonry walls are the homes of snakes, lizards, and other unpleasant reptiles and creatures which probably were more abundant here three thousand years ago when, as competent scientists affirm, the climate was more humid. Whether for the exclusion of sound, for the securing of privacy, for the protection of their dwellings from reptiles, or to avoid the tearing by rough granite blocks in very narrow passages of such garments as they might have worn, or for the purpose of artistic effect-and these ancients practised several fine arts-the fact has recently been revealed that at any rate some of the ancient walls were once covered with these cement dadoes. ${ }^{1}$

Built-up crevices.-On the Acropolis Hill cliffs and boulders form such prominent features that these have often been employed as sides of enclosures. The ancients were in many instances at great pains to build up crevices and fissures in rocks, especially where these are in or near the enclosures. Even small crevices only a foot or so wide, and penetrating into the face of the cliffs and rocks for but two or three feet,

1 Since the above was written further exploration in the ruins shows several lengths of these granite cement dadoes, one $16 \mathrm{ft}$. and another $33 \mathrm{ft}$. long, still intact. Cement dadoes have also been found round the faces of buttresses and on the side walls of entrances, thus reducing the width of such passage ways by at least 5 in. 
the front being the only part giving access to such fissures, are carefully built up flush with the face of the rock. Some large perpendicular fissures in the cliffs have been so built up to an immense height. One fissure on the south side of the Rock Holes Path has been built up for $40 \mathrm{ft}$. above the ground. This fissure is from I ft. to $3 \mathrm{ft}$. wide. The effect caused by this column of blocks running up the face of the cliff is very strange. Some fissures are so narrow that very small blocks have been used. From some of such fissures the built-up courses have fallen away, leaving a few courses here and there at different heights wedged in between the sides of the fissures, and occasionally one sees a single block wedged into a fissure at an immense height above any ruin. This building-up of crevices and fissures is to be found almost over the whole face of the hill where no ruins are now to be seen. If two boulders are near together, it may be taken as almost a moral certainty that on examining the boulders they will be found to be connected with a wall, even if the space be only a foot or two wide.

In a similar manner the holes under overhanging boulders have been neatly built up so as to effectually hide the hole. The natives have in two or three instances removed sufficient of the blocks to enable them to pass a corpse through, after which, with their peculiar style of building-column formthey have filled up the gaps with walling.

Holes in walls other than drains.-This peculiar feature of ancient architecture is especially prominent at the Acropolis, also in East Ruins, and in almost all the ruins in the Valley of Ruins. There are holes, generally square, in the lower parts of the walls at two or three feet above any ancient floor. They are found only on the inside faces of walls, not one as yet having been discovered on the outer face. That they are intentionally made is a matter of ocular demonstration, for many have lintels either of large granite slabs or of 
slate beams. The blocks of the side framings are all built flush with each other. Their peculiarity is that they do not extend back into the wall for more than the length of a block, in one case of two blocks, and the internal packing blocks in the wall are seen inside. One such recess on the Acropolis shows traces of having once been lined with granite cement. The bottom portion of a similar recess in Upper Passage also has remains of cement lining. The largest recess is to be seen on the west side of a divisional wall in East Ruins. This is $3 \mathrm{ft}$. high and I $\mathrm{ft}$. Io in. wide. No such recess has so far been discovered in the Elliptical Temple, but at least fifty have been found elsewhere among the ruins.

Blind steps and platforms.-In several enclosures in the principal ruins at Zimbabwe, but mainly at the Elliptical Temple, and in the angles formed by the meeting of side walls of the enclosures, are to be seen small raised platforms approached by two or three steps. These steps could not have led to higher positions than the small platforms, that is, they could not have been intended for mounting to the summit of the wall, for the bottom steps are at far too short a distance from the walls in comparison with their heights, besides which, the steps and platforms are perfect in themselves, and their summits, judging by the condition of the cement floor, terminated as is seen to-day. Nor are there any signs on the faces of the walls above such platforms of any steps, or that the blocks in the angles of the walls were at any time protected from the weather by any higher structure.

These blind steps surmounted by miniature platforms are made of blocks thickly covered with granite cement similar to that found on the lowest floors of the temple-the steps being large and deep and boldly rounded off. The shape of these erections reminds one of the steps and raised platforms which are frequently seen in stableyards at 
home, and were once very generally used as mounting blocks.

Bent, unfortunately, discovered only one of these platforms, and this was the one on the north side of the Sacred Enclosure (west), and when he saw it the platform was covered with débris, evidently débris, judging by its age, put there by Dr. Mauch, who had been exploring in this portion of the enclosure. This débris was foreign to this particular spot and had evidently been removed from nearer the Conical Tower. Bent therefore conjectured that these blind steps once led to the summit of the south wall of The Platform. The height of the wall here, $12 \mathrm{ft}$., could not have been surmounted by these steps, for if carried upwards with the same class of step as below, they would have failed to reach half-way up the wall.

These erections might have served a similar purpose for the enclosures in which they were erected, as did the large Platform immediately in front of the Conical Tower for the whole of the Temple. The best examples are in the north-east corner of No. 12 Enclosure, the south corner of No. 7 Enclosure, both in the Elliptical Temple, and in the south-east corner of the Western Temple and in the north, east, and west angles of the Eastern Temple, both on the Acropolis. Possibly the platform and steps in the South Passage of the Elliptical Temple were used for a similar purpose, for this latter structure, though not built into any angle of walls, is of exactly similar construction to the others.

Ancient walls at a distance from any main ruins are of a less superior construction.-There is another class of building found in walls erected at a distance from any main ruins, and these, though constructed in a somewhat rougher form, are otherwise all built upon the principles of the First Period of Zimbabwe architecture. These walls can be clearly shown to have formed part of the original purpose, plan, and con- 
struction as the main ruins, and prove that the original ancient builders, while devoting their best skill to the temples and residential portions of the building, were satisfied with a somewhat inferior quality of workmanship for their more distant walls, and for such of their outlying buildings as were used for some purpose, judging by the finds, other than those of workshop or residence, most probably as forts, workshops, stores for grain, or as the housing places of slaves.

The close connection between the well-built walls of the main ruins and these outlying walls and buildings is, in many instances, easy to establish, and this may be shown as follows :-

I. The sole difference between the construction of the main ruins and the outlying buildings lies in the quality of workmanship and material, these outlying walls showing all other features of first-period architecture to the exclusion of any feature of the second or later periods of construction.

2. Connecting passages between the inner portions of main ruins and the outlying buildings are well built in and near the main ruins, but are excellently constructed as distance is reached, though the line of foundations throughout, as also the cement flooring, are one and the same.

3. Undoubted ancient floors are laid up to and against such walls.

4. Relics of prehistoric character, similar to those discovered within any of the main ruins, have been found beyond main walls in connecting passages and in the more distant ruins.

These evidences as to the early period during which some of the more distant walls were erected are also found in other large ruins of Southern Rhodesia, but at Zimbabwe, where the Acropolis affords such a commanding view of the lines of walls of the outer ruins and of the directions of recently unburied passages of great length, and of the sweep of the walls connecting main ruins with outlying 
buildings, the original purpose of many of the walls and minor ruins appears to be very manifest.

In these outer walls the blocks are of far greater size, their shape is frequently irregular, and unhewn stones are employed, but their faces are even on either side and the internal parts are neatly filled in with stones. All these walls have the usual Zimbabwe batter-back, have rounded entrances, and the steps are not built in between the side walls, but are formed by the courses of the foundations. Plumb walls and angular entrances are very rarely met with.

Cement.-The original builders of the Zimbabwe ruins, as well as those of later ancient periods, can be seen to have shown a peculiar partiality for the employment of cements for all constructive work save that of building the walls, which are all, without exception, of dry masonry. Evidently the ancients, judging by the immense quantity of cementwork throughout the ruins, much of which is still in splendid condition, deliberately avoided the use of cement in the construction of the walls. Probably in this respect, and in the employment of blocks of a certain size, they were but following the methods of building to which they were accustomed before their arrival in this country.

(I) The cement-work of the oldest periods has been pronounced by practical builders to have been made of crushed fragments of decomposed granite mixed with a large proportion of lime, the latter being found in Suku Glen (see Suku Glen) in extensive areas. This cement is exceedingly hard, and has a glaze on the outer surface which, once broken, has caused the internal body of cement to rapidly decompose into yellow soil. Thus on the faces of steps, dadoes, and all perpendicular work, the cement is more intact, while on flat surfaces where rain-water could not be carried away owing to the stopping up of drains the cement floors are in many instances considerably ruined. Tree roots are rarely found 
to have penetrated any cement floor which was in a whole condition, and where a root has so penetrated the cement, the root, acting as a conductor of water, has caused all the cement along the line of root to become decomposed. All the roots of trees which have recently been removed from above cement floors are flat, while some of them assume the shape of the structure that was underneath. In one instance the roots of an immense fig tree, which was thought to be over one hundred years old, had wound round and round a circular cement platform which they had failed to penetrate.

This class of cement has been very extensively used by the older occupiers for $(a)$ flooring, $(b)$ dadoes, $(c)$ covering steps and platforms, $(d)$ construction of steps and platforms made entirely of cement, (e) raised rims for dividing floors into separate catchment areas, so confining rain-water over certain areas to particular drains, $(f)$ foundations of walls, $(g)$ for short, low divisional walls made entirely of cement.

(2) There is another class of granite cement which closely resembles the first-mentioned, and this is found on the higher levels. It is also yellow, but in it occur pieces of granite, and it has a decidedly coarser appearance. This is not so lavishly laid, being only one or two inches thick, whereas the former cement is most frequently found to have a thickness of at least 6 in., that is, in those instances where the structures are not entirely composed of this cement. A great quantity of this cement-work can be seen on the Acropolis or in the Valley of Ruins.

(3) A further class of cement is of a dull reddish colour, containing more soil than granite. Practically it is clay, but so fine and well polished that it deserves the designation of cement. This work had been burnt white, and its material is very strong and far superior to the best clay used by the oldest native occupiers.

(4) A greyish-coloured cement, in which there are large proportions of lime. This is found in ruins. On the summit 


\section{ANCIENT ARCHITECTURE}

of Rusivanga Kopje there are floors and walls made of it. There is difference of opinion between builders and native authorities as to the makers of this cement. It is most certainly superior to any such material made by the natives of to-day. It closely resembles, if it is not identical with, the material used in building the two classes of huts Nos. I and 2 (see Native huts found in ruins). The natives state it is not of any known Makalanga make. It is found in large slabs, as if from the side walls of circular huts, fully $\mathrm{I} 4 \mathrm{ft}$. in diameter, also in bevelled ruins of all sizes. This cement can be seen in some of the ruins, also on Zimbabwe Hill, where the natives state there has been no occupation, excepting, of course, Mogabe's brief residence, for at least five generations. Judging by the high-class quality of Kafir "finds" here, it is quite possible that this cement is that of the mediæval Makalanga.

(5) The other descriptions of daga (clay) vary in quality from fairly good to most inferior. These are mere veld soil, without being mixed with lime, and are seen in portions of distinctly old Kafir huts resembling the types Nos. 2 and 3. It is also to be found in quantities on the Bentberg and on Rusivanga Kopje. In many trenches can be seen three or four layers of this daga one above another, each layer being about one inch thick, and there are layers of ashes between the floors.

Ancients and caves and rock holes.-There are innumerable rock holes, chasms, and large fissures among the cliffs and boulders of the Acropolis Hill, but there is only one - the Balcony Cave-that actually deserves the title of cave, though this name is bestowed upon them all by several writers. Perhaps Balcony Cave approaches nearest to the general conception of what is a cave. But the holes under beetling boulders which constitute these "caves" are as a rule shallow, low, and narrow. 
There are no evidences in any of these holes, so far as they have been examined, that the ancients cut into the rock or quarried to make or improve these holes, the faces of the rock being all natural, and devoid of any traces of their having been worked. Sir John Willoughby makes a similar statement as to the rock never having been cut. It is also noticeable that small spurs of formation rock jutting up through the floors of enclosures have never been cut away. But the ancient builders were very clever in artificially improving the fronts of the rock holes, so as to add extra space to the size of the holes. This was done in at least two instances, though there are traces of its having been done elsewhere. A wall was built at some feet immediately in front of the hole, and this was carried up so high that its summit was connected with the cliff or boulder which rose above and arched outwards in front of the hole. This is seen at South Cave, where a wall was carried up to the over-arching boulder, thus more than doubling the area of the cave (see descriptions of each cave).

There are a series of such rock holes on the north-east side of the hill and on the south of Rock Holes Path. The covered holes between the large boulders look very romantic, and their appearance suggests the probability of there being large caves here, but the appearance is most deceptive. The greatest number of such hollows are to be found at the east end of the Acropolis Hill, and some few of these are worth visiting, but the irregular and rugged contour of that face of the hill makes climbing there a most difficult matter, besides which our labourers have recently killed two tigercats at these holes, and they state that there are more of such animals there.

Some few only of the caves near the main ruins of the Acropolis have had cemented floors, the formation rock being in most instances sufficiently smooth and level to make it unnecessary to lay cement floors. Platform Cave 
has at least three levels of cement flooring one above another.

The purposes for which these caves have been used cannot be determined, for the finds made in them were very meagre and common, most being Makalanga hoes, spearheads, brass wire bangles still containing hair or grass, and fragments of pottery of poor and modern make. The only caves which yielded anything of antique character were Platform and Balcony Caves. In the former were sections of soapstone monoliths and fragments of soapstone bowls. In the latter were about a dozen large slate beams and plain soapstone beams. The soil in this cave has often been panned by visitors, as there has always been an idea that gold dust was once stored here. Almost all the pannings showed faint traces of gold, and one or two rather richly. Theodore Bent, Sir John Willoughby, and also many searchers for relics, have practically cleared the most important of these caves of all finds.

A cave hole under an immense boulder on the south side of the Gold Furnace Enclosure is about I $5 \mathrm{ft}$. square, but one has to crouch low down to move about in it. Here have been found quantities of quartz, copper ore, and ironstone, pieces of beaten copper and copper wire, sections of gold crucibles, and pottery whorls. No industry could have been carried on in this low-roofed area, but gold-, copper-, and iron-smelting were evidently conducted in the adjoining and higher Gold Furnace Enclosure, and this hole or chasm, as Bent calls it, was used for depositing the débris from such furnaces.

Nearly all the rock holes on Zimbabwe Hill had been used for some purposes - up to four years ago by the Makalanga as burial-places, the hill abounding in such graves. Now the local Makalanga are prohibited burying on this hill, and at the same time their kraal was removed from the Acropolis. The bodies were placed in the corners 
of these rock holes and piled over with stones; the pot, assegais, knobkerries-and in one instance a large bark-string hunting-net, $5 \mathrm{ft}$. high and about $30 \mathrm{yds}$. long-which belonged to the deceased, were laid upon the top of the stones.

There are no Bushman paintings in any of these caves, nor on the immense rocks which are strewn all over the hill. Nor does the district round about possess any of these paintings. Almost every kopje within a few miles of Zimbabwe has very recently been carefully examined for walls, relics, caves, and paintings, several of the hills having been within the last few months ascended several times from various points. Natives, farmers, and prospectors state that these are altogether absent from this portion of the Victoria district.

But caves and rock holes are very numerous on some of the kopjes which are within an easy walk of the ruins, and if some of these were cleared out some discoveries might possibly be made. It will be recalled that both the ancient cylinder with rosettes, the wooden platter with the signs of the zodiac, and the notorious pot "Fuko-ya-Nebandge" were all found in caves at some little distance from Zimbabwe. 


\section{CHAPTER IX}

\section{THE ELLIPTICAL TEMPLE}

Main Walls - Plan - Construction-Measurements - Summit-Foundations--Chevron Pattern-Ground Surface of Exterior.

PLAN of main wall.-Though popularly spoken of as the "Circular Temple," 1 the building is of elliptical plan, "a form of temple," says Bent, "found at Marib, the ancient capital of the Sabæan kingdom in Arabia, and at the Castle of Nakab al Hajar, also in that country." The resemblance between the temple at Marib and the Elliptical Temple at Zimbabwe is remarkable, and several scientists of repute, who have considered the plans of both these ruins, emphasise the remarkable resemblance, not only in the plan, but in the forms of worship practised by the ancients, as evidenced also by the relics discovered at both temples. For instance, Professor Müller, of Vienna, the great South Arabian archæologist (Burgen und Schlösser, ii. 20.) compares these two ruins as follows:-

Marib.

Plan, system of curved walls, geometrical building, orientation.

Inscription on Marib is in two rows, and runs round a fourth of the circumference.

Half of elliptical wall, on side of inscription, is well built and well preserved, but opposite side is badly buil and ruined.

\section{Zimbabwe.}

Practically the same.

Two rows of chevron pattern run round a fourth part of the circumference.

The same at Zimbabwe, where the pattern side of the wall is well built. The other portion is rough.

1 Most of the Sabæan temples were round. El Masoudi (940 A,D.). 
Temple was dedicated to the goddess Almaquah-the star Venus, which is called in the Himyaritic tongue Ialmaquah, or Almaq = illuminating.
Highly probable that Zimbabwe was a Sabæan Almaquah temple, as it is orientated and geometrically built for astronomical purposes, as in all cases of such buildings used for the worship of Almaquah. Sacred birds found at Zimbabwe are said to represent Venus the "Morning Star." 1

Herr Brugsch believes the images of the birds found at Zimbabwe emphasised a Sabæan occupation, while M. Naville is especially of opinion that there exists a strong connection between Venus, the star of the Sabæans, and the goddess worshipped at Zimbabwe. The evidences pointing to the close connection of the South Arabian temples and Zimbabwe are almost inexhaustible. On this point Bent and Schlichter are at one with each other (see Petermann's Mitteilungen I 892 ; also The Gold of Ophir by Professor A. H. Keane; and M. Arnaud's plan of the temple at Marib).

Professor Müller also states that the elliptically formed wall appears to have been always used in the temple buildings of ancient Arabia, and states that at Sirwah the Almaquah temple is built in an oval form. In these old temples, he says, sacred inscriptions to the deities were set up on stylæ (stone beams). At Zimbabwe some scores of carved soapstone beams have been discovered in the three temples, also ten birds perched on tall soapstone beams and three other birds detached from their beams, also four miniature birds on pedestals carved out of soapstone.

The Elliptical Temple at Zimbabwe is a much larger building than that at Marib, having a circumference of about $833 \mathrm{ft}$. as against the $300 \mathrm{ft}$. of the Marib temple.

On entering the building it is at once seen that the most massive and excellently constructed portions of the main

1 All the birds found at Zimbabwe occupied eastward positions. 
IAIN or NORTH

INTRANCE

Doorway

हों।
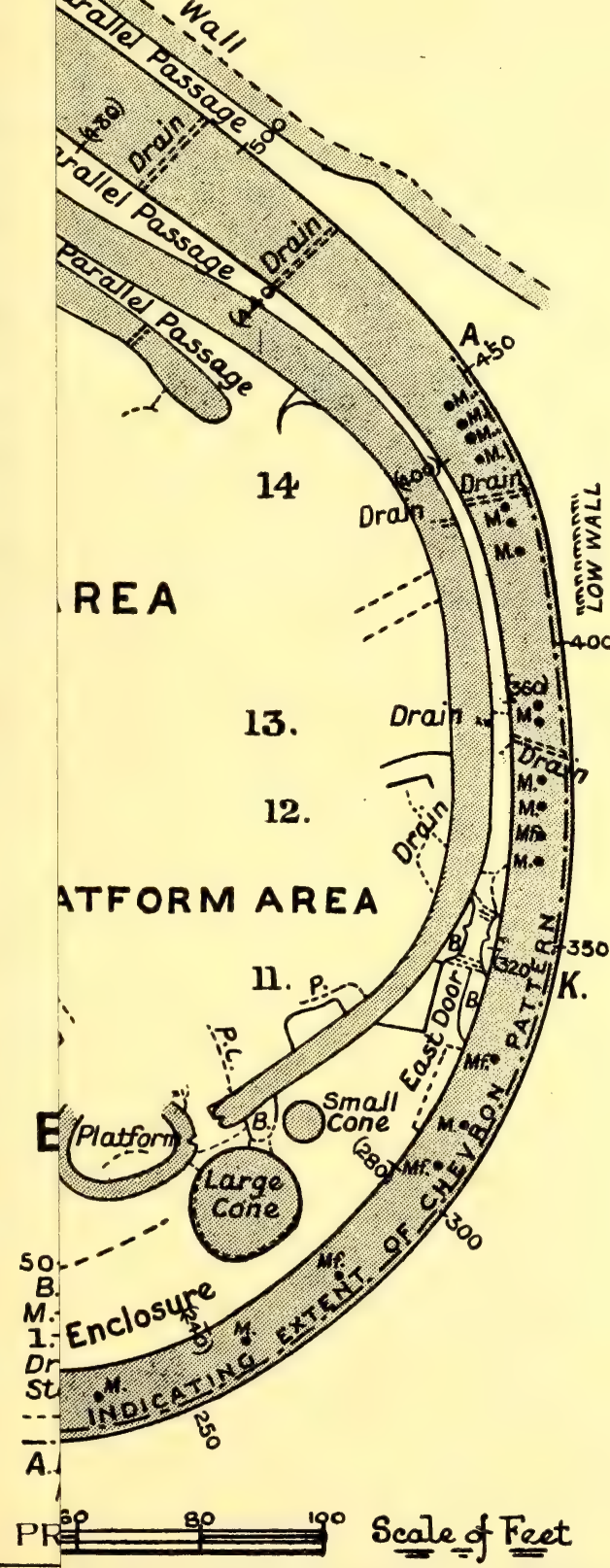

Methuen \& $\mathrm{CO}$. 



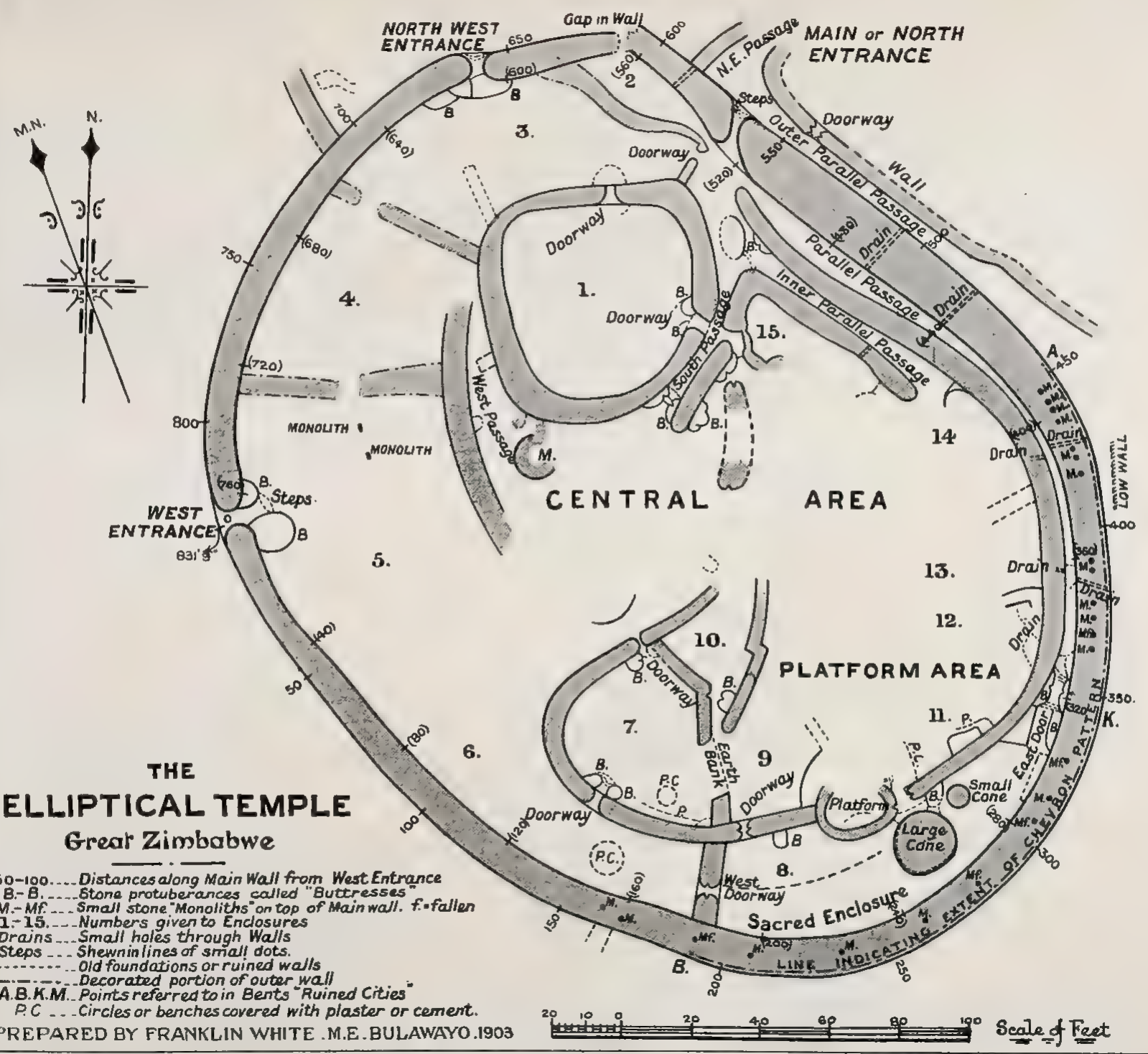

Methuen \& $\mathrm{Co}$ 

wall extend from slightly north of the North Entrance to the east and south and south-west, and that the other portions, particularly the north-west and west, are slighter, and though showing fairly good workmanship, it is not nearly so well built as the other portion of the wall, the average width of the summit of the poor wall being barely a third of the average width of the better-built portion. The general line of the summit is also fairly level, but it averages some $5 \mathrm{ft}$. to $8 \mathrm{ft}$. less in height than that of the northern and eastern walls. The distinct character of the two portions of the main wall is very plainly noticeable on viewing the temple from the summit of the Acropolis Hill.

But this temple does not stand alone in showing its main wall massive and exceptionally well built at one point of its circumference and slighter built on the other part. This feature is common to many ruins in Rhodesia, excepting, of course, ruins of forts and those ruins built upon the angular plan and terraced. Bent was fully aware of this feature, and cites instances of its occurrence. Mr. Swan does the same, and so does Schlichter. At some time or another before the north-west and west wall was built that portion of the original wall had become dilapidated, and the temple had become " half-moon," "section of a circle," or "crescent" shaped, these being the terms applied by all writers, without exception, to such of the circular ruins in the First Period Ruins' Area, ${ }^{1}$ where portions of the main wall had fallen down. The published plans of ruins demonstrate this fact. Probably Zimbabwe will again become a "section of a circle," for it stands to reason that the weaker wall will be the first portion to disappear.

The massive and well-built portions of the ruins, built upon a system of curves, almost always bear the mural pattern of the oldest types, while the slighter portions are without

${ }^{1}$ For Areas of varying styles of Ancient Architecture see Ancient Ruins, p. I64, section (a). 
pattern. It is so at Marib, it is so at Zimbabwe, and it is so in some score of ruins built upon the same principles, as shown in the Elliptical Temple. This has been found to be so invariable a rule that on sighting a building of this class of ruin even at some distance one can almost fix the position of the pattern, that is, if the wall is not so reduced in height that the decoration, if originally any, has not disappeared. Assuming no principle of orientation to attach to such ruins, there yet remains something to be done in explaining the directions of the massive curved and decorated walls of the circular ruins, for the existence of so many scores of parallelisms can hardly be explained away as being but so many coincidences.

It has now (June, 1903) for the first time been shown by ocular demonstration that the slighter wall, though ancient, is a reconstruction of a still more ancient wall which curved outwards more to the north and north-west. Recently some thirty tons of granite blocks which lay in the gap on either side of it were removed, and the foundations at this spot uncovered, showing the meeting in a mis-joint at an oblique angle of two distinct walls, the foundations of the massive north wall being $9 \mathrm{ft}$. Io in. wide, and that of the later wall $6 \mathrm{ft}$. wide, while the class of building in the two walls is obviously distinct. The face of the end of the north wall was extended further outwards towards N.W. $40 \mathrm{ft}$., and the line of its foundation, according to its curve, points in that direction, where, it is believed, the old extended foundation has been come upon at $36 \mathrm{ft}$. outside the later wall. The slighter wall approaches the massive wall from W. 80. The bases of the foundations are practically on the same level.

Though the later wall is not so well constructed as the older wall, it must not be taken as poorly built. (See "Construction of main wall," later.)

The wonderful feature is that no joint in the wall has so far been discovered in its south-west portion. Practical builders 
who have examined the wall on this side for such a joint are perplexed at not being able to discover it, and some consider, from certain circumstances noticeable, that it must have been at the West Entrances where this later wall was commenced, in which case no such joint would in all probability be found.

Construction.-The construction of the main wall from the north to the east, and round to the south and south-west, is admittedly by far the finest specimen of ancient constructive work yet found in Rhodesia; it has consequently been made the standard by which the best-known writers and greatest authorities judge of the quality of the work shown in other walls in the country. Certainly two large and important ruins in the Lower Sabi Valley, which are much larger in area but with lower walls than Zimbabwe, closely rival the Great Zimbabwe in construction and boldness of design. But with regard to the more massive and highest portion of the main wall every practical builder who visits Zimbabwe is amazed at the equal distribution of the joints, the conscientious bonding of the outer courses, the good quality of stone selected, the careful dressing and the regularity of the sizes of the blocks, the neat packing throughout the whole width of the wall, and the tiling of the summits of the wall with "throughs." The filling-in of the wall has been most conscientiously executed, and is seen to have been done course by course with the faces of the wall, as the courses throughout are pronounced to correspond with the outer courses of the wall on either side, and some builders have positively stated that some sort of a levelling instrument must have been used. "Straight joints" for more than two or three courses are absent, and these are rare, "false courses" are also rare, and there is little seen of chips levelling up the corners of the blocks.

The marvellous symmetry of the batter-back of the dry masonry, especially in the boldly conceived and most ex- 
cellently constructed sweep of the wall on its inner face from north to north-east and south-west, secures the admiration of every visitor, and forms one of the chief features by which the Great Zimbabwe stamps itself on one's memory. The scrupulously careful workmanship displayed here, and particularly in the courses near the Chevron Pattern and on the outer face of the north-east portion of the wall, show undoubtedly the most superior of any ancient building yet discovered in Rhodesia, if not also of the important ruins lying at some distance, to the south-east, of which only sketchplans and a few photographs are yet to hand. The massive solidity and excellent construction, together with its batter (see Architecture, section "Battering of Walls"), which this wall displays, have, no doubt, secured its wonderful preservation in spite of earthquake, effects of tree and creeper growth, and the ravages of some millenniums of time.

The construction demonstrates the fact that the ancients in their own home in the north were thoroughly well-practised in the building with either stone blocks or bricks. Moreover, as suggested by Bent and Schlichter, the extensive use of granite cement in making floors both inside and outside the ruins at Zimbabwe proves that it was by design that the ancients adopted the system of building with dry masonry.

Concerning the construction of the north-west and west portions of the main wall there has been much controversy, Bent and Schlichter being emphatic in stating that not only was it most inferior to that of the other portions of the main wall, but that it was obviously of later construction on contracted lines, but still ancient. These two archæologists could have arrived at this conclusion only by the measurement of the wall and by its quality of workmanship. Sir John Willoughby, on the other hand, contended that it is built as well as any other portion of the main wall. It is certainly not poor building that renders it less easy to climb along its summit, the difficulty being the number of loose stones which line the 


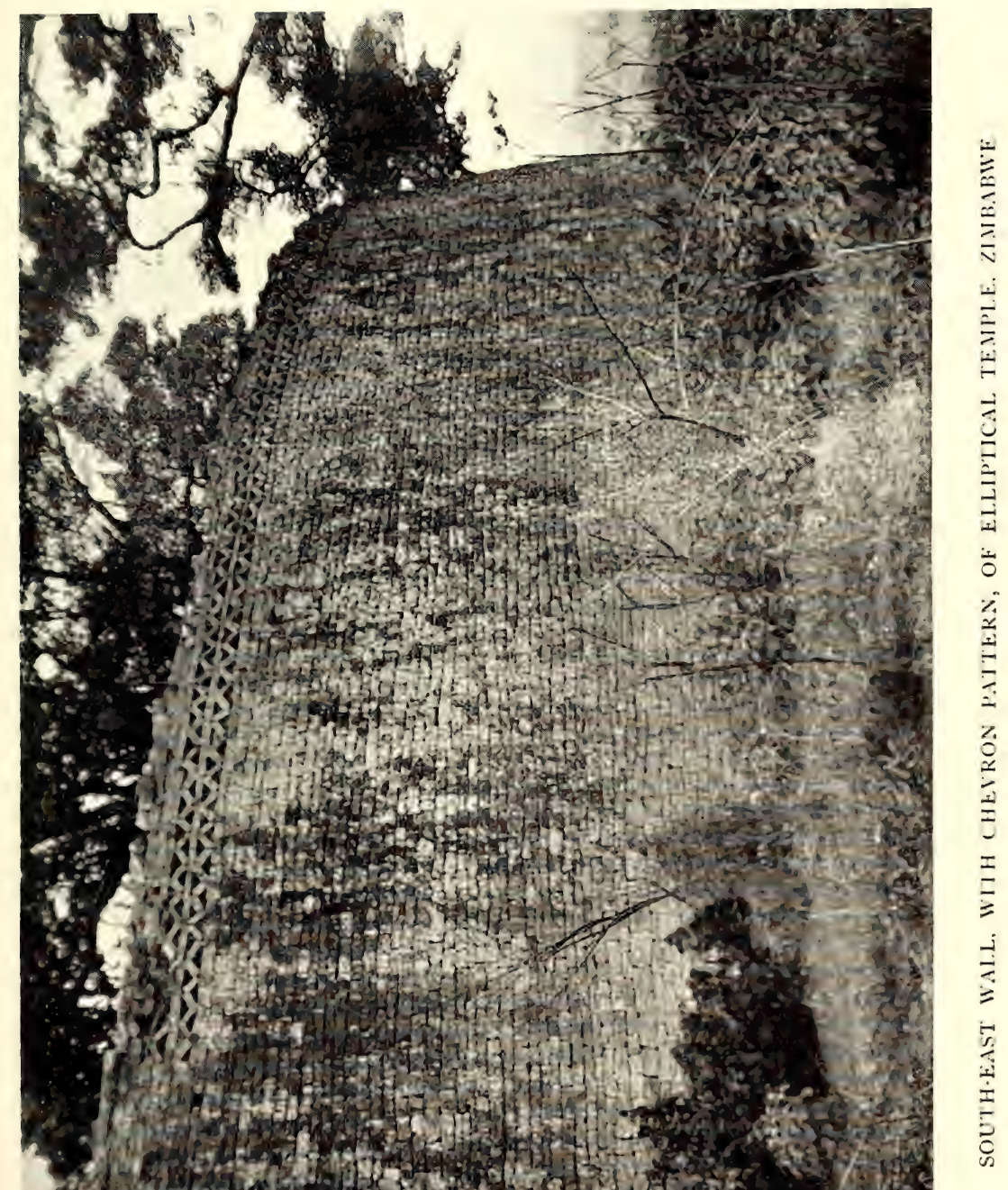



top owing to the summit having been threshed by branches of large trees.

This wall-now recently shown to be a reconstruction in a later ancient period ${ }^{1}$-is in every point better built than many walls on the Acropolis, and is superior in workmanship to many of the divisional walls of the Elliptical Temple. The outer face is fairly well constructed.

Measurements of main wall.-The circumference of the outer face of the main wall taken at the level of the threshold of the entrances measures about $83 \mathrm{I} \mathrm{ft}$. As the foundations throughout the circumference are, as is shown later, some $3 \mathrm{ft}$. to $5 \mathrm{ft}$. below this level, and as the usual Zimbabwe batter-back prevails, the circumference of the foundations of this building may safely be estimated at a further $40 \mathrm{ft}$., which would make a total circumference of the base of the temple some $873 \mathrm{ft}$.

The circumference of the inside face of the entire main wall measured at a corresponding level is about $776 \mathrm{ft}$. 6 in., the foundations, as shown later, being from $3 \mathrm{ft}$. to $5 \mathrm{ft}$. below the level at which this measurement was taken.

Granite slabs with painted figures now mark the distances both outside and inside round the main wall, commencing in either case at the south side of the West Entrance and going south. The distances on the outside are marked at every $50 \mathrm{ft}$., and those on the inside at every $20 \mathrm{ft}$. A small black spot is painted on the wall just above each slab to denote the exact spot in each length measured.

In this description of the Elliptical Temple all measurements in angular brackets are exterior measurements of the main wall only, and those in rounded brackets are those of interior measurements of the main wall, all commencing at the south side of the West Entrance and going south. For instance, "The North-West Entrance is situated between the

1 See Preface, West Wall Controversy. 
following points in the main wall- $[656 \mathrm{ft}$.] and [66o ft.] and ( $606 \mathrm{ft} .6 \mathrm{in}$.$) and (6 \mathrm{I} \mathrm{ft}$.$) ," or "A large granite beam lies at$ the base of the main wall at (338 ft.)."

\section{MEASUREMENTS OF EXTERIOR OF MAIN WALL COMMENCING AT SOUTH SIDE OF THE WEST ENTRANCE AND GOING SOUTH}

\begin{tabular}{|c|c|c|c|c|c|}
\hline $\begin{array}{l}\text { Position } \\
\text { of wall. }\end{array}$ & $\begin{array}{c}\text { Point of } \\
\text { compass } \\
\text { faced. } \\
\text { W. }\end{array}$ & $\begin{array}{c}\text { Height above } \\
\text { cleared } \\
\text { surface. } \\
7 \mathrm{ft} .6 \text { in. }\end{array}$ & $\begin{array}{l}\text { Height above } \\
\text { bottom of } \\
\text { foundation. } \\
\text { I I ft. }\end{array}$ & $\begin{array}{c}\text { Width of } \\
\text { present } \\
\text { summit. } \\
6 \mathrm{ft} .6 \text { in. }\end{array}$ & $\begin{array}{c}\text { Batter-back } \\
\text { of face of } \\
\text { wall. } \\
8 \text { in. }\end{array}$ \\
\hline \multicolumn{6}{|c|}{ Between [o ft.] and [ $\mathrm{Io} \mathrm{ft}$.] summit of wall rises from $7 \mathrm{ft}$. to $22 \mathrm{ft}$. } \\
\hline [ $\mathrm{Ioft}]$. & - & $22 \mathrm{ft}$. & $23 \mathrm{ft}$. Io in. & 4 ft. 2 in. & $2 \mathrm{ft}$. \\
\hline [25 ft.] & - & $21 \mathrm{ft} .6 \mathrm{in.}$ & $23 \mathrm{ft} .6$ in. & $5 \mathrm{ft} .6$ in. & $2 \mathrm{ft}$ \\
\hline [50 ft. $]$ & 一 & $22 \mathrm{ft}$. & $24 \mathrm{ft}$. & $6 \mathrm{ft} .6 \mathrm{in}$. & $2 \mathrm{ft} .6 \mathrm{in}$. \\
\hline
\end{tabular}

Between [98 ft.] and [ $104 \mathrm{ft}$.$] are traces of a wall of this width$ running towards S.W.

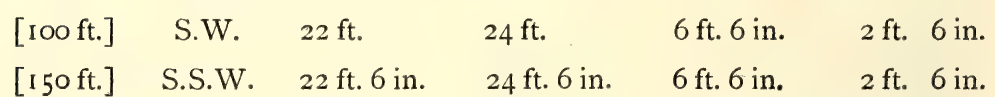
Between [I6I ft.] and [I66 ft. $6 \mathrm{in}$.] are traces only of wall of this width protruding from main wall towards S.W.

Chevron Pattern commences at [ $189 \mathrm{ft}$. ] and extends to [455 ft. $6 \mathrm{in}$.].

[200 ft.] S. $22 \mathrm{ft} .8 \mathrm{in} .25 \mathrm{ft} .2 \mathrm{in.} \quad 10 \mathrm{ft} .2 \mathrm{in.} \quad \mathrm{ft}$. $10 \mathrm{in}$.

[250 ft.] S.E. $25 \mathrm{ft} . \quad 26 \mathrm{ft} .6 \mathrm{in} . \quad 8 \mathrm{ft} .2 \mathrm{in.} 2 \mathrm{ft} .6 \mathrm{in}$.

[300 ft.] S.E. $29 \mathrm{ft} . \quad 30 \mathrm{ft} .6 \mathrm{in} . \quad 8 \mathrm{ft} .6 \mathrm{in} . \quad \mathrm{Ift} .8 \mathrm{in}$.

[350 ft.] E. $29 \mathrm{ft} . \quad 3 \mathrm{Ift} .6 \mathrm{in} . \quad 9 \mathrm{ft} .6 \mathrm{in.} \quad \mathrm{Ift} .4 \mathrm{in}$.

At $[380 \mathrm{ft}$. $]$ outer end of drain-hole through main wall.

[400 ft.] E. $30 \mathrm{ft} . \quad 3 \mathrm{Ift} .9 \mathrm{in} . \quad 7 \mathrm{ft} .4 \mathrm{in} . \quad 2 \mathrm{ft} .6 \mathrm{in}$. At [425 ft. 9 in.] outer end of drain-hole through main wall.

[450 ft.] E.N.E. $32 \mathrm{ft} . \quad 34 \mathrm{ft} . \quad 9 \mathrm{ft} .6 \mathrm{in} . \quad 3 \mathrm{ft}$.

From [45o ft. $]$ to $[565 \mathrm{ft}$.] is Outer Parallel Passage.

Chevron Pattern ends at $[455 \mathrm{ft} .6 \mathrm{in}$. $]$.

At $[482 \mathrm{ft}$. $]$ outer end of drain-hole through main wall.

[500 ft.] N.E. $33 \mathrm{ft} . \quad 35 \mathrm{ft} .6 \mathrm{in} . \quad 12 \mathrm{ft} .2 \mathrm{in.} \quad 3 \mathrm{ft} .6 \mathrm{in}$. At [5 10 ft. $6 \mathrm{in}$.$] outer end of drain-hole through main wall.$

At [530 ft.] line of summit falls to $28 \mathrm{ft}$.

[550 ft.] N.E. I9ft. $2 \mathrm{Ift} . \quad \mathrm{I} 3 \mathrm{ft} .4 \mathrm{in.} \quad \mathrm{Ift} .4 \mathrm{in}$. Summit of wall very considerably dilapidated.

At [560 ft.] outer end of drain-hole through main wall. At [57 I ft. 6 in.] to [576 ft. 6 in.] steps of North Entrance. 


\section{THE ELLIPTICAL TEMPLE}

\begin{tabular}{|c|c|c|c|c|c|}
\hline $\begin{array}{l}\text { Position } \\
\text { of wall. }\end{array}$ & $\begin{array}{l}\text { Point of } \\
\text { compass } \\
\text { faced. }\end{array}$ & $\begin{array}{l}\text { Height above } \\
\text { cleared } \\
\text { surface. }\end{array}$ & $\begin{array}{c}\text { Height above } \\
\text { bottom of } \\
\text { foundation. }\end{array}$ & $\begin{array}{l}\text { Width of } \\
\text { present } \\
\text { summit. }\end{array}$ & $\begin{array}{l}\text { Batter-back } \\
\text { of face of } \\
\text { wall. }\end{array}$ \\
\hline $75 \mathrm{ft}$. & N.E. & I I ft. & (not examined) & I $4 \mathrm{ft}$. & $2 \mathrm{ft} .6$ in. \\
\hline
\end{tabular}

West side of North Entrance, I I ft. high, rises to I $7 \mathrm{ft}$. at [580 ft. ].

Between [586 ft.] to [590 ft.] wall this width, forming north-west side of North-East Passage, protrudes from main wall towards N.E.

From [6ro ft.] to [620 ft.] is gap in main wall and mis-joint of earlier and later walls.

[625 ft.] N. I $\quad$ ft. 6 in. I9 ft. $\quad 5 \mathrm{ft} . \quad$ I ft.

Original height of wall reduced to $16 \mathrm{ft} .6 \mathrm{in}$. on west side of gap.

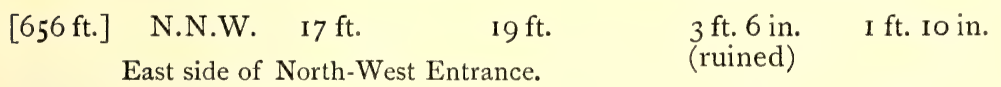

[660 ft.] N.N.W. I7 ft. I9 ft. $5 \mathrm{ft} .6 \mathrm{in} . \quad$ I ft. 10 in.

West side of North-West Entrance.

[675 ft.] N.W. $17 \mathrm{ft} . \quad 18 \mathrm{ft} .6$ in. $5 \mathrm{ft} .2 \mathrm{in.} \quad 1 \mathrm{ft} . \mathrm{so}$ in.

Face of wall bulges outwards above foundations.

[700 ft.] N.W. I $8 \mathrm{ft} . \quad$ I9 ft. Io in. $4 \mathrm{ft} .6$ in. I ft. 6 in.

For several feet on either side of [700 ft.] summit of wall is considerably depressed by tree boughs hitting it.

A wall connecting No. I Ruin with Elliptical Temple protrudes from main wall between $[705 \mathrm{ft}$.] and [7 $10 \mathrm{ft}$.$] .$

[750 ft.] W.N.W. $2 \mathrm{Ift}$. $23 \mathrm{ft} . \quad 4 \mathrm{ft} .8 \mathrm{in} .2 \mathrm{ft} .6 \mathrm{in}$.

[80o ft.] W.N.W. $20 \mathrm{ft} .6 \mathrm{in} . \quad 22 \mathrm{ft} .4 \mathrm{in} . \quad 4 \mathrm{ft}$. Io in. $3 \mathrm{ft}$.

From [8I4 ft.] to $[829 \mathrm{ft}$.] the line of summit breaks downwards abruptly from $20 \mathrm{ft}$. to $8 \mathrm{ft}$. in height.

[827 ft. 9 in.] W. $8 \mathrm{ft}$. (not examined) $6 \mathrm{ft}$. Io in.

This is the north side of West Entrance.

[83I ft. 9in.] This is the south side of the West Entrance, where the first measurement started.

\section{MEASUREMENTS OF INTERIOR FACE OF MAIN WALL COMMENCING AT SOUTH SIDE OF THE WEST ENTRANCE AND GOING SOUTH}

$\begin{array}{ccccc}\begin{array}{c}\text { Position } \\ \text { of wall. }\end{array} & \begin{array}{c}\text { Side of } \\ \text { temple. }\end{array} & \begin{array}{c}\text { Height above } \\ \text { cleared surface. }\end{array} & \begin{array}{c}\text { Batter-back of } \\ \text { face of wall. }\end{array} & \begin{array}{c}\text { Point in interior } \\ \text { of temple. }\end{array} \\ \text { (o ft.) } & \text { W.N.W. } & 7 \mathrm{ft} .6 \mathrm{in} . & 8 \mathrm{in} . & \text { No. } 5 \text { Enclosure }\end{array}$

Between (o ft.) and (Io ft.) is a large rounded buttress projecting into the temple. (See description of West Entrance.)

Between (o ft.) and (Io ft.) summit rises sharply from $7 \mathrm{ft} .6$ in. to I $8 \mathrm{ft}$. 6 in., measurement from present surface of interior soil. 


\begin{tabular}{|c|c|c|c|c|}
\hline $\begin{array}{l}\text { Position } \\
\text { of wall. }\end{array}$ & $\begin{array}{l}\text { Side of } \\
\text { temple. }\end{array}$ & $\begin{array}{l}\text { Height above } \\
\text { cleared surface. }\end{array}$ & $\begin{array}{l}\text { Batter-back of } \\
\text { face of wall. }\end{array}$ & $\begin{array}{l}\text { Point in interior } \\
\text { of temple. }\end{array}$ \\
\hline ( $10 \mathrm{ft}$. ) & W.N.W. & I $8 \mathrm{ft} .6$ in. & $2 \mathrm{ft}$. & No. 5 Enclosure \\
\hline$(20 \mathrm{ft})$. & W.N.W. & $2 \mathrm{It}$. & I ft. Io in. & \\
\hline
\end{tabular}

(40 ft.) W.N.W. $2 \mathrm{I} \mathrm{ft} . \quad$ I ft. 8 in. No. 5 Enclosure

Measured from bottom of trench showing an old cement floor now decomposed.

(6o ft.) W. $2 \mathrm{Ift} .4$ in. I ft. 6 in. No. 5 Enclosure

Measured from bottom of trench showing an old cement floor now decomposed.

(8o ft.) W. $2 \mathrm{I}$ ft. 6 in. I ft. 2 in. No. 5 Enclosure

Measured from bottom of trench showing an old cement floor now decomposed.

( $100 \mathrm{ft}$ ) W. $\quad \mathrm{I} 8 \mathrm{ft} .6 \mathrm{in} . \quad \mathrm{Ift} .9 \mathrm{in.} \quad$ No. 6 Enclosure Measured from top of débris on summit of low divisional wall.

( $20 \mathrm{ft}$ ) S.W. $20 \mathrm{ft}$. Io in. $2 \mathrm{ft}$. I in. No. 6 Enclosure

Measured from red clay floor, believed to be of Makalanga construction.

At ( $134 \mathrm{ft}$.) to ( $138 \mathrm{ft}$.) are traces only of a divisional wall.

( $140 \mathrm{ft}$ ) S.W. $2 \mathrm{Ift} .8 \mathrm{in} . \quad 2 \mathrm{ft} .2 \mathrm{in.} \quad$ No. 6 Enclosure

Measured from a yellow granite cement floor.

(16oft.) S.W. $22 \mathrm{ft} .4$ in. $2 \mathrm{ft} .2 \mathrm{in.} \quad$ No. 6 Enclosure

Measured from a yellow granite cement floor.

( $179 \mathrm{ft} .3$ in.)

Angle of walls.

( $180 \mathrm{ft}$ ) S.W. $2 \mathrm{I} \mathrm{ft} .6 \mathrm{in} . \quad 2 \mathrm{ft} . \quad$ No. 6 Enclosure

Measured from a yellow granite cement floor.

At (I8o ft.) step down of foundation of $5 \mathrm{ft}$.

(200 ft.) S.S.W. $\quad$ I 7 ft. 6 in. I ft. 2 in. No. 8 Enclosure

Measured from summit of old excavated débris, Sacred Enclosure

$5 \mathrm{ft}$. high (since removed). (west)

(220 ft.) S.S.W. $22 \mathrm{ft} . \quad$ I ft. 6 in. No. 8 Enclosure

Measured from summit of old excavated débris, Sacred Enclosure $5 \mathrm{ft}$. high.

(west)

(240 ft.) S. $\quad 23 \mathrm{ft} .6 \mathrm{in} . \quad 3 \mathrm{ft} \quad$ No. 8 Enclosure

Measured from summit of old excavated débris, Sacred Enclosure $5 \mathrm{ft}$. high.

(west)

The large Conical Tower stands between $(246 \mathrm{ft}$.)

to $(264 \mathrm{ft}$.). 


\section{THE ELLIPTICAL TEMPLE}

Position Side of Height above Batter-back of of wall. temple. cleared surface. face of wall.

(26o ft.) S. $26 \mathrm{ft} .6 \mathrm{in} . \quad 2 \mathrm{ft}$. 10 in.

Measured from yellow granite cement floor.

(28o ft.)

S. $\quad 26 \mathrm{ft} .6$ in.

$2 \mathrm{ft} .4$ in.

Measured from yellow granite cement floor.

The roughly built buttress at $(286 \mathrm{ft}$. $)$ to $(303 \mathrm{ft}$. $)$ is not ancient.

(300 ft.)

S. $\quad 28 \mathrm{ft}$.

$2 \mathrm{ft} .6$ in.

Measured from yellow cement floor.

There are doubts as to the antiquity of buttress at $(306 \mathrm{ft}$.$) to (319 \mathrm{ft}$.).

(320 ft.)
S.S.E.
$29 \mathrm{ft}$.
$2 \mathrm{ft} .4$ in.

Measured from yellow granite cement floor.

Granite monolith (conjected) fallen from wall at (340 ft.).

Drain-hole through wall at $\left(35^{2} \mathrm{ft}\right.$.).

(340 ft.) S.S.E. $\quad 28 \mathrm{ft}$. Io in.

$2 \mathrm{ft} .2$ in.

Measured from cement floor.

At ( $35^{2} \mathrm{ft}$.) is a drain-hole.

(36o ft.)

S.S.E. $\quad 30 \mathrm{ft} .6 \mathrm{in}$.

$2 \mathrm{ft} .2 \mathrm{in}$

Parallel Passage

Measured from cement floor.

(380 ft.)

S.E. $\quad 30 \mathrm{ft} .4 \mathrm{in}$.

$3 \mathrm{ft}$.

Parallel Passage

Measured from cement floor.

Drain-hole at (39r ft. 6 in.).

(400 ft.)

S.E. $\quad 29 \mathrm{ft}$.

3 ft. 2 in.

Parallel Passage

Measured from cement floor.

(420 ft.) E.S.E. $30 \mathrm{ft} .4 \mathrm{in.}$

Measured from cement floor.

(440 ft.) E.S.E. $30 \mathrm{ft} .6 \mathrm{in.}$

Measured from cement floor.

Drain-hole at ( $442 \mathrm{ft}$.).

(46o ft.)

E. $\quad 3 \mathrm{Ift}$.

Measured from soil surface.

Drain-hole at (47 I ft.).

(48o ft.)

E. $\quad 3 \mathrm{Ift}$.

Measured from soil surface.

(500 ft.) N.E. $27 \mathrm{ft}$.

3 ft. 2 in. Parallel Passage

$4 \mathrm{ft}$.

Parallel Passage

Sacred Enclosure

(east). At West

Entrance to Par-

allel Passage.

Parallel Passage

No. 8 Enclosure

(east)

No. 8 Enclosure

No. 8 Enclosure

Sacred Enclosure (east)

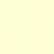

\section{Sacred Enclosure} (east)

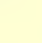




$\begin{array}{ccccc}\begin{array}{c}\text { Position } \\ \text { of wall. }\end{array} & \begin{array}{c}\text { Side of } \\ \text { temple. }\end{array} & \begin{array}{c}\text { Height above } \\ \text { cleared surface. }\end{array} & \begin{array}{c}\text { Batter-back of } \\ \text { face of wall. }\end{array} & \begin{array}{c}\text { Point in interior } \\ \text { of temple. }\end{array} \\ (520 \mathrm{ft} .) & \text { N.E. } & \text { I } 3 \mathrm{ft} .6 \mathrm{in} . & \text { I } \mathrm{ft} .6 \mathrm{in} . & \text { Parallel Passage }\end{array}$

Between $(520 \mathrm{ft}$.) and $(530 \mathrm{ft}$.) is the North Entrance. Wall on east side $6 \mathrm{ft}$. high, on west side $6 \mathrm{ft}$. $6 \mathrm{in}$. high, but on each side rises sharply within a few feet of the entrance.

From ( $536 \mathrm{ft}$.) to $(544 \mathrm{ft}$.) are remains of small banquette below summit, and at $6 \mathrm{ft}$. above ground.

(540 ft.) N.N.E. $18 \mathrm{ft} . \quad$ I ft. 8 in. No. 2 Enclosure

Drain-hole at $(549 \mathrm{ft}$.).

( $560 \mathrm{ft}$ ) N.N.E. I $2 \mathrm{ft}$. $2 \mathrm{ft}$. No. 2 Enclosure

Centre of line of summit is $3 \mathrm{ft}$. higher than reduced inside edge.

Between ( $566 \mathrm{ft}$.) and $(570 \mathrm{ft}$.) is the mis-joint in earlier and later walls.

( $580 \mathrm{ft}$.) N. $\quad 3 \mathrm{ft}$.

No. 2 Eñclosure

At $(580 \mathrm{ft}$.) the wall on west side of gap rises abruptly.

(6oo ft.) N. I $8 \mathrm{ft}$. I ft. io in. 'No. 3 Enclosure

Measured from an old cement floor.

Between $(606 \mathrm{ft} .6 \mathrm{in}$.$) and (6 \mathrm{I} \mathrm{ft.} 6 \mathrm{in}$.$) is the North-West$ Entrance.

(620 ft.) N.W. $6 \mathrm{ft}$. $\quad$ io in. No. 3 Enclosure

At $(6 \mathrm{I} 4 \mathrm{ft}$.) this wall rises perpendicularly to $16 \mathrm{ft}$.

(640 ft.) N.N.W. I6 ft. 6 in. I ft. 6 in. No. 3 Enclosure

Measured from granite cement floor.

(66o ft.) N.N.W. $19 \mathrm{ft} .6$ in. I ft. 4 in. No. 3 Enclosure

Measured from granite cement floor.

Depression on summit caused by a tree.

(680 ft.) N.N.W. $20 \mathrm{ft} .6$ in. I ft. 2 in. No. 4 Enclosure

Measured from granite cement floor.

(700 ft.) N.N.W. $20 \mathrm{ft} .6$ in. $2 \mathrm{ft} . \quad$ No. 4 Enclosure

Measured from granite cement floor.

( $720 \mathrm{ft}$ ) $\quad$ N.W. I $8 \mathrm{ft} .6$ in. I ft. 4 in. No. 4 Enclosure

Measured from granite cement floor.

Depression on summit caused by a tree.

(740 ft.) N.W. $\quad$ I $9 \mathrm{ft}$. $\quad 2 \mathrm{ft}$. I in. Wall separating

Measured from base of divisional wall. Nos. 4 and 5

Enclosures

(750 ft.) N.W. I $8 \mathrm{ft}$. Io in. I ft. Io in. No. 5 Enclosure

Measured from surface of soil.

Near $(54 \mathrm{ft}$.) summit of wall drops to $9 \mathrm{ft}$. at north side of West Entrance.

(763 ft. 6 in.) W.N.W. $7 \mathrm{ft}$ Io in. No. 5 Enclosure Opening of West Entrance between $(763 \mathrm{ft}$.) and (766 ft.).

(776 ft. 6 in.) This is the south side of West Entrance, where first measurement started. 


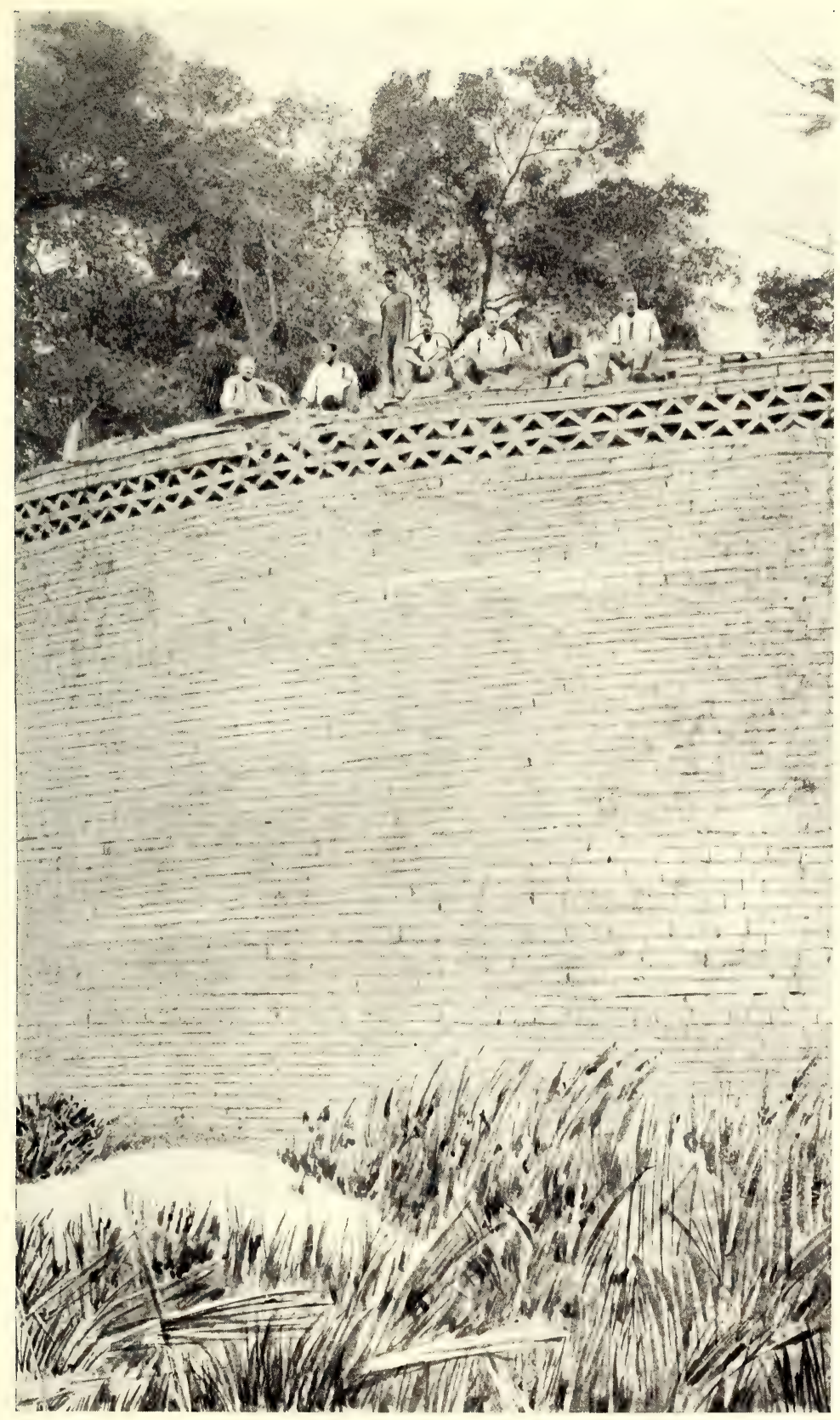

CHEVRON PATTERN ON EAST WALL, ELLIPTICAL TEMPLE 

Summit of main wall.-For some fairly extensive lengths along the summit of the more massive portion of the main wall the blocks and stones are higher on the centre of the floor of the summit than at top outer edges on either side, from which edges the measurements of the heights above the exterior and interior surfaces of the ground were taken. Branches of trees beating in high winds upon the summit, the weight of heavy festoons of creepers hanging from the summit, and the growth of monkey-ropes and wild vines in the joints of the dry masonry have destroyed some of the upper courses on either side of the wall. Therefore to the heights stated in the foregoing tables should be added at least $\mathrm{I} \mathrm{ft}$. or $2 \mathrm{ft}$., this being a fair average height of the whaleback ridge along portions of the summit of the wall.

An interesting question arises: What was the original height of the massive portion of the wall? There are some evidences that the original height could not have been more than six courses above the chevron pattern which runs on a true level on the upper and outer face of the wall between [ I $89 \mathrm{ft}$.] and [455 ft.]. The greatest number of courses now remaining over this pattern is five, but these are only found at two points and for the length of a few blocks. At most points above the pattern there are no upper courses remaining; at other points one or two courses are perfect for some distance; the most frequent are three courses; while at several points there are four courses. To the heights given in the tables can safely be added I ft. to $2 \mathrm{ft}$. Were the obviously missing courses to be restored, the raised ridge along the centre of parts of the summit would be cleared, for these ridges of stones are formed of blocks once carefully packed, all on their flat sides, between side walls, and are similar to the existing internal portions of other well-built walls at Zimbabwe.

Adding this further height of from I ft. to $2 \mathrm{ft}$. to the tabulated heights, we can carry the investigation much further. The 
upper faces of the blocks of the fourth and fifth courses above the pattern are too free from decomposition, weather-stain, and lichen to have formed the topmost courses; in fact, their upper surfaces are decidedly fresh, as if the courses above them had not long disappeared, and when it is recollected that experience shows that the exposed top surfaces of blocks are found to take on signs of decomposition and of exposure to weather, and also to become covered with lichen quicker than the side faces of blocks in the body of the wall, and that the upper courses would have given some evidences of long exposure, which they do not, we may be certain that the wall was carried a further course, or possibly two courses of the wall higher than the fifth course above the pattern. Therefore at many points along the highest portions of the wall, as shown in the tables, $2 \mathrm{ft}$. $6 \mathrm{in}$. may be added to the tabulated heights, and this would include the height of the six courses above the pattern throughout its whole length.

Whether the original summit was higher than these six courses is a matter of conjecture. Possibly the wall was two or three courses higher than the six courses. Here, as elsewhere in the first period ruins in Rhodesia, the best-built portion of the edifice is that which bears the decorative designs. This appears to be an invariable rule in such older ruins. But at this temple the whole wall, and especially the courses immediately above and below the pattern, are the best-built portions of the most superior wall of the building, the courses being far truer. Moreover, a good quality of stone is employed, giving the impression that it was specially selected for the purpose, so much so that their back parts are as well squared as their front faces. It is most obvious, as practical builders claim, that the pattern itself and its enclosing courses show the best workmanship on the part of the ancients, and this notwithstanding that this wall is admitted by all to stand pre-eminent among excellently constructed walls to be found anywhere in Rhodesia. 


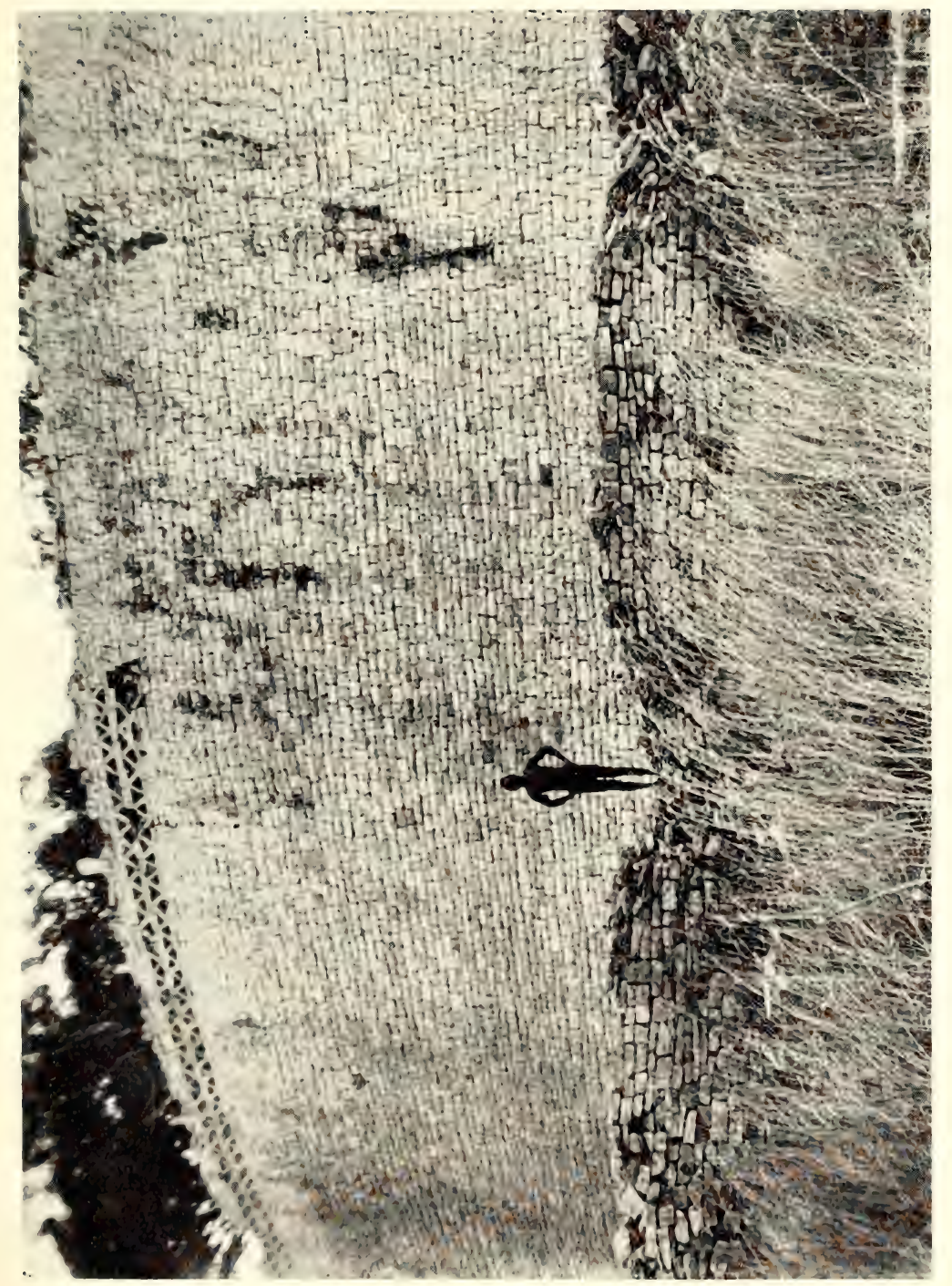

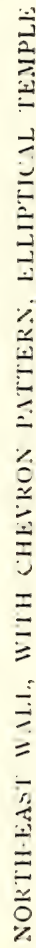



In removing the wall débris at the outer base of the wall containing the chevron pattern for the purpose of forming catchment areas for draining the ground near the wall, two classes of stone blocks were found, a quantity of large, shallow, flat stones similar to those lying in the middle parts of the summit of the walls, and also a quantity of well-shaped blocks as used both in the pattern and in the enclosing courses, but it was estimated that there were not enough of these blocks to have carried the outer face of the wall more than some two courses above the fifth course above the pattern. It is impossible to draw any corresponding inferences with regard to débris on the base of the interior side of the wall, for excavators have moved this out of all relative position to the wall from which it fell.

But there is also some evidence as to the original height of the wall. Such of the undoubted monoliths as still stand more or less erect on the summit of the wall-and as is shown later, not every upright stone on this wall is necessarily a monolith-have no signs on their faces of having been built in by blocks up to any height above the level of the six courses above the pattern. In the case of any fallen monolith from the faces of which supporting blocks or any of them have disappeared, it can be ascertained to what depth the base of the monolith was built into the wall, and in this respect there is some evidence to guide one in estimating the original height of the ancient wall so adorned. The wearing of their sides by the edges of supporting blocks can almost always be noticed, in addition to which the rain of many centuries is guided to the base by the position of the supporting blocks which guide the water downwards, thus causing small rimlets to form on the lower part of the beams, especially those of slate or soapstone, where the rimlets have become in time beautifully smooth and glazed. Therefore it is highly probable that the height of the six courses above the pattern, with the present height of the wall above its foundations as given 
in the tables, formed the original height of the massive portion of the enclosing wall.

The discovery in December, 1902, of what are believed to be traces of a line of small round towers on the outer edge of the summit immediately over the chevron pattern-and these are referred to later-affords very strong evidence as to what was the original height of the wall, and points to the limit of six courses above the chevron pattern. The line of small round towers (recently found to have been conical) on the outer edge of the west wall of the Western Temple on the Acropolis have their foundations a few inches below the present summit of the wall. The foundations of the towers on the wall at the Elliptical Temple, now being described, have their foundations on the present surface of the central ridge along the summit of the wall, but were the pattern made good at the height of the six courses alone, the positions of these foundations would be identical in several respects with those of the towers on the Acropolis. Thus these foundations provide a fourth important corroborative clue as to the original height of the wall.

Along the floor of the summit are laid some large, broad, but shallow slabs of granite of irregular form, while down below on either side were a score of others which have fallen off the wall. Bent suggested that the summit was once paved with these slabs. In view of the four proofs just adduced with regard to the original height of the wall being somewhat higher than is seen to-day, the purpose of the slabs could hardly be that of providing a pavement for the summit. Most probably they were the "ties" or "throughs" to bind the wall at its top courses, as invariably found near.the summits of the best class of walls, especially so in all rounded ends of walls, summits of rounded buttresses, and in the Conical Tower where, near its summit, the back and inside ends of the blocks are frequently longer than in the lower courses where they are short. Many of these slabs on the main wall lie across 
the wall on its present surface, but these are frequently covered with laid blocks. The best instances at Zimbabwe of the "tying" and bonding of the highest courses of walls are to be seen on the Acropolis, but this feature is elsewhere in Rhodesia common in several ruins which are not built upon the angular principle. It is natural to suppose that, if the ancients not only carefully tied the upper courses of almost all walls with "throughs," and also tied several points between base and summit, this main wall bearing the decorative pattern, and once having on its summit, as is now believed, both round towers and soapstone beams, the ancients, admittedly being skilful builders, would regard the effective tying and bonding of such a wall as an important necessity, especially as the wide and commodious summit was, as stated by Bent, in all probability a look-out and muchfrequented elevation. The stones which are uncovered are decomposed and lichen- and moss-covered on their upper faces, but are on their under side as fresh and as clean as if they had just been brought from the quarry. Some visitors, supposing these tie-stones to have been fallen monoliths, have placed four of them in an upright position where they now stand, but unlike all true monoliths, they are not weathered or time-eaten all round, and two so erected have all their faces perfectly clean and fresh.

The summit of the north-west portion of the main wall is fairly level, save at north-west and west entrances where the wall is reduced in height, and also at several points where large branches of trees have beaten off the blocks of the upper courses. The narrow width of the summit, as shown in the foregoing tables, and the number of loose stones lying upon it, make it somewhat awkward for walking along it, still this can be done far more easily than might be supposed from Mr. Swan's description. The battering-back of its outer and inner faces appears to point to its original summit being only slightly higher than its present top at its highest 
point. If the wall were once more than three or four courses above its present highest point, the débris must have been removed, for no greater quantity of blocks were found than would have sufficed to maké good that height.

Foundation.-For such massive walls it is astonishing to find that the bottom courses of the foundation are not more than from $2 \mathrm{ft}$. to $3 \mathrm{ft}$. $6 \mathrm{in}$. below the present level of the ground immediately surrounding the building. The foundation has been examined at eighteen equi-distant points along the outer circumference, and in no single part does it rest on formation rock, the nearest proximity of which is at a further depth of $4 \mathrm{ft}$. on the north, $5 \mathrm{ft}$. on the west, $9 \mathrm{ft}$. on the south, and $4 \mathrm{ft}$. on the east. Nor are the bottom courses formed of large blocks, as is so frequently seen in foundations of other ruins, but blocks no larger than those in the upper courses have been employed almost without exception. Near ( $177 \mathrm{ft}$.) there is a step-up in the foundation westwards of $5 \mathrm{ft} .9 \mathrm{in}$. Near $[625 \mathrm{ft}$.] there runs for a few feet a very narrow stepback in the three lowest courses of the foundation, but this is the only point in the circumference of the wall where this feature can be noticed.

The foundation bed upon which the wall is built is purely artificial. Evidently the ancient architects prepared a level surface for the wall, because there is only from $3 \mathrm{ft}$. to $5 \mathrm{ft}$. difference in the level of the foundations all round, notwithstanding that on the south-east the ground towards the "Valley of Ruins" and the temple which is erected on the edge of its slope commands the "Valley of Ruins."

The surface of the prepared foundation consisted of fine cement, now decomposed ${ }^{1}$ to firm dry sand. This cement is in places at least $3 \mathrm{ft}$. deep, is laid on the granite forma-

1 Report on the examination and analysis of No. 2 Sample of mineral.This was a sample of powdery, earthy mineral. One-half of it has been assayed with the view to the presence of gold, and was found to contain $I \frac{1}{2} d w t s$. of gold 
tion for Io $\mathrm{ft}$. and $\mathrm{I} 5 \mathrm{ft}$. beyond the wall on both inside and outside the building, and later, when the lower courses of the foundation had been laid, a further flooring of cement was laid, making the side of the lower portion of the foundations at least $\mathrm{I} \mathrm{ft} .6 \mathrm{in}$., if not $2 \mathrm{ft}$. 6 in. deep.

The enormous amount of time and labour required to be expended merely in preparing the surface on which to erect the temple is bewildering to contemplate, and fairly rivals as a demonstration of patient labour, length of time of construction, and good workmanship the massive walls themselves. The decomposed cement, which has now become mere sand, was very finely ground, there being not the smallest splinter of granite in its composition. The cement being yellow suggests that the ancients, to save breaking up large pieces of stone, were content to collect small fragments of granite which had become decomposed, and therefore were easier to grind, for everywhere in this locality, especially in damp places and near any granite boulder or glacis, are to be found quantities of small granite chips all yellow with decomposition. Possibly granite sand from neighbouring streams might also have been utilised.

\section{CHEVRON PATTERN}

On the upper portion of the exterior face of the south-east main wall is the celebrated chevron pattern which forms one of the most interesting features at the Elliptical Temple. This

per ton. The other portion has been analysed as to its chemical composition, which was found to be as follows:

\begin{tabular}{|c|c|}
\hline Silica & \\
\hline Oxide of Iron & \\
\hline Alumina & \\
\hline Lime . & • \\
\hline
\end{tabular}

This powdery earth is most probably formed through the disintegration of the slag and furnace ashes, which make an excellent foundation for the floor of a large building. On exposure to the action of the weather it crumbles to powder.

P. Daniel Hahn, Ph.D., M.A., Professor of Chemistry. 
pattern runs for $265 \mathrm{ft}$. 6 in. from [ $189 \mathrm{ft}$.] to [ $456 \mathrm{ft}$. $6 \mathrm{in}$.] on the line of measurement of the exterior circumference of the temple, that is, from south-south-east to east-north-east.

The pattern is in two rows or bands, which together are I 8 in. deep, and Bent states that "it extends along the part of the wall which receives directly the rays of the sun when rising at the summer solstice." The portion of the main wall carrying the pattern is in the form of an arc, and is the best built and most substantial part of the wall. Granite monoliths still stand more or less erect on the summit of the wall above the pattern, but not elsewhere. Over the pattern are the foundations of what appear to have been small circular towers resembling in size and position those on the main west wall of the Western Temple on the Acropolis.

In 1903 a quantity of sections of worked soapstone beams were found on the summit of the wall over the pattern. On no other portions of the summit are there traces of monoliths, round towers, or soapstone beams. Bent was unaware of the existence of the traces of round towers or of the soapstone beams on the wall over the pattern, yet he writes, as seems perfectly correct, "Those parts only of the wall which receive the direct rays of the sun when rising at the summer solstice are decorated by this symbolical pattern." This statement equally applies to the Eastern Temple on the hill and to the large curved wall in Philips Ruins, also to the Western Temple, only in this latter case the great main wall, which is in the form of an arc and is decorated, receives on its face the rays of the setting sun at the winter solstice. A very strong corroboration of this statement is afforded by several other of the more important ruins in Rhodesia which are built upon the curved plan.

In this pattern the blocks are placed on end with the top of each supported by the neighbouring block on one side, thus forming a series of triangular spaces with the bases 
alternately up and down. The sides of these angular spaces are about 7 in. long, and the openings have been neatly filled in with small stones set back inside 2 in. or 3 in. from flush with the face of the wall. The pattern is somewhat dilapidated in places owing to creeper growths on the wall and to the swinging of large tree branches, which in every wind beat the pattern and loosened the stones forming it.

Chevron pattern was in ancient times the symbol for Fertility. It closely resembles the Egyptian hieroglyphic symbol for water, and also the zodiacal sign of Aquarius, and represents the sea on such Phønician coins as have engravings of ships.

This pattern is found on several of the ruins of the oldest type, and not on such as by their style of architecture may be considered to be of a later ancient period. It is found in several of the large ruins between Zimbabwe and the Sabi, also at Umnukwana Ruins. A portion of chevron of small size is to be seen at Dhlo-dhlo.

Ground surface of exterior of main wall.-Till August, 1902, the area surrounding the Elliptical Temple was mere veld and bush, and trees and shrubs grew so thickly near the main wall that it was impossible at certain points to penetrate the jungle to make a complete examination of the wall, while piles of soil from excavations lay along the base of the wall, and some up against the wall itself, in some cases to a height of $6 \mathrm{ft}$. above the average level of the exterior ground.

Trenches and deep holes, the main wall forming one side of them, were lined with mud, and filled with ferns and plants which could only flourish in a situation which was perpetually damp. There was every evidence that these trenches and holes were filled with water during each wet season, and that they retained a considerable amount of moisture even during the dry seasons. At two points this constant state of damp 
held by these cuttings had caused the foundations, which at no place rest on the bed-rock, to sink some inches, thus imparting wave-like lines to the courses of the wall close to such holes.

To remove this source of injury to the wall by causing it to sink and also by stimulating tree and creeper growths which were damaging the wall, it was decided to remove all such débris piles, and also the veld soil, most of which had in the course of ages silted down from the lower slopes of the Bentberg some $200 \mathrm{yds}$. distant on the south side of the temple, and to leave a floor of hard soil which would serve to drain off all rain-water and protect the bases of the walls from being washed by the storm streams from the higher ground. This work was carried out for a width of some 6 to $8 \mathrm{yds}$. round the entire circumference of the temple. Five catchment areas were formed on the north-west, west, south, and east sides, and from each such area a run-off now leads all rain-water into a hole sunk in the ground at some I 2 yds. distance from the main wall.

These five holes, as shown later, have proved useful in demonstrating certain features connected with the temple which so far had been impossible of examination :-

(I) The rock formation is at almost every point some feet below the lowest course of the foundations of the main wall, in most cases $3 \mathrm{ft}$. to $4 \mathrm{ft}$., and in one instance--the southfully $6 \mathrm{ft}$.

(2) The ground outside the temple has been raised by the silting of soil from the slopes of the Bentberg, by the spreading out of both ancient and old native débris piles, by the levelling up of the surface for laying clay floors of Makalanga huts, and by block débris from the main and several minor walls. This filling in, both natural and artificial, averages to a height of at least $5 \mathrm{ft}$. above the level known to the ancients, thus reducing the comparative elevation of the temple to that extent. It is now clear that the temple 


\section{THE ELLIPTICAL TEMPLE}

once stood on a comparatively higher and far more imposing elevation than it stands at present.

(3) The granite plateau which underlies the soil upon which the temple is built is irregular, and resembles on a larger scale the granite plateaux which extend eastward from the temple. ${ }^{1}$

${ }^{1}$ See Appendix, Note G, as to formation rock under the temple. 


\section{CHAPTER $\mathrm{X}$}

\section{THE ELLIPTICAL TEMPLE \\ (Continued)}

\section{MAIN ENTRANCES \\ North-West Entrance}

7 HIS entrance is on the north-west side of the temple 1 at $(606 \mathrm{ft} .6 \mathrm{in}$.$) to (6 \mathrm{I} \mathrm{ft} .6 \mathrm{in}$.$) inside, and [656 \mathrm{ft}$.] to [660 ft.] outside. As in the case of North and West Entrances, the foundations of the main wall are carried from side to side of the entrance and from the floor of the passage, and in them the outer steps are built. The east side wall is $4 \mathrm{ft}$. wide where it starts to curve inwards to form the passage and at $6 \mathrm{ft}$. above the floor of the entrance. The west side is $7 \mathrm{ft}$. wide where it starts to round inwards and at $6 \mathrm{ft}$. above the entrance floor.

Evidently this entrance was not of the importance of either of the other two portals to the temple. No internal passages converge upon it ; it is less massive, and its purpose appears to have been limited to serving as a communication with No. I Ruins only, as a substantial wall which encloses these ruins runs round to the north-west main wall of the temple between $[705 \mathrm{ft}$.] and [7 $\mathrm{IO} \mathrm{ft}$.], where it joins it at right angles to the main walls. These enclosing walls thus cut off on either side the exterior of the North-West Entrance from the other portions of the exterior of the temple, and in these enclosing walls no signs have so far been discovered of there having been any entrances.

This entrance is built on well-curved lines, but the rounded 216 

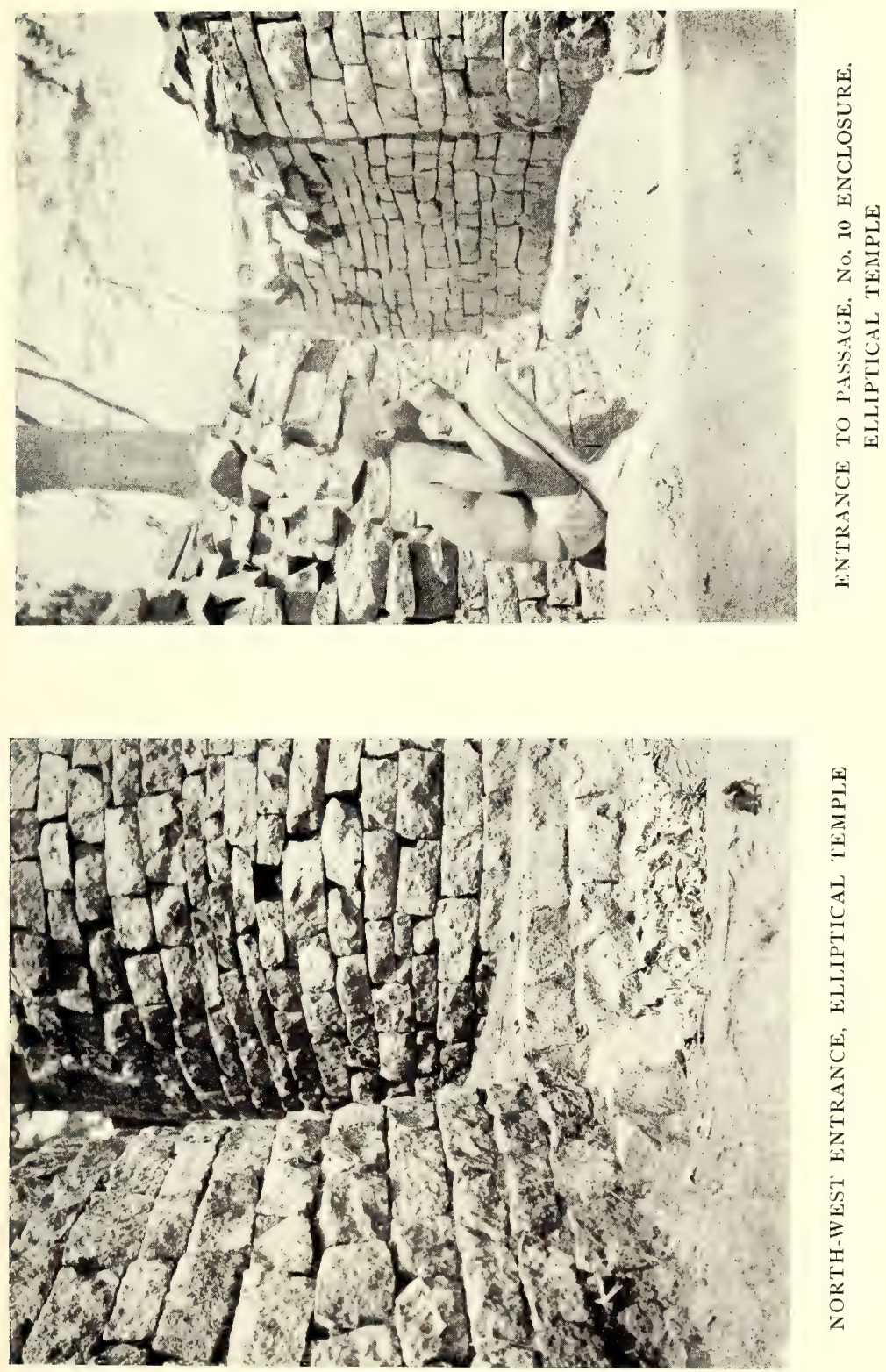

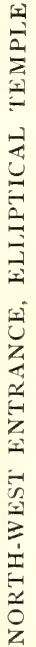



faces of the two side walls do not exactly face one another, since the outside face of the west side projects some 12 in. further north than that on the east side, the west wall being wider than the east one, though on their inside faces they are flush with each other. There are no buttresses on the outside of this entrance. The summits of the side walls, some $6 \mathrm{ft}$. above the outside level, are less ruined than those of the other two entrances; the gap between the two summits including the width of the entrance is only $8 \mathrm{ft}$. 6 in., the

\section{North West Entrance}

\section{ELLIPTICAL TEMPLE}

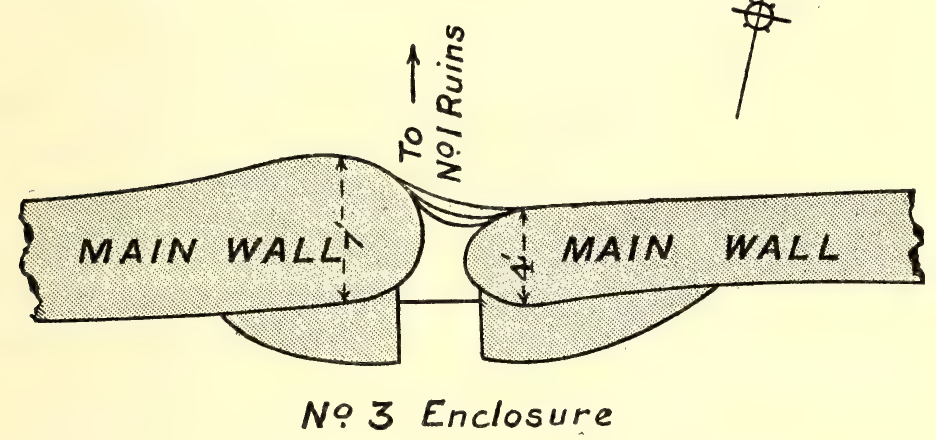

broken faces of the upper portions of the walls rising perpendicularly on either side.

This entrance is $2 \mathrm{ft} .9$ in. wide in the centre. The wall on the west side is perfect up to $5 \mathrm{ft}$. in height, and that on the east side to $6 \mathrm{ft}$. $6 \mathrm{in}$. There are two steps on the outer side, and these are formed by the courses in the foundation being carried across the entrance and curved inwards at the centre of the passage.

On either side of the entrance in the interior of the temple there are plumb and angular buttresses of poor construction resting upon soft soil. Each projects $5 \mathrm{ft} .6$ in. into No. 3 Enclosure, and each is I $\mathrm{ft}$. $9 \mathrm{in}$. high, the width between their straight faces being $2 \mathrm{ft}$. 8 in. Each buttress is rounded 
off on the outer side and joins the main wall, that on the east side being $7 \mathrm{ft}$. long, and that on the west side $9 \mathrm{ft}$. 6 in. long.

When Bent arrived at Zimbabwe in I89I he found this entrance built up to a height of $9 \mathrm{ft}$. This had then been done some fifty years previously by the Makalanga when the previous Mogabe Chipfuno was only a boy. This walling-up was for the purpose of closing in No. 3 Enclosure, which was used as a cattle kraal. It is highly probable that the Makalanga took the upper portions of the two buttresses which are on either side of the inside of this entrance for building material in so walling it up, for these buttresses, judging by the absence of stone débris and the condition of the faces of the main wall where the buttresses were once built up against it, appear to have been deliberately denuded of their courses for at least some feet of their original height.

Bent removed the walling-up, but left its foundation in the entrance at $2 \mathrm{ft}$. below which the paved passage and steps were unburied in September, 1902. This foundation of the Makalanga wall was laid across a pile of blocks thrown promiscuously on to the floor of this entrance, and this again rested on soil black with charcoal, decomposed vegetable matter, and bones of buck split open for the marrow, and this débris contained broken articles of Makalanga make, but of superior quality to those made by them to-day.

\section{The North Entrance}

This entrance is in the north-east wall of the temple, and its exit faces north-east, twenty-five degrees, and is situated between the $(523 \mathrm{ft}$. $6 \mathrm{in}$.) and $(536 \mathrm{ft}$.) points of the measurement of the inside base of the main wall from the south side of the west entrance, and between the $[566 \mathrm{ft} .6 \mathrm{in}$.$] and$ [57 I ft. $6 \mathrm{in}$.$] points of the measurement of the outside base$ of the main wall from the south side of same entrance. It has always been known as the North Entrance, as it is on the north side of the centre of the temple. Bent terms it the 


\section{THE ELLIPTICAL TEMPLE}

North Entrance, as do other writers, and in our description it will be so styled.

Its massive size and excellent construction exceed those of any other known ancient entrance, unless it be the West Entrance, which, however, at present remains uncleared, and, except for the dilapidation of the higher portions of its

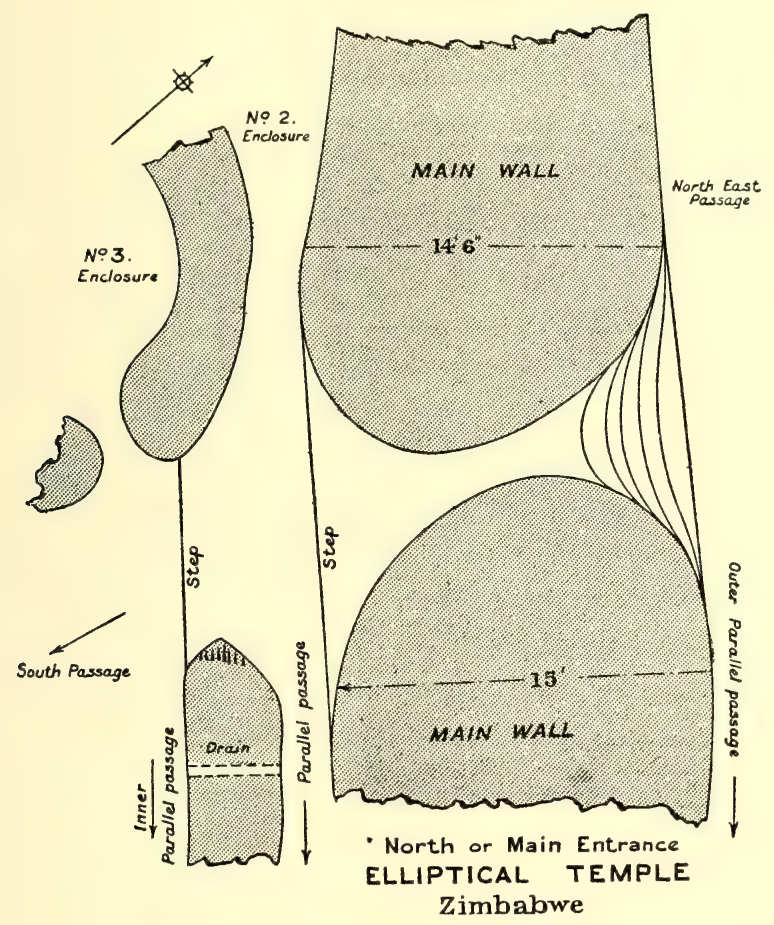

rounded sides, it is certainly the best-preserved entrance so far discovered at Zimbabwe. Until November, 1902, the existence of its symmetrical and massive steps was altogether unsuspected, for these and the outer face of the entrance had been buried to a depth of $5 \mathrm{ft}$. in débris, the major portion of which could not have been disturbed for apparently many scores of years. The opening out of this entrance and also of the walled-in area immediately in front and to the north 
of it has revealed another leading architectural feature in addition to those already known at this temple. Photographs of the North Entrance, as it previously appeared, now only represent the tops of the side walls of the entrance.

Though its outer side faces towards north-east, twenty-five degrees, the entrance passage itself runs somewhat obliquely through the wall, the south end being slightly more to the east than is the outer end, and standing in the middle of the south end the line of passage further to the north than does its outer face, and there is a view of the eastern end of the Acropolis, the lower portion of which is at present hidden by a pile of granite block débris removed from the interior of the temple.

The main walls on either side of the entrance are exceedingly massive and exceptionally well built, the entrance and steps forming a handsome piece of dry masonry, which reveals the artistic plan and bold conception of the ancient architects, admirably executed by the builders. On the east side the wall is $15 \mathrm{ft}$. 6 in. wide at the points where the main wall starts to curve in forming the east side of the entrance, and this measurement is taken at $\mathrm{I} 3 \mathrm{ft}$. above the level of the outside area. On the west side the main wall is I $4 \mathrm{ft}$. 6 in. wide at the points where the wall starts to curve in forming the west side of this entrance, this measurement being taken at $\mathrm{I} 2 \mathrm{ft}$. above the level of the outside area.

The entrance passage is $15 \mathrm{ft}$. 9 in. long. It is $7 \mathrm{ft}$. 10 in. wide at the foot of the steps on the north side, and $12 \mathrm{ft}$. wide at the south end between those points on either side where the walls start to curve in forming the entrance. The steps occupy $4 \mathrm{ft}$. 4 in. of the north end of the length of the passage, and the rest is paved level; but at the south end the flooring is slightly uneven owing to roots having moved some of the paving blocks. The level at the south end terminates in a step-down, which runs from the south face of one side wall to the south face of the other side wall. 


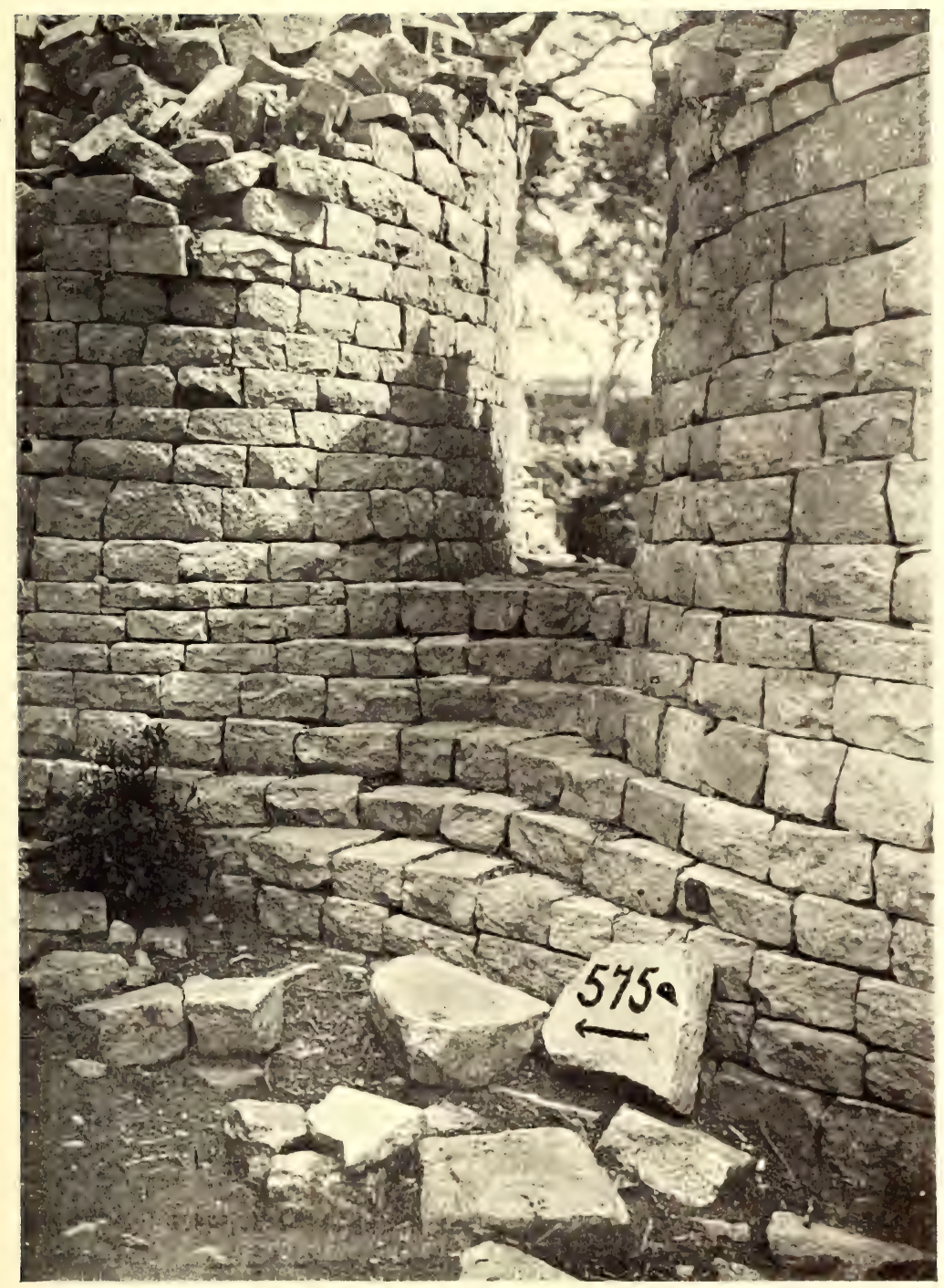

EXTERIOR OF NORTH ENTRANCE TO ELLIPTICAL TEMPLE

DISCONEKED 1903) 

The present heights of the reduced walls of the entrance are : east side, $7 \mathrm{ft}$. 6 in.; west side, $6 \mathrm{ft}$. Io in.

There are six rows of steps each 7 in. high, and each row in its centre recedes Io in. beyond the one below it, the row curving inwards at its centre. The walls on either side of this entrance are not separate walls, but a common foundation runs under both, forming the floor of the passage, which floor is $3 \mathrm{ft} .4 \mathrm{in}$. higher than the level of the outer area.

The steps are formed by the courses of blocks of the outer face of the wall on one side passing to the outer face of the wall on the opposite side, where they are continued, making a curve inwards, each curve receding with mathematical precision behind the curve in front. The courses on either side assume a fan-like form, thus making the curved courses of the steps wider in the middle than on the sides. The steps were built before the side walls of the passage were erected, and their marvellous regularity demonstrates the foresight of the builders. The end blocks of each row are partly built into the walls on either side. The courses in the main wall at this point are remarkably even and correct, the courses on the one side corresponding with the courses on the other. These steps are identical in measurement with all steps, so far discovered, found built in any ancient wall of the oldest type of ruin, and are of altogether different construction from those of the angular and terraced ruins of the later period in which the angular side walls of an entrance are first erected, and the steps afterwards built in between them.

Bent frequently refers to this entrance as the main entrance of the temple. In so doing he is in all probability correct, though many of the facts concerning it, which give it an importance not possessed by either of the other two entrances, were then unknown to him. These were discovered in November, I902. But the fact that three passages-Parallel Passage, Inner Parallel Passage, and 
South Passage-all converge on this entrance shows that it must have possessed considerable importance. But the recent clearing away of the débris to a depth of some $6 \mathrm{ft}$. has revealed the lower portion of the entrance with its wellconstructed flight of steps, as well as the admirably proportioned structure of the entrance, which can now be seen to be by far the finest entrance to the temple.

But the further discovery in November, 1902, of the longburied North-East Passage, and the clearing out of the Outer Parallel Passage, both of which converge on the outer face of this entrance, have disclosed the fact that an even greater importance attached to this entrance than Bent or Sir John Willoughby could have supposed, for the existence of the North-East Passage was unknown to them, seeing that the summits of its side walls were buried at least $2 \mathrm{ft}$. under the veld. This passage, with buried enclosures on either hand, has now been cleared out for 108 yds., with traces of an extension for a further 70 yds. in a direct line towards the south-east Ancient Ascent to the Acropolis, and as the large area, known as the "Valley of Ruins," lies along this route, and is connected with the passage by numerous side passages and openings, the importance of the North Entrance is very considerably enhanced, and Bent's conjecture is shown to be fully confirmed.

\section{Western Entrance}

This is the second largest entrance to the temple, and would appear to have been of some importance. It is by the West Entrance that visitors now usually enter the building. The gateway opens directly into No. 5 Enclosure.

The entrance is situated between [ $827 \mathrm{ft} .9 \mathrm{in}$.$] and [83 I ft.$ 9 in.] on the line of the measurement of the circumference of the exterior of the building, which starts on the south side of the entrance, and between ( $763 \mathrm{ft} .6 \mathrm{in}$.) and ( $766 \mathrm{ft}$. $6 \mathrm{in}$.) on the line of the measurement of the circumference of the 


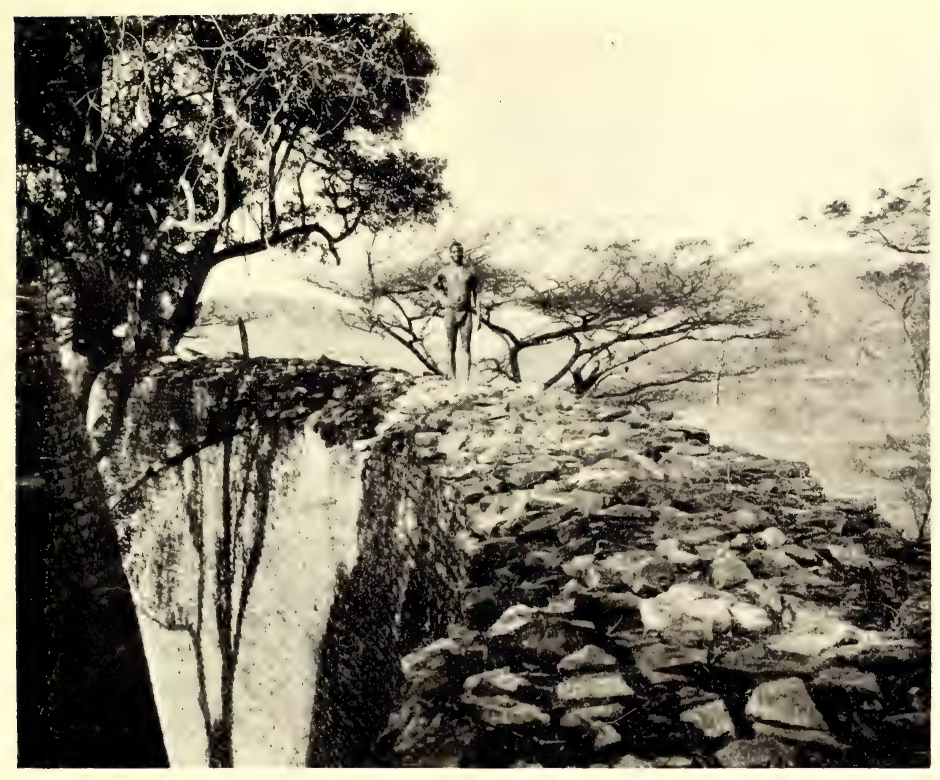

SUMMIT OF SOUTH-EAST MAIN WALL, ELLIPTICAL TEMPLE

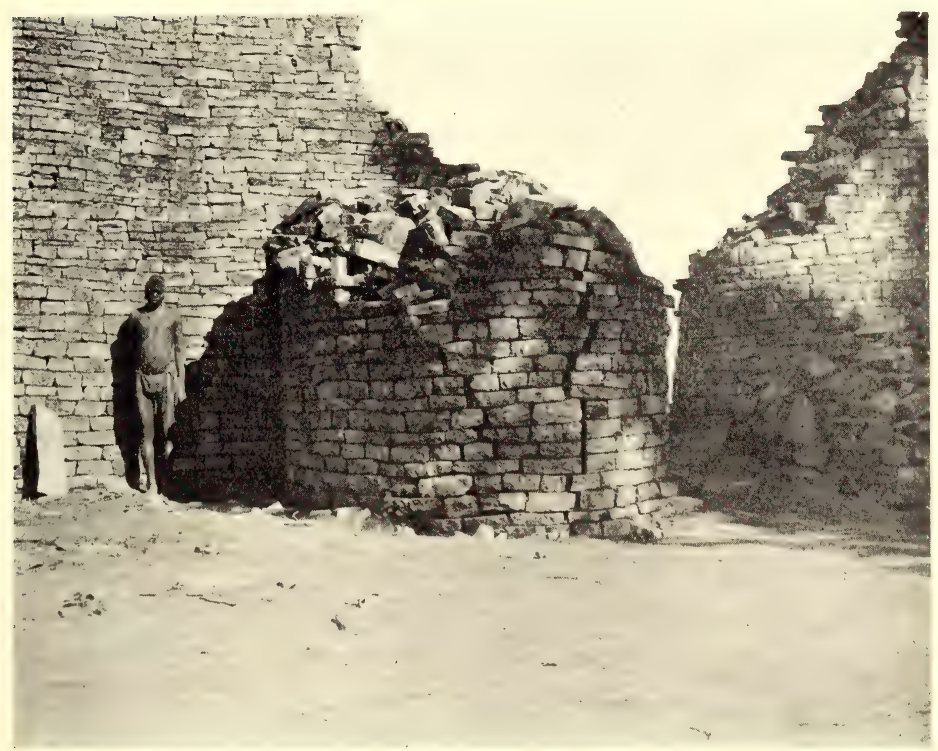

WEST ENTRANCE FROM INTERIOR, ELLIPTICAL TEMPLE 

interior of the main wall, which also starts on the south side of this entrance. (See Main Wall.)

The south side is formed by the boldly rounded end of the main wall, which is here reduced in height to $7 \mathrm{ft}$. 6 in., or including foundations to I I $\mathrm{ft}$. The reduced summit is $6 \mathrm{ft}$. 6 in. wide, and has a batter of 8 in. At $10 \mathrm{ft}$. from the side wall the main wall rises abruptly from $7 \mathrm{ft}$. to $22 \mathrm{ft}$.

The north side is formed by the main wall, which has a rounded end. Its height is $8 \mathrm{ft}$., but rises sharply to $20 \mathrm{ft}$. The reduced summit is $6 \mathrm{ft}$. wide, and there is a batter of Io in. on the face of the side wall.

The passage way is $4 \mathrm{ft} .2$ in. wide between the rounded ends of the two walls, and it has a total length of $20 \mathrm{ft}$. 6 in., $9 \mathrm{ft}$. $6 \mathrm{in}$. being over the foundation and I I ft. over the semicircular platform, which supports the two rounded buttresses on the inner side of the entrance. Unlike the Main Entrance this passage passes through the wall at right angles.

The semi-circular platform projects into No. 5 Enclosure for I I ft., and upon it, and on either side of the entrance, are two buttresses, that on the south side being $9 \mathrm{ft}$. high and Io $\mathrm{ft}$. wide at the back; the one on the south side being very much dilapidated is now only $6 \mathrm{ft}$. high on the north side and $6 \mathrm{ft}$. wide at back. These buttresses and the platform are one structure, the courses in the buttresses are carried across the passage in a semi-circular form, thus forming steps.

The problem as to the entrance having ever been covered over is at present an open one, and there is much to be said on either side. The old men of the Amangwa state that it once had wooden beams across, and that the entrance was blocked up with stones. The North-West Entrance was in I 89 I found by Bent, who reopened it, to have also been built up at a very late date, and so completely blocked. (See Entrances, Chapter VII.)

On the exterior, and on either side of the entrance, stood, till 1903, very large débris heaps, each of which was at least 
$8 \mathrm{ft}$. high and many yards in circumference. These on being removed were found to represent several distinct occupations of the temple, and two-thirds of their height was accounted for by native occupations and the removal by explorers of débris from the interior of the building. The native portion contained ashes and bones in large quantities, iron assegai heads, hoes, brass and iron wire bangles, clay whorls, and ordinary native pottery. Some few small relics were found in the soil which had been taken from the temple. In the lowest portion, which was not thicker than 18 in., were found phalli, splinters of soapstone beams, excellent pottery, gold crucibles, beaten gold and gold wire. There were several layers of ashes, but very few animal bones. The two heaps had been piled up against the main wall. 


\section{CHAPTER XI}

\section{THE ELLIPTICAL TEMPLE \\ (Continued)}

\section{Enclosures Nos. I TO 7}

\section{NO. I ENCLOSURE}

$\mathrm{T}$ HIS enclosure is on the north side of the temple, the outer face of its north-eastern wall being $18 \mathrm{ft}$. southwest of the North Entrance. This is the most perfect of all the enclosures. It is roughly circular, and there are no angular features in the body of the wall, though both entrances have their outer corners squared. The area is : north to south $56 \mathrm{ft}$. 6 in., and east to west $55 \mathrm{ft}$. 6 in.

The average height of the walls all round the enclosure is $7 \mathrm{ft}$. above the present surface of the filled-in area. At the north-east end the summit of the wall is $\mathrm{II} \mathrm{ft}$. above the bottom of an old hole excavated at that point, and in the hole the foundation is exposed. On the north-west side the summit of the wall is $9 \mathrm{ft}$. above the red cemented floor of an old Makalanga hut which had solid clay sides.

The walls are very substantial, being $5 \mathrm{ft}$. 6 in. wide and $4 \mathrm{ft}$. and $5 \mathrm{ft}$. above the surface of the area, as it was before clearing operations were commenced.

There are two entrances, one on the north side and the other on the east side.

The north entrance leads from No. 3 Enclosure, and is $2 \mathrm{ft}$. 6 in. wide, and its walls are rounded on the inside and angular on the outside, the side walls being between $3 \mathrm{ft}$. and $4 \mathrm{ft}$. high. There are four rows of steps, somewhat 
rudely constructed, each being about Io in. from front to back. A small parapet wall carries the steps from the lower level of No. 3 Enclosure.

The walls of the east entrance are rounded on the inside and angular on the outside. The entrance is $2 \mathrm{ft}$. wide, $5 \mathrm{ft}$. long, with a level floor for this length, the foundation being carried across the opening, and the walls on either side are $4 \mathrm{ft}$. high. There is one step inside at the end of the 5 - $\mathrm{ft}$. length, and one step outside from the floor of South Passage. There are no portcullis grooves to this entrance. On the inside of this entrance is a stone platform which might once have carried buttresses.

This enclosure has been subjected to the filling-in process more than any other enclosure of the temple, probably because of its proximity to the North-West Entrance through which the material could easily have been brought in from outside. On the present surface there are remains of an old Makalanga hut, which must be more than sixty years old, seeing that the Makalanga have not resided in the temple for over that period. At a depth of from I ft. 6 in. to $2 \mathrm{ft}$. below this surface the remains of a still very much older Makalanga hut have been exposed. This was constructed of red clay, beautifully polished, the flooring being on a very true level. This class of old huts had their clay sides altogether independent of the roof, which was supported by poles inserted at a distance of some inches from the outside of the walls. (See Architecture-Makalanga Huts.)

The only "finds" made here were fragments of large soapstone bowls carved with herring-bone and cord patterns, small clay animals, assegai heads, and pottery of old, but not ancient, design or make, and comparatively recent native pottery.

A drain passes through the west wall of this enclosure, and has a fall into No. 3 Enclosure.

Bent stated that this enclosure was not a portion of the 
original building. There are indications that this conjecture is correct. The walls are built without any regularity in courses and of stones of all shapes and sizes, the west wall crossing over the foundations of an older wall.

\section{NO. 2 ENCLOSURE}

This is a pear-shaped enclosure at the north-north-west side of the temple, and is built up immediately against the main outer wall from ( $530 \mathrm{ft}$.) to $(578 \mathrm{ft}$.), and is on the west side of the North Entrance.

It is $47 \mathrm{ft}$. long from south-east to north-east, and I $3 \mathrm{ft}$. wide from north-east to south-west at its broadest part.

From ( $560 \mathrm{ft}$.) to $(565 \mathrm{ft}$.) the main wall is considerably broken, having fallen outwards. It is between these points that there is a narrow break in the foundations, which supports the view regarding the reconstruction of the western wall at a later ancient period, a matter dealt with in the description of the main wall, and in the Preface.

This enclosure has only one entrance, and this is at the south-east end. It has rounded walls, is $8 \mathrm{ft}$. long, $2 \mathrm{ft} .2 \mathrm{in}$. wide, and the wall on the south-west is $4 \mathrm{ft}$. high, and that on the north-east side $7 \mathrm{ft}$. high. The floor of this enclosure is between $2 \mathrm{ft}$. and $3 \mathrm{ft}$. below the floor of the adjoining North Entrance, and there is one stone and one cement step in the entrance passage of this enclosure.

A substantial wall, $4 \mathrm{ft}$. to $8 \mathrm{ft}$. high, and $4 \mathrm{ft}$. wide at $4 \mathrm{ft}$. from the ground, but evidently of later construction, is on the south side, and separates this enclosure from $N o .3$ Enclosure, but it has a deep depression on its summit, and is very considerably ruined for about $20 \mathrm{ft}$.

There is a drain-hole through the main wall at ( $545 \mathrm{ft}$.).

This enclosure has suffered very considerably at the hands of unauthorised searchers for ancient gold relics, some of the flooring having been torn up, and the foundations of part of the southern wall have been undermined. 
Here in a débris heap was found the large plain flatrimmed soapstone bowl which was lent by the late Rt. Hon. C. J. Rhodes to the South African Museum at Cape Town.

\section{NO. 3 ENCLOSURE}

This is the most north-westerly enclosure of the temple, the north-west main wall from ( $590 \mathrm{ft}$.) to (66o ft.) forming its north-westerly boundary. The south side is formed by No. I Enclosure, the west by No. 4 Enclosure, and the north and east by No. 2 Enclosure.

The area is keystone-shaped, being $76 \mathrm{ft}$. long on its northwest side, $45 \mathrm{ft}$. 6 in. on its west side, $7 \mathrm{I} \mathrm{ft}$. on the south side, and $50 \mathrm{ft}$. 6 in. on the north and east side.

The North-West Entrance to the temple is at ( $606 \mathrm{ft} .6 \mathrm{in}$.) to (6I I ft. $6 \mathrm{in}$.) on the north-west side of the enclosure. (See Main Wall, North-West Entrance, for description.)

The entrance in the west wall between Nos. 3 and 4 Enclosures was not at the present gap in the débris of this wall, as the gap was made for the convenience of visitors. The foundations of this wall end abruptly at $25 \mathrm{ft}$. from its east end, this portion of the wall being in a fairly good condition for $14 \mathrm{ft}$., and being from $3 \mathrm{ft}$. to $6 \mathrm{ft}$. high.

The entrance to No. I Enclosure is in the south wall at $45 \mathrm{ft}$. to $49 \mathrm{ft}$. from the west wall.

The east entrance has rounded sides, is $2 \mathrm{ft}$. wide, and the side walls are $4 \mathrm{ft}$. high. This entrance leads from South Passage, and is immediately inside the North Entrance to the temple.

A drain from No. I Enclosure is in the angle formed by the west and south walls.

Possibly this enclosure was once subdivided, but when mediæval and even later Makalanga occupied the temple for their residence and cattle kraal the subdivisional walls were removed. That this portion of the temple was used for this purpose is demonstrated both by "finds" and the condi- 


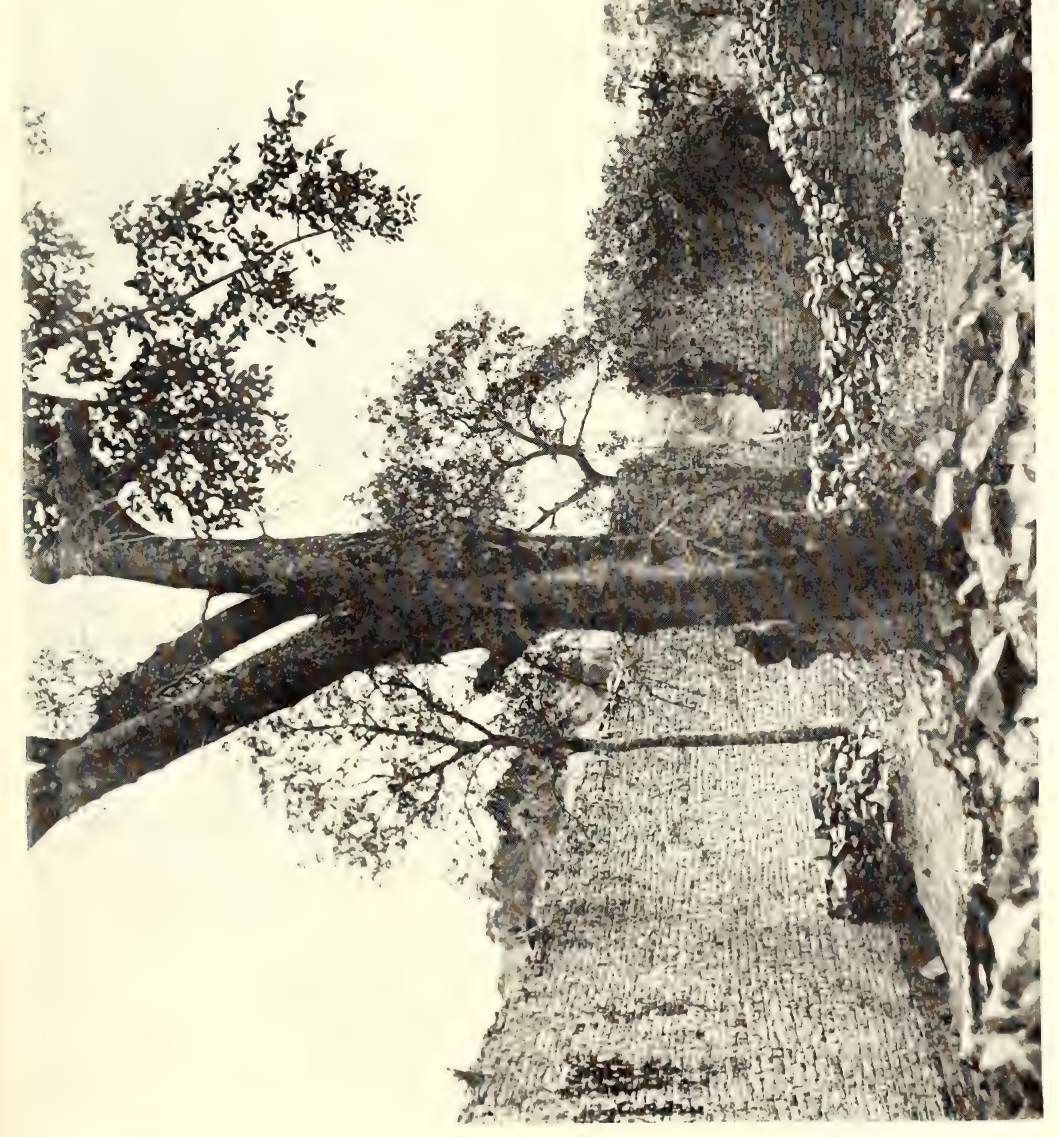

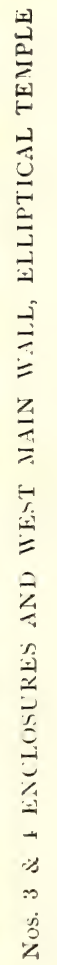



tion of the enclosure, and these support the native assertion to this effect. The remains of a wall runs north-west from the south-west corner of the enclosure towards the west side of the North-West Entrance. This is $16 \mathrm{ft}$. long, $2 \mathrm{ft}$. high, and $3 \mathrm{ft}$. 6 in. wide. A second wall is believed to have once stood between the west side of the entrance to No. I Enclosure and the north and east side wall.

At (640 ft.) is a long granite slab, which has evidently fallen from the summit of the main wall. Probably it was a tie or "through" stone, as the summit of the main wall had been bonded with similar stones.

In the angle formed by the north-east and north-west walls are the remains of a large rounded buttress now only $2 \mathrm{ft}$. high. Possibly this might be one of the platforms with "blind steps" (see Architecture-Blind Steps) which are found in the angles in several of the temple enclosures.

This enclosure appears to have been filled in with stones and earth at a very late period, as the filling-in contains at all depths portions of Makalanga pottery and lumps of iron slag. The ancient floor is believed to be some $2 \mathrm{ft}$. below the present surface.

\section{NO. 4 ENCLOSURE}

This is the most westerly of the temple enclosures. Its form resembles that of a keystone with the broad side on the west main wall, along the inside of which it extends for $67 \mathrm{ft}$. from (666 ft.) to (730 ft.)

It is bounded on the north side by the divisional wall separating it from No. 3 Enclosure, and this side is $47 \mathrm{ft} .6 \mathrm{in}$. long. This wall extends from the outer face of the west portion of the wall of No. I Enclosure for I4 ft., from which it is in a good state of preservation, except for reduction in height, it being now only between $4 \mathrm{ft}$. and $6 \mathrm{ft}$., while the rest of the wall is ruined, and is lost in a line of débris which marks where the wall once stood. At the west end of this débris are a few blocks still retaining their position, and these 
show where the north wall joined the main wall. As on the north side of this wall, where there is now no trace of entrance between Nos. 2 and 3 Enclosures, so is it on its south side, where the face of the wall is even more ruined than on the opposite side.

On the south side this enclosure is bounded by the divisional wall between it and No. Enclosure. This wall is $58 \mathrm{ft}$. long, and bends southwards in the middle of its length for $5 \mathrm{ft}$. from a line between the two extremities of the wall. At the east end of the wall it is $6 \mathrm{ft}$. high for $5 \mathrm{ft}$. in length, when it is reduced to $2 \mathrm{ft}$. with débris $3 \mathrm{ft}$. higher lying along the summit. The west end of the wall is very poorly built, and as this enclosure has also been used by the Makalanga as a cattle kraal, probably finding the wall broken down at its western end, they rebuilt it in order to keep in the cattle. The wall throughout is built on a raised cement foundation only slightly wider than the wall itself.

Though there is at present no trace of any entrance between this and No. 5 Enclosure, there are reasons for believing that traces of one may be discovered near the spot where a large fig tree grows on the line of wall.

The east side is $33 \mathrm{ft}$. in length, and is formed for Io $\mathrm{ft}$. from the north side by the west outer face of the wall of No. I Enclosure, which is here I I $\mathrm{ft}$. high; for the following I $2 \mathrm{ft}$. by the opening into the West Passage which runs parallel to the south-west and west sides of No. I Enclosure; and for $13 \mathrm{ft}$. by the outer and west face of the West Passage, the wall of which is Io ft. high, and is well built, substantial, and in a good state of preservation.

The whole of the interior of this enclosure has been deliberately and rudely filled in with soil, débris, also with stones which have fallen into it, and for almost $2 \mathrm{ft}$. in depth it is covered with rich vegetable mould. [This latter was removed in I903.] 


\section{NO. 5 ENCLOSURE}

This enclosure is immediately inside the West Entrance to the temple, the western and south-western main wall forming its boundary on those sides from ( $735 \mathrm{ft}$.) to ( $760 \mathrm{ft}$.) on the north side of the entrance, and from (o ft.) to (IOO ft.) on the south side of the entrance, thus making its length on the side of the main wall to be $\mathrm{I} 30 \mathrm{ft}$.

The area was once subdivided, but at present it is difficult to say exactly where the subdivisional walls ran, though the faint traces of these are to be seen in several directions, but all appear to radiate from the eastern side of the enclosure towards the inside face of the main wall.

The north side is $59 \mathrm{ft}$. long, the south wall of No. 4 Enclosure being its northern boundary. The face of this wall at its eastern extremity is well built, but the western portion of it is very poorly constructed. The probable cause of this difference in the building of the wall was explained in the description of No. 4 Enclosure, and also in the Preface.

The eastern side for $36 \mathrm{ft}$. in length from the north side is formed by a very well-built wall which forms the southern extremity of West Passage. This wall is now only $6 \mathrm{ft}$. in height, but the great amount of wall-débris lying at its bases suggests that it was once some $7 \mathrm{ft}$. higher. It is $6 \mathrm{ft}$. wide on its present summit. From this point to the southern end of the enclosure the rest of the eastern side is open space, with traces of substantial wall foundations all along this length. The total length of the eastern side of this enclosure is $93 \mathrm{ft}$.

The south side, which is $37 \mathrm{ft}$. long, is formed by faint traces of a wall which divides this area from No. 6 Enclosure, extending from the west outer side of No. 7 Enclosure to the main wall.

The width at the centre of this enclosure from east to west is $57 \mathrm{ft}$. 
A flat granite monolith stands at $30 \mathrm{ft}$. north-east of the north buttress of the West Entrance with a flat face towards the west. It rises from the ground $6 \mathrm{ft}$. $9 \mathrm{in}$., is $3 \mathrm{ft}$. broad, narrowing to $\mathrm{I} \mathrm{ft}$. IO in. at the top. It is 3 in. thick, and leans slightly towards the east. No artificial markings can be discovered on either of its faces.

A triangular-shaped granite beam stands $2 \mathrm{ft}$. I I in. above the ground at $26 \mathrm{ft}$. north-east of the south buttress of the West Entrance. A fractured portion of the beam, until lately buried, lies near. This section is $8 \mathrm{ft} .2 \mathrm{in}$. long. Twelve years ago this beam was complete. It then had a tilt towards the north, and its base must be deep to have supported its heavy weight in a leaning position.

Other sections of fractured granite monoliths were buried at this spot; one set of sections exceed together $8 \mathrm{ft}$., without taking into consideration a section which is missing.

The latest floor of this enclosure is at least $2 \mathrm{ft}$. below the present surface, the soil on the top being vegetable mould thickly matted with roots of wild vines and other creepers. [In August, 1903, this top soil was removed from the whole area. Several pieces of beaten gold and some Arabian glass were found lying on the hard soil underneath it.]

\section{NO. 6 ENCLOSURE}

This adjoins No. 5 Enclosure, which forms its western boundary. The south side is formed by the south main wall of the temple from ( $100 \mathrm{ft}$.) to ( $179 \mathrm{ft} .3 \mathrm{in}$.). The north and north-east side is formed by the south wall of No. $7 \mathrm{En}$ closure. This wall is from $5 \mathrm{ft}$. to I I ft. high. The eastern side is formed by the west wall of the Sacred Enclosure, which is from $8 \mathrm{ft}$. to I I ft. high.

The measurements of this area are: south side, $79 \mathrm{ft}$.; north side, $58 \mathrm{ft}$; east side, $22 \mathrm{ft}$. ; and west side, $3 \mathrm{I} \mathrm{ft}$.

This enclosure has two entrances. Probably another 
entrance may be discovered on the western side on the removal of débris.

The northern entrance is at $35 \mathrm{ft}$. to $37 \mathrm{ft}$., measuring from the eastern end of the north wall. This leads into No. 7 Enclosure. It has rounded walls, and the floor forms part of the foundation. There are no portcullis grooves.

The eastern entrance is at $13 \mathrm{ft}$. to $15 \mathrm{ft}$., measuring from the north end of the east wall. This leads into the Sacred Enclosure. Its walls are rounded, and there are portcullis grooves. The steps are built into the wall. On either side of the entrance there are traces of rounded buttresses.

Monkey-rope roots have done serious injury to the eastern end of the north wall, and have caused a depression of $5 \mathrm{ft}$. from the average height of the reduced wall.

This enclosure is interesting because it showed three floors below the soil surface. On removing the mould which form the top surface for a depth of $\mathrm{I} f \mathrm{ft}$. to $2 \mathrm{ft}$., was found the common red clay foundation of a Makalanga hut, about which lay iron hoes, assegai heads, and also pottery of no great age. Below this, for a further depth of I ft. to I $\mathrm{ft}$. 6 in., was a promiscuous filling-in of blocks and soil, and below this again was a very hard soil, probably of decomposed cement, and on this hard surface was a pile of about $20 \mathrm{lbs}$. weight of portions of pottery scorifiers and small crucibles, all of which showed gold richly on the flux. These had evidently been piled up as rubbish, for they were all found within an area of $2 \mathrm{sq}$. $\mathrm{ft}$., and no other portions of scorifiers or crucibles were found elsewhere in this enclosure. A pair of iron pincers made of two pieces of iron welded together at one end, an iron gong, and a soapstone amulet were discovered together, while on the lowest floor was a portion of a large soapstone bowl carved with herringbone on cord pattern, and the fractured bases of what are believed to be true phalli. This lowest floor is 9 in. deeper than the one on which the gold crucibles were found, and 
is made of whitish cement, and has been exposed for about 4 sq. $\mathrm{ft}$. in the north-east corner of the enclosure at II ft. below the summit of the east wall.

The reconstruction of the north wall at its eastern end is very conspicuous. This reconstruction is referred to in the description of No. 7 Enclosure.

In the soil débris pile, which had been removed from No. 7 Enclosure into this enclosure in 1891 by Bent, was (in August, 1902) found a piece of glass, being the lip portion of a bowl. This had bosses on its surface, with gold rims round each boss, indicating that the upper part of the neck of this bowl was once covered with gold enamel. This glass is believed to be identical with that found by Sir John Willoughby, and pronounced by authorities at the British Museum to belong to the thirteenth century.

\section{NO. 7 ENCLOSURE}

This enclosure is on the south side of the temple, the south and south-west wall running for $55 \mathrm{ft}$. parallel with the main wall at a distance of about $2 \mathrm{Ift}$. This enclosure, next to No. I Enclosure, is in the best state of preservation of any chamber within the temple. Its area is $54 \mathrm{ft}$. $6 \mathrm{in}$. from north to south, and $39 \mathrm{ft}$. from east to west, and its form resembles a quarter-section of a circle, with its rounded side extending from south-west to north, the centre of which quarter-circle is at the south-south-east end of the area. The present surface of the area is very uneven, owing to the operations of excavators and searchers for relics.

There are two entrances still more or less intact, one on the south-west side leading into No. 6 Enclosure, and the other at the north corner, but facing west. Possibly there was also an entrance on the east side, where a gigantic fig tree, $50 \mathrm{ft}$. high, now stands.

The south-west entrance (see section) is protected on the inside by rounded buttresses on either side, which project 

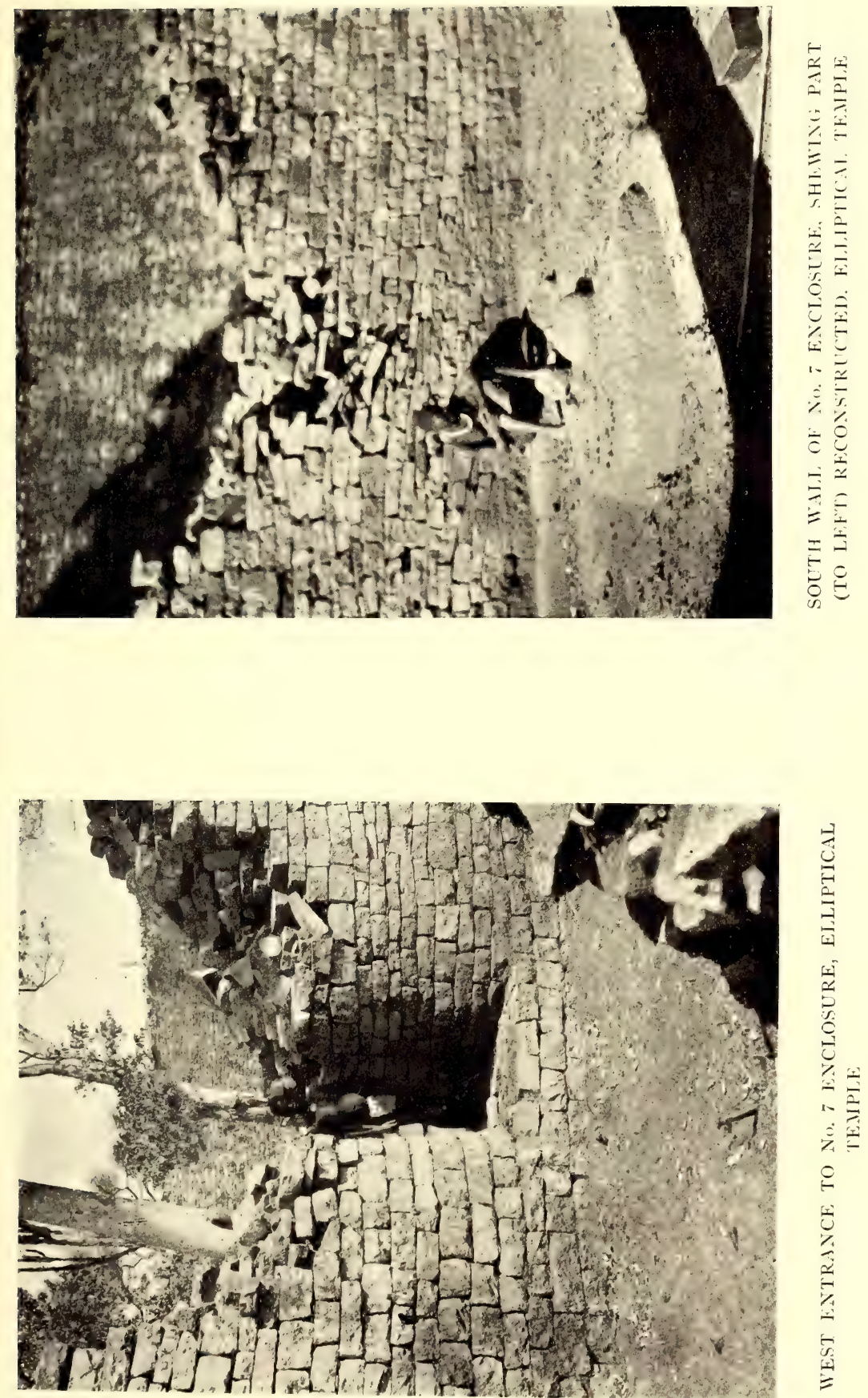

$2 \mathrm{ft}$. 6 in. into the enclosure. These buttresses, of which only the lower courses now remain, are built upon, and at each end of, a semi-circular base I I ft. long protruding $4 \mathrm{ft}$. 6 in. into the enclosure, the face courses of which curve inwards, one above and behind, the other between the side buttresses, and so form steps up to the entrance, the courses above the steps being carried round the buttresses. There are no traces of portcullis grooves. This is a form of steps found in the entrances through the main wall of the temple, and in the entrances in many ruins of the oldest or first-period style of architecture, whether at Zimbabwe or elsewhere in the country.

The north entrance is of exactly similar construction, but is in a better state of preservation, the one buttress remaining being still $5 \mathrm{ft}$. high. This entrance has portcullis grooves.

The best-built portion of the walls of this enclosure is undoubtedly that of the curved wall which extends from south-west to north. This is a fine piece of work, and the face of the wall is very regular. This wall is from I $\mathrm{ft}$. to I $3 \mathrm{ft}$. high on the inside, and I $\mathrm{ft}$. to I $4 \mathrm{ft}$. high on the outside, and is $4 \mathrm{ft}$. $6 \mathrm{in}$. wide in its present summit, the line of which is even except at its extremities. Judging by the block débris, this wall might once have been fully $2 \mathrm{ft}$. to $3 \mathrm{ft}$. higher. The centre of the outward curve of the wall is I I ft. west from a line drawn between the extreme points of the curve.

The south wall may be divided into two sections, the westerly portion being well built, and the easterly portion very poorly constructed, having numerous straight joints, disappearing and false courses, and is built of stones of all sizes and shapes. This latter part is evidently a reconstruction at a later date and on the old foundations. Where the joint was made between the old and the later walls is very clearly discernible, while there is a deep depression in the summit of the wall at this point. These depressions almost 
always exist in joints between old and later walls. This wall is $32 \mathrm{ft}$. long, between $8 \mathrm{ft}$. and $9 \mathrm{ft}$. high, and is $4 \mathrm{ft}$. wide on its reduced summit.

The eastern side is in four lengths: (I) a small portion of wall in the south-east corner $6 \mathrm{ft}$. long, $6 \mathrm{ft}$. high, and $4 \mathrm{ft}$. wide; (2) a gap of $14 \mathrm{ft}$., evidently made by past and present trees; (3) a wall $7 \mathrm{ft}$. high, I $3 \mathrm{ft}$. long, and $3 \mathrm{ft}$. wide on its summit (the lower portion of this section is built up against 4), but in the upper section it is built into it); and (4) a wall I6 ft. long, $9 \mathrm{ft}$. high, $4 \mathrm{ft}$. wide on summit. This wall has been partly ruined at its western end by the roots of a large tree.

The connection between sections (3) and (4) where the lower portion of (3) is built up against and is independent of (4), while the upper portion of (3) is built and bonded into and forms part of (4), has an exact parallel in the west wall of Recess Enclosure on the Acropolis, where the lower portions of two walls are independent of each other, but their higher portions are bonded and built as one wall.

In August, I902, some thirty tons of explorers' débris of old date were removed from this enclosure, and a floor of granite cement was disclosed at its south end, in the middle of which, and forming part of the cement work, is a raised circular platform 7 in. high, $16 \mathrm{ft}$. Io in. in circumference, and with rounded sides. Close to it was found a rounded piece of diorite extensively marked with hammerings, as if it had been used for an anvil.

Along the base of the south wall is a cemented edging $6 \mathrm{in.} \mathrm{high,} 7 \mathrm{ft}$. long, with rounded edges, protruding 8 in. to I 2 in. from the wall. In the south corner are two blind steps made of granite cement (see Architecture-Blind Steps). 


\section{CHAPTER XII}

\section{THE ELLIPTICAL TEMPLE \\ (Continued)}

Sacred Enclosure-Conical Tower-Small Tower-Parallel Passage.

No. 8

THE SACRED ENCLOSURE

THIS enclosure, which contains the Conical Tower and

1 the now ruined "Little Cone," lies on the south-east of the temple area, the main east wall from south-east to eastnorth-east being its eastern boundary from ( $186 \mathrm{ft}$.) to (3 I $5 \mathrm{ft}$ ).

In shape it is long and narrow, the Conical Tower practically dividing the area into two almost equal sections: Sacred Enclosure (east), and Sacred Enclosure (west).

The length of this enclosure measured along the inside face of the main wall is $129 \mathrm{ft} .2$ in. The northern side is formed by sections of walls which in the main run parallel with the south wall of the temple. The northern sections of walls are at the following distances from the main wall: at the extreme west $25 \mathrm{ft}$; ; at (I $86 \mathrm{ft}$.) $3 \mathrm{I} \mathrm{ft.;} \mathrm{on} \mathrm{either} \mathrm{side} \mathrm{of} \mathrm{the} \mathrm{Conical}$ Tower $26 \mathrm{ft}$; ; at ( $300 \mathrm{ft}$.) I $7 \mathrm{ft}$.; and at the extreme east $5 \mathrm{ft}$., this last portion for $\mathrm{I} 3 \mathrm{ft}$. being greatly narrowed by large buttresses on either side up to the entrance of the Parallel Passage.

The northern wall sections commencing at the west end are as follows :--

A wall $28 \mathrm{ft}$. long forming the south wall of No. I I Enclosure. The first section of $20 \mathrm{ft}$. is indifferently built, but the last $8 \mathrm{ft}$. well constructed. The joint between the two classes of walls is obvious, and the inferior wall is considerably dilapi. 
dated at its western end, especially at the western entrance. The highest portion is $9 \mathrm{ft}$. $6 \mathrm{in}$. above the present surface of the interior.

The second section is the south wall of The Platform, which rounds on a length of $24 \mathrm{ft}$. into Sacred Enclosure (west) for $7 \mathrm{ft}$., and recedes again directly north of the Conical Tower. This rounded wall is exceedingly well built. Its summit is practically level, and its height is I I $\mathrm{ft}$. to I $4 \mathrm{ft}$., according to the rise and fall of the floor or steps of the enclosure.

The third section is a wall $48 \mathrm{ft}$. long, extending from north of the Conical Tower to the entrance of the Parallel Passage. From the south side of this wall, and just inside the north entrance, is a wall $\mathrm{I} 3 \mathrm{ft}$. high, $5 \mathrm{ft}$. wide, narrowing as the Conical Tower is approached, projecting towards the north-east side of the Conical Tower. The last $27 \mathrm{ft}$. of this third section is evidently of a later period construction. The joint of the older and later walls is very clearly defined, and there is a depression on the summit at this point. The height of the wall varies from $14 \mathrm{ft}$. to $16 \mathrm{ft}$.

The Sacred Enclosure has four entrances-south-west, west, north, and east.

The south-west entrance is from No. 6 Enclosure. This has rounded walls and portcullis grooves, and is $5 \mathrm{ft}$. high on either side, $2 \mathrm{ft}$. wide, and runs through a wall $4 \mathrm{ft}$. Io in. thick. On the inside of this entrance are the remains of steps which relic prospectors have destroyed. The floor of the entrance is $4 \mathrm{ft}$. above the floor of the enclosure.

The western entrance, which leads from No. 9 Enclosure, is also rounded, and had portcullis grooves, and its floor was once paved with cement. This entrance is in a very dilapidated condition, owing to trees and creepers.

The north or main entrance to this enclosure is rounded on either side, and has portcullis grooves. It is $2 \mathrm{ft}$. IO in. wide, and is directly north of the Conical Tower, between 

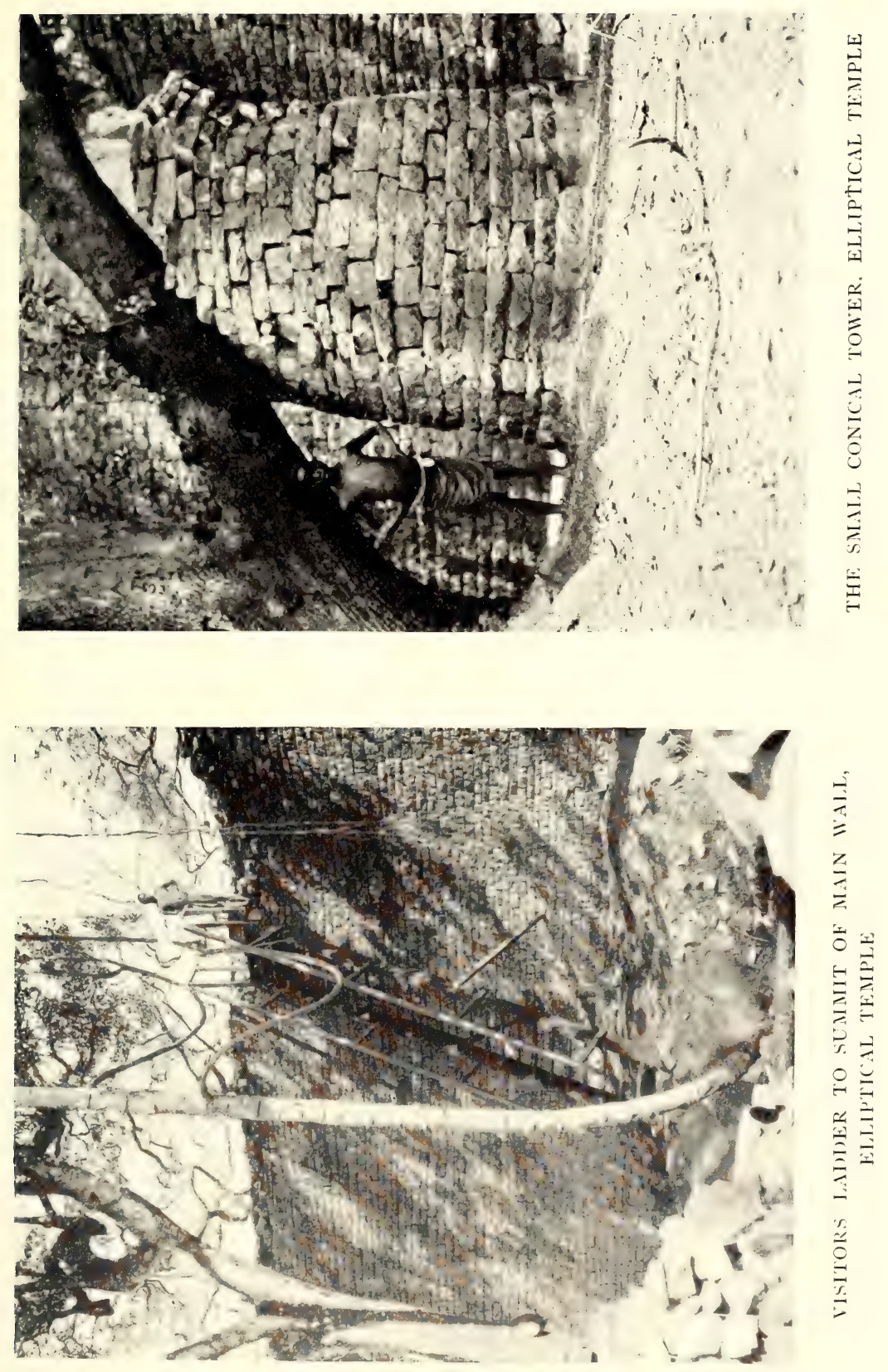

which and this entrance the floor is substantially paved with cement, and has cement steps leading down into the enclosure on the west side of the Conical Tower.

The east entrance leads from the Parallel Passage, and measurements of it are given in the description of that passage.

The buttresses on either side of the inner side of the eastern entrance have not the appearance of being ancient, unless they had once collapsed and been roughly rebuilt at a much later period.

The eastern section of this enclosure has been cleared of débris down to the level of a yellow granite cement floor. In several places this flooring has been destroyed by roots of both past and present trees of great size. This section appears to have had to absorb all rainfall from the south-east area of the temple, as this enclosure is at a much lower level than the adjoining enclosures, and this may account for the decomposition at some points of the cement floor. The clearing to the cement floor has also been carried round the base of the Conical Tower, which now stands upon an almost level floor. The spot where Bent sank the hole through the cement can plainly be seen on the south side of the tower. The clearing also disclosed a granite cement step at the north entrance with a level cement floor on the inner side between it and the north side of the tower. This floor is $2 \mathrm{ft}$. above the cement floor round the base of the tower, from which raised floor two granite steps between the tower and The Platform lead down to the floor of the western section of the enclosure.

In the western section the floor along the base of the main wall is buried in débris to a depth of $\mathrm{I} \mathrm{ft}$. 6 in. to $5 \mathrm{ft}$. From the base of the northern wall of this section to the centre of the area is a cemented floor laid on a pavement of blocks, but in some places the cement has become decomposed. In the west corner of this section of the enclosure is a floor 
raised $3 \mathrm{ft}$. above the cement floor, but this is very roughly built, and appears to have been a filling-in by some late occupiers of the temple. On the east side of this raised floor, and acting as its retaining wall on that side, are the remains of a wall $4 \mathrm{ft}$. high and $4 \mathrm{ft}$. wide projecting from the reconstructed portion of the north wall, and most probably of even a later date than the obviously reconstructed wall, seeing that it is built up against it.

In the angle formed by the 28 -ft. section of the north wall of the western area and the wall of The Platform is a set of "blind steps," two in number, and with a platform $8 \mathrm{ft}$. by $6 \mathrm{ft}$. square, the steps and the platform being covered with granite cement (see Architecture-Blind Steps).

Small portions of granite cement are to be found in the joints of the blocks of the main wall up to a height of $7 \mathrm{ft}$., and also to a similar height on the north wall of the eastern section of this enclosure, while in the angle of this latter wall and the buttress built up against it are the remains of a granite cement dado (see Architecture-Cement Dadoes).

\section{THE CONICAL TOWER ${ }^{1}$}

This celebrated tower, which forms one of the chief architectural features of the Zimbabwe ruins, stands in the centre of the Sacred Enclosure, dividing it into two areas. The south-east of the tower is $3 \mathrm{ft}$. Io in. from the main wall of the temple (at $255 \mathrm{ft}$.) from the south side of the west entrance. It is $3 \mathrm{I} \mathrm{ft}$. high on its south-east face; $30 \mathrm{ft}$. on the south-west side; $26 \mathrm{ft}$. 6 in. on its north-east side; and $29 \mathrm{ft}$. on the north-west side. These measurements are taken from the actual foundation, which is only a few inches below the granite cement flooring surrounding its base on all sides but the north. The average height of the reduced summit of the tower in 1894 was $32 \mathrm{ft}$., and it was then far more level than as seen to-day. Bent believed the original height

\footnotetext{
1 See Frontispiece.
} 
to have been $35 \mathrm{ft}$., at which point he thought it once had a level top, $4 \mathrm{ft}$. in diameter. Photographs taken in I89I give a very good impression of what the tower was like previous to the dilapidation, which took place immediately after that time.

It is difficult to state the exact circumference of the base throughout the extent of the foundations, as a granite cement raised floor, with steps, is constructed up against the base of the north side, but it may be taken to be about $57 \mathrm{ft} .6 \mathrm{in}$. The measurements of the circumference of the tower at different heights are as follows: at $5 \mathrm{ft}$. above floor $53 \mathrm{ft} .8$ in. ; at Io ft., $50 \mathrm{ft} .4$ in. ; at I $5 \mathrm{ft}$., $46 \mathrm{ft}$. I in. ; at $20 \mathrm{ft}$., $39 \mathrm{ft}$; at $25 \mathrm{ft}$., $32 \mathrm{ft}$; at $27 \mathrm{ft}$. 6 in. (where the broken portion of the summit commences), $30 \mathrm{ft} .2 \mathrm{in}$. The average battering back of the tower, so far as the broken edges of the present summit will permit of approximately correct measurements being taken, is, at the following heights, as follows : at Io ft. above floor I ft. 7 in.; at $15 \mathrm{ft}$., I ft. IO in.; at $20 \mathrm{ft}$., $2 \mathrm{ft} .6$ in. ; at $25 \mathrm{ft}$., $4 \mathrm{ft} .2$ in.; and at $27 \mathrm{ft}$., $5 \mathrm{ft} .5$ in.

The battering is far more regular on the west and south sides, where it is also a few inches less severe. To secure the inclining back of the sides of the cone, the blocks from front to back on its circumference are laid on the flat on a dead level, and yet so slightly do the blocks of one course lie back beyond the edge of the faces of the blocks of the course below that, except at one or two points, it is almost impossible to notice where the batter takes place. Even the blocks in the bulge on the north side have been ascertained to be still perfectly level.

There is a slight bulging on the east and north-east sides at $\mathrm{Io} \mathrm{ft}$. to $\mathrm{I} 5 \mathrm{ft}$. above the floor, and this somewhat reduces the extent of battering-back on those sides at that height. This bulging creates an optical delusion, for visitors almost always declare that the tower has tilted slightly to the north-east. But this tilting has now been proved not to exist. 
There are many causes which may have brought about the bulging. A large branch of hardwood tree, the trunk of which is believed to have been over one hundred years old, had for years, even in light breezes, scraped up and down this side of the tower, and also it was on this side that most of the monkey rope, creepers, and bushes were growing out of the crevices of the tower from base to summit.

The foundations are exceedingly shallow, being only some Io in. to $\mathrm{I} 8 \mathrm{in}$. below the granite cement flooring. The foundation of the main wall near this point is only Io in. below the same flooring. The lowest course of blocks of the tower is of the average size of the blocks used in the face of the structure. These rest on what was originally granite cement, but which, with the dripping of storm water for centuries down the large area of the face of the tower, has now become mere yellow sand. This, however, remains very firm, and still makes a good foundation. The foundations have not at any point sunk below their original level, but there are evidences that its enormous weight has caused the tower to settle firmly on to its bed.

The present reduced summit of the tower, where it is intact, slants down from the west and south and south-east edges some $4 \mathrm{ft}$. towards the north-east, but the block débris on the summit only slants for $2 \mathrm{ft}$. in the same direction. In the centre of the summit is a hole sunk down into the top of the tower some $4 \mathrm{ft}$. It will be remembered that Dr. Karl Mauch (I87I) admitted having made this hole for the purpose of ascertaining whether the tower was solid. The hole was once much deeper, but débris has filled it up to $4 \mathrm{ft}$. from the summit. Mauch also made a second hole in the west face of the tower at $5 \mathrm{ft}$. from the floor. This also showed the tower to be solid. Theodore Bent (I89I) also made a hole for a similar purpose. This is on the south face, and extends from the foundation to $4 \mathrm{ft}$. above the flooring, and he pronounced the tower to be perfectly solid. A certain Rhodesian, bent, 
as he confessed, on finding "The Treasure Chamber" (!), made another hole on the east side, at $5 \mathrm{ft}$. from the ground, and with the same result, but this hole is so neatly built up afresh that it can only just be located. The hole made by Mauch remained unbuilt up until 1902, and several courses above it have consequently swagged. In 1902 a thin wire rod inserted in this last hole and passed through joints of internal dry masonry for $8 \mathrm{ft}$. towards the centre showed the tower to be solid.

The dentelle pattern, which Mauch stated ran round the eastern portion of the summit of the tower, is now represented by only ten blocks. These form three sets of double courses of the dentelle pattern, as on the summit of the eastern face of the Eastern Temple on the hill, and two blocks of a lower course more to the east, and two loose dentelle blocks lying on the summit of the tower. One extremity of the pattern was undoubtedly, as can be seen on close inspection, facing the south-east, but it extended some little distance round towards the east, but how far it is now quite impossible to ascertain. Mauch owned to having destroyed a portion of the pattern in making the hole on the summit.

The pattern was formed by two rows of wedge-shaped blocks placed to project 2 in. beyond the face of the wall, while above them, just as in the dentelle patterns elsewhere, were placed heavy blocks and throughs or ties, as if to bind effectively the stones forming the patterns, as the introduction of a decorative pattern in ancient walls anywhere in Rhodesia can be seen to have proved a point of weakness in the durability of the faces of the walls. The summit of the tower has been greatly dilapidated by small trees and bushes growing on the top, the stumps and roots of which can still be seen.

The best idea of the symmetry and accuracy of the contour of the tower can be obtained by standing on the summit of the main wall, near the top of the visitors' ladder. 


\section{THE SMALL TOWER}

The base of this stands in Sacred Enclosure (east), at $5 \mathrm{ft} .2$ in. north-east of the large tower. Its circumference at the cement floor is $2 \mathrm{Ift} .7$ in. At $4 \mathrm{ft}$. above the floor it has a circumference of $19 \mathrm{ft}$. Io in., the dilapidation not being so serious as to prevent this measurement being taken. The present reduced height is as follows: west side, $3 \mathrm{ft} .2 \mathrm{in}$.; south side, $4 \mathrm{ft}$. 6 in. ; east side, $6 \mathrm{ft}$. 6 in.; and north side, $5 \mathrm{ft} .3$ in.

Unfortunately this tower, which Bent proved to have been solid, has, within the last few years, been subject to serious dilapidation. Photographs taken in 1894 are now but a record of the appearance of this tower at that time, for now, on comparing the photographs with the tower, they have become obsolete. A large branch of the tall hard-wood tree, which stands $3 \mathrm{ft}$. from the east side of this tower, had thrown over the summit on to the floor on the west side, and in 1902 nothing of the tower was left save the outer face of the wall, the internal blocks having been taken out by some unauthorised relic prospectors. These were replaced, and all the blocks which belong to the tower preserved.

Bent (p. I I5) states :-

"The religious purport of these towers would seem to be conclusively proved by the numerous finds we made in other parts of the ruins of a phallic nature, and I think a quotation from Montfaucon's L'Antiquité Expliquée will give us the keynote of the worship: "The ancients assure us that all the Arabians worshipped a tower, which they called El Acara, or Alquetila, which was built by their patriarch, Ismael.' 'Maximus of Tyre says they honoured as a great god a great cutstone. This is apparently the same stone resembling Venus, according to Euthymius Zygabenus. When the Saracens were converted to Christianity they were obliged to anathematise this stone, which formerly they worshipped.' This tower (at Zimbabwe) doubtless corresponded to the sacred 
tower of the Midianites, called Penuel, or the 'Face of God,' which Gideon destroyed (Judges viii. 7). Allusions to these towers are constant in the Bible, and the Arabian historian, El Masudi (940 A.D.), further tells us that this stone or tower was eight cubits high, and was placed in an angle of the temple, which had no roof. Turning to Phœnician temple construction, we have a good parallel to the ruins of the Great Zimbabwe at Byblos (in Phœnicia), as depicted on the coins ; the tower, or sacred cone, is set up within the temple precincts, and shut off in an enclosure. Similar work is also found in the round temples of the Cabiri, at Hadjar Kem, in Malta, and the construction of these buildings bears a remarkable resemblance to that of those at $\mathrm{Zimbabwe}$, and the round towers, or nuraghs, found in Sardinia may possibly be of similar significance. MM. Perrot and Chapiez, in their History of Art in Sardinia, speak of these nuraghs as forts or temples, around which the primitive inhabitants of the island once lived. They are truncated cones, built with stone blocks of different sizes, narrowing at the top. The stones are unhewn as a rule, and laid on without mortar. Here, too, we have a parallel for our monoliths, mention of unhewn stone, and also for the phalli, specimens of which are to be found carved on stone, and here, too, the intricate plan of the fortresses suggests at once a parallel to those at Zimbabwe; hence it would appear that the same influence was at work in Sardinia as in South Africa. In Lucian's De Syria Dea we find a description of a temple at Hierapolis, in Mesopotamia, in the propylæa of which, he tells us (p. I6), 'there stood two very large phalli, about thirty cubits high.' Our tower at Zimbabwe stood apparently twenty cubits high, and ten in diameter. He further says (p. 29), 'these phalli are solid, for when a priest had to ascend he had to put a rope round himself and walk up.'”

Dr. Schlichter, I898, remarks :-

"We have in the Great Zimbabwe an enormous gnomon (dial calculating point) before us, comprising a total angle of $120^{\circ}$. Taking all the details into account, I found 
that the obliquity of the ecliptic was somewhat more than $23^{\circ} 52^{\prime}$, which brings us (considering that we have a good Chinese observation of the same period) to a time somewhat I 100 B.C. for the erection of the Zimbabwe ruins." 1

\section{THE PARALLEL PASSAGE}

This passage, which is one of the most interesting features of ancient architecture at Zimbabwe, is $220 \mathrm{ft}$. long, and extends from (329 ft.) from the West Entrance to (5I3 ft.) from the same point, and runs along the inside of the east and north-east of the main wall of the temple, that is, from the Sacred Enclosure to the North Entrance of the temple.

The ancient priests could by means of this long, deep, and exceedingly narrow passage reach the Sacred Enclosure from the exterior of the temple altogether unobserved, seeing that along its whole length it has no communication with any other part of the interior of the temple. It is therefore possible that this passage might have been exclusively used by the ministers of the sacred rites. In it have been found the bulk of the phalli yet discovered at Zimbabwe, and a number of both plain and decorated phalli were found here in August, 1902, when the débris which had covered its floor was being removed. The same surmise might be made with regard to the purpose of the Parallel Passage at the Western Temple on the Acropolis.

The summit of the main wall on the outer side throughout the length of the passage averages from $28 \mathrm{ft}$. to $3 \mathrm{I} \mathrm{ft}$. above its present floor (see Tables of Measurements of Main Walls). The inner parallel wall varies in height, owing to dilapidations caused by past and present trees. This wall averages from $8 \mathrm{ft}$. to $16 \mathrm{ft}$. in height. The long and narrow passage between such high walls imparts a most weird and romantic aspect to this portion of the temple. The high, magnificently

\footnotetext{
${ }^{1}$ Several independent astronomical calculations point to the age of the Elliptical Temple being from I 100 to I 300 years B.C.
} 


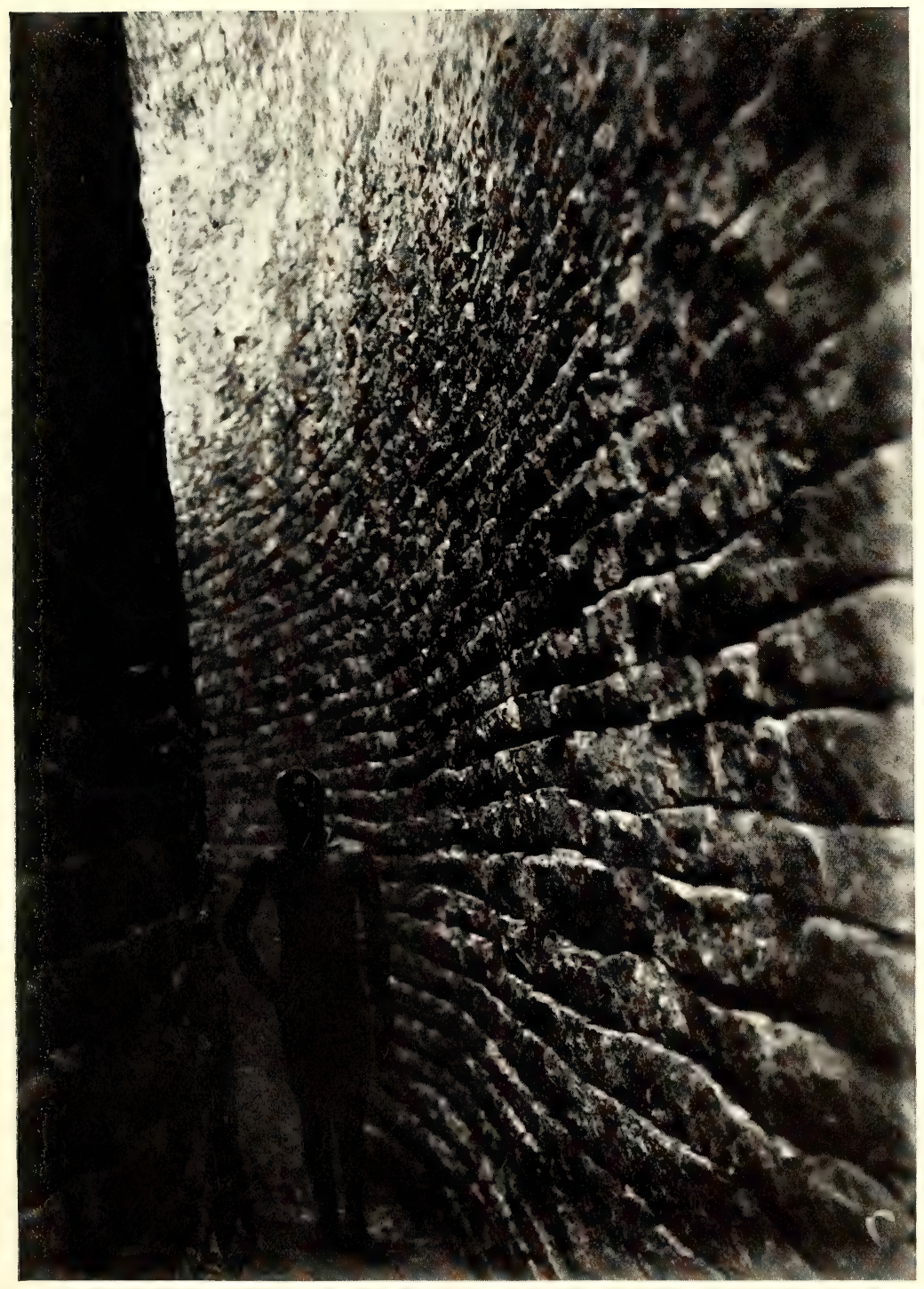

THE PARALLEL PASSAGE, FROM SOUTH, ELIIPTICAL TEMPLE 

sweeping, and massive walls tower on either side for a considerable distance on a bold masterly curve that displays in the well-built and regular courses of the walls design and workmanship which always strongly impress the modern builder with unfeigned surprise and wonder.

At the extremity near the Sacred Enclosure the passage is $4 \mathrm{ft}$. wide, but at $30 \mathrm{ft}$. further north-east it is $3 \mathrm{ft}$. 6 in. wide, at $55 \mathrm{ft}$. it narrows to $2 \mathrm{ft}$. $6 \mathrm{in}$., which width is maintained for about $40 \mathrm{ft}$., at the end of which it widens out owing to the inner parallel wall being here built upon a comparatively straight line. At ( $440 \mathrm{ft}$.) it is $4 \mathrm{ft}$. 6 in. wide, at

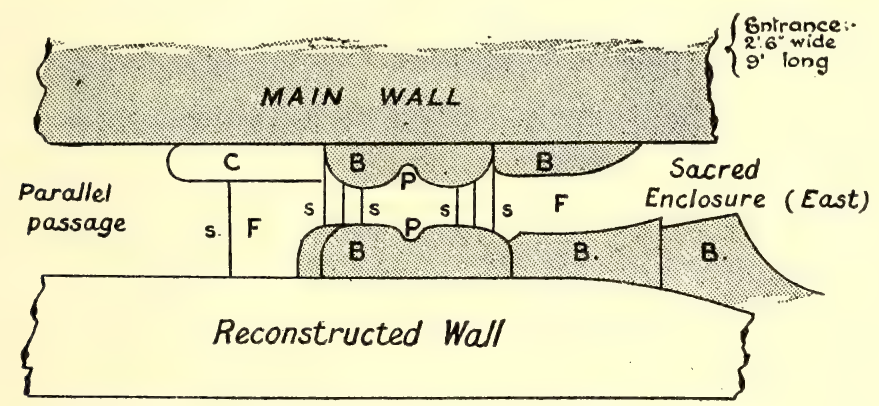

\section{West Entrance to}

PARALLEL PASSAGE Elliptical Temple
B. Buttresses

P. Portcullis Crooves

s.s. Steps

C. Cement Platforms

F. Cement Floors

( $460 \mathrm{ft}$.) $5 \mathrm{ft} .6 \mathrm{in}$. wide, at ( $48 \mathrm{oft}$.) $7 \mathrm{ft}$., and at $(5 \mathrm{r} 3 \mathrm{ft}$.), which is its northern extremity, it narrows to $2 \mathrm{ft}$. 6 in. Between ( $490 \mathrm{ft}$. ) and ( $5 \mathrm{I} 3 \mathrm{ft}$.) there is a large gap in the main wall, where its inner face has collapsed into the passage. The bottom of the gap is about $6 \mathrm{ft}$. above the present level of the passage floor.

Between (349 ft.) and ( $362 \mathrm{ft}$.) the inner parallel wall has collapsed into the passage, but the débris has now been cleared away. Between (470 ft.) and ( $500 \mathrm{ft}$.) the inner wall has been reduced by falls to a height of only $6 \mathrm{ft} .9 \mathrm{in}$.

The north wall of the Sacred Enclosure (east) is continued for $55 \mathrm{ft}$. as the west wall of the passage. This section is 
obviously a reconstruction of a later date, the joints with this wall and the rest of the older and better-built wall at the south end can be seen near the small conical tower in the Sacred Enclosure, the opposite side of this joint being distinctly noticeable in No. I I Enclosure. The joint at the north-eastern end of this reconstructed section of wall can be seen near $(375 \mathrm{ft}$.), where the older wall recommences. This less excellently reconstructed wall shows a far greater amount of dilapidation than does the older portion. This circumstance is to be noticed in more than a score of other instances of reconstruction of lengths of older walls, the invariable experience in Zimbabwe architecture being that the reconstructed portions are much less lasting, although they are of later date, and these reconstructions always show a depression in their summits at the joints with the older portions of the wall.

The entrance into this passage from the Sacred Enclosure is the east entrance mentioned in the description of that enclosure, and is at ( $320 \mathrm{ft}$.). It is formed by rounded buttresses, $7 \mathrm{ft}$. high, on either side of the passage. The entrance is $2 \mathrm{ft}$. 6 in. wide, $9 \mathrm{ft}$. long (including the steps at either end), and has portcullis grooves of unusually large size. It is approached from the Sacred Enclosure by three large, broad, and deep block steps, which are still in a very good state of preservation, not one block being missing or even out of place. The floor is excellently paved with blocks. On the passage side of the entrance are three block steps also in a splendid condition, but these are narrower, as the rounded foundation of the west buttress projects 7 in. into the passage further than the upper portion of the buttress.

Immediately inside this entrance, and against the base of the main wall, is a raised level with rounded edges made of granite cement. This is $7 \mathrm{ft}$. long, I ft. Io in. wide, and 3 in. higher than cement flooring, and $6 \mathrm{in}$. high at its north-east end above a step-down in the floor. Between this raised 


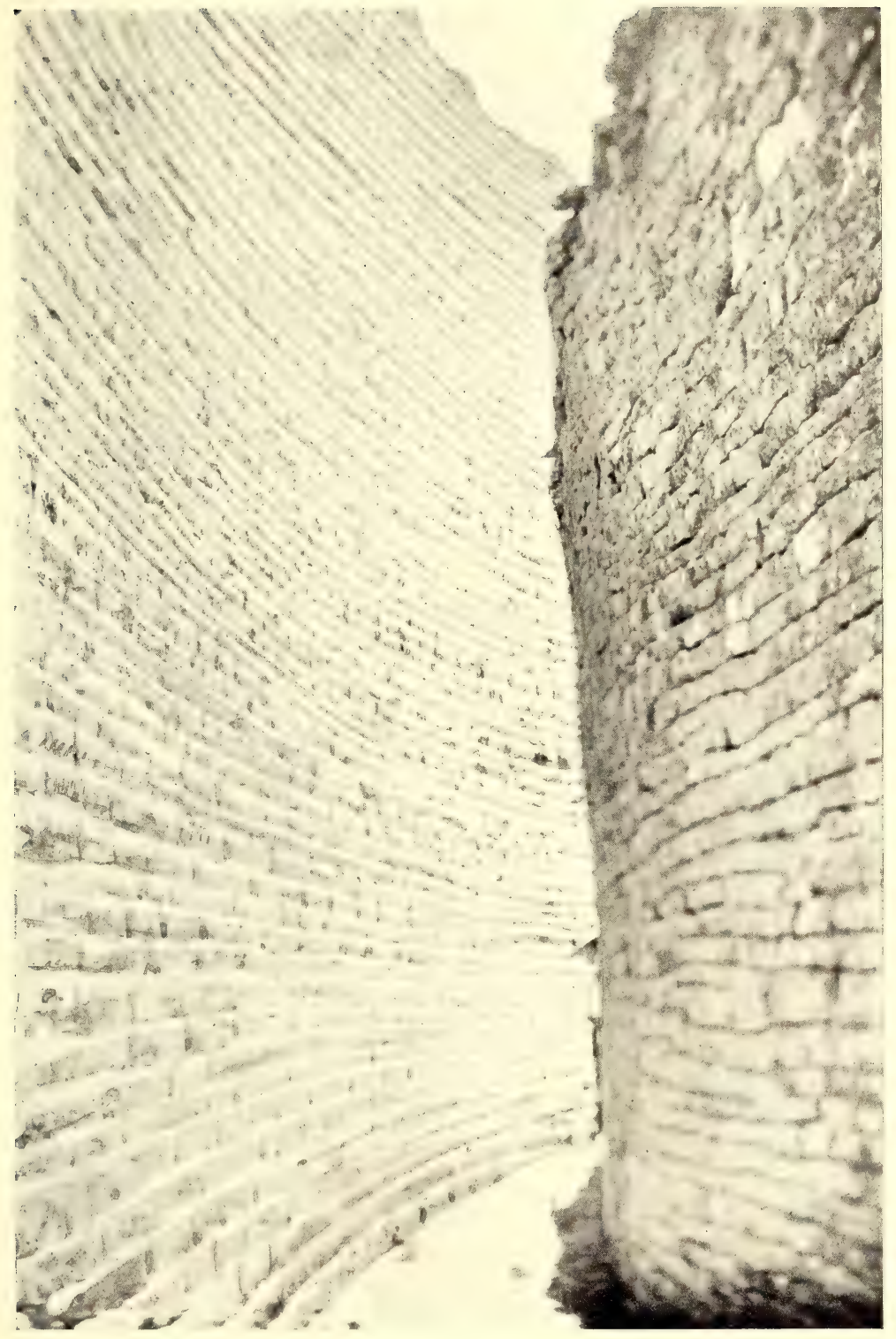

PARALLEL PASSAGE, FROM NORTH, ELLIPTICAL TEMPLE 

cement level and the west wall of the passage is a cemented floor $4 \mathrm{ft}$. 4 in. long, with a rounded face at its north-east end, this face forming the step-down just mentioned. The floor from this point northwards to $(335 \mathrm{ft}$.) has been broken through by excavators, but from ( $335 \mathrm{ft}$.) northwards to $(425 \mathrm{ft}$.) the cement flooring still remains intact. From $(425 \mathrm{ft}$.) to the northern end of the passage the floor has been torn up by explorers.

Evidently the ancients were thoroughly well versed in the art of sanitation, for the lengths of cemented flooring are divided into catchment areas, separated from each other by raised step-barriers $4 \mathrm{in}$. high, $3 \mathrm{ft}$. Io in. broad, laid across the passage. These are made of granite cement and have rounded edges. The floor has a slight fall on either side of these raised barriers, and in the lowest part of each area is a drain-hole passing through the main wall, the object evidently being to divide up the rainfall so that each drain should only have such a quantity of water as its capacity would allow it to carry off. The drain-holes passing outwards and downwards through the main walls are at $(352 \mathrm{ft}$.), (39 I ft. 6 in.), ( $442 \mathrm{ft}$.), and ( $47 \mathrm{Ift}$.). These are believed to have once been lined with yellow granite cement. It is possible that other drains from this passage-way may yet be found.

Near ( $396 \mathrm{ft}$.) is a drain-hole leading into the passage from No. I4 Enclosure.

The floor at the extreme north end of the passage has not yet been uncovered, as it would be unsafe to remove any more depth of soil owing to the threatening condition of the wall at the gap before mentioned.

Near ( $338 \mathrm{ft}$.) is a flat granite beam $6 \mathrm{ft}$. long, which has evidently fallen from the summit of the main wall.

The Parallel Passage and Sacred Enclosure were used by old and recent generations of Makalanga as places in which to deposit their ash, pottery, iron, and bone débris, and this 
was found in places to a height of $3 \mathrm{ft}$. and $4 \mathrm{ft}$. The bones were of animals, mostly of buck, but some of oxen, and all had been split open for the marrow, as is usually found to be the case in all Makalanga débris heaps whether at any ruins or at their villages. Being sunless and damp these two places for occupation purposes appear to have been avoided by them. 

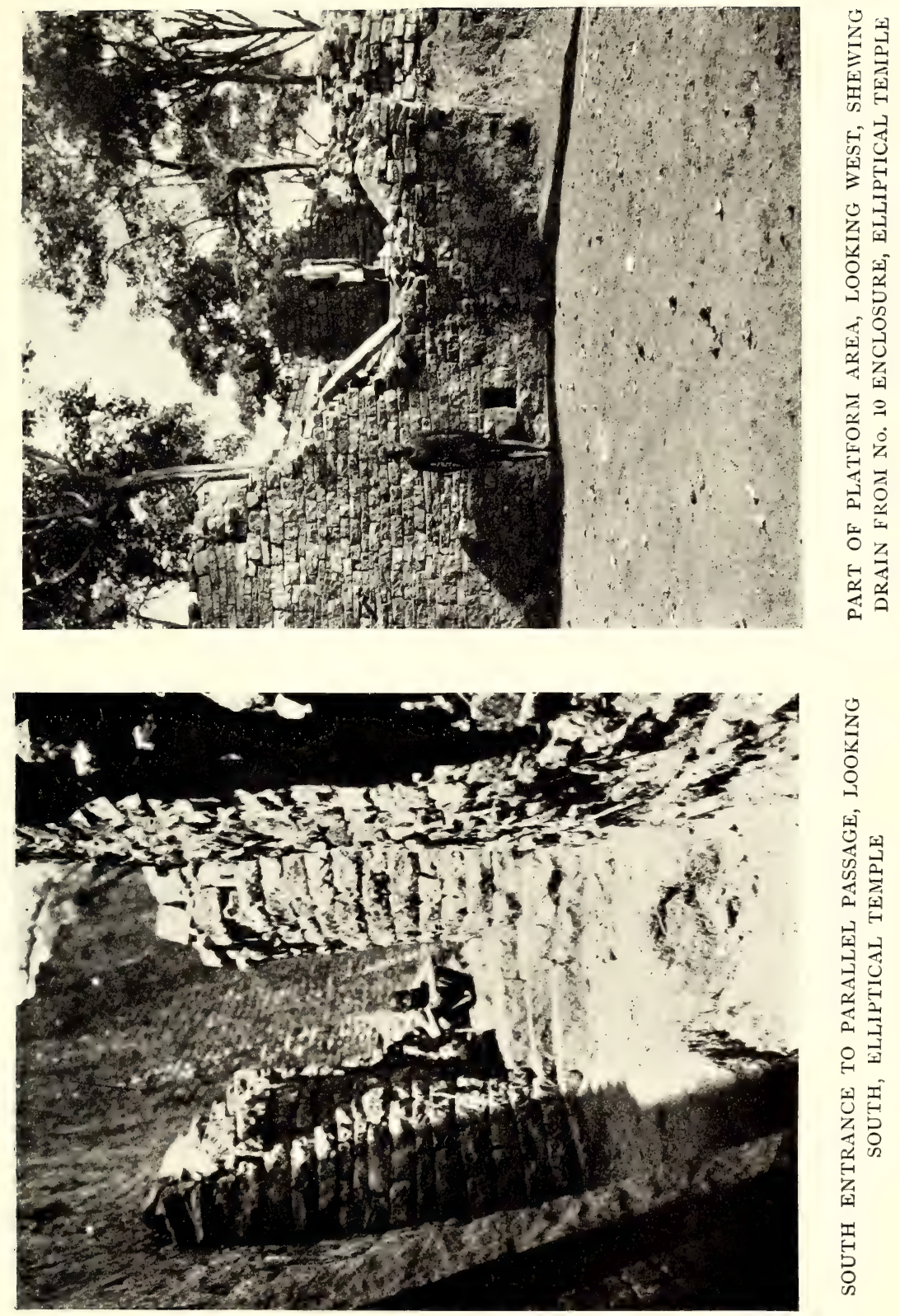



\section{CHAPTER XIII \\ THE ELLIPTICAL TEMPLE \\ (Continued)}

The Platform-Enclosures Nos. 9 to 15 -Central area-Platform areaInner Parallel Passage-South Passage-West Passage-North-East Passage-Outer Parallel Passage.

\section{8a. THE PLATFORM}

THIS is a raised platform standing immediately in front 1 of the Conical Tower at a distance of $4 \mathrm{ft}$. from north to north-west. The proximity of this structure to the Conical Tower, its position in front of it, its summit commanding a view of the interior of the temple, particularly of the interior of the Sacred Enclosure, its peculiar form as compared with other structures in the temple, and the excellent workmanship displayed in its walls, as well as the decoration of green chlorite schist on its east wall, would appear to show that it possessed some highly important significance in the minds of the ancient worshippers. So much is this so that visitors most frequently remark that this structure must have been the "pulpit" from which the priests addressed the crowd of worshippers.

The Platform possesses no angular feature. Its plan is oval, the entrance is rounded, and the curves of the walls are excellently worked out. The southern and eastern half of this building now only remains intact, the northern half, though still traceable, having been pushed over northwards by a huge tree. 
The inside area of the southern half is $\mathrm{I} 4 \mathrm{ft}$. from north to south, and $\mathrm{I} 6 \mathrm{ft}$. from east to west. The heights of its sides are as follows: east side, $9 \mathrm{ft}$. from granite cement step on floor of No. I I Enclosure; west side, Io ft. above floor of No. 9 Enclosure, including $3 \mathrm{ft}$. height of terraced wall; south side, I $2 \mathrm{ft}$. above floor of Sacred Enclosure (west), and I I ft. from top of "blind steps" in the same enclosure; the north side is ruined. The wall on its present summit is from $2 \mathrm{ft}$. to $2 \mathrm{ft} .6 \mathrm{in}$. wide.

On the inside, and at a height of from $2 \mathrm{ft}$. to $4 \mathrm{ft}$. below the summit of the wall, is a raised platform $2 \mathrm{ft}$. wide running round the inside of the wall. This platform, which, in fact, is banquette work, is paved with stones, and these are covered with granite cement. This banquette was approached by well steps ascending up in the centre of the interior, and these were made of blocks covered with granite cement.

The entrance to The Platform is on the north-east side, but only one side is now remaining. It is $9 \mathrm{ft}$. high and is rounded. The large upper granite cement step on the floor of No. II Enclosure led up to this entrance. The decorative pattern on the outer face of the north-east wall is described in the account of No. I I Enclosure.

This Platform appears to have served an identical purpose as that of the elevated Platform at the Western Temple on the Acropolis, and as that of the Ancient Balcony which commands the interior of the Eastern Temple on Zimbabwe Hill.

Bent stated that in I89I a tall unhewn granite monolith stood erect immediately north of The Platform, but there is no trace now of its existence, and several old residents of Victoria say it must have disappeared before they first visited the ruins. ${ }^{1}$ The positions of all three of the platforms suggest some purpose in the ancient religious services.

${ }^{1}$ This has been now found by the author. It had been removed in 1892 by relic hunters. 


\section{NO. 9 ENCLOSURE}

This enclosure lies to the north of the western end of Sacred Enclosure (west), to the east of No. 7 Enclosure, to the west of The Platform, and to the south of the south passage to No. Io Enclosure and of No. Io Enclosure.

Its area is : north side, $26 \mathrm{ft}$. ; west side, $26 \mathrm{ft}$; east side, $42 \mathrm{ft}$. ; and south side, $24 \mathrm{ft}$.

The south side is formed by the wall dividing this enclosure from Sacred Enclosure (west), and this is $9 \mathrm{ft}$. high, and shows the two classes of building as does the opposite side. The west side for $6 \mathrm{ft}$. from its south end is formed by a wall of this length, and which is $6 \mathrm{ft}$. high. This wall at its northern end terminates abruptly and leans northwards, being supported by a bank of soil débris. The rest of this side is formed by the bank of soil débris as far as the south passage to No. Io Enclosure. The north side is formed by the south wall of that passage and of No. Io Enclosure. The passage wall is $6 \mathrm{ft}$. high, and the enclosure wall $8 \mathrm{ft}$. high. The east side for $\mathrm{I} 4 \mathrm{ft}$. from the south end is formed by The Platform, and a terraced wall projecting westwards for from $5 \mathrm{ft}$. to $7 \mathrm{ft}$. The rest of the eastern side was an open space, until recently covered with soil débris.

An entrance from Sacred Enclosure (west) is in the southwest corner, and this is described in the account of that enclosure. This entrance on the north side has two stone steps covered with granite cement. The entrance from $N o$. IO Enclosure is described in the account of the passage to that enclosure.

At the south side there is a mass of granite cement rendered shapeless by roots of trees and creepers, and also considerably decomposed by annual accumulations of rainwater, as this is the lowest part of the enclosure. Traces of rounded faces can be seen at several points in this cement.

On the eastern side the floor is made of granite cement. 
This is only 4 in. thick, and underneath it are several thin layers of floors made of granite cement.

It is believed that the angle between The Platform and the south wall once held "blind steps." The quantity of decomposed granite cement found in this corner, together with traces of two steps on the terraced wall, rather confirms this belief.

\section{NO. IO ENCLOSURE}

This enclosure lies on the north side of No. 7 Enclosure. Until August, I902, nothing was known concerning it, nor could it have been examined during the last fifty years. The Makalanga, as previously stated, whose last occupation of the temple as a kraal was some sixty years ago, had filled it in with stones and rubble and laid a common clay floor over the filling-in, as was their usual practice in almost all the ancient ruins in Rhodesia which they occupied. On this clay floor was built a circular hut of clay. The filling-in completely buried portions of the walls of the enclosure.

In addition to this filling-in, the area had been used as a dumping-ground for soil excavated from neighbouring enclosures, and so much so that the soil heap was at least $6 \mathrm{ft}$. higher than the filling-in by the Makalanga, and it contained some twenty-five tons of soil, all of which has now been removed.

In form the enclosure has the shape of a quarter of a section of a circle, the square sides being on the south and west.

The south side is $27 \mathrm{ft}$. 6 in. long, the south entrance to this enclosure being at $20 \mathrm{ft}$. to $23 \mathrm{ft}$. from the west end. The south wall is the divisional wall between No. 7 Enclosure and this enclosure. It is massive and very well built, and is still from $6 \mathrm{ft}$. to $7 \mathrm{ft}$. in height.

The west side is $3 \mathrm{I} \mathrm{ft.} 6 \mathrm{in}$. in length. The first $2 \mathrm{I} \mathrm{ft}$. from its south end is well built, and is in a good state of preservation save for a reduction in its summit. It is $4 \mathrm{ft}$. 
wide at present level of ground. The northern extremity of the $2 \mathrm{I}-\mathrm{ft}$. length is rounded. The wall at its southern end is $8 \mathrm{ft}$, high, but for Io ft. at its northern end it averages only $4 \mathrm{ft}$. to $5 \mathrm{ft}$. in height. At $2 \mathrm{Ift}$. to $23 \mathrm{ft}$. along the west side of the enclosure is the western entrance, the northern side of which is formed by a rounded buttress, now only $2 \mathrm{ft}$. in height. The rest of the wall towards the north is very dilapidated.

The east side, which curves outwards towards the east, measures $40 \mathrm{ft}$. along the face of the wall. The length of $27 \mathrm{ft}$. from the north end is formed by a wall of this length, which is $3 \mathrm{ft}$. to $4 \mathrm{ft}$. high and $3 \mathrm{ft}$. wide. This wall is obviously of poor and late construction as compared with the west and south wall of this enclosure, and crosses in the middle of its length, at right angles, an old substantial foundation running east and west. The foundation of the upper wall is laid on the block and soil débris on the summit of the buried wall. Probably this buried wall was the north side of this enclosure at a lower level, and this would have once made the enclosure square in form. The eastern wall terminates at its south end with an angular buttress $2 \mathrm{ft}$. 6 in. wide, which protrudes westerly 16 in. into the enclosure, where it terminates abruptly in a broken end. From the 27 -ft. point to the sound end of the wall is a very well-built substantial wall $4 \mathrm{ft}$. 6 in. wide at base, but for $5 \mathrm{ft}$. from its north end it is I ft. only above the present floor, but for the rest of its length it is $6 \mathrm{ft}$. in height. Where the wall so rises in height it is rounded across the wall, and this may have been the south side of an eastern entrance into the enclosure.

Though this enclosure has been cleared, the coarse red clay of the Makalanga still remains in the centre of the area, but in the angles of this enclosure and along its south side is some yellow granite cement of a far greater age.

On the yellow granite cement a quantity of what appear to have been gold-burnishing tools were found. All these 
were originally water-worn, but showed signs of having been artificially worn as tools. Five of these showed gold richly on the sides used for burnishing, others also showed gold. This was the only enclosure in this temple where such tools were found, and the number of them discovered at and near one spot suggests that this enclosure was in pre-Kafir occupation days a gold-burnisher's workshop, just as No. 7 Enclosure was evidently a goldsmith's workshop, while for corresponding reasons No. 6 Enclosure was a chief place for the smelting of gold. A quantity of pottery made of soapstone clay, the first of such pottery yet discovered, was found in this enclosure.

\section{SOUTH APPROACH TO NO. IO ENCLOSURE}

This is formed by a passage Io $\mathrm{ft}$. long, which enters this enclosure at its south-east corner. It is probable that this passage was much longer, and that it once extended to the north-west corner of the Sacred Enclosure, where is an entrance facing the passage.

The west side of the passage is formed by a wall $\mathrm{I} 4 \mathrm{ft}$. $6 \mathrm{in}$. long, $4 \mathrm{ft}$. high, and $3 \mathrm{ft}$. 6 in. on its present reduced summit, which wall is also the east wall of $\mathrm{No} .7$ Enclosure.

On the east side is a very well-built wall ro ft. 6 in. long, $4 \mathrm{ft}$. 6 in. high, and $3 \mathrm{ft}$. wide on its present summit, with a finely constructed rounded end tapering upwards and facing south. The rounded end is $7 \mathrm{ft}$. high, and rises from the floor of No. 9 Enclosure, which is on the east side but on a lower level.

The south end of the passage is $4 \mathrm{ft}$. wide, but the north end is $6 \mathrm{ft}$. $6 \mathrm{in}$. wide, but is narrowed to $2 \mathrm{ft}$. 6 in. by a rounded buttress $4 \mathrm{ft}$. $6 \mathrm{in}$. high, and this and the rounded wall opposite, which forms the other side of the entrance, have upright portcullis-like grooves.

The floor of the passage is paved with flat shallow stones covered for 2 in. in depth with granite cement. 


\section{NO. I I ENCLOSURE}

This immediately adjoins on the north side of Sacred Enclosure (east). On the west side it is bounded by The Platform, on the east by a large rounded buttress which separates it from No. I 2 Enclosure, but its northern boundary, if any, is at present difficult to determine.

Through this enclosure is the northern entrance to the Sacred Enclosure, and this entrance is within $8 \mathrm{ft}$. of the north face of the Conical Tower. Evidently both from its close proximity to the Sacred Enclosure, the Tower, and The Platform, the ancient occupiers considered this enclosure to be of importance, and the splendid construction of the massive steps leading toward the tower would appear to further confirm the correctness of this conjecture.

The area is, south side I $8 \mathrm{ft}$. ; west $\mathrm{I} 4 \mathrm{ft}$; ; east $\mathrm{I} 4 \mathrm{ft}$. ; and north $\mathrm{I} 7 \mathrm{ft}$.

The wall on the south side is $13 \mathrm{ft}$. high at its western end, but is reduced by dilapidation to $6 \mathrm{ft}$. at the entrance to the Sacred Enclosure. At its highest point are five parallel horizontal bands of green chlorite schist ${ }^{1}$ separated from each other by two courses of granite blocks. This wall is excellently built, and most patently differs in style and excellence of construction from the same wall which also forms the southern side of No. I 2 Enclosure, and the difference strongly suggests that during the later ancient occupation the part of the wall which was continued into the adjoining enclosure fell down and was rebuilt only in a poorer style. This can also be seen on the opposite face of the wall in the Sacred Enclosure.

1 Report on the examination and analysis of No. I sample of minerals :-

This was a piece of metamorphic slate, such as may be found in the vicinity of the contact-zone of clay slate and granite or other crystalline rock. Its composition does not present any peculiar features.

P. DANiel Hahn, PH.D., M.A. 
The wall on the west side is the outer face of the east wall of The Platform. This is $9 \mathrm{ft}$. high, measuring from the granite cement step at its base, and Io ft. long. At the north end of this wall, which is rounded, is the approach to the summit of The Platform. On the face of this wall, and starting from the entrance to the Sacred Enclosure, is a decoration of seven parallel and horizontal rows of green chlorite schist, with two courses of granite blocks between each. Each row begins close up to the entrance, but all terminate towards the north of the wall, each lower row extending some 6 in. more north than the one above it.

On the east side the rounded buttress projects $6 \mathrm{ft}$. 6 in. from the south wall, and is still $4 \mathrm{ft}$. $6 \mathrm{in}$. high, and I I ft. long measuring towards the east. This length may be divided into two portions, the eastern part which is angular and of poor construction, being in all probability a later erection to support the joint in the superior and poorer portions of the south wall, also the western portion already described. On the north side of this buttress is a granite cement floor raised 4 in. above the floor of the enclosure, and the step is rounded along its edge. The western and northern sides of this buttress were once faced with granite cement 3 in. thick in the form of a dado. A portion of this cement still remains on the north side, and the quality of the cement is identical with the cement found in dado fashion on the taces of other walls in the temple and on the Acropolis. The eastern addition to this buttress does not appear ever to have had a cemented dado.

The most striking features of this enclosure are its most excellent granite cement floor and its massive rounded steps. Until October, I902, this enclosure was filled up to a height of $5 \mathrm{ft}$. above the present opened-out floors. The lowest strata of filling-in, $2 \mathrm{ft}$. thick, had been made by rains washing in the soil from adjoining and higher enclosures, the drain-hole through the south wall having become blocked. There was 


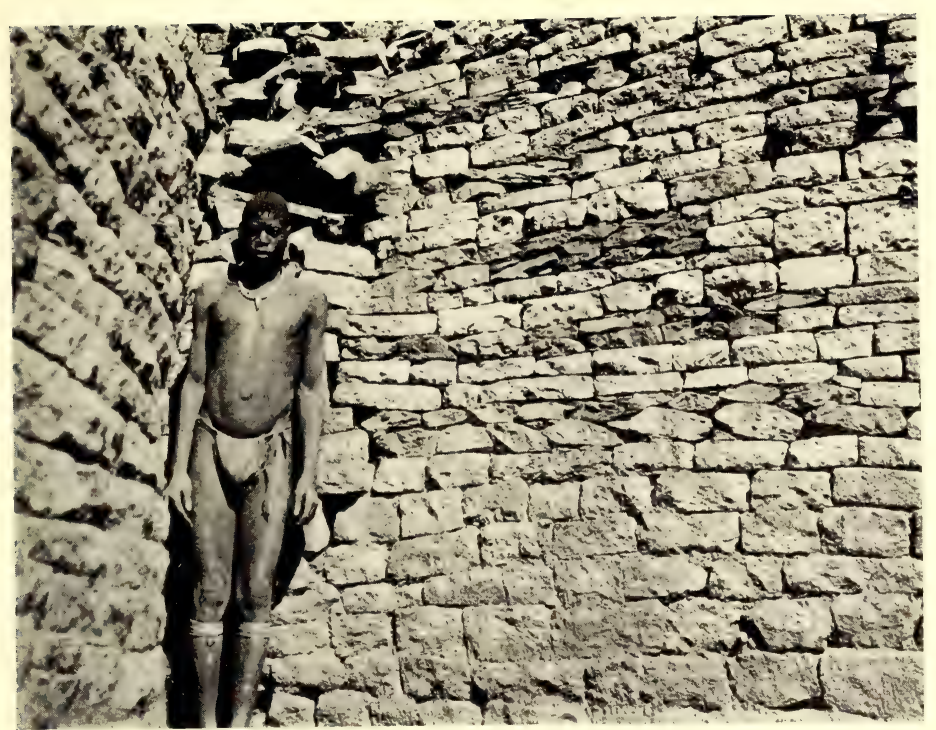

SOUTH WALL WITH PATTERN, No. 11 ENCLOSURE, ELLIPTICAL TEMPLE

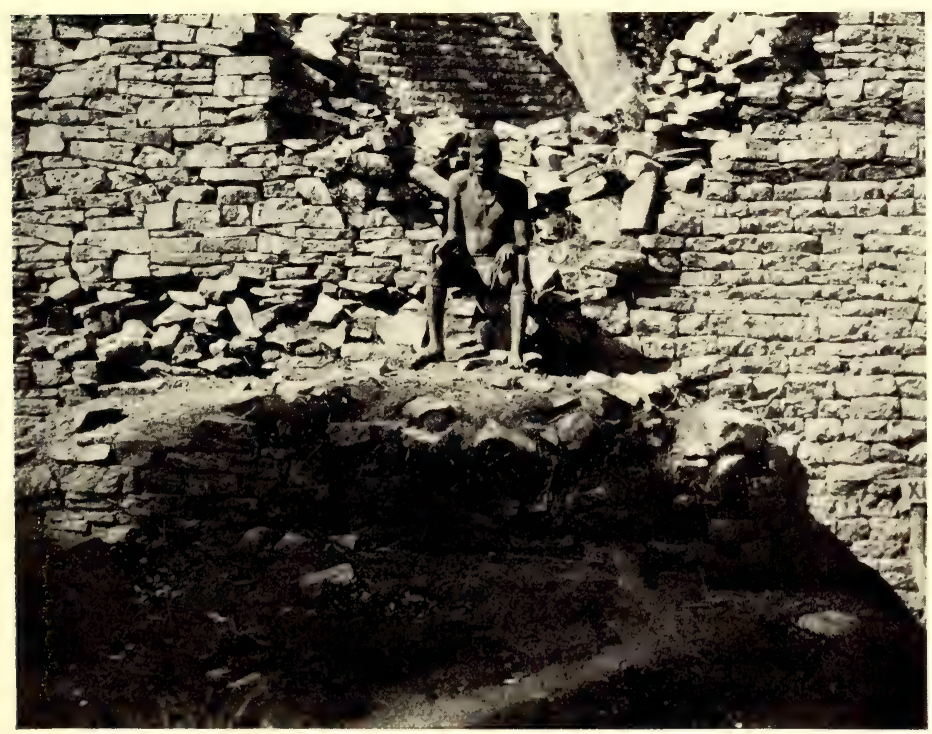

JOINT BETWEEN ORIGINAL AND RECONSTRUCTED WALLS, Nos. 11 \& 12 ENCLOSURE, ELLIPTICAL TEMPLE 

no vegetable matter in this stratum. The stratum of fillingin above the lowest one was a deliberate filling-in and levellingup by Makalanga of a very early period, for this débris contained articles such as pottery, assegai-heads, clay whorls, which, though strongly resembling those of the present Makalanga pattern, were of a somewhat better quality than those made by them either to-day or within the last few generations. This stratum of filling-in was done at one and the same time, for the line of stratification was perfect and unbroken. Above this stratum was one of ordinary daga (clay) and not cement, and this contained articles more closely resembling those of present Makalanga make, but this stratum must have been filled in, judging by the quantity of débris found, more than seventy years ago, for according to local native accounts it was fully seventy years ago when the Makalanga ceased to occupy the Elliptical Temple as a place of residence, though sacrifices of oxen on certain feast days, as mentioned by Mauch, Phillips, and Bent, and local chiefs, took place in the temple down to thirty years ago, if not somewhat later. Above this stratum and forming the surface was a stratum of very rich leaf-mould about 18 in. thick, and this was matted with vegetable growth.

On digging out the roots of a large parent monkey-rope tree, which had done considerable damage to the south wall of this enclosure, and which tree appears in all the old photographs of the Conical Tower, a section of an ancient floor was discovered at a depth of $5 \mathrm{ft}$. Some twenty tons of filling-in were removed, and the whole of the cement floor as seen to-day was exposed. The old visitors' path crossed this enclosure $5 \mathrm{ft}$. above this cement floor.

The cement-work in this enclosure is most excellent, hardly a scratch being seen upon its surface. It is the finest and most perfect specimen yet found either at Zimbabwe or any ancient ruin in Rhodesia. The granite powder in the cement is so firmly set that picks cannot make any 
impression upon it. This flooring averages $\mathrm{I} 8 \mathrm{in}$. to $2 \mathrm{ft}$. in thickness, and must rest on a splendid foundation, for the levels of the floor are almost true to this day.

A large cement step runs north and south at $2 \mathrm{ft}$. from the west side. This is $\mathrm{I} 4 \mathrm{in}$. high and $5 \mathrm{ft}$. long, but originally, according to its curve and traces of its continuation, $7 \mathrm{ft}$. long. The step which has a rounded edge forms the lower portion of the approach to The Platform.

A second step runs from north to south at $5 \mathrm{ft}$. from the front of the first step, and slightly curves out eastwards. This step is I $2 \mathrm{ft}$. high, I I ft. 6 in. long, and has a boldly rounded edge. The floor has a slight fall to the south-east corner, where is a drain-hole which has its exit near the small tower in Sacred Enclosure (east).

The entrance to the Sacred Enclosure, which is in the south-west corner of this enclosure, is $2 \mathrm{ft}$. 6 in. wide, is rounded, and has portcullis grooves on either side.

\section{NO. I2 ENCLOSURE}

This immediately adjoins No. I I Enclosure on its northeast side. Its east wall for $28 \mathrm{ft}$. is formed by west wall of Sacred Enclosure (east), and for $2 \mathrm{I} \mathrm{ft}$. by the west wall of Parallel Passage. These walls are one, and curve outwards towards the east to the extent of $6 \mathrm{ft}$. from a line drawn from end to end of the wall in this enclosure. This east wall is $49 \mathrm{ft}$. long and ro $\mathrm{ft}$. high, and from the angular buttress at the south-west corner has a banquette wall, $4 \mathrm{ft}$. high, projecting I ft. 6 in., and continued north-east for $32 \mathrm{ft}$. from the buttress. This wall is of inferior construction to the same wall on the east side of No. I I Enclosure, the courses being most irregular, the stones ill-sorted, and there is no decoration on its face. The north-eastern portion is reduced to $3 \mathrm{ft}$. $6 \mathrm{in}$. in height for a length of $\mathrm{I} 7 \mathrm{ft}$., the upper portion having fallen into Parallel Passage. The angular buttress in the south-west corner appears to have been built at a later 
period, when the west wall of Sacred Enclosure (east) was rebuilt, for the buttress covers the joint between the original portion and the later portion, as if to strengthen the wall at this point. The north side for $\mathrm{I} 2 \mathrm{ft}$. is formed by a wall of this length, which is $4 \mathrm{ft}$. high and $3 \mathrm{ft}$. $6 \mathrm{in}$. wide on its present summit. But it is impossible at present to define either the western boundary or those of the remainder of the north and south sides, owing to the fact that all divisional walls in this portion of the temple have been covered over and buried during the period of some later occupiers.

In the angle formed by the east and south sides is a platform $6 \mathrm{ft}$. high and I I ft. wide, which is approached by five steps, the platform and the steps being covered with granite cement. Similar steps and platforms are found in the angles of other enclosures both in the Elliptical Temple and in the ruins on the Acropolis. These are all remarkably alike in position, dimensions, and construction, and all appear to have answered an identical purpose. The sizes of the steps, the nearness of the lowest step to the walls preclude the suggestion that they were flights on the summits of the walls. (See Blind Steps-Architecture.)

A drain passes under the small platform and it has cement rims to lead the water to it.

\section{NO. I 3 ENCLOSURE}

This adjoins No. I2 Enclosure on the north side, the west side of the inner wall of the Parallel Passage forming its eastern boundary for $25 \mathrm{ft}$. $6 \mathrm{in}$. This wall is $5 \mathrm{ft}$. high for I $8 \mathrm{ft}$. from the south end of the enclosure, and I I ft. 6 in. high for the last $7 \mathrm{ft}$. of its northern end.

The south side is formed for $12 \mathrm{ft}$. by the wall separating this enclosure from No. I2, but No. I 3 being at a lower level, this wall is $6 \mathrm{ft}$. high from the present filled-in surface of the enclosure.

The north and north-west side is formed by a wall $32 \mathrm{ft}$. 
long, with a rounded entrance from No. I4 Enclosure between the $2 \mathrm{I}-\mathrm{ft}$. and $23 \mathrm{ft}$. points of this length, measuring from the east end of this wall. The wall is fairly well built at its eastern end, where it is still $4 \mathrm{ft}$. high and $3 \mathrm{ft}$. 6 in. to $4 \mathrm{ft}$. wide on its present reduced summit. This wall is built upon a red cement foundation. The south-west end of the wall is very dilapidated, but appears to have been originally of good construction. [Owing to piles of soil débris on the south-west side of this enclosure, it is impossible at present to define the exact limits on that side, but the shape of the enclosure is that of a keystone, its widest and rounded end being on the east side.]

\section{NO. I4 ENCLOSURE}

This enclosure, which is on the east side of the temple, is where the Inner Parallel Passage opens into the interior of the building. The area is $47 \mathrm{ft}$. from north to south, and $42 \mathrm{ft}$. east to west. It is open on the north and west sides where it adjoins No. 15 Enclosure and the Central Area respectively.

The east side is formed by the south entrance to Inner Parallel Passage by the large buttress, $7 \mathrm{ft}$. high, projecting into, and forming, the south side of the entrance to that passage, and by a length of $\mathrm{I} 7 \mathrm{ft}$. of the west wall of the large Parallel Passage which is here $\mathrm{I} 4 \mathrm{ft}$. high.

The south side is bounded by the divisional wall, $5 \mathrm{ft}$. high, between this enclosure and No. I 3 Enclosure. In this wall is a rounded entrance between the two enclosures.

The west side is open to the interior of the temple, but at $42 \mathrm{ft}$. in that direction there are traces of a wall running north and south which probably formed its west side.

The north side was once formed by a wall of which traces can yet be seen, and which once divided this enclosure from No. I 5 Enclosure.

Projecting from the north face of the south wall are the remains of a subdivisional wall. Several large, rounded 
structures of cement are on the south-west side of the enclosure. The topmost floor of the enclosure is made of a pinkish-coloured clay, which evidently has been burnt. Under this floor was found sections of carved soapstone beams, a few pieces of beaten gold, and other relics. On the surface of this floor only superior-made native articles were found, and the floor was covered by at least $2 \mathrm{ft}$. of rich black vegetable mould. Several trees which were growing in this enclosure have recently been removed.

\section{NO. I 5 ENCLOSURE}

From an archæological point of view this enclosure is one of the most interesting compartments in the temple, for here are to be seen several layers of floors of a succession of occupiers each for a long period of time.

In 1903 this enclosure was found to be filled in with soil, ashes, and bones to a depth of $\mathrm{I} 2 \mathrm{ft}$., and on the top was a large tree at least seventy to a hundred years old. When this great body of filling-in was cleared away several most interesting architectural features were revealed.

The area is $56 \mathrm{ft}$. from east to west, and at its widest point I $8 \mathrm{ft}$. from north to south. The east, north, and west sides are formed by the south wall of the Inner Parallel Passage, and by a continuation of the same wall which curves outwards towards the north-west and forms the south wall of the South Passage. This wall is $12 \mathrm{ft}$. high all round and is well and massively built, the curve at the north-west end being exceedingly well carried out. A drain passes through the east end of the wall and opens into the Inner Parallel Passage.

The south side is formed by two walls and a series of semi-circular cement buttresses. The first or western end wall is rounded, being $7 \mathrm{ft}$. round the face and $8 \mathrm{ft}$. high. A straight wall joins on to the rounded length, and is $6 \mathrm{ft}$. 6 in. long and $7 \mathrm{ft}$. high. This length has a drain-hole 
passing through it from the passage which forms the eastern approach to the South Passage. A large rounded cement buttress follows the two walls, and this is $14 \mathrm{ft}$. long and $7 \mathrm{ft}$. high. A length of a few feet of soil showing several floors at different heights is on the east side of the cement buttress, and another rounded cement buttress, $3 \mathrm{ft}$. high, completes the boundary of the enclosure on the south side.

The lowest of the floors is formed of paving stones and granite cement, and the level of this is flush with the bottom course of blocks in the drain. But underneath this undoubtedly old floor, which was apparently laid down when the east wall was built, there are cement steps and buttresses at a depth of some 18 in. below the level of the drain. Underneath the floor were found two phalli, fragments of ornamented bowls and soapstone beams, clearly showing that the space underneath this lowest floor had been occupied before the floor was laid.

A floor of a pinkish-coloured cement, similar to that found in other enclosures, is at some distance above the granite cement floor, and on this floor were found very old native articles and quantities of buck bones and ashes. Above this are floors of thin daga (clay), and on each of these were also bones and ashes and native articles which are not now manufactured.

The position of the east wall of this enclosure and the fact of its covering some older enclosure seem to point to it as not being a portion of the original building.

\section{CENTRAL AREA}

This area of unexplored ground lies at the centre of the temple. It was originally very much larger, but recent excavations have reduced it in extent. The space covered is $80 \mathrm{ft}$. from east to west, and $30 \mathrm{ft}$. from north to south, and it extends between Nos. 5 and I4 Enclosures, and Nos. I and Io Enclosures. 


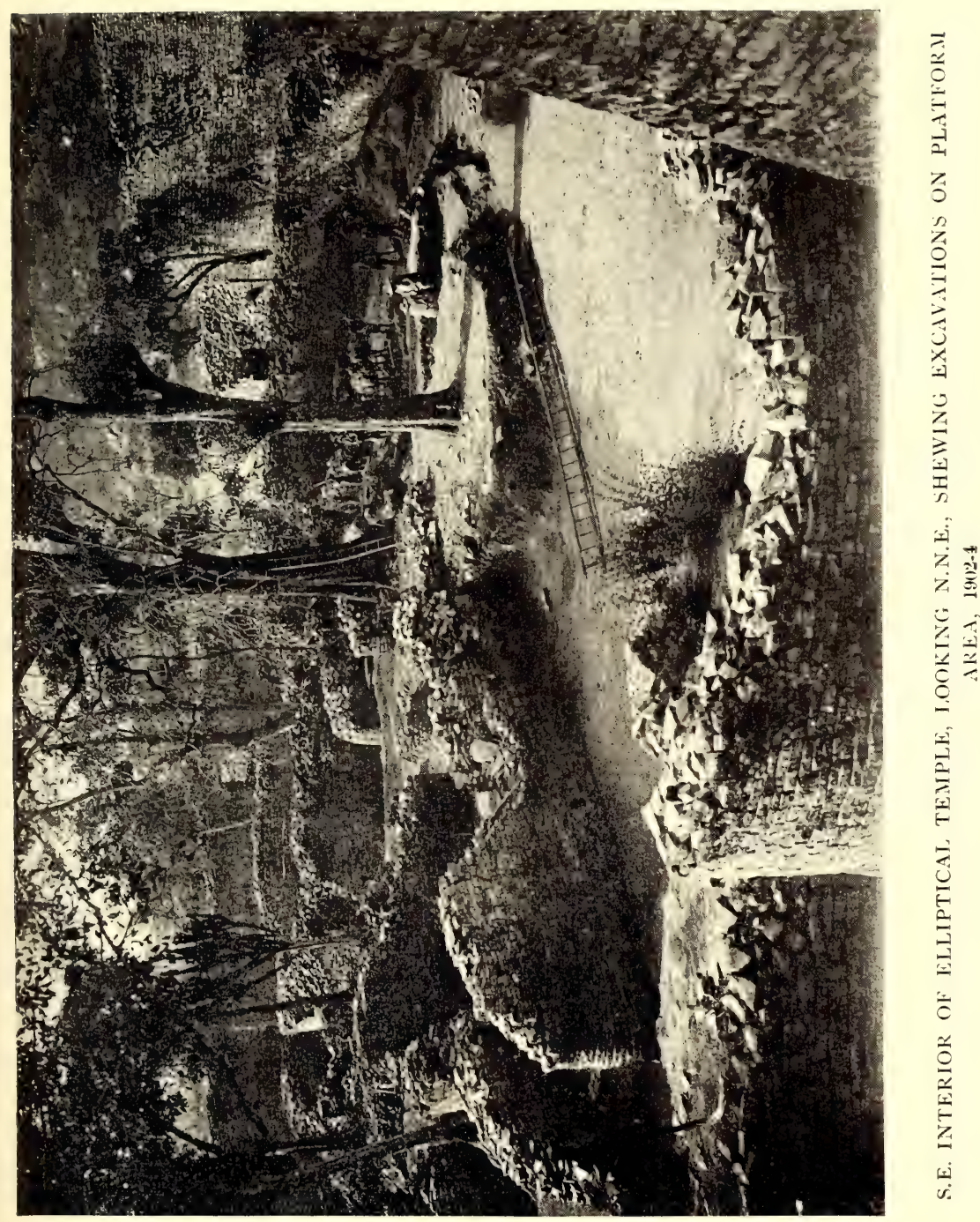



Some plans of the temple show dotted lines to mark position of conjectured walls, but most of these have been found not to exist. On the surface of the highest portion of this area are slight walls of shallow foundations and poor construction built across soil and blocks thrown promiscuously together, and probably the blocks and the débris of some buried structures at a lower level.

\section{PLATFORM AREA}

Immediately in front of and adjoining the Sacred Enclosure in which stands the Conical Tower, and overlooked by The Platform, is a large open area in the form of a bow, the rounded side-east and south-east-being formed by No. 9 Enclosure, The Platform, and Nos. I I, I2, and I 3 Enclosures, while the straight side, from south-west to north-east, is formed by Nos. 7 and Io Enclosures, a circular platform, and No. I 3 Enclosure.

The area covered by this open space is $126 \mathrm{ft}$. from south-west to north-east and $5 \mathrm{I} \mathrm{ft}$. from east to west. This space had not been previously examined by any modern explorer. Nor does any published plan of the temple attempt to deal with it, it having been always left as an unmarked space.

Bent found a similarity between The Platform which overlooks this area from its east side and the Agora or platformpulpit of the ancient temples in the Near East to which references are so frequently made in classic history, and he considered that this platform at Zimbabwe, especially in view of its position in front of the Conical Tower, was used for religious purposes, and that the open space immediately at its foot and in front of it most probably held the crowd of worshippers that might have been addressed from the elevated Platform.

The examination of this area in 1903 shows that Bent in I89I made a very shrewd conjecture as to the nature of 
the area. Over twelve years ago and until 1903 the space held out a prospect of its containing under its surface any number of walls, for in the Elliptical Temple divisional walls and other structures are closely packed together. Now that the space for $\mathrm{I} 26 \mathrm{ft}$. by $5 \mathrm{I} \mathrm{ft}$. has been cleared to a depth of from $4 \mathrm{ft}$. to $8 \mathrm{ft}$. following the lines of old cement floors which were completely buried, the space is shown to be actually an open area without walls or traces of walls of any sort crossing it at any point. Excepting such granite blocks as lined the bases of the boundary walls of this area, not ten hundred-weight of blocks were found, and these were scattered about at different heights and in almost every position in the soil débris which was removed.

In excavating this large space down to the floor which runs throughout the area at a similar level-a work occupying forty native labourers for three months - "finds" of any antique character were only made on the cleared floor and not in the soil débris which was removed, and all such relics which included fragments of both plain and carved soapstone beams, gold plates, beads and wire, were about equally distributed over the whole area.

The most important architectural features disclosed in the clearing of this area were as follows :-

Drain from No. Io Enclosure into this area.

A rounded terrace wall on the west side of The Platform.

Excellent granite cement dado work, several square feet being still intact.

Two massive granite cement steps leading up to the north entrance to the Sacred Enclosure.

The large granite cement steps leading up to the small platform in the angle formed by the north and east walls of No. I2 Enclosure.

Drain-hole in buttress in No. I2 Enclosure with large cement guides to lead water to it.

The suggestion made in description of the slight and 

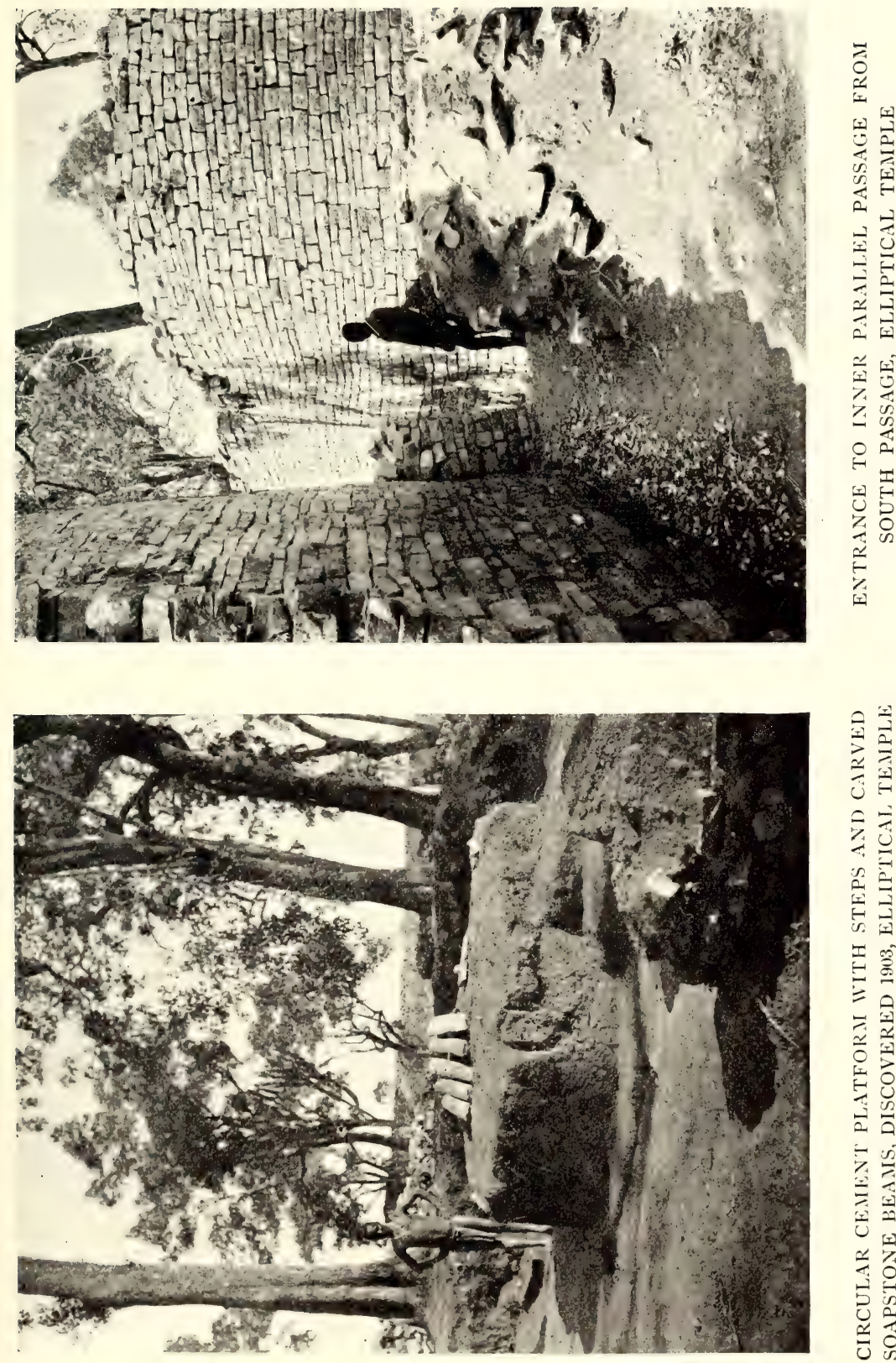

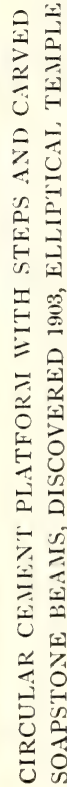



poorly built east wall of No. Io Enclosure that it was of later construction is confirmed.

Circular granite cement platform with steps leading to summit.

This last-mentioned structure is worthy of more than a mere mention; as apart from its excellent construction and its position, its summit was found to be covered with soapstone beams, plain and decorated, while fragments of beams were lying all round its base. Near this spot numerous soapstone phalli, including one of very large size, were discovered.

This platform is $69 \mathrm{ft}$., N. 20, from the north face of the Conical Tower measured through the centre of the north entrance to the Sacred Enclosure. It has a circumference of $30 \mathrm{ft}$. 6 in., and is from $2 \mathrm{ft} .4$ in. to $2 \mathrm{ft} .8$ in. in height, with a rounded bevel at base $3 \mathrm{in}$. high and projecting $6 \mathrm{in}$. There are two boldly rounded steps, each 8 in. high, on the east side, and on the east side of the steps is a low cement parapet. This platform occupies a somewhat isolated position. Its summit was found to be buried for at least $2 \mathrm{ft}$. in soil. Close to the north side was a large tree, judged to have been almost one hundred years old. The roots of the tree had arched over and also encircled the structure, and so had preserved it. The roots had attempted to penetrate the cement, but failing to do so they passed completely round its face, and when cut away they were almost all semi-circular in shape.

\section{INNER PARALLEL PASSAGE}

This passage lies between the main Parallel Passage and No. 15 Enclosure. It runs north-west to south-east from the South Passage near the North Entrance to the temple into No. I 5 Enclosure, and is parallel with Parallel Passage. The three parallel walls forming the two passages are generally known as the Triple Walls. Whereas the Parallel Passage led from the North Entrance to the Sacred Enclosure only, 
this leads from near the North Entrance right into the interior of the temple.

Its length is $7 \mathrm{I} \mathrm{ft}$., and at its eastern end it is $7 \mathrm{ft}$. wide for a short distance, but rapidly closes in to a width of $3 \mathrm{ft}$. 6 in., which is maintained throughout the greatest part of its remaining length.

The north-eastern wall is the south-western wall of the Parallel Passage, and from the eastern end for $29 \mathrm{ft}$. this wall averages in height I $2 \mathrm{ft}$. to $\mathrm{I} 4 \mathrm{ft}$. above the present floor of the passage, and from the 29 - $\mathrm{ft}$. point to $67 \mathrm{ft}$. the face of the wall is damaged by roots, and the height here is only $7 \mathrm{ft}$.

The south-western side is formed by the wall dividing this passage from $N o$. I 5 Enclosure. It averages io ft. in height, and is well and very substantially built. On this side, at $32 \mathrm{ft}$. from the eastern end, is a drain leading from $N o$. I 5 Enclosure.

The western entrance to this passage has on the northeastern side a rounded buttress $5 \mathrm{ft}$. high, $6 \mathrm{ft}$. long, and protruding I $\mathrm{ft}$. Io in. from the face of the wall. This buttress has a portcullis groove, but this has recently been built up in order to strengthen the buttress. On the opposite side there are traces only of a corresponding buttress in the shape of some foundation stones, and there are also signs that there were once steps extending from buttress to buttress.

It is probable that the ancient floor was only a few inches below the present cleared-out floor, as what appear to be paving stones, together with small sections of granite floor, can be seen outcropping at several points along the passage, but vine and tree roots have lifted the rest of the stones out of place.

At the eastern end is a large, substantial, and well-constructed rounded buttress protruding $9 \mathrm{ft}$. towards south-west from the north-eastern side of the passage, where it here opens on to No. I4 Enclosure. This buttress gives the passage-way a turn south at almost right angles. This 


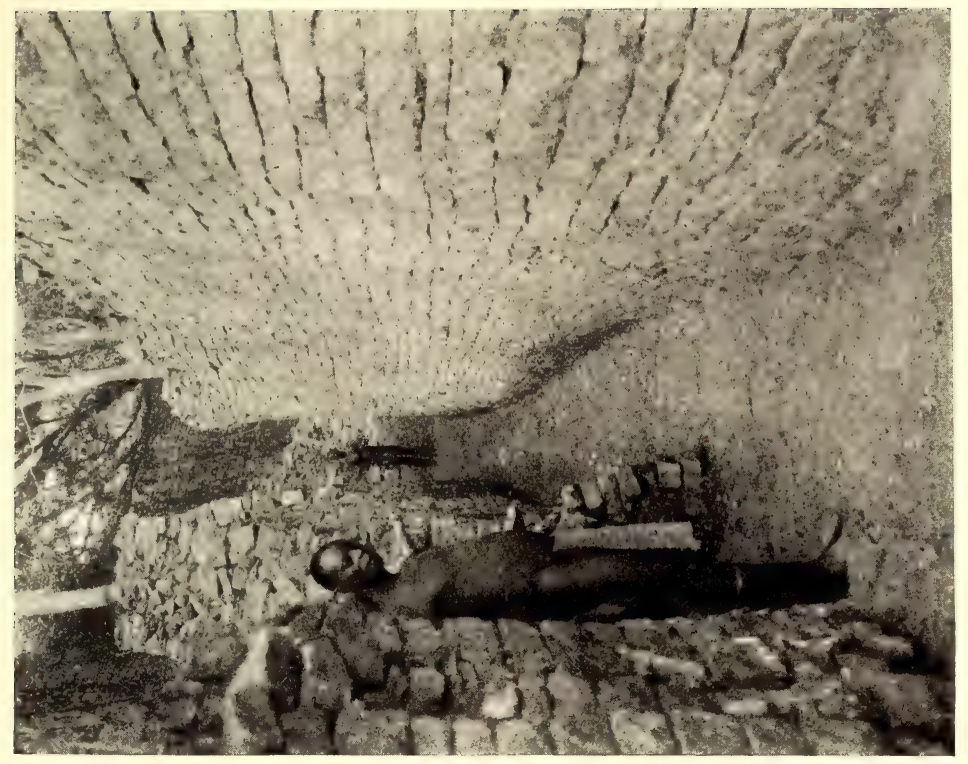

年

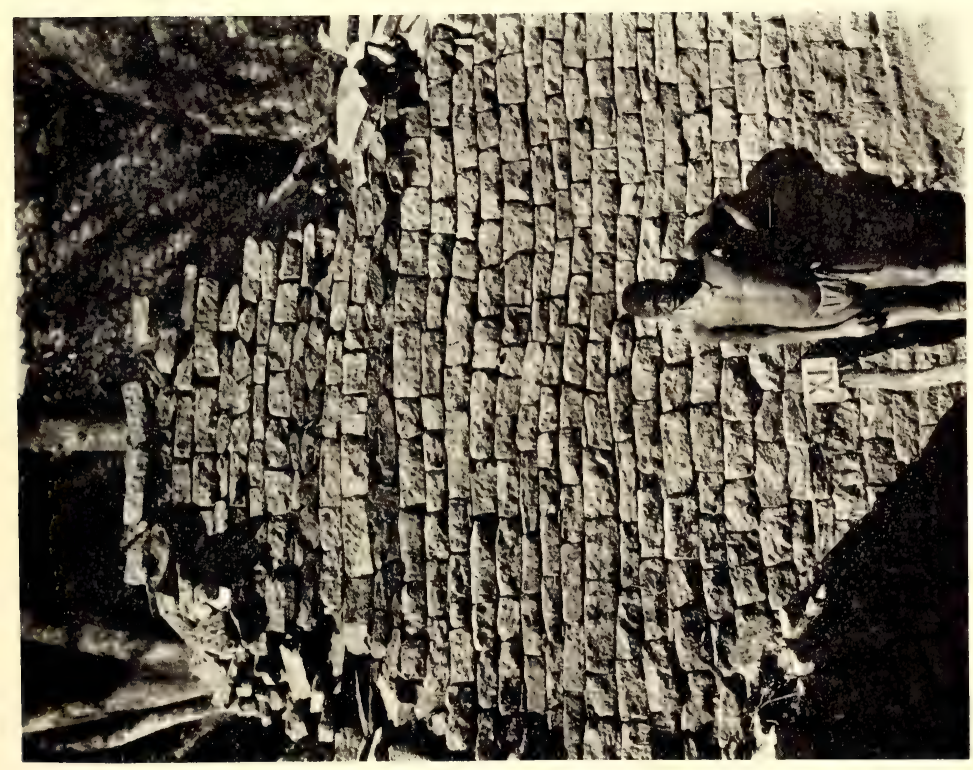

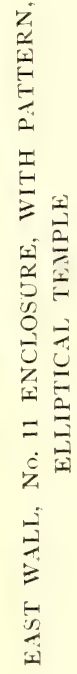



buttress is from $4 \mathrm{ft}$. to ro $\mathrm{ft}$. in height on its front face, but $2 \mathrm{I} \mathrm{ft}$. at its rear, and this buttress forms part of the boundary of No. I4 Enclosure.

It is possible that this buttress which is hollow, and to which there are traces of an entrance from the passage, once enclosed steps leading on to the summit of the wall between the Parallel Passage and the Inner Parallel Passage. ${ }^{1}$ Certainly the way the stone débris inside the buttress has fallen tends to support this conjecture.

\section{SOUTH PASSAGE}

This passage appears to have been the main artery leading from the main and North Entrance of the temple right into the central portion of the building, where it has its terminus. It is $68 \mathrm{ft}$. long from the broad step on the south side of the North Entrance to the steps at the south end of the passage.

For $23 \mathrm{ft}$. from the north end where is the broad step there is an almost triangular area, $23 \mathrm{ft}$. from north to south, and $30 \mathrm{ft}$. from east to west, having its base on the north side. The western end of Inner Parallel Passage enters it at the eastern corner, and the entrance from No. 3 Enclosure is at its western corner. The heights of the walls forming this area are: north side being the south wall of the Parallel Passage, I $5 \mathrm{ft}$. ; south-west side being the north-east wall of No. I Enclosure, I $2 \mathrm{ft}$; ; the west side being the divisional wall between the area and No. 3 Enclosure, $6 \mathrm{ft}$; the east and south being the wall dividing the area from No. I 5 Enclosure, I $2 \mathrm{ft}$. All these walls are well built and are very substantial.

In the centre of this area is a raised platform, commencing at $9 \mathrm{ft}$. from the north side of the area and terminating at $2 \mathrm{I}$ ft. from the same point, thus giving it a length of $\mathrm{I} 2 \mathrm{ft}$. It is $9 \mathrm{ft}$. $6 \mathrm{in}$. wide and $3 \mathrm{ft}$. high, and has granite cement covering, where not broken, the whole summit. An old

1 Two rounded buttresses are built on the larger buttress, and are against the summit of this wall. 
euphorbia tree was found growing out of this cement, its roots having played havoc with the side walls of the platform, the best portion now remaining facing the north-east side. The tree has now been removed. This platform is approached by three large granite cement steps, the two lower ones still being in a fair condition. These steps are each 12 in. high, and from front to back are from 10 in. to I 2 in., while they are $2 \mathrm{ft}$. $6 \mathrm{in}$. wide, and are rounded on the edges.

The most peculiar circumstance about this platform is that under a foot depth of vegetable mould which completely covered it and rendered the platform shapeless, and lying on the surface of the cement floor, were found some hundredweights of bones of oxen. There were no bones other than those of oxen, and the bones had not been split open for the marrow, as is so frequently found to be the case in very old Makalanga débris heaps. Nor were any broken pottery, iron implements, or iron and brass bangles, such as are most usually found together in such débris, to be seen, but carbonised wood was found in large quantities.

It should be remembered that Mauch and others of the early writers on Zimbabwe state that they had witnessed sacrifices by the Makalanga of those days of black oxen in the Elliptical Temple, and the local natives also state that this was their practice up to within the last fifteen years. Possibly this was the spot where these sacrifices took place, for though Thomas Baines in a painting he made of one of these ceremonies places the Conical Tower in the background, there are no signs anywhere near that structure that such sacrifices ever took place in its immediate vicinity, all of which has now been cleared of débris down to the cement floor at every point where the Conical Tower could possibly have formed a background for such a ceremony. It is now almost certain that Baines painted this and other pictures of Zimbabwe from the descriptions given him by Renders, 
Phillips, and Mauch. But in the south-western end of the Parallel Passage for about $20 \mathrm{ft}$. or $30 \mathrm{ft}$. from its exit into the Sacred Enclosure (east) the débris was very mixed, and included bones of oxen and buck, the larger bones all split open. Probably this was one of the spots in the temple where these annual sacrifices of black oxen by Makalangas took place.

The platform faces the north, the steps being on the southeast side. The area containing this platform was evidently once laid with granite cement, but sections of it only remain in the western corner and on its north-east side. A drainhole leading into the Parallel Passage is at $6 \mathrm{ft}$. east of the broad steps ascending from this area to the North Entrance. This step is I I $\mathrm{ft}$. broad.

At $23 \mathrm{ft}$. south from its north end the area narrows to $3 \mathrm{ft}$. Io in., which width is maintained for $18 \mathrm{ft}$., the passage for this length running between No. I6 Enclosure on the east side and No. I Enclosure on its west side. At this point in this section of the passage a large flat slab of granite has been banked up with stones to keep the upper portion of the wall on the west from collapsing into the passage. The walls here on either side are from $7 \mathrm{ft}$. to Io $\mathrm{ft}$. high.

At $43 \mathrm{ft}$. south from the north end of the passage are two entrances, the one from the west being from No. I Enclosure, and this is angular, while the other facing it on the east being from a short passage on the south side of No. I6 Enclosure, is rounded, and has portcullis grooves. From the 43 -ft. point the width of the passage is $2 \mathrm{ft}$. $8 \mathrm{in}$., but at its southern extremity it is increased during the last few feet to $4 \mathrm{ft}$. Io in. The side walls are very well built, and are still in a good state of preservation. The entrance at the south end of the passage has a rounded buttress with portcullis groove on either side leaving a width of $3 \mathrm{ft}$. This entrance has five large stone steps practically perfect. The buttresses are $5 \mathrm{ft}$. high. 
WEST PASSAGE

This passage lies on the west side of the interior of the temple, and is between Nos. 4 and 5 Enclosures on the west and No. I Enclosure and Central Area on the east. It runs north and south, and is formed on the west side by a massive and well-built wall, which is in the form of an arc; the length of the inside face of the wall being $65 \mathrm{ft}$., and that of the line drawn from extremity to extremity of the wall being $57 \mathrm{ft}$., and this passes at $8 \mathrm{ft}$. from the inner face at the centre of the curve westwards.

This large curved wall is independent of any other structure, and stands entirely by itself. It is clearly the bestconstructed wall in the western half of the temple, and the excellent workmanship displayed in the regularity of the courses, the bold and well-executed curve, and its immense width, at once strike the attention of anyone who enters the temple at the western portal. Its width is $8 \mathrm{ft}$. at $6 \mathrm{ft}$. above the ground, and its height ranges from $6 \mathrm{ft}$. to Io $\mathrm{ft}$.

The position and character of this wall induced Bent to conjecture that this arc was one of the proofs that the entire temple was a "multiform temple," such as are found in SouthWest Asia, and these "little temples ... were dedicated to the cult of particular stars." Bent considered that the massive and well-built curved walls in Enclosures Nos. 7 and I 5 were also employed for particular observations independently of the great temple itself. At the time Bent made this conjecture he was unaware that up against the centre of the inner face of this curved wall was a platform raised some $4 \mathrm{ft}$. above the level of the ground, and of the numerous relics of the older type found at and near it, or that there were originally three granite monoliths once standing parallel with, and at equal distance from, the west face of this wall. These discoveries have only just recently been made, as well as other corresponding discoveries in the other two enclosures 
which Bent took to be minor temples. Each of the monoliths is $29 \mathrm{ft}$. from the west face of the wall, and each is $9 \mathrm{ft}$. apart.

At its south end the passage is Io $\mathrm{ft}$. wide, at the north end it narrows to $4 \mathrm{ft}$., but at its centre it averages a width of Io $\mathrm{ft}$. to I $2 \mathrm{ft}$.

The east side of the passage is formed for $49 \mathrm{ft}$. from the north end by the wall of No. I Enclosure, which here appears to be of poorer and later construction, also by a roughly built wall, I I ft. long, with foundation some $4 \mathrm{ft}$. above the foundation of the wall of No. I Enclosure, and by a rounded buttress, I $2 \mathrm{ft}$. length of facing and $7 \mathrm{ft}$. high, which has its foundation on the platform which overlooks the west curved wall.

The platform, which is of cement, once had retaining walls at two levels, and portions of these still remain.

\section{NORTH-EAST PASSAGE ${ }^{1}$}

This passage is on the north-east side of the temple and immediately outside the North Entrance, running north-east at right angles from the main wall between that entrance and [590 ft.]. Its total length is $360 \mathrm{ft}$., but there is some evidence that it once extended further towards the north-east for at least some hundred yards beyond the $360 \mathrm{ft}$. Only a portion of the $360 \mathrm{ft}$. length has at present been cleared of débris.

On the north-west side it is bounded by a well-built wall $4 \mathrm{ft}$. 6 in. high and $\mathrm{I} 2 \mathrm{ft}$. long, at the north-east end of which is a large rounded buttress with portcullis groove. This buttress projects $3 \mathrm{ft}$. into the passage, and is $3 \mathrm{ft}$. 6 in. high. Probably another buttress containing a corresponding portcullis groove faced it on the opposite side of the passage.

The eastern side is bounded by the entrance to the Outer Parallel Passage and by the north wall of that passage, which curves round in front of the North Entrance to the temple, and runs at right angles to its former position. This 
wall, which is well built, is $7 \mathrm{ft}$. high, and forms the east side of the passage for some $35 \mathrm{ft}$., but at this point it is reduced to $3 \mathrm{ft}$. in height, and is carried on toward the north-east in a less carefully constructed style.

The widths of the passage and the heights of the side walls, measuring from the North Entrance to the temple, are as follows :-

\begin{tabular}{|c|c|c|c|}
\hline & & $\mathrm{Hei}$ & \\
\hline & Width. & West side. & East side. \\
\hline S. Extremity & - $\quad$ I $2 \mathrm{ft}$. & $4 \mathrm{ft} .6$ in. & $7 \mathrm{ft}$. \\
\hline $35 \mathrm{ft}$. & $2 \mathrm{ft}$. Io in. & $3 \mathrm{ft}$. & $4 \mathrm{ft}$. \\
\hline $50 \mathrm{ft}$. & $2 \mathrm{ft} . \quad 6$ in. & $3 \mathrm{ft}$. & $3 \mathrm{ft}$. \\
\hline
\end{tabular}

Between $35 \mathrm{ft}$. and $50 \mathrm{ft}$. are remains of pavement.

This passage, with its length of $660 \mathrm{ft}$., is believed to have formed the chief line of communication between the Elliptical Temple and the Acropolis, seeing that it runs from the main entrance of the temple down into the valley at a point almost facing the lowest extremity of the South-East Ancient Ascent to the Acropolis.

\section{OUTER PARALLEL PASSAGE}

On leaving the temple by the North Entrance one enters a walled-in area. This area is formed by the southern extremity of the North-East Passage and the western extremity of the Outer Parallel Passage, both of which meet at, and converge upon, the North Entrance.

The Outer Parallel Passage runs for I $25 \mathrm{ft}$. east-south-east from the North Entrance parallel with the north-east wall of the temple between the points [450 ft.] and [ $575 \mathrm{ft}$.] of its outer circumference. At its extremity near the North Entrance this passage is $7 \mathrm{ft}$. wide, and $25 \mathrm{ft}$. further eastsouth-east of the entrance it is $3 \mathrm{ft}$. 8 in. wide, which width is maintained for a length of $50 \mathrm{ft}$., beyond which point it commences to widen out till the east-south-east extremity is reached, where it is $2 \mathrm{ft} .6 \mathrm{in}$. wide. 
Opposite the North Entrance the outer wall of the passage is $6 \mathrm{ft}$. high ; at $25 \mathrm{ft}$. further east-south-east, $5 \mathrm{ft}$; ; at $75 \mathrm{ft}$., $8 \mathrm{ft}$; ; at IOo ft., $7 \mathrm{ft}$. ; and at I $25 \mathrm{ft}$., $5 \mathrm{ft}$., the line of summit from the $25 \mathrm{ft}$. point to the east-south-east extremity being fairly level throughout. This outer wall is well built. It is $4 \mathrm{ft} .2 \mathrm{in}$. wide on the summit at $5 \mathrm{ft}$. from the floor of the passage, and $3 \mathrm{ft}$. Io in. wide at $7 \mathrm{ft}$. from the ground.

At $25 \mathrm{ft}$. from the North Entrance is a rounded entrance through the outer wall. This has portcullis grooves. It is I $\mathrm{ft}$. Io in. wide, and has three steps formed of the courses of the foundation of the wall, the upper step being curved back into the entrance.

At the extremity near the North Entrance there are the remains of a small rounded buttress projecting into the passage from the main wall of the temple. 


\section{CHAPTER XIV}

\section{THE ACROPOLIS RUINS}

South-East Ancient Ascent-Lower Parapet-Rock Passage-

Upper Parapet-Western Enclosure.

$\mathrm{O}$

$\mathrm{N}$ Zimbabwe Hill, at a height of some $230 \mathrm{ft}$. to $250 \mathrm{ft}$. above the valley which runs along its west and south sides, stands the Acropolis or Hill Fortress. Its prominent and strategic position on this precipitous and practically isolated granite kopje gives it a grandly imposing appearance among the many large ruins included within the $\mathrm{Zim}$ babwe Reserve.

Viewing the hill from the valley, one can well realise that Nature alone made the place impregnable, while the builders of almost four thousand years ago applied their highly developed engineering skill and ingenuity to make the stronghold even more absolutely unassailable.

The south side of the hill is defended by a precipice some $90 \mathrm{ft}$. high, running without break from the western end for over $300 \mathrm{yds}$. to the eastern side of the hill, where the precipice loses itself in gigantic boulders, each of many hundred tons weight, which, owing to their beetling form, render that side of the hill inaccessible. Great boulders form the summit of the hill, and are in a cliff-shaped line running from west to east. Several of the highest boulders appear to be most delicately poised on the edges of the shoulders of gigantic cliffs, and these rise up at least $50 \mathrm{ft}$ to $70 \mathrm{ft}$. above the highest portion of the Hill Ruins, thus 


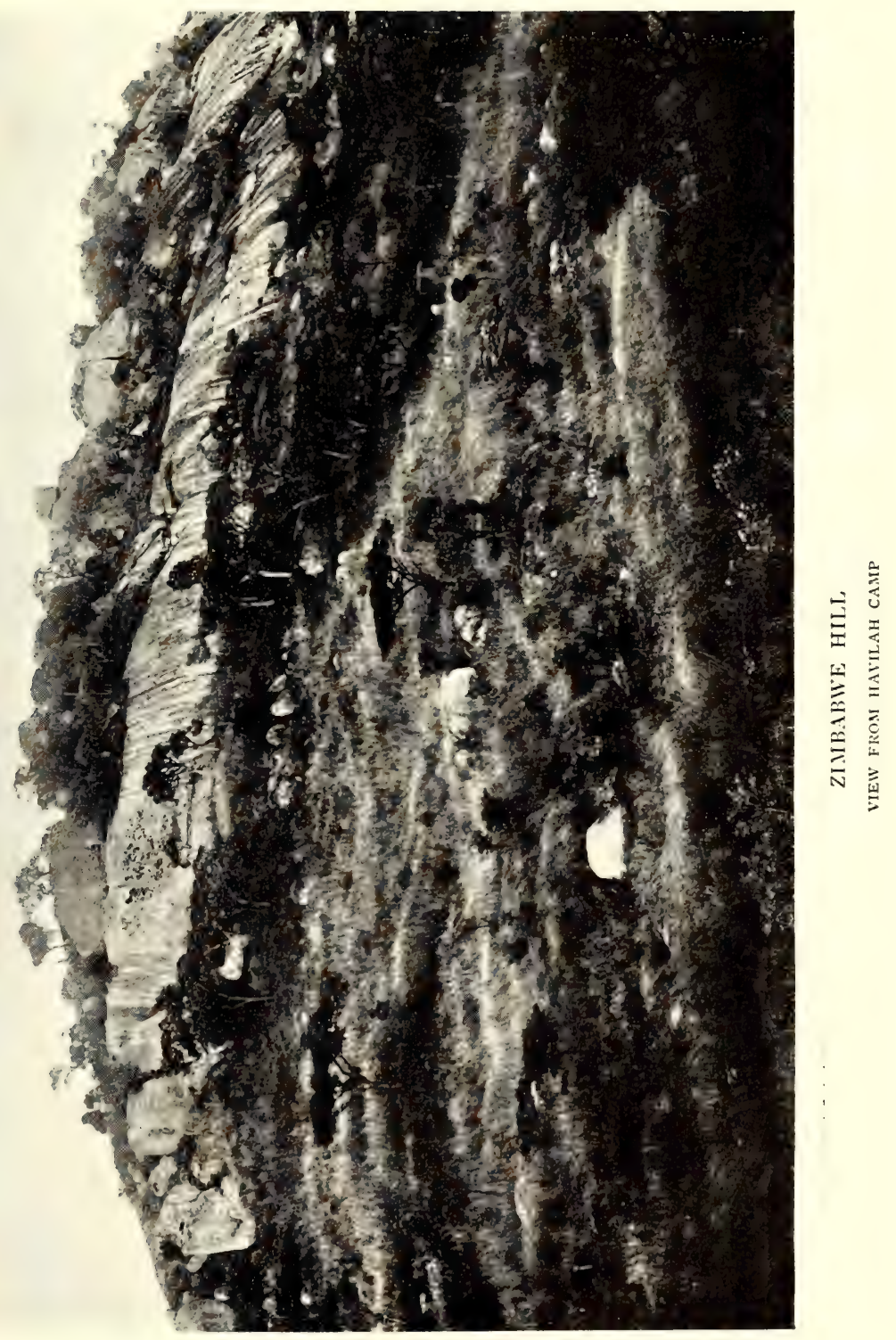



making the total height of the kopje to be slightly more than $320 \mathrm{ft}$.

The bases of the southern walls are built on the outward slope of the brink of the line of steep granite cliff, the lowest row of stones being deep at their front and narrow at the back. So markedly are these wedge-shaped rows of stones laid over the brink of the precipice that at first sight one hardly notices where the wall ends and the precipice begins, especially as the blocks in the walls present in the dry season the same colourings and tints as the line of cliff itself. Below the precipice the ground has a very sharp fall of some $70 \mathrm{ft}$. into the valley.

The feelings provoked in one's mind on visiting the Elliptical Temple and Sacred Cone, which are in the valley, are those of awe and reverence; but on inspecting the Acropolis the visitor is overcome by a sense of absolute amazement and sheer bewilderment, which are intensified at every step taken along its numerous labyrinthine passages on climbing the hill.

Above the precipice, as seen from the valley, are massive walls, on the summits of which some dozen monoliths, more or less erect, are still to be seen standing clear against the sky-line. From this point of view alone-and this but represents a small fraction of the walls of which these ruins are composed-one realises that many thousands of tons of granite blocks (those in the outer faces having been squared and dressed) have been transported up the precipitous kopje to a height of no less than $230 \mathrm{ft}$., for examination of the rocks on the hill proves that the greater quantity of stone used in the walls was not quarried on the kopje itself.

Apart from the infinite patience and painstaking toil of the ancients as displayed in their careful and correct building and complicated plan and style of architecture, this one fact of so much stone quarried and dressed elsewhere and carried up to such a height as a man could hardly climb who 
bore no burden, is one to amaze and perplex even the most casual and indifferent visitor. Later, on reaching the ruins it will be seen that very many thousand tons of granite blocks have been carried up the hill. This fact serves to still further accentuate the statements made by the authors on pages 60 and 65 of Ancient Ruins of Rhodesia that (I) not only did the ancients of the first period of Zimbabwe architecture realise that they were occupying a hostile country, but (2) the ancient builders had at their disposal slave labour to an enormous and incalculable extent, and this apart from the overwhelming evidences pointing to the same conclusion presented by the thousands of ancient workings spread over Southern Rhodesia, and the hundreds of massive fortresses and temples occupying a corresponding area.

These and many other obvious suggestions present themselves most forcibly at even the partial view of the Hill Fortress as seen from the valley.

The first question occurring to one ascending the hill is: Where is the ancient ascent? It is obvious that the path used by visitors could not be the ascent of the ancients, for were it not for the gaps in the walls, access to the summit by the ordinary path would be absolutely impracticable. Indeed, the ordinary path runs at several points along the reduced tops of broken walls, and crosses the foundations of some dozen outer defence walls, which are now practically demolished and barely traceable.

There are two well-defined ancient approaches to the summit of the Acropolis, one being on the south side of the hill and the other on the face fronting the west-north-west. It is believed that at least two other ancient ascents exist. The N.N.W. ascent has not been completely cleared out, though it is very well defined, and some $320 \mathrm{ft}$. of its $940 \mathrm{ft}$. length can now be traversed by the visitor, but the south-east ascent has recently been cleared out of large trees, shrubs, and many tons of wall débris and silted soil, so that it is now 


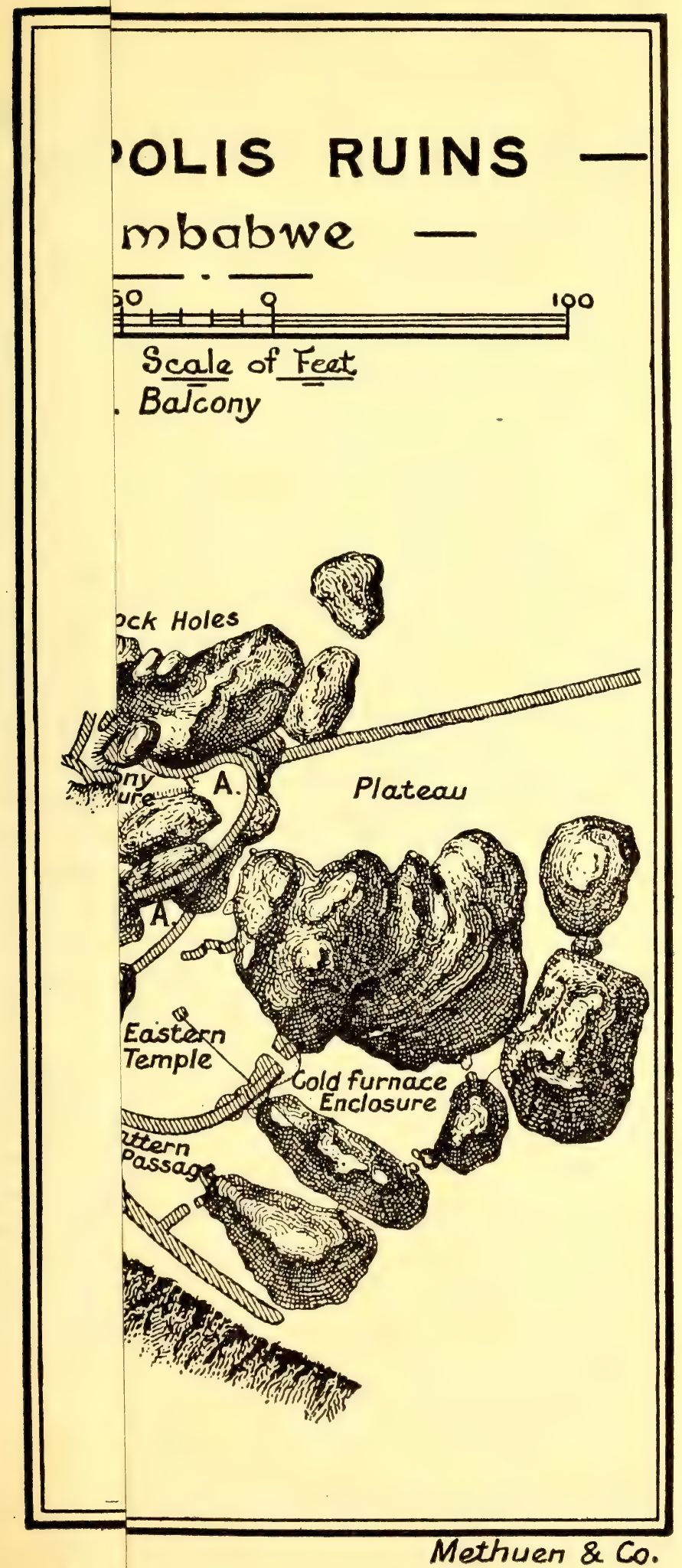





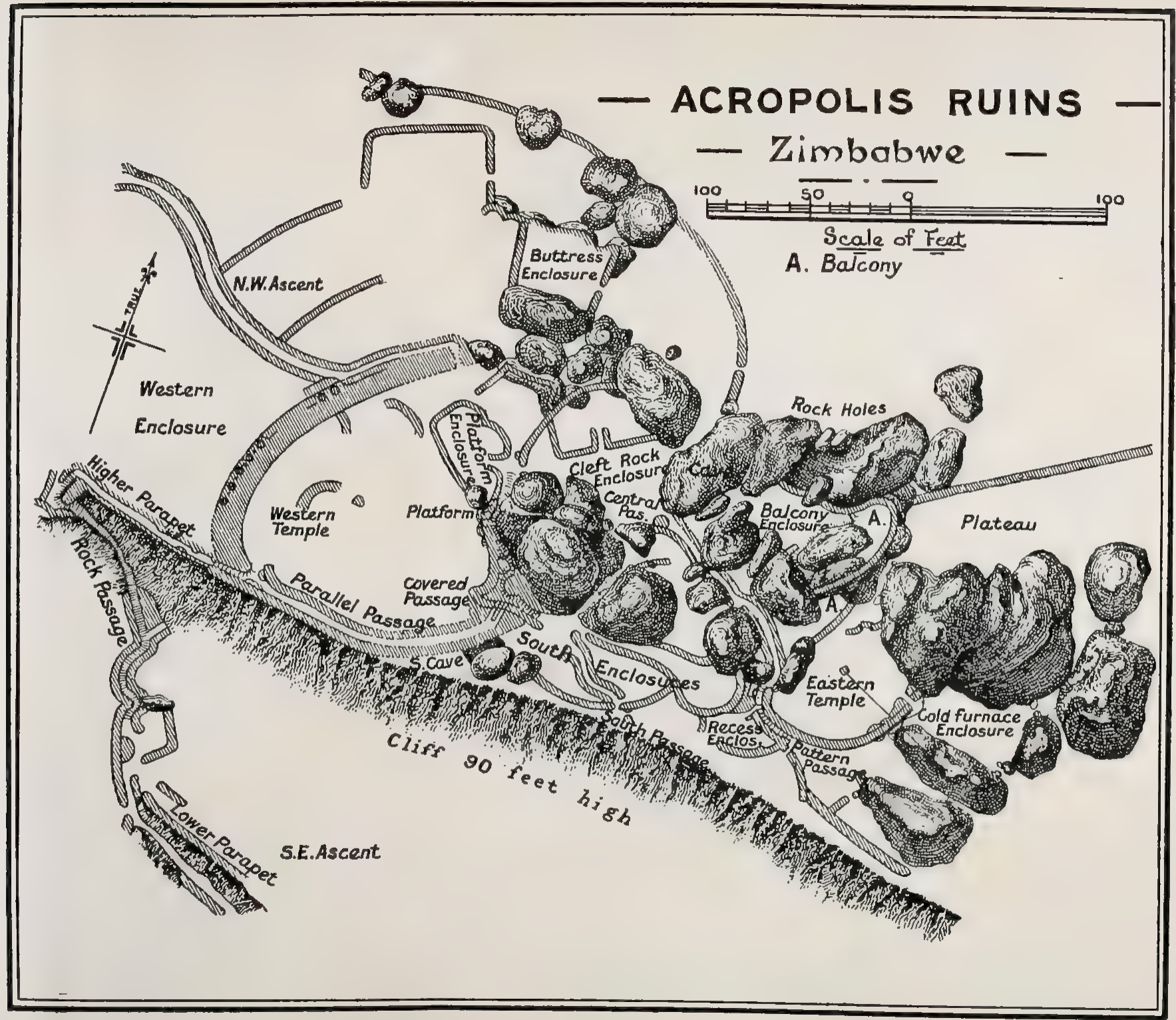

Methuen \& Co. 

possible for visitors to use it with ease. Mogabe, the Zimbabwe Makalanga chief, now seventy years of age, who at one time had his kraal on the northern side of the summit of Zimbabwe Hill, as well as the older of his headmen, all state they had never before seen this ancient ascent so cleared out. They say that the late Chipfuno's people, and subsequently their own, used it as an approach to the kraal, but not generally, and this was only possible by climbing along the tops of the walls and over the large wall-débris heaps that blocked up the passage-way. Certainly for at least one hundred years this ascent could not have been used, for the débris piles were covered with lichens, and had every appearance of great age. The Makalanga had also purposely blocked up the passage with a substantial wall, which was erected in Chipfuno's time. Some of the trees cleared from the passages proved by their size that they had stood there long before the Chartered Company's advent into the country.

In fact, the ascent by this ancient approach now occupies a little more than half the time required to walk round by the circuitous path till recently used by visitors, besides affording to the climber a revelation as to the ingenuity and wonderful engineering skill of the ancients in effecting the defence of the hill. Unless this ancient approach be traversed by the visitor, one of the principal features provided by the Acropolis or Hill Ruins will have been missed.

\section{SOUTH-EAST ANCIENT ASCENT}

Leaving the huts at Havilah Camp, which occupy a low granite knoll on the north side of the Shangani Grave and overlook the narrow valley running at the south foot of the hill, one crosses the outspan and passes through the "Outspan Ruins," ${ }^{1}$ which face the camp at a distance of $70 \mathrm{yds}$. due north, which ruins are part of an inner line of defence wall running round the base of the hill on the west, south, and east sides, and which lie within the main outer wall sweep-

\footnotetext{
${ }^{1}$ For description of these ruins, see p. $35^{8}$.
} 
ing round from the west side of the Elliptical Temple to the north side of Zimbabwe Hill, enclosing the large water-holes believed to have been made by the ancients. From the ascent facing the camp a newly-cut path leads in a direct line up some $70 \mathrm{ft}$. higher towards the ancient approach, but with a slight trend to the east.

Before striking the walls of the passage-way, the path crosses at right angles the foundations of some seven or eight outer defence walls and walls of terraces and buried enclosures all rising in tiers one above and at the back of the other. The soil here is black with ash débris, and in cutting the rough steps in the path to the ascent, each shovelful of this black soil contained a large quantity of broken pottery and bones of animals. This débris on being examined shows most evidently that it is not ancient; further, it is pronounced by local natives to have been thrown out from the ruins above by previous generations of Makalanga, but not by the mediæval Makalanga, who, according to Portuguese records (I 560 to I 750 ), occupied these ruins as one of the courts or chief residences of the succession of dynastic chiefs, each known as the Monomotapa or "The Lord of the Mines." This débris is believed to cover that of the mediæval Makalanga and of the ancients, for all débris would by the formation of the cliff above be guided to this part of the lower southern slope, and the heavy downfalls of very many rainy seasons would distribute it over the steep face of the southern slope, and spread it into the valley, where any quantity of such débris may be found.

The path from the camp strikes the ancient ascent at $70 \mathrm{ft}$. above the valley. The length of the approach, measured in the centre of the passage in all its turnings, is $349 \mathrm{ft}$. from this point to its termination on the summit of the precipice. It extends in a westerly direction from the $70 \mathrm{ft}$. to the $2 \mathrm{IO} \mathrm{ft}$. level on the hill. This passage can be traced downwards into the valley to clear of the end of the kopje for $420 \mathrm{yds}$. 
The ascent is, for an ancient ruin, in a remarkably good state of preservation, except at a few points where whole lengths of walls have fallen into the narrow passage which runs between high walls. All this wall débris, which effectively blocked the passage, has just recently been removed. At one point the end of a wall had collapsed bodily into the passage, and being on higher ground had filled it up to the height of the walls below, but this débris has also been cleared away, so that visitors can now walk without the slightest hindrance up the ascent on practically what was the ancient flooring, and ascend the old flights of steps. To such an extent had the passage become choked up that it required some fifteen native labourers, working at different points, no less than four days to cut away sufficient growth as would enable a mere scramble to be made over the débris in the passages, while the thorough clearing away of wall débris occupied the whole gang for nearly a fortnight. Now that this ancient ascent has been made an easy approach, this passage to the summit of Zimbabwe Hill has become the most popular ascent.

The chief architectural features represented in the ascent are the (a) Lower Parapet, $(b)$ the Rock Passage, and (c) the Upper Parapet, as also the flights of steps occurring in several lengths.

The point where the path from the camp strikes this ancient ascent is not its most easterly extremity nor its lowest point, for, as before stated, this passage can be traced for 420 yds. further east, where its emergence into the valley is protected by one, if not two, large fort-like ruins of some importance.

On turning into the ascent from the camp path, an outer wall on the left-hand side runs for $42 \mathrm{ft} .6 \mathrm{in}$., and this wall is now only about $2 \mathrm{ft}$. high. The foundations are $4 \mathrm{ft}$. wide. The upper courses of this wall are not ancient, though the foundations and lower courses undoubtedly are, for it is evident 
that blocks which have fallen from terrace walls overlooking the passage into the ascent have been laid neatly, probably by mediæval Makalanga, on the tops of the wall which had already become ruined. The right-hand side of the ascent from this point, for a length of $65 \mathrm{ft}$., is formed by huge boulders. The passage throughout this length is $3 \mathrm{ft}$. 6 in. to $4 \mathrm{ft}$. wide.

\section{(a) THE LOWER PARAPET}

At the upper end of this $45 \mathrm{ft}$. length of wall, and on the left-hand side, is a natural parapet artificially improved. This is the Lower Parapet, the outer and left-hand side of which is formed by the summit of a large boulder $25 \mathrm{ft}$. long, and its highest point not more than $4 \mathrm{ft}$. 6 in. above the floor of the ascent. From this vantage ground a fine view is obtained of the hills to the south, with the Bentberg (Matusa) directly opposite, and the Elliptical Temple and the valley of Ruins below.

On the inner and right-hand side of the Lower Parapet the rock glacis is surmounted by two terrace walls, really enclosures filled in, the second being behind and higher than the first. The lower terrace wall has a frontage to the south of $24 \mathrm{ft}$., and the upper terrace wall starts at $\mathrm{I} 4 \mathrm{ft}$. to the rear of the top of the lower wall. Portions of the higher wall are still intact, and judging by the line of wall débris, it had a frontage to the south of some $20 \mathrm{ft}$.

Facing the passage at the west end of the Lower Parapet is a wall $3 \mathrm{ft}$. $6 \mathrm{in}$. high, running north for $\mathrm{I} 2 \mathrm{ft}$. The top of this wall is $4 \mathrm{ft}$. wide, and is built upon a large granite boulder, which beetles considerably at the outer and southern extremity of this wall. The northern end of the wall is wedge-shaped, the point being well made with finely tapering sides. A similar wedged-shaped buttress is to be seen at the entrance to the Upper Parapet, and also on the south side of the east entrance in the interior of the Eastern Temple on Zimbabwe Hill. 
The wall thus described acts as a division or parting of the ways, as in the case of the wedge-shaped end of the wall at the Upper Parapet, and a short passage $4 \mathrm{ft}$. wide and $\mathrm{I} 2 \mathrm{ft}$. long runs along the west face of the wall to the brink of the boulder which beetles to a steep drop below.

The object of this short passage jutting out from the main ascent to the brink of the boulder's edge is inexplicable, unless it was intended as a débris shoot, for at the base of the south front of this boulder, and some $20 \mathrm{ft}$. below, is a large débris pile of past and present Makalanga ashes, pottery, and bones of animals. This is contained in a loose black soil, but the débris of the ancients underlying the obviously Makalanga débris is contained in a light yellow soil the surface of which has become almost as hard as cement. The examination of this lower stratum of débris fully confirms the suggestion that this short passage which terminates, so to speak, in space was one of the spots where the ancients shot their débris.

At the north end of this short side-passage the main ascent takes a long curve for $5 \mathrm{I} \mathrm{ft}$. westwards, from southwest to north-west, and is formed on the outer side by a wall $5 \mathrm{ft}$. to $6 \mathrm{ft}$. wide on its present reduced summit and from $6 \mathrm{ft}$. to $9 \mathrm{ft}$. in height, which runs still ascending to the top end of the $5 \mathrm{I} \mathrm{ft}$. length. Here the ascent is steeper than near the Lower Parapet, and steps, and traces of steps, can be seen at several points.

The inner or cliff side of the ascent, from the Lower Parapet to the higher end of the $5 \mathrm{I} \mathrm{ft}$. wall on the opposite side, is formed by large walls $3 \mathrm{ft}$. 6 in. wide on their present summits, and averaging $5 \mathrm{ft}$. in height, but are built back on a much higher level of foundation than the outer wall of the passage. These inner walls enclose an almost square open space on the inner side of the ascent, the area being $16 \mathrm{ft}$. on the south-east, I $2 \mathrm{ft}$. on the north-east, and I I ft. on the north, the lower and south-east wall slanting down-hill 
towards the passage, so that the lowest corner of the area is at the point where the ascent enters the area. The enclosure is entirely thrown into the passage. This lower corner of the area is about $8 \mathrm{ft}$. north-west of the wedge-shape dividing wall just described. The arrangement of the walls and of the area, with its lowest point resting on the passage, is most patently an intentional design of the ancient military engineers, as the slanting-down wall on the south-east side would provide room within the area for a hundred defenders, while the narrow passage immediately below where the ascent enters the area could barely have held two invaders fighting abreast. But this narrow point was once much narrower, for the foundations of a projecting buttress, rounded into the lowest corner of the area, are to be seen about $2 \mathrm{ft}$. above where the south-east wall slopes down-hill to within $3 \mathrm{ft}$. of the inner face of the outer wall. The foundations of this projecting buttress are very indistinct, and probably will disappear, as, now the buttress has collapsed, visitors walk across the remaining foundation stones as a short cut. The wall débris here suggests that the buttress was a high structure. The Zimbabwe Makalanga headmen, who were watching the clearing operations, informed the author that this buttress was once a high one, but this was in their early days and many years before their kraal was removed from Zimbabwe Hill.

From above the enclosed area to the end of the $5 \mathrm{I} \mathrm{ft}$. length of outer wall before mentioned the passage on the inner side is bounded by a wall which runs parallel to the outer wall in its curve from the south-west to the north-west.

From the higher end of the $5 \mathrm{I} \mathrm{ft}$. length of wall the passage turns directly west for $43 \mathrm{ft}$., where it curves to the north-east for $26 \mathrm{ft}$., averaging a width of $3 \mathrm{ft}$. 6 in., except just lower than the curve and through its continuation where it narrows to $2 \mathrm{ft}$. The heights of the outside wall run from $3 \mathrm{ft}$. to $4 \mathrm{ft}$. $6 \mathrm{in}$. before it reaches the curve. On 

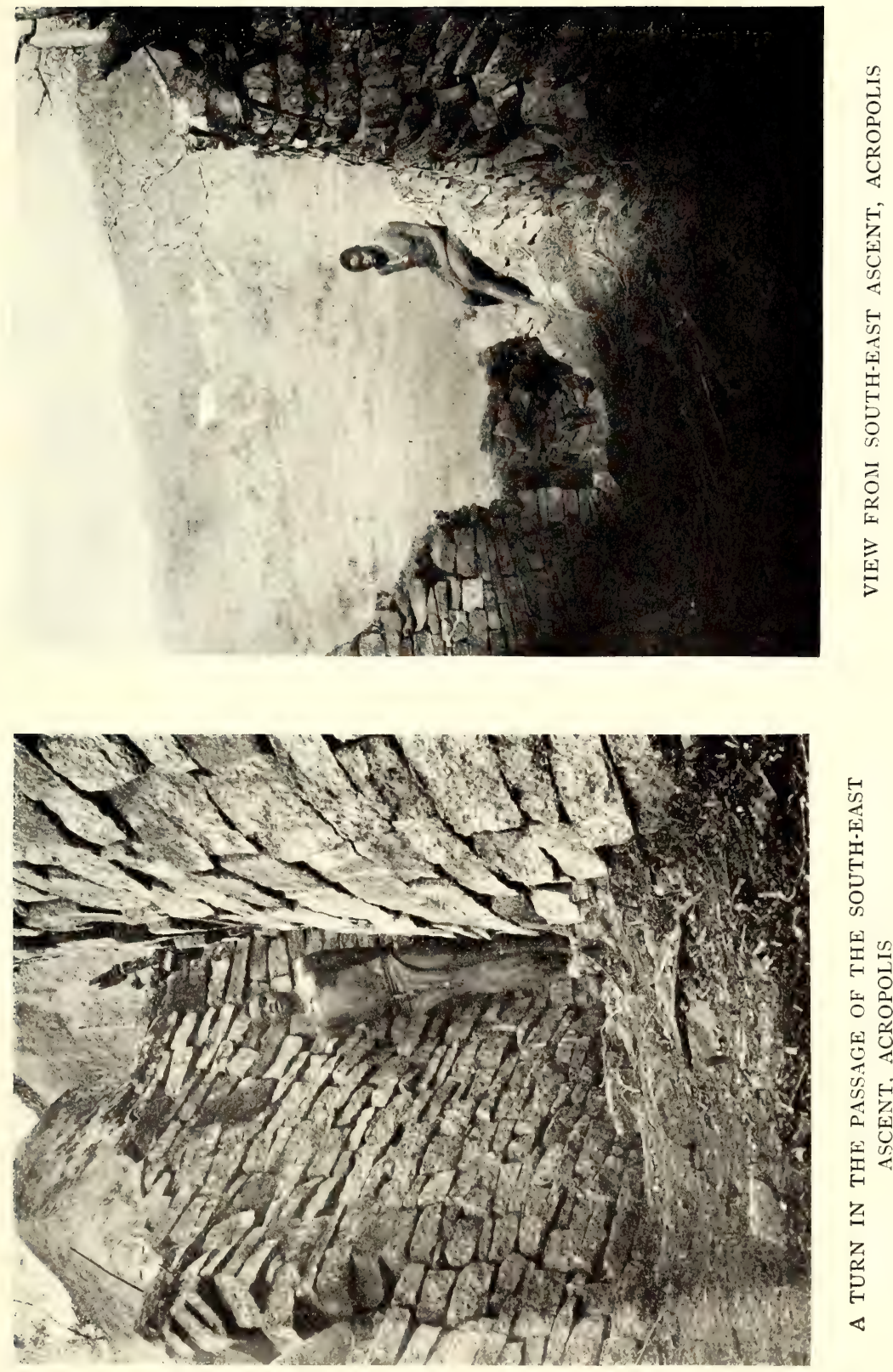

the inner side wall of the lowest part of this length the wall is much broken, especially a length of I I ft., which once held dentelle pattern, facing south.

The end walls or frame of this dentelle pattern are still to be seen, and many of the small blocks used in making this pattern were found in the passage-way. The blocks can always be identified by their exact similarity in size, and also on two faces they are exceedingly time-worn, if not decomposed, as they are built up in columns with one corner projecting outwards and flush with the face of the wall. This pattern has now become completely destroyed by wild vine trees growing inside the wall and forcing out its outer face on to the passage floor. This damage must have been done within the last ten years.

This was one of the finest examples of dentelle pattern so far discovered in Rhodesia, and had it not been destroyed would have been by far the largest pattern of all the five instances. Dentelle pattern is one of the many distinguishing features of the first period of Zimbabwe architecture.

On the floor of this passage at this point and upwards there is a flight of some thirty or forty steps. Each is very narrow from front to back, so much so that it is exceedingly awkward for anyone wearing boots to climb or descend them, though the Makalanga with their bare feet climb them with the greatest ease. The steps extend from side to side of the passage, but their end blocks, which here are very small, are not built into the foundations of the side walls as are the large steps to be found in the entrances and passages of all the original buildings at Zimbabwe. It is therefore believed that these steps in the ascent, or at least these particular steps, are not ancient, but are laid upon the original steps by mediæval Makalanga, for there is a freshness in their appearance which is never seen in steps which are undoubtedly ancient. This belief is strengthened considerably when one compares the flight of toe-lines with the broad, 
deep, and massive steps at several points in the ascent, which were built when the foundations of the passage walls were laid.

At the top end of the curve in this length of passage the heights of both walls are $9 \mathrm{ft}$., with a width of passage at this point of $2 \mathrm{ft} .4 \mathrm{in}$. In this curve are traces of several rows of large steps.

At $12 \mathrm{ft}$. above the curve the passage turns with a sharp angle to due west-north-west. On the north or inner side at this turn is a large buttress built up against the face of the cliff. This buttress is $19 \mathrm{ft}$. 6 in. in height at its rear and abuts from the cliff for $2 \mathrm{ft}$. 6 in. The front of the buttress is only $7 \mathrm{ft}$. in height. The buttress is I9 $\mathrm{ft}$. long, but wall débris fallen from the summit of the cliff extends upwards towards the entrance to the Rock Passage for another $8 \mathrm{ft}$. The outer wall here averages from $2 \mathrm{ft}$. 6 in. to $3 \mathrm{ft}$. 6 in. in height. This wall has every appearance of having been reconstructed at a later period. Its face is exposed to the fall of every stone from the walls on the summit of the precipice, and no wall débris could descend without damaging it. Up against its face were piles of blocks which had come from above, but some of these piles were comparatively modern. This point in the ascent, owing to the formation of the face of the cliff, would have guided to it all débris falling from the southern wall of the Eastern Temple, some portions of which have fallen into the ascent. The passage between the buttress of the outer wall is $2 \mathrm{ft}$. wide, but at the top end of the buttress it widens out to $4 \mathrm{ft}$. where it enters the Rock Passage.

(b) THE ROCK PASSAGE

From this point the ascent is continued in the same direction between the main cliff of the hill on the inner side (which at this elevated level of the ascent is only $50 \mathrm{ft}$. above the passage) and a colossal boulder on the outer side. This boulder beetles inwards towards the cliff and over the heads 


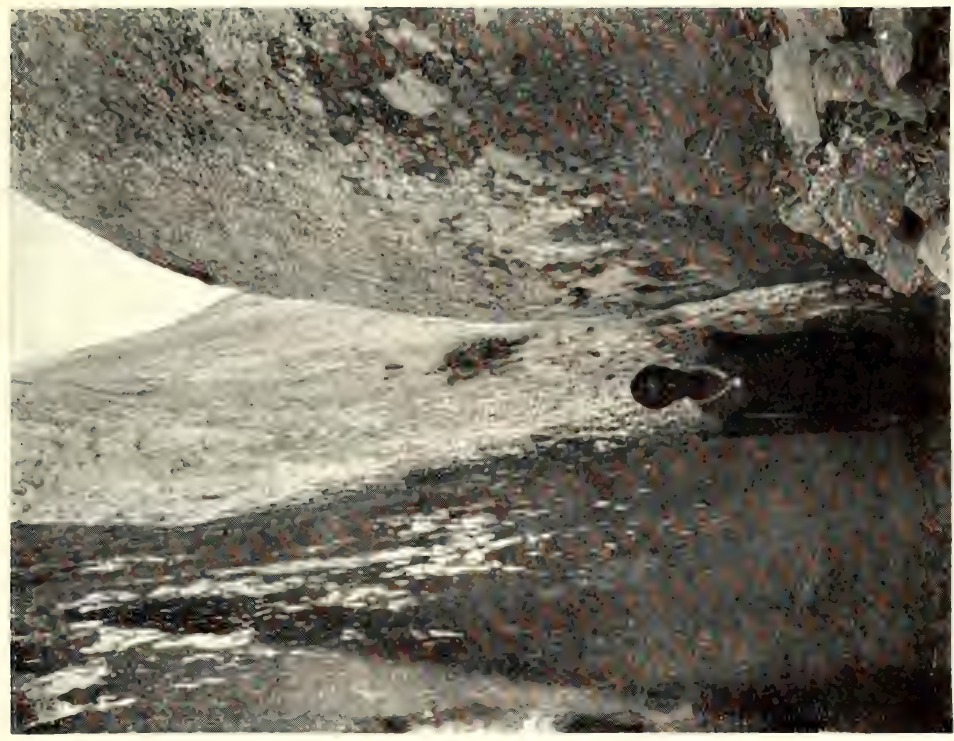

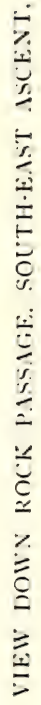

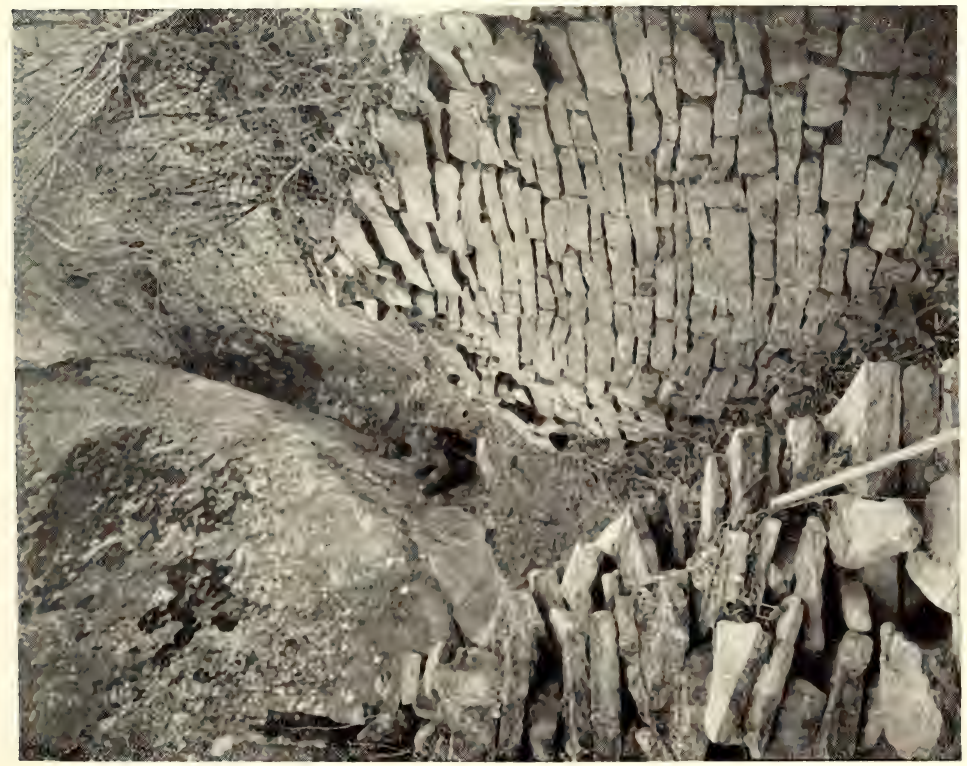

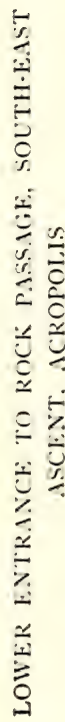





\section{THE ACROPOLIS RUINS}

of passers-by. The outside height of the boulder appears to be some $80 \mathrm{ft}$. or $90 \mathrm{ft}$., and at one time before the occupation of the hill by the ancient builders it formed part of the main cliff from which it had fallen away for some feet, both outwards and downwards; the depression in the face of the cliff from which it slipped is still the exact shape of the boulder. In the Rock Passage the height of the inside face of the boulder above the artificially made raised floor is about $40 \mathrm{ft}$. to $20 \mathrm{ft}$., according as the ascent rises. The ancients are believed to have filled in the split opening between cliff and boulder to the needed height to carry their ascent. This practice was a common one with the ancients, and a good instance of this work is seen in the Buttress Passage in the Acropolis ruins.

Once inside the Rock Passage the path rises rapidly till it reaches the open at the $200 \mathrm{ft}$. level of the hill. The passage is $48 \mathrm{ft}$. long, and its average width is $2 \mathrm{ft}$. $6 \mathrm{in}$., but at one point it is barely I ft. IO in. wide. Where the boulders end on the higher side a wall runs up on the outer side for $8 \mathrm{ft}$., and this is $4 \mathrm{ft}$. to I $\mathrm{ft}$. higher, lessening as the path ascends. The cliff here still forms the inner side for this distance, and at the top end is a rounded buttress jutting out from the cliff for $3 \mathrm{ft}$., and below it, and on the south side, are several welldefined large steps of the undoubtedly ancient type ascending on the outer side of the buttress for $12 \mathrm{ft}$.

At the end of this $\mathrm{I} 2 \mathrm{ft}$. length the passage turns north and north-east for $2 \mathrm{I} \mathrm{ft}$., and passes on the west side of the wedge-shaped-ended wall, which forms the division where the path to the Higher Parapet leaves the ascent. At the end of the $2 \mathrm{I} \mathrm{ft}$. length the walls of the ascent appear to terminate, but the path to the Western Temple and to the other ruins on the hill is continued through a gap made recently, for the sake of visitors, in a Makalanga-built wall erected on ancient foundations. This reconstruction of the wall by Makalanga without leaving any entrance down- 
wards to the ascent deliberately blocked it up. This bears out the Zimbabwe headmen's statement that within the last fifty years they rarely used the ancient ascent in climbing up to their kraal on the summit of the hill. Passing through the gap in the Makalanga wall one enters the Western Enclosure, which lies at the foot of the west face of the west wall of the Western Temple.

But the description so far given of the ascent is incomplete, for on the east side of the wedge-shaped buttress, which is on the west side of the Rock Passage, is a passage to the Western Temple by the Higher Parapet.

\section{(c) THE HIGHER PARAPET}

The length of this parapet, which extends from within $9 \mathrm{ft}$. 6 in. of the summit of the ancient ascent, is $78 \mathrm{ft}$., and it runs in an easterly direction from the right-hand side of the ascent at the point where is the upper wedge-shaped buttress and the outer parapet wall is built along a narrow ledge at the very utmost edge of the cliff. Its front foundation stones are wedge-shaped to suit the declivity of the rock on which they are placed. At certain points this parapet wall has fallen over the brink into the Rock Passage below, but the foundations remain. This dilapidation is more apparent at the eastern end of the parapet, where it passes on the precipice side of the face of a projecting boulder and also of a rounded buttress $7 \mathrm{ft}$. high, which is very well built. The boulder is erected up against the bottom part of the rounded end of the main west wall of the Western Temple on its southern extremity. This rounded buttress is $4 \mathrm{ft}$. west of the point where the Higher Parapet joins the Parallel Passage, which is a still more easterly and more elevated extension of the ancient ascent to the Western Temple.

Coming up the ascent, and $9 \mathrm{ft}$. 6 in. from its summit, the path divides as before mentioned at the wedge-shaped buttress, the right-hand path being the approach to the Higher Parapet. 


\section{THE ACROPOLIS RUINS}

Three feet above this wedge-shaped end of wall are clear traces of large steps, and at this point and on the right-hand side is a portion of dentelle pattern introduced into the wall, and this faces due west. This pattern originally consisted of five columns of blocks with projecting edges, but the lower portions of four columns now only remain. The blocks are in five courses. Unlike the dentelle blocks lower in the ascent, and also the blocks in this pattern on the Platform of the Western Temple, these blocks are of the ordinary size used in building the walls, and in size resemble the blocks used in this pattern on the east main wall of the Eastern Temple, and also those in this pattern on the Conical Tower in the Elliptical Temple.

The highest part of the outer wall of the Higher Parapet is now only $2 \mathrm{ft}$. 6 in., with a similar width on the top. The width of the approach to this parapet from the wedge-shaped end of the dividing wall is $2 \mathrm{ft}$. on the floor. The wall on the inner side of the parapet at its western end is $4 \mathrm{ft}$. 6 in. to $6 \mathrm{ft}$. high, and rounds off to the south to the wedge-shaped end where it terminates.

Visitors should refrain from passing along the Higher Parapet unless they are perfectly certain no one is in the Rock Passage at the time, as any block put in motion even by the careful climber must fall into the passage below. As before stated, the parapet wall is very dilapidated and blocks might fall at the slightest movement near them. But even with this caution the Higher Parapet is not a safe place for visitors, for, as can be seen from below, the foundations of the parapet, which are built over the brink of the precipice, show a bulging out which must sooner or later effect the destruction of the parapet.

The Higher Parapet would enable the ancient defenders to effectually block the approach of any enemy through the Rock Passage, however great their number. 
There are two points worthy of notice in connection with this ancient ascent :-

I. Original heights of walls.-The walls of the ascent in their original state were considerably higher than even the highest ( $9 \mathrm{ft}$.) as seen at two points to-day. In discussing this matter with some of the Makalanga headmen, it was ascertained that even within their day, say fifty years-for Mogabe is fully seventy years of age-some of the highest walls were $4 \mathrm{ft}$. or $5 \mathrm{ft}$. higher than they are at present. But on examining the numerous and immense wall-débris piles which were removed in August, 1902, the estimate as to the heights of the walls in their original form has to be very considerably increased, for these piles were only the débris of the inner side walls and of the inner faces of the outer walls, since the main portions of the outer walls which have fallen have gone down the precipice, for at its base one can walk for over Ioo yds. on wide and high piles of wall débris which has fallen down from the outer walls of the ascent.

The present widths of the walls also are some guide in forming an estimate of their original heights. . Some of these walls are from $5 \mathrm{ft}$. to $7 \mathrm{ft}$. wide on their present very reduced summits, and taking the usual Zimbabwe batter-back of I $\mathrm{ft}$. in $6 \mathrm{ft}$. which is found in many of the buildings of the first period of Zimbabwe architecture-and these buildings are most manifestly of that period-it would be within a safe limit were it stated that these passage walls were at least I $5 \mathrm{ft}$. high on either side throughout the greater length of the ascent. This estimate would then fairly account for the great amount of wall débris with which whole lengths of the ascent were completely choked up, in some places to the tops of the walls on either side, and also for the wall débris at the foot of the ascent.

Certainly most of the damage to the walls was done centuries ago, for the ancient blocks on the sides and tops 
of the débris piles have, since they fell into their present position on the piles, become on all their exposed faces and sides, and even on their back parts, as weathered and timeeaten, and in some cases as decomposed, as the front faces of the blocks remaining in the walls.

But, unfortunately, irreparable damage has been done to these walls within the last twenty years, and certainly within the last ten years, for trees of not older growths than these periods were found to be growing right in the centres of the walls, their roots pushing out lengths of wall faces. This is the cause of the destruction of the lower set of dentelle pattern, which has certainly been effected during the last ten years. The inside of the wall from which the dentelle blocks have fallen has every appearance of being quite fresh, and is not in the slightest degree weather or time worn.

2. The ascent from the coast route.-This ancient ascent being on the south side of the hill, and running for $600 y d s$. from the valley at the clear east end of the hill up the south face to the summit, it may naturally be taken for granted that this was the path along which all arrivals by the route from the coast at or near Sofala would approach Zimbabwe Fortress. As there are only two ancient ascents, the southern and the north-western, and all other parts of the hill being inaccessible, this conjecture may probably be the correct one, for to have traversed the North-Western Passage for such a purpose would have taken the ancients at least one mile out of their way. Every step taken down the Southern Passage was one taken nearer to the coast.

On referring to The Ancient Ruins of Rhodesia, it will be found that chains of ruins of forts, occupying strategic positions at comparatively equal distances from each other, run in a south-easterly direction along the Motelekwe River, and are further carried along the Sabi far into Portuguese South-East Africa. The south ascent appears to be the north-west termination of this line from the coast, and the 
importance of this approach is demonstrated by the presence of two outer distinct and large ruins in the valley at the south-eastern end of the hill, and these guard the lowest extremity of the ascent. The Mapaku Ruins, misnamed Little Zimbabwe, which lie eight miles south-east of the Great Zimbabwe, would form the first posting-station and fort for the protection of the road to the Motelekwe chain of forts.

Besides, the contour of the country round Zimbabwe very clearly points this route out as the ancient line of road to the south-east coast, any other line, as can be seen from the summit of Zimbabwe Hill, being barred by ranges of steep and high kopjes, in addition to which it may be observed that the wagon road from Zimbabwe towards the Motelekwe and Sabi rivers runs to-day along this identical line, as the formation of the land permits of no other route from Zimbabwe.

It was shown in chapter vii. that discoveries demonstrated that the ancients exported a large quantity of the gold won from the thousands of ancient workings on the numerous gold-belts of Southern Rhodesia. This amount authorities have placed, on a conservative estimate, at no less than $£ 75,000,000$. Most probably a portion of whatever gold was won in the northern gold districts of Southern Rhodesia went to the coast by a northern route and not via Zimbabwe. But the gold collected from each of the capital towns in the more southern portion of Southern Rhodesia, the capital towns having collected the gold from their respective subdistricts on the reefs, would come to the metropolitan centre at Zimbabwe, ready for transmission by caravan to the coast. The districts that in all probability sent from their capital towns their stores of gold as they became accumulated, so far as the lines of forts and the contiguity, geographical position, and convenience indicate, would be the present Tati, Bulawayo, Bembesi, Selukwe, Gwanda, Filabusi, Belingwe, etc., and the gold districts of Southern Mashonaland. For the service of 
these districts the north-west ascent at Zimbabwe would appear to be extremely natural. The gold therefore, in all probability, was brought from these districts to Zimbabwe along its north-west ascent, and was taken away to the coast by the marvellously protected path leading to the south-east.

This argument is not mere romancing. It is one which has every evidence in its favour so far as any evidence can at present be secured. Passing along the south-eastern ascent we may be pardoned if some poor attempt be made to reconstruct some of the scenes that have taken place in ancient times within its narrow and tortuous walls. Here may have occurred the greeting of fresh arrivals from the coast, or from the mother country of the ancient colonists; the bringing of news from a far country, possibly news from Yemen, and later from Tyre and Sidon; news of changes in home dynasties or of the progress of those ancient and classic wars which shook the world and started fresh eras and epochs in its history.

There, too, might have been seen the train of slaves carrying their golden burden in claw-hammer-shaped ingots as stated to have been shown on the monuments of Punt, and as they are pictured in the tombs of ancient Egypt, of which the ancient soapstone moulds are represented in collections of relics found in Rhodesia. Ivory, apes, ostrich feathers, and gorgeous birds would be borne in the caravan, while gangs of slaves, doomed to exile, would follow in the convoy, for all these, since before the dawn of history, have been exported to the "Near East" from Sofala and ancient Rhodesia.

Again, there might have been seen the dusky Semitic crowd watching the departure of the results of their toil on so many ancient gold-bearing districts, dressed in short, armless tunics (p. I08), ${ }^{1}$ and displaying massive gold bangles, exquisitely made and chased with Zimbabwe designs, on arms, wrists, legs, and ankles, and with chains of heavy gold beads round their necks, and in their hands the rods of office with 
the beaten gold sun images on the tops, gold ferules at the ends, or copper battle-axes and spearheads thickly plated with gold-for all these are articles plentifully found with the buried ancients of Rhodesia.

One can almost see the vantage grounds seized by the younger members of the ancient crowd to view such spectacles, for on the same granite cliff-ledges, foot-polished by ages of wear, the young men of the Makalanga love to climb and squat.

At the lower end of the passage, and near the two ancient forts which protect its south-eastern extremity, would be the soldiery in readiness to take up their position in guarding the caravan. One can realise how the ancients climbed on to the boulders at the very summit of Zimbabwe Hill to strain anxious eyes in watching the progress of the convoy down the valley towards the south-east till it disappeared in the blue distance of the lower land.

Romance is most undoubtedly buried on the floors of all Zimbabwe ruins throughout Rhodesia, but Romance rivalling that of Rider Haggard at his best pervades the massive walls of this ancient ascent as it insinuates its upward way along the precipitous side of Zimbabwe Hill.

\section{WESTERN ENCLOSURE}

To reach the Western Temple on the hill from the SouthEast Ancient Ascent, the Western Enclosure must first be crossed, seeing that the Higher Parapet path is now become dangerous.

This enclosure lies on the west side of the main west wall of the Western Temple. The highest part of the enclosurethe east-is $2 \mathrm{I} 2 \mathrm{ft}$., and the lowest-the west part-is $205 \mathrm{ft}$. above the valley. The main west wall of the Western Temple forms its easterly boundary for $7 \mathrm{I} \mathrm{ft}$., the other walls making the enclosure nearly square. The wall on the north side is $52 \mathrm{ft}$. long, $4 \mathrm{ft}$. to $6 \mathrm{ft}$. high, and $3 \mathrm{ft}$. to $4 \mathrm{ft}$. wide on 
present summit. The west wall is $8 \mathrm{I} \mathrm{ft}$. long, and similar in width and height. The south side, with no wall now remaining, is $6 \mathrm{I} \mathrm{ft}$. long, and at $4 \mathrm{ft}$. to $7 \mathrm{ft}$. below the south edge, on the outside of this enclosure, runs the Higher Parapet previously described.

None of these enclosing walls, except, of course, the main wall of the temple, are ancient. They are rudely built, or, rather, neatly piled. This is obviously Makalanga work of a generation or two past, and the Zimbabwe Makalanga admit this to be the case. But at several points the walls run on ancient foundations. These modern natives, in imitation of the monoliths on the temple wall above, have erected a slate monolith on their north wall, but upside down. Slate beams, evidently fallen from the wall above, have been used by the Makalanga as building material, as using them saved labour.

But there are strong evidences that the builders of the ruins themselves used this ground as an enclosure, and these in addition to the remains of the enclosing walls' foundations. At a distance of $15 \mathrm{ft}$. in front of the main wall of the temple is a wall built in good style and, till recently, perfectly buried in soil. This portion of a wall runs from north-east to southwest for $7 \mathrm{ft}$. 6 in., and is $2 \mathrm{ft}$. 6 in. high, ending at each extremity abruptly, the south-west end showing a tendency to curve more to the south.

Also in the north-east corner and at the foot of the main wall of the temple, and at $7 \mathrm{ft}$. and $\mathrm{I} 5 \mathrm{ft}$. respectively from it, there are very decided traces of terrace walls, with parapets descending into the interior of the enclosure. The probable purpose of these terraced walls is alluded to in the description of the Western Parapet, as this parapet runs through other enclosures described later.

The drop of $7 \mathrm{ft}$. towards the west in the level of the surface of this enclosure rather tends to support the theory advanced by Messrs. Bent and Swan that the main west wall 
of the Western Temple once stood some yards more to the west of the present west main wall. This theory is at present somewhat difficult to accept, for the existing wall is the widest wall yet known in any ruin in Rhodesia, not excepting the huge main walls of the Elliptical Temple in the valley. This main wall of the Western Temple is I I $\mathrm{ft}$. wide on its summit at $\mathrm{I} 8 \mathrm{ft}$. above the ground. Still there are other points, mentioned later in connection with the Western Temple, which would seem to support Messrs. Bent and Swan's theory.

Passing from the Ascent, along the south side of this enclosure, climbing the wall débris in front, and passing through a gap in the dilapidated part of the main wall directly opposite, one enters the Western Temple at its southwest corner. 


\section{CHAPTER XV}

\section{THE ACROPOLIS RUINS \\ (Continued)}

\section{THE WESTERN TEMPLE}

HIS temple is the most westerly portion of the main ruins
on Zimbabwe Hill, and is built upon the steep edge of the western side of the kopje at $220 \mathrm{ft}$. above the valley and also immediately on the summit of the precipice, some $90 \mathrm{ft}$. in height, which runs along the south face of the hill. A splendid view of the Elliptical Temple in the valley, as well as of the many ruins within the Zimbabwe Reserve, is obtainable from this point.

The Western Temple has the form of an amphitheatre, its area being in the shape of a little less than a quarter of a circle, the centre from which the south and north walls radiate being at its most easterly point and $\mathrm{I} 22 \mathrm{ft}$. from the centre of the inner face of the massive main west wall which curves with a magnificently bold and perfect sweep towards due west, connects the north and south walls at their westerly extremities, and runs for $\mathrm{I} 37 \mathrm{ft}$. on its inner face from southwest to north-west.

This curved west wall is the most massive structure so far discovered in any ancient ruin in Rhodesia, though it is not the longest. It has a width of summit at $25 \mathrm{ft}$. from the ground of $\mathrm{I} 4 \mathrm{ft}$. 6 in., the general average width being I I ft., and is still liberally decorated with huge granite and slate monoliths and a row of small conical towers which are now more or less imperfect. 
The lengths of the walls along their inner faces are as follows: north wall, $90 \mathrm{ft}$; ; south wall, with gaps, $127 \mathrm{ft}$. ; and the curved west wall, $\mathrm{I} 37 \mathrm{ft}$.

The present surface of the area is very irregular owing to the soil and wall débris having been piled up at several points by excavators whose trenches and digging are still to be seen. Disregarding these piles the highest part of the area is at its eastern end, the lowest being at the inside base of the west wall.

North wall.-This wall may be divided into several lengths from east to north. The $22 \mathrm{ft}$. length from the east reaches to The Platform Cave. This length of wall supports The Platform on its south-west side. Here the wall is I $2 \mathrm{ft}$. high, measuring from the present surface of the temple, which is, so far as can be ascertained, some $3 \mathrm{ft}$. to $5 \mathrm{ft}$. above the highest and latest ancient floor. Towards the $\mathrm{I} 5 \mathrm{ft}$. point the wall is carried over a huge boulder I I $\mathrm{ft}$. high, also over a smaller boulder partly resting on the first boulder and partly against another boulder, which forms part of the north side of The Platform Cave, along which boulders the height of the wall is I I ft. over the large boulder, and $6 \mathrm{ft}$. over the smaller and higher one, but including the height of a rounded end of wall on The Platform above which is built upon this wall, the height of the wall above the smaller boulder is I I $\mathrm{ft}$.

The I4 $\mathrm{ft}$. length of this wall clears the entrance to The Platform Cave and the steps, now dilapidated, leading from the floor of the temple to the upper flight of steps to The Platform. In addition to these steps on the west side of the cave, there was once a wall on the summit of the boulder up which the steps ran, but the boulder is now bare save for a small cap of red daga (clay) which once formed the foundation of a small Makalanga granary, such positions being usually selected on account of their freedom from white ants.

The $28 \mathrm{ft}$. length is built upon and along the top of a long boulder. This wall on its inner face is in good condition, 
but its back part which forms a portion of the south wall of the Platform Enclosure is very dilapidated. The heights of this wall are $7 \mathrm{ft}$. 6 in., Io $\mathrm{ft}$., and $5 \mathrm{ft}$. at three different points going north-west. The last $7 \mathrm{ft}$. of this length is a gap, the foundations only remaining.

The $26 \mathrm{ft}$. length of this wall extends from the gap to the inside of the north end of the main west wall, where it acts as the south side of the west extremity of the deep passage recently unburied which runs down the centre of the Platform Enclosure. It is $5 \mathrm{ft}$. to $6 \mathrm{ft}$. high on the temple side. This $26 \mathrm{ft}$. length of wall has been very seriously damaged by roots of large trees.

The widths of the summits of the north wall range between $3 \mathrm{ft} .6 \mathrm{in}$. and $5 \mathrm{ft}$., but as The Platform ends where the west end of The Platform comes flush to the temple face of the wall, it is difficult to state any width, but still it must be exceptionally wide to carry the wall which here rises to $18 \mathrm{ft}$. from the present filled-in level of the centre of the temple.

West wall.-The west wall of the temple runs from northwest to south-west, and is $137 \mathrm{ft}$. long on its inner face, and may, for the purposes of this description, be divided into two lengths, i.e., $29 \mathrm{ft}$. and $108 \mathrm{ft}$. commencing at its north end.

The $29 \mathrm{ft}$. length extends from the north end of the west wall to the south-west side of a divisional wall of the same height, but only $4 \mathrm{ft}$. wide on its summit, which is built up against the inner face of the main west wall and protrudes $9 \mathrm{ft}$. into the temple in a south-easterly direction. This divisional wall has a drain-hole right through it at $6 \mathrm{ft}$. below its summit. It is evident that the bottom of the drain, which passes through dry masonry, once had a lining of cement which resembles in make and quality that used in the lowest floor of the temple. This length of the main wall is still intact.

The $108 \mathrm{ft}$. length extends from the south-west side of the divisional wall just mentioned to the southern extremity of 
the main wall. At Io $\mathrm{ft}$. south of this divisional wall is the lowest point in the interior of the temple. At $33 \mathrm{ft}$. along this length, still measuring in a southerly direction, the wall has been considerably damaged, there being a wide and deep gap on the outer side and a depression in the general line of summit of the wall on its inner face. From this point in this length to $86 \mathrm{ft}$. the wall is again intact, and at its original height. The last $22 \mathrm{ft}$. of the $108 \mathrm{ft}$. length is very considerably dilapidated. The west wall terminates on the south-south-west in a rounded end, the lower part of which is exceedingly well built and stands I I ft. above the ground. This rounded end is one of the two rounded buttresses which form the north or right-hand side of the west end of the Parallel Passage on approaching it from the Higher Parapet.

The widths of the west wall at the summit are as follows: north extremity, I $3 \mathrm{ft}$. 8 in.; at north end of the $108 \mathrm{ft}$. length, $14 \mathrm{ft} .6$ in.; at the gap, $2 \mathrm{ft}$. to $3 \mathrm{ft}$; ; at south-southwest of gap, $12 \mathrm{ft}$. The gap is $23 \mathrm{ft}$. long on the inner part and $29 \mathrm{ft}$. long on the outer or west side.

The heights of the wall above the present levels of the ground, outside and inside, are as follows: northern extremity, $25 \mathrm{ft}$. outside, and $6 \mathrm{ft}$. inside ; at northern extremity of the $108 \mathrm{ft}$. length, $22 \mathrm{ft}$. outside, and $16 \mathrm{ft}$. inside; at south-west of gap, $2 \mathrm{I} \mathrm{ft}$. outside, and $10 \mathrm{ft}$. 6 in. inside. The $22 \mathrm{ft}$. portion of the $108 \mathrm{ft}$. length is simply a great pile of wall débris. The outside measurements are taken from the top of the Western Parapet, which runs along at the foot of the west face of the wall.

There are two points which will make this curved west wall of great interest to archæologists :-

(I) It has the widest summit of any ancient wall yet discovered in Rhodesia, and

(2) The Monoliths and Conical Towers alternating along its summit. It should be stated that there are two lengths of summits of this wall still remaining intact at their original 

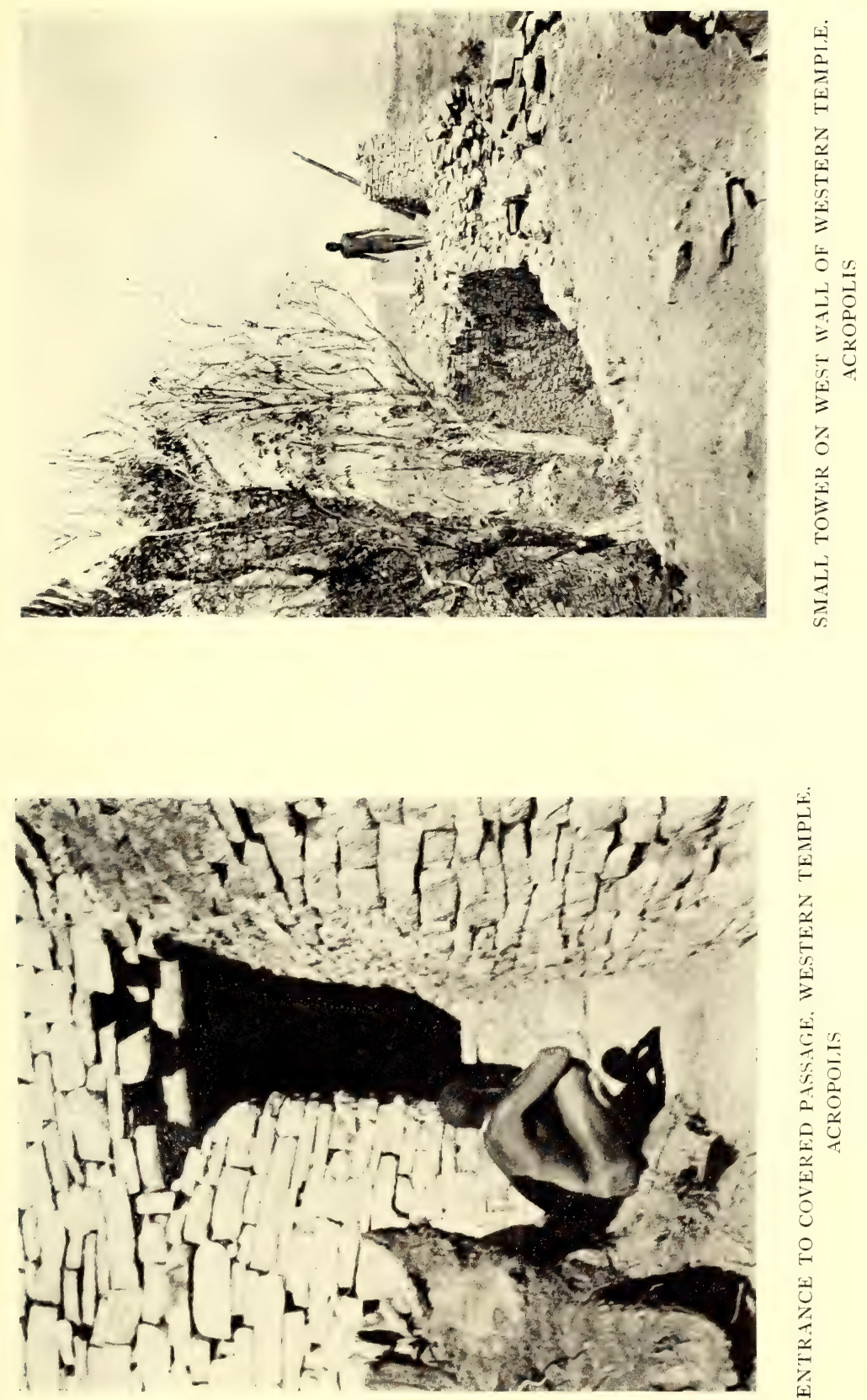

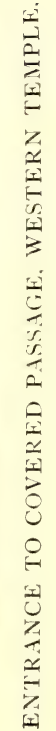



heights. One length is at the northern end of the wall, and is $44 \mathrm{ft}$. in length, and the other at the south of the gap, and this is $46 \mathrm{ft}$. in length.

On the first line of summit the centres of the towers, foundations, or traces, are at the following points, measuring from the northern end: $6 \mathrm{ft}$., north face of tower $2 \mathrm{ft}$. high only now remains; $12 \mathrm{ft}$., foundations of tower with débris stones with rounded faces ; $18 \mathrm{ft}$., portion of foundation only; $24 \mathrm{ft}$., tower in good condition to $2 \mathrm{ft}$. in height ; $30 \mathrm{ft}$., ditto ; $36 \mathrm{ft}$., débris only; and $42 \mathrm{ft}$., traces of foundation and débris.

On this length of summit there are three slate monoliths with tops, some fractured, standing $3 \mathrm{ft}$. to $5 \mathrm{ft}$. above the summit of the wall. These are practically equi-distant. Two other slate monoliths were found in the débris at the outer base of the wall, and judging by the spot where found, there are probably two others still buried in the débris.

On the second line of summit, which extends for $46 \mathrm{ft}$. from south of the gap, one round tower remains intact to a height of $3 \mathrm{ft}$. 6 in., where it has a diameter of $3 \mathrm{ft} .4 \mathrm{in}$. The towers or traces of towers on this line of summit are at the following points, commencing from the gap; $4 \mathrm{ft}$., tower, the most perfect specimen remaining; Io ft., traces of tower; I $5 \mathrm{ft}$., ditto; $20 \mathrm{ft}$., foundations only; $27 \mathrm{ft}$., ditto; $33 \mathrm{ft}$., traces ; $42 \mathrm{ft}$., ditto.

On this line of summit there are four slate monoliths, more or less erect, standing at equi-distant points. One flat granite monolith lies on the wall by the side of the hole in which it once stood. One slate monolith was found at the outer base of the wall where the gap divides the two lines of summits. The heights of these monoliths, some fractured, range from $5 \mathrm{ft}$. to $9 \mathrm{ft}$. above the summit of the wall. One of these must, in all probability, be $5 \mathrm{ft}$. long.

There seems to be little doubt that these towers, as erected originally, were conical. The most perfect tower shows a very decided drawing-in of the upper courses, while among 
the débris of each tower are smaller blocks, showing by the contracted curve of their rounded faces that the courses they represented had much smaller radii than those of the courses below.

Architecture and construction of west wall.-Both the architecture and construction of this wall are most obviously of the First Zimbabwe Period; but most of the material used is of an inferior quality to that in the other walls of this temple. This is patent to anyone inspecting the western face of the wall, where very many of the granite blocks are cracked, and in some places considerably decomposed. Some of the courses are also very irregular, and have steep gradients, while many courses disappear, or are false in order to restore the level of depressed courses, besides which the blocks vary greatly in size. Still, the wall does not show any other feature of the Second Period Zimbabwe architecture. As stated before, it is undoubtedly the most massive wall of any ancient ruin yet discovered in Rhodesia, but it was most probably built, or rather reconstructed, during a late portion of the First Period, and, as Bent suggests, later than other walls of this temple. He further suggests that this is a reconstruction of the west wall on a curve some yards further east of its original position. In the description of the Western Enclosure (see later), of which this wall forms the eastern side, it is stated that there is much difficulty in accepting this conjecture. The opportunities opened to the author for examining the ground to the west of the wall were far better than those opened to Bent, and the failure to discover any ancient foundation which could have carried even a much smaller wall was complete; in fact, no foundations whatever anywhere within the point of distance mentioned by Bent. Moreover, the southend of the present wall, as seen at the eastern end of the Higher Parapet, is most excellent work, and appears to have been erected at the same time as the other walls of this 
temple. Bent's suggestion as to a reconstruction of this wall at a later period is highly probable, but this reconstruction was only partial, it did not include the south end, and it was upon the original foundations. The radius of the segment of the south end demonstrates that the correctness of the curvature of this wall would have been destroyed had the reconstructed portion been built upon any other line of foundation.

South wall.-This wall is the large massive wall seen from the valley on the south and west sides of the hill. It is built upon the actual brink of the south precipice, and is $78 \mathrm{ft}$. long, but including the foundations in the gap at its eastern extremity, its total length is $127 \mathrm{ft}$.

The first $2 \mathrm{I} \mathrm{ft}$. measuring from the western end forms the outer wall of the narrow passage from the Higher Parapet in the South-East Ascent to the Western Temple, and also forms the south wall of the western end of the Parallel Passage. This wall at its western end is much reduced by dilapidation, and here its height rising from the bare rock of the precipice is Io ft. above the floor of the passage. The wall at this point terminates in a beautifully rounded end, which is a splendid work of art, rivalling in this respect the round end of the wall on the south side of Pattern Passage. From the western extremity the south wall rises in height on its outer face as it extends east to $25 \mathrm{ft}$., and $35 \mathrm{ft}$. for the rest of the wall as far as the gap. Here the original summit is practically intact as far as the west side of the gap, where the foundations of the wall are level with the ground and are about $8 \mathrm{ft}$. wide. The inside face of the wall above the interior surface of the temple ranges from i I ft. to $\mathrm{I} 7 \mathrm{ft}$. according as the ground rises and falls.

There are no traces of round towers on this wall, but three slate monoliths and one of granite are still more or less erect on the higher portion of the wall. Two slate monoliths were 
found by the writer at the inner base of the wall, and these would have made the line equi-distant.

East side of temple.-This is $36 \mathrm{ft}$. long. The first io $\mathrm{ft}$. from the south side is a débris heap ; from $10 \mathrm{ft}$. to $26 \mathrm{ft}$. is a wall rounding towards the east, and this wall is $\mathrm{I} 8 \mathrm{ft} .6$ in. high ; $26 \mathrm{ft}$. to $29 \mathrm{ft}$. is the Covered Passage where the wall is $9 \mathrm{ft}$. over the passage; $29 \mathrm{ft}$. to $36 \mathrm{ft}$. is a wall extending to The Platform, where the height of the wall is $14 \mathrm{ft}$. from the lower end of the boulder some $9 \mathrm{ft}$. above the pile of débris lying on the floor. It is at this point that the north wall before described commences.

Centre of arc.--Schlichter suggested that the centres of the arcs of those massive and decorated walls, which are curved either towards the west or east, might have had some peculiar importance in the minds of the ancient builders. This suggestion is based on his examination, not only of the temples at Zimbabwe, but of the larger elliptical buildings elsewhere in the country.

At the centre of the arc of the curved, decorated, and massively built west wall in the Western Temple on the Acropolis (and this is the widest wall yet discovered in Rhodesia) a discovery has been made which may possibly bear on the question of the orientation of these temples, though in the matter of orientation or otherwise it would be much safer to keep an open mind till more information can be placed before accredited experts acquainted with this branch of science.

The spot marked $\mathrm{R}$ on Bent's plan- "centre of arc of great wall"-was covered on the surface by a very old Makalanga daga floor broken in pieces by an old and decayed tree. These loose slabs of clay flooring having been removed, about $2 \mathrm{ft}$. depth of blocks and soil was found. The blocks had no relative position to one another, and they were in all positions. Immediately below this débris was found a yellow granite cement structure. This is semi- 
circular in shape, measuring I I ft. 8 in. round the curved base from end to end. The straight back part is $6 \mathrm{ft} .3$ in. across. The structure is formed by two rounded curved rims, one on the other, the top one receding 4 in. from the face of the lower one. The lower $\operatorname{rim}$ is $\mathrm{I} \mathrm{ft}$. high, and the upper one $8 \mathrm{in}$. The structure is hollow to a depth of 9 in., and the interior extends evenly all round to within Io in. from the front upper face of the structure.

At $8 \mathrm{ft} .6 \mathrm{in}$. from the centre of the front of this structure, and immediately due south behind it, is a granite cement cone in splendid condition. This cone is $4 \mathrm{ft}$. I I in. in circumference at base, and is I ft. 4 in. high. At ro in. due east of the first cone is a smaller one with a circumference at base of $2 \mathrm{ft} .4 \mathrm{in}$., and this is $6 \mathrm{in}$. high. The semi-circular structure and the two cones are connected by a flooring of the same excellent quality of cement, and are structurally one.

On following the cement floor towards the north-east it was found to be decomposed by water and to have become like bright yellow clay. The lowest part of the surface of the interior of the eastern end of this temple is at this point, and from it rain-water could not escape. This decomposed cement was swagged and depressed considerably by the damp, but it was easily followed for $28 \mathrm{ft}$. 6 in. The granite cement floor runs in all directions from the semi-circular structure, but in most parts it is still solid, exceedingly hard, and in good condition.

At the $28 \mathrm{ft}$. 6 in. point and at $5 \mathrm{ft}$. below the filled-in surface of the interior of the temple a cement cylinder was found. This is beautifully rounded and has four bevelled bosses, equi-distant, on its side. The cylinder was found upon a platform of the best cement yet discovered at $\mathrm{Zim}$ babwe. It has a diameter of I ft. 8 in., is 5 in. high, and has a circumference at the curved-in base of rounded side of $4 \mathrm{ft} .2 \mathrm{in}$. The bosses or knobs, which are bevelled, project 
outwards $\mathrm{I}$ in. The side is formed by three flat bevelled faces running all round, the centre bevelled face projecting half an inch beyond the others. The top is level, and the bottom part curves inwards at its base. The cylinder is perfectly free of any damage and is without the slightest scratch on its smooth surface. The workmanship is of so excellent a character that it is still almost equal in design and construction to any similar object that could be turned out at a European workshop.

The cylinder stands on a platform at $3 \mathrm{ft}$. $6 \mathrm{in}$. from its front on west side, the face of the platform being formed of two almost semi-circular faces meeting and turning inwards some few inches eastwards towards the cylinder. The platform is I ft. I in. high on the northern curve, the southern extremity being well rounded off, while the northern extremity runs into and under a bank of débris not yet cleared away.

The "finds" at the centre of the arc in this temple included the usual unpleasing emblems of Nature Worship; a piece of forked iron, more rust than iron, with six gold bosses the size of peas at equi-distant points; these are riveted on the iron with corresponding gold bosses on the opposite side, the rivets through the iron being of gold; a sheet of beaten gold $3 \frac{1}{2}$ in. by $2 \frac{1}{4}$ in., also some fragments of beaten gold and gold tacks ; fragments of soapstone bowls and beams, old pottery, some peculiarly shaped natural stones, including serpentine stones, and an Isafuba game stone.

The "finds" at the cylinder were three large black beads with white lines possibly identical with a similar bead found by Bent on the Acropolis, to which (p. 205) he ascribes a very great age ; also under the curved-in side of the cylinder were scratched out some fifty light green beads with encircling ribs, and these both local Makalanga and Barotse natives state are completely strange to them; some yellow and green glass beads of microscopic size, the holes being scarcely visible with- 
out the aid of a magnifying glass; a miniature phallus carved, old pottery, and a small block of mica split up into sheets. In the side of the trench on a clay floor I $\mathrm{ft}$. above, and at the back of the cylinder, is a stratum of ashes out of which a quantity of beaten copper sheetings, copper tacks, a large copper battle-axe, and a very thick copper bangle were drawn.

Above the cylinder were at least four floors with ashes on each, and the remains of a furnace on two of them. Above the top floor were $3 \mathrm{ft}$. of very hard soil, and $18 \mathrm{in}$. of black soil, and on the top were the remains of a decayed tree, which must have been at least fifty or sixty years old.

Covered Passage.-This passage is at the eastern end of the temple, to which it served as an approach from The Platform. It is $2 \mathrm{ft}$. wide, $6 \mathrm{ft}$. 6 in high, has a rounded end on the north side, is Io $\mathrm{ft}$. long, and the high wall over it is supported by five large slate lintels. The passage opens out at the east end at the foot of The Winding Stairs. In the passage the writer found (August, I902) a Makalanga grave, and with the permission of the local chief, the skeletal remains were removed and re-interred elsewhere.

Platform Cave.-This cave is immediately below The Platform, and opens on to the floor of the temple. It is $8 \mathrm{ft}$. to ro $\mathrm{ft}$. high throughout a length of $22 \mathrm{ft}$. At I I $\mathrm{ft}$. from the entrance the width is $2 \mathrm{ft}$. IO in., and at the innermost point $4 \mathrm{ft}$. 6 in., where it is walled up with blocks. The cave is formed by an immense boulder on the east side and by two large boulders on the west side. It had two floors, the higher floor being $4 \mathrm{ft}$. above the lower one. The top floor, which was of red clay, was obviously of Makalanga make, but the lower one, which is made of granite cement, is believed to be of a late ancient period. Probably a still more ancient flooring may be found lower. On the top floor was a modern Makalanga grave, and the remains were removed elsewhere and re-interred. On the lower floor some of the fragments of the decorated soapstone found by Bent, and of 
which he mentions what fragments were missing, were discovered by the writer within a few feet of the spot where Bent found the larger portions of this beam.

Stairs to Platform.-The entrance to the Platform Cave is narrowed by the lower steps of a flight of stairs rising from the interior of the temple over the two boulders, which form the northern side of the cave, up to the upper flight of stairs on the north side of The Platform. The steps are considerably ruined, but can be traced, the stones being covered with a cement not believed to be ancient.

Parallel Passage.-This passage extends from the point where the Higher Parapet enters the temple at its southwest corner, the south wall of the temple forming its south side. The eastern extremity of this passage is at the wide gap in the south wall. Its total length is $7 \mathrm{I} \mathrm{ft}$. The walls on the north side vary in height from $5 \mathrm{ft}$. to I $3 \mathrm{ft}$., according to the rise and fall of its floor. Its width varies from $2 \mathrm{ft}$. to $3 \mathrm{ft}$. Half-way along are traces of steps, also at its lowest point. This Parallel Passage appears to be similar in purpose, so far as can be surmised, to that of the Parallel Passage in the Elliptical Temple in the valley.

Internal walls.-These are five in number, so far as discoveries have been made; and for the purposes of this description, and for the assistance of visitors, are lettered $\mathrm{A}$ to $\mathrm{E}$ on boards affixed to the walls.

$A$. This is the wall mentioned in the description of the main west wall as being built up against the inner face of the main wall, and as protruding $9 \mathrm{ft}$. into the temple in a southeasterly direction.

$B$. This is a small isolated section of a wall with broken ends, and is $28 \mathrm{ft}$. south-west of the north wall, and $38 \mathrm{ft}$. from the west wall. It is $4 \mathrm{ft}$. long., $2 \mathrm{ft}$. 6 in. wide, $4 \mathrm{ft}$. high, and its faced sides are north-east and south-west.

C. A small isolated section of wall $38 \mathrm{ft}$. 6 in. from the north wall, and $44 \mathrm{ft}$. from the west wall. It is $5 \mathrm{ft}$. high and 


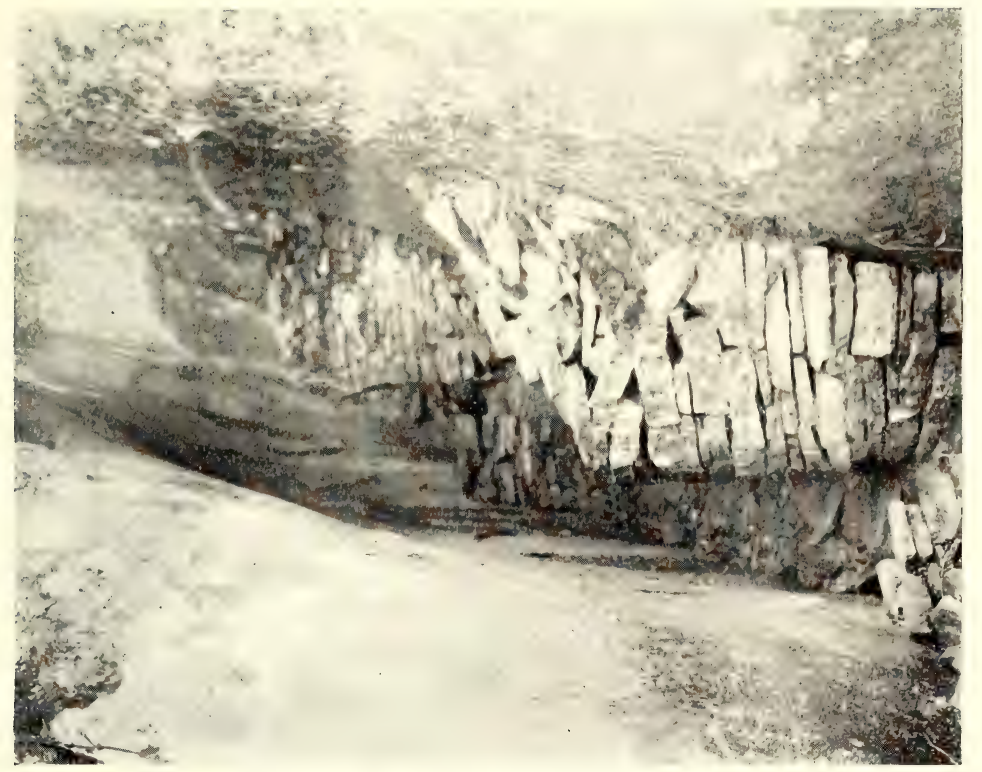

0
3
0
2
0
0
0
4
0
0
0
0
0
0
4
0
0
0
0
0
5
5
0

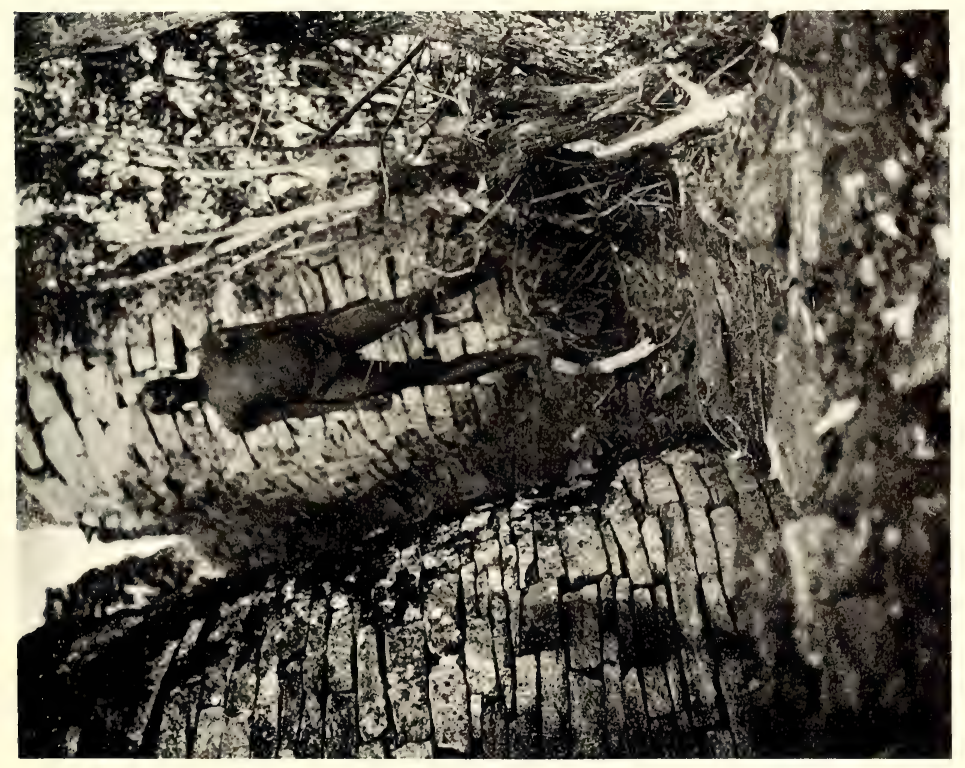

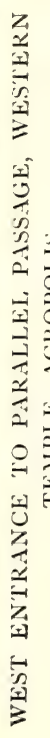





\section{THE ACROPOLIS RUINS}

$7 \mathrm{ft}$. wide, and its ends are broken. Its faces are fairly well built, its foundations rest on made ground, and red clay, not cement, can be seen on the trench all round the wall.

$D$. A large wall stands at $9 \mathrm{ft}$. 6 in. from the west wall at a point $42 \mathrm{ft}$. north from the south end of that wall. It has an abrupt and unfinished end facing south, from which end it rounds boldly towards the east, where it appears to terminate in a bank of soil débris. The quality of material and workmanship displayed in this wall are very similar to those of the west wall. Its height is $9 \mathrm{ft}$. where it faces the south, but where it faces west is a portion of wall $6 \mathrm{ft}$. high erected on its summit, and this upper wall is $6 \mathrm{ft}$. long and $4 \mathrm{ft}$. wide, being rounded at its end facing west. The sides of the upper and lower walls are flush to each other.

$E$. At the foot of the boulder over which the north wall is carried is a trench, and at a depth of $4 \mathrm{ft}$. below the present level of the interior of the temple is a very strong cemented floor, on which stands about $4 \mathrm{sq}$. $\mathrm{ft}$. of the rounded end of a cement wall of most excellent material and make. These are believed to be ancient, and if such be the case, then no antiquity could be claimed for walls $B$ and $C$, which are built upon the filled-in soil of a higher level. The remains of a rounded stone buttress are also to be seen in this trench. This trench was sunk through the red clay of a Makalanga threshing-floor.

Sections of floors.-Three sections of what are believed to be ancient floors can be seen in the cutting at the angle formed by the north and west walls. At $5 \mathrm{ft}$. below the present surface of the temple is an ancient floor of strong yellow granite cement I ft. 4 in. thick; above this is a red cement floor I $\mathrm{ft}$. thick; above this is another red cement floor I ft. 2 in. thick; while the top floor is made of ordinary Makalanga clay. A red cement bed lies under the lowest floor. 


\section{CHAPTER XVI \\ THE ACROPOLIS RUINS \\ (Continued)}

Platform Enclosure-Cleft Rock Enclosure-The Platform-Balcony Wall-Little Enclosure-The Winding Stairs-Upper PassageEast Passage-Buttress Passage-South Enclosures A, B, and CSouth Cave-South Passage-Central Passage.

\section{PLATFORM ENCLOSURE}

THIS enclosure is on the north side of the Western 1 Temple, and immediately at the foot of the stairs leading up the north-west side of The Platform. The east side is $46 \mathrm{ft}$. long, and is formed by a wall $19 \mathrm{ft}$. high and $7 \mathrm{ft}$. wide at $5 \mathrm{ft}$. above the present level of the interior. The north wall is $33 \mathrm{ft}$. along its face, and including a rounded corner at the north-east. It is $3 \mathrm{ft}$. wide at its present reduced height, which averages from $2 \mathrm{ft}$. $6 \mathrm{in}$. to $5 \mathrm{ft}$. above the rock floor. The north wall is built upon the edge of a high boulder, which boulder forms the floor of the enclosure on its north side. From north to north-west is an open space enclosed by a Makalanga-built wall which is carried across and blocks up an ancient entrance. From north-west to south the wall is $5 \mathrm{I} \mathrm{ft}$. long, and forms part of the north wall of the Western Temple. It is $4 \mathrm{ft}$. 6 in. wide on its present reduced summit, which is very dilapidated, its length including a wide gap. The extreme south-eastern side is formed by the walls supporting the steps from this enclosure to the summit of The Platform.

In the south-east corner of this enclosure is a passage 310 
leading into the Cleft Rock Enclosure. This passage is Io ft. long, the walls on either side are $6 \mathrm{ft}$. in height, and the width varies from $2 \mathrm{ft}$. to $4 \mathrm{ft}$. IO in. This passage was only discovered in July, I902, when it was found to contain a Makalanga grave apparently about twenty years old. The remains were removed and re-interred at the right side of the entrance to the Cleft Rock Enclosure. There were traces of steps in this passage, but these had been destroyed by masses of falling débris.

On the east side and at $2 \mathrm{I} \mathrm{ft}$. from this passage is a large squared entrance, also leading into Cleft Rock Enclosure. This appears to be a reconstruction of an older entrance or a late construction altogether, or possibly a new entrance through an old wall. The entrance is $6 \mathrm{ft}$. high, $2 \mathrm{ft}$. 6 in. wide, $7 \mathrm{ft}$. long, and has squared walls. Most probably this entrance was originally covered, for the remains of slate lintels can be seen on either side in the wall above it, and quantities of long pieces of fractured slate beams were found on its floor.

The area of this enclosure is divided into different levels. The floor on the south-west side for $28 \mathrm{ft}$. by I $4 \mathrm{ft}$. is formed by the top of a huge flat-topped boulder. The floor at the extreme north is also formed by the top of a boulder. The middle portion between these two floors consists of a depression of some $10 \mathrm{ft}$. to $\mathrm{I} 4 \mathrm{ft}$. lower than the rock floors on either side, the lowest portion being at the north-west end.

In this depression, and running from the north-west toward the squared entrance in the east wall, is a deep and narrow passage, the wall of which on the south-west side is the retaining wall for the higher floor on that side. The northeast wall of the passage appears to have been a Makalanga reconstruction of an ancient wall, especially as several of the walls in the immediate vicinity are undoubtedly Makalanga, and claimed by them as such, and, moreover, Makalanga articles were found at the base of its foundation. Still, the 
wall is so dilapidated that it is difficult to state one's opinion as to its age. This passage runs west for $72 \mathrm{ft}$. throughout the length of this enclosure, and passes out on to the Western Parapet, which runs along the west base of the west wall of the Western Temple. The width of the passage varies from $2 \mathrm{ft}$. to $4 \mathrm{ft}$., and with side walls averaging in height $5 \mathrm{ft}$. to $\mathrm{I} 4 \mathrm{ft}$. on the south side, and $4 \mathrm{ft}$. to $7 \mathrm{ft}$. on the north side. In the description of the newly discovered North-West Ancient Ascent, it will be seen that this passage forms an important section in that ascent.

At the south-east corner of the enclosure, and extending for $6 \mathrm{ft}$. from the east wall, is a small wall of three different faces at different levels all facing north. It was evidently intended to act as a buttress to the steps from The Platform down into the narrow passage between the two side floors of this enclosure.

\section{CLEFT ROCK ENCLOSURE}

This enclosure lies to the east of the Platform Enclosure, and its west wall is the same as forms the east wall of that enclosure. At all other points its sides are formed by cliffs and large boulders rising to the height of some $50 \mathrm{ft}$. and $60 \mathrm{ft}$. The west side is $46 \mathrm{ft}$. long, and its north and south sides are about $86 \mathrm{ft}$. each in length, these meeting at their extreme east.

Cleft Rock, which is so very often seen in photographs of the Zimbabwe ruins, rises for about $25 \mathrm{ft}$. above the surface of the enclosure on its north side and extends downwards for I $5 \mathrm{ft}$. below it on the outside. It is $3 \mathrm{ft}$. Io in. to $4 \mathrm{ft}$. 6 in. wide throughout. Possibly it was an ancient ascent from the Rock Holes Walk, as a quantity of wall débris lies at its outside base.

All the divisional walls of the interior are undoubtedly of Makalanga construction, and the local Makalanga claim them as having been made early in the time of Mokomo, 

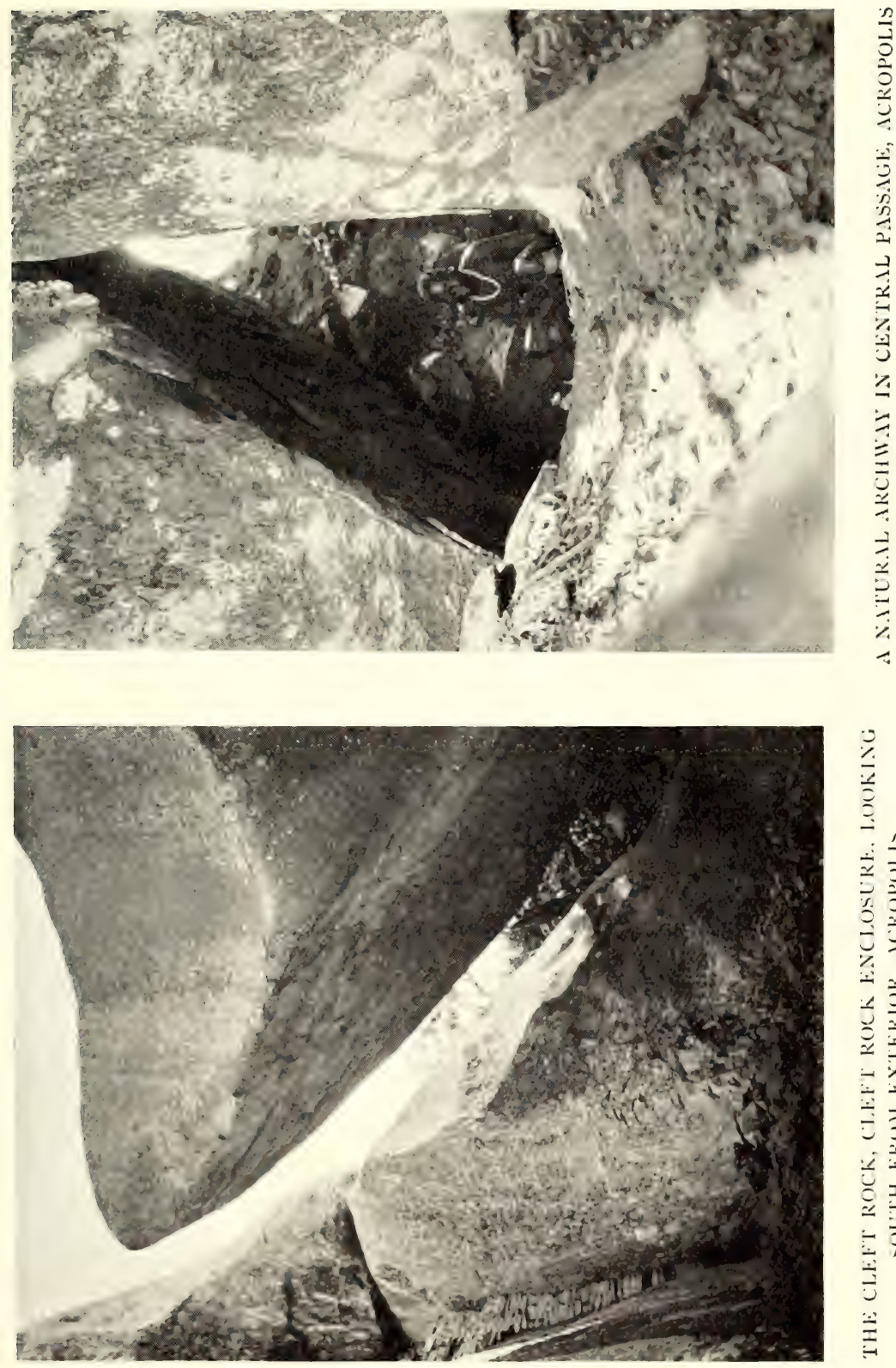

0
0 

the previous Zimbabwe chief, whose kraal occupied the north summit of this hill. This remark does not apply to the buttresses on either side of the west entrance.

The enclosure is approached on the south-west by the recently opened passage at the north foot of The Platform steps, also on the west by the squared entrance from the Platform Enclosure, and on the south it is believed to have had an entrance through the Buttress Passage (described later). The huge pile of stone-wall débris on the south side was recently stacked here, having been removed from the Platform Enclosure and passage.

\section{THE PLATFORM}

This is an elevated position at the east corner of the Western Temple, commanding a splendid view of the whole of the interior of the temple and of the surrounding enclosures. It appears to have been erected for the same purposes as were The Platform in the Elliptical Temple in the valley, and the Ancient Balcony in the Eastern Temple on the hill.

Its height is $27 \mathrm{ft}$. 6 in. above the present floor of the temple, and about $32 \mathrm{ft}$. above any of its ancient floors. It is $250 \mathrm{ft}$. above the level of the valley. The summit of The Platform projects out towards the west from the upper face of a huge boulder which forms the west end of the cliffs and boulders which ridge along the summit of this hill.

A wall $2 \mathrm{ft}$. high and from I ft. Io in. to $2 \mathrm{ft}$. 6 in. wide runs west from the boulder at the back across the centre of The Platform and terminates in a rounded end overlooking the temple. On the east side of this low wall is an embrasure $3 \mathrm{ft}$. wide, also overlooking the temple, at the south end of which is a parapet wall now from I ft. to $3 \mathrm{ft}$. high and $\mathrm{I} 2 \mathrm{ft}$. long, also on the edge of the temple wall. This forms the west side of the approach to The Platform from the south, which is further formed by the Winding Stairs. 
On the north side of The Platform is a flight of stairs, now considerably ruined by roots of trees forcing out the steps. This flight ascends from the granite rock floor of the Platform Enclosure from between two rounded buttresses. Half-way up the steps pass between two small, low walls, the space between them being $2 \mathrm{ft}$. These walls are parallel for a few feet, but as the steps descend they round off on each side away from the steps. This flight of stairs is the last and highest section of the North-West Ancient Ascent from the valley where are the large water-holes or dongas (see NorthWest Ancient Ascent).

At the top of these steps and on the east side of The Platform is the celebrated Dentelle Pattern.

This ancient wall decoration is the sixth yet discovered in Rhodesia, and until more is known of the similar pattern at Matendele Ruins, it can be tentatively concluded that this pattern on The Platform is by far the best and the most complete specimen extant in Rhodesia.

Its present dimensions are $3 \mathrm{ft}$. 6 in. wide and $3 \mathrm{ft}$. 6 in. high, and it consists of four columns of small, shallow blocks laid flat, with corners outwards, and flush with each other, each block thus showing two faces, the whole enclosed on top, bottom, and south sides by an angular frame of large blocks. The north side of the frame has disappeared. It is probable that this pattern once possessed a fifth column of dentelle blocks, as the foundations, providing sufficient space for another column, still remain, and there are more of these small blocks lying in the débris below, each with two faces, generally time-worn. This pattern faces west, but very slightly to the south of west. In the summer of the Southern Hemisphere it exactly faces the setting sun, the great slanting monolith then being between it and the setting sun.

The other special features of The Platform are the Monoliths.

Two tall and flat-faced granite monoliths are still standing 

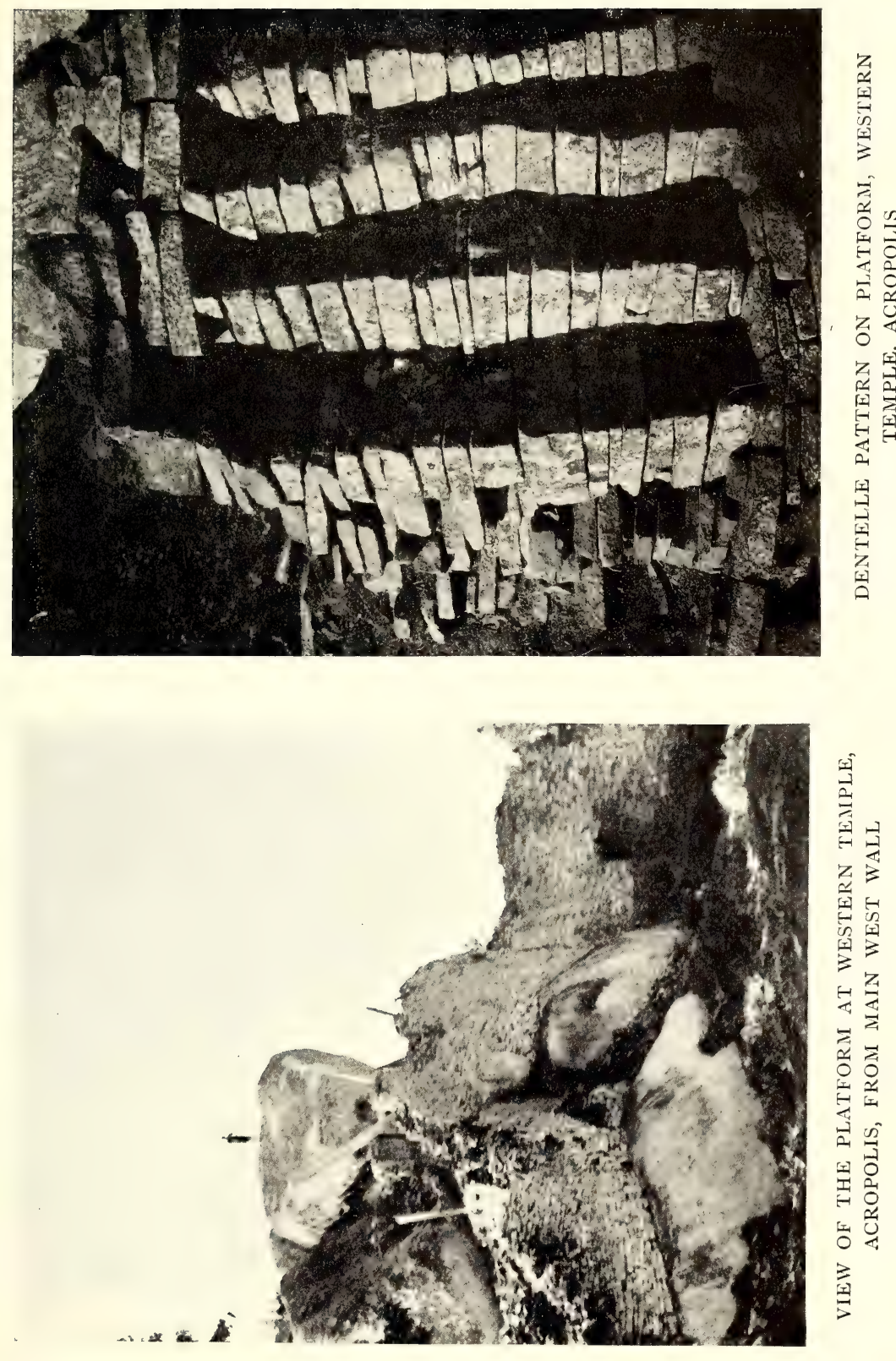

on The Platform, while one slate monolith lies prone on the south floor of The P.latform, with a few feet of its length projecting over the temple wall. This last monolith is $\mathrm{IO} \mathrm{ft}$. long, and at its centre part is $2 \mathrm{ft}$. 2 in. in circumference. This monolith is intact.

The heights of the two standing monoliths are: the erect monolith $8 \mathrm{ft}$. above The Platform, and the slanting monolith I I ft. 6 in., and their respective circumferences are $2 \mathrm{ft} .2 \mathrm{in}$. and $2 \mathrm{ft} .9 \mathrm{in}$. The one in front of the Dentelle Pattern slants considerably to due north. ${ }^{1}$ Its base, built into the wall, must be of great length to support the enormous weight of this large and slanting slab of granite, especially as this monolith had once been of greater length. The fracture on its top can be seen from the summit of the boulder behind. The fractured portion was found at the foot of the stairs, and this measures $3 \mathrm{ft} .2$ in., thus making the exposed portion of the monolith not less than I4 ft. 8 in. in length. There is no evidence of the slanting of the monolith having taken place since its erection.

\section{BALCONY WALL}

This is on the south side of The Platform, from which it is reached. The top of this wall is level with the top of the Winding Stairs, and it forms the western end of East Passage, and the eastern wall of the Western Temple. It is $2 \mathrm{Ift}$. long and from $4 \mathrm{ft}$. to $6 \mathrm{ft}$. wide. Through it is the Covered Passage (see Western Temple).

\section{LITTLE ENCLOSURE}

This can be seen from the Balcony Wall between the southern end of which and the Upper Passage it lies. It is $8 \mathrm{ft}$. deep, $5 \mathrm{ft}$. wide, and I I ft. long. The entrance appears to have been at outside of the south-western end of the Upper Passage. It is almost entirely filled up with débris. It once had a granite cement dado 3 in. thick on its sides,

1 See Author's Report on Slanting Monolith, Note E, Appendix. 
some of which still remain intact. It is from this enclosure that the drain-hole on the west side of the Upper Passage emerges.

\section{THE WINDING STAIRS}

These lead from The Platform to the East Passage, which again leads to the eastern extremity of the Acropolis Ruins. The stairs are $14 \mathrm{ft}$. long, and descend $8 \mathrm{ft}$, and are $4 \mathrm{ft}$. to $6 \mathrm{ft}$. wide. The wall on the south side is $4 \mathrm{ft}$. to $7 \mathrm{ft}$. high as the stairs descend. The wall at the east end is $7 \mathrm{ft}$. high. The face of a huge boulder forms the north side. The foot of the stairs, where they turn towards the south, is covered by a narrow wall supported by an old wooden beam. This beam is not ancient, but the old Makalanga who occupied these ruins may have inserted it to make the stairs safer to use. Fragments of slate lintel were found in the débris at the foot of the stairs.

\section{UPPER PASSAGE}

This passage, which is $28 \mathrm{ft}$. long, connects the bottom of the Winding Stairs and the south side of the interior of the Western Temple. On the east side the wall is from $4 \mathrm{ft}$. $6 \mathrm{in}$. to $6 \mathrm{ft}$. high, and $5 \mathrm{ft}$. to $10 \mathrm{ft}$. on the west side. It is $3 \mathrm{ft}$. $6 \mathrm{in}$. wide throughout. It is approached at the northern end between buttresses, the one on the west side being round, while the one on the eastern side is rounded on the inner side and angular on the outer side. On the west side are the remains of a drain emerging from the Little Enclosure and a fragment of the slate beam which once carried the wall across it is still to be seen in the hole. This passage, though at the foot of the Winding Stairs, is some $8 \mathrm{ft}$. higher than the present floor of the Western Temple.

\section{EAST PASSAGE}

This passage is $80 \mathrm{ft}$. long from the foot of the Winding Stairs to the north side of South Enclosure C. At the foot 


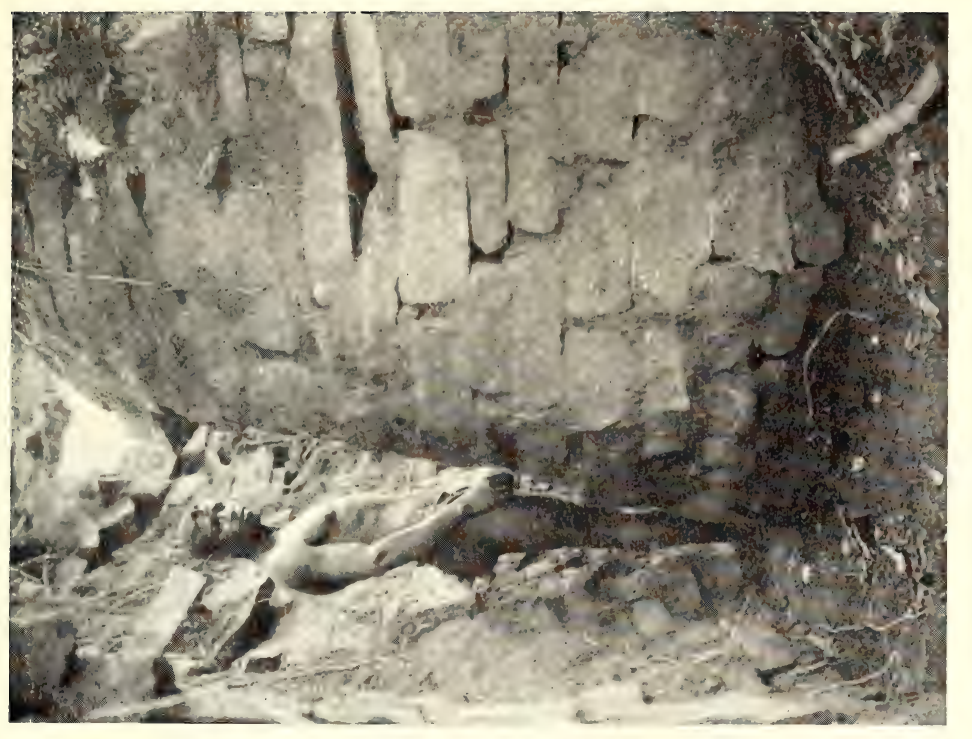

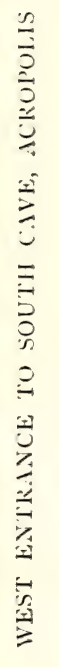

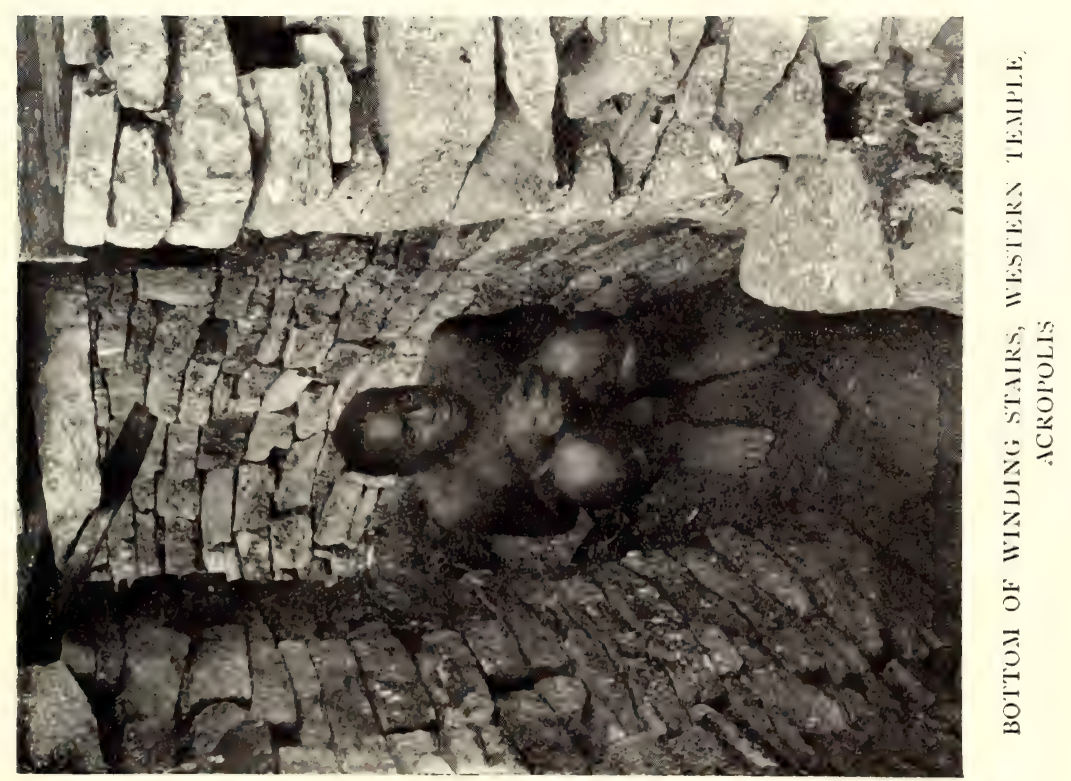



of the Winding Stairs the passage-way turns east, the north side for $\mathrm{I} 3 \mathrm{ft}$. being a large rounded buttress $6 \mathrm{ft}$. high. On the south side at this point is the eastern end of the Covered Passage leading up from the floor of the Western Temple, and a few feet further east is the northern entrance to the Upper Passage.

From the $14 \mathrm{ft}$. length to the $3 \mathrm{I} \mathrm{ft}$. length of the passage going east are remains-only very ruined-of cement steps descending to a lower level. On the south side of this passage are South Enclosure A, South Passage, and South Enclosures $B$ and $C$. The north side is formed by high, cliff-like boulders. The Buttress Passage starts north at the north side of the $5 \mathrm{I} \mathrm{ft}$. length going east. At the entrance to Buttress Passage a tree has lifted up a granite block $6 \mathrm{ft}$. from the ground. It is firmly fixed in the bark of the tree.

\section{BUTTRESS PASSAGE}

This passage runs north and south for $39 \mathrm{ft}$. between two gigantic cliff-boulders on the summit of the hill. This passage connected the enclosures on the north and south sides of the cliff. The rocks on either side of the passage at its bottom and south end are $50 \mathrm{ft}$. high on the east side, and $35 \mathrm{ft}$. high on the west side, and at the upper or north end are from $15 \mathrm{ft}$. to $20 \mathrm{ft}$. high. The path ascends throughout its length, and its upper end is $\mathrm{I} 4 \mathrm{ft}$. above the lower end. The width between the rocks varies from $4 \mathrm{ft}$. to $6 \mathrm{ft}$., but the top exit of the path goes between rocks only $3 \mathrm{ft}$. apart.

The floor between the two cliffs is artificially made, and near the summit it has crowned in, and this crowning in now bars the ascent to the Cleft Rock Enclosure, to which it formed an entrance from the south.

The passage has been considerably narrowed by buttresses alternating on either side, these making the passage a true zigzag. The first buttress at the south end and on the west 
side is much reduced in height, being now but $\mathrm{I} \mathrm{ft}$. 6 in. This buttress is angular, and protrudes $2 \mathrm{ft}$. On the east side is a long rounded buttress, which leaves the passage $2 \mathrm{ft}$. wide between it and the first buttress. This second buttress is $4 \mathrm{ft}$. high, $7 \mathrm{ft}$. long, and protrudes $4 \mathrm{ft}$., the width of the passage between it and the opposite cliff being I $\mathrm{ft}$. 3 in. The third buttress is $I 7 \mathrm{ft}$. from the south end of the passage; it is angular, and projects from the west side $2 \mathrm{ft}$., and is now only $2 \mathrm{ft}$. $6 \mathrm{in}$. high. The fourth buttress is angular on the bottom side and rounded on the top side. This projects $3 \mathrm{ft}$. 6 in. from the west side, and is $5 \mathrm{ft}$. high. Between the third and fourth buttresses the passage is $2 \mathrm{ft}$. wide. Above the fourth buttress the floor has crowned in, and on the upper side of the crowning-in is a wall $5 \mathrm{ft}$. high built across the passage. Judging by block débris, this wall, the summit of which is level with the floor of the Cleft Rock Enclosure, was once surmounted by steps.

\section{SOUTH ENCLOSURE A}

This enclosure is $5 \mathrm{I} \mathrm{ft}$. long from east to west, and is $25 \mathrm{ft}$. wide at its broadest point. Its shape is that of a long, narrow triangle, the apex resting at its south-east end. Most of the south wall has fallen over the edge of the precipice. There are two rounded entrances on the north side from the East Passage. The walls remaining are from $5 \mathrm{ft}$. to $7 \mathrm{ft}$. high. There is a drain-hole through the south wall at the south-east corner. The South Passage forms the eastern side. On the west side is a narrow recess between two boulders, and this appears to have been roofed over with slate and granite lintels, but the recess is now blocked up by wall débris. This enclosure appears to have been once divided into two enclosures, as a broken wall, $5 \mathrm{ft}$. long, $3 \mathrm{ft}$. high, and $3 \mathrm{ft}$. 6 in. wide, juts out into the interior from the east side. 


\section{SOUTH CAVE}

This "cave" hardly deserves the name of cave, but as previous writers gave it this designation the title is retained in this description.

The cave is situated immediately under South Enclosure $A$, and it opens on to the actual brink of the south precipice, being approached from both west and east sides by a path built along the top slope of the precipice. It is formed by a large boulder I $6 \mathrm{ft}$. high and I $7 \mathrm{ft}$. long, and is between this boulder and the top of the precipice, the floor being the natural rock of the declivity. It recedes but $3 \mathrm{ft}$. to $6 \mathrm{ft}$. under the boulder and is $7 \mathrm{ft}$. wide. It is $5 \mathrm{ft}$. high on the outside and only I ft. 6 in. to $2 \mathrm{ft}$. at its innermost part. It has been thoroughly cleaned out, but nothing of any antiquarian value was found. The boulder beetles outwards towards the face of the precipice.

Immediately in front of this cave and on the south side and at $4 \mathrm{ft}$. distance a wall averaging $8 \mathrm{ft}$. in height runs for $37 \mathrm{ft}$. towards the west. The boulder which forms the cave beetles outwards over this wall, and judging by the block débris, the wall was once continued up to, and connected with, the rock above. This wall at its western extremity has a well-built rounded end in a good state of preservation.

On the north side and starting at $\mathrm{Io} \mathrm{ft}$. from the cave and running west for $46 \mathrm{ft}$. is a wall $8 \mathrm{ft}$. high with a rounded end at its eastern extremity. It starts from the face of the boulder forming the cave, and is continued until it reaches the interior of the Western Temple.

These two walls form a passage averaging a width of $4 \mathrm{ft}$., though at the end of the south wall it narrows to $2 \mathrm{ft}$. 6 in. In the passage are traces of granite cement steps. This passage on entering the Western Temple is directly end on with the Parallel Passage, which is on the inside of the main south wall and is separated from it only by the gap in the 
outer wall, the main wall having at this point fallen down the precipice and taken with it the side wall of the passage from the cave. It is almost certain that this passage was but the extension of the Parallel Passage.

On the eastern side of the cave is a built-up space between the boulder forming the cave and another boulder further east which beetles parallel to the precipice for $\mathrm{I} 3 \mathrm{ft}$. This wall is Io $\mathrm{ft}$. high and is $6 \mathrm{ft}$. across.

The path to the east passes under this outer and beetling boulder, and between the outer side of South Enclosure $A$ and the edge of the precipice, but here it is so much dilapidated by wall débris falling from above, that the safer approach to the cave is from the Western Temple.

On the summits of these two large boulders are traces of a substantial wall once having been carried across them.

\section{SOUTH PASSAGE}

This passage is almost opposite the south end of Buttress Passage and leads from the East Passage to the edge of the south precipice, dividing South Enclosures $A$ and $B$. It is $38 \mathrm{ft}$. long, from I ft. 6 in. to $2 \mathrm{ft}$. wide, and at each extremity has rounded ends on either side. The wall on the east side averages $3 \mathrm{ft}$. to $7 \mathrm{ft}$. in height, the highest being at the southern end. The wall on the west side averages $7 \mathrm{ft}$. to I $2 \mathrm{ft}$. in height.

The existence of this passage was, until July, 1902, unsuspected, as it had been filled up and entirely covered over with wall débris, across which was the visitors' path, which crossed the débris at $7 \mathrm{ft}$. above the present exposed floor.

\section{SOUTH ENCLOSURE B}

This enclosure is on the east side of South Passage, and overlooks the south precipice. Its area is $37 \mathrm{ft}$. from east to west, and $3 \mathrm{I} \mathrm{ft}$. from north to south. The wall on the north side is $16 \mathrm{ft}$. high, and $4 \mathrm{ft}$. $6 \mathrm{in}$. wide at $5 \mathrm{ft}$. from the floor, 
and is the best-built portion now remaining. It has three rounded entrances, one from South Passage and two from East Passage. Low walls of poor construction subdivide the enclosure into three compartments, but some portions of these walls are not believed to be ancient.

\section{SOUTH ENCLOSURE C}

This is on the north-east side of South Enclosure B, but on a level of some $6 \mathrm{ft}$. higher. The area is $4 \mathrm{I} \mathrm{ft}$. from east to west, and $19 \mathrm{ft}$. from north to south. The eastern wall curves outwards, and is $9 \mathrm{ft}$. high. The north side is formed by a large boulder, the west side by a raised parapet which is the eastern extremity of East Passage. There is one entrance only, and this is in the south-western corner. Here the south wall is very well built. A wall $3 \mathrm{ft}$. 6 in. high and $9 \mathrm{ft}$. long juts out southwards from the boulder on the north side.

\section{CENTRAL PASSAGE}

This passage connects Cleft Rock Enclosure and the Eastern Temple and forms the most direct communication between the western and eastern extremities of the Acropolis. This passage is practically the north-east extension of Pattern Passage, the two joining end on at the west entrance to the Eastern Temple. Cliffs and huge boulders form the main portion of its sides.

Its length is $76 \mathrm{ft}$., and its width varies from $3 \mathrm{ft}$. to $4 \mathrm{ft}$. $6 \mathrm{in}$. There is a sharp rise of $6 \mathrm{ft}$. going west, at about halfway along its length.

At the eastern end it lies between two large boulders, the one on the north side being $\mathrm{I} 2 \mathrm{ft}$. long and Io ft. high. This boulder has fallen from the position it occupied at the time of the ancients, and is come $6 \mathrm{ft}$. further south, destroying and blocking up the west entrance to the Eastern Temple. The boulder on the south side is $8 \mathrm{ft}$. long and $\mathrm{I} 4 \mathrm{ft}$. high, 
and up against it, and projecting into the passage, was once a rounded buttress, traces of which now only remain.

At $22 \mathrm{ft}$. going west is another large boulder, which forms the south side of the passage for a further $24 \mathrm{ft}$. This rock beetles right over the passage, and the open space under the boulder has been carefully walled up. At $48 \mathrm{ft}$. the south side is formed for a further $\mathrm{I} 4 \mathrm{ft}$. by a low wall, in which are enclosed two boulders. On this side wall are the remains of a path leading from the passage to South Enclosure C, but a portion of this has crowned in and disappeared.

The north 'side of the passage from its eastern end is formed by the boulder, I $2 \mathrm{ft}$. long, just described, and for a further $35 \mathrm{ft}$. by a step-back wall $8 \mathrm{ft}$. high, along the summit of which was a path with steps leading into the Eastern Temple, but now blocked up by large scales of granite which have fallen from the face of the cliff above.

The western extremity of this passage is formed by two boulders, one on either side, the one on the south side leaning up against the one on the north side, thus forming a natural arch I4 ft. long and Io $\mathrm{ft}$. high, the path descending about $4 \mathrm{ft}$. in passing through the archway, and rising sharply again where it emerges on the opposite end of the archway into Cleft Rock Enclosure, and runs for $27 \mathrm{ft}$. further west into the enclosure, where it ends on the south side in a rounded wall $5 \mathrm{ft}$. high. Large rocks form the north side. In the archway and on the south side under the boulder is a rock hole $5 \mathrm{ft}$. broad, $4 \mathrm{ft}$. deep, extending under the base of the boulder for $6 \mathrm{ft}$.

In the passage are traces of steps, but the passage has been greatly damaged by falls of large slabs from the cliffs. 


\title{
CHAPTER XVII
}

\author{
THE ACROPOLIS RUINS \\ (Continued)
}

Eastern Temple-Ancient Balcony-Balcony Enclosure-Balcony Cave - Gold Furnace Enclosure-Upper Goidd Furnace EnclosurePattern Passage-Recess Enclosure-North Plateau-North Parapet.

THE EASTERN TEMPLE

THIS temple is situated at the most easterly part of 1 Zimbabwe Hill Ruins, on the south side of the line of high cliffs and gigantic boulders which extend from the east to the west along the summit of the hill. The centre of the present surface of the interior of this temple is $222 \mathrm{ft}$. above the valley.

The main wall is built on a wide curve towards the east extending $98 \mathrm{ft}$. from the south face of the cliff on the north side round to the south side, thus disposing the area in a quarter section of a circle with the apex of the section at the north-north-west of the interior.

A cliff rising perpendicularly for $70 \mathrm{ft}$. from the floor of the temple forms the north side of the area, and the west side is formed by colossal boulders some $30 \mathrm{ft}$. to $50 \mathrm{ft}$. in height. The heights and the massiveness of the cliff and boulders lend a peculiar awe-inspiring appearance to this temple. These granite rocks, tapestried by Nature in all possible colours and shades of lichen, enclose two sides of the interior in the form of an amphitheatre, with the highest portion of the temple floor at the north end, the present surface gradually sloping down in a fall of $\mathrm{I} 2 \mathrm{ft}$. towards the curved 
main and outer wall to its east and south-eastern points. On the highest part of this slope are two well-built retaining walls forming terraces behind them. These are described later.

This temple is considerably better built than is the Western Temple on this hill. The blocks in the walls are more care-

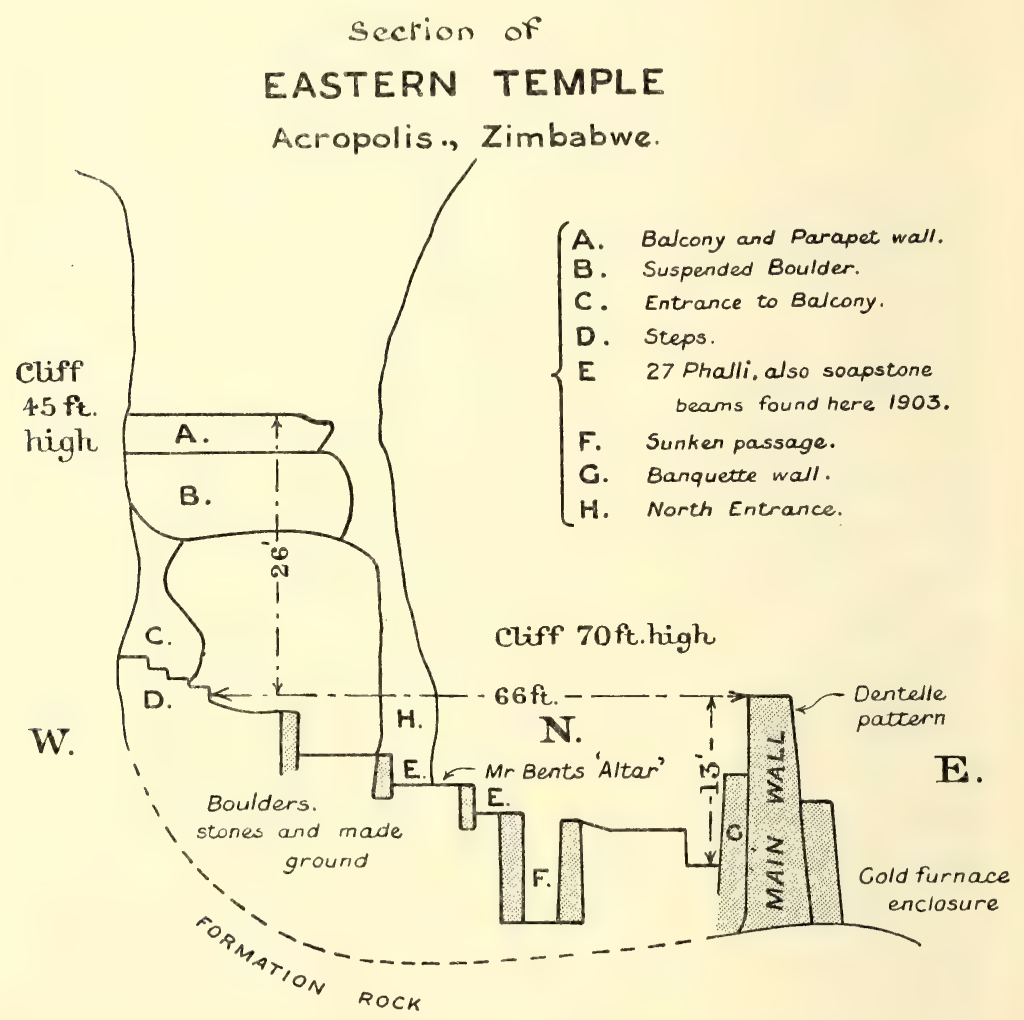

fully selected and fit together more perfectly, are of a better class of granite, and the courses are truer, while it would appear from the extent of purely artistic detail and finish introduced by the original builders that far greater skill was bestowed upon its construction than on that of the Western Temple.

Both temples are built strictly upon the lines of the First 
Period of Zimbabwe architecture, all of the features of the Second Period being altogether absent. Certainly some of the cement work of the higher floors appears to be ancient, but not of the period of the original builders, and it is possible that the Second Period ancients occupied the buildings, and finding them in such excellent condition, had no need to make repairs or extensions to the walls as they did in so many scores of First Period ruins throughout the country. The floors of the original builders of this temple have been opened out by a trench and exposed at a minimum depth of $4 \mathrm{ft}$. below the latest floor.

Bent and other writers have stated that this temple is orientated to the rising of the sun, which can be seen on a level and fairly distant horizon. The temple obviously affords a splendid natural means for observing the meridian.

On midwinter day (1902), in the Southern Hemisphere, the sun rose facing the eastern end of the main wall, and shone on the line of Dentelle Pattern, and also for an hour afterwards shone on the inside of the south-western end of the wall, and also on that of the floor. At the end of that time, and until I0.30 a.m., the sun did not shine on the temple, but only on the inside face of the summit of the south-west end of the curved main wall, the sun being hidden by the $70-\mathrm{ft}$. cliff on the north side of the interior. At I I a.m. it shone over the cliff on to the south-western side of the interior. Half an hour before midday the sun shone on the inside of the southern wall and on the south floor from over the cliff, and also in a single narrow bar across the floor of the building through the north entrance to the temple, which is formed by a long and narrow passage between the high cliffs and some gigantic boulders. The sun shone through this narrow opening till about half an hour after midday, when the sun had passed the face of this narrow entrance, and only shone on the south-west and north-west portions of the interior from over the Ancient Balcony, which is much lower than the cliff, till a little after 
one o'clock, the sun then ceasing to shine on the interior for the rest of the day. At the spot where the line from the point of sunrise at the summer solstice cuts the midday beam of light which comes through the cliff entrance on the north, is the site of the ancient altar as determined by Bent, the site being true south of the north passage. It was at this
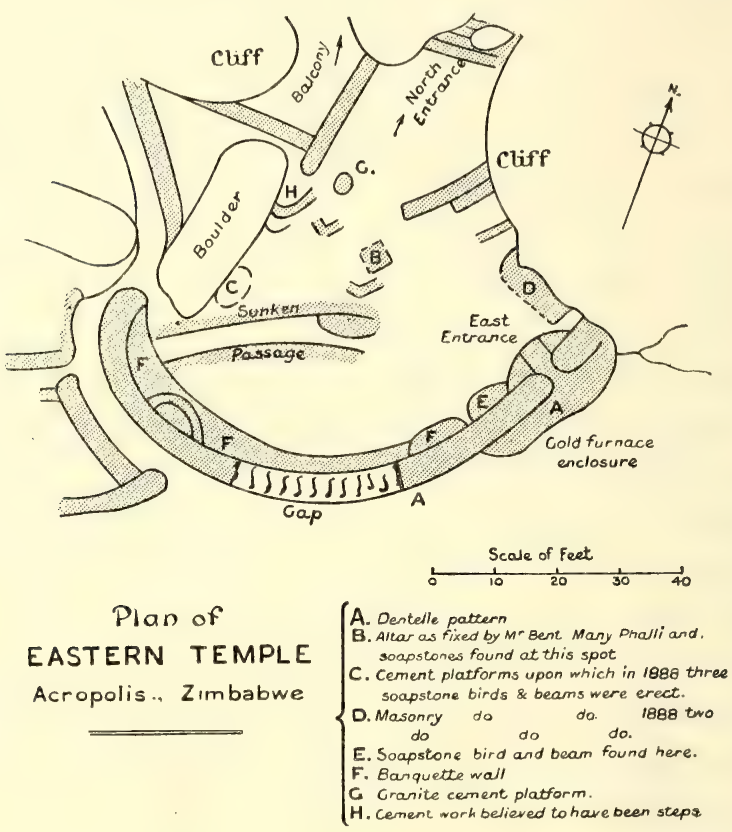

spot that Bent found the pottery and soapstone solar discs, the decorated and plain phalli, the soapstone birds, carved beams, and decorated bowls resembling Phœnician ware. The writer's examination of this spot was rewarded by "finds" of carved soapstone in great quantities.

So obviously noticeable is the beam of light at midday that as the sun quickly passed the end of the long and narrow rock passage the natives working for the writer fixed their noon "Tjiya!" ("Cease work!") by it, and this they did on their own initiative. 
Another feature may be noticed. A small circle of sunlight, about $2 \mathrm{ft}$. diameter, crosses the floor of the temple in a course equal to about a fifth part of the radius of a circle from the entrance to the Balcony Enclosure across the floor where Bent fixes the site of the ancient altar and passes over the eastern wall. This must have been observed by the ancients, for it is caused by a small opening between two boulders which they have utilised in "forming" the Ancient Balcony. At 3 p.m. this circle of light in the sunless interior, on the same day, rested on the spot at which, according to Bent, the ancient altar stood.

On Midsummer Day, 1903, the whole temple area was flooded with sunlight at noontide.

These particulars are given merely as matters of interest to the general reader, and scientists are referred to The Ruined Cities of Mashonaland, by Bent, for his calculations as to the orientation of this temple. Bent has given his opinion, based upon survey, that this temple was used for observing the summer solstice.

Two points, however, which may bear upon the orientation of this building and its use in the observation of sunrise and meridian may be noticed.

(a) No other temple which has been surveyed by scientists for the purpose of ascertaining its orientation, whether at Zimbabwe or elsewhere in Rhodesia, was so plentifully adorned with monoliths of carved slate or soapstone as was this temple, no less than thirty fallen monoliths, and the fractured portions of many others, having been found at the bases of the walls both inside and outside, while the débris heaps, which have only been very partially searched, must yet contain other specimens. No other temple, so far discovered, had such a profusion of geometrically carved soapstone beams as were unearthed by Bent and by other explorers before him. This would appear to still further testify to the importance the ancients attached to the decoration of this temple, whether 
used for observing the seasons of the year and astronomical occurrences or not.

(b) The position of the Dentelle Pattern in two courses on the eastern face of the summit of the main wall is fixed on exactly the same plan as is shown in so many other ruins of temple buildings in Rhodesia (and the discovery of the ancient emblems of faith have so far only been made in buildings so decorated, on identical positions, with one of the three oldest patterns, namely, Dentelle, Chevron, or Herring-bone), and as this is so unmistakably seen in the case of numerous other ruins of similar buildings, the position of the pattern in this instance can hardly be a mere coincidence.

The Dentelle Pattern, which forms a distinguishing feature at the Zimbabwe ruins both on the hill and in the valley, and which is only found in First Period buildings, is, in this instance, believed to have originally extended some $30 \mathrm{ft}$. further towards the south-west, as a trace of it still remains on the highest remaining portion of the $39 \mathrm{ft}$. length of the main wall. The pattern throughout the $24 \mathrm{ft}$. length of main wall is somewhat damaged at several points, and the rows of stones which in all instances elsewhere covered this pattern have almost disappeared.

The interior measurements of this temple are as follows: $59 \mathrm{ft}$. 6 in. from north to south, the northern point for measurement being the large roughly built step at the south end of the North Passage; $66 \mathrm{ft}$. from south-east to north-west, the north-west point for measurement being the step at the bottom of the stairs leading from the temple to Balcony Enclosure; and $50 \mathrm{ft}$. from west-south-west to north-north-east.

The main wall is $98 \mathrm{ft}$. long, measuring along its inside face, and starts on the eastern side from the south face of the cliff for Io ft. to the rounded entrance to the Gold Furnace Enclosure. This Io ft. length of wall is $8 \mathrm{ft}$. higher than the interior floor at the cliff end, and is $5 \mathrm{ft}$. high at the entrance. The entrance is $3 \mathrm{ft}$. wide at the present top and $2 \mathrm{ft}$. on its floor. From the 

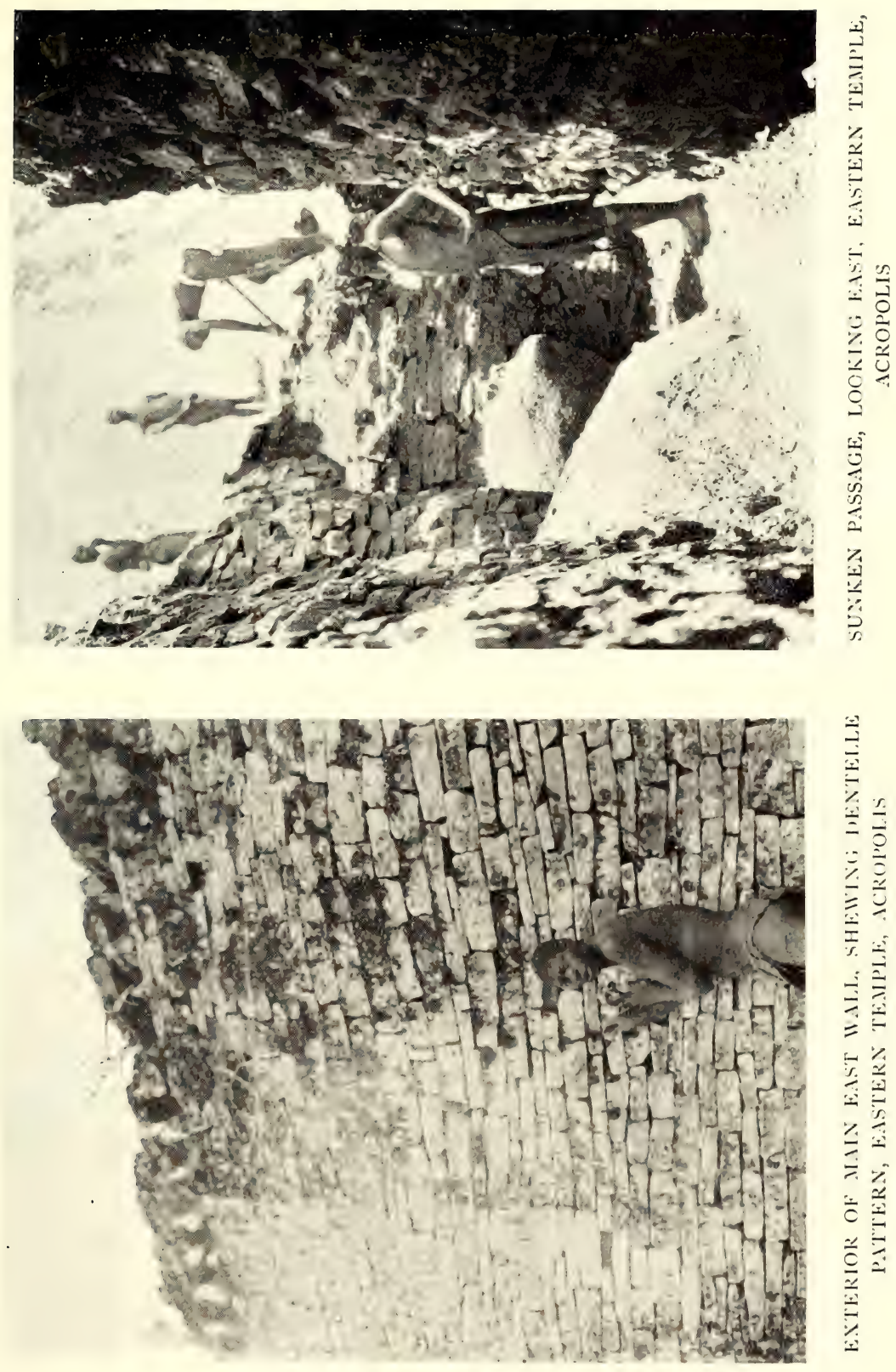

0
0
0 

rounded entrance the wall runs facing east-south-east for $24 \mathrm{ft}$. This section of the main wall stands $8 \mathrm{ft}$. above the present level of the interior, but $\mathrm{I} 2 \mathrm{ft}$. 6 in. from an ancient floor exposed in a trench sunk some $4 \mathrm{ft}$. 6 in. into the present floor. At the south end of this length there is a gap in the wall of $22 \mathrm{ft}$., the wall which remains rising only $6 \mathrm{in}$. above the present surface of the lowest part of the temple. The wall starts again at the south end of the gap, and runs for $39 \mathrm{ft}$. towards the south-south-west. The highest portion of this length is I I ft. 3 in. above the ancient floor as exposed in the trench cut along the interior face of the main wall, the southwestern end of the wall being only $4 \mathrm{ft}$. higher than the Western Entrance, which has been raised at a later period $5 \mathrm{ft}$. 6 in. above the original floor of the entrance.

The widths of the main wall are as follows :-

The Io $\mathrm{ft}$. length is $7 \mathrm{ft}$. wide at the present floor, but was probably wider, as its eastern face has fallen out into the Gold Furnace Enclosure, which is immediately below. The angle between the east outside face and the cliff was filled in by a rounded buttress, which has also collapsed and fallen into the enclosure below.

The $24 \mathrm{ft}$. length is $4 \mathrm{ft}$. 7 in. wide on the present summit. At $12 \mathrm{ft}$. south of the Eastern Entrance, an inner or banquette wall runs along the inside of the main wall, and stands out $2 \mathrm{ft}$. at its north end, $7 \mathrm{ft}$. at south end, till it narrows into and becomes part of the main wall at the Western Entrance.

The $22 \mathrm{ft}$. length is $5 \mathrm{ft}$. wide at the bottom of the gap, with a further width of $3 \mathrm{ft}$. 6 in., which includes that of the banquette wall.

The $39 \mathrm{ft}$. length of main wall is $5 \mathrm{ft}$. wide on the summit, and this with the width of the banquette wall, which at this point is $5 \mathrm{ft} .6 \mathrm{in}$. wide, makes a total width of $\mathrm{Io} \mathrm{ft} .6 \mathrm{in}$.

The heights of the main wall from the outer bases are as follows :-

The ro $\mathrm{ft}$. length is $24 \mathrm{ft}$. above its base, and this, with the 
$24 \mathrm{ft}$. length of main wall, forms the western side of the Gold Furnace Enclosure.

The $24 \mathrm{ft}$. length is $25 \mathrm{ft}$. high, and is divided into two depths, one below the other, I I $\mathrm{ft}$. and I $4 \mathrm{ft}$., the I I $\mathrm{ft}$. being the wall and the $14 \mathrm{ft}$. being a long buttress which starts at $9 \mathrm{ft}$. from the south side of the $22 \mathrm{ft}$. gap and runs to the cliff. The main wall, however, is continued down to the base of the buttress which is built up against it. This buttress forms a terraced passage, and was probably the way the ancients passed from the Eastern Temple to the Gold Furnace Enclosure below by means of a natural bridge formed by a long and narrow boulder, the west end of which is built into the buttress, down the north side of which is a narrow descent with a few block steps still remaining.

The $39 \mathrm{ft}$. length is $22 \mathrm{ft}$. higher than the débris at its outer base, it is $I 7 \mathrm{ft}$. higher than the débris at the centre of the main wall, and I I ft. at the steps which lead up from Pattern Passage to the Western Entrance of the Eastern Temple.

On the top of the south banquette wall were most probably steps leading up to within $2 \mathrm{ft}$. or $3 \mathrm{ft}$. of the summit of the wall as if for a look-out. A rounded buttress stands out $2 \mathrm{ft}$. 6 in. from the main wall, and between it and the inner edge of the banquette wall are some blocks which, though displaced, have fallen in such a way as to provide very strong grounds for this conjecture.

The Eastern Entrance has a pair of buttresses on a semicircular platform projecting $7 \mathrm{ft}$. into the temple area, the faces of the buttresses being rounded and flush with the outside edge of this platform. The buttress on the north-east side is $3 \mathrm{ft}$, and judging by débris, it was once at least $7 \mathrm{ft}$. high. The opposite buttress is now only I ft. 6 in. high. (For measurements of this entrance, see Main Wall.)

Between the south buttress and the banquette wall which runs southwards along the inside of the wall is another raised platform or "blind steps," but very ruined and pro- 
jecting now only $2 \mathrm{ft}$. from the main wall. Among the loose stones on the top of this small platform, which is $6 \mathrm{ft}$. long, Bent found one of the soapstone birds which has a cystos, with sections of a carved soapstone beam, all of which are now in the museum at Capetown.

At the north side of this entrance is a wall $\mathrm{I} 5 \mathrm{ft}$. long reaching from the entrance to an angular point in the north cliff. This space so enclosed was built up inside in the form of steps, or blind steps, for they led nowhere, resembling the blind steps in Nos. 7, 9, and I 2 Enclosures, and in the Sacred Enclosure (west) in the Elliptical Temple in the valley. The face of a small buttress protrudes some i $8 \mathrm{in}$. from the face of this wall at about midway. Possibly this may have been the lowest step of the blind steps built up in this corner. In I 888 this raised platform had on its summit a soapstone bird and beams. In I903 two phalli and sections of four soapstone beams were found here, also small gold beads on and near this platform.

The North Entrance is a narrow and deep rock passage $23 \mathrm{ft}$. long. The east side is formed by the north-west end of the north cliff, and is $45 \mathrm{ft}$. higher than the floor of the passage, but it beetles over the passage for $6 \mathrm{ft}$. beyond its north-western side, and so forms, with the immense boulders on the north-west side, an almost complete archway right over the passage. The passage is from $2 \mathrm{ft}$. to $7 \mathrm{ft}$. IO in. wide, but with rounded buttresses, the foundations and débris of which still remain, and also with a boulder that almost blocks the passage; the width of the passage throughout its whole length could not have been more than $2 \mathrm{ft}$. before the buttresses had become dilapidated. The passage emerges at its north end on the North Plateau (described later).

The West Entrance is formed by the rounded end of the western extremity of the main wall and a large boulder between which it passes. On its present floor it is only I ft. Io in. wide, the wall side having some six courses 
of blocks exposed. The boulder on the north side has moved some $2 \mathrm{ft}$. into the entrance since the wall was built, and so partially closed it up, for originally the floor of the entrance was fully $5 \mathrm{ft}$. lower, and passed into the temple without steps. This was discovered to be the case when the upper portion of Pattern Passage was cleared out (July, I902), when steps were made over the entrance débris to enable visitors to pass from Pattern Passage into the temple.

The remains of another raised platform-but this one of granite cement-are on the west side of the interior immediately on the left-hand side on entering the temple at the west entrance. This platform is now ruined owing to its having been trodden on by oxen when this temple was used as a cattle kraal. In I 888 three large soapstone birds on tall beams stood on this platform, but in 1890 were removed by Bent, and are now in the museum at Capetown. The holes in the cement made by Bent on digging out the bases of the beams can still be seen.

From $6 \mathrm{ft}$. north of this last-mentioned platform is some semi-circular clay-work rising in three tiers. Possibly these were steps leading up to the highest terraced level of the interior, but it may be doubted whether they had any claim to antiquity.

Sunken Passage.-This passage runs from south-west to north-east under the present floor of the Eastern Temple for $23 \mathrm{ft}$., starting from inside the banquette wall at $8 \mathrm{ft}$. east of the west entrance. Its depth is $9 \mathrm{ft}$. below the surface of interior of temple, but its side walls are only $7 \mathrm{ft}$. high. It is $4 \mathrm{ft}$. wide at the south end and $6 \mathrm{ft}$. wide at the north. At north-east end is a rounded buttress $5 \mathrm{ft}$. high. No approach or steps down into the passage have so far been discovered. The passage terminates at the large buttress (already mentioned), the summit of which is $4 \mathrm{ft}$. below the surface, is situated within $3 \mathrm{ft}$. and immediately in front of Bent's "altar." The east side wall of the passage is better built than the west side. 
Bent's "altar."-This "altar" was stated by Bent to be Io $\mathrm{ft}$. nearer to the rising sun at the solstice than the centre of the arc of the curved, massive, and decorated main wall. Surveyors having located this spot, examinations were made in 1903, with the result that some twenty-five phalli, also some sections of phalli, and of carved portions of soapstone beams and bowls, were found within $3 \mathrm{ft}$. of this spot on two sides, and all within a few minutes of each other. This is by far the largest "find" of phalli ever made at Zimbabwe. At this spot Bent also made his largest "find" of phalli, solar discs, and other relics. The large soapstone birds were found $3 \mathrm{ft}$. or $4 \mathrm{ft}$. further south-west of the "altar." Messrs. Posselt, who resided and farmed at Zimbabwe in I 888 and before the Occupation, wished to remove these birds, but the previous Mogabe (Chipfuno) refused his consent.

Internal walls.-On the north side of the interior of this temple is a wall acting as a retaining wall, with filled-in ground behind it forming a terrace. This upper terrace is at the highest point of the floor of the temple, and is $\mathrm{I} 6 \mathrm{ft}$. long, $4 \mathrm{ft}$. high, and $2 \mathrm{ft}$. 6 in. on the summit. Judging by the amount of débris, this terrace had in all probability a parapet wall along its summit. The wall runs from N. $25^{\circ}$ E. to S. $20^{\circ} \mathrm{W}$., and starts from the south side of a huge boulder at $16 \mathrm{ft}$. north-west of the North Entrance.

On the south-west side and at the north-west end of the interior of the temple, and corresponding with the first terraced wall just described, is another terrace wall $\mathrm{I} 2 \mathrm{ft}$. long and $3 \mathrm{ft}$. high, running eastwards from the south side of the cliff which forms the north-west side of the temple and the south-west side of the passage which runs from the Cleft Rock Enclosure to this temple. The two corresponding terraces form a junction with an abutment wall projecting south-east for $2 \mathrm{ft}$. $6 \mathrm{in}$. This projection is $2 \mathrm{ft}$. high and $5 \mathrm{ft} .6$ in. wide.

Immediately in front of this projection on the south-east 
side and sloping down for some distance towards the lower part of the temple is some cement work, which, though old, does not appear to be ancient, for it contains splinters of timeworn monoliths which show signs of having once stood upon one of the walls. The purpose of this cement projection is not clearly seen, for tree-roots have easily passed through such rough cement and have torn it out of all shape, besides which it has become decomposed and soft.

Between the angle formed by this last-described terraced wall and the projection just mentioned is a very rudely cemented floor also much decomposed. The few steps leading up from the flooring at this point towards the path to the Cleft Rock Enclosure are quite modern, having been built by the writer to enable visitors to pass over the débris of a large rounded buttress which once stood against the north-west side of the nearest boulder. From the top of this débris pile steps of an ancient character, and more or less defined, continue up the slope at the foot of the south side of the cliff where runs a path towards the Cleft Rock Enclosure.

A second and lower terrace is $4 \mathrm{ft}$. long and $4 \mathrm{ft}$. high, and is carried on a red cement foundation 18 in. thick. It terminates abruptly on the south-west extremity in a broken end. This wall juts out from the south side of the north cliff at I $5 \mathrm{ft}$. east of the North Entrance, and runs southwest. Immediately behind this wall is a second wall running parallel with it, the face of the second or back wall actually touching the back of the front wall. This back wall runs south-west for $5 \mathrm{ft}$. beyond the end of the front wall, where it also terminates in a broken end. It is $3 \mathrm{ft}$. high, but in all probability it was once much higher.

The Balcony Enclosure, which is at the north-west end of the temple and is described later, provided another entrance to this temple, the Balcony Enclosure being approached from the west and north sides respectively by the 
passage through the Balcony Cave and the ascent from Rock Holes Path.

The Ancient Balcony is at the north-west end of the temple, the whole interior of which it overlooks, and appears to have acted for this temple in the same manner and for the same purposes as The Platform of the Western Temple and The Platform in the Elliptical Temple in the valley. This Ancient Balcony is described later.

The interior of this temple has been used by the past and present Makalanga as a cattle kraal, and very possibly the cattle have trodden any cement work out of shape. It was found to be covered with a thick stratum of cattle manure, which again was covered by wall débris, and still further by a foot depth of rich vegetable mould thickly matted with roots of creepers, shrubs, and trees.

\section{THE ANCIENT BALCONY}

At the north-west end of the Eastern Temple, and at the highest point of the interior and immediately behind the higher of the terraced walls before described, fourteen steps, eight of granite cement and six of blocks, lead for $26 \mathrm{ft}$. in a north-westerly direction up a passage-way formed on the south side by a cliff, and on the north side by two large boulders. Each step is 5 in. high and extends back 18 in. The ascending passage is $7 \mathrm{ft}$. wide at its lowest part, and narrows to a creep-hole between the cliff and the upper of the two large boulders to just the size that will permit of a man passing through by stooping.

Over this passage are two colossal boulders, held up in a horizontal position by the cliff, the level top of the southernmost being $26 \mathrm{ft}$. above the bottom of the steps, which are exactly underneath. The steps are laid on cement, and probably are of a late period, at any rate there is evidence that they have been very considerably repaired.

Immediately facing the top of the steps, and $4 \mathrm{ft}$. above 
the creep-hole, is a rounded buttress projecting from the side of the cliff, and measuring $15 \mathrm{ft}$. in circumference. The highest part faces east, and is still $9 \mathrm{ft}$. 6 in. in height, while the north-west side is considerably dilapidated.

This passage is the approach to the Ancient Balcony and Balcony Enclosure. Following up the passage, and turning to the right at the top, one ascends a bank with traces of steps between the boulder which forms the creep-hole, and a wall on the north, and arrives on the Balcony.

The Balcony is formed by the level and parallel tops of the horizontal boulders, and is $39 \mathrm{ft}$. long, and at its widest part I $2 \mathrm{ft}$. Io in. On the south-east side is a parapet wall from I to $3 \mathrm{ft}$. present reduced height, and $2 \mathrm{ft}$. 6 in. wide.

The Balcony is $248 \mathrm{ft}$. above the valley, and commands a most extensive view to the south-east, including the Elliptical Temple in the valley, and the Schlichter Gorge, which extends into a sea of romantically shaped summits of kopjes and blue distances. The Balcony commands a complete view of the whole of the interior of the Eastern Temple.

\section{BALCONY ENCLOSURE}

The length of this enclosure from north to south is $5 \mathrm{I} \mathrm{ft}$, and the average width from $15 \mathrm{ft}$. to $20 \mathrm{ft}$., the whole of the sides being formed by cliff and boulders, except on the north side, where a space between two large boulders has been built up by the ancients. This wall is $9 \mathrm{ft}$. long and I I ft. high.

The wall extending from the north-east corner of the Balcony, and on the north side, except for one short length, is not ancient. Local Makalanga state their people of some two or three generations back re-erected the wall on the old foundation. This is obviously the fact. But an entrance from the North Plateau was once at this point, and led down steps on the outside, going west between two large boulders zigzag downwards to the Rock Holes Path. 
BALCONY CAVE

At the west end of this enclosure is a steep descent of $36 \mathrm{ft}$. between two boulders into Balcony Cave formed by a cliff, the east face of which beetles over the descent. The cave is $19 \mathrm{ft}$. wide at the bottom and is very much filled in with wall débris, silted soil, and large scales of granite off the face of the overhanging rock. This cave formed an entrance into the Balcony Enclosure from the Rock Holes Path, which runs along the north-west face of the cliff, only on a very much lower level. A wall i $8 \mathrm{ft}$. high starts from the bottom of the cave and is built across it on the north side, running west to east. This wall is partly rounded on the upper portion. At $7 \mathrm{ft}$. from the ground the lower part of this wall has collapsed and blocked up the exit. Another wall $8 \mathrm{ft}$. long and $6 \mathrm{ft}$. high and in two rising tiers crosses from side to side at a higher level. Two almost perfectly shaped monoliths, very much weather-worn, were found among the débris in this cave.

\section{GOLD FURNACE ENCLOSURE}

This enclosure is $\mathrm{I} 2 \mathrm{ft}$. lower than the Eastern Temple, the outer face of the eastern main wall for $\mathrm{I} 5 \mathrm{ft}$. forming its west side. On all other sides it is surrounded by cliff and boulders, a continuation of the north cliff of the Eastern Temple forming its north side. The area is $46 \mathrm{ft}$. from west to east, and $32 \mathrm{ft}$. from north to south. At the south-west corner is a chasm I4 $\mathrm{ft}$. long, $2 \mathrm{ft}$. to $5 \mathrm{ft}$. wide, and I I $\mathrm{ft}$. high running between the front base of the temple wall and the west end of the huge boulder, $44 \mathrm{ft}$. long, which forms the southern side of the enclosure. The chasm leads out of the enclosure to the south side of the outer wall of the temple. It was once much larger, but owing to silting in of soil and débris, and the falling of decomposed slabs of granite from its roof, it has become narrowed and shallowed. Along the buttress which forms the lower part of the east 
front of the temple wall was a path from the east entrance of the temple to the top of the chasm, which was further arched with granite slabs making a wider bridge, and this led to the floor of this enclosure by means of steps which ran down the north face of the boulder on the south-west side of the enclosure.

It was in this enclosure that Bent believed he had discovered ancient gold furnaces. At the south-east corner is an open space $9 \mathrm{ft}$. wide, which once had a rounded buttress on either side. Beyond this point the ground falls rapidly to the south towards the edge of the precipice. Under the cliff are holes hardly deep enough to be termed caves, and these have been reduced in size by the silting in of soil.

\section{UPPER GOLD FURNACE ENCLOSURE}

This is situated at the north-east corner of the Gold Furnace Enclosure, but on a level of $4 \mathrm{ft}$. higher. Separating the two enclosures is a well-built wall Io $\mathrm{ft}$. long with a rounded entrance in the centre.

The greatest width of this enclosure is $9 \mathrm{ft}$. at the entrance, and its length is $44 \mathrm{ft}$., but it is very narrow except for about I $2 \mathrm{ft}$. in the middle of the length. The south end runs between and under boulders, while the north end includes a cave under the continuation of the cliff which forms the north sides of the Eastern Temple and the Gold Furnace Enclosure. This cave has also been reduced in size by the filling in of débris and soil.

\section{PATTERN PASSAGE}

This passage runs for $5 \mathrm{I} \mathrm{ft}$. along the outside of the south and south-west portion of the curved main wall of the Eastern Temple. In the south-west portion the passage is $2 \mathrm{ft}$. wide, and formerly its floor throughout this section was level with that of the present floor of Recess Enclosure, but a large boulder at the west entrance to the Eastern Temple 


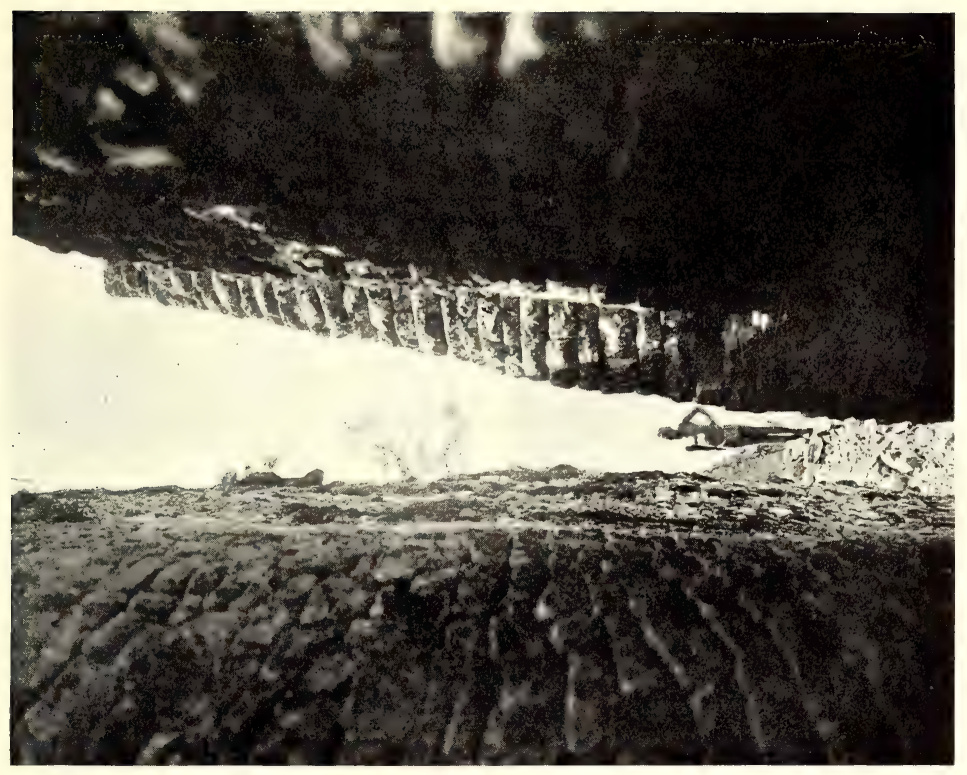

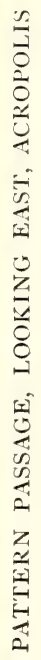

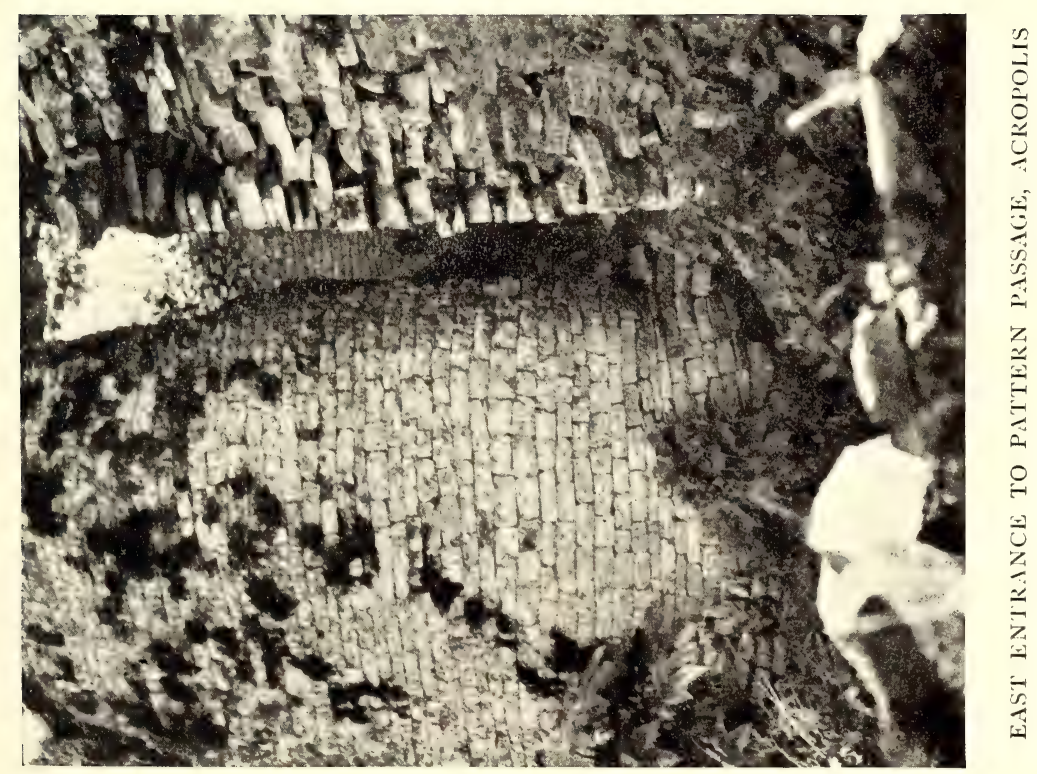



having slipped and disturbed the entrance walls, steps have recently been erected to enable visitors to climb over the débris heap.

On the west side of the northern length of the passage the wall is I I ft. high, the upper portion receding from the passage at $8 \mathrm{ft}$. above the level of the floor at the foot of the newly-erected steps, and in the recess so formed is what appears to be a decorative pattern of original form made of rows of blocks, each row at the back of the other, and rising backwards in miniature steps or shelves. But these rows are not believed to have been intended or used as steps, as the lines of blocks on either side round off to come flush with the face of the wall and become part of the wall at each end, and are continued as ordinary courses in the faces of the wall. The exact correctness of these step-like rows and curves of blocks is remarkable. For the present, and until the purpose of these steps can be ascertained, this feature is called Step Pattern. It has been suggested that these steps must have formed a post for a guard to protect the Western Entrance to the temple.

The wall opposite the approach to Pattern Passage from Recess Enclosure is $8 \mathrm{ft}$. high, and rises to I7 ft., as the floor of the southern section of the passage descends somewhat sharply. The southern section terminates at the rounded end of the east wall of Recess Enclosure, which here is rather a fine piece of dry masonry. Formerly this section had steps let into the wall on either side, fragments of such stones still projecting from the walls, the foundations of which have been laid bare, and at one point undermined. This vandalism is not the work of archæologists, but of unauthorised prospectors for gold relics, who have torn up the whole length of stairs and pavement, not only in this passage, but in every other passage on the hill which was not protected by being filled in with wall débris. 


\section{RECESS ENCLOSURE ${ }^{1}$}

This is an almost complete enclosure on the south side of the Eastern Temple, and separated from it by a deep and narrow passage, now known as Pattern Passage. Formerly a passage-way ran along the west side of the enclosure from north to south. The area of this enclosure is-south side, I $7 \mathrm{ft}$. 6 in., north side I $8 \mathrm{ft}$., west side $25 \mathrm{ft}$., and east side $20 \mathrm{ft}$. The surface shows signs of the enclosure having been filled in above its original floor by some later occupiers. The south wall has collapsed except for about $4 \mathrm{ft}$. at its west end, and this section is $8 \mathrm{ft}$. high, but the foundations of the rest of this wall are practically intact. The north wall is considerably broken, its highest point being now only $5 \mathrm{ft}$. above the present floor. The west wall, which is intact, is formed by the outer wall of a building erected at a much higher level, called South Enclosure C. This wall is $22 \mathrm{ft}$. high, and is in two parts - the upper part being rounded outwards at the extremities, and the centre rounded inwards. This wall is exceedingly well built, and is one of the finest pieces of masonry to be seen on the Acropolis, and shows very great architectural skill on the part of the ancient builders.

The south wall is now only $8 \mathrm{ft}$. to $9 \mathrm{ft}$., and on the inside face has a row of five vertical recesses built in the wall and flush with its face. These are altogether unlike anything yet discovered in any ancient ruins, ${ }^{2}$ except, perhaps, at No. I Ruin at Khami. The widths of the faces of the wall between the recesses from north to south are $2 \mathrm{ft} .4$ in., I ft. 9 in., I ft. ro in., I ft. 7 in., and I ft. 8 in., and these are separated from each other by perpendicular crevices, each

1 The author was the first to break through the old habit of bestowing misleading or suggestive titles to various architectural features. These recesses unfortunately have thus always been known as "buttresses." A long list of such incorrect titles could easily be compiled from printed descriptions of ruins.

${ }^{2}$ The author has since discovered similar recesses elsewhere at Zimbabwe. 

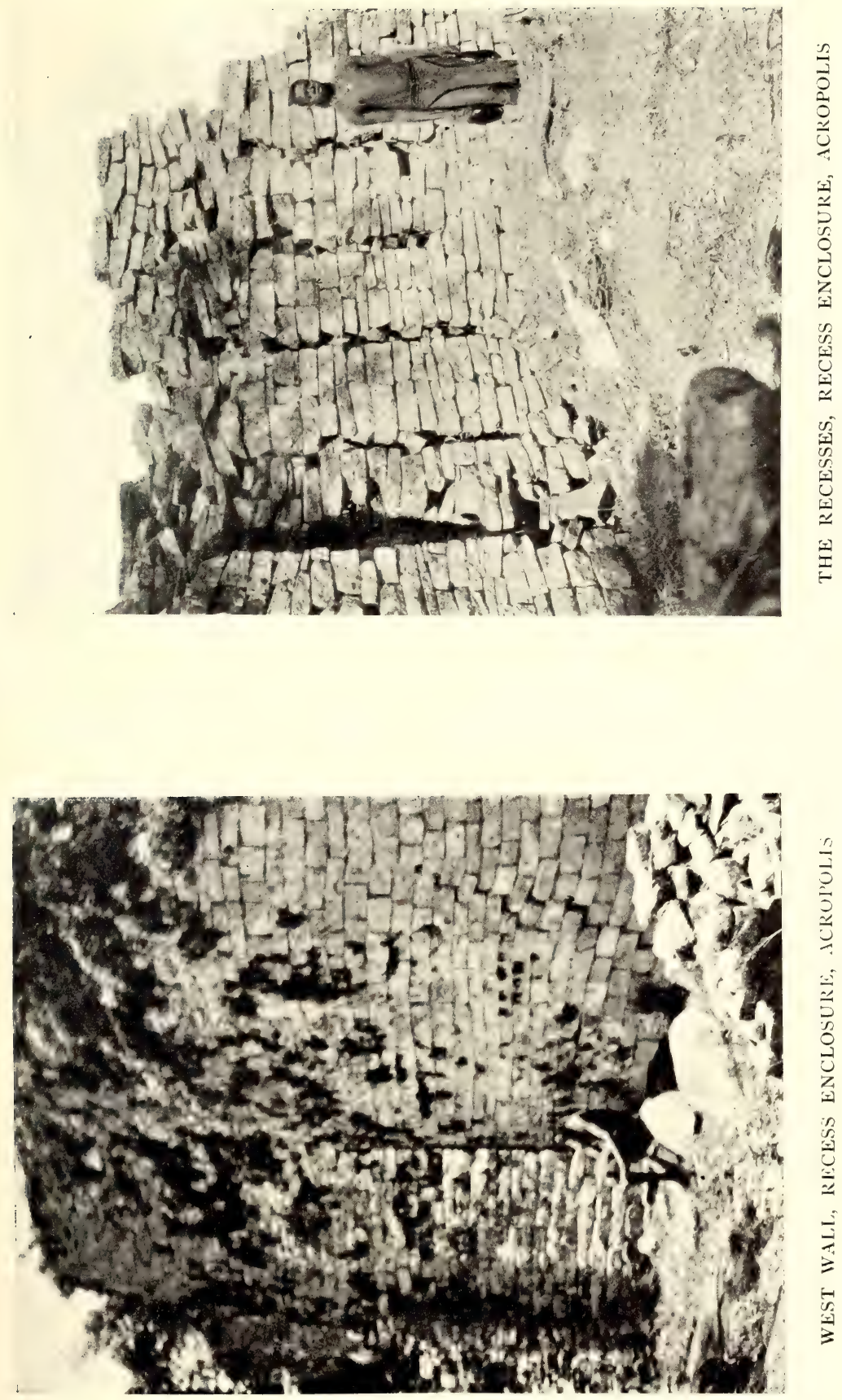



\section{THE ACROPOLIS RUINS}

5 in. wide. Most probably the recesses were once considerably higher. What practical purpose they could have served is at present impossible to state, but it has always been held that they probably once contained wooden beams.

The north-west entrance has rounded walls, and from the east side of this entrance are the remains of a passage wall running south. This wall is $6 \mathrm{ft}$. long, $2 \mathrm{ft}$. $6 \mathrm{in}$. high, and $2 \mathrm{ft}$. $6 \mathrm{in}$. wide; the foundations of this wall run almost as far as the south wall of the enclosure.

All the walls of this enclosure are well built.

In the north-east corner is an excavated hole, showing a wall running parallel to the east wall at a depth lower than the present floor of the enclosure. The north end of the east wall is beautifully rounded and tapers from its base to present summit, its face forming the south side of the east end of Pattern Passage.

\section{NORTH PLATEAU}

This plateau is situated to the north of the Eastern Temple and at the north of the cliffs, which form its north-east and north sides. Its shape is that of a quarter of a circle-the east side being formed by cliffs running towards the northeast, and the south side by huge boulders running out towards the north-west, the apex being at the north end of the North Passage of the Eastern Temple. The area from north to south is $67 \mathrm{ft}$., and from east to west $53 \mathrm{ft}$., the outer and open side being supported by a terrace wall extending along the front for $43 \mathrm{ft}$. This terraced wall is well built for this length. It has a drop from the outer surface edge of this plateau of I I ft. Traces of a continuation of this wall across the gorge on the north side on to the opposite shoulder of the kopje can be seen; but the Makalanga state that the superstructure built upon these traces was made by their people long ago, and, indeed, this is very obvious. A Makalanga-built wall juts out from the north-east side a 
few feet towards the Visitors' Path to this plateau. The plateau is covered with the clay foundations of the circular huts of the Makalanga, who up to four years ago had their kraal on the northern summit of the hill.

\section{NORTH PARAPET}

This structure is at the outer and northern base of the large curved main wall of the Western Temple, on which are the small towers and monoliths, where it curves towards the north-east and runs parallel with it for $44 \mathrm{ft}$. In this parapet is a rising passage with steps leading from the North-West Ancient Ascent up to the main wall, where it once passed through it and curved into Platform Enclosure where it can still be walked along. The point where this passage went through the main wall has been blocked up by the Makalanga, and the wall is so very dilapidated that it would be altogether unsafe to clear the entrance of the obstructing blocks.

The parapet was evidently once more extended towards the east, but the fall of débris from the broken end of the main wall has carried the parapet below away.

The western extremity of this parapet is formed by a wall I I $\mathrm{ft}$. long projecting at right angles from the foot of the main wall. This wall is $8 \mathrm{ft}$. high and is $4 \mathrm{ft}$. wide on its present reduced summit. From opposite the north end of this wall commences the west side wall of the ancient ascent described later.

Immediately on the east side of the wall forming the western extremity of the parapet there are steps rising $3 \mathrm{ft}$. 6 in. facing north and leading up to the sunken passage on the parapet, and above these steps the passage turns east at right angles along the centre of the parapet.

The width of the parapet is I I ft., and this width is divided as follows: width of passage $3 \mathrm{ft}$., of outer parapet wall $4 \mathrm{ft}$., and of inner wall $3 \mathrm{ft}$. $6 \mathrm{in}$. The passage rises $8 \mathrm{ft}$. between 
where it enters the North Parapet and where it rounds off towards the south-east through the main wall. The outer and inner walls are $3 \mathrm{ft}$. to $4 \mathrm{ft}$. above the passage floor, but the outer wall was probably once very much higher. There are traces of steps in the passage.

The height of the north face of the North Parapet from above the filled-in floor on the outside is from $9 \mathrm{ft}$. to I I ft. This floor contains the remains of a rather old Makalanga hut.

A parapet-wall of a similar character runs from the western end of North Parapet along the outer base of the main wall, and this is described later under the title of Western Parapet. 


\section{CHAPTER XVIII}

\section{THE ACROPOLIS RUINS}

(Continued)

North-West Ancient Ascent-Water Gate Ruins-Terraced Enclosures on North-West Face of Zimbabwe Hill-South Terrace-Ruins on South Face of Zimbabwe Hill-Outspan Ruins.

\section{NORTH-WEST ANCIENT ASCENT}

T NFORTUNATELY in describing this ascent it is necessary to commence at the summit and work downwards instead of upwards. The amount of débris which covered its lower lengths precluded the tracing of the ascent from below, and further it is only the higher lengths which have been cleared out, though now the lower parts can be easily followed.

The ascent begins at the Water Gate at the north-west base of the hill, and terminates at The Platform which overlooks the Eastern Temple on the Acropolis. Its total length is a little more than $500 \mathrm{ft}$.

Walking across the north-west face of the hill it would have been impossible to discover this ascent owing to the confusing number of lines of foundations and outcrops of walls running in all directions over the side of the hill, and the intermediate ground being so much covered with blocks. The idea that this ascent existed along its present lines was suggested by viewing the face of the hill from Mogabe's kraal, which is on the opposite side of the north-west valley. From this point the step-like form of the side of the hill can be seen as a whole, and it appears obvious that artificial 


\section{THE ACROPOLIS RUINS}

means had been employed in making the lines of projection on the side of the hill. These were subsequently examined, with the result that sections of a passage-way downwards were found in one chain extending from the summit to the base of the hill, though there were some long gaps between the sections, while the sections themselves were filled in up to where the side walls out-cropped for a few inches.

The sections of this ancient ascent, commencing at the summit, are as follows:-

(a) Passage through Platform Enclosure $72 \mathrm{ft}$. long (see Platform Enclosure).

(b) Passage through main wall $16 \mathrm{ft}$. long (do.).

(c) Passage along Northern Parapet $28 \mathrm{ft}$. long (see Northern Parapet).

(d) Section of ascent between Northern Parapet and the old visitors' path which the ascent crosses $233 \mathrm{ft}$. long.

(e) Section between Visitors' Path and the Water Gate, which is at the lowest point of the ascent, over $600 \mathrm{ft}$. long.

(f) Water Gate (see Water Gate).

The first three sections have already been described.

Section (d).-This extends from the Northern Parapet to the old visitors' path. The passage on leaving the parapet turns north-west for 4I ft. The walls on either side are from $3 \mathrm{ft}$. to $5 \mathrm{ft}$. high, but these heights are increased on either side by a further $2 \mathrm{ft}$. or $3 \mathrm{ft}$., owing to the depth of soil and block débris lying along the summits of the side walls, the passage for this length being found buried for this depth below the surface of the face of the hill. This length of passage is $2 \mathrm{ft}$. to $3 \mathrm{ft}$. in width. At $3 \mathrm{I} \mathrm{ft}$. from the upper end of this length and on the east side is a rounded entrance leading into an enclosure which is completely buried under débris and silted soil.

At the bottom end of this length of $4 \mathrm{I} \mathrm{ft}$. the passage turns due east for $32 \mathrm{ft}$., the corner wall being rounded. At this corner a passage from the west side enters the ascent, but 
this passage is at present buried in débris. The width of the ascent here averages $4 \mathrm{ft}$. to $5 \mathrm{ft}$. 6 in., but it is narrowed at one point to $2 \mathrm{ft}$. $6 \mathrm{in}$. by a rounded buttress projecting from the north side into the ascent. The heights of the walls for this length are: south side $6 \mathrm{ft}$. to $8 \mathrm{ft}$., with several feet depth of débris on its summit; north side $4 \mathrm{ft}$. to $8 \mathrm{ft}$. The ascent in this length has a fall of $6 \mathrm{ft}$. At the bottom of this length on the south side, and fronting up the ascent, is a rounded buttress in form of a quarter section of a circle, and this is I I ft. round its base. It has a further buttress on its west side and traces of another on its east side, and between these two buttresses are the remains of steps, but a tree growing out of the steps has caused their dilapidation.

From this buttress the passage turns due north for $75 \mathrm{ft}$. ; its eastern side from $28 \mathrm{ft}$. to $56 \mathrm{ft}$. of this length had fallen into the passage, but the rest of that side of the passage is still practically intact. Along this length the passage is deeply sunk into the face of the hill. The widths average from $2 \mathrm{ft}$. Io in. to $6 \mathrm{ft}$. The side walls are of the following heights above the passage floor : east side, $7 \mathrm{ft}$. to Io ft. ; west side, $5 \mathrm{ft}$. to $\mathrm{I} \mathrm{ft}$. On either side of this length are enclosures which are completely filled in with débris and buried, but the entrances to these can be seen. This length of passage was found (October, I902) to be completely buried, even for some feet above the Io ft. side walls, and the floors of Makalanga huts were built across them and the passage.

At the $\sigma_{3} \mathrm{ft}$. point in this length are two entrances, one on either side of the passage. The one on the east side is rounded and is $6 \mathrm{ft}$. high, and steps are formed by the curving inwards of the courses of the wall. This leads into an enclosure until recently filled in and buried, and this enclosure is mentioned in the description of the North-West Face of Zimbabwe Hill, where it is described as being typical of so many other enclosures on this side of the hill. On the opposite side of the passage the entrance there is angular on 


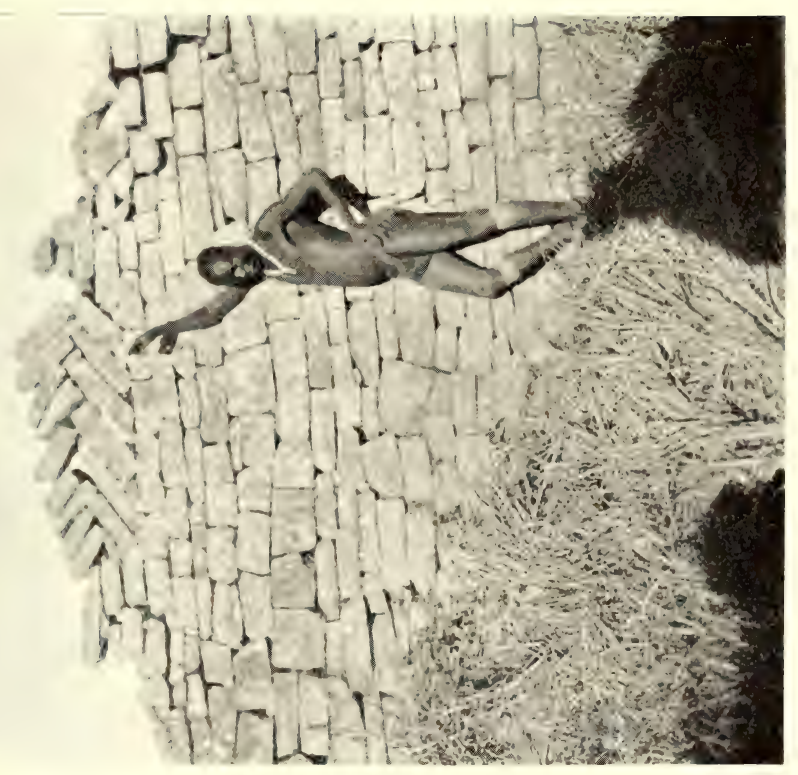

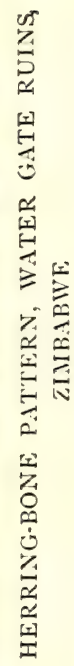

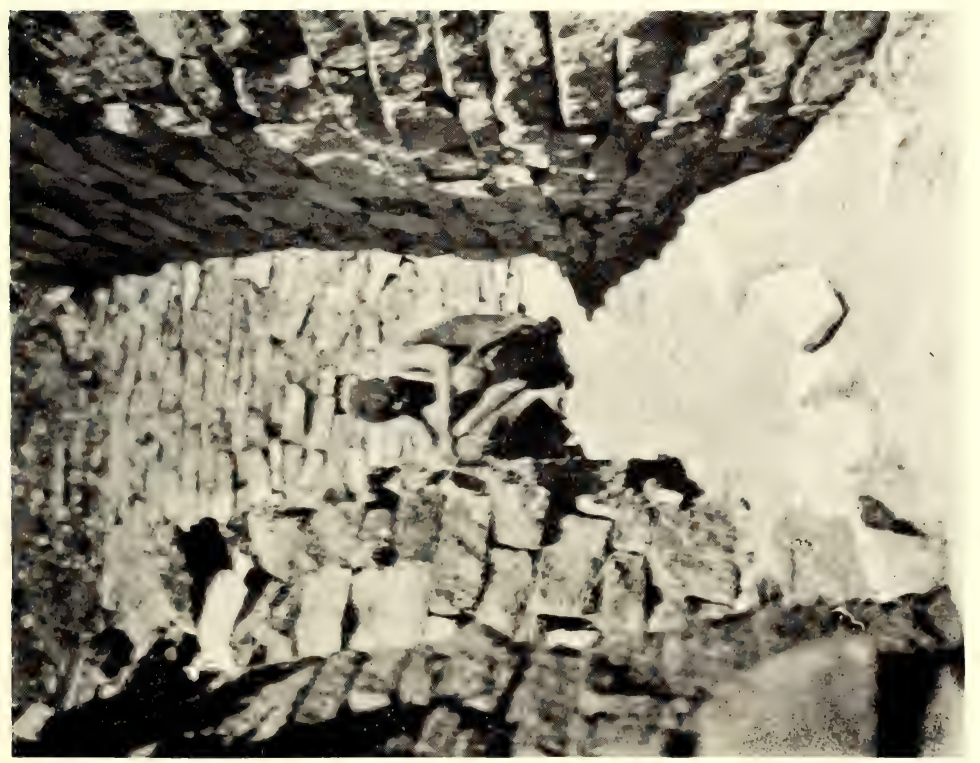

垈 

one side and rounded on the other. Its side walls are $6 \mathrm{ft}$. high. This entrance is blocked up in the same manner as was the ascent. This leads into another buried enclosure, a portion of which has been cleared out and examined. The passage along the $75 \mathrm{ft}$. length has a fall of i I $\mathrm{ft}$.

At the bottom end of this length and going north is an enclosed area triangular in shape $47 \mathrm{ft}$. long, and with the apex resting in the lower end, where the passage becomes narrowed to $2 \mathrm{ft}$. $6 \mathrm{in}$. This area and the corresponding area of similar shape in the South-East Ancient Ascent appear to have been intended to serve a similar purpose-that is, to enable a crowd of defenders on a high level to act against two or three bands of the attacking party on a lower level and in a narrow passage. Into this area open out at least three entrances from buried enclosures on either side. The area has in its length a fall of $9 \mathrm{ft}$.

At the foot of this triangular-shaped area the passage runs north for $38 \mathrm{ft}$. It is $2 \mathrm{ft}$. to $4 \mathrm{ft}$. wide, and the side walls are $4 \mathrm{ft}$. high. The fall in this length is $5 \mathrm{ft}$. At the northern end of this length and crossing it at right angles is the old path used by visitors in making the ascent of the hill.

Section (e).-This extends from the old path used by visitors ascending the hill, down to the Water Gate.

From the Visitors' Path the descent to the Water Gate is somewhat uninteresting, the passage walls being very much dilapidated, the upper side wall being particularly damaged, having been subject to the full force of falls of block débris down the face of the hill. In this way the lower side walls, having been so protected, are in a somewhat better condition.

Starting down from the path there appears to be a chaos of stones for some $15 \mathrm{ft}$., but still the passage can be traced. As there are several lines of well-laid blocks close to the crossing of the path and passage, it is quite probable that side passages ran into the main passage at this point. At 
the $15 \mathrm{ft}$. down a very wide wall $4 \mathrm{ft}$. to $5 \mathrm{ft}$. high runs down the north side of the passage for $140 \mathrm{ft}$.

The south side shows an unburied wall $30 \mathrm{ft}$. long and about $3 \mathrm{ft}$. high. At $80 \mathrm{ft}$. from the Visitors' Path the passage opens out into a triangular space $25 \mathrm{ft}$. wide, with the apex resting at the lowest point of the steep enclosure. Such triangular spaces on the lines of steep passages are not uncommon, being found at several ruins. There is one higher up the same ascent, and another on the South-East Ancient Ascent. In each case the descent is steep, and the lowest point of the triangular area rests on a narrow passage coming up from below.

At I4O ft. below the Visitors' Path the north wall alone is standing, and this runs downwards for $50 \mathrm{ft}$. This wall is $4 \mathrm{ft}$. high and is rather wide. The south wall is now represented only by a line of wall débris running parallel with the north wall.

At $\mathrm{I} 90 \mathrm{ft}$. the passage becomes lost, but exactly parallel and at a distance of $20 \mathrm{ft}$. south is the commencement of another passage. Probably the upper length takes a sharp turn west under a pile of débris which lies between the two passages. This second passage has a buried wall $3 \mathrm{ft}$. high on the south side. On the north side the wall is I $50 \mathrm{ft}$. long, and on this length the south wall has practically disappeared.

At the down side of this length the passage becomes far better defined, having side walls from $3 \mathrm{ft}$. to $5 \mathrm{ft}$. high, and $3 \mathrm{ft}$. wide on their summits. The passage here takes a sharp turn towards the north for $50 \mathrm{ft}$., then to the south-west for $25 \mathrm{ft}$., and again to the north for almost Ioo ft., the side walls being intact for this length, the east wall being from $4 \mathrm{ft}$. to $7 \mathrm{ft}$. high, and the passage $2 \mathrm{ft} .6 \mathrm{in}$. wide. This is the bestpreserved portion of the lower half of the Ascent. The west side walls are from $3 \mathrm{ft}$. to $4 \mathrm{ft}$. high. Between these walls are traces of steps, also a few buttresses, all rounded. 


\section{THE ACROPOLIS RUINS}

At the end of this length the passage is continued between walls $4 \mathrm{ft}$. high to its extremity, before reaching which it takes some sharp $\mathrm{W}$-shaped turns and terminates in very well-built walls.

The Water Gate faces this point at $100 \mathrm{ft}$. distance, only at a lower level of some $30 \mathrm{ft}$. to $40 \mathrm{ft}$. The side of the hill is here very steep, and is faced in parts with granite glacis, between which the path descended to the Water Gate. Converging on the extremity of the passage are traces of other passages from each side, which give the impression that the North-West Ascent was the main approach to the summit of the Acropolis from this side of the hill.

\section{THE WATER GATE RUINS}

This is situated at the lowest extremity of the North-West Ancient Ascent to the Acropolis, and forms its approach and entrance from the valley on the west and north sides of Zimbabwe Hill. It has been styled the Water Gate on account of there being immediately in front of it a large donga (water-hole), one of the chain of dongas which run round the hill from the south-west to the north-east, and are believed to be artificial, but have become reduced from the original area and depth by the silting in from the side of the hill during a very long period of sub-tropical rains. Sections of walls have been discovered at great depth in these dongas.

This entrance forms part of a long line of wall which runs round the base of the hill for some two or three hundred yards, and is called the Inner Defence Wall, in which on the south-west side of the hill is another large entrance, known as the Outspan Ruins. This line of wall is in some places very well defined, being from $2 \mathrm{ft}$. to $4 \mathrm{ft}$. above the level of the veld, but some lengths of it are mere lines of stone débris or ridges of mounds full of blocks; but seen from 
some heights up the face of the opposite hill it can be traced throughout its length.

The gateway is exceedingly well constructed, and the curves of the ends of the walls which form its sides are very bold and massive. Though it is distant over $900 \mathrm{ft}$. from the main ruins on the summit of the hill, it must be admitted to be a very good example of entrances of the earliest ancient period. But the construction of the wall on either side of this entrance, and at some little distance from it, becomes only fairly good, and at a still greater distance roughly built, and yet the entrance and the line of wall are of the same original plan. This grading off of the quality of construction on either side of the entrance and at some little distance from it is also seen in many other entrances which are not in proximity to the main ruins. The line of the Inner Defence Wall in which this entrance is inserted curves outwards towards the west-north-west from about $30 \mathrm{ft}$. on either side of it. The entrance is thus in the centre of the curve, and faces west-north-west. It is $2 \mathrm{ft}$. IO in. wide, and $7 \mathrm{ft}$. from outside to inside. The side wall on the south is $7 \mathrm{ft}$. 6 in. high above the steps, and on the north $5 \mathrm{ft}$. 6 in., though on either side the present reduced summit of the wall is from $2 \mathrm{ft}$. to $4 \mathrm{ft}$. higher at a few feet from the entrance. Like all main entrances, save one, at Zimbabwe, it is without portcullis grooves, these having been found in rounded entrances in internal and divisional walls. The wall on the south side is $8 \mathrm{ft}$. wide on the floor of the entrance, and $7 \mathrm{ft} .6 \mathrm{in}$. on the north side. There are remains of three steps on the entrance which commence flush with the front faces of the two side walls. These are greatly dilapidated, but it can be seen that they form part of the foundations of the wall. One stone of what is left in the front row is considerably worn on the top, as if it had been trodden on for many generations.

As in very many entrances of the earliest style of ancient 


\section{THE ACROPOLIS RUINS}

architecture-for instance, the main entrance to the Elliptical Temple-the walls on either side widen out as they approach the entrance. In this instance the walls widen out from $4 \mathrm{ft}$. and $5 \mathrm{ft}$. to $8 \mathrm{ft}$. as the entrance is neared. There are also traces of buttresses on either hand on the inner sides of the entrance, also of a few steps ascending into the interior of the enclosed area.

The front face of the wall on the north side is $5 \mathrm{ft}$. above the veld, but the summit increases in height towards the interior face of the wall, as most of the dilapidations have taken place on the outer side of the wall. The front face of the south wall is $7 \mathrm{ft}$. in height, and the summit of this wall ascends much higher towards its inner face. At $12 \mathrm{ft}$. from the entrance, along the face of the south wall, it is clearly seen where the excellent workmanship of the entrance grades off to an inferior construction in the continuation of the wall southwards. The line of wall on the south side is more or less intact for $48 \mathrm{ft}$., at which point it becomes lost in débris and silted soil, though its line of route can of course be traced much further. The wall on the north side extends for $90 \mathrm{ft}$., but from this point northward it is very easy to follow the course of its débris.

The interior faces of the wall, for about $30 \mathrm{ft}$. on either side of the entrance, are still in a good condition, and are from $4 \mathrm{ft}$. to $7 \mathrm{ft}$. above the inside cleared-out level.

On the inner face of the south wall, at $5 \mathrm{ft}$. above the present level of the enclosed area, is a herring-bone pattern which directly faces east-south-east. The pattern remaining is $3 \mathrm{ft}$. $6 \mathrm{in}$. long, and I ft. 2 in. deep, and is formed of tilelike blocks, varying from Io in. to I ft. 3 in. in length. Judging by the positions of the stones, it is highly probable that this pattern extends at least $2 \mathrm{ft}$. further towards the entrance. The usual frame for this pattern, and also for Dentelle and Chevron Patterns, is still good for three courses at its south end. The size of the stones employed in this 
pattern is above the average size used for the same pattern in other ruins, and is somewhat larger than those in the pattern at Little Umnukwana Ruins, in the M'Pateni district, where the average length of the stones is ro in. So far this is the only herring-bone pattern discovered at Zimbabwe. It was first noticed by Mr. J. W. Clarke, of Victoria, in September, I902.

From immediately behind this entrance the north-west face of the hills rises very sharply, so much so that the rains of many years have silted soil to a great depth behind the walls. Rain-water would naturally be guided by the contour of this part of the hill towards this entrance, so that the area behind it has become filled up to a very much higher level than in the time of the original occupiers. Some two dozen cubic feet of this silted soil was cleared out of the entrance in October, 1902, and while the work was progressing a heavy storm, lasting only an hour, broke over Zimbabwe. On visiting the entrance later in the day it was found that this one shower had caused the almost entire filling up of the excavation by mud-streams, which had washed down the side of the hill.

Immediately in front of the outer faces of this entrance and running parallel with this length of the Inner Defence Wall, and at a distance of $90 \mathrm{ft}$. from it, are the remains of a line of wall almost hidden in débris. This wall can be traced for a distance of at least I $30 \mathrm{ft}$., and there appears to have been a passage or entrance through it at a point almost due north of the Water Gate. Further to the north and north-west of this wall is a donga, and on the northnorth-west of this donga runs the outer defence wall, which is at least 600 yds. long, and encloses the line of dongas from west of the Elliptical Temple with the north-east of the base of Zimbabwe Hill. In this Outer Defence Wall is an opening, and in all probability, judging by the arrangement of the wall débris and the contour of the ground, a gateway or 
entrance was once situated at this point. This opening in the Outer Defence Wall, the traces of an entrance in the ruined wall in front of the Water Gate, and the Water Gate entrance are all in one line, and the line is further made complete by the remains of two small walls in the donga itself, which equally divide its width, as if these walls either carried or supported a bridge; or at any rate afforded the means for crossing the donga. In fact, the size of these dongas and their relative positions appear to indicate that on this side of the hill the Acropolis was further defended by water. These two small walls show signs of having had rounded entrances in their centres.

Taking into consideration the line of the three entrances, the fact that the ancient ascent through the Water Gate leads into the heart of the main ruins of the Acropolis, and further that the contour of the ground beyond the Outer Defence Wall indicates the direction in which a road from Zimbabwe to the north and north-west must take, it is reasonable to conjecture that the ancient road from Zimbabwe in that direction passed on the north side of the Makuma Kopje, on which Mogabe's kraal is now located.

TERRACED ENCLOSURES ON NORTH-WEST FACE OF ZIMBABWE HILL

About forty or fifty ledges protrude in step form up the north-west face of Zimbabwe Hill from the valley below up to the front of the west main wall of the Western Temple, and these projections are not only upwards in terrace form, but broadways, extending across the entire length of the north-west face of the hill.

The best view of these ledges is obtained from Makuma Kopje, on which is Mogabe's kraal. From this point it is seen that these projections must have been artificially made. So great has been the fall of wall débris, and the washing of soil for many centuries by heavy sub-tropical rains down the 
hillside, that even the outer faces, or retaining walls, of many of these projecting ledges or platforms are completely buried, and their outline can but barely be traced owing to the absence of any outcrop of walls. In fact, the whole of this face of the hill for over 300 yds. upwards, and the same distance broadways, is but a chaos of fallen blocks, and the visitor, while walking over this area, sees infinitely less of their arrangement and plan than can be seen at a distance of a third of a mile from the opposite kopje.

These terraces are not disposed in lines across the hill as are the Hill Terraces of Inyanga, but each is independent of the other. Nor do they in any point resemble the terrace system of the retaining walls so often met with in ruins of the Second Period of Zimbabwe architecture.

Several of these projecting areas on the steep face of the hill have recently been cleared of the débris which has in so many instances completely covered them, and rendered their form but a mere suggestion of an outline. The outer faces of some of the terrace walls have been laid bare, and their construction is seen to be of true Zimbabwe building of the First Period, all features of the Second Period, so far as examinations have extended, being altogether absent.

The walls are not built on straight lines but on curves, some of the curves being laid on bold lines, in some instances amounting to a semi-circle. The angular wall is absent. The construction of most of the walls is superior to that of Second Period walls. There is no promiscuous filling up of the interiors of the walls. The walls are as well built on the inside as they are on their outside faces, and they possess the true Zimbabwe batter-back, and such entrances as have been discovered are excellently rounded.

The spaces between the outside edge of the summits of these walls in front and the rising surface of the hill behind them have been levelled by falling débris, but there is no lack of evidence to show that, where not wholly filled in naturally 
in the course of time, the work of their complete filling-in has been systematically carried out by people who were not the original builders. On clearing the irregular surfaces of these ledges of débris it was found that the areas were rudely covered with red clay or daka, and on this flooring were the clay foundations of Makalanga huts, with piles of buck bones and quantities of charcoal and bits of iron slag. Mogabe's headmen state that these hut foundations are not those of Makalanga of their time, as Mogabe's kraal, and that of Makomo before him, though on the north side of the hill, were situated much higher up the hill and much nearer to, or even among, the main ruins. Nor do they belong to Makalanga of sixty years ago, for Mogabe's people say that when Chipfuno arrived as a boy some seventy years ago this portion of the hill was then in the same state as is seen to-day. Judging by the weathered blocks piled and strewn upon these areas, it is very possible that these rough clay floors and hut foundations are at least seventy years old, if not considerably older. Portions of iron assegais and Makalanga hoes found on these floors are so eaten by rust that they have become thin, and are almost as brittle as glass.

But the most interesting feature of these terraced areas lies in the fact, obvious to anyone who inspects the areas cleared out in July and August, 1902, that these areas were not originally terraces but ordinary enclosures, with floors from $4 \mathrm{ft}$. to Io $\mathrm{ft}$. lower than the present reduced summits of the outer walls. Some people of times later than those of the original builders had deliberately taken the blocks from the outer or down-side walls of the enclosures and thrown them inside till the interiors were filled up level with the reduced height of the walls, and over such filling-in had spread a clay floor, and so made these enclosures into terraced platforms and dry vantage ground on which to build their huts, lay their corn-drying, threshing, and winnowing floors, and also 
their small daka granaries, which, occupying these welldrained and soilless positions, would be free from the ravages of white ants.

By clearing the outer faces of these walls from block débris, which has fallen or rolled down from higher positions on the hill-and these falls have in some instances utterly ruined the walls beneath-and following the curve of wall round to its opposite side on the face of the hill, the rounded entrances into some of these enclosures have been unburied, the floor of such entrances being on an average $5 \mathrm{ft}$. to $9 \mathrm{ft}$. below the débris. These entrances, so far as discoveries have been made, are all at the rear of the enclosure and close to the face of the hill. These entrances are narrow, I ft. IO in. and $2 \mathrm{ft} .2 \mathrm{in}$. being a fair average width, and once the line of floor which is level with the floor of the entrances is cleared, it is seen that there are no steps inside the enclosures, though outside the entrances there are in a few instances steps leading up to the entrances only, but never steps leading upwards from inside the entrances. The floor of the entrance, in each case, is the level of the floor of the enclosure. Inside is seen a mass of dry blocks without soil, and many of these blocks show a face that was once exposed to the weather and become timeeaten if not greatly decomposed, which shows that they once formed part of the face of an ancient wall.

In removing this block débris from these enclosures no pick or spade was necessary. The blocks were picked up and handed outside, and when the enclosures had been emptied there was not 12 in. depth of soil, and what was there was mainly fine granite chippings caused by the throwing in of the blocks, and of decomposed daka, which had formed the floor, and which, being of poor quality, constant rainfalls had practically rotted into sand. It was on these cleared-out floors that portions of large carved soapstone bowls were discovered in July and August, 1902. The "finds" on the bottom and original floors bore undoubted 
evidences of antiquity, and were totally different in character from the unmistakable Makalanga objects found on the daka floor some feet above.

As before stated, these terraces of enclosures are in some points independent of each other-that is, they extend across the face of the hill most irregularly. The second enclosure may be $20 \mathrm{ft}$. or $30 \mathrm{ft}$. in front of the level of its neighbour on either hand, the third $20 \mathrm{ft}$. or $30 \mathrm{ft}$. to the rear of the level of the first enclosure, and so on. But the enclosures are built very nearly one behind the other up the face of the hill, the front wall of one being the back wall of the next below. Between these ascending lines of enclosures are narrow sunken passages, the existence of which, until August, 1902, was altogether unsuspected, as such passages showed no outcrop of their side walls. Two of these passages are now known to be at least $350 \mathrm{ft}$. long, and one of them has been cleared out for this length. They were exceedingly narrow, so that at many points only one person could pass at a time. The widths average $2 \mathrm{ft}$., and their floors are from $3 \mathrm{ft}$. to $\mathrm{I} 2 \mathrm{ft}$. below the present débris-strewn surface of the slope of the hill. Into these passages the entrances to enclosures on either side open.

Evidently the same people who filled in the enclosures and converted them into platforms likewise deliberately filled in the passages for the foundations of old Makalanga huts, and granaries were laid across the filled-in passages. The "finds" on the floors of these passages and those found on their "filled-in" tops showed as great differences in every respect as were presented by the objects found on the original floors of the enclosures and those on the later clay floors above them.

\section{SOUTH TERRACE}

This is a natural ledge of ground artificially improved, running east at the foot of the south precipice for 200 yards from the foot of the Rock Passage, and extending beyond the 
point where the most easterly ruins of the Acropolis are built along the summit cliff. This terrace is supported on its south side by several retaining walls.

Almost all the enclosure walls along this terrace have been demolished by the falls of great masses of walls from the ruins on the summit of the cliff. Barely the foundations of such enclosure walls now remain, the only exception being the enclosure adjoining the bottom end of the Rock Passage.

\section{THE “OUTSPAN RUINS"}

These ruins, which lie $75 \mathrm{yds}$. to the north of Havilah Camp, are on the outspan in the valley which runs along the south side of Zimbabwe Hill, and also on the path leading from the camp to the South-East Ancient Ascent. This block of ruins was entirely cleared out of wall débris and silted soil in September, I902, and now visitors may walk upon what was practically the ancient floor. The cement which once formed the floor has become decomposed to granite sand, and owing to the enclosures of the ruin having been buried some $3 \mathrm{ft}$. to $5 \mathrm{ft}$. under the veld, the enclosures held all the water which in rainy seasons would pour down the side of the hill immediately behind.

These ruins form part of the line of Hill Inner Defence Wall, which encloses the whole of Zimbabwe Hill on its west, south, and east sides and runs along the foot of the lower slopes of the hill. The most complete view of this continuous line of wall is obtained from the summit of the hill. This line of defence wall is again enclosed on the west side by the Outer Defence Wall, which runs from the north side of the hill almost as far as the Elliptical Temple, and between these two walls are the three large dongas on the west side of the hill.

The "Outspan Ruins" form the most perfect section of the Hill Inner Defence Wall, not excepting the fine entrances to 
the North-West Ancient Ascent with its herring-bone pattern, which is also another section of the same line of inner defence wall, only on the north-west side of the hill. They also must have served as an important entrance through the south-west portion of the Hill Inner Defence Wall. The entrance is complicated and rendered very difficult of attack by a number of rounded buttresses, in addition to which there are small enclosures most substantially built, which, most probably, were guard-rooms.

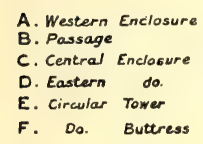

A. Western Enclosure
B. Passage
C. Central Enclosure
D. Eastern do.
E. Circular Tower
F. Do. Buttress

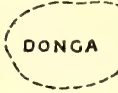

Skerch Plon

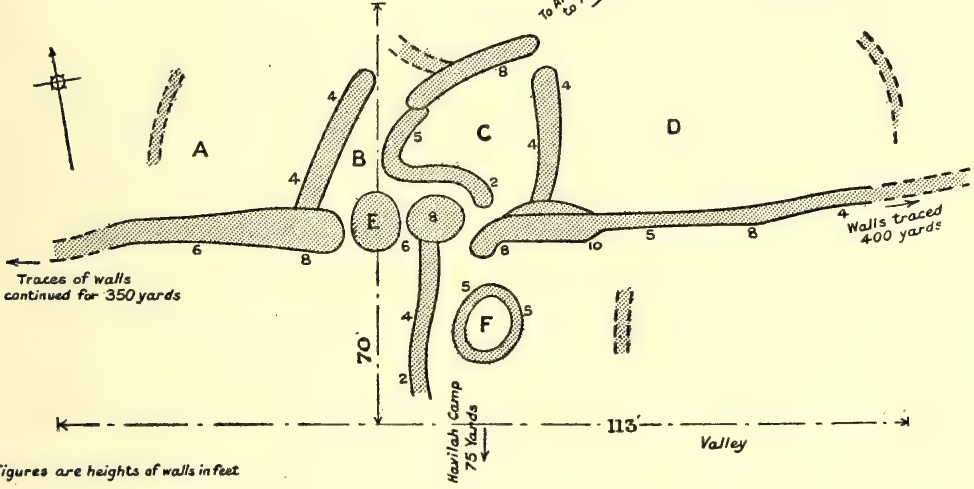

There is nothing angular in the plan and construction of these ruins. They very patently resemble other outlying buildings which obviously formed part of the original plan of the main Hill Ruins. The courses in the wall are not very regular, and stones of all shapes and sizes have been introduced. There is no decorative pattern in this section of the Hill Inner Defence Wall, but there is one peculiarity in its architecture, and in that of a conical tower which is described later.

These ruins occupy an area of I $3 \mathrm{ft}$. from south-east to north-west, and $70 \mathrm{ft}$. from north-east to south-west. 
The main wall faces south. The I I $3 \mathrm{ft}$. length only includes the line of main wall which still stands some $5 \mathrm{ft}$. to I I ft. in height, the wall at either end of this length can be traced extending for $500 \mathrm{yds}$. to the east and $350 \mathrm{yds}$. to the west and north.

The entrance which has rounded walls on either side is $4 \mathrm{ft}$. wide, and passes diagonally south-west through the main wall, thus giving it a length of $8 \mathrm{ft}$. On its eastern side the wall is $7 \mathrm{ft}$. high, and $5 \mathrm{ft}$. on the western side.

The ruins on the north side of main wall form a central enclosure to the north of the entrance with an enclosure on either side of it, also a passage on the south and west sides of the central enclosure.

The central enclosure is formed by a wall $22 \mathrm{ft}$. long, $4 \mathrm{ft}$. high, and $5 \mathrm{ft}$. to $7 \mathrm{ft}$. wide on the present reduced summit, which runs north at right angles from the inside of the main wall at $4 \mathrm{ft}$. east from the east side of the entrance. The wall, which at its northern extremity is rounded, forms the divisional wall between the central and eastern enclosures. The west side of the central enclosure is formed by a wall, rounded at each end, which starts at $4 \mathrm{ft}$. from opposite the inside of the entrance, and goes west for I $3 \mathrm{ft}$. and north-east for $19 \mathrm{ft}$. This wall averages $3 \mathrm{ft}$. to $8 \mathrm{ft}$. in height, and is from $4 \mathrm{ft}$. to $5 \mathrm{ft}$. 6 in. wide at base, and $3 \mathrm{ft}$. 6 in. on the highest summit. Where the east wall of this enclosure comes opposite the end of the north-east wall is an entrance $3 \mathrm{ft} .6$ in. wide. The area of this enclosure is $14 \mathrm{ft}$. from west to east and I9 $\mathrm{ft}$. from north to south. It is possible that in the centre of this enclosure once stood a round buttress or tower, and the position of a few blocks in the floor makes this something more than a mere conjecture.

On passing through the main entrance from the south, one enters a passage which runs parallel with the north side of the main wall for $17 \mathrm{ft}$. towards the west, and then curves sharply towards the east-north-east for $19 \mathrm{ft}$. At its two 
extremities the passage is from $3 \mathrm{ft}$. to $3 \mathrm{ft}$. 6 in. wide, but at the curve at the end of the first length of $\mathrm{I} 7 \mathrm{ft}$. it is $6 \mathrm{ft}$. wide. The western wall of this passage is $19 \mathrm{ft}$. long, $5 \mathrm{ft}$. wide at base, and $3 \mathrm{ft}$. 6 in. on the highest portion of the summit, this being at the south end, where the wall is $8 \mathrm{ft}$. high. This wall is rounded at its northern extremity, and forms the divisional wall between the passage and the eastern enclosure. Neither the eastern nor the western enclosures can at present be defined on their northern sides, though lines of block débris would appear to fix their boundaries.

The most interesting architectural feature in the "Outspan Ruins" is the conical tower built to form part of the main wall. This is an independent structure from its base upwards. It is $9 \mathrm{ft}$. high, and though built of irregularly shaped stones and without much adherence to courses, it is symmetrical in appearance. On its west side between it and the rounded end of the main wall is a space $2 \mathrm{in}$. wide on the floor and $5 \mathrm{ft}$. wide at $6 \mathrm{ft}$. from the floor. This narrow loopholed space still remains open, save for a single slab which at $6 \mathrm{ft}$. above the floor is built into the tower and the main wall, thus forming a sort of stone shelf. On the eastern side of the tower the space between it and the rounded wall of the entrance is neatly built up, and a slab is laid from the rounded wall into the courses of the tower at $5 \mathrm{ft}$. above the floor. Possibly these slabs on either side of the tower formed raised platforms to afford a view over the wall, while the narrow loophole might have served as a look-out. The circumference of the tower at $5 \mathrm{ft}$. from its base is $19 \mathrm{ft} .3 \mathrm{in}$.

The portion of these ruins which lies to the south of the main wall comprises (I) a wall running south at right angles to the main wall at $4 \mathrm{ft}$. from the west side of the entrance. This wall is $24 \mathrm{ft}$. long, and averages $3 \mathrm{ft}$. 6 in. in height, and is $2 \mathrm{ft}$. wide on its present summit; (2) a circular buttress built independently and standing opposite the outside of the main entrance at a distance of $8 \mathrm{ft}$. $6 \mathrm{in}$. Its height is now 
only $3 \mathrm{ft}$. Io in., and its circumference at base is $28 \mathrm{ft}$. 4 in. It is hollow in the centre, and it has collapsed from summit to base on its southern side for a width of $3 \mathrm{ft}$. The obvious object of this buttress is to divide the open space on the outside of the entrance into two narrow passages, each of which could easily be defended by a few even against a great number of besiegers.

At $36 \mathrm{ft}$. east of the south side of the entrance is an outcrop of a wall $6 \mathrm{ft}$. long, and this runs due south at some $5 \mathrm{ft}$. in front of the main wall. 


\section{CHAPTER XIX}

\section{"THE VALLEY OF RUINS"}

"THE Valley of Ruins" is on the north-east and east sides of the Elliptical Temple, and almost half-way between it and the south side of the east end of the Acropolis Hill. This conglomeration of ruins extends from the edge of the slope which runs along the north-east sides of both Elliptical Temple and No. I Ruins to within $60 \mathrm{yds}$. of the west side of East Ruins, and covers an area of about $250 \mathrm{yds}$. from east to west and $\mathrm{I} 20 \mathrm{yds}$. from north to south. This area is the upper portion of the Zimbabwe Valley, which descends towards the east, the streams from this valley during the rainy season falling into the Mapudzi stream, which runs southwards down the Schlichter Gorge towards the Moshawasha Valley, and later finds its way into the Motelekwe River.

Till 1902-3 these extensive ruins, some of which are massive and most excellently constructed, remained not only unexplored but unexamined, and no particulars or plan had ever been attempted to be given, all writers being content to refer to them as "The Valley of Ruins," while some writers altogether ignore the existence of the group. Dr. Helm, of Morgenster, whose professional duties have taken him twice every month for the last six years within a few score yards of the ruins, states that he never supposed the wood and the jungle contained any walls.

Since the Occupation in 1890 no attention has been paid to these ruins. No visitors' or even native paths crossed the 363 
area, nor are there the slightest traces in the shape of trenches of relic hunters and gold prospectors having worked here. So unfrequented has it been that some fair-sized buck have recently been shot within the walls. The area was found to be covered with an almost impenetrable jungle of trees, bushes, and creepers. The local natives declared the place to be bewitched, and consequently they avoided it.

"The Valley of Ruins" has recently (1903) been found to consist of three groups, each of which includes several distinct ruins, some being of an important character.

The area is divided as follows :-

I. Lower or north-eastern section, including the Posselt, Philips, and Maund Ruins.

2. Middle section, which lies between the lower section and the edge of the slope of land on the north-east side of the Elliptical Temple.

3. Upper section, including all ruins between the Elliptical Temple and the edge of the slope overlooking lower portions of "The Valley of Ruins."

Before describing these complicated groups there are some features represented by them which may be mentioned.

(a) Several of these ruins, especially those in the lower section, are exceedingly massive and well built, the courses marvellously true with an absence of straight joints. The curves of the wall are beautifully designed and are laid on boldly sweeping lines. The material is good, and is also most carefully selected and sized. The masonry of many of the walls is far superior to that of some of the divisional walls of the Elliptical Temple and to the majority of the walls on the Acropolis.

(b) The absence of the angular style of buildings, except with certain structures in the middle section. Rounded entrances and buttresses and gracefully rounded ends of walls form the most prevailing features of most of these ruins. Two conical towers, several very large semi-circular buttresses 
or platforms form prominent features. Two drains were discovered (1903) in Philips Ruins and three in Posselt Ruins (B).

(c) The middle section is poorly built, and possesses some angular features. The upper section is well built.

(d) The discovery (1903) in the lower section of these ruins of gold articles, decorated and plain soapstone beams and relics of the oldest type, including the soapstone beam with bird on summit-the finest specimen yet found in Zimbabwe - point to the fact that certain of these ruins were used for somewhat higher purposes than those of forts or workshops, possibly, as many now suggest, as residences for priests or officials connected with the temple. This surmise is justifiable, seeing that the north-east passage connects such wellbuilt and substantial portions of these mines directly with the North Entrance and Parallel Passage and Sacred Enclosure of the Elliptical Temple. In the lower section of these ruins there are no traces of ancient or native industries having been carried on.

(e) In the lower section of these ruins there are fewer signs of modern or even of very old Makalanga clay huts, such as are fully described in "Native huts found in ruins." No modern articles were found here. The consequence is there has been in this lower group of ruins very little artificial filling-up of the enclosures, and the ruins are more open and are easier of examination than most of the other ruins at Zimbabwe. But being on lower ground, with a huge bank of granite and soil on the south-western flank, there has been a considerable amount of soil silted into the ruins during the course of hundreds of years, but not to any great depth. The filling-in, both natural, is no more than about $2 \mathrm{ft}$., as compared with $5 \mathrm{ft}$. and $7 \mathrm{ft}$. in other ruins elsewhere where there are abundant signs of native occupation. 


\section{LOWER SECTION OF THE "VALLEY OF RUINS" POSSELT RUINS}

These ruins are the most westerly of the lower section of The Valley of Ruins. They consist of two almost ovalshaped buildings adjoining each other, and for the purposes of this description are marked $A$ and $B$ respectively on the plan. This set of ruins lies at the north-east extremity of the North-East Passage leading from the Elliptical Temple.

$A$ is $175 \mathrm{ft}$. long from north to south, and 9. $\mathrm{ft}$. from east to west. $B$ lies at almost right angles to $A$ on its south-west side, and is I IO ft. from east to west, and $75 \mathrm{ft}$. from north to south.

The interesting points concerning the Posselt Ruins are :-

(I) The discovery of beaten gold and of the older class of relics.

(2) Two entrances with unworked soapstone beams used as lintels in portcullis grooves.

(3) Complicated entrances; a small conical tower ; cement dadoes; a parallel passage; circular and semi-circular buttresses; only slight artificial filling-in of interior; some evidence of occupation by old or modern natives.

(4) Massive character of walls originally averaging at least I $5 \mathrm{ft}$. in height; excellent construction, main walls being superior to many divisional walls in the Elliptical Temple and to most of the walls on the Acropolis; the overwhelming predominance of the rounded style of architecture.

(5) No evidence of either ancient or native industries having been carried on in these ruins.

\section{SECTION A OF POSSELT RUINS}

Main walls. - The main walls average from $7 \mathrm{ft}$. to $\mathbf{2} 2 \mathrm{ft}$. in height above the surface of the veld, while the height of the interior faces, which are some $3 \mathrm{ft}$. above the outside level, averages $6 \mathrm{ft}$. to $9 \mathrm{ft}$. The great amount of wall débris 
at the foot of the walls suggests an original average height of at least $15 \mathrm{ft}$. above the cement floors. Some practical builders have computed it to have been almost $20 \mathrm{ft}$., and the batter-back would permit of this. The average of $15 \mathrm{ft}$. is a very conservative estimate of the original height. There is more dilapidation on the outside top edges of the walls than on the inside. The width of the main walls at base averages $6 \mathrm{ft}$., and on the reduced summit at $9 \mathrm{ft}$. above the outer surface of the ground $4 \mathrm{ft}$. Some of the divisional walls are

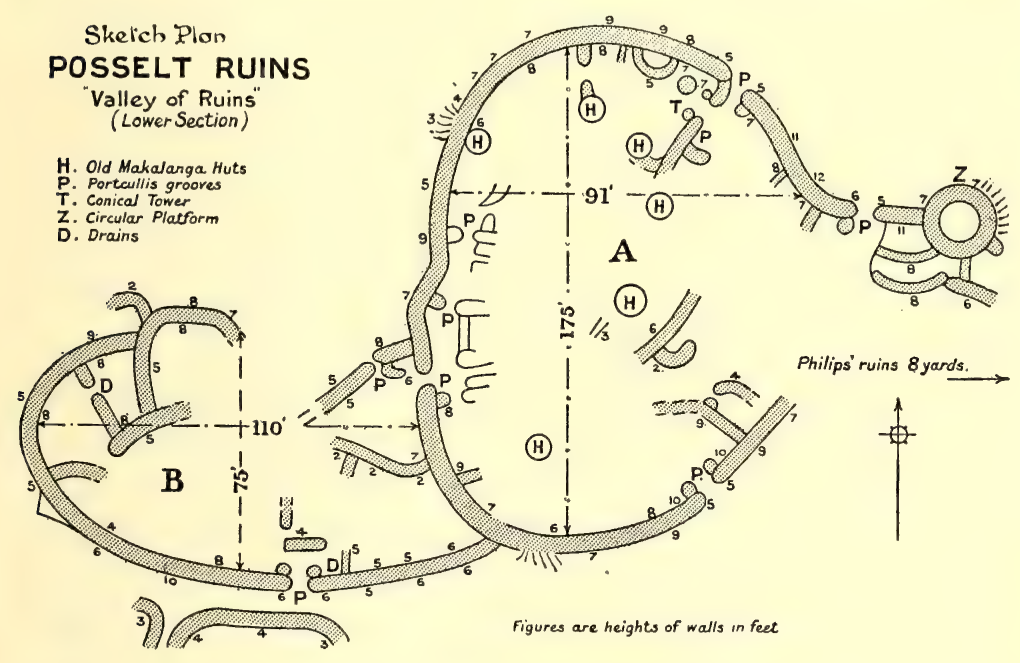

almost equally as massive. As is usual in the rounded style of building, the main walls, also the foundations, widen out as they near an entrance. The curves of the walls are most symmetrical, especially of the wall which curves outwards from the north to the east-south-east. Two granite beamsone $6 \mathrm{ft}$. 3 in. high-once stood erect on the north-east portion of the main wall. A flat granite slab still stands erect on the west wall. Other long granite beams were found at the foot of the wall both outside and inside. The foundations of the main walls are carried under the entrances and form their floors. 
Construction.-The construction of the main walls and also of some of the divisional walls is good, though there are places where a rather inferior workmanship can be noticed. On the whole, the courses are regular, straight joints are infrequent, and the sizes of the blocks of each course show they were carefully selected. There are a few short lengths of walls in the interior which do not appear to have been parts of the original building. These are erected upon the black vegetable mould, and are poorly constructed, are slight and of indifferent material, being almost identical, if not quite so, with old Makalanga walls, the noticeable feature of which is the building of one stone exactly above and squarely on the block below without any pretence at bonding. This is known as the column style, and can be seen in walls in native villages as well as within certain ruins at Zimbabwe, mainly on the Acropolis, where, as in these ruins, there are the remains of very old Makalanga cement huts.

Entrances.-There are four rounded entrances through the main wall; possibly there was a fifth on the east side where there is a wide gap. There are twelve entrances in divisional walls, nine of which are rounded, two being partly angular and partly rounded, and one angular, this last being before referred to as probably of later construction. It is almost certain that many more divisional entrances will yet be discovered, as several of the divisional walls only just outcrop above the surface of the interior. Almost every entrance has portcullis grooves. All four of the entrances through the main wall have rounded buttresses on either side projecting into the interior of the building. Three of the more important divisional entrances also have rounded buttresses on each side of the entrance.

The E.N.E. entrance was evidently the main entrance. Its walls are very massive, and the arrangement of the inner walls strongly suggests the intention to protect the entrance and afford a second line of defence. This entrance generally 
is the most imposing of all four approaches. It opens directly on to the exterior of the building, which the west entrance does not; nor most probably did the S.E. entrance, which opens out towards other ruins. The E.N.E. entrance varies in width from $2 \mathrm{ft}$. Io in. to $4 \mathrm{ft}$., and the passage is I $2 \mathrm{ft}$. long. The side walls are $5 \mathrm{ft}$. high, but rise sharply towards the exterior to $8 \mathrm{ft}$. and I I $\mathrm{ft}$. respectively, and both are about $6 \mathrm{ft}$. wide on floor level. As in the entrances through the main wall of the Elliptical Temple, the foundations run under the entrance and form its passage floor. The entrance has two buttresses on the inner side, and these have portcullis grooves.

The west entrance opens in Section B of the Posselt Ruins. This is I ft. Io in. wide, $7 \mathrm{ft}$. long, and the side walls are $7 \mathrm{ft}$. high above the floor and $6 \mathrm{ft}$. wide on the floor level. The entrance shows remains of portcullis grooves. The floor of the entrance is $2 \mathrm{ft}$. above the cement floor of the interior of the building, and there are the remains of large rounded cement steps down on to the floor. On the inner side is the Parallel Passage, described later, and as in this passage are a quantity of buttresses, these show that the entrance was well protected from attack from the side of Section $B$, especially on the north outer side of the entrance, where is what visitors have called a "sentry-box," a small walled-in area immediately adjoining and opening directly upon the entrance into Section $A$. The elaborate protection of this entrance from attacks from Section $B$ would appear to show that Section $A$ was regarded by the builders as the more important portion of these buildings.

The south-east entrance opens out on to the veld, but there are extensive ruins, portion of the middle section of "The Valley of Ruins," at a few yards' distance in front of it with traces of walls between. This entrance is $2 \mathrm{ft} .4$ in. wide between the buttresses, and $3 \mathrm{ft}$. wide between the sides of the main wall. It is I I $\mathrm{ft}$. long, and the side walls are $7 \mathrm{ft}$. 
high on either side, rising rapidly on the east side to Io ft. There is a pair of rounded buttresses $5 \mathrm{ft}$. high on the inner side, and these have portcullis grooves. It is probable that this was the entrance used by the ancient occupiers on ascending from these ruins to the Elliptical Temple, as the north-eastern extremity of the North-East Passage is not many yards away from this entrance.

An entrance through a divisional wall just within and on the west side of the E.N.E. entrance is worthy of notice. This passes through a wall $6 \mathrm{ft}$. wide on floor level, and $7 \mathrm{ft}$. high on the south-west side and $6 \mathrm{ft}$. high on the north-east side. In this entrance, which has rounded buttresses on the inner side, a length of unworked soapstone beam was found acting as a side lintel in a portcullis groove, also the fragments of a corresponding soapstone lintel. In this entrance was discovered (March, I903) beaten gold and fragments of decorated soapstone bowls.

Parallel Passage.-This is the sixth parallel passage so far discovered at Zimbabwe, and is about the fifth in importance. It runs for $66 \mathrm{ft}$. on the inside of, and parallel to, the west main wall. The inner or east wall of the passage is formed by a line of buttresses with short walls between each, and in these walls are various entrances leading towards the interior of the building. No portion of this inner wall is more than $5 \mathrm{ft}$. in height, though the wall débris along their summits rises $2 \mathrm{ft}$. higher. The passage is defended by several pairs of rounded buttresses with portcullis grooves, and averages in width from $5 \mathrm{ft}$. to $8 \mathrm{ft}$.

The passage commences on the south side of the west entrance which leads from Section $B$ of these ruins. Two large rounded buttresses form its southern extremity. The buttress on the west side, which is $5 \mathrm{ft}$. high, projects $5 \mathrm{ft}$. into the walled-in area opposite to the inside of the west entrance, and the eastern buttress, which is $4 \mathrm{ft}$. high, projects $3 \mathrm{ft}$. to meet it, leaving the entrance between them $3 \mathrm{ft}$. wide. There 
are no portcullis grooves, but it is probable, judging by the position of the débris, that a pair of rounded buttresses once stood on either side of the entrance. Portcullis grooves are most usually found in such additional buttresses. In this walled-in area, facing the inside of the west entrance, is a passage-way leading into the interior of the building, but this still remains unexplored.

Going north from this point, the Parallel Passage is narrowed to $4 \mathrm{ft}$. by a rounded buttress $5 \mathrm{ft}$. high projecting from the inner or eastern side of the passage. From this buttress a wall $5 \mathrm{ft}$. high runs north-east and parallel to the inside of main wall for $13 \mathrm{ft}$., the passage along this length being about $4 \mathrm{ft}$. 6 in. wide. At the northern end of this length of wall are a pair of rounded buttresses $4 \mathrm{ft}$. 6 in. high with portcullis grooves. The entrance between the two is I $\mathrm{ft}$. Io in. wide, and these are built upon the same foundation which forms the floor of the entrance. At $16 \mathrm{ft}$. further north is another pair projecting from either side into the passage. The one on the west side is $5 \mathrm{ft}$. high, is rounded, and has a portcullis groove. The opposite is $3 \mathrm{ft}$. high and greatly dilapidated. It is angular on one side and rounded on the other, and there are traces only of a portcullis groove. The quality of the construction differs, the rounded buttress being the better built. Possibly the other buttress is a reconstruction of a much later date. The entrance between the buttresses is $2 \mathrm{ft} .6$ in. wide. Both buttresses are erected on the same foundation which forms the floor of the entrance.

Between the last-described two pairs of buttresses and on the east side is a roughly built entrance $\mathrm{I} f \mathrm{ft}$. Io in. wide, with the two buttresses angular on the outside and rounded on the inside. This leads into the interior of the building. At the northern end of the passage and on the east side and leading into the interior is an entrance with portcullis grooves built upon a curved line. The west corners, which are $3 \mathrm{ft}$. 6 in. 
high, are angular, but the inside walls are rounded. This is altogether better built and more substantial than the entrance previously described. The northern extremity of the passage is abrupt on its eastern side, which faces the south end of the gap in the main west wall, and the presumption is that the passage was originally continued further north, but that when the main wall fell the eastern side of the passage was also destroyed.

In places the floor of the passage shows by the wall of a large semi-circular buttress which projects II ft. from the inner face of the main wall. All the walls surrounding the area are very well built. The south side is formed by an opening $2 \mathrm{ft}$. 4 in. wide between the semi-circular buttress and the west side of the conical tower, by the conical tower, by an opening $2 \mathrm{ft}$. wide between the east side of the tower and a rounded buttress $4 \mathrm{ft}$. high, which projects $3 \mathrm{ft}$. 6 in. from the wall forming the east side of the enclosure. The floor, which is made of granite cement, is I ft. above the floor on the south, and is approached by a rounded step.

Conical Tower.-This tower and the Conical Tower in the adjoining Philips Ruins are almost identical in construction and position. It has a circumference at 14 in. above its foundation of $\mathrm{I} 7 \mathrm{ft}$. $\sigma$ in., and at $3 \mathrm{ft}$. 6 in. above this level the circumference is $15 \mathrm{ft}$. 6 in. It is impossible to measure its circumference at base owing to the cement floor enclosing its north and north-east sides. It is $5 \mathrm{ft}$. 8 in. high from base on the north side and $4 \mathrm{ft}$. on the south side. The filling-in process of very late occupiers has caused its dilapidation. The tower has been proved to be solid.

Semi-circular Buttress. - A large remains of pavement, portions being cemented and portions paved with blocks. A large rounded granite cement step crosses the northern end of the passage.

Dadoes.-In the passage and on the lower inside face of the main wall are several lengths of granite cement dadoes, 
the longest being Io $\mathrm{ft}$. and $\mathrm{I} 2 \mathrm{ft}$. The dadoes are still $2 \mathrm{ft}$. to $3 \mathrm{ft}$. high, and about 3 in. to 5 in. thick.

Enclosures.-It is probable, judging by the number of sections of divisional walls outcropping above the surface of the interior, that there are some eight or ten distinct enclosures within Section $A$ of these ruins. Some enclosures have several entrances, all so far discovered being rounded. The divisional walls of most of the enclosures are massive and well built, some being far superior in construction and material to several of the divisional walls in the Elliptical Temple.

The most perfect enclosure is on the inner side of the north-east, immediately west of the E.N.E entrance. This was entirely filled in with soil and blocks up to the tops of the walls, which are $7 \mathrm{ft}$. and $8 \mathrm{ft}$. high. All this filling-in has now been removed (March, 1903), and a conical tower, which had been completely buried, was discovered. The area is formed on the north-east side by the inner face of the main wall, which is $7 \mathrm{ft}$. high and I $\mathrm{ft}$. long, on the east side by a wall $7 \mathrm{ft}$. high and $9 \mathrm{ft}$. long, and on the west side it averages from 2 in. to 4 in. in thickness. Its faces are usually smoothed and the tops are rounded off inwards.

Native huts.-There are the remains of seven old native huts in this section of the ruins. These are identical with No. 3 huts described in "Makalanga huts within ancient ruins," see "Notes on Architecture." They are built about $2 \mathrm{ft}$. and $3 \mathrm{ft}$. above the ancient cement floors. Two are built across gaps in divisional walls, and one partially covers a portion of the gap in the north-west main wall, which, had it been intact, would not have enabled the builders of the hut to find room for the erection of their dwelling.

\section{POSSELT RUINS. SECTION B}

This lies to the west of Section A of the Posselt Ruins, which it immediately adjoins on its south-west side and practically forms part of the same ruins. 
Its area is I Io ft. from east to west, and $75 \mathrm{ft}$. from north to south, and is oval in plan. The construction of the walls is excellent, and this section appears to be one of the earliestperiod ruins. Its central portion has been filled in, and some of the walls dividing off the enclosures are still buried beneath the débris. There are no signs of native occupation of the interior of the ruins, but on the outside of the building are the circular ruins of old native huts and débris consisting mostly of ashes, bones, and pottery.

Only the three enclosures at the west end have been cleared out to their old floors, but nothing was found of any antique character.

Walls.-The outer walls are massive and show excellent construction, and average in height between $5 \mathrm{ft}$. and $10 \mathrm{ft}$., their width being $6 \mathrm{ft}$. at $5 \mathrm{ft}$. above the ground. The inner walls are also massive and are fairly well built, being $5 \mathrm{ft}$. wide at $4 \mathrm{ft}$. above the ground. There is a narrow and low divisional wall of poor construction cutting off the northeast portion of these ruins, and this most probably is of later date.

Entrances.-There are only two entrances through the main or outer walls. The one on the north-east side is $2 \mathrm{ft}$. $6 \mathrm{in}$. wide, and has very massive walls, which are rounded, and all exceptionally well constructed. There is a pair of rounded buttresses immediately inside, and these have portcullis grooves. The foundation of the main wall forms the floor of the entrance passage.

The south entrance is $4 \mathrm{ft}$. wide, and is built upon the foundation of the main south wall. It is narrowed to $2 \mathrm{ft}$. by two rounded buttresses, and these have portcullis grooves.

"Sentry-box."-This class of structure has been popularly termed "sentry-box." In the angle at the north-east corner is a rounded wall with a narrow opening into the inside. This is situated close to the entrance leading into Section $A$, and its position suggests the idea that it was used as a 
sentry-box guarding the entrance. There are several of these structures at Zimbabwe, and they all occupy a similar position near entrances.

Drains.-There are three drains through the walls of this section of the Posselt Ruins, one in the south wall passing through a wall $5 \mathrm{ft}$. 6 in. wide, one in a divisional wall, $4 \mathrm{ft}$. wide, which projects from the south main wall towards the north, and one in a divisional wall $5 \mathrm{ft}$. wide at the northwest of the building.

A semi-circular buttress projects I I ft. into the interior from the cunei face of the north-east main wall. It is $27 \mathrm{ft}$. round its outer face. On the east side the buttress is $8 \mathrm{ft}$. high, and on the south and west sides, owing to dilapidations, and also to a higher floor, these faces are only $4 \mathrm{ft}$. and $5 \mathrm{ft}$. high. The top surface is covered with a foot depth of granite cement.

Circular platform.-This is at the eastern extremity of the ruins. It is $2 \mathrm{I} \mathrm{ft}$. in diameter and $5 \mathrm{ft}$. above the floors of the adjoining enclosures. On the east side the summit is approached by granite cement steps which are large and wellrounded, and on the south by stone steps.

On the west of this platform are two raised enclosures immediately on the inside of the main wall. The northern one has steps leading some way towards the west side of the Circular Platform, and there probably once reached its summit.

Cement dadoes.-In these ruins are many lengths of granite cement dado work, the greatest length intact being $33 \mathrm{ft}$., and this is on the east of the west main wall. This work is also extensively found in the Parallel Passage. Not only is it found on the faces of walls, but also on round buttresses and on the side walls of entrances, thus reducing their widths by about 5 in. It runs about $3 \mathrm{ft}$. higher than the cemented floors. 


\section{PHILIPS RUINS}

These ruins lie to the east of the Posselt Ruins, which they almost adjoin, being only 8 yds. apart at their nearest points. These ruins present several most interesting features :-

(I) The discovery (March, 1903) of the finest, most perfect, and most elaborately decorated soapstone beam with bird on summit yet found at Great Zimbabrve, also of phalli and beaten gold.

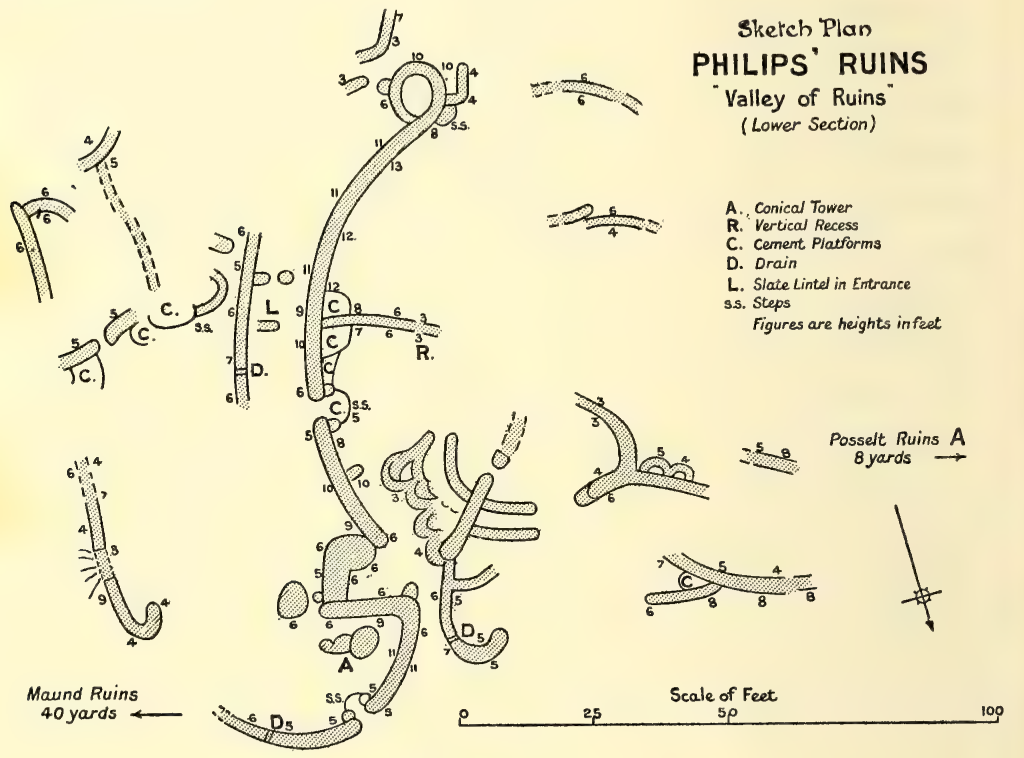

(2) An excellently constructed and massive wall, built upon the plan of a section of a circle, with its centre facing due east, and the discovery of quantities of sections of worked soapstone beams along its base, together with fragments of carved soapstone bowls, and also ancient relics of the oldest type.

(3) A small conical tower uncovered March, I903.

(4) Excellent and massive character of the construction of the walls of the numerous rounded entrances, buttresses, and 
ends of walls. There are two drains, also a tall slate beam, built into a portcullis groove to form a side lintel post in an entrance.

(5) The complete absence of signs of native occupation of these ruins except on the east side of the large curved wall, and these are slight.

Area.-The area occupied by these ruins is $\mathrm{I} 40 \mathrm{ft}$. from east to west, and $\mathrm{I} 5 \mathrm{ft}$. from north to south. There is no main outer wall on the south side, and it is probable, judging by wall débris, that these ruins extended some $20 \mathrm{yds}$. further south.

Main walls.-These extend from the west side round the north to the south-east, the rest having disappeared; or possibly Posselt Ruins and these were originally one immense ruin, so that an outer wall on the west side might never have existed; but this could not have been the case with regard to the south side.

The main outer walls average from $5 \mathrm{ft}$. to $9 \mathrm{ft}$. in height on their outer faces, and $3 \mathrm{ft}$. to $8 \mathrm{ft}$. on their inner sides, the interior of the building being on a considerably higher level than the exterior. This is owing mainly to the natural fall of the ground towards the north-east and east on which the ruins are built. The widths of the main walls vary from $6 \mathrm{ft}$. to $8 \mathrm{ft}$. on floor level, $5 \mathrm{ft}$. at $6 \mathrm{ft}$. above the floor, while some reduced summits have a width of $5 \mathrm{ft}$. at $9 \mathrm{ft}$. above the floor.

Construction.-These ruins, especially some portions, such as the massive curved wall, are most excellently built. The selection of the blocks, the good and even quality of the granite employed, show that some special importance was attached to these portions of the ruins. Except for one small buttress, the angular style of building is absolutely absent from these structures.

The divisional walls are also well built, and are superior to the main and outer walls of several ruins at Zimbabwe. 
Curved wall.-This wall forms the most prominent feature in these ruins, and it at once attracts the attention of all visitors on account of its symmetrical and massive character, excellent workmanship, and the height of its reduced summit, which has the extraordinary width of $5 \mathrm{ft}$. at $\mathrm{I} 3 \mathrm{ft}$. from the ground. The curve is laid on so exact a plan that it was an easy matter for a surveyor to definitely determine the centre of the arc. The centre of the curve faces outwards due east, and standing at the centre of the arc the extremities of the wall are found to be E.N.E. and E.S.E. respectively. It is I $25 \mathrm{ft}$. round its inner face at $6 \mathrm{ft}$. above the remains of cement flooring, and $84 \mathrm{ft}$. round its outer face at the same height from the ground, but its outer extremities are hidden behind rounded walls and buttresses. The distance between the two extremities across the bow is $75 \mathrm{ft}$., and from that line to the centre of the curve the distance is $23 \mathrm{ft}$. The batter-back of the wall is I $\mathrm{ft}$. 3 in. in Io $\mathrm{ft}$.

The height of the reduced summit for $60 \mathrm{ft}$. averages $9 \mathrm{ft}$. to $\mathrm{I} 3 \mathrm{ft}$. on either side of the wall, but as these heights are taken from raised cement steps, platforms, and sections of floors, at least another $2 \mathrm{ft}$. or $3 \mathrm{ft}$. may be added to their present reduced height, for the greatest height from foundation to summit is $15 \mathrm{ft}$. 6 in. The original height may safely be estimated at $20 \mathrm{ft}$. above the cement flooring. This estimate is justified by the great amount of wall débris found along the bases of either side of the wall. On the summit near the south end of the wall are the remains of a banquette, and these inner terraces or look-outs are almost invariably behind walls which are at least breast high above the floor of the banquette; moreover, the batter-back of the faces of the wall would well allow of a wall $20 \mathrm{ft}$. high and yet leave a fairly wide summit. Where the entrance facing the E.N.E. passes through this wall, the side walls are reduced to $5 \mathrm{ft}$. in height on either side above the floor of the entrance, which is $3 \mathrm{ft}$. above the foundation of the wall. 
This entrance, like those in the main walls of the Elliptical Temple, is carried over the foundation of the wall, and this forms its passage floor. It is $2 \mathrm{ft}$. wide and $6 \mathrm{ft}$. $6 \mathrm{in}$. long, and has two rounded buttresses on the inner side, and these have portcullis grooves. These buttresses are built upon a semi-circular platform projecting $6 \mathrm{ft}$. into the interior of the building, thus making the entrance passage about $12 \mathrm{ft}$. in length. The floor of the entrance is covered with granite cement.

One peculiar feature in the construction of this wall is that, while the northern end is rounded off, the southern end is continued in the form of a portion of a loop, which circles southwards and eastwards, and then runs back into the east face of the curved wall, enclosing an almost circular area of Io $\mathrm{ft}$. in diameter. The wall in this loop is well built. The average height of the loop-wall is $6 \mathrm{ft}$., but on the south side it rises to Io ft., where the width of the summit is $3 \mathrm{ft}$. The interior was rudely filled up with stones, below which was a cement floor $3 \mathrm{ft}$. higher than the outside level and $6 \mathrm{ft}$. above the foundation. This raised platform or pulpit is approached on the west side by a few steps leading up to a rounded opening into the loop.

This curved wall, massive as it is, does not form an outer wall of these ruins, but crosses their centre, dividing them into two parts. It is apparently independent so far as its plan, superior character of construction, and purpose are concerned.

At the west side of the curved wall, and at the centre of the curve, is a wall $23 \mathrm{ft}$. long projecting towards the interior of the building. This is $3 \mathrm{ft}$. high at its western extremity, but its summit rapidly rises to $8 \mathrm{ft}$. in height. It has a slight curve towards the south. On its north side is a small recess extending from base to summit, and this is exactly similar in construction to the recesses in "Buttress" or "Recess Enclosure" on the Acropolis. 
On either side of this wall, and in the angles formed by the curved wall, are low granite cement platforms which are rounded on the front faces. These resemble the "blind steps" found in all the main ruins at Zimbabwe.

The purpose of the erection of the curved wall might possibly have been for solar or astronomical observations, and though this is a mere conjecture, the following points may lend it some support :-

(I) In close proximity to this curved wall, and on its eastern side, was discovered the soapstone beam with carved bird on the summit-this being the finest specimen yet discovered at Zimbabwe-also phalli and ancient relics of the oldest type. The soapstone birds had so far been discovered only at the Western and Eastern Temples on the Acropolis.

(2) The discovery under the wall débris which lay along each side of the wall at its base of quantities of lengths of broken soapstone beams which, though not carved, had been worked with tools, the widths of the edges of the chisel being very plainly discernible, some sections being beautifully rounded and polished. These are believed to have originally decorated the summit of the wall, a suggestion supported by the shape and markings on the bases of several beams so discovered. Soapstone beams once fixed on the summits of walls had previously been discovered only at the three temples.

(3) The proximity of a small conical tower in an adjoining enclosure at the north-eastern end of this wall.

(4) The large raised platform formed by the looped wall, and originally approached by steps on the west side, somewhat corresponds in position with the Platform in the Elliptical Temple and at the Western Temple, and with the Balcony at the Eastern Temple.

Conical Tower. - This is situated in the most north-easterly enclosure of these ruins. It is still $6 \mathrm{ft}$. $6 \mathrm{in}$. in height, but judging from the block débris it was once much higher. At 
$3 \mathrm{ft}$. 6 in. above the granite cement floor at its base it has a circumference of $18 \mathrm{ft}$. Io in. It is impossible to measure the circumference of its base, as a large rounded cement step extends between it and the south wall of the enclosure. The tower, which has a fair and noticeable batter-back, is very well built. It has been proved to be solid. Its foundations are 6 in. below the cement floor. There are four of these small conical towers at Zimbabwe, two having been discovered in March, 1903. On the east side of this tower, and built up against its east side, is a small rounded platform $3 \mathrm{ft}$. high, covered with granite cement, which is approached by two large steps.

Entrances.-There are three entrances to these ruins-the north, north-east, and east-and most probably others will be found as further exploration work is carried on here.

The north entrance appears to have been the main approach. This is an intricate entrance, and one which appears to have possessed considerable importance in the minds of the original builders. It lies between two outer rounded walls, each $6 \mathrm{ft}$. high, which curve inwards towards each other so as to form a passage-way about $6 \mathrm{ft}$. wide, which is again narrowed at its southern extremity to $2 \mathrm{ft}$. $6 \mathrm{in}$. by two rounded buttresses on either side. These buttresses have portcullis grooves. The area opens into a small walled-in area, Io ft. by Io ft., the walls being $6 \mathrm{ft}$. high, and very well and substantially built. The floor is made of granite cement. There are three rounded walls in this area. A buttress with a portcullis groove is in the south-western corner of the area, but the corresponding buttress has disappeared. The walledin area would have enabled twenty defenders to protect the $2 \mathrm{ft}$. 6 in. wide entrance from being forced by an attacking party. The west side of the entrance passage is carried further south by two walls, each built upon a semi-circular plan.

The north-east entrance opens into the enclosure which 
contains the Conical Tower already described. The side walls are $5 \mathrm{ft}$. high, and $4 \mathrm{ft}$. and $5 \mathrm{ft}$. wide at this height from the floor. The entrance is $2 \mathrm{ft} .4 \mathrm{in}$. wide, and including the steps it is $9 \mathrm{ft}$. long. A semi-circular platform projects $6 \mathrm{ft}$. into the enclosure, and on it are built two rounded buttresses with portcullis grooves. These buttresses are in an advanced state of dilapidation. There are three steps between these buttresses, and these lead down on to the floor of the interior. An immense slate beam rises out of the ground immediately on the north-east side of the exterior of the entrance.

At present only the south side of the east entrance has been opened out. This is $4 \mathrm{ft}$. high, and is rounded. On the inner side is a semi-circular buttress hollow inside with an opening into it from the south side.

All the entrances, of which there are seven in the divisional walls, are rounded, and most have portcullis grooves.

At the centre of the eastern face of the curved wall is a rounded entrance with portcullis groove, in which is built a slate beam which stands $8 \mathrm{ft}$. above the floor. The total length of the beam is at least I I ft. This is the most perfect specimen of all the stone lintels built in portcullis grooves.

Enclosures.-Judging from sections of divisional walls, there were in all probability no less than sixteen enclosures in these ruins. Some were of large area, but subdivided. All the divisional walls are laid on curved lines. The only complete enclosure is the one on the north side, where is the Conical Tower. The wall on the south side is from $5 \mathrm{ft}$. to $9 \mathrm{ft}$. high, on the west side $5 \mathrm{ft}$. to Io $\mathrm{ft}$., and on the north side, which is the main outer wall of the ruins, $5 \mathrm{ft}$. This latter wall, which is curved outwards towards the north-east, is $4 \mathrm{ft}$. wide at $5 \mathrm{ft}$. above the ground. A cement floor is laid around the tower. The west entrance was described earlier under the heading of "Entrances."

Buttresses.-In these ruins are numerous rounded buttresses. A large semi-circular buttress $4 \mathrm{ft}$. to $5 \mathrm{ft}$. high, $22 \mathrm{ft}$. round 
the face, $9 \mathrm{ft}$. from back to front, and $\mathrm{I} 2 \mathrm{ft}$. across the back, faces the east and outer side of the centre of the curved wall, from which point the buttress is due east at $25 \mathrm{ft}$. distance. On the west side of this buttress is a passage with cement floor, rounded steps, and dadoes.

Drains._-So far as these ruins have been cleared, only two drains have been exposed, one through a wall $5 \mathrm{ft}$. wide, which wall runs parallel to the east side of the large curved wall, and one through the main wall leading from the north-east enclosure.

Cement.-Granite cement has been extensively employed at these ruins, both for flooring, dadoes, and steps, also for platforms in the angles of walls, which somewhat resemble the "blind steps" in the angles of the divisional walls of the Ellipitical Temple.

\section{MAUND RUINS}

These ruins, though not extensive, appear to have been of some importance. They are situated at a distance of 60 yds. from the east-north-east side of Philips Ruins, and lie almost half-way between those ruins and the East Ruins.

Their construction is excellent, and the walls are massive, while all the entrances are rounded, most having possessed a pair of granite lintel beams. Although built upon by far the lowest level of any ruin at Zimbabwe, it is the least filledin, either naturally or artificially, by any native occupiers. There are very few traces of Makalanga occupation. The granite cement floors are at a depth of I ft. to $2 \mathrm{ft}$. below the surface soil within the interior. No ancient relics, save fragments of soapstone bowls carved with chevron pattern, have been found here.

The most interesting points as to these ruins are :-

(I) Two very fine rounded ends of walls, both being excellent pieces. of masonry.

(2) Two structures facing east and west respectively, the 
summits being approached by large steps, and each associated with one of the rounded walls.

(3) Sections of red clay walls in the gaps of the stone walls.

The area of these ruins is $143 \mathrm{ft}$. from east to west, and I $38 \mathrm{ft}$. from north to south. There is some evidence that these ruins once occupied a larger area.

There is only one entrance, so far discovered, through the

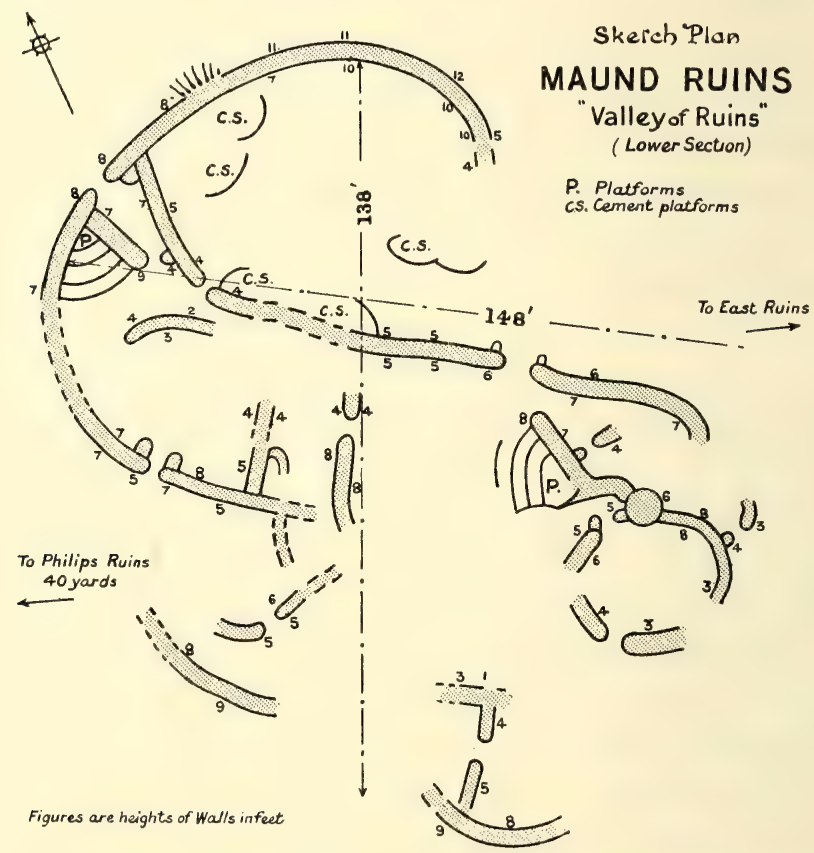

main wall, and this faces north. It is massive and well built, and opens into a vestibule enclosure I $5 \mathrm{ft}$. long, $9 \mathrm{ft}$. wide, and $5 \mathrm{ft}$. and $7 \mathrm{ft}$. in height. The side walls of the entrance are $5 \mathrm{ft}$. high, the width of the main wall is $6 \mathrm{ft}$. 6 in., the width of the passage $3 \mathrm{ft}$., but narrowed on the inside to less than $2 \mathrm{ft}$. by two rounded buttresses with portcullis grooves, the south one of which has almost disappeared.

The east end of the south wall of the vestibule enclosure is 


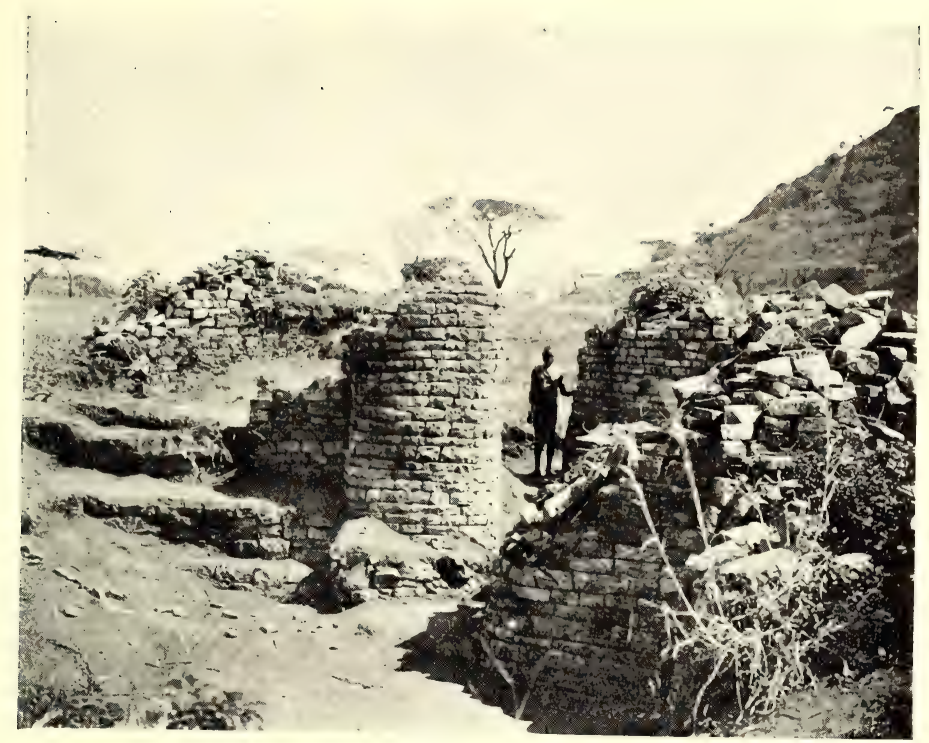

ROUNDED END OF WAIL ON WEST SIDE OF MAUND RUINS, SHEWING STEPS TO PLATFORM, VAILEY OF RUINS

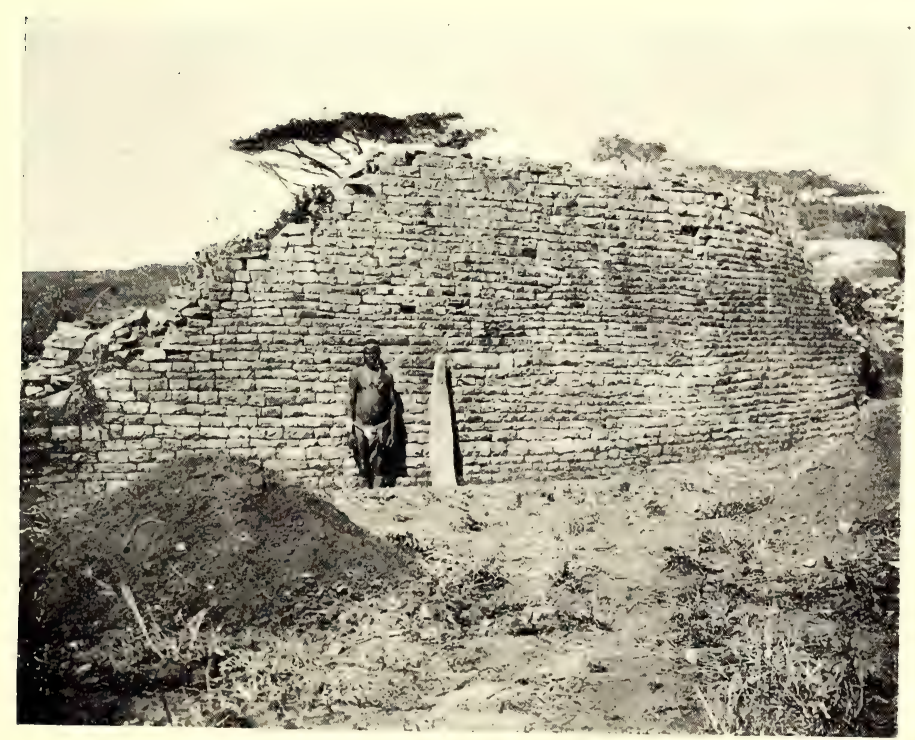

NORTH-EAST WALL, MAUND RUINS, VALLEY OF RUINS 

one of two beautifully rounded ends of walls before referred to. The symmetry of the batter-back is perfect. This wall is $7 \mathrm{ft}$. high, $5 \mathrm{ft}$. wide at base, and $3 \mathrm{ft}$. Io in. at summit. The vestibule has a granite cement floor. At the east end of the vestibule is one large rounded buttress with portcullis grooves. The corresponding buttress on the south-west side is much ruined.

On the west side of the ruins, and immediately west of the west wall of the vestibule wall, and built from wall to wall in the angle of the main and vestibule wall, is a raised platform $6 \mathrm{ft}$. high approached by four rows of stone steps once covered with granite cement. This structure is apparently different in purpose and construction from the "blind steps" found in some of the ruins at Great Zimbabwe, for in this instance the platform must have afforded a good position for seeing over the outer wall, and also for watching the entrance which it overlooks.

A similar structure is to be found on the east side of these ruins. This also is an excellent piece of workmanship. The steps in this instance lead from the west side of the base of the wall to its summit, and were once covered with granite cement, portions of which still remain. The wall is $8 \mathrm{ft}$. high, and its north end is beautifully rounded. It is $4 \mathrm{ft}$. 6 in. wide at its base, and $3 \mathrm{ft}$. wide on the summit. The north or rounded end of the wall, at $6 \mathrm{ft}$. above the ground, turns on each side towards the centre of the summit, forming a small round tower $2 \mathrm{ft}$. high. There are four steps, but it is possible that other steps were in between each of the steps now seen. The summit of the steps faces due east. This wall is not an outer wall.

There appear to have been at least ten enclosures. There are eleven divisional entrances, all rounded, of which eight have portcullis grooves and several have rounded buttresses on the inside. Two long granite beams and some sections of broken beams were found in most of the entrances, but 
not in those in which the portcullis grooves had been carefully built up.

In the northern enclosures and $2 \mathrm{ft}$. under the surface were found several large and massive cement steps laid on curved lines.

\section{MIDDLE SECTION OF “THE VALLEY OF RUINS" \\ RENDERS RUINS}

These are the best-defined ruins of the Middle Section of the Valley of Ruins, are of better construction, and have walls still standing of a fairly good height. All the other ruins in this section are almost, if not quite, impossible to trace, and a view of them gives the impression that they are of much later construction than the Renders Ruins.

These ruins, which lie east and west, cover an area of $300 \mathrm{ft}$. from east to west, and $200 \mathrm{ft}$. from north to south. They lie within $30 \mathrm{yds}$. of the south and south-west sides of Posselt Ruins. A and B, the intervening space, being full of outcrops of walls. On the south and south-west sides of these ruins is the Upper Section of the Valley of Ruins.

The most striking features of the Renders Ruins are (I) their complicated plan; (2) the banquette wall on the summit of the south wall of No. 3 Enclosure; and (3) the great amount of ancient gold, Arabian pottery and glass, and other relics discovered in No. I Enclosure.

The ruins are built upon the formation rock which slopes down from south-west to north-east, the floors of all the enclosures being the bed-rock itself, and this has such a steep gradient that at some points it makes it difficult for those wearing nailed boots to ascend from the lower to the higher portions of the ruins.

These ruins are approached from the Mauch Ruins by a passage and steps, also from the Motelekwe wagon-track, and by a path passing the west end of Posselt Ruins B. The North-East Passage leading from the Elliptical Temple is 
scarcely any longer an approach, as the passage walls have in some places fallen inwards and blocked the passage.

No. I Enclosure.-This is the most easterly of the enclosures of these ruins. It is oval in plan, being $73 \mathrm{ft}$. from east to west, and $52 \mathrm{ft}$. from north to south. The walls are substantially built, but are constructed in the style usually found in ruins built at some distance from any of the main ruins. The highest walls are on the west and southern sides, and these average from $7 \mathrm{ft}$. to $9 \mathrm{ft}$. in height, $4 \mathrm{ft}$. to $5 \mathrm{ft}$. at $5 \mathrm{ft}$. above the floor in width, and are $4 \mathrm{ft}$. wide at the summit.

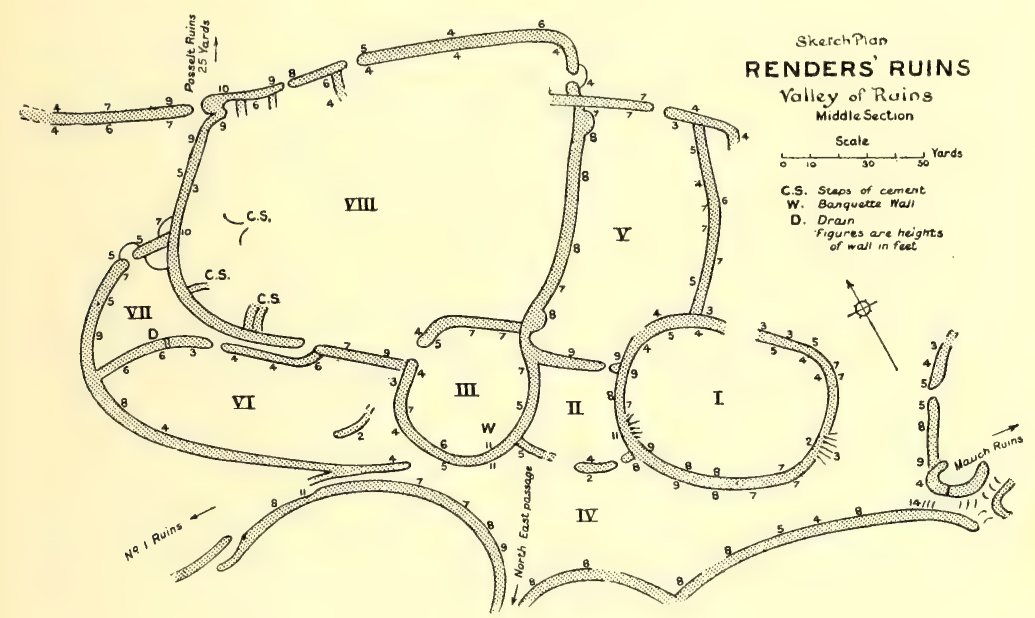

The other walls are considerably dilapidated and average about $4 \mathrm{ft}$. in height. The bare formation rock forms its floor, and it slopes considerably from south to north.

On the rock floor the following "finds" were made: Twenty pieces of beaten gold and gold wire, a few gold beads, amounting altogether to 3 ozs. In the yellowish soil above the floor and at a depth of $4 \mathrm{ft}$. Arabian glass with arabesque patterns most delicately engraved, beautifully glazed pottery of white clay with different bevels on the edges, and sunken designs under the glazes which are both sea-green and a delicate shade of forget-me-not blue, also very 
thin china of white clay with rich deep blue-and-gold enamel, also some minutely thin green glass, a large soapstone bowl, a fine copper chain, and some other pottery of excellent make and covered with green glaze, which has the appearance of being ancient or certainly of being of very antique character. On the upper level was found half a hundred-weight of twisted iron wire in coils ready to be cut off in lengths for bangles. The coils were fused together. Coils of fine brass wire similarly fused, over 200 ivory and glass beads unrecognisable by local natives, two pairs of double iron gongs, brass bangles, large cakes of copper, crucibles used for smelting copper, and two hundred-weight of hoes, axes, and chisels far superior in make to those of the Makalanga of to-day. The local natives examined this last class of "finds" with much wonderment. There was a total absence of articles of modern native make.

There is overwhelming evidence that during the last two periods of occupations of this enclosure it was most extensively occupied as a copper and iron-smelting place.

On the outer side of the south wall is a remarkable instance of the silting of the soil from higher ground. The depth of soil on the south face of the wall is at least $5 \mathrm{ft}$., and this has been washed into its present position by the rainstorms of many years. The triangular space formed by the wall and the sloping granite rock was thus filled in for a length of fully $70 \mathrm{ft}$.

There are no signs of any entrances into this enclosure except on the north-east side, where there is a long gap in the wall.

No. 2 Enclosure.-This is situated due west of No. I Enclosure. Its area, which is square save on the south side where it slightly rounds outwards, is $30 \mathrm{ft}$. by $20 \mathrm{ft}$. The débris from the high east wall of No. 3 Enclosure has almost filled it up to the summit of its walls. Nothing of any antiquarian value was found here, but the examination work 
was only partial. This enclosure probably acted as a passage-way from the North-East Passage to Nos. I and 5 Enclosures, and possibly towards the Lower Section of "The Valley of Ruins."

No. 3 Enclosure.-The plan of this enclosure, which lies directly west of No. 2 Enclosure, is almost circular save that its north-east wall is slightly squared. The area is $39 \mathrm{ft}$. from north to south, and $36 \mathrm{ft}$. from east to west. The walls are exceedingly massive, some being $7 \mathrm{ft}$. wide at base and $5 \mathrm{ft}$. wide on the present summit at $7 \mathrm{ft}$. from the ground. They are obviously of better construction than any of the other walls of these ruins.

On the summit of the south wall are the remains of a banquette wall still $4 \mathrm{ft}$. long and $4 \mathrm{ft}$. high, which makes the total height of the wall at this point I $\mathrm{ft}$. There is only one entrance, which is on the north-west, is rounded, and has portcullis grooves.

This enclosure has not as yet yielded any article of an antique character, but modern native articles are practically absent.

No. 4 Enclosure.-This is practically an open space separating these ruins on the south side from the ruins which are on higher ground, and extend up to the north-east walls of the Elliptical Temple. In area it is $150 \mathrm{ft}$. long from east to west, and averages in width from north to south some $50 \mathrm{ft}$. It is bounded on the south by three long semicircular terraced walls, each about $8 \mathrm{ft}$. in height. Its floor on the north side is of formation-rock, which slopes at a steep gradient to the north side where soil has silted in to a depth of $5 \mathrm{ft}$. On the north-east side it is bounded by the outer faces of Enclosures Nos. 1, 2, and 3.

The North-East Passage runs into the south-west corner of the area, and there are steps and a passage leading down from Mauch Ruins at the south-east corner of the area.

In this enclosure were found some fine pottery with Arabic 
lettering on the rim with beautiful designs, also a few gold beads.

No. 5 Enclosure.-This area is $86 \mathrm{ft}$. from north to south, and $40 \mathrm{ft}$. from east to west. It is bounded by No. 8 Enclosure on the west, by No. 2 Enclosure on the south, and by No. I Enclosure and a large open space not yet explored on the east and north sides. The walls are still fairly high, averaging $9 \mathrm{ft}$. on the south side, $8 \mathrm{ft}$. on the west, $7 \mathrm{ft}$. on the north and east sides. The construction is massive, the walls averaging $5 \mathrm{ft}$. to $6 \mathrm{ft}$. in width at base.

The entrance on the north-east side is rounded and had portcullis grooves. The foundations of the wall, as in all the older buildings, form the floor of the passage.

The only other entrance is in the south-east corner, and this leads into No. 2 Enclosure.

No. 6 Enclosure.-This enclosed area is directly on the west side of No. 3 Enclosure, and is $90 \mathrm{ft}$. from east to west, and averages $35 \mathrm{ft}$. from north to south. Possibly it contained sub-divisions, for small walls and traces of walls are to be found within it. The average height of the walls, so far as they are intact, is from $6 \mathrm{ft}$. to $8 \mathrm{ft}$. The floor of this enclosure is formed of granite rock which slopes slightly to the north. The eastern end of the south wall runs up a steep rock incline sideways, and is in consequence much dilapidated.

The North-East Passage runs from No. 4 Enclosure into this area at its south-east corner where it divides, one part going down into "The Valley," while the other, following along the higher ground, trends to the west as far as No. I Ruins.

The two entrances at the south-east corner of the enclosure where the North-East Passage divides are both roundedthe entrance on the north-east side is also rounded.

No. 7 Enclosure and Passage.-This enclosure, which is triangular in form, is the most westerly of all the clearly 
defined areas of the Renders Ruins. It is $28 \mathrm{ft}$. long on its western side, $18 \mathrm{ft}$. on its north-east side, and $29 \mathrm{ft}$. on its southern side. The inner faces of the walls average $8 \mathrm{ft}$. in height. A large entrance, evidently of some importance, is on the west side. This is rounded and has portcullis grooves, while the side walls are $5 \mathrm{ft}$. high and the passage is $3 \mathrm{ft}$. 6 in. wide. Steps led from the entrance downwards on the outward side.

A drain runs through the south wall leading from No. 6 Enclosure.

A passage $3 \mathrm{I} \mathrm{ft}$. long with side walls $6 \mathrm{ft}$. high leads from this enclosure into No. 8.

No. 8 Enclosure appears to be of a very chaotic and irregular character, mounds of soil, piles of stones, and traces of sub-divisional walls being the principal features of this area, the surface measurements of which are $150 \mathrm{ft}$. from east to west, and $70 \mathrm{ft}$. from north to south. Soil has been evidently brought into the enclosure for the purpose of forming platforms on which are the remains of very old Makalanga clay huts.

Probably there were at least six sub-divisions of this enclosure. On the north, north-west, west, and south-west the walls average $6 \mathrm{ft}$. to $9 \mathrm{ft}$. in height, and about $4 \mathrm{ft}$. on the other sides. The walls are substantial and are fairly well built in places, the more substantial building being on the west side, where there is a prominent end of an angular wall I $5 \mathrm{ft}$. high facing the north.

There are at least four entrances to this enclosure, viz. one on the north side which is rounded, a second on the south side which is also rounded and has portcullis grooves, one on the north-east side which is angular, and the fourth on the east side, and this is rounded. 


\section{UPPER SECTION OF "THE VALLEY OF RUINS" MAUCH RUINS}

These are well-defined ruins, and they form part of the Upper Section of "The Valley of Ruins," and are situated on the north-east of the north-east extremity of the chevron pattern on the Elliptical Temple at a distance of IO5 yds. They occupy the granite plateau on the edge of steep ground overlooking the Middle and Lower Sections of "The Valley of Ruins."

The plan and the excellently constructed portions of some of the walls, and the class of relics found here in 1903, when these ruins were partially cleared out, all point to the building having a distinct claim to some antiquity, although of a more subsequent age than that of some of the main ruins.

The distinctive features of this ruin are its high walls, a passage running parallel with the inside of the main northeast wall, a large semi-circular buttress or platform, and the quantity of beaten gold and gold wire discovered here.

Main walls.-The workmanship of some of the lengths of main walls is excellent, but some are of inferior construction, portions being obviously reconstructions with the joints plainly visible. There are at least two reconstructed wallsone on the west side of the main wall, and the other on the north-east side of the Parallel Passage. In the inferior portions blocks of all sizes and shapes have been employed. The best-built portions are the north-east main wall and the divisional wall which runs north-east to south-west. All the main walls are built upon a curved plan.

The main walls are still high, though evidently somewhat reduced from their original heights. The heights from the outside surface average from $9 \mathrm{ft}$. to $12 \mathrm{ft}$., and in places the level of the summits is very fairly maintained. From the interior surface the heights vary from $7 \mathrm{ft}$. to $10 \mathrm{ft}$.

The widths of the walls are evenly maintained throughout, 
being about $4 \mathrm{ft}$. $6 \mathrm{in}$. wide at $4 \mathrm{ft}$. above the ground, and $3 \mathrm{ft}$. to $3 \mathrm{ft}$. $6 \mathrm{in}$. at a summit of $12 \mathrm{ft}$, , the battering-back being about $\mathrm{I} f \mathrm{ft}$. in $8 \mathrm{ft}$. Some of the walls have been thrown out of batter, and the upper edges overhang.

All the ends of the walls are rounded, except in the large divisional wall, where is an unfinished end facing north, which terminates abruptly.

Interior Area.-The measurements of the interior are:

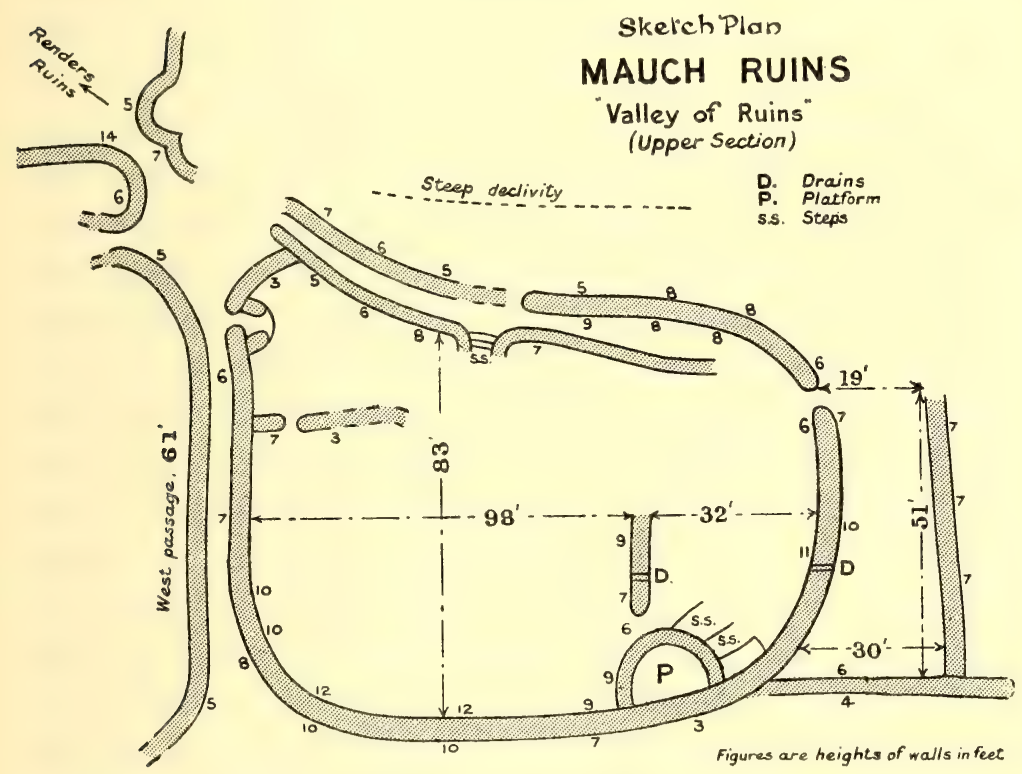

$98 \mathrm{ft}$. from east to west, and $83 \mathrm{ft}$. from north to south. The area is of a rough oval shape. It originally contained at least three enclosures. The soil filling-in is artificial. The elevation of the ruin precludes any suggestion of silting-in naturally. This work is believed to be that of all local natives of some few generations past.

Parallel Passage.-This is $99 \mathrm{ft}$. long down its centre, and was most probably much longer, as its extremities disappear in débris. The north-east side wall of the passage, which is 
the main wall, is from $7 \mathrm{ft}$. to $9 \mathrm{ft}$. high at the eastern end, and there is a break owing to dilapidations at $50 \mathrm{ft}$. west of this point, while near the lower or western end the walls on either side are $7 \mathrm{ft}$. high. The north-west end is formed by a wall $7 \mathrm{ft}$. high, a low wall, a semi-circular wall, and boulders. On the south side, and opposite the opening in the north-east wall, steps to a somewhat higher level can be traced, leading southwards up from the passage, and these steps have a rounded wall on each side. The rounded end of the northeast main wall is a fine piece of workmanship. The passage is from $3 \mathrm{ft}$. to $4 \mathrm{ft}$. wide.

Entrances.-There are five entrances, and each is rounded, and all the buttresses are also rounded. One entrance leads into the ruin on the west side, and there are rounded buttresses on either side, which are erected on a semi-circular platform projecting $16 \mathrm{ft}$. into the interior. This entrance opens into a passage which was discovered by Bent (I891), but was not opened out till 1903. A second entrance is in the north-east wall, but on its western side only traces of the side wall remain. A third entrance is on the east side of the building. This is $6 \mathrm{ft}$. high on either side, and is without buttresses or portcullis grooves. The floor of the passage is formed by the foundation walls. This entrance leads into an outer enclosure on the eastern side. The last entrance is between the south end of the large divisional wall and the semi-circular buttress or platform. Possibly a buttress has disappeared from the south side of this entrance.

Divisional walls. - There are two divisional walls, one being the wall already mentioned as separating the two main enclosures. This runs north-east from the large semi-circular buttress for $16 \mathrm{ft}$. It is $9 \mathrm{ft}$. high and is well built, and has a drain passing through the lower courses. The north-eastern extremity of this wall is $32 \mathrm{ft}$. from the inside face of the main north-east wall. The other wall is $15 \mathrm{ft}$. long, and runs out eastwards from the inside face of the main west wall. 
This is $7 \mathrm{ft}$. high, but its height is reduced to $3 \mathrm{ft}$. at its eastern extremity. It is $3 \mathrm{ft}$. wide at the surface level.

Drain-holes.-There are three well-constructed drains running through walls; one passes the divisional wall which is on the eastern side of the building, another passes through the main eastern wall into the outer enclosure, and the third is in the east wall of the outer enclosure.

Semi-circular Buttress.-This structure lies on the south side of the ruins, and projects $16 \mathrm{ft}$. into the interior. The total length round the face is $32 \mathrm{ft}$. It is $24 \mathrm{ft}$. across the back, and Io ft. high on the west, $6 \mathrm{ft}$. high on the north, and $6 \mathrm{ft}$. high on the east. It appears to be perfectly solid, and once to have had a level surface. Large trees have grown on its south and west sides, and have done considerable damage to it. Two small walls are on its north-east side, and these run towards the buttress as if they once had formed the approach to the summit.

Outer Enclosure.-On the eastern side is an enclosure, but somewhat roughly built. It is $5 \mathrm{I} \mathrm{ft}$. from north to south, and $30 \mathrm{ft}$. from east to west at its southern end, and $\mathrm{I} 9 \mathrm{ft}$. from east to west at its northern end. This enclosure has been extensively filled in with soil and the usual Kafir débris, among which were found two pairs of double iron gongs.

West Passage.-This passage, which was discovered by Bent in I89I, runs along the outer side of the main west wall for $60 \mathrm{ft}$. It is $3 \mathrm{ft}$. to $4 \mathrm{ft}$. wide, and the wall on the west side of it is very much dilapidated. From the western entrance to these ruins the passage runs $27 \mathrm{ft}$. further north, and descends some $29 \mathrm{ft}$. by means of stairs, and then passes out between high walls on to the granite floor of Renders Ruins, which are in the Middle Section of "The Valley of Ruins."

General.-The position of the Mauch Ruins on their east and north-east sides is strengthened for defensive purposes by a steep drop of about $12 \mathrm{ft}$. down on to the level occupied by the Middle Section of "The Valley of Ruins." This drop 
is formed by an almost vertical granite glacis, which it would have been very difficult to climb.

Finds.-Gold wire, beaten gold, and gold beads, and portions of sea-green glazed pottery of white clay.

\section{SOUTH-EAST RUINS}

These ruins are situated at the south-eastern extremity of the Zimbabwe Ruins' area where the Valley of Ruins terminates on its eastern side, and are only ten minutes' walk from Havilah Camp. They occupy a summit of a bare and rounded kopje, commanding most extensive views of the country beyond Schlichter Gorge to the south and of the Arowi district towards the east-north-east. Its position is highly strategetic, and there is a steep descent on the south-west side into a deep gorge, down which the stream rising on the east side of the Elliptical Temple flows toward the Mapudzi.

The area of well-defined walls is $140 \mathrm{ft}$. from north to south, and $\mathrm{I} 20 \mathrm{ft}$. from east to west, but there are traces of walls in all directions-on the south at $70 \mathrm{yds}$. and on the south-west at $20 \mathrm{yds}$. distance. The formation rock crops to the present surface at many places, and the depth of soil elsewhere is inconsiderable.

The style of building very closely resembles that of Ridge Ruins, which lie between the Elliptical Temple and Havilah Camp, as to which there are considerable doubts of its being of very remote antiquity.

The walls, the majority of which are of massive proportions, are not at all well built, blocks of all sizes and shapes having been employed, and there is little or no attempt to adhere to courses. The present reduced average height of the walls is from $4 \mathrm{ft}$. to about $6 \mathrm{ft}$., but, judging from wall débris, every wall must have originally been at least some $7 \mathrm{ft}$. or $8 \mathrm{ft}$. in height. The walls are from $4 \mathrm{ft}$. to $5 \mathrm{ft}$. wide at base, and $3 \mathrm{ft}$. to $4 \mathrm{ft}$. wide at their very much reduced summits. 
The plan of the building is laid on curved lines, and the only entrance which remains intact has rounded sides. It is possible these buildings once had six outer and inner entrances. The main entrance appears to have been on the west side.

There are about eight enclosures, and in some of these there are remains of very old Makalanga huts, and the soil of the interior is filled with great quantities of Kafir pottery,

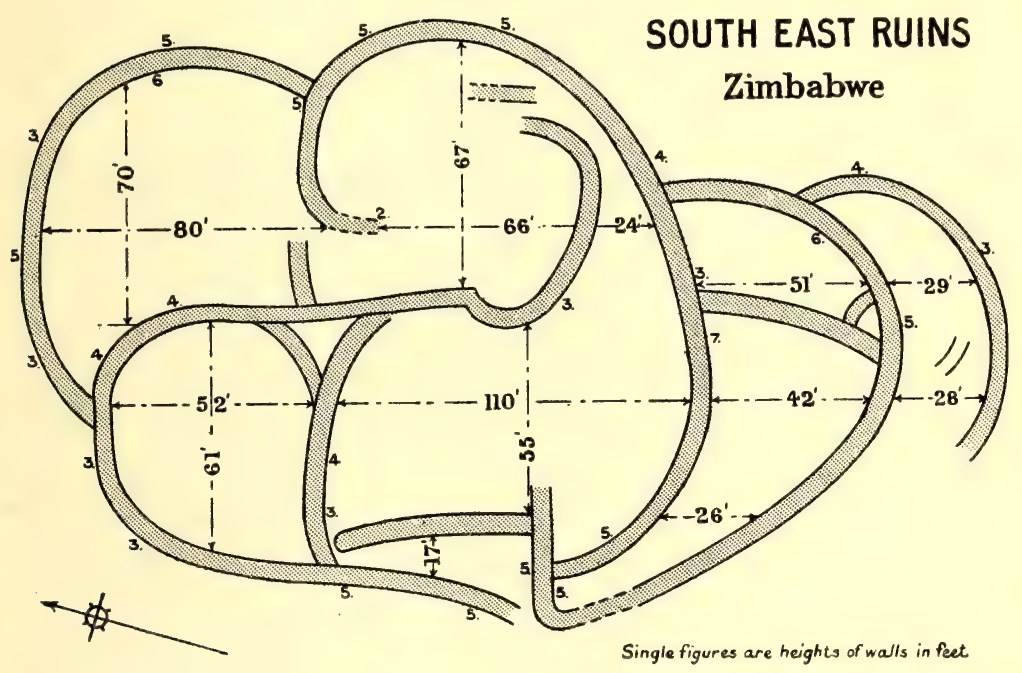

iron work, iron slag, cattle bones, and ashes. Two Kafir graves were found, but these were not of any great age. Local natives state their own people once lived here, but not in their time, and this is extremely probable; but they do not think the walls were built by any Makalanga.

On the east side, just outside the main wall, there are three sets of isafuba game holes cut into the formation rock. Each set has four rows of eight holes each.

The ruins have been but partially examined at several points, but nothing of any antique character has been found here. 


\section{CHAPTER XX \\ "THE VALLEY OF RUINS" \\ (Continued)}

No. I Ruins-Ridge Ruins-Camp Ruins, Nos. I and 2.

\section{NO. 1 RUINS}

THESE ruins, which are of an important character, lie on

1 the north side of the Elliptical Temple at a distance of $63 \mathrm{yds}$. from the north-west entrance to that building, with which it is connected by a substantial and well-constructed wall running out due north from the north-west outer face of the main wall of the temple at $43 \mathrm{ft}$. west from the north-west entrance and at the points [705 ft.] and [7 IO ft.].

Visitors would know this ruin as the one which lies back on the left-hand side of the path leading from Havilah Camp to the west entrance of the Elliptical Temple, and as the one with the tall column-like forms of the aloes crowned with fleshy leaves which line the summit of its walls, as also do the candelabra-shaped branches of numerous large euphorbia trees which together impart to these walls a pre-Raphaelite appearance peculiarly striking because of its old-world-looking character. But though this ruin may be known to visitors, they rarely examine its enclosures, for the internal portions, owing to extensive excavations during past years, are most uneven, and require some climbing over their irregular surfaces.

Whether the age of this ruin synchronises with that of the Elliptical Temple is for several obvious reasons open to some question, but that it is "ancient" admits of no possible doubt. 
Its architecture and construction are both inferior to those of the Elliptical Temple, and to many ruins throughout the country which belong to the earliest type of Zimbabwe buildings, though it must be admitted that great care is shown in its construction. Possibly these buildings are of somewhat later date than the Elliptical Temple, while the purpose to which it was devoted was such as not to warrant such elaborate care being lavished upon it as on the temples and the buildings used as residences.

Excavators have literally turned this ruin inside out, and have excavated whole areas to depths of $5 \mathrm{ft}$. to $7 \mathrm{ft}$. till the granite formation was reached, and have left some of the foundations both bare and undermined. There is no doubt that the building has thus been completely ransacked, and yet there is nothing to show that it was either a temple or a place where at any time gold-smelting was carried on, there being no traces of gold furnaces, blow-pipes, crucibles, scorifiers, or cement spattered with gold; in fact, pannings of such soil as still remains within it has not so far shown any "traces" or fragments of gold wire or beads and pellets of gold such as are so frequently and abundantly found in other ruins at Zimbabwe. Nor have any indications of copper-smelting been found here as in other ruins. There is no suggestion in its plan that it was a temple. Certainly there is no decorative pattern on its walls, nor are there any monoliths, nor even fragments of what might have been monoliths. Certainly stones said to be phalli have been found there, but a few years ago it was the fashion in Rhodesia to style every stone of peculiar shape a phallus. But supposing some of these objects were undoubted phalli, these might easily have come from the Elliptical Temple a few yards away, especially seeing that the northwest entrance to the temple was enclosed on either hand by walls of No. I Ruins, and that phalli and miniature soapstone birds have been discovered by almost all explorers of these ruins among the débris deposited outside all three entrances 
to the temple. The inner banquette walls on either side of the north-west entrance to these ruins, as well as the massively built outer walls, strongly suggest a fortification, and the conglomeration of tall buttresses overlooking the Elliptical Temple, and also "The Valley of Ruins," rather confirms this view, especially as the ruins contain no evidences of any industry having been carried on by the ancients within them. Moreover, these are the only ruins of any importance on the north and west sides of the Elliptical Temple which could possibly have served as a fort for the protection of that side of the temple, and its site occupies a strongly strategetic position on the summit of sloping ground. Unless it was a fortification, the whole flank of the area of small ruins in the vicinity of the north entrance would have been undefended, for on the northern and eastern sides of such area of ruins are very substantially built forts occupying elevations of vantage.

Sir John Willoughby states that the design of this building is very irregular, the inner walls terminate abruptly and form only three sides of an enclosure with floors ever varying in their relative levels, the wall foundations are of unequal depths, and the interiors of some of the walls are carelessly filled in with stones, this latter being a feature absent in the earliest types of Zimbabwes, but present in later ruins.

All these departures from the style of construction as employed in the Elliptical Temple, and in very many of the ruins at Zimbabwe, are obvious to anyone on making an inspection, as also the irregularity in the sizes of the stones of any single course, the poorer quality of the granite, the employment of unhewn stones, and the introduction of the angular and plumb style of building so peculiarly absent in the Elliptical Temple and elsewhere at Zimbabwe. There are no drainholes in any of the walls of these ruins.

Of old and recent Makalanga occupations of these ruins there is ample evidence. Kafir pottery, bones, ashes, and 
scraps of iron are abundant, and the clay foundations of Makalanga huts and granaries can be seen in every enclosure on floors overlying rudely filled-in areas.

These ruins occupy an area of $62 \mathrm{yds}$. from east to west, and 54 yds. from north to south. The portion of the ruins in the best condition, as well as the most important parts, are

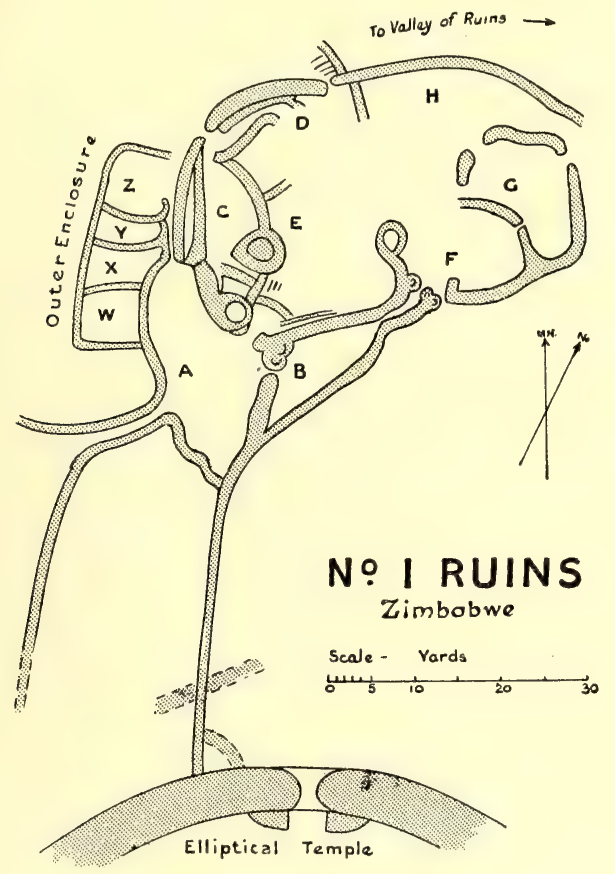

situated on the west side. The north and east portions are the most dilapidated. The building on the north and northeast sides is on the edge of a sharp slope down into a valley which contains the walls of several minor ruins.

The main or outer wall of these ruins runs for $\mathrm{I} 85 \mathrm{ft}$. from the west entrance on the west side of the building round in a curve outwards towards the west-north-west, north, and northeast. There are three short gaps in the northern portion of the wall. On the whole, the greater portion of the wall is still $2 \mathrm{D}$ 
in a fairly good condition, it being from $\mathrm{I} 2 \mathrm{ft}$. to $15 \mathrm{ft}$. high above the outside level of the bed-rock on which its foundations are laid. The wall is practically plumb as compared with the main wall of the Elliptical Temple, besides being angular at the entrances. It is $4 \mathrm{ft}$. wide at $6 \mathrm{ft}$. above the outside level, but the north-western side is slightly wider. The wall, though substantially constructed, does not show great evenness of courses, while the sizes of the blocks vary considerably. Near the west entrance it is very poorly built, while the wall on the opposite side of the passage is excellently constructed. Possibly this indifferently built portion was repaired at a much later date. It is on this wall that grew the tall aloes and large euphorbia trees, some of which have recently been removed. The north and north-east portions of the wall, being built upon the edge of the declivity, tend to give the wall a more imposing appearance, while its elevated position commands a splendid view of "The Valley of Ruins." The large mound on the north side of the north-west entrance is soil débris brought by explorers from the interior of the ruins in 1892 .

Three entrances pass through this wall, on the west, northwest, and north sides.

The west entrance is $2 \mathrm{ft}$. 6 in. to $3 \mathrm{ft}$. wide, the west side wall being $4 \mathrm{ft}$. to $5 \mathrm{ft}$. high, and the east side $5 \mathrm{ft}$. to $7 \mathrm{ft}$. high. The entrance walls are plumb and angular. There are no buttresses on either side, and no portcullis groves. The entrance leads into Enclosure A, but there are traces of a wall which runs across the inside at a short distance, and might have been that of a sort of vestibule to Enclosure A. Immediately on the outside of this entrance there is a passage between the outer face of the main wall on the east side and the east wall of Enclosures $\mathrm{W} \mathrm{X} \mathrm{Y} \mathrm{Z} \mathrm{on} \mathrm{the} \mathrm{west}$ side, and this passage, which is $46 \mathrm{ft}$. long, $3 . \mathrm{ft}$. 6 in. wide and has the west side wall $5 \mathrm{ft}$. high, actually forms part of the entrance. At $3 \mathrm{I} \mathrm{ft}$. from the north end of the passage 
there is one side of a rounded entrance into Enclosure Y. There are no traces of steps having been built here.

The north-west entrance was evidently the main entrance. It is the largest and best-constructed of all these entrances. It has a banquette wall on either hand in the interior, also a strongly built vestibule with entrances into Enclosures $\mathrm{C}$ and $\mathrm{D}$, and opposite the entrance on the outside are walls of other ruins.

It is $3 \mathrm{ft}$. 6 in. wide, $7 \mathrm{ft}$. long, and the walls on either side are only $6 \mathrm{ft}$. high, but they rise sharply to the level of the general line of summit of the wall. Three feet of the length of the entrance on the east side are formed by the end of the banquette wall, but on the west side the banquette wall is only about 16 in. wide. The entrance is angular and plumb and has portcullis grooves. This is the only instance so far discovered where a completely angular entrance has portcullis grooves, also the only instance where the main or, indeed, any outer entrance has such grooves, except the north entrance to this ruin, which is partly angular and partly rounded. There is no indication that this entrance was once covered in.

Immediately on the inside of this entrance is a small enclosure which served as a vestibule and as an approach to enclosures $C$ and D. This is $9 \mathrm{ft}$. long, $6 \mathrm{ft}$. wide, and the walls are from $5 \mathrm{ft}$. to $8 \mathrm{ft}$. above the paved floor which was destroyed some years ago. At the west end there is a passage $4 \mathrm{ft} .4$ in. long and $2 \mathrm{ft}$. Io in. wide with angular sides leading into Enclosure C, the walls on either side being $4 \mathrm{ft}$. to $5 \mathrm{ft}$. high. At the east end of this vestibule is a passage $9 \mathrm{ft}$. long and $2 \mathrm{ft}$. Io in. wide leading to Enclosure $\mathrm{D}$, the walls on either side being $5 \mathrm{ft}$. to $7 \mathrm{ft}$. high.

The north entrance opens into Enclosure D at its northeast corner. It is angular on the outside but rounded on the inside. It is $2 \mathrm{ft}$. Io in. wide, $4 \mathrm{ft}$. $6 \mathrm{in}$. long, and the walls on either side are now only from $3 \mathrm{ft}$. to $5 \mathrm{ft}$. high. There are 
portcullis grooves in the rounded portions of the side walls. The entrance does not pass through the wall at right angles, but obliquely towards the north, which the opening faces. A wall runs north for $15 \mathrm{ft}$. from the east outer side of the entrance, but its extremity terminates in block débris. In the angle of the two walls at the outer foot of the entrance are traces of steps leading for a few feet down the declivity along the west side of the projecting wall.

The banquette wall rounds round the inside face of the main wall on either side of the north-east or main entrance, and forms a terrace behind it which would afford a good view over the main wall. Practically the main wall and the banquette wall are one and the same structure at certain points, since the stones of the main wall project into the banquette; but at other points they are independent of each other, and at these points the space between the two structures is filled in with stones to the level of the summit of the banquette.

The eastern length of banquette starts from the east side of the north-west entrance and runs along the inside of the main wall into Enclosure $D$ for a length of $I 7 \mathrm{ft}$., the summit being $6 \mathrm{ft}$. high and $3 \mathrm{ft}$. 6 in. wide at the entrance and $5 \mathrm{ft}$. wide at its eastern extremity. This length of banquette cannot be described as of excellent workmanship.

The western length of banquette is $48 \mathrm{ft}$. long and $4 \mathrm{ft}$. to $8 \mathrm{ft}$. high, and is $\mathrm{r} \mathrm{ft}$. wide at the north-west entrance, but widens out to I I ft. at the west end, where it connects with the "conglomeration of buttresses," all rounded, which overlook every part of this ruin. The workmanship in this length of banquette is somewhat inferior.

There are at least ten enclosures, and these, for the purposes of this description, are lettered from $\mathrm{A}$ to $\mathrm{H}$ or named. On the west side there are four outer enclosures, and these are lettered $\mathrm{W}$ to $\mathrm{Z}$.

Enclosure A.-The area of this enclosure is $105 \mathrm{ft}$. from 
north to south, its longest points, and $5 \mathrm{I} \mathrm{ft}$. from east to west, its widest points. It has four entrances.

The north-west entrance is the west entrance to these ruins, and has already been described.

The south-west entrance is approached by an outer passage on this side, but the actual entrance, owing to the amount of débris, can only be traced, the débris being level with the summits of the walls on either side. These walls are from $4 \mathrm{ft}$. to $5 \mathrm{ft}$. high, $3 \mathrm{ft}$. $6 \mathrm{in}$. on their present summits, and are fairly well built. The passage walls are $8 \mathrm{ft}$. apart for a length of $64 \mathrm{ft}$. from this enclosure towards the south-west, at which point they curve off in different directions, the west side wall running a further $5 \mathrm{I} \mathrm{ft}$. towards the west, with traces of continuation. The east side wall curves round towards the south-south-east for I05 ft., including gaps, and at its extremity it becomes lost in débris, but in all probability, judging by recent clearing away of débris and also by excavations, it ran up to the west outer face of the Elliptical Temple. There are no signs of any entrance passing through these side walls. The workmanship of both walls is fairly good.

The north-east entrance is from Enclosure E, which lies on the north-east side. This was a wide entrance with rounded sides, and appears to have been built at a higher level than the floor of Enclosure A, but the entrance and the steps leading up to it are now almost lost in débris.

The east entrance is from Enclosure B. This was rounded, but is now filled in to the top by wall débris.

The floor of this enclosure is formed by bed-rock. The highest parts of the walls are as follows: south side, $4 \mathrm{ft}$.; east side, $7 \mathrm{ft}$; ; north side, $14 \mathrm{ft}$; ; and west side, $5 \mathrm{ft}$. to $8 \mathrm{ft}$.

Enclosure B.-The area of this enclosure, which lies at the south-east side of Enclosure A, is $49 \mathrm{ft}$. from north to south and $23 \mathrm{ft}$. from east to west. This enclosure has two entrances, the one on the west side being the east entrance 
to Enclosure A, while the one on the north side is from a passage which connects this enclosure with Enclosure F. Both entrances are rounded. This enclosure appears to have been cleared out to below the levels of the bottom of the foundations.

The passage connecting Enclosures $\mathrm{B}$ and $\mathrm{F}$ runs from south-west to north-east. Including the two entrances, it is $23 \mathrm{ft}$. long, and $3 \mathrm{ft}$. wide at the south-west end, and $5 \mathrm{ft}$. wide at the north-east end. The side walls, which are very substantial, are still $8 \mathrm{ft}$. high. The entrance from this passage into Enclosure $F$ is formed by two large rounded buttresses with portcullis grooves.

Enclosure C.-This enclosure is on the west side of the ruins, and is on the south side of the main and north-west entrance to these ruins, and north of Enclosure A, and is on the inner side of the west portion of the main wall. Its length from north to south is $43 \mathrm{ft}$., and its width from east to west $\mathrm{I} 7 \mathrm{ft}$. The western length of banquette wall forms its west side, and the face of this wall is poorly built. The south wall must be considered as badly built. On its south and south-east sides is the "conglomeration of buttresses," the character of which can better be seen by glancing at the accompanying plan. The buttresses are almost circular, and have their centres filled with stones, thrown in most promiscuously. The east wall is well built; still it is inferior to any of the main walls of the Elliptical Temple. Through this wall is an aperture $2 \mathrm{ft}$. wide and with side walls $3 \mathrm{ft}$. high. The floor of this enclosure has been cleared away in places, showing the foundations of the walls.

Enclosure D.-This enclosure is on the inner side of the north portion of the main wall, and east of the north-west entrance to these ruins and of the Entrance Enclosure.

The area of this enclosure is $4 \mathrm{I} \mathrm{ft}$. from north to south, and $45 \mathrm{ft}$. from east to west. It is bounded on the north, west, and south sides by the banquette and main walls for $23 \mathrm{ft}$., 
on the west by the Entrance Enclosure for $5 \mathrm{ft}$., and by Enclosure EE for $18 \mathrm{ft}$., on the south by a wall dividing it from Enclosure $\mathrm{E}$ for Io $\mathrm{ft}$., but the rest of the southern boundary wall for $\mathrm{I} 2 \mathrm{ft}$. is now only débris, and in places can barely be traced. On the east side is a wall $\mathrm{I}_{5} \mathrm{ft}$. long, $4 \mathrm{ft}$. high, $2 \mathrm{ft}$. $10 \mathrm{in}$. wide on present summit, which separates this enclosure from Enclosure $\mathrm{H}$; the rest of the eastern boundary is lost in débris.

From the north inner side of the main wall at $20 \mathrm{ft}$. from the north-west corner of this enclosure there is a wall $4 \mathrm{ft}$. high projecting southwards into the enclosure for $5 \mathrm{ft}$., and this has an angular end.

A wall $6 \mathrm{ft}$. long, forming part of the passage from the north-west entrance, projects into this enclosure. Judging by the arrangement of débris in the space between this wall and the main wall, it is very probable that there were steps here leading up to the summit of the banquette wall.

At the eastern corner of this enclosure is the north entrance to these ruins. This has already been described.

Enclosure EE.-This enclosure is bounded on the north by Enclosure D, on the north-west by Entrance Enclosure, on the west by Enclosure C, and on the south by Enclosure E. Its area is $26 \mathrm{ft}$. from north to south, and $27 \mathrm{ft}$. from east to west.

The floor of the south-west corner was once at a higher level than that of the rest of the enclosure, and to this originally raised portion there are remains of a narrowrounded entrance on the south side, now filled up with débris, from Enclosure E. There are traces of steps up to this raised entrance. The floor of the aperture in the wall on the east side of Enclosure $\mathrm{C}$ appears to have been on the level of this raised floor.

Enclosure E.-This lies directly to the south of Enclosure EE. Its area is $49 \mathrm{ft}$. from north to south, and $48 \mathrm{ft}$. from east to west. It is bounded on the west for $49 \mathrm{ft}$. by 
a wall and the "conglomeration of buttresses" already mentioned, which respectively separates it from Enclosures A and $\mathrm{C}$; on the south for $45 \mathrm{ft}$. by Enclosures $\mathrm{B}$ and the passage which connects Enclosures $\mathrm{B}$ and $\mathrm{F}$; on the east for $36 \mathrm{ft}$. by a wall and a large rounded buttress, which is one of the prominent features of these ruins ; the rest of the east boundary cannot be traced, owing to débris piles; lastly, on the north by Enclosures EE and D.

There are still two entrances remaining-one from Enclosure A and the other from Enclosure C. Both are approached from the enclosure by steps, now ruined but traceable, leading up either side of the central buttress of the "conglomeration of buttresses."

The large buttress on the east side is semi-circular, the centre of its face is towards the west. It is $6 \mathrm{ft}$. high, $30 \mathrm{ft}$. round its face, and is fairly well built, it being a wall with its internal portion promiscuously thrown in till its summit was levelled throughout.

On the south-west are two rounded buttresses with their faces towards the east and west respectively.

The enclosure contains piles of excavators' soil débris of some age.

Enclosure F.-This is situated on the east side of Enclosure $\mathrm{E}$, and lies between that enclosure and Enclosure G. Its area is roughly circular, it being $37 \mathrm{ft}$. from north to south, and $42 \mathrm{ft}$. from east to west. Its southern boundary is formed for $37 \mathrm{ft}$. by the outer south wall of these ruins, which wall is $5 \mathrm{ft}$. high and $4 \mathrm{ft}$. wide on its present very reduced summit. There is a gap of $12 \mathrm{ft}$. on its north-west side, where there are now only traces of a wall.

The enclosure has two entrances now remaining-the entrance from the passage leading from Enclosure B, which has already been described, and an entrance through the outer south wall. This entrance which is rounded is $2 \mathrm{ft}$. $6 \mathrm{in}$. wide, the side walls are $3 \mathrm{ft}$. high, and there are portcullis 
grooves on either hand, and these have been deliberately built up. This enclosure resembles the other portions of these ruins with regard to large piles of soil débris on its area.

Enclosure G.-This is the most easterly enclosure in these ruins. It is bounded on the south by Enclosure F, on the west by Enclosure $\mathrm{H}$, and on the north and east by the outer east wall of the ruins, which wall is $8 \mathrm{ft}$. high and $3 \mathrm{ft} .6 \mathrm{in}$. wide on its present summit. Its area is $35 \mathrm{ft}$. from east to west, and $47 \mathrm{ft}$. from north to south. It possessed three entrances, and these were on its west, north, and east sides. The west entrance is barely distinguishable, but has traces of its having been angular. The north entrance has rounded sides, and leads from Enclosure $\mathrm{H}$, a wall $22 \mathrm{ft}$. long and $5 \mathrm{ft}$. high forming a division between the two enclosures. The enclosure has been filled in with débris up to the level of this wall and overlooks the east end of Enclosure $H$, which here is very much lower. The east entrance through the outer wall is rounded on its south side, but the north side has disappeared.

Enclosure H.-This lies on the inner side of the north and north-east portions of the main wall, which here is considerably broken. It is bounded on the west by Enclosure D, on the south by Enclosures $\mathrm{E}$ and $\mathrm{F}$, and on the east by Enclosure G. Most probably there was an entrance between the main wall on the east side and Enclosure G, and this led to the network of ruins which are built up against this side of No. I Ruins and extend for some $300 \mathrm{yds}$. towards the east. The area of this enclosure is $53 \mathrm{ft}$. from east to west, and $3 \mathrm{I} \mathrm{ft}$. from north to south. The western end of this enclosure is considerably higher than the eastern end.

Outer enclosures.-Four enclosures lie to the west of the south-west extremity of the main wall, and are separated from it by the passage which leads to the west entrance of these ruins, and connects these enclosures with Enclosure A. 
These enclosures adjoin one another in a single line broadways from south to north, there being a common wall for all of them on their west sides. These enclosures are lettered $\mathrm{W}$ to $\mathrm{Z}$, commencing at the south end.

Their areas are as follows :-

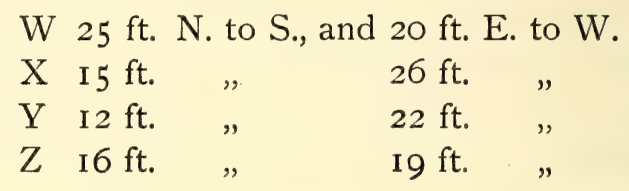

\section{RIDGE RUINS}

These ruins are situated on the highest point of the bare granite ridge which extends from the north-west of the Elliptical Temple towards the north-west, and curves towards the north, where it terminates at Havilah Camp.

The southern extremity of these ruins is I $40 \mathrm{yds}$. from the north-west side of the Elliptical Temple and $100 \mathrm{yds}$. west of No. I Ruins. The path from the outspan and camp to the water springs and the Elliptical Temple passes close to its west side, while another path to the Temple passes close to its east side. The Outer Defence Wall, which runs from the west side of the Temple round towards the west, north-west, and north of the Acropolis Hill, runs parallel to the west side of these ruins at a distance of $96 \mathrm{ft}$. A number of euphorbia trees and aloes line its walls, which are now comparatively low, the highest parts being about $9 \mathrm{ft}$.

The whale-back granite glacis on which these ruins are built dips sharply from immediately outside the walls all round these ruins, except at the south-east end, which is here only slightly higher than the present ground level outside the Elliptical Temple. Except for vegetable mould at a few points, the whole of the floors of these ruins are formed by the formation rock.

The plan of these ruins shows an oval area, with a long and wide outer passage running along its east side for $246 \mathrm{ft}$. 
from the north to the south of the oval enclosure, this passage having its southern extremity well protected by traverses and buttressed entrances.

These ruins, though built of irregularly sized stones, have the faces of the walls which still remain remarkably true and even, so much so that experienced builders after examining the walls state that with such irregularly sized stones it would be most difficult to erect walls with faces as true as

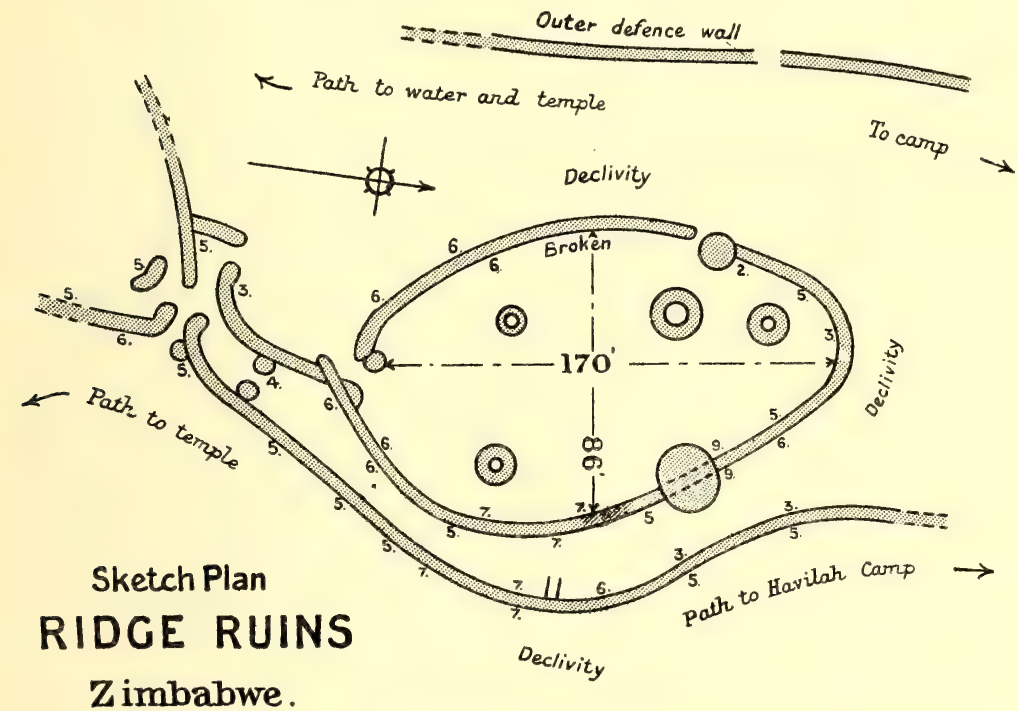

Single figures are heights of walls in feet.

those of these ruins. There appears to be no similarity whatever between the second-period architecture and construction and these ruins, except that the filling-in of the walls between their faces is more promiscuous than is the case with walls of first-period architecture and construction. Its entrances and buttresses are all rounded, and the walls have a fair batter-back, there being no plumb wall present.

It would be difficult to state the purpose these ruins were intended to serve, but seeing they occupy the most westerly position of the main ruins' area, and that they are built on a 
commanding and strategetic position, it might be inferred, if their claim to any great antiquity were established, that their purpose was that of a fort, defending not only the westerly side of the main ruins' area, but also part of a main line of communication, of which the Parallel Passage formed a section, between the Elliptical Temple and the west end of the Acropolis Hill. This suggestion is, in fact, apparently supported by the numerous traverses in the passage, traces of which can still be noticed, and by the fact that the oval enclosure overlooks the passage throughout its length. But, as stated before, these ruins cannot at present be classed as ancient, though they are undoubtedly of great age.

Oval Enclosure.-The area of the oval enclosure is $170 \mathrm{ft}$. from north to south, and $86 \mathrm{ft}$. from east to west. These are its longest and its widest points. The floor is formed by comparatively level surfaces of granite rock. There is very little soil within the enclosure, and this consists of black mould, decomposed cement, and native clay. The walls still standing average some $4 \mathrm{ft}$. to $7 \mathrm{ft}$. in height, and are about $3 \mathrm{ft}$. $6 \mathrm{in}$. wide on their present reduced summits, and are battered-back. Plumb and angular walls are absent. The east wall is at one point carried over a large boulder $8 \mathrm{ft}$. high, and a few courses of blocks on the summit still remain. The north wall is considerably dilapidated, and the débris of this portion lies on the face of the declivity. The external faces of the walls are in a much better condition than the inner faces, for trees and shrubs which could not grow on the outer granite slopes manage to thrive in the very scanty soil of the interior. This enclosure has been used by the natives as a cattle kraal. Though cattle could not climb into the enclosure from outside, they no doubt damaged the inside faces of the walls by attempting to get outside from over the walls. The material for the stone foundations of circular huts of no very great age, which are to be seen in 


\section{RIDGE RUINS}

the enclosure, was very probably taken from the inside faces of the walls.

These Makalanga stone foundations, which are identical with those found in old Makalanga kraals, occupy the following positions. At $60 \mathrm{ft}$. from the south end and $\mathrm{i} 2 \mathrm{ft}$. from the west side, foundations of stone blocks $19 \mathrm{ft}$. in diameter. At IIo ft. from south end and almost facing the west entrance, stone foundations of hut $22 \mathrm{ft}$. in diameter. At $8 \mathrm{ft}$. from north end foundation blocks disarranged and exact measurement impossible. At $60 \mathrm{ft}$. from south end and Io ft. from east side is another foundation, but here again the blocks have become considerably disturbed.

This enclosure has two entrances, and these are on the south and west sides respectively. The south entrance is comparatively intact, but the west entrance is buried in wall débris and can only be traced on one side. Both are rounded. The south entrance walls are $3 \mathrm{ft}$. $6 \mathrm{in}$. high, the passage is $2 \mathrm{ft}$. wide and $7 \mathrm{ft}$. long, and there are portcullis grooves. The north side of the west entrance is formed by a large boulder $6 \mathrm{ft}$. high.

There is no trace of ornamentation on the walls, but if it ever existed, the walls having become so reduced, it must have disappeared. No article was found for which the slightest antiquity could be claimed, all the finds being obviously of native make, though somewhat superior to their make of to-day.

Parallel Passage.--Roughly speaking, the passage throughout its length of $246 \mathrm{ft}$. from north to south runs parallel with the east wall of the oval enclosure and follows it round in its curves, but narrowing towards its southern extremity. There is no entrance from the passage to the oval enclosure except at the south end. At the north end the passage is $47 \mathrm{ft}$. wide, and the formation rock forms the floor; at $40 \mathrm{ft}$. further south the passage is $36 \mathrm{ft}$. wide; at $80 \mathrm{ft}$. from the north end $22 \mathrm{ft}$. wide; at $160 \mathrm{ft}$., $19 \mathrm{ft}$. wide; at $190 \mathrm{ft}$., I $3 \mathrm{ft}$. wide, which 
width is maintained as far as the southern extremity. The heights of the outer wall vary from $5 \mathrm{ft}$. to $7 \mathrm{ft}$., the best-preserved lengths being near the southern end, where a pair of traverses with rounded ends stand at a few feet north of the south entrance to the passage. This entrance has rounded sides.

A passage crosses from east to west at the southern extremity, and in it are three entrances with rounded sides. Opposite the south face of the southern extremity of the passage, and at $6 \mathrm{ft}$. distance is an independent screen wall, $16 \mathrm{ft}$. long and $5 \mathrm{ft}$. high, covering the approach to the entrance from the south. At several points in the parallel passage there are distinct traces of traverses.

The new path from Havilah Camp to the Elliptical Temple now runs through the parallel passage of these ruins.

\section{CAMP RUINS NO. 1}

Camp Ruins Nos. I and 2 lie north and south respectively of the Shangani Grave, which separates them, the huts of the camp being built on the north and west sides and within a few feet of the remains of Camp Ruins No. I, which is Sir John Willoughby's No. 3 Ruins in his Further Excavations at Zimbabye, 1892 .

Sir John describes this ruin as follows :-

"Previous to my arrival, the only trace of ruins here was one small stone buttress on the eastern side. My original intention was to find any wall foundations that might exist, and then to cross-cut right through the mound at their level from east to west, and from north to south. But I was deterred from carrying this out, because as the work proceeded, traces of cement floors at different levels were discovered. By starting low down the mound, I came upon a wall, varying in height from $4 \mathrm{ft}$. to $6 \mathrm{ft}$., which encircled it. The original height of this wall can only be estimated by comparing the existing structure with the fallen débris which was buried by an accumulation of soil. At the foot of this 
wall, and on the outside, I found many specimens of arrowheads, Kafir pottery, bracelets, and necklaces of iron and copper. I also found something which may perhaps prove to be an object of special interest. This was a piece of copper about 6 in. in length and a quarter of an inch thick, covered with a green substance (whether enamel, paint, or lacquer, I am unable to determine), and inlaid with one of the triangular Zimbabwe designs. It was buried $5 \mathrm{ft}$. below the surface, almost in contact with the east side of the wall itself.

"I also discovered a small cave under a big rock that

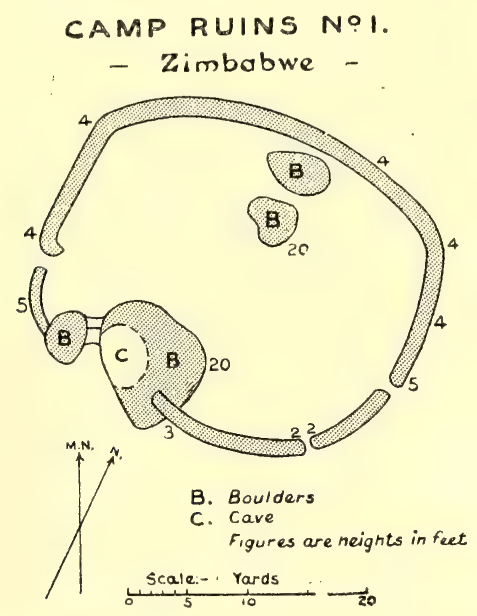

culminates in the highest point of the mound, but the only object of interest here found, besides bits of coarse pottery, was a piece of crystal or glass. On driving into the mound through a somewhat broken entrance in the inside wall of the west side, I was much puzzled by striking a level cement floor some $4 \mathrm{ft}$. above the wall foundations, and on following this level I came upon a second floor about $2 \mathrm{ft}$. above the first. It would therefore seem that originally there were a series of cement terraces, one above the other, culminating in a point of observation on the south side on the summit of a large rock, or that different occupants at varying dates had made new floors. It was near this rock that I came upon one of the few pieces of masonry inside the other wall, 
and that only very fragmentary in character. In following the outside wall on its inner face, I found it varied in width between $2 \mathrm{ft}$. $6 \mathrm{in}$. and $4 \mathrm{ft}$, and that its foundations also varied much in depth. In the cutting thus made I came upon three small furnace holes close together on a level with the top of the wall as it now stands, the foundations of which increased in depth as I proceeded, and disclosed here and there what appeared to be an extensive layer of ashes with the bones and teeth of animals. A notable peculiarity in this mound is the variety of stratified soil with folding concave towards the centre. The surface soil is more or less black; then comes a bright red clay divided by a broad yellow streak, and below this a dash of yellow, with here and there a vein of decomposed sandstone or other rocky substance. During this excavation I was not very successful in finds, which were only represented by three pieces of sea-green china, one of which was lying in the solid red clay below the surface, and $8 \mathrm{ft}$. to Io $\mathrm{ft}$. into the side of the mound, and two dull green porcelain beads, found $7 \mathrm{ft}$. deep and near its centre. Taking into consideration the ash beds and furnace holes already referred to, I feel justified in suggesting that once a workshop was here the scene of useful activity, and at that time surrounded by an irregular wall for protective purposes, with a point of outlook to guard against surprise, such as the big rock with the summit would represent."

As the author resided actually within Camp Ruins for fully two years (1902-4), very frequent opportunities of thoroughly examining the walls have presented themselves, the result being that it is now ascertained that these ruins as seen to-day can be shown to be not ancient but of a some very old Makalanga period. The furnace holes alluded to have been used for iron-smelting, and to the depth of I I ft. no single article approaching an antique or even mediæval character has been found within or near its walls. The brass-wire bangles found at depth still have their grass, hair, or fibre intact. Garden hoes, assegai heads, and 
coarse pottery of ordinary Kafir make are here found in abundance. The green pottery beads are found in almost every ruin at Zimbabwe, and never at lower depth than the yellow soil which lies immediately under the black vegetable mould on the floors of all the ruins. Certainly, the present natives do not know this class of beads. That this building, as suggested by Sir John Willoughby, was once a workshop is obvious from the quantities of iron slag and ashes and burnt clay floors and iron furnaces found in the vicinity. The bones of animals are mainly those of buck of all kinds. The construction of the walls precludes any suggestion that they could have been standing very many centuries, certainly not extending back to any period which could, even by long inference, be considered "ancient." The workmanship is decidedly poorer than that shown in modern Kafir buildings in the district.

But while this ruin, as seen to-day, may not itself be ancient, there is some evidence that the ancients must have fortified this knoll; and when we consider its strategetic position on the granite ridge, extending from the south-west foot of the Acropolis Hill and the Elliptical Temple, it becomes highly probable that later people have utilised the material of some older buildings once occupying this position in the erection of their poorer structures. Foundations of walls surround the knoll at distances of some fifty and one hundred yards from these ruins, and these show a fair claim to be recognised as ancient, or, at any rate, as older than the walls on the summit. The "cement" mentioned by Sir John is common soil daga (clay), similar to that found in old Makalanga huts and floors.

The ruin crowning the knoll is roughly circular, with a diameter of about $100 \mathrm{ft}$., with walls varying in height from $4 \mathrm{ft}$. to $6 \mathrm{ft}$. The accompanying plan, with explanatory notes, kindly lent to the author by Sir John Willoughby, shows the character of this ruin. The "finds" made here in 
I902-3 are identical with those discovered by Sir John Willoughby.

\section{CAMP RUIN No. 2}

This ruin lies $50 \mathrm{ft}$. south of Camp Ruins No. I, and is on the same knoll, the two being separated from each other by the Shangani graveyard.

Sir John Willoughby writes:-

"I carefully attacked Ruin No. 2, but with a disappointing

\section{CAMP RUINS N:2}

- Zimbabwe -

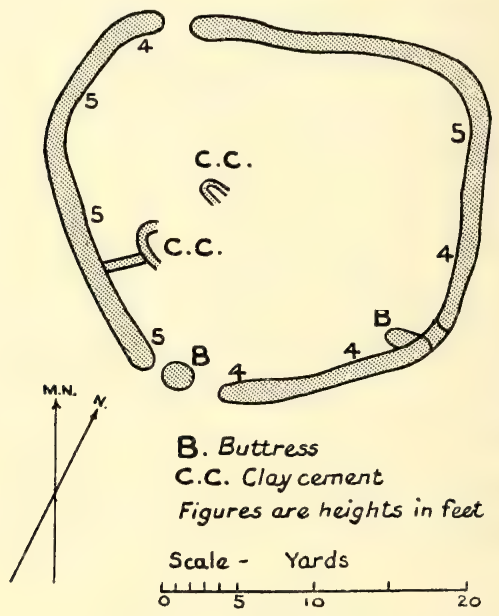

result. It merely appears to be an enclosure formed by an irregular outside wall, varying in thickness and in the depth of its foundations. In tracing this wall, the bed-rock was occasionally exposed at a depth of $3 \mathrm{ft}$. The only 'finds' here were two small pieces of sea-green china, one small piece of white china, a few Kafir arrow-heads, whorls of poor make, two fragments of pottery having a kind of basket design, and a copper or brass clasp or fastening, which probably formed part of a box of modern date."

This ruin has recently been re-examined with similarly 


\section{CAMP RUINS NO. 2}

disappointing result, and the remarks made with regard to No. I Ruin apply equally to this ruin. Clay foundations and floors of old Kafir huts fill the interior at different levels. Probably in the most ancient period, long before the present structures were erected, one large ruin occupied the site of both Nos. I and 2 Ruins, and encircled and crowned the knoll, for judging from very old foundations, walls surrounded the knoll. At least there were two such walls, one being within and higher than the other. 


\section{CHAPTER XXI}

\section{RUINS NEAR ZIMBABWE}

East Ruins-Other Ruins within the Zimbabwe Ruins' Area.

\section{EAST RUINS}

THESE ruins lie $20 \mathrm{yds}$. to the south of the Motelekwe

1 Road at 550 yds. east of Havilah Camp, and face the east end of the Acropolis Hill at a distance of $300 \mathrm{yds}$. south.

They occupy a rise overlooking the Valley of Ruins, and are built upon an open granite glacis which originally formed its floor. Their elevated and strategetic position at once claim the attention of visitors. These ruins have always been written and spoken of as being a fort for the defence of the east side of the Valley of Ruins, and, in fact, for all the ruins of the lower Zimbabwe group, including the Elliptical Temple, and especially for the eastern end of the South-East Ancient Ascent to the Acropolis. Judging from the contour of the country round about, the only possible line the ancient road from the east and the coast could have taken must have passed within a few yards of this ruin.

The view from East Ruins towards the east is most extensive and picturesque, for the land slopes on that side for over two miles towards the Beroma Range and the valley of the Motelekwe, while in the hollow are the Chipopopo and Mapudzi rivers. Opposite are the peculiar and romantic columns of granite near Chenga's kraal.

For the purposes of defence these ruins are ideally situated. On the south side they are protected by a steep declivity of 


\section{EAST RUINS}

some $40 \mathrm{ft}$. into the valley, and down this the original builders and later occupiers have shot their débris in great quantities. The space between the ruin and the declivity, some $25 \mathrm{yds}$. in width and Ioo ft. in length, is covered with short lengths of walls and wall débris.

The area covered by these ruins is $140 \mathrm{ft}$. from north to

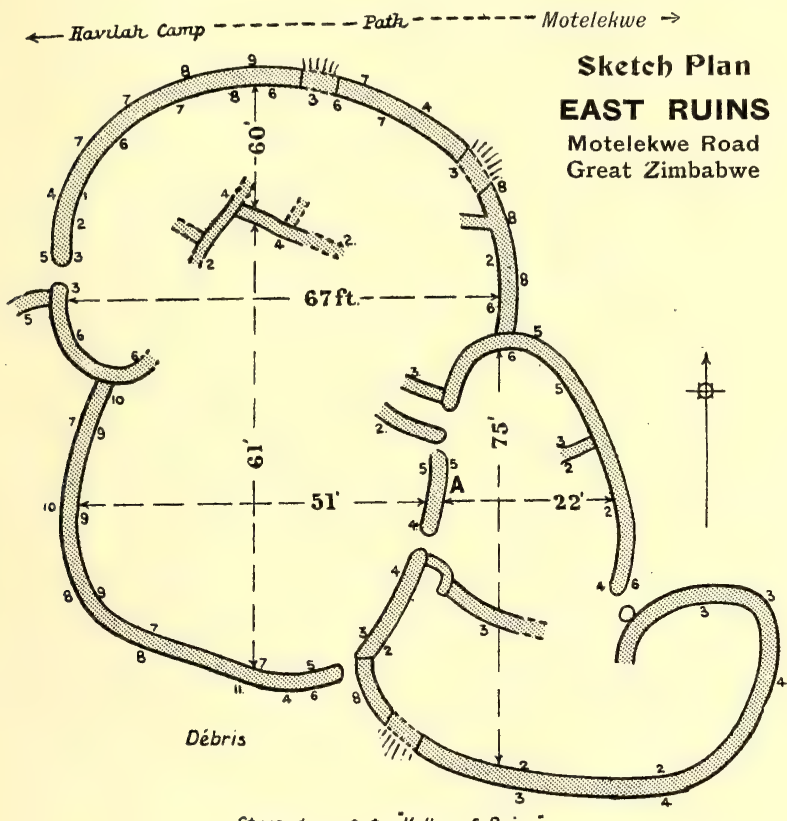

Steep descent to "Valley of Ruins"

Single figures are heights of walls in feet.

south, and $93 \mathrm{ft}$. from east to west. It is most probable that on the south and east sides there were other enclosures.

The walls on the north, west, and south are fairly well built and massive, and are still some $8 \mathrm{ft}$. to Io ft. in height, and average $3 \mathrm{ft}$. $6 \mathrm{in}$. to $4 \mathrm{ft}$. width of summit at those heights. The walls on the south-east and east average a height of from $4 \mathrm{ft}$. to $7 \mathrm{ft}$., while the divisional walls which remain have a reduced height of $4 \mathrm{ft}$. and $5 \mathrm{ft}$., and these latter are also substantially constructed. 
There are four well-defined enclosures, the two on the west side being the most perfect. The northern enclosure had once been subdivided into at least six separate compartments.

Both in plan and construction these ruins excel most of the minor ruins, including No. I Ruins, and many walls on the Acropolis. The curved lines of the walls on the northern and southern sides are bold and striking, and well and exactly carried out. Their solidity is very noticeable, especially on both outer and inner faces. Not only are the courses in these walls fairly even, but the blocks are wellsized and are of a good quality of granite. In some portions of the walls the workmanship is of an inferior character.

But, whatever the style of construction may be, the faces of the walls are beautifully even from base to summit and also lengthways, for placing one's eye close up against the wall and glancing along an area of wall-face, there is hardly to be seen half an inch of front of block protruding in front of its neighbours. This, of course, does not apply to the batter-back, which is only that of an average wall at Zimbabwe. The impression gained on viewing these massive walls, which occupy such an excellently strategetic position, is that the original builders intended the building to be used for some important purpose.

The northern enclosure is $60 \mathrm{ft}$. from north to south, and $67 \mathrm{ft}$. from east to west. The south-west enclosure is $6 \mathrm{I} \mathrm{ft}$. from north to south, and $5 \mathrm{I} \mathrm{ft}$. from east to west. The eastern enclosure is $55 \mathrm{ft}$. from north to south, and $22 \mathrm{ft}$. from east to west. The south-eastern enclosure, which is rather rudely constructed, and the walls of which are very considerably dilapidated, is $20 \mathrm{ft}$. from north to south, and $80 \mathrm{ft}$. from east to west.

There are three entrances through the outer walls, and these are on the west, south, and east, and all are rounded; two have buttresses, one has portcullis grooves, and the 
foundation forms the passage floor in each case. Two divisional entrances now only remain, and these are also rounded.

Immediately inside the west entrance and on the north side is what appears to have been a raised platform, facing west, about $4 \mathrm{ft}$. above the original floor. This may have an area of $15 \mathrm{ft}$. from north to south by $12 \mathrm{ft}$. from east to west, but the artificial filling-in of the ruin with soil has raised the interior surface to the level of this platform. Probably, as at other ruins at Zimbabwe with identical platforms in corresponding positions, this afforded a look-out overlooking the entrance. On the eastern side of these ruins there is a similar but smaller structure which may have answered the same purpose.

In the eastern enclosure and on the east face of the west wall is a recess starting upwards from the ground. This is $3 \mathrm{ft}$. high, I ft. Io in. wide, and the blocks on each side respectively are flush-edged with each other. The recess goes back about the length of two blocks (see ArchitectureBlind Recesses).

These ruins have been artificially filled in with soil to a depth of $3 \mathrm{ft}$. to $5 \mathrm{ft}$. by native occupiers of a comparatively late date, for the soil on the surface and downwards to the bottom of the filling-in is thick with old native pottery and the broken-up remains of Kafir huts.

Although almost every relic-hunter seems to have paid attention to these ruins, nothing of any antique value has been found here. Probably when the original occupiers left' the granite floors were still exposed, and any objects found there may have been removed long before the filling-in took place. So far, there is no evidence that any industrywhether of ancient, mediæval, or modern occupiers-has ever been carried on in this building. 


\section{OTHER RUINS WITHIN THE ZIMBABWE}

\section{RUINS' AREA}

Bentberg (Matusu).-This kopje, which is $240 \mathrm{ft}$. above the threshold of the West Entrance to the Elliptical Temple, lies immediately south and south-west of the temple. Only 200 yds. separate the building from the foot of the hill. Here are many signs of very old occupations in the form of ruined terrace walls apparently of the Zimbabwe style, but of a very late period. The local Makalanga state that though their predecessors of the same race have had kraals on this hill, the terrace walls are not of any Makalanga construction; and this appears to be obvious. Further, though Makalanga pottery is abundant, yet there can be found both pottery and cement of a very superior quality and make; and such are repudiated by the natives as having been made by Amangwe, Makalanga, or Barotse. Great quantities of quartz broken into very small splinters are to be found in large areas on the hill. The nearest quartz reefs are six miles west of Zimbabwe. The older remains of terraces-many buried in silted soil-are to be found on the north side of the hill, but traces of walls can be met with extending almost to the summit and round the western flank. It is impossible to imagine that the ancients did not in some manner occupy the hill, as otherwise the Elliptical Temple would have been exposed on its south side without any defences. The old Barotse had a kraal at the foot of the north side of the hill just above the spot where are still the traces of Bent's camp,

Rusivanga Kopje.-This hill (I9o ft.) rises from the Zimbabwe Valley at some $300 \mathrm{yds}$. west of Havilah Camp. It is directly on the right of the road from Victoria to Zimbabwe at about a third of a mile from the main ruins, the road passing between it and Makuma Kopje on which is Mogabe's kraal. The northern and eastern faces of this hill 
show in places from base to summit abundant evidence of occupations by ancients and also by very old Makalanga and Barotse. The remains of walls are in most instances of inferior construction, though at some points the courses of excellently built wall can be traced. There are also rudely built ramparts and enclosure walls of some later period. On the summit of the hill was once a fort. Fragments of soapstone, slate, quartz, and ironstone are to be found, also large stone-crushers, some excellent pottery, and cement work of superior quality. At one point is a cement wall carried across the top of a boulder. There are stone foundations of Makalanga huts which are circular and lined with cement, and winnowing floors with raised edges. On the eastern side of the hill two sets of isafuba game-holes have been cut into the surface of the granite rock. Each of these has thirty-six holes. On the west side and near the summit there are at least thirty different sets of game-holes cut into the granite, the holes of the sets varying in size. On the open granite areas on the hill are several places where deep depressions have been worn into the rock, evidently by the sharpening of tools or by grinding stones.

Ruin on Bingura's Path.-This is located on the left-hand side of the path leading to Bingura's kraal at about half a mile from the camp. Only its south-east wall is now standing, but its outlines can be traced by piles of blocks on all other sides. The area covered is about half an acre. The wall is well and substantially built, and is still $6 \mathrm{ft}$. high. This appears to be of very old construction. There have been no important "finds" made here, the ruin not having yet been examined. It occupies a strategetic position on slightly raised ground in the valley between the Bentberg and Rusivanga. 


\section{RUIN NEAR CHENGA'S KRAAL}

This is situated one mile and a quarter east of Havilab Camp, and is the most easterly ruin of the Zimbabwe group. It stands upon a low ledge on the west side of the Beroma Range, and is a quarter of a mile west of Chenga's kraal, and directly overlooks the Mapudzi stream, which flows at about $60 \mathrm{ft}$. immediately below the west face of the ruin. The position is strategetic and affords a view over several valleys. The area covered by walls and stone débris is fully an acre and a half, but the actual walls now standing in any recognisable form of plan only cover $100 \mathrm{ft}$. by $80 \mathrm{ft}$.

A cluster of large boulders has been utilised, and over these and between them the walls have been erected, the interior being filled up with earth almost up to the summits of the walls by some later occupiers. On clearing this foreign soil from the interior faces of the walls, two buried entrances, both rounded, were discovered, and it was then possible to prepare a plan of such of the walls as were so cleared. Nothing of any antique value was found during these operations, all the "finds," which were not numerous, being of old native articles.

All the walls are curved, and all buttresses, entrances, and ends of walls are rounded, and have a distinct batter-back. The granite blocks in some portions of the walls are as regular in size and shape as those to be seen in the Elliptical Temple, but the construction is not of the best. The outer faces of the walls have been first raised, and the internal portions afterwards filled in with stones of all sizes and shapes, but larger than those seen in the filling-in of the interiors of many of the walls at Khami Ruins. The courses at some points are very regular, but at others there has been no attempt at making any courses. The column style of building adopted by old Makalanga and Barotse is present in parts. The walls average about $4 \mathrm{ft}$. in width at base and $3 \mathrm{ft}$. 
on present reduced summit. There is no mural decorative work introduced.

The natives state that this ruin was not built by the same people that built the rough walls of the minor ruins at $\mathrm{Zim}$ babwe, their theory being that it was erected by Barotse very many generations ago, and on this point they are very emphatic. The translations of the native expressions for relics

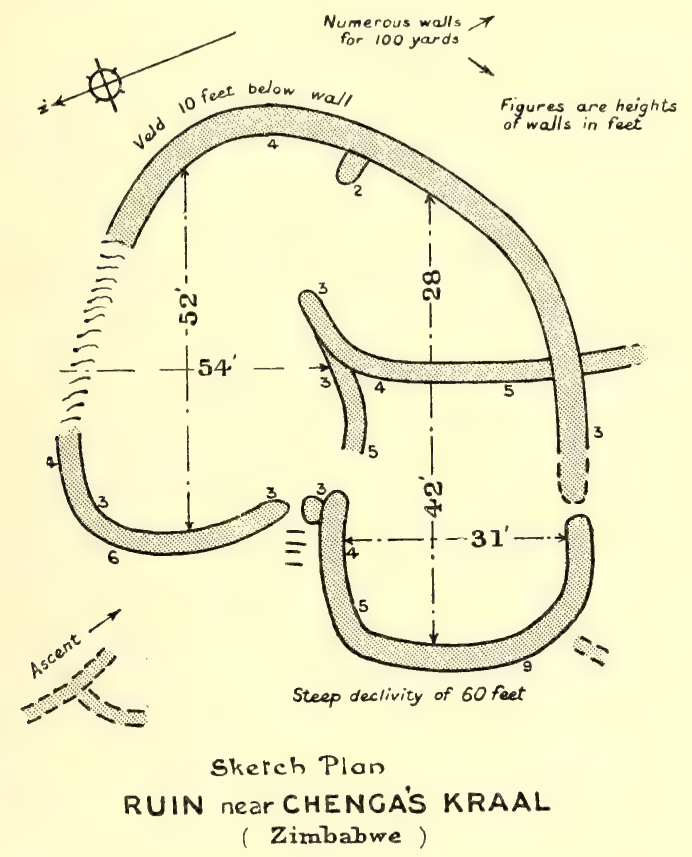

are "pretty stone" and "money." In starting work here, the labourers, who receive small rewards for discovering relics, grumbled considerably, and informed the author that it was useless to work there, as no "pretty stones" or "money" would be found there. Similar remarks were made about other small ruins, and in every case they have been proved to be correct. Whether this ruin has actually any claim to antiquity is a matter which, at present, it would be unsafe to dogmatise upon. 


\section{CHENGA'S AND MADAVID PATH RUINS}

These ruins are in a valley which runs north and south on the Beroma Range at one mile distance south-east of Chenga's kraal, and lie a few yards to the west of the native path leading from Chenga's to Madavid's kraal. Madavid is the native name for David, a Basuto, who lives near.

The area covered is fully a third of an acre on the summit of a knoll, which rises some $30 \mathrm{ft}$. above the valley. Traces of walls covering an area of an acre and a half are to be seen on the south, west, and north sides. Large granite boulders have been utilised in the construction, the walls being carried in curved lines from boulder to boulder, enclosing a rudely drawn circular area $5 \mathrm{I} \mathrm{ft}$. from east to west, and $42 \mathrm{ft}$. from north to south. In one instance the wall is carried over a boulder.

The faces of the walls show good workmanship, the courses being fairly even, the joints uniformly distributed, and the blocks regular in size. The bases of the walls average from $4 \mathrm{ft}$. to $5 \mathrm{ft}$. in width, while the very reduced summits are $3 \mathrm{ft}$. 6 in. wide at $5 \mathrm{ft}$. from the ground. The walls display a carefulness in construction which is absent from some of the divisional walls of the main ruins at $Z$ imbabwe. The side walls of the entrance on the east side of the building are most perfectly rounded. There is no mural decoration. The interior of the building is of earth, which contains Kafir pottery, etc. No exploration work has been done here.

\section{MAPAKU, OR “LITTLE ZIMBABWE” RUINS}

These ruins are situated at a distance of seven miles southeast of Zimbabwe, and occupy a position overlooking the Motelekwe Valley, and are on the eastern side of the lower shoulders of the southern extremity of the Beroma Range. On the south side of the ruins the ground falls in the direction of the Motelekwe River, which here flows south to south-west of the ruins at the distance of about a mile. The 
Mapaku kraal is a quarter of a mile north-west of the ruins. At the village are some caves (I-Baku, cave; Mapaku, caves). The headman is a Molinye, younger brother to the Mogabe Handisibishe of Zimbabwe. Good water can be obtained from several places in the vicinity of the ruins.

The area covered by these ruins, excepting traces of outlying walls, is $70 \mathrm{ft}$.. from north to south, and $80 \mathrm{ft}$. from east

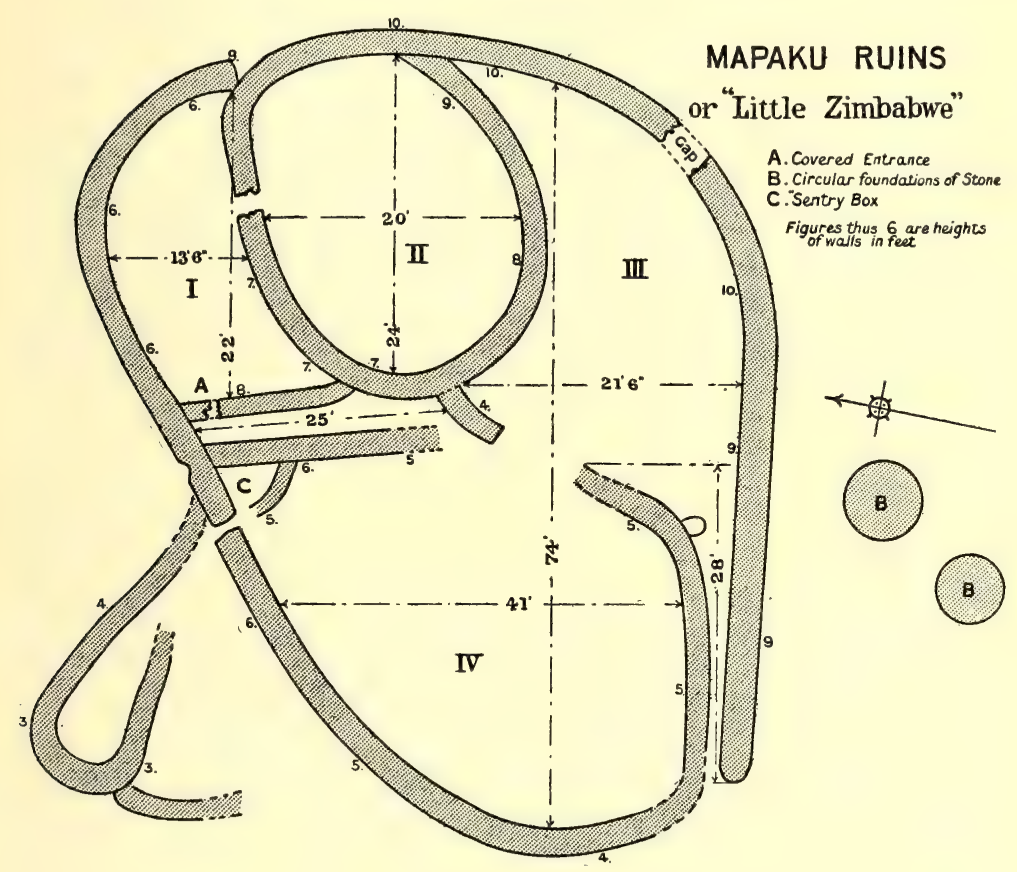

to west. Though the ruins are small in area, yet they have a considerable importance, seeing that they form one of the ruins of the chain of such structures which stretches at certain intervals from Zimbabwe along the Motelekwe River, which chain again connects with the chain of a similar class of ruins running from the lower Sabi in Portuguese territory in the direction of Sofala. The chains of ruins appear to point out the ancient approach from the coast to the metro- 
politan centre at Zimbabwe and the gold districts of Southern Mashonaland and Matabeleland.

The thickness and height of the walls are the first features which will strike anyone on entering the building, especially when the small size of the centre ruins are taken into consideration. The walls are all built on curved lines, and average a width of 4 to $5 \mathrm{ft}$. at the base, and $3 \mathrm{ft}$. at present reduced summits at $8 \mathrm{ft}$. above the ground. All the walls are built upon the granite rock formation, and there is comparatively very little soil on the floors, and most of this is black vegetable mould. Fortunately these ruins have not been subjected to the filling-in operations of the very old Kafir peoples as have so very many ancient ruins in Rhodesia. The absence of sufficient soil for the growth of large trees has no doubt saved the walls from more serious dilapidation. The walls are white with lichen, this being a feature in all the ruins along the Motelekwe Valley, which, seen from Zimbabwe, is usually filled with mist-fogs.

The main entrance evidently is the one on the south-west side of the building, for here is a long narrow passage leading from the interior, the passage running parallel to the south main wall forming an easily defended approach. The ruins have only two entrances-the main entrance and an angular entrance on the north side without portcullis grooves. This latter entrance leads into an outer enclosure only, and is protected on the inside by what may be described as a "sentrybox." This is a curved wall $7 \mathrm{ft}$. long and $5 \mathrm{ft}$. high, enclosing a small area large enough to hold two or three men, and its entrance opens on to the inside of the entrance in the main wall. There are several of these "sentry-boxes" at Zimbabwe occupying exactly similar positions near entrances.

The interior of the building contains at least four enclosures and two long passages, and these may be described as follows:-

No. I Enclosure, which is on the north-east side of the 


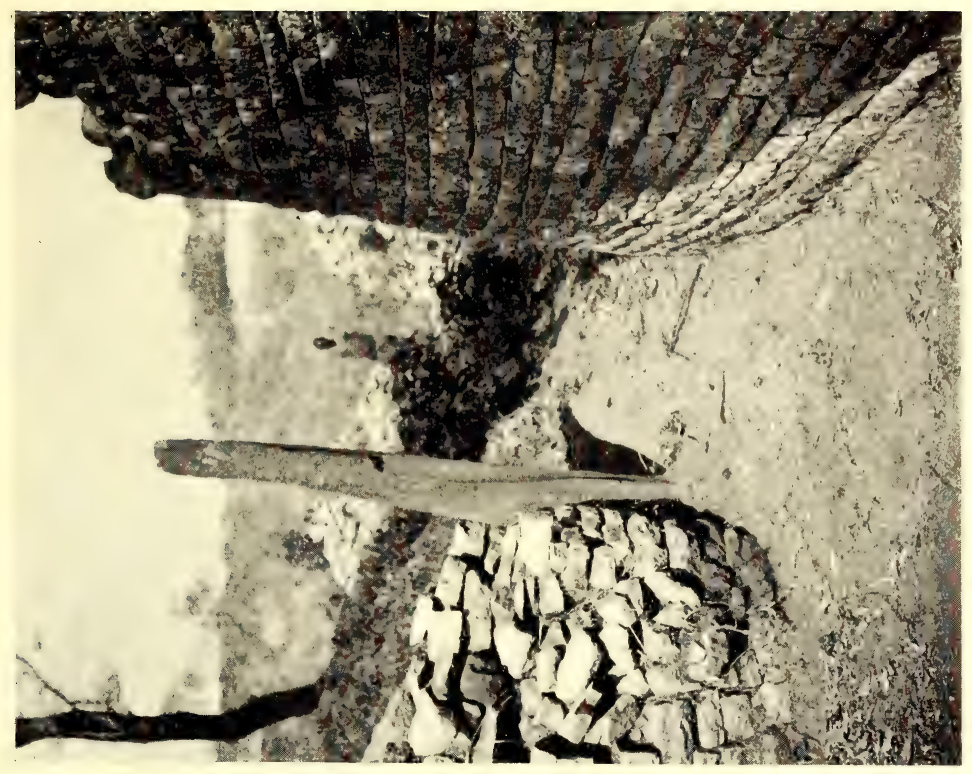

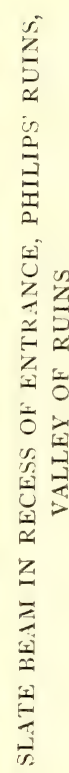

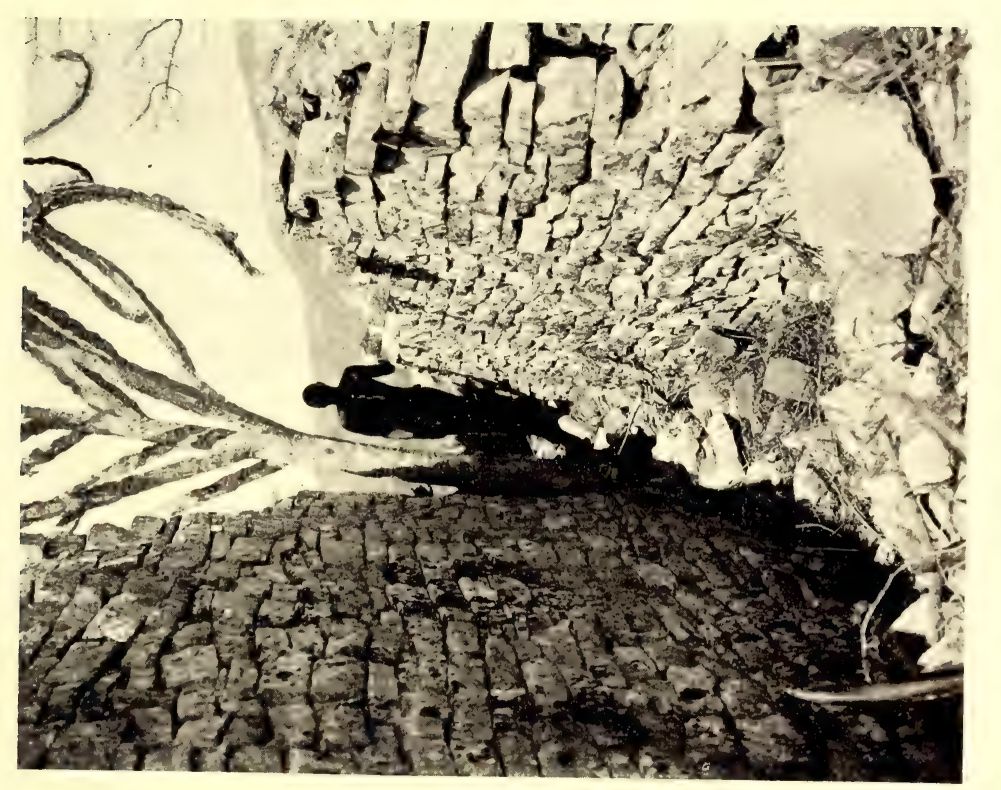

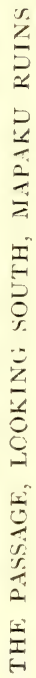



ruins, is $22 \mathrm{ft}$. from east to west, and $13 \mathrm{ft}$. 6 in. from north to south. The floor is formation rock covered over (1903) with a few inches' depth of vegetable mould. The main wall, which forms its north and east sides, is $6 \mathrm{ft}$. high throughout, the wall on the west is $8 \mathrm{ft}$. high, and the curved walls which divide this enclosure from No. 2 Enclosure average $6 \mathrm{ft}$. and $7 \mathrm{ft}$. in height, except at the entrance to No. 2 Enclosure, where the height on either side is reduced to $5 \mathrm{ft}$.

No. 2 Enclosure, which is roughly circular in form, is only approached by one entrance, and this is on its north side, and leads from No. I Enclosure. This entrance is angular, and has portcullis grooves, and is $2 \mathrm{ft}$. $8 \mathrm{in}$. wide and $3 \mathrm{ft}$. $6 \mathrm{in}$. long. The walls of this enclosure are substantially built, being $3 \mathrm{ft}$. wide at their summits, which average $7 \mathrm{ft}$. to $9 \mathrm{ft}$. in height. The area enclosed is $20 \mathrm{ft}$. from north to south, and $24 \mathrm{ft}$. from east to west. This enclosure, judging by its complicated approach, was evidently the principal part of the ruins.

Nos. I and 2 Enclosures are only approached by a passage $25 \mathrm{ft}$. long running north and south, which is $2 \mathrm{ft}$. Io in. wide at its northern end and widens to $6 \mathrm{ft}$. $6 \mathrm{in}$. at the south end. The west wall of the passage is from $5 \mathrm{ft}$. to $6 \mathrm{ft}$. high, and that on the east side $7 \mathrm{ft}$. to $8 \mathrm{ft}$. high.

Leading from the north end of this passage into No. I Enclosure is a covered entrance, $5 \mathrm{ft}$. high, $2 \mathrm{ft}$. 6 in. wide, and $5 \mathrm{ft}$. long. The roof is supported by flat granite slabs. On either side, and extending from floor to roof, are portcullis grooves. This entrance is somewhat dilapidated, and it is feared that one side of it may soon fall down.

No. 3 Enclosure is bounded on the north by the divisional wall of No. 2 Enclosure, on the east and south by the curved main wall, and on the west by a very dilapidated divisional wall, which separates it from No. 4 Enclosure. It is $2 \mathrm{I} \mathrm{ft}$. 6 in. from north to south at its widest point, and about $35 \mathrm{ft}$. from east to west at its longest point. 
This enclosure is the first to be approached from the main or west entrance to the building, with which it is connected by a passage running parallel to the south main wall for $28 \mathrm{ft}$. Where the passage enters No. 3 Enclosure are the remains of a rounded buttress on the north side. From this buttress the passage westwards is $4 \mathrm{ft}$. 6 in. wide, but quickly narrows to $2 \mathrm{ft}$. 8 in., which width is maintained till it reaches the main entrance. The wall on the south side of the passage is from $6 \mathrm{ft}$. to $9 \mathrm{ft}$. high, and that on the north side averages $5 \mathrm{ft}$., but is greatly dilapidated toward its eastern end.

No. 4 Enclosure is on the western side of the building, and is $4 \mathrm{I} \mathrm{ft}$. from north to south at its broadest part, and $39 \mathrm{ft}$. from east to west at its longest part.

On the south side of the exterior are two circular stone foundations of one course each. These are $9 \mathrm{ft}$. in diameter. A number of granite blocks lie to the east of the building, and suggest the former existence of some structure.

The construction as a whole is somewhat similar to that seen in some of the buildings in the Valley of Ruins at Zimbabwe. Straight joints and tilted blocks, long and shallow in form, and a disregard of courses, are the principal features in the workmanship shown in these ruins. There is no mural decoration. 


\title{
APPENDIX
}

\author{
NOTE A
}

\section{GREAT ZIMBABWE}

NOTICE TO VISITORS

r. The only outspan is between Havilah Camp and the south side of the Acropolis Hill.

2. No trees or bush on the Zimbabwe reserve to be cut by visitors or their native servants. Cut firewood is provided on the outspan.

3. No visitor shall take into any ruin any spades or other tools for the purpose of prospecting for relics or gold, or use the same within the reserve. No excavated soil shall be panned, nor any stones removed from the ruins. Surveys can only be made on the written authority of the chief secretary.

4. Visitors are requested not to touch or damage old cement work, or shake any ancient monoliths, or climb on walls or places marked "Dangerous," and are asked to assist the Government in the preservation of the ruins by giving immediate notice to the magistrate at Victoria, or to any official in charge of the ruins, of any of the above offences being committed.

5. The provisions of the "Ancient Monuments Protection Ordinance, 1902," with regard to the illegal possession of relics, prospecting for same, or damage to ruins, and the consequent penalties of fines and imprisonment for such offences will be strictly enforced.

6. The attention of visitors is also directed to the subjoined rules framed under the said ordinance.

$$
\text { By order, }
$$

H. H. CASTENS, Chief Secretary.

Chief Secretary s Office, Salisbury. Ist May, I904. 


\section{GOVERNMENT NOTICE No. IO3 OF 1904}

Chief Secretary's Office, Salisbury. 28th April, 1904.

It is hereby notified for public information that His Honour the Administrator has been pleased to approve of the subjoined rules, framed under the provisions of Section 7 of the "Ancient Monuments Protection Ordinance, 1902," for visiting and inspecting the ruins of Zimbabwe.

By command of His Honour the Administrator.

\section{H. H. CASTENS, Chief Secretary.}

I. The public will ordinarily be permitted to visit and inspect the ancient ruins at Zimbabwe between the hours of $6 \mathrm{a} . \mathrm{m}$. and 6 p.m., subject to the conditions prescribed by these rules.

2. Any person producing a written permit granted to him by the Administrator, or by a magistrate, or a printed ticket in the prescribed form for the admission of visitors to the ruins, will be allowed access to them. All such permits and tickets shall, before admission, be delivered to the caretaker or person in attendance at the time.

3. No person shall :-

(I) Dig or search within or about the walls of the ruins for minerals, precious stones, or curiosities ; or

(2) Carry into any part of the ruins any spades or other tools; or

(3) Pan or sift any excavated soil in or about the ruins; or

(4) Remove any stone, wood, brick, or material from the ruins; or

(5) Remove trees, shrubs, or plants growing within or about the ruins, under a penalty, upon conviction, of a sum not exceeding $£ 5$.

\section{NOTE B}

\section{ROBERT M. W. SWAN}

We regret to record the death, which took place on March 26th last, of Mr. R. M. W. Swan, well known for his share in the earlier investigations of the ruins of Mashonaland. Mr. Swan was born in $185^{8}$, and after receiving a technical training in Glasgow University and in the laboratory of Mr. R. Tattock, went out to Spain 
in 1878 in the capacity of a mining expert. In 1879 he went to Greece, and the next seven years were spent in mining work, principally in Antiparos and neighbouring islands. In addition to his professional employment, he devoted much attention to archæology, publishing several papers on his researches, and sending many specimens to the British Museum. It was during this period that he first made the acquaintance of Mr. and Mrs. Theodore Bent, whom he accompanied during their visits to several of the islands, afterwards taking part in the expedition to Mashonaland, carried out by them in I89I, for the examination of the Zimbabwe and other ruins. During this expedition he undertook the cartographic portion of the work, executing for the first time a careful plan of the ruins, besides mapping the country along the routes followed, and fixing the positions of a number of points astronomically. When, after his return to this country, Mr. Bent described the results of his journey before the Society, Mr. Swan added some notes on the geography and meteorology of Mashonaland, and subsequently contributed to the Proceedings (May, I892), a short paper on the orientation of the ruins, showing in a striking way the close connection which existed between the arrangement of the structures and the astronomical phenomena to which, as sun-worshippers, their builders had paid so much attention. The subject was more fully discussed in the section which he contributed to Mr. Bent's Ruined Cities of Mashonaland. The theory which he developed was subjected to some criticism; but on returning to South Africa to continue his investigations, he collected data, which, as he claimed, fully bore out his ideas. During this journey, carried out in I893, he examined various ruins, till then undescribed, besides doing something to improve the mapping of the country along his route, which led inland by way of the Limpopo.

This visit to South Africa lasted about two years, spent in part in geological and mining work. In 1896 he examined the mining districts of Western Australia and Tasmania, and in 1898 went to Siam with a similar object, leaving again, after a short visit to this country, for the Malay Peninsula, where he was engaged in mining work until his death, which took place at Kuala Lumpur after an operation for abscess of the liver. Here, as in South Africa, he did much careful cartographical and geological work.

Mr. Swan was an expert linguist, and from his residence in Greece had acquired a great love for the classics. He possessed a large 
store of knowledge on varied subjects, which he was always anxious to share with others. He was a Fellow of the Geological and Chemical Societies, as well as of our own, which he joined in 1893 , having received the Murchison Grant in 1892. (Royal Geographical Society's Journal, May, I904.)

\section{NOTE C}

NOTE ON OLD POTTERY FOUND AT DEPTH AT RENDERS RUINS, GREAT ZIMBABWE, JULY, I903

This "find" consists of pottery of a very good quality about a quarter of an inch thick, but covered with a most excellent glaze of blue, white, and gold enamel, the white forming the background.

There are at least four bands of pattern which encircled a large open bowl. No. 8 is a part of the rim, which was straight. No. I appears by its form to have been portion of the upper band; Nos. 2, $4,5,6$, and 7 the second band; No. 9 the third band; and a decoration of palm fronds, in brown paint and in outline only, its lowest band.

The clay is a light brown and of fine quality.

The lettering or pattern is outlined with faint gold, with yellow paint scroll-work filling the spaces between, and so minute are these decorations that very few would notice them. They resemble, only on a very minute scale, No. 3 .

I cannot piece the fragments together, but Nos. 4 and 7 seem to fit.

The glaze is very thickly laid on, and both inside and outside are covered, and it is of such splendid make, colour, and appearance that many who have seen it say it is of the highest quality.

The inside is white, and has lines of faint blue artistically drawn without being of any set pattern.

No portion of the base found would enable one to judge whether the bowl had been made on a potter's wheel or not.

All the fragments were found together on a deeply buried floor, and at the same spot a quantity of large pieces of beaten gold and some gold beads were discovered.

Some very thin light-brown pottery covered with white enamel, extending some inches down from the rim inside and with thick bars of dull blue enamel running from rim to centre, were also found at the same spot. 


\section{NOTE D}

\section{ZIMBABWE RUINS}

[Extracted, by permission, from the Reports (1900-1902) of the British South Africa Company.]

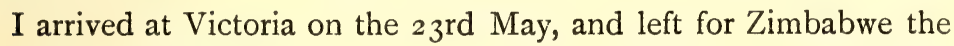
following morning.

On inspecting the ruins I found the interior of the Elliptical Temple one impenetrable jungle of trees, bushes, creepers, tall grass (6 to ro ft.), and decayed tree stumps and branches, so that it was impossible to see beyond a few feet, while the surface of the ground was most irregular and thickly covered with wall débris. The air inside was fetid and heavy-smelling from the rank vegetation. There being no opening on the eastern side, the interior is protected from the prevailing winds, and the sun shining on the damp, dense, and almost tropical foliage and plant growth made the air oppressive and unhealthy, so that one could not remain long at a time in the building.

Our first work was to clear away the undergrowth, but it was so dense and matted with creepers that, with fifteen men working for a whole day with hatchets, sickles, and spades, we were only able to advance a few feet into the interior from the west entrance. It required nine days for fifteen men to clear the interior of undergrowth alone. A further three days were given to pulling up grass and shrub roots. The atmosphere of the interior is completely changed, as the sun has dried the surface of the ground. It is now possible to stand in the centre of the building and obtain an uninterrupted view of the walls all round, and at the same time to see at a glance the whole of the divisional walls and enclosures.

The north side of the summit of the Conical Tower has in very recent years been denuded of several courses of blocks owing to the boughs of large trees swinging upon it in the high winds. The tower is more reduced than is shown in photographs taken six years ago. The dentelle ornamentation on the summit has practically disappeared within the last ten years. Some ancient blocks in the top courses are likely to fall. These blocks could be pushed back flush with the face of the tower, and some of the blocks which have very recently fallen might be restored to their original position. 
The summit when cleared of vegetation should be cemented over. It is a feature in Zimbabwe construction everywhere in Rhodesia, for a block, when it falls, to carry with it the stones of the course beneath it.

Visitors point out that the tower has lately shown a tendency to tilt somewhat towards the north-east. This is mainly due to the dense tree growth enveloping the tower, which keeps it constantly dripping with moisture, especially on the north side, where the main wall further screens it from the morning sun. The only remedy appears to be to so thin out the trees that the tower and its foundations may become perfectly dry. The wet state of the tower has caused it to become overgrown with lichen, which, decaying, produces vegetable matter which lodges in the crevices of the courses, and out of which grow small plants and shrubs, many of which we have removed. A large bush was growing out from the side in mould so formed, and the remains of a large bush on the summit are still to be seen. Should the tilting not be prevented by such means as the thinning out of adjacent trees, the value of the tower to scientists as a means of calculating the orientation of the temple, and therefore its age, would become lost. Three or four trees from close to the northeast, north, and north-west sides of the tower have been cleared away, and the vicinity has already a much drier appearance.

The dank air and soil round the tower have caused the extensive growth of large parent monkey-rope trees, which with their ropes spread in great lengths in all directions, thickly interlacing the tops of the trees, while their roots have in very many places pierced into both main and divisional walls and torn out lengths of stone-work. Monkey ropes appear to be the most active source of the dilapidations of the walls near the tower, but wild vines also have done considerable harm. Several hundred yards of monkey rope have been cut down and taken outside the temple, also very long stretches of monkey rope roots have been pulled up. All lower branches are being removed, so as to give a clear view all round the temple. Some of the upper branches are being thinned out.

The surface of the ground within the temple is covered with rich leaf mould soil to a depth of at least one foot, and sometimes under trees to a depth of one foot and a half. It is in this mould that the thickets of large shrubs, creepers, especially monkey ropes and wild vines, seem to have thriven, as also in the débris heaps left by Mr. Bent (r89r) and Sir John Willoughby (1892), where the turning 
over of the old time-hardened soil has ventilated it and caused most sturdy growth of plants and trees. This leaf mould has been removed from the floors of the inner parallel passage and in the passage on the north-east, east, and south-east sides of No. I Enclosure, and has been passed through sieves, and the soil neatly piled for future examination. Thus has been removed in these places the unhealthy smell formerly noticed. This work ought to be done in all internal enclosures of the building.

All wall débris is being neatly stacked and piled near where it obviously came from. All scattered stones on the floors are being collected and placed in piles. This work has made the enclosures to appear neat and tidy. Messrs. Bent and Willoughby's débris is also being stacked in much smaller compass. All débris heaps are being marked "débris" on painted boards. A large quantity of such débris might after examination be removed outside the building and stacked.

The summits of the main walls have been damaged at several points by past and present boughs overspreading the walls and beating them till several courses, the whole width of the walls, have disappeared, thus causing depressions in the top line of walls at several points. All branches, whether from trees within or without the temple, which overhang the walls, are being carefully removed with the aid of guide-ropes. Leaf mould has collected on the summits of the main walls to such an extent that large shrubs and small trees are thriving on the summits; these will be removed.

Seven monoliths have been found under the leaf mould and grass and shrub roots both inside and outside the foot of the main walls. Their former positions on the walls are being ascertained, and where obvious they will be re-erected.

The chevron pattern on the outside of the walls of the temple has been damaged, and in three places partially destroyed by large swinging boughs. It is also destroyed in two places by heavy festoons of creepers which had their roots in the open work of the pattern, the roots pushing out some of the blocks of which the pattern is composed. Some of these fallen blocks have been found, and there is a probability that a portion of the pattern, where damaged, may be restored. It is proposed to hand-pick all vegetable soil from the open spaces of the pattern to prevent future growths of creepers.

A clearing 8 yds. wide has been made round the outside of the 
whole of temple, and an inspection of the walls by visitors is now possible.

All the tops of divisional and broken portions and ends of walls, and all interstices on both faces, are having the leaf mould carefully hand-picked from them. This is a slow process, but will check their dilapidation by vegetable growth for a very long time.

The trenches made by Mr. Bent and Sir John Willoughby are being cleared of grass and silted soil, and their spade and pick marks on the bottoms can be seen. No ancient floor or soil has been disturbed, the ancient floors being some $3 \mathrm{ft}$. to $5 \mathrm{ft}$. below the present surface.

Roots of monkey ropes and trees are binding the inside of main walls below the present surface, as does a large plant in a small pot, and are in most places, and below the surface, penetrating into the dry masonry with damaging effect. I would suggest that a trench $2 \mathrm{ft}$. wide by $3 \mathrm{ft}$. deep be made on the inside of all walls, and all such roots removed. A yearly inspection of such trenches could be made, and any new roots and runners lopped off as they appeared. Run-offs could be made to prevent any accumulation of water in the trenches.

Architectural features.-(a) Four ancient drains, in addition to those mentioned by Bent and Willoughby, have been discovered.

(b) A rounded entrance with double curves; the only instance so far known.

(c) Three sets of stone steps and several square yards of ancient cement flooring (not of the original builders) have been carefully uncovered.

(d) A second-period architecture building with terraces superimposed on the walls of a first-period ruin.

(e) An enlarged plan of the temple, based on Mr. Bent's and Sir John Willoughby's measurements, is being prepared, and a quantity of altogether fresh architectural detail included.

Though the present is not a treasure-seeking expedition, yet there is strong probability that some "finds" of historic value may be made.

I have visited the Hill Fortress several times. Both the Western and Eastern Temples on this hill are so full of undergrowth that it is quite impossible to make any examination until it is cleared away. Within a week I hope to put on men to make a good path up to the fortress. 
The following new features in ancient architecture have been discovered :-

I. A dentelle pattern till recently covered with wall débris. A portion destroyed by roots (Acropolis Ascent).

2. A small enclosure with cemented lining on face of walls (Acropolis).

3. Three wedge-shaped buttresses, first set discovered in Rhodesia (Acropolis).

4. Two drains, one showing signs of having been cemented (Acropolis).

5. A northern ancient ascent between parallel walls from large rounded entrance near donga in the valley.

6. Passage $7 \mathrm{ft}$. deep and about $20 \mathrm{ft}$. long, completely buried in fallen wall débris, over which the visitors' path had crossed (South Enclosure, Acropolis).

7. Passage $8 \mathrm{ft}$. deep and $30 \mathrm{ft}$. long, completely covered by wall débris, over which the old visitors' ascent path had crossed (Platform Enclosure).

8. The round towers on the large west wall of Acropolis can now be shown, by the radii of stones of the top courses recently discovered, to have originally been conical.

9. Two large ancient entrances, hitherto unknown, deliberately filled in by Makalangas for graves, the remains removed and reburied with Mogabe's consent (Cleft Rock Enclosure).

Io. The covered passage at foot of platform which had been blocked up by Makalangas for graves (fifteen years old) cleared, the remains removed and reburied with Mogabe's consent. Visitors can now traverse this passage.

\section{NOTE E}

[Extracted from Report presented to the Chief Secretary, Government Offices, Salisbury, Rhodesia, November, 1903.]

Zimbabwe, Acropolis Ruins.-I regret having to report that the slanting granite beam on the platform at the Western Temple of the Acropolis Ruins has fallen and is fractured. This happened during the heavy thunder and rain storms of last week. The discovery of its fall was made to-day by Mr. Molyneux (Scientific Association, Bulawayo), Mr. Herbert Hayles (Sheriff of Victoria), and myself. No clearing or any other operations have been conducted here 
within a distance of twenty feet. Mr. Molyneux thoroughly agrees with me that the fall was perfectly natural.

The beam has for at least twelve years leant over at a severe angle, and now it can be seen that it was once perpendicular. The base was only fixed in the stonework for $\mathbf{I} \mathrm{ft}$. $8 \mathrm{in}$. The length of the beam from the base was $\mathrm{I} 2 \mathrm{ft}$. II in., but this was longer by $2 \mathrm{ft} .4$ in. some time previously to Mr. Theodore Bent's visit in $189 \mathrm{I}$.

The great marvel is that no one has been killed by its fall, for many visitors climbing to the platform have used the beam to assist in the ascent, and also in descending, and I have, as is well known, on scores of occasions warned them not to do so.

The beam in falling did but slight damage to the surrounding masonry. The portions of the beam are now laid together.

I have photographs of the platform, and showing this beam, taken from all points of the compass.

\author{
RICHD. N. HALL, \\ Curator of Great Zimbabrwe.
}

\title{
NOTE F
}

INVENTORY OF RELICS AND “FINDS" DISCOVERED BY THE AUTHOR AT GREAT ZIMBABWE IN 1902-3

No. Article.

Where found.

I. Gold wire bangle, $3 \frac{1}{2} \mathrm{oz}$. $\left\{\begin{array}{c}\text { South Terrace, } \\ \text { Acropolis. }\end{array}\right.$

2. Beaten gold round carbonised wood. A few gold tacks in the wood Do.

3. Head and neck of carved soapstone bird (the ninth yet discovered); be- Western Temple, lieved to be the largest and best- $\}$ Acropolis. preserved specimen

4. Fragment of carved soapstone bowl. Two horned animals .

Do.

5. Fragment of carved soapstone bowl. \South Enclosure, Herring-bone on cord pattern . $\}$ Acropolis.

6. Fragment of carved soapstone bowl. \} Western Temple, Horned animal . . . . $\}$ Acropolis.

7. Fragment of rim of carved soapstone South Enclosure, bowl, cord pattern . . . . Acropolis. 
8. Two sections of large soapstone bowl; believed to be two of the three missing sections of bowl lent by the Right Hon. C. J. Rhodes to the Cape Town Museum

No. 2. Enclosure, Elliptical Temple.

$\left.\begin{array}{c}\text { 9. Phallus in two sections; found broken; } \\ \text { undecorated soapstone. . . . . }\end{array}\right\}$ Elliptical Temple.

ı. Phallus (section of), with "breast and furrow" pattern, which was an ancient symbol of fertility; soap-

Do. stone

I I. Phallus (section of), found with true phalli; soapstone; undecorated . $\}$

Do.

I 2. Phallus; soapstone .

Do.

I3. Phallus (section of), "breast and fur-) row" pattern; soapstone . .

Do.

I4. Base of phallus; soapstone; found ) with true phalli . . . .

Do.

I5. Cut soapstone, plain, found with true ) phalli .

Do.

16. Phallus (section of, conjectured), found ) with true phalli; soapstone. . $\}$

Do.

I 7. Soapstone amulet . . . . Acropolis.

18. Soapstone whorl . . . . . Elliptical Temple.

19. Ten fragments of neck of carved soap-? stone vase. . . . . . .

Do.

20. Fragment of carved rim of soapstone No. I० Enclosure. bowl; cord pattern . . .

2 I. Carved soapstone bead . . . Elliptical Temple.

22. Four pottery whorls and two frag-
ments . . . . . .

23. Serpentine stone, with veins of asbestos chrysotile (not chrysolithic, as stated by Mr. Bent); not ordinary asbestos, but similar to Canadian. Veins have decomposed before body of stone

Western Temple, Acropolis.

24 .

Do.

Do.

25. Copper spearhead

Do.

26. Two copper spearheads, broken

Do. 
27. Two iron ringed instruments, conjectured to have belonged to Arab Elliptical Temple. colony once settled at Zimbabwe .

28. Two wedge-shape headed nails . Do.

29. Beaten copper . - Acropolis.

30. Iron handle of double-pointed iron $\}$ Elliptical Temple.

3I. Jasper stone with gold embedded. Found with burnishing stones . $\}$ No. 10 Enclosure.

32. Quartz pebble, showing visible gold; also artificially worn. Found with burnishing tools

33. Quartz pebble, showing visible gold.

Found with burnishing tools . . .

Do.

Do.

34. Collection of stone tools, artificially worn; some are burnishers. $3 \mathrm{ft}$. deep . . . . . . .

Do.

35. Fragments of soapstone beams; crude $\}$ Acropolis.

36. Collection of iron articles from depth in Elliptical Temple which has not been occupied as a Makalanga kraal for over sixty years

Elliptical Temple.

37. Collection of seven fragments of soap- Acropolis and stone bowls . . . . . . Elliptical Temple.

38. Section of soapstone mould $\cdot \quad \cdot\left\{\begin{array}{c}\text { No. } 7 \text { Enclosure, } \\ \text { Elliptical Temple. }\end{array}\right.$

39. Cake of gold . . . . . North-East Passage.

40. Stone, both water and artificially worn, 7 No. 1o Enclosure, showing gold on both sides. Found $\} \begin{aligned} & \text { No. ro Enclosure, } \\ & \text { Elliptical Temple. }\end{aligned}$

4I. Flat stone showing gold on one side. Found with burnishing tools. . .

42. Three portions of crucibles, six clay scorifiers, one portion of clay lining of furnace, all showing gold in flux

No. 6 Enclosure, Elliptical Temple.

43. Fragment of soapstone bowl, herring- No. I Enclosure, bone pattern on cord . . . $\}$ Elliptical Temple.

44. Fragment of soapstone bowl, herring- \} No. 6 Enclosure, bone pattern on cord . . . $\}$ Elliptical Temple.

45. Fragment of soapstone bowl, carved $\left\{\begin{array}{c}\text { No. } 7 \text { Enclosure, } \\ \text { Elliptical Temple. }\end{array}\right.$ 


\section{APPENDIX}

46. Fragment of soapstone bowl, cord No. 6 Enclosure, pattern . . . . . . $\}$ Elliptical Temple.

47. Fragment of large soapstone bowl, $\begin{gathered}\text { carved } \\ \text {. }\end{gathered}$

$\left.\begin{array}{l}\text { 48. Section of soapstone mould ; conjec- } \\ \text { tured old Makalanga }\end{array}\right\} \quad$ Do.

49.

Do.

Do.

50. Soapstone I-daha pipe bowl, carved ; $\begin{aligned} & \text { old Makalanga } \\ & \text { ol . . }\end{aligned}$

51. Soapstone amulet . No. 6 Enclosure,

52. Iron pincers; conjectured old Maka- $\begin{aligned} & \text { langa } \\ & \text {. }\end{aligned}$

53. Iron gong; do. . . . . . Do.

54. Do. Do.

55. Barbed copper spearhead . ..$\left\{\begin{array}{c}\text { Western Temple, } \\ \text { Acropolis }\end{array}\right.$

56. Twenty-three pottery whorls.$\quad \cdot\left\{\begin{array}{l}\text { On old Makalanga } \\ \text { floors. }\end{array}\right.$

57. Conjectured base of soapstone phal-
lus, converted by old Makalanga $\left.\begin{array}{l}\text { lus, converted by old Makalanga } \\ \text { into a crude mould }\end{array}\right\} \begin{gathered}\text { No. } 6 \text { Enclosure, } \\ \text { Elliptical 'Temple. }\end{gathered}$

$\left.\begin{array}{l}58 a . \\ 58 b .\end{array}\right\}$ Three sections of soapstone beams $\left\{\begin{array}{l}\text { Summit of main wall } \\ \text { above chevron pat- } \\ \text { tern, Elliptical } \\ \text { Temple. }\end{array}\right.$

59. Section of soapstone beam $\left\{\begin{array}{c}\text { Eastern Temple, } \\ \text { Acropolis. }\end{array}\right.$

60.

Do.

Do.

$6 \mathrm{I}$.

Do.

Do.

62.

Do.

Do.

63.

Do.

Do.

64. Do. (showing tool marks) .

Do.

65. Section of cement cylinder with bevel
round base. Age uncertain. . Mauch Ruins.

66. Beaten gold . $\left\{\begin{array}{c}\text { Western Temple, } \\ \text { Acropolis. }\end{array}\right.$

67. Forked iron instrument, with six gold bosses riveted with gold; spiral
grooves at base.

Do.

68. Beaten gold $\left(2 \frac{1}{8}\right.$ oz. $)$. . . . . Valley of Ruins. 
69. Phalli (8) and fragments of phalli.$\left\{\begin{array}{l}\text { W. and E. Temples, } \\ \text { Acropolis, and } \\ \text { Philips Ruins. }\end{array}\right.$

70. Fragments of rim of soapstone bowl carved with procession of horned animals. Pieces fit each other . Elliptical Temple.

7 r. Pottery animals (3); conjectured old ) No. I Enclosure, Makalanga . . . . 5 Elliptical Temple.

72. I-daha pipe bowls (2) of soapstone, No. 5 Enclosure, carved; conjectured old Makalanga $\}$ Elliptical Temple.

73. Iron with gravitating holes for drawing wire; old Makalanga. These wire drawers were in use until a few years ago

No. 6 Enclosure, Elliptical Temple.

74. Copper finger rings (2); snake pattern Renders Ruins.

75. Copper sheathing (2 lbs.). f Western Temple,

76. Single iron gong $\{$ Acropolis.

77. Large piece of coral . . . . Renders Ruins.

78. Pottery whorls $(200)$. . . . . Old native floors.

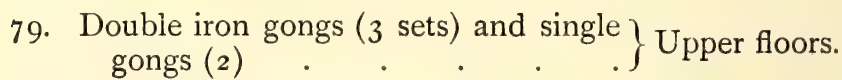

8o. Serpentine stone . . . . . Elliptical Temple.

8r. Nozzle of blow-pipe . . . . Do.

82. Porcelain beads, unknown to present Western Temple, natives. $5 \mathrm{ft}$. deep . . . $\}$ Acropolis.

83. Pottery beads, unknown to present
natives. . . . . . .

84. Soapstone amulet or seal (?) . . . Renders Ruins.

85. Block of solid copper . . . D Do.

86. Iron striker found with gong . . Do.

$\left.\begin{array}{c}\text { 87. Quantity of fragments of carved soap- } \\ \text { stone. Ribbed pattern . . . . }\end{array}\right\}$ Elliptical Temple.

88. Fragments of rim of soapstone bowl carved with ring pattern. (These
fit together).

89. Portion of carved soapstone beam $\left.\begin{array}{l}\text { converted into double claw-hammer } \\ \text { shaped ingot moulds } .\end{array}\right\}$ Elliptical Temple.

90. Soapstone phallus $\cdot . \quad \cdot \quad \cdot\left\{\begin{array}{c}\text { Platform Area, } \\ \text { Elliptical Temple. }\end{array}\right.$ 
9I. Copper barbed spearheads (2).$\quad\left\{\begin{array}{l}\text { Platform Area, } \\ \text { Elliptical Temple. }\end{array}\right.$

92. Soapstone with gravitating holes . Renders Ruins.

93. $2 \frac{1}{8}$ oz. beaten gold, gold beads, gold bar, and gold wire

94. Fifteen sections of soapstone beams (plain) .

From near arc wall in Philips Ruins; also from circular cement platform in Platform Area, Elliptical Temple. 95. Case of sections of soapstone bowls,
plain and decorated ips Ruins.

96. Section of carved soapstone beam

No. I 5 Enclosure, Elliptical Temple.

97. Iron spoon

Renders Ruins.

98. Iron lamp and stand (conjectured)

Do.

99. Iron pick

Elliptical Temple.

roo. Iron pick and 2 handles

Do.

IоI. Twisted iron wire in coils . . . Renders Ruins.

ro2. Bar mould of soapstone . . . Elliptical Temple.

103. Section of soapstone beam carved Western Temple, with maize pattern . . . . Acropolis.

104. Bundle of brass wire bangles . . Renders Ruins.

ro5. Three iron nails . . . . Elliptical Temple.

so6. Ornamented iron spearhead . . . Western Temple,

107. Bevelled cement . . . . General.

ro8. Spearhead . . . . . Renders Ruins.

ro9. Two stone balls . . . . Elliptical Temple.

I I0. Collection of specimens of hoes, assegai - heads, arrow - heads, axes, and ironwork found in ruins.

I I I. Several pieces of worked soapstone .

I I 2. Soapstone bird on beam . . . Philips Ruins.

r 3. Packet of large gold beads, $\mathbf{r}$ in. fine $\left.\begin{array}{l}\text { gold chain, one single gold wire } \\ \text { bangle, gold wire, and beaten gold . }\end{array}\right\}$ Various Ruins.

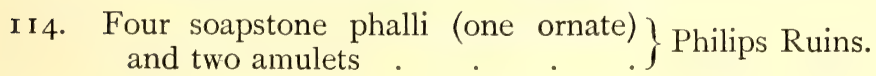


I 15. Two small bronze bells . . . . Renders Ruins.

i 6. Two large enamelled beads . . Western Temple.

I I 7. Collections of copper ingots, copper Elliptical Temple, bars, copper wire, copper bangles, $\}$ Renders Ruins, and cakes of copper . . . and Acropolis.

I18. Copper band 12 ft. 6 in. long and $\}$ Renders Ruins.

r 19. Box of Nankin china, sections showing plates of various sizes and
designs From most ruins.

r20. Portions of glass basin, engraved No. 7 Enclosure, and hand-painted . . . . Elliptical Temple.

I 2 I. Glazed pottery, with conjectured post- $\}$ Renders Ruins.

I 2. Fragments of Venetian glass - . Do.

I 23. Fragments of antique glazed earthen-
ware, showing potter's wheel marks $\quad$ Do.

124. Three fragments of antique pottery, $\}$ Do.

I 25. I 2 ft. fine copper chain . . . D Do.

I26. Pottery nozzle of blow-pipe . . Do.

1 27. Fused brass wire ; . . . . Do.

I28. Two iron instruments . . . Do.

I 29. Bronze axe-head, and fractured bronze $\quad$ arrow-head $\}$ Western Temple.

I 30a. Part of young lion's jaw . . . Renders Ruins.

„b. Large lump of resin . . . D Do.

„c. Wart-hog tusk . . . . . D Do.

„d. Two sections of glass prism . . Do.

I3I. Remains of antique copper box . Do.

I32. Oldest form of gold crucible, show- Exterior (west) of ing gold in flux . . . . .

133. Piece of slag showing gold . . Do.

134. Packet of sheets of beaten gold $\cdot\left\{\begin{array}{c}\text { Parallel Passage, } \\ \text { Elliptical Temple. }\end{array}\right.$ I35. Several cases of duplicates of soap-
stone, iron, copper, and pottery
articles . 


\section{NOTE G \\ FORMATION ROCK UNDER ELLIPTICAL TEMPLE}

Examinations made by the Author, August, 1903

No. $I$ Hole. - No. 5 Enclosure. 6 yds. south-east of west entrance.

$3 \mathrm{ft}$. Io in. diameter.

9 in. to $\mathrm{I}_{2}$ in., burnt clay floor (pinkish), 2 in. layer of small stones.

Below floor, bright yellow granite sand, set very hard, contains no stones.

On north side to $3 \mathrm{ft}$. depth, old trench of prospectors, filled in with blocks and red soil.

Formation rock exposed at $8 \mathrm{ft} .7 \mathrm{in}$., and this has a fall of $\mathrm{I} \frac{1}{2} \mathrm{in}$. in $3 \mathrm{ft}$. ro in. towards east.

Surface of bed-rock is rough and decomposed to a depth of $\frac{1}{3}$ of an inch, and can easily be chipped with pick.

Above formation rock is I ft. depth of granite sand, filled with flakes of decomposed granite from rock, and of deep orange colour.

Water passes along surface of bed-rock, and soil was damp and wet for 3 in. in depth.

No. 2 Hole.-No. 5 Enclosure. $6 \mathrm{ft}$. north-east of monoliths.

3 ft. 9 in. diameter.

I ft. burnt clay floor and scattered blocks and granite chips, soil damp for $2 \mathrm{ft}$. and wet for a few inches above formation rock, which is decomposed and easily scaled.

Formation rock disclosed at $\mathrm{I} 2 \mathrm{ft}$. 7 in., with fall of 7 in. in 3 ft. 6 in. towards E.N.E.

Sides show bright yellow granite sand set hard, and no stones.

No. 3 Hole.-South side of No. 5 Enclosure.

$3 \mathrm{ft} .9$ in. diameter.

6 in. burnt clay floor.

Sand red at top and yellow beneath; no stones.

Bed rock covered with I $\mathrm{ft}$. depth of decomposed granite with aphite chips, surface of rock rough and greatly decomposed; aphite chips.

Formation rock disclosed at $\mathrm{r} \circ \mathrm{ft}$. I in. depth.

Fall of rock 4 in. in $3 \mathrm{ft} .4$ in. towards east.

Bottom very wet. 
No. 4 Hole.-Between No. 5 Enclosure and Central Area. $3 \mathrm{ft} .6$ in. diameter.

9 in. burnt clay and small stones, forming bedding for clay. $2 \mathrm{ft}$. red veld soil.

I ft. 8 in. decomposed granite above rock.

Rest bright yellowy and set hard.

Formation rock disclosed at $\mathrm{I} 2 \mathrm{ft}$. I in. depth, showing fall of 3 in. in $3 \mathrm{ft}$. towards north and north-east.

Bottom very wet.

No. 5 Hole.-West side of No. 6 Enclosure.

At depth of I I ft. no formation rock, but rods showed rock at $3 \mathrm{ft} .4$ in. lower; unsafe to make hole deeper. Soil very wet.

No. 6 Hole.-East end of No. 6 Enclosure.

At depth of $14 \mathrm{ft}$. no sign of rock.

No. 7 Hole.-Centre of Platform Area.

At depth of $\mathrm{I} 2 \mathrm{ft}$. no sign of rock; bottom wet.

No. 8 Hole.-Centre of Central Area.

At depth of $8 \mathrm{ft}$. no trace of rock. Hole passed through two clay floors, and below one granite cement floor.

The Central Area had previously been cleared to a depth of $5 \mathrm{ft}$. before hole was sunk. 


\section{IN DE X}

\section{Abolosi. See Barosie}

\section{Acropolis Ruins-}

Situation, 3

First impressions of, 5

View from, 6-II

Sunset on, 24-30

Description of, 276-362

S.E. ascent, 276-294

Lower Parapet, 282-286

Rock Passage, 286-288

Higher Parapet, 288-290

Original heights of walls, 290, 291

Ascent from coast route, 29I, 292

Possible ancient scenes on ascent, 293, 294

Dentelle Pattern on ascent, 285, 289

Western Enclosure, 294-296

Western Temple, xxviii, xxix, 297309

North Wall, 298, 299

West Wall, 299, 300

Monoliths and Conical Towers, 30o, 302

Architecture and construction of West Wall, 302, 303

South Wall, 303, 304

East side of Western Temple, 304

Centre of arc of West Wall, 304-307

Covered Passage, 307

Platform Cave, 307,308

Stairs to Platform, 308

Parallel Passage, 308

Internal walls, xxix, 308, 309

Sections of floors, xxviii, xxix, 309

Platform Enclosure, 310-312

Cleft Rock Enclosure, 3I 2, 313

The Platform, 3I3-3I 5, 44I, 442

Balcony Wall, 3 I 5

Little Enclosure, 315, 316

The Winding Stairs, 316

Upper Passage, 316

East Passage, 316

Buttress Passage, 317, 318

South Enclosure A, 3 I 8

South Cave, 319, 320

South Passage, 320

\section{Acropolis Ruins-}

South Enclosure B, 320, 32 I

South Enclosure C, 32 I

Central Passage, $32 \mathrm{I}$

Eastern Temple, 323-335

Section of Eastern Temple, 324

Plan of Eastern Temple, 326

Dentelle Pattern at Eastern Temple, 328

Bent's "altar" at Eastern Temple, 333

The Ancient Balcony, 335, 336

Gold Furnace Enclosure, 337, 338

Balcony Cave, 337

Balcony Enclosure, 336

Upper Gold Furnace Enclosure, 338

Pattern Passage, 338, 339

Step Pattern, 339

Recess Enclosure, 340, 34 I

North Plateau, 34I, 342

North Parapet, 342, 343

N.W. ascent, $344-349$

Water Gate Ruins, 349-353

Terraced Enclosures on N.W. face of hill, 353-357

South Terrace, 357,358

Outspan Ruins, 279, 358-362

Aden (Eudaemon), 67

Almaquah (Venus or Ashtaroth), Sabæan Divinity, I08, 194

Amangwa Tribe, 53, 57, 59, 84, 85, 9I

Ancient Architecture at Zimbabwe, I35-I92

Sabæans (Himyarites) as builders, xxxii, xxxvii (note), I36, I93, I94

Degree of durability of walls, 138

Dilapidations, I39-148

Makalanga walls within ruins, $x x i x$, I49-1 52, 312, 336, 373

Some other walls not ancient, xxvii, $\mathrm{xxix}, \mathrm{I}_{5} 2$

Makalanga huts within ruins, $\mathrm{xx}$, xxix, I 49-1 56, 365, 368, 373, 4' 3

Passages, $156-\mathrm{I} 62$ 
Ancient Architecture at Zimbabwe-

Entrances and buttresses, 162-166

Dilapidations to entrances and buttresses, I66, I67

Drains, I68-172

Battering of walls, I72-I 74

Monoliths, I 74-I 76

Soapstone monoliths, I76-178

Number of monoliths still more or less erect, 178-i 80

Slate and granite beams, I8o, I8I

Cement dadoes, I8I-182, 240, 372, 375,383

Built-up crevices, 182,183

Holes in wall other than drains, I83, I 84,423

Blind steps and platforms, 184,185 , $236,240,254,26 \mathrm{I}, 385$

Ancient walls at a distance from any main ruins are of less superior construction, I85-187

Cement, $187-189$

Ancients and caves and rock holes (see Caves), I89-192

Recesses, 340, 34I, 379

"Sentry-boxes," 374, 430

Ancientroad, Zimbabwe and Sofala, Taunton, 63, 74

Ancient clothing, surmise as to, 293

Ancient output of gold, 292

Ancient relics discovered at $\mathrm{Zim}$ babwe, IO2-I 35

Inventory of, $\mathrm{I}_{42}$, $\mathrm{I}_{4} 8$

Arab "finds" at Zimbabwe-

Box, I 16

Lamp chain, I 6

Lamp-stand, I i 8

Iron keys, 122

Calcedony beads, 126

Glass, I 28

Pottery, I3I, 436

Arab gold and ivory traders, 67

Arab trading station at Zimbabwe, I 32-I 34

Area of Zimbabwe Ruins, xv-xvii

Arowi Kopje, II, 66, 69, 95

Ashtaroth. See Almaquah

Bailey, Thomas, grave of, 19

Baranzimba's kraal, Io, I6, 52

His old kraal, 52, 57

The headman, 4I, 88

Barbosa, Duarte (15I4), on the Makalanga, I23, I32, 133
Barotse (Barosie, Marosie, Varosie, Abolosi) -

Derivation and origin of, 81,82

Excellent stone-builders, 82, 85

Jerri's people Barotse, 82

Head kraal at Zimbabwe, 8, 83, 424

Resided in the ruins, 83

Resided on Bentberg, I 53

Totem of race, $9 \mathrm{I}$

Totem of tribe, 91-92

Pottery, I 29

Kraal of Motumi, $5^{8}$

Baduma Tribe, 9I, 94

Beads, 126

Gold, II3

Calcedony, I26

Porcelain, I 32

Glass, 132

Ivory and bone, $\mathrm{I} 26$

Unknown to natives, 306

Bent, F.R.G.S., Theodore, xv, xvii, xxix, 3, 8, 18, 35, 39, 55, 64, 106, I08, I09, III 112, I25, I35, I5 I, 161, 17 I, 193, 195, 198, 208, 209, $218,221,222,223,226,234,242$, $244,245,265,272,273,295,296$, $304,306,327,338$

Bentberg Hill (Matusa), 7, 8, 9, I 37 Ruins on, 424

Benzi, nickname of the present Mogabe, 42

Beroma Range, I I, 3I, 49, 5I, 63

Beroma Ruins, 68, 69

Besa Mountains, Io

Bethûl, "dwelling-place of God" of Phœnicians, I5

Bingura, Amangwa chief, 57

Bingura's kraal, 9, 17, 57, 58, 84

Bingura's Path, 56, 59, 137

Bingura's Path Ruins, 425

Brass articles, bangles and wire, 123, I 24

Brass bartered for by Makalanga (I5I4), I23

"Breasts, Queen of Sheba's," on Beroma Range, Zimbabwe. See Marsgi and Sueba

British South Africa Company, 2, 3, 279

Bryce, Professor, on Makalanga stone buildings, I 5 I 
Budge, Dr. (British Museum), opinion on Arabian glass, I 28

On "finds" in later ruins, xviii, xix, $\mathrm{xxvi}$

Bungu, Makalanga Headman, 55

Burial places of ancients, searches for, xvii-xviii

Bushman paintings absent from Zimbabwe district, 192

Byblos, Temple of, in Phønicia, compared with Great Zimbabwe, xxxix, 245

Camp Ruins Nos. I and 2, 4I4-4I9

Calcedony beads, I26

Prof. Flinders Petrie's opinion on, 126

Caves, I89-192

At Wuwuli, 55

Chibfuko, 59

Chicagomboni, 6 I

Mapaku, 63, 70

Majerri, 73

Nini, 86

South Cave, 319, 320

Balcony Cave, 337

Chamananga (Middle Kopje), 56

Chenga, Makalanga headman, derivation and position, II, I 7, 3I, 4I, 57

Chenga Ruins, 66, 67, 426, 427

Chenga and MaDavid's Path Ruins, 428

Cherimbila, Makalanga chief, Io

Renders died at kraal, 62

Stone buildings at kraal, I 52

Chevron pattern at-

Majerri Ruins, 73

Elliptical Temple, 147, 21 I-213

Chib-fuko Hill, to

Caves at, 59

Chicagomboni Hill, 6I

Chickwanda's kraal, 95

Chinaka's kraal, 72

China, Nankin, 130

Arabian, I3I

Sketch of, with Arabic lettering, I3I, 436

Chinongu's kraal, I I

Chipadzi's kraal, 52, 59, 60, 6I

Chipfuno (late Mogabe), 42, 55

Chipo-popo Falls, 5 I

Comoro Islands, peopled by Jews under Solomon, xxxvii
Condor, Colonel, Syro-Arabian archæologist, 4

Conical towers at-

Elliptical Temple, 240-246

Traces on walls, 208

Western Temple, 297, 300-302

Outspan Ruins, 36I

Philips Ruins, 380, $38 \mathrm{I}$

Posselt Ruins, 372

Byblos, xxxix, 245

Copper articles, II 5-II6

Sheathing, II 5

Spearheads, I I5, I 16

Wire, I 16

Cakes and slag, I 16

Ore, II 6

Cupolas, I 16

Chain, I 16

Box, bangles, finger-rings, I 16

Coral, finds of, I34

Cotopaxi Mountain, Io

Cowrie shells, finds of, I 33

De Barros (1552) mentions Zimbabwe, xxvi, I 32

Delitzsch, F., on the signs of the Babylonian Zodiac, xxxviii

Dentelle pattern on-

Conical Tower, 243

S.E. ascent, 285,289

Platform of Western Temple, 3I4

Eastern Temple, 325, 328

Derembghe's kraal, 95

Doro (Dorah), native beer, $16,18,45$, 46

Drew, Mr. Alfred, Native Commissioner, Victoria district, 2, 59, $81,82,85,86,152,156$

East Kopje (Mazanda), 64

East Ruins, 420-423

Edwards, M.E., the late Telford, on the ancient mines of Rhodesia, xxvii; on the terraced slopes of Inyanga, xxxiv

Elliptical Temple, 3

First impressions of, 4

Sunday morning in, 13-16

Midnight in, $16-24$

Goldsmith's shop in, 256

Formation rock under, 449, 450

Plan, xxiii, I93-197

Construction of, 197-199

Measurement of main wall, 199-204

Summit of main wall, xxiii, 205-210 


\section{Elliptical Temple-}

Foundations of, 2 IO-2 I I

Probable ages of walls of, xxiii

Chevron pattern, 2I I-2I 3

Ground surface of exterior of, 213$215,449,45^{\circ}$

N.W. entrance, $216-218$

Plan of, 217

North entrance, xx, 218-222

Plan of, 219

West entrance, 222-224

Enclosure Nos. I-7, xxii, 7, 225-236

Sacred Enclosure, 237-240

Conical Tower, 240-244

Small Tower, 244

Bent on import of, 244,245

Dr. Schlichter, do., 245, 246

Parallel Passage, xx, 246-250

The Platform, 25I, 252

No. 9 Enclosure, xxii, 253, 254

,, I0 ", xxii, 254, 256

,, II , 257-260

,, 12 ,, 260, 26I

, $13 \quad$, $26 \mathrm{I}, 262$

, I4 ,, 262, 263

, I 5 ,, 263,264

Central Area, xxii, 264, 265

Platform Area, xxi, xxii, 265-267

Cement platform, 267

Inner Parallel Passage, 267-269

South Passage, 269-27I

West Passage, 272, 273

N.E. Passage, 273,274

Outer Parallel Passage, 274, 275

Eudaemon (Aden), 67

Explorations at Zimbabwe-

Extracts from Reports by author to Government, 437-442

Ezion-geber, a gold mart, xxxii Joint port of Jews and Phœnicians, 67

Finger Rock (Morgenster), 5I

Flux on gold scorifiers, analysis of, I 4

Foreign stones at Zimbabwe: dolorite, quartz, jasper, serpentine, calcedony, crystal, metamorphic slate, mica schist, ironstone, copper ore, flint, 125

\section{Frond Glen, 5I}

Fuko-ya-Nebandge-the Mashonaland relic, 86-88

Gallois, L., attributes the Rhodesian monuments to the Himyarites, xxxvii

\section{Glass finds-}

Venetian, I27

Arabian, 128

Dr. Budge's opinion thereon, I 28

Gobele's kraal, 60, 7 I

Gold articles-

Two periods of gold manufacture at Zimbabwe, xix, $x x$, II I

Gold crucibles, I I2, II 3

Gold beads, II 3

Beaten gold, II 3

Gold tacks, I I 3

Bar and cake gold, II 3

Gold bangles, I I4

Gold scorifiers, I I4

Dr. Hahn's opinion on, I I4, II 5

Goruma Hill, 7 I

Government notices to visitors, 3, 433,434

Grandidier, Alfred, on the early relations of the Israelites with Madagascar and the Comoro Islands, xxxvii

Hahn, Dr. P. Daniel, metallurgical chemist, opinion on gold scorifiers, I I I I I 4, I I 5

On soil under west wall of temple, xxv, 2IO, 2 I I

On metamorphic slate, 257

Haig, General, on terraced slopes of South Arabia, xxxiv

\section{Hand-clapping, Ioo}

Havilah, of Scripture, identified with Rhodesia, xxxii, I5, 68

Havilah Camp, Zimbabwe-

Residence of author, 2, I6

A day at, 3I-50

Evening at, 48-50

Hayles, Mr. H. H., of Victoria, 3

Helm, Dr. John, of "Morgenster," $53,81,363$

\section{Herring-bone pattern-}

Carved, I Io

On wall, 352

Himyarites, builders of the earliest Rhodesian monuments, xxxii, xxxvii (note)

Source of their food supplies, xxxiii

Their old Semitic language long survived in Abyssinia (Geez), and still survives in South Arabia (Ehkili), xli

Humours of Explorations, 48 
I'daha (hemp) smoking, 45

Idumean Jew, impression of, xxxvii, IOI

Ingot moulds, double claw-hammershaped, I Io

Straight bar moulds, I I I

Ingumaruru Hill, $7 \mathrm{I}$

Inner Defence Wall, 358, 359

Inscription, the vanished Great Zimbabwe, probably post-Koranic, xlii

Himyaritic and Phoenician, absence of, on Rhodesian monuments explained, xxxix-xlii

Searched for, xviii, xix

Inventory of Relics and Finds discovered by author at Zimbabwe, 442- 448

Iron articles discovered-

Hoes, I 16

Picks, I I 7

Chisels, I 8

Spoon, spear-head, lamp-stand, bangles, II 8

"Collars" and "shoes," I I9

Forked instrument and pincers, I2O, I 2 I

Gongs, I 2 I, I 22

Rod or sceptre, keys (conjectured), I 22

Smelting furnaces, 123

Inyanga district, its terraced slopes, xxxiv

Its "slave-pits" relatively recent, $\mathrm{xxxv}$

Its terraces dissimilar to Zimbabwe terraces, 354

Inyuni Hills, I I, 69

Isafuba game, $32,43,44,45$

Holes on Rusivanga, 425

Holes at S.E. Ruins, 397

I'zhuba Kuru (Sunday), 46

Jerri's people, Barotse tribe, 82

Lived at Khami Ruins till 1836,82

Now live at Jerri Mountains, South Mashonaland, 82

Kaprazine, the Monomotapa in 1620 , I 33

Kafir (Kaffir), derivation of, 30

Keane, Dr. A. H., his solution of the "Gold of Ophir" question, xxxixliii, 3
Khami Ruins

Jerri's people (Barotse) lived here till I 836,82, I2 I

Some walls at, similar to Barotse walls in Zimbabwe district, 426

Livouri Mountains, 9, 10

Niande Hill at, Io, 62, 69, 76

Louw, Rev. A. A., "Morgenster," $53,8 \mathrm{r}$

\section{Lovugwe country, II}

\section{Lumbo Rocks, 8}

Described, 52

Stones from, I80

Lumbo kraal, 88

Madagascar, its early relations with the Jews, xxxvii

Magdoshu kingdom, xxvi

Mahobohobo trees, 53, 60, 79, I 55

Majerri Ruins, 65, 73

Makalanga "People of the Sun," 8O-IOI

Appearance of, 2, 6

Feasts of full moon, I6-24

Feasts of new moon, 27

Dread of ruins at night, 19

Labourers, 3I-50

Letter-runners, 33

Dual character, 38

Defilement by touching dead, 43

I'daha smokers, 45

Doro drinkers, 45,46

Talking distances, 47

Blood-cupping, 55

Sunday, 46

Mystic Bar, 57

Chibfuko Hill, veneration of, 59

Will not disclose ruins, 68

Light-skinned boy, 73

Women's skin pattern, 74, 96

Where found to-day, 8I

Language polished, $8 \mathrm{I}$

Makalaka, a nickname for, 8I, 90

Once a powerful nation, 80

At Zimbabwe, sixteenth century, 80

Excellent stone-builders, 82, I 5 I

Used ruins as cattle kraals, 83

Barbosa, refers to, I23, I32, I33

Check pattern on huts, 74

Name for Elliptical Temple, 85

Idea of origin of ruins, 85,86

Agricultural and pastoral people, 89, 95

Intellectual and physical superiority of, 89 


\section{Makalanga-}

Contact with Portuguese, 90

Totem of Zimbabwe, 90

Objects of veneration, 9I

Insects eaten by, 92

Astronomical ideas, 92

Sacrifices by, 93, 259, 270

Burial customs, 94, 95

Manufactures, 95

Dress, 96

Witchcraft, 97

Harmony, 97

Proverbs, 98

Whorls, 99

Salutations, IOO

Jewish customs, IO0, IOI

Of $\mathrm{r}_{5} \mathrm{I} 4$ bartered gold for brass, I 23

Pottery, 40, 4I, I29, I30

Occupied Elliptical Temple until sixty years ago, 254

Makuma Kopje, 9, 26, 32, 33, I60

Mamba, or Mombo, old dynastic title of Barotse chiefs, 82

Manamuli's kraal, 72

Mandarali's kraal, 65

Mandindini's Ruin, 7 I

Mangwa (Morgenster), 84

Mapaku Ruins ("Little Zimbabwe"), 7, II , 60, 63, 292, 428-432

Mapaku kraal, 70

Mapudzi Stream, 7, 59, 6I, 66

Marosie. See Barotse.

Marota's kraal, 72

Marsgi Hill (one of "Sheba's Breasts"), II, 66, 69

Mashona, derivation of, 80

Masua's kraal, 63, 95

Masungye, 84

Mauch, Dr. Karl, German scientist, $9,62,185,242,243,270$

Mauch Ruins, 392-396

Maund Ruins, "find" at, I Io

Description of, 383-386

Matgwaine, a Barotse, 59

Mazanda (East Kopje), 64

Mazilli River, 72

Meziro River, 71, 72

Middle Kopje (Chamananga), 56

Milton, Sir W. H., xxx

Mogabe, the, Handisibishe, 2, 6, 39, $40,42,83,84,85,279$

His kraal, 16

Mogabe, the late, Chipfuno, 6, 55, $84,218,279,333,355$
Mogabe, the late, Molinye, 84

Mogabe, the late, Mokomo, $3^{12}$

Mogoma's kraal, 62, 63

Mojejèje (Mystic Bar), 55, 57

Molembo Tribe, their Jewish customs, IOI

Metal-smiths, I I I

Monomotapa, the, 80,85

Kapranzine (1620), I 33

Pedro (I643), I33, 280

“Morgenster Mission," 52

Moro! salutation, origin of, roo

Moscha, a port of "Ophir," 67

Moshagashi Valley, I, II

Moshagashi River, 10, 51, 69

Mowishawasha Valley, 8, 53

Mowishawasha Hill, IO, 54, 59

Motelekwe River, derivation of, 7, 9, II $53,54,60,125,29$ I

Motuminshaba Hill, II

Motumi (a Barotse headman), $5^{8}$

His kraal, 58, 59, 63

Motusa (Bentberg), 7, 8

M'Tigeni's kraal, II

M'Tima's kraal, Io

M'uali (the chief spirit; in some districts the prophet of the Deity), 19, 94

Müller, Professor, on Zimbabwe, 193

Munda (a Makalanga headman), 73, 74

Mystic Bar. See Mojejèje

N'Djena Valley, 53

Neal, the late W. G., co-author of The Ancient Ruins of Rhodesia, 82

Niande Hill (Livouri), Io

Nini country, near Zimbabwe, 9, 6r, $62,84,85,95$

No. I Ruins, location of, 8, I9

Description of, 398-4IO

North-East Passage, discovered by author in 1902, 273, 274

Omar l'Wardi (circa I200 A.D.) on gold of S.E. Africa, 123

Ophir, not a gold land but a gold mart, xxxii

Is identified by Oppert with Tharshish, xlii

Dr. Keane, author of The Gold of, 5 
Oppert, Professor G., his solution of the "Tharshish-Ophir" problem examined, xlii-xliii

Outer Defence Wall, 210, 358, 4 IO

Outer Parallel Passage, 274, 275

Outspan Ruins, 279

Described, $35^{8}-362$

Output of gold, ancient, 292

Paphos, embossed cylinder from, compared with one from Great Zimbabwe, xxxix

\section{Pasosa Ruins, 10}

Passages, $\mathrm{xx}, \mathrm{I} 56-\mathrm{I} 62$ At Elliptical Temple-

Parallel Passage, 246-250

Inner Parallel Passage, 267, 268

South Passage, 269-27 I

West Passage, 272, 273

No. Io Enclosure Passage, 256

Passages outside Elliptical Temple-

Outer Parallel Passage, 274, 275

N. E. Passage, 273, 274, 390

Passages on Zimbabwe Hill-

S. E. ascent, 279-294

Central Passage, 321, 322

Sunken Passage (Eastern Temple), 332

South Cave Passage, 3 I9

Covered Passage, 307

Parallel Passage, 308

Winding Stairs, 3 I6

Upper Passage, 3 I 6

East Passage, 316, 317

Buttress Passage, 3I7, 3 I 8

South Passage, 320

Pattern Passage, 338, 339

N.W. ascent, 344-349

In Minor Ruins-

Outspan Ruins, 360, 36I

Ridge Ruins, 4I3, 4I4

No. I Ruins, 402, 406

In Valley of Ruins-

N.E. Passage, 390

Bent's Passage, 395

Posselt Ruins, 370-372

Philips Ruins, 38 I

Maund Ruins, 384

Mauch Ruins, 393, 395

Renders Ruins, 390, 39I

Near Zimbabre-

Mapaku Ruins, 430

Pedro, the Monomotapa in I643, I33

Petrie, Professor Dr., Egyptologist, opinion on pattern on bowl, i io

On calcedony beads, 126
Phalli, IO4

Phœnicia, xxxvii, xxxix, xl, 213, 245

Philips, George, elephant hunter from Natal, 9, 62

Philips Ruins, I03, I05, I07, I08, $376-38_{3}$

Plunket, Hon. E. M., on the Babylonian Calendar and Zodiac, xxxviii

Posselt, The Brothers, big-game hunters, resided at Zimbabwe, I 888-9, 7

Camp at, 8

Visited Majerri ruins, 74

Discover "Fuko-ya-Nebandge," 86, 87

Soapstone birds, 333

Posselt Ruins, 366-375

Pottery, Barotse, I29

Makalanga, I29, I30

Of uncertain date, 130, r3 r, r 32, 436

Providential Pass, 9

Relics and "finds" at Zimbabwe (I902-I904)-

Inventory of, 442,448

Descriptions of, 102-I 34

Positions and associations of "finds," sections of floors, 103, I34

Soapstone articles, IO4-I I I, 333

Gold articles, I I I-I I 5

Copper articles, I I 5, I I6

Iron articles, I I6, 123

Brass articles, I23, I 24

Foreign stones, 124-126

Glass, pottery, and china, I27-1 32

Mediæval Arab articles, I32-I34

Arabian glass, 128

Arabian pottery, I3 I

Venetian glass, 127

Tin, I 6

Renders, Adam, “Sa-adama," ivory trader, rediscoverer of Zimbabwe, 9

Camp at Zimbabwe, 9

Camp at Nini, 9

Cave at Chicagomboni, 6r

Death, 62

Renders Ruins, 386-39I

Ridge Ruins, location of, 8

Descriptiou of, 4IO-4I4

Rock Holes Path, I90, 3 I2

Rugutsi Kopje, 54

Rumeni Ruin, 7I

Rushumbi Hill, 72

Rusinga Rocks, 69 
Rusingu, native name for Elliptical Temple, 85

Rusivanga Kopje, derivation of, 9 References to, I25, I37, I89

Ruins on, 424

\section{“Sa-adama." See Renders}

Sabæans (Himyarites) of South Arabia, worshipped Almaquah (Venus, Ashtaroth), ro8

As original builders, 136

Parallelisms with Sabæan architecture, 193, I94

Sabi (Sabæ, Saba) River, no native derivation, 67

Ruins in Sabi Valley, 197, 291

Salutations, native, 100

Sana, South Arabia, its decorative art compared with that of the Rhodesian monuments, xxxvi

Sanuto, Livio (1588), I32

Sayce, Dr. A. H., on the Ophir of Scriptures, xxxii

On the Babylonian Zodiac, xxxix

Schlichter, Dr., German archæologist, 7

Camp at Zimbabwe, 7

References to, 198

On Conical Tower, 245, 246

On centres of arc walls, 304

On the Zimbabwe Zodiac, xxxviii

Schlichter Gorge, 7, I I

Description of, 60, 6I, 64

Selous, Mr. F. C., big-game hunter, on moulds, IIO, I5I

"Sheba's Breasts." See Marsgi and Sueba

Skardusa's kraal, 72

Soapstone beams, I04-106

Birds, $106-108$

Position of birds, 106

Bowls, I08-III

Ingot moulds, I IO-I I I

Sofala, identified with Tharshish, xxxii

Zimbabwe road to, 63, 67, 74

South Arabia, its terraced slopes, xxxiv

South-East Ruins, 396, 397

Stanley, Sir H. H., on double iron gongs used in Upper Congo, 122
Step pattern, 339

Sueba Hill (one of "Sheba's Breasts"), derivation and position, II , 66, 72

Suku Dingle, 56, 187

Swan, the late M. W., explorer of Zimbabwe, biographical notice of, 434,436

\section{Tchivi Kopje, I I}

Thabas Imamba, 82, 9I

Tharshish, probably the present Sofala, xxxii

Identified by Oppert with "Ophir," xlii

Tokwe River, derivation of, 9

Valley of Ruins, the, 3, 363-397, 398-4I9

Varosie. See Barotse

Veroma Range. See Beroma

Victoria, township of, I, 2, I0, 33, $4 \mathrm{I}$

Native names for, 99

Visitors to Zimbabwe, regulations, 433

\section{Washa. See Mowishawasha}

Water-Gate Ruins, 349-353

Welsh Bardic emblem (parallelism), I8, 96

"West Wall controversy," xxivxxvii

White, M.E., Mr. Franklin (Bulawayo), $\mathrm{xxx}$

Whorls, soapstone, II I

Pottery, I 27

Willoughby, Sir John, xv

On extent of Great Zimbabwe Ruins, xxxiii

Explorations, 8, I35, I37, I70, 190, I9I, 222, 234, 400, 4I 4

Wilson, Major Alan, grave at Zimbabwe, 5, 8, I9

Removal of remains, 5

Wuwuli Village and Caves, 54

Yemen, South Arabia, 15, 293 
Zimbabwe, The Great-

Derivation of, I, 85

Author's arrival at, I, 2

Lord Milner's visit, 2

Dr. K. Mauch at, 9

Bent's camp at, 3

Dr. Schlichter at, 7

Posselt Brothers reside at, 7,8

Willoughby's camp, 8

Adam Renders' camp, 9

George Philips' camp, 9

Reserve, map of, 3

Ruins' area, plan of, 7

\section{Zimbabwe, The Great-}

Bentberg, 7

Makuma Kopje, 9

Arab station at, I32-I 84

Zimbabwe creeper, 4, 78, I47

Zimbabwe Hill, 2, 276-362

Zimbabwe revival, xxix

Zimbabwe, Sofala Road, 63, 74

Zodiac, the Zimbabwe, its antiquity vindicated, xxxviii 




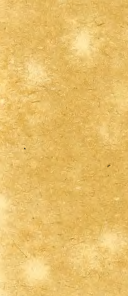

$x^{2}=$

cins

ser $x=0$
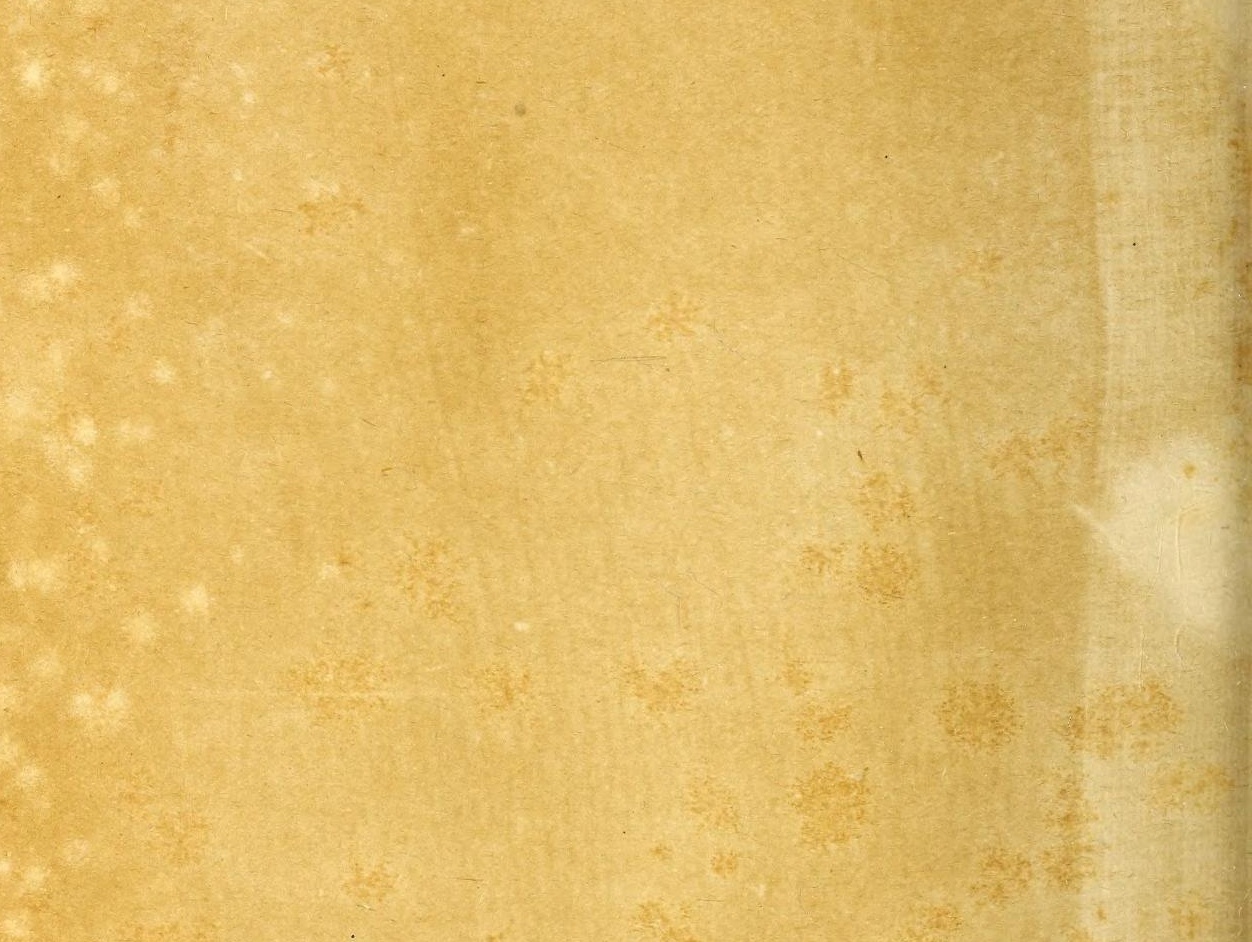

castis
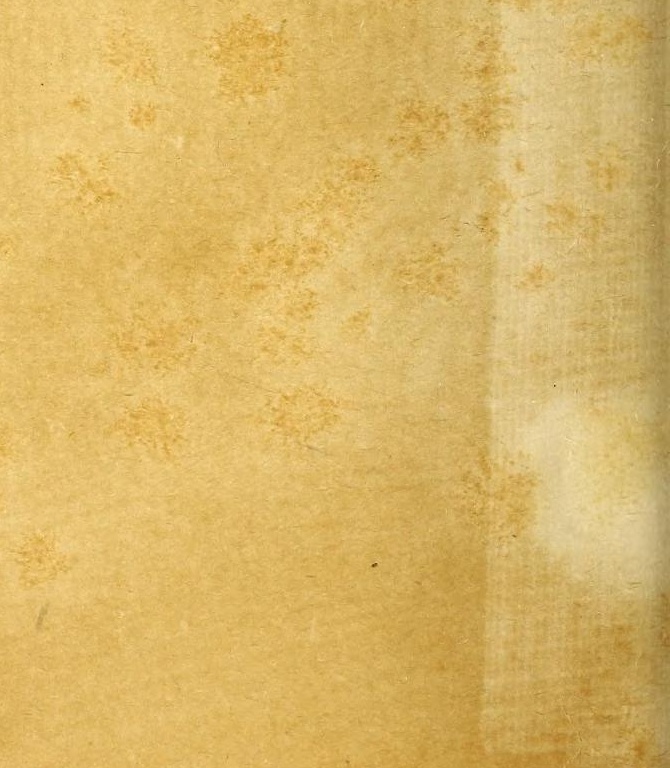


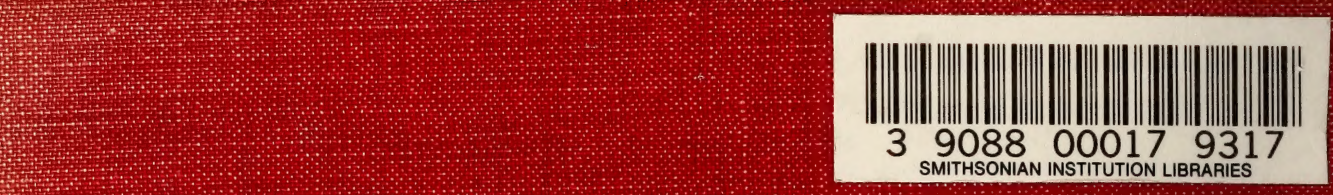

SMITHSONIAN INSTITUTION LIBRARIES 